
LIPYARY

UNIVERSITY OF CALIFORN

DAVIS 


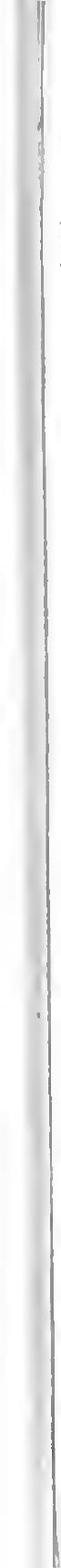




\section{EVOLUTION OF THE CALIFORNIA LANDSCAPE}

BY NORMAN E. A. HINDS

Associope Professor, Deportment of Geologicol Sciences University of Colifornio, Berkeley, Colifornio

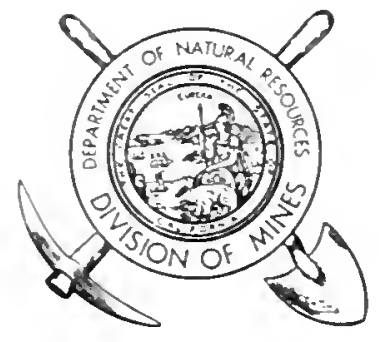


P 


\section{LETTER OF TRANSMITTAL}

To HIS EXICHLENCY

TUE HWNORABLE EARI. WARREX

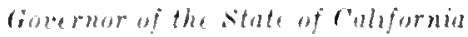

DEar SIR: I have the honor to transmit herewith Bulletin 15a, Erolution of the C'diforma Lamdacale, prepared under the direction of Wlaf P. denkins. Chief of the Division of Nines. Department of Xatural Resources. Thin volume is profusely illustrated with photographs, man. and drawing daractorizing the significant surfane features of the entire state. The author. l'rofessor Surman E. A. Hink of the Department of Ceological cienens. Iniversity of California. has systematically Aceribed those surface features as they are related to the greology and rock struetures of the state, and has shown how these features have developed through natural processes operating over the long periods of time required to produce California s diversitied lantseape.

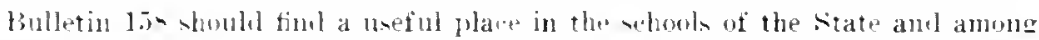

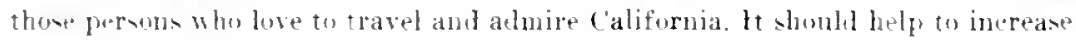
enjuyment of what in to be seen by explaining thoroughly why the surliace features are what they are.

Revreetfully submitted.

APPROVED:

IV. T. H

Norember 17,1952
Warkex T. Hascey, Director

Department of Natural Resources 

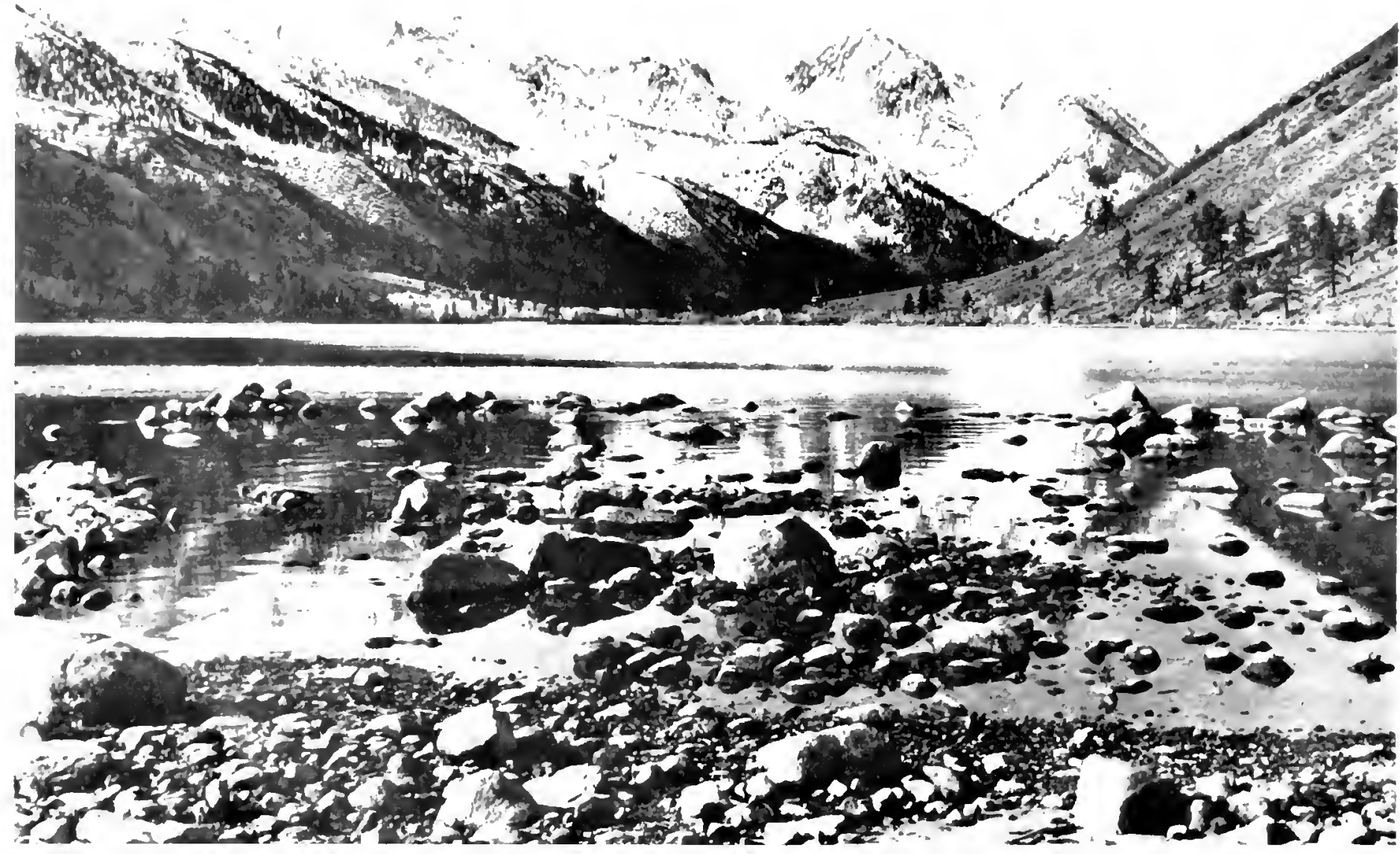
TABLE OF CONTENTS

Introluetion

sierra cinvadal

bavin-Ranges

Mlojave Desert tiI

Colorado Desert

Modue Plateau

cascale lange

Kilamath Mountains

Great Valley ....

Cuat Rangev

Tram-Vorse Ranges

1.i. 231

Penimular Ronges

Stra Flowr

linis

$\operatorname{lnth} x$ 

INTRODUCTION

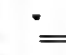





\section{INTRODUCTION}

California may be divided into a number of units called geomorphic proliners (the Sierra Nerada, Basin Lanees, Mnjave Desert, Colorado Desert. Modow Platean. Cascade liange, Klamath Momntains, Great Valley. Coast Ranzes. and Transverse liantes enomorphi provinces shown un plate: earh of whin is chararterized ly a distinguishing greologieal record, particularly in the later part of earth listory, and ly more or less uniturm relinf features or combinations of features throughout its area. The'se geomorphic provines are remarkably diverse, and in the milst of some of them great numbers of people live; others, more distant, are visited by an increasing host each year. Frequent requests are made for the geologie story of Yosemite Valley. Lake Tahoe. Death Valley, Irunt Shasta. the great ranges extending east ward from Los Angeles and the hold shore features of California. As with nusic, literature, the arts, or anything else, the more one understands about what he is hearing. reading. or seeing. the more interesting it becomes. So far no book has been written whieb tells the story of the evolution of California's lantseape. There are technical papers and reports about many areas. but they are in the language of the seientist, much of which is like a foreign tongue to the layman. and the cuntain a great amount of information of interest only to the specialist on the whject. Therefore, in this rolume an attempt is nade to bring turether information about the varions parts of the state in a fashion which those uninitiatel in the comples voeabulary of geology can understand. The book is not intended for the trained geologist, but fur the layman who wants to learn more about places he has seen or may see. Incluled are abumlant pietures. sketehes. and diarrams. for these often make clear what written words ean not. Furthermore, the illustrations may awaken many people to the myriad of seenic womlers lying vithin California's boundaries, wherein is perhaps the nost remarkable eollection of natural masterpieees to be found in any state of the Lnion.

Berause of ('alifornia's huge area, studies of many parts are inconplete or vot "ven mald. so we have only a partial pieture of how the landscape reached its present form: none the less, enough information is available so that all of the major divisions ean be deseribed in, general outline at lrast. The state is so large and its geologieal history is so complex that no single person can know by any means all of it, for field study is slow. Therefore it has been neeessary to draw frety. on the writings of others. In order to aroid referring to so many writers in the text, practically all names have been omitted, but the significant publieations have been listed at the end of each chapter. Ry these lists acknowledgment is made of use of information whieh many workers lave gathered ; they serve as sources for further reading for any who are particularly interested in a certain section.

The following books give funclamental presentations of landseape crolution: the first three are intended for elementary college courses in the subject and for the lay realer; the last three are somewhat more advanced.

Itinuls, N. E. A., Gemmorphoiggy, Preatice-Hall, Inc., New York, 1943.

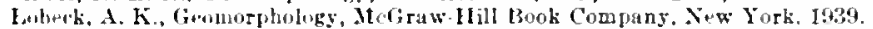

Worcester, P. (i., A textbook of gromorphologs, 2d ed., D. V'an Nostrand Company. Int-

('oton. C. A., Landscupe, 2 ed., Whitcombe and Tombs, Ltd., Wellington, S. Z.. 1948

cotton. C. A., Geomorphology, 5th ed., John Wiley and Sons, I949.

Von Engwln, O. D., Geomerphologs. The MacMillan Company, 1942.

Gcomorphology is the technieal name for the scientific study of land forms and landseapes, being derived from three Greek words geearth; morphos-form; logos, science or study. In former years, this subject was termed physiography and a number of books, now largely out of date and mostly out of print, were written under this title.

The reference volumes listed above are well illustrated, so that they give the reader an excellent pietorial view of the earth's land forms, as well as deseriptions of their origin.

For those who are partieularly interested in roeks and minerals, the following books of rather popular nature are suggested:

English, O. L., Getting acquainted with minerals, Mineralogical Publishing Co., Rochester, $X . Y_{\text {. }} 1934$.

Fentun, C. L., and Fenton, II. A., The rock book, Doubleday and Company. [nc. New Iork. I946.

Ilurlbut. C. S., and Dana, E. S., Minerals and bow to study them, John Wiley and Sons. Inc., 1949.

Murdoch, J., and Webb, R. W., Minerals of California, California Division of Jines Bull. 136, 1948.

\section{The Earth's Age}

Although the age of the earth has been a much-debated topie for eenturies, reeent improvements in seientifie tools have allowed a more aecurate estimate to be made now than ever before. With the advent of our knowledge of radioactivity, a new means for determining the age of some earth materials was evolved, and the findings enormonsly expamled the known length of earth listory. Radium is an element developed by the natural breakup of atoms of parent elements like uranium, thorium, and actinium, which are contained in a few min. erals of the earth. During the disintegration of the atoms, the valuable gas helium also is generated. Radium itself decomposes into other elements, so that we have a radioactive scries. The final produet of this natural ehange seems to be one of the isotopes of lead. Isotopes are varieties of elenents having the same atomic numbers, virtually 
the sane chemical properties, but differing slightly in atomie weights. The lead-isotope formed from deeay of parent radioactive elements apparently does not break up, and the rate of deemposition has been itecurately measuret in terms of the half period of decay. Therefore if an uranimm- or thoriun bearing mineral is present in a rock, the ratio of the uranium and thorium eontent and the helium and lead isotope eontent can be determined. Only minerals from fresh or relatively fresh voleanie roeks can be used, for in these alone the significant mineral grains have been altered or disturbed to the least extent and material of mixed source is not present. Certain corrections have to he made to allow for changes which have ocurred since the mineral was formed so that the ealeulations are complieated. Jefium seems less satisfactory for the determinations than lead, probably beeause it ean eseape more easily from roeks than the solid element. The oldest known minerals come from Russia and Nanitoba, Canada; their ages are 1,850 and 2,300 million years respectively. Because volcanie rocks have been erupted at various places orer the earth or emplaced befow its surface during the entire known history, an approximate time scale has been set up. This undoubted ly will be made more acenrate and fuller as techniques are improved and more determinations of mineral age are made.

There are serious diserepancies between determinations based on lelium and those based on radio-lead, but, in spite of this, all measurements so far made indicate that the recorded history of the earth probably exceeds a billion and a half years. Back of this known record there is a long interval, perhaps a half billion or more years, from the parth "s origin to the formation of the oldest known rocks. The age of the earth thus is between two and three billion years.

To facilitate discussion of events which lave taken place over this immense span of time, it has been divited into major units ealled eras: these are composed of briefer intervals termed prriods, which in turn are separable into still shorter time units known as epochs. The passage from one geological era to another has been marked by many profound changes. Over long intervals, but short as eompared witl the length of the era, the continents have grown very large, and mountain ranges have been built in various narts of the earth. Cir. (nlation of the ocean and the atmosphere has been conspicuously altered by these geographie changes, with consequent important dimatic modifications. The ehanges between periods and epoehs are less pronounced. For example, an era, called the Mesozoic, ended about 60 million years ago as the result of such events as are described above, and a new one, the Crnozoic was initiated. We live in the latter era, whieh is composed of one perior, the Tertiary, and this period is divided into five epochs, the Eovene and Oligocene, or early Tertiary, imeluding 40 to 43 million years, and the Hiocene, Plioeene, and Pleistocene, or late Tertiary, covering 15 to 17 million years. The
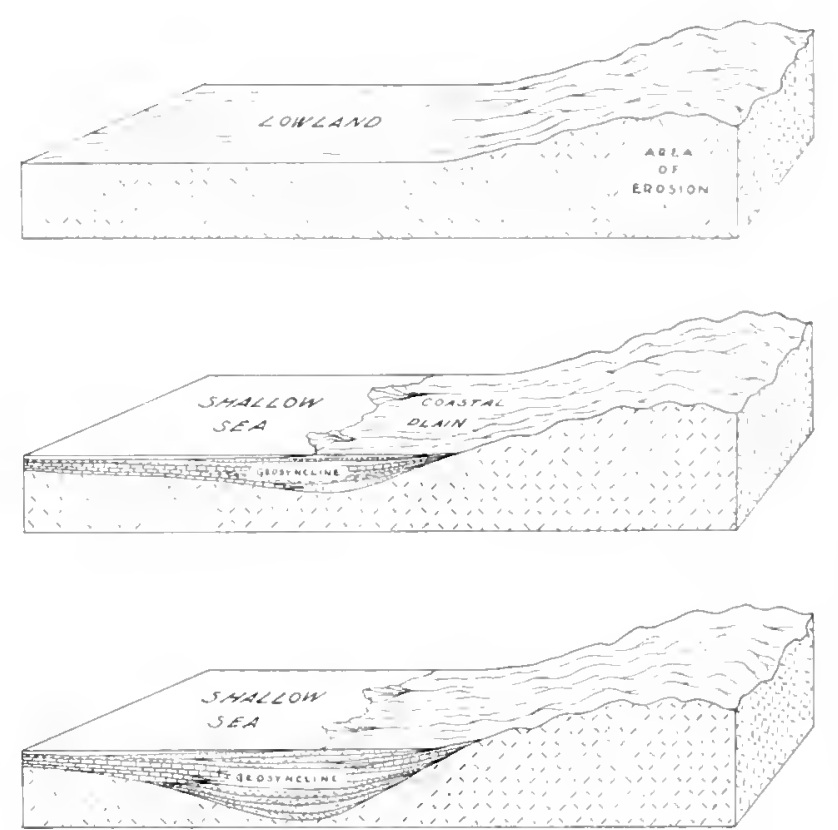

Diagram showing three stages in the evolution of a geosyncline. Top: llighland and aljoining lowland sidiment transported from the erosion aren is deposited on the lowland. (enter: Lowland invaded by shallow man. F"low of the basin sulsides under loal of debris, Bottom: Troukb. liki depression callenl pensuncline is formed hy continued deposition. Strata

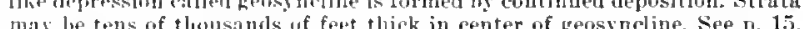

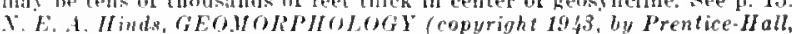
Inc. New York). Reproduced by permission of the publisher.

l'leistocene epoch commenced one or two million years ago, and is one of the most remarkable interludes of earth history.

The following diseussion of the landscape of Califoruia is coneerned prineipally with events whiel took place during the Cenozoie era; but some dating as far back as the Jurassic and Cretaceous periods of the Mesozoic era also are of great significance. Mesozoie time is divided into tliree periods, the Triassic (which represents about 30 million years), the Jurassic ( 40 million years), and the Cretaceous ( 55 million years) elosing the era. Each of these periods left an imposing record in various parts of the state. In landscape evolution, the first imprints reeognizable in California today were made in Jurassie time, when the aneestors of the Klamath Mountains, the Sierra Nevada, part of the Transverse Ranges, the Peninsular Ranges, and some other ranges appeared. 
SIERRA NEVADA 


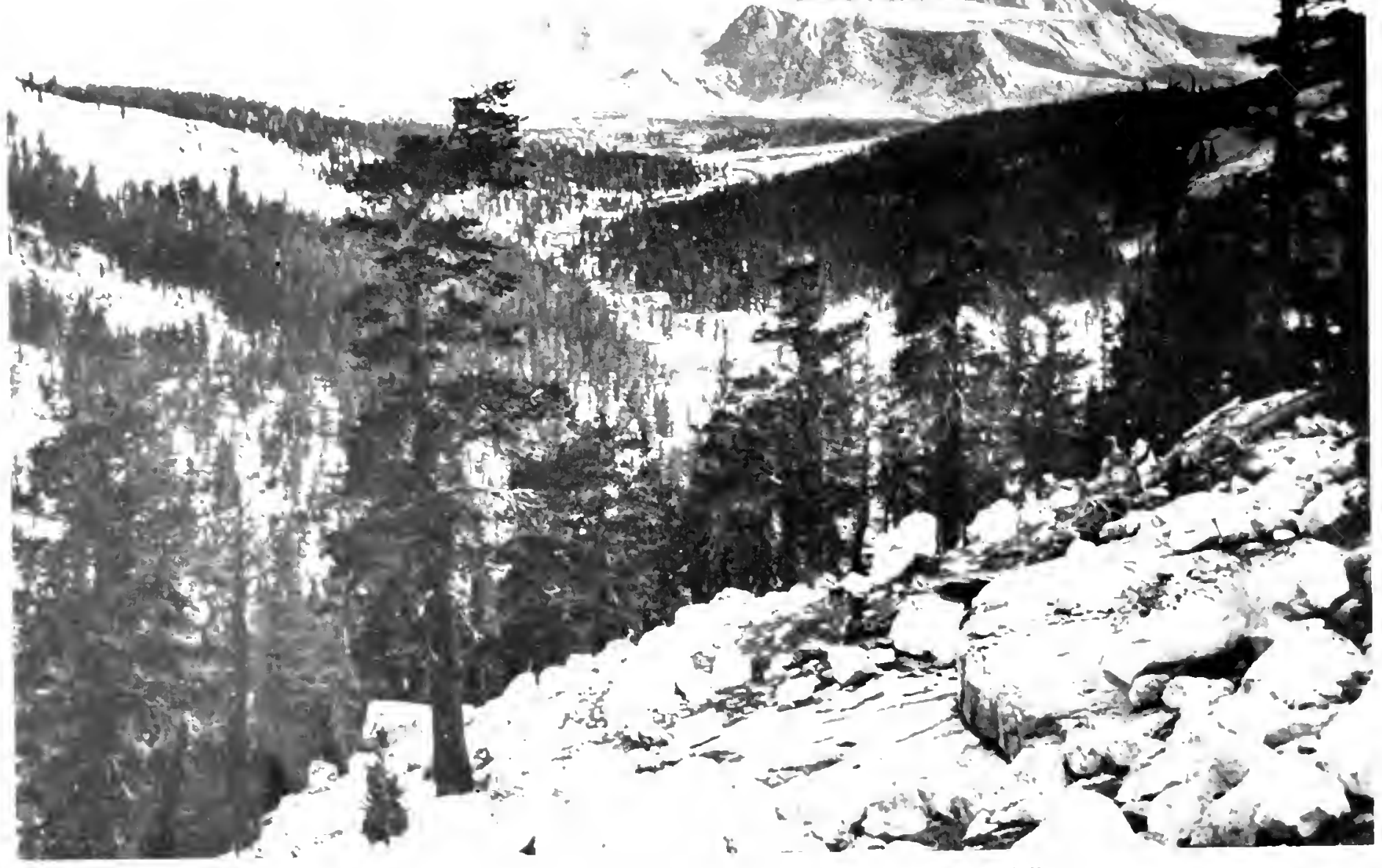
A) 


\section{SIERRA NEVADA}

Hugest of the mountain ranges in California and one of the most massive in North America is the Sierra Nevala, which hies along a considerable streteh of the eastern boumdary of the state. In length the range measures about 430 miles, in width from 40 to 80 miles; a goodly number of its peaks exceed an elevation of 12.000 feet above sea level, and Inount Whitney (14.496 feet) is the hirhest spot in the Cnited States. Dr. F. E. Matthes of the C'nited states ficological Survey, who for many years studied sierran geolowy, states that "the range stands higher above its immediate base than any other" in the country. "The Rocky Mountains, many of whese sumnits rise above 14,000 feet, stand only 9,000 feet ahove the (ireat l'lains to the east which attain altitudes of about 5.000 feet at the foot hills; but the Sierra Nevala stands not less than 11.000 feet above $1 /$ wens Valley at its eastern base and 14.000 feet above the Great Valley of California at its west base."

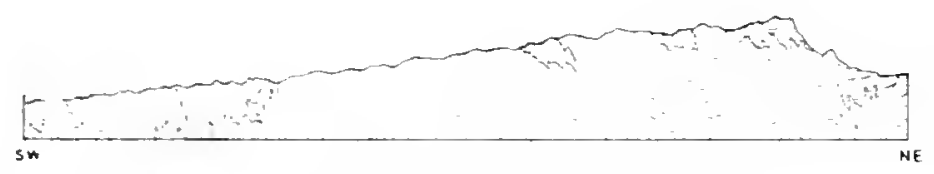

Fuc. 2. Crone section of the Sierra Xevada, Culifornia, through Mt. Whitues its highes peat. The laundary fault arstemalung which the range has been elevated by rilting is shown an the right-haw sibe of the sertion. In this part of the range. mose of the resck expund at the surfalce is granite. but there are considerable areas

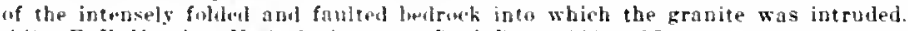
After F. E. If atthes, $l$.s. Geol. surcey Prof. Paper 160. p. 2.j.

Most of the range trends slight y west of north, but at the southern end the direction thanges to west of south. Strikingly eontrasted are the two slopes: that to the west of the erest is broad and gentle, but that to the east is much more steeply inclined. Because of this nnsymmetrical eross seetion, the crests of high peaks lie only a fer miles from the eastern boundary of the Sierra Nevada, but from 30 to 70 miles from the western base. At the northern end of the Sierra, peaks of highest elevation are between 6.000 and 7,000 feet; near Lake Tahoe, Pranid l'ak, Mount Tallac. and other mountains in the vieinity are 9.000 to more than 10,000 feet high : in Yosemite National Park, the peaks reach 12,000 to 13,000 feet in elevation; and in Mount Whitrey region the highest peaks are found-Mounts Williamson (14.384 feet) and Langley (14.04: feet), and. of course, Mount Whitney itself $(14,496$ feet). Farther sonth elevations decrease to about 6,500 feet where tbe Sierra Nevada provinee adjoins the California Coast Ranges near Telachapi l'ass. nearly 100 miles from Jount Whitney.
Because of the gentle aswent from the Great Valley, the western side of the Sierra Nevala does not present a particularly imposing speetacle. themgh the "rent peaks, in th" highest part of the range, stand out in striking fashion. Part of the eastern side, on the other hand. is one of the most imposing muntain esearpments in the world. The northern sertion is not impressire. for it is lower and is split into minor ranges branching off in a murtherly direction from the main range. From near Lake Tabue southward the east front is higher and less broken. It rises about t,000 feet above Mono Lake, 10,000 feet at the head of Owers Yalley west of Bishop. and more than 11,000 feet near Mount Whitney. Then as the range dew rases in height farther south, the escarpment hwors. In the Owens Valley section in partieular, the eastern face appears to be an almost vertical declivity towering ahove a rather even lowland. This illusion is dispelled, how. ever, by actual measurement of the shpe of the front which in fest places exceeds 25 degrees. The highest sertion is immediately west of Lone l'ine. From there Monnt Whitney is sisible. but elsewhere in Owens Valley this peak cannot be seen since it is heated at the head of a great eanyon far bark from the main front. The most conspicuous peak seen from Owens Valley is IIount Williamson, which stands out because of its particularly rayed form and its position more than a mile to the east of the main divide. Mount Langley is a somewhat lower peak but also presents an imposing appearance: Ione Pine Peak (12.95I feet), which stands about 2 niles east of the main crest, rises direetly above Owens Valley, and appears to be even higher than Jount Whitney.

\section{Climate}

Since the Sierra Nevada fractlels the lacific "oast. it forms a gigantie barrier lying athwart the path of the prevaling westerly winds. whieh most of the time carry moist air from the Pacific Ocean over the eontinent. The Coast Ranges farther west are too low to rob the air enrrents of much of their moisure exiept at their northern end where rainfall is hay. Is the winds ascend sierran slopes to elevations where temperatures are lower, condensation gives abundant winter and spring snow and rain. Most of the precipitation falls on the western cide inereasing rapidly from about 4.000 feet and decreas. ing above 6.500 feet, aceording to the $[$. . . Weather Bureau, thongh Dr. Watthes puts the limit of heary snow and rain at 9.000 feet. Below 4,000 feet the dimate is semi-arid but less dry than in the Great Valley to the west. Above 9,000 feet it also is relatively dry because of the heary extraction of moisture below that level however. snow hangs mnch later in the year on the higher peaks bea ase the longer duration of eold weather retards melting, the snow disappearing in June. July, or even August, and returning commonly in Oetober 


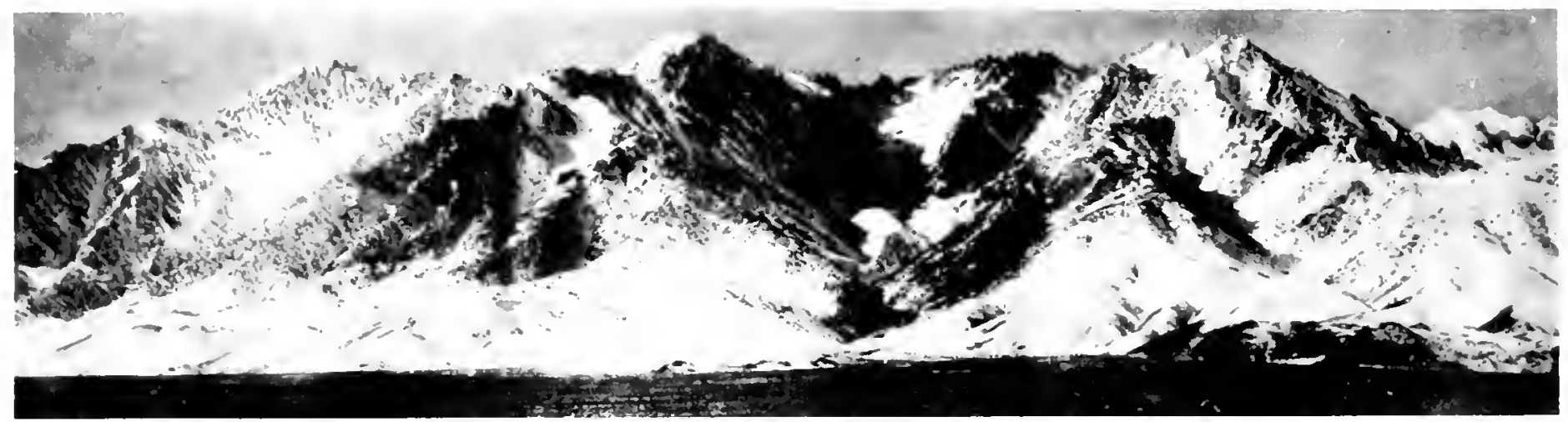

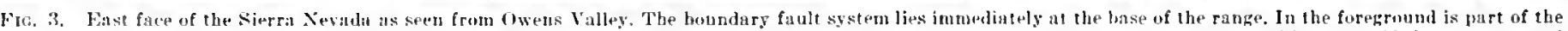

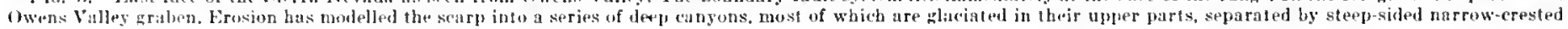

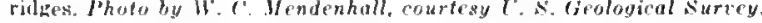

Within the zone of heavy presipitation, depth of winter snow exceeds that in any other part of the United States exrept the Olympic Mountains in northwestem Wasbington, the northern part of the Caseade liante farther east in the same state, and perhaps certain sections of the Rocky Mountains. Between elevations of 6,000 and 7,000 feet along the Southern Pacifie Railroad, the annual snow fall amounts to 30 or 40 feet with as much as 60 feet falling in some years; at Norden Station (elevation 6.871 feet) the average vearly fall over a 34 -year period is 34 feet. At Tamarack in Alpine County (elevation 8,000 feet ). 73.5 feet of snow fell in 1906, the greatest amonnt ever recorded for the entire Sierra Nevada. Frequently there are 10 to 12 feet of snow on the ground at a single time and in protected spots the pile may reach 30 to 40 feet deep. Again at Tamaraek during the winter of 1906-07, 8.8 feet of snow fell during a single storm, another record for the whole of the range.

Beeause the winds lose so much of their moisture as they travel up the western slope, relatively little passes to the eastern side, though considerable snow does accumulate at high elevations on aceount of the long duration of the cold. As the winds descend the east slope, they are warmed and consequently are able to evalorate moisture from the wround. The lower eastern slopes therefore are quite arid, exeept in the seetion near Hono lake where the range base stands 7,000 feet and more above sea level. In the northern Sierra Nevada, the erest is considerably lower and more moist ure is earried over to the eastern side, though again the lowest slopes are quite dry

Dry summers are characteristic of the range. Little rain falls for periods of two or three months, but oceasional thunderstorms oceur, which generally are of short duration.
Nost of the streams draining the range run rouglly at right angles to its trend, that is, they flow south of west on the western side and north of east on the eastern side. There are some exceptions; for example, part of the course of the upper Kern River, the head of the Middle Fork of the San Joaquin River, Granite Creek and Chiquito Creek which parallel the erests of peaks. Beeause the divide between the eastward and westward flowing drainage is roughly the erest of the range, eastern streams are short and western are long; most of the eastern streams are comparatively small because of less available supply of water, ant most disappear either within the lower parts of their canyons or very quickly after they emerge onto the desert basins at the base of the range. The prineipal exeeption is the Truckee River, towing from Lake Tahoe and emptying into beantiful Pyramid Lake which lies in a desert basin more than 30 miles northeast of Reno. Some streams flow into Mono and other lakes in the section where the range base is at highest elevation, and Owens liver, ferl by Sierran tributaries, flows sonthward into Owens Lake.

The heavy concentration of precipitation on the western slope of the Sierra Nevada yives its streams much greater volume, though there is notable flnctuation caused by the dry season during summer and fall. The western streams, with the exception of the Kern River, are tributary either to the San Joaquin River in the southern part of the Great Valley or to the Sacramento in the northern part. These two trunk rivers join not far from Carquinez Strait, the single opening in the mountainous rim surronnding the Great Valley, and flow into San Franeiseo Bay. The Kern Fiver is kept from joining the San Joaquin by a great barrier of sediment in the southern part of the San Joaquin Valley and flows into Tulare basin formerly oecupied 
by a large, shallow lake, most of which has been drained to levelop agricultural Jand.

The prineipal rivers flowing down the western slope, named in orlur from south to north, are the Kern. Kaweah. Kings. San loanuin. Tuolumne, Stanislaus, Mokelumne, American, Iuba, and Feather. In the upper reaches of the range, these streans are formet by the union of large as well as small tributaries, so that we find the Midule and North Forks of the Kings, and similar divisions of the others.

Because of the high elevation of the Sierra Nevalu and sufticient slope in both directions from it, the main streams and their tributaries have eut narrow eanyons. On the eastern side. the gorges ar leep to the hase of the range, but on the western side, the lower part of the range has quite gentle slope and consequently valley depth becomes much less. Some of the eanyons in their headward parts range from 2,000 to 7,000 feet deep. The Tulumne and the Fern, for example, are 4.000 to 5.000 teet deep in places, and the kings ant some of its tributaries measure 6.000 to 7.000 feet. (m the western slope. the "anyons are separated by consiatrablo stretthes of colling upland. while between the gorges eutting the steeper eastern side, there are sharp-crested, narrow ridges.

\section{Evolution of the Mountains}

Mountains and mountain ranges are evolved in four principal ways: (1) by deformation. which is responsible for the principal eminences of the eontinents and larger islands: (2) volvanic action, which has produced some of the most conspicuous and splendid peaks of the lands and the only type of mountains rising above sea level from the floors of the very deep aceans: (3) eroxion: and (4) deposition. Volcanie mountains are formed either by Jeformation of the surfaue as voleanie rock is forced into the outer part of the earth. or by eruption. which builds rolcanoes and plains on the surface. Streans are prineipally responsible for erosion mountains. which in rerions high above sea level may be mighty foatures of the relief. Deposition mountains are better termed hills and ridges, generally they are quite low, though some sand dunes rise a thousand feet above their base.

In terms of the length of parth history mountains and mountain ranges, the most ponspicuous features of the landscape, are relatively ephemeral. being buitt at various times and then destroyed. It many plaees in the earth. there is record of ranges great and small which have been worn down to rolling plains, with perhaps a few liver eminenees, and then buried by hundreds of foet of debris deposited partly below and partly above sea level. The development of primcipal mountain ranges either by deformation or voleanie action is a revolutionary event because of the profund whanges in rocks. rokek structures, and relief which take place; but, as with all revolutions, many ur must of their effects are later wiped out. From time to time parts of many ranges may be rebuilt and their span of life thus increased, but finally even these rejusenated seetions are subdud and their former presence is provol only by eertain rocks ant rock struetures which remain.

Deformation mountains are of three types, the principal being fold-fault rangrs evolved by emincesion of long. narrow belts of the earth's rocky shell with eonseduent ahumbant folling and faulting. The major and most of the ninor ranges of the contulents and large islands are of the fold-fault variety, and somp very important incoups rise from the floor of the shallow ocean, as for example the great island galaxy off the west shores of Asia and Austratia. Also. there are fold mounfuins, which are more or loss simple anticlinal domes, usually of small size and molerate height, hike the Kettleman and Elk llills in the soluthwestern san foaruin Valley. Fault mountains are blocks of the rocky shell bounded by faults along which they have been elevated. generally with some tilting.

The Klamath Mountains, the Sierra Cevada, the Transverse and

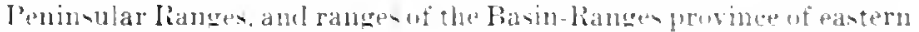
and southeastern California were originally fold-fault mountains, but they were built so lone ago that they have been re-elevated on various oceasions after erosion had greatly molified their initial topouraphy. The Coast Ranges. on the other haml. are fold-fault mountains which have been created during the last half million or million vears.

Evolution of the Sierra Vevalla started perbaps 120 or 130 million years ago. when, in the late part of the Jurassic period, the western half of a great debris-filled trough or geosyncline was erumpled into mountains. The uldest rocks known irm the sierra Nevala belong to the silurian perind and are about 390 million years old; but there is plenty of indirect evidence, though not in the sierra itself, which suggests that the geosynchine existed hon before. The younirest forma. tions involved in the deformation are late but not latest Jurassic, and were lail down in an ocean. Therefore it is quite possible that the first rilges of the ancestral sierra Nevala aplowad as islands projecting above this sea and later were whltel into more continuous land. Compression was intense, so that once-hurizontal layers are now steeply inelined am broken by wreat numbers of faults. Magnifieent sections of the formations showin both sedimentary and roleanic roeks may be seen along High ways 411 and 50 traversing the sierra Sevada, along Iighway at following the cangon of the Feacher River, and along Jighway l20 leading from Jariposa to Yosmite National Park. There are of course grond sertions in many other places, most less accessible.

IIow far the belt of Jurassic leformation extended is not definitely known. Some believe that it included most of California, western Nevala. Oregon. Wanhington, and muh of British Columbia. cren extending into Alaska and Jower california Otliers think that considerably less territory was afiented. Muh of the belt has been very deeply eroked since the deformation. curered by denosits of later age. and bruken to pieces by more molern faulting 
Those who have studied the Sierra Nevarla think that the Jurassie fold-fanlt mountains were not particulaly ligh-perbaps 6,000 or 7,000 feet maximum.

Prior to the building of the Sierra Nevala fold-fault ranges very" different geography existed. West of the present California eoast there was a long land area or sories of land areas known as Caseadia which extended for some distance into the eastern part of what is now the I'acific basin. Intil late in Cenozoic time, Casuadia was the principal erosion area in this part of America, for it stood hirher than most of the land stretching off to the east. This picture strikingly enntrasts with that of the present. for Cascadia no longer exists and the great mountainous belt fron the I'avifir Coast to the liockies has beeome the princtpal center of erosion. Streams flowed down the eastern slope of Caseatia either aeross lowlands whol lay at its base or into shallow oceans whieh spread from time to tinte nver these plains. For a very long period, the low conntry fronting the land now gone was a basin of deposition, thongh at times acoumulation of sedimert was inter. rupted and erosion modelled the deposits which had formed. Also there were important voleanic eveles when immense fuantities of lava were poured out and framents were violently hlasted from roleanoes. Part uf these cruptions occurred beluw sea level and part above. This complex history is reconded in the multitude of rock layers and rock masses found in the mountain ranges of tho state; the time involved extended from before the beginning of the I'aleozoie era to the end of the last puots of cemozoio time, very likely ineluding more than a hillion years.

l'robably a slallow tromoh-like depresion was first formed by de. Jormat ion atomg the matrin of the Cascadian highlant. This depression was enlarged and deepened by the loar of sedinnent aecumulated within it, whing generated stressos in the weak zone helow the crust, (ausing solid outflow of naterial from beneatl the belt of maximun leposition. Eruption of volcanie material nnto the sunface within this belt also aided evolution of the trough. Eventually thomsands of feet of sedimentary and voleanie deposits were formed. The sediments and romains of life buried within them show that most of the deposits were aceunulated under the ocean which in fow places was deeper than 600 feet at any time and over nost of its extent was nuch shallower. From this evidence it is elear that, while the base of the trough sank many thousands of feet (the total thickntss of the deposits is not known but (ertainty exceeds 30,000 fect in many places), the upper surface when below sea level sloped gently from tlle water's edge to very sliallow depths. This was part of the continental shelf, which is the continuation of land under the ocean to where stopes increase and lead to the floor of the deep oeean. When the shelf rose above sea level. it rarely stood more than a few bundred feet high. A sediment-filled trough of huge dinensions evolved in the fashion desioribed abore is called a geosyncline.

Over the continental interior east of the geosyncline deposition of sediment was much lighter and the surface of the rocky shell in consequence was not depressed so far.

As weathered rock was removed from Caseadia, that land was gradually toweren, but fron time to time, deformine forces elevated it, aecelerating the crosive processes and inereasing the ruggedness of its relief. Some sedinent came into the geosveline from other bor. dering lands, but the coarseness and mass of the deposits adjacent to Castadia elearly prove that rexim to lave been the prime source of the debris.

Geological evidenew shows that aecumulation of sediment and vol. canic material in a geosvetine eontinues, though not without inter. ruptions, for tens or even bundreds of millions of years. Fossils present in strata in the Sicrra Nevala and in other California mountains clearly show a span of about half a hillinn years, and there are roeks long antedating these strata containing indireet evidence of life but no actual fossils. Deposition in a geosyche is always voluminous but never contimuons. From time to time the soa bottom is lifted out of the ocean to form low plains which suffer some erusion though they also may receive a vencer of continental seciment or voleanic rocks. Proof of such interrmptions is clearly shown in breaks separating the various formations exposed in the mountains.

Athough deposition in a geosyneline may go on for an immensely. long period, it eventully ends: these troughs are woak belts in the erust because they eontain so much unconsolidated or poorly consolidated debris and consequently they are rather easity deformed. Even. tually the trough yields to the stlesses coustantly at work in the earth and begins to buckle and hreak. In a large section of California this happened more than a hundred million years ago. The roeks were folded intogreat arches called antictines and troughs alled synclines; also they were broken apart by faults of rarious sizes along which minor or major dislocations oteurred. The architecture of the eartl in this region was revolutionized, lor, previous to the deformation, most of the rocks had been nore or less nearly horizontal sheets. The rrowing rideres were upfolds and blocks bounded by faults and between them tay basins or troughs which were downfolds and fault blocks. Such a mountainous complex is called a fold-fault system. Sections which have been re-clevated in recent time are the Klamath Mlountains of northwestern Califormia, the Sierra Nevala, part of the Transverse Ranges east of Los Angeles, the Peninsular Ranges in the southwest eorner of the state, and some of the fault block ranges lying beyond all of these mountains and extending across the Nevada border. 
The deformation of this belt did not procest without interruption, for the re wera times of areater artivity separated by times of relative quiescence fune the less. over a relatively short geological intervala few million !ear-in the later part of the Jurassie period, the bulding of the intial ranges was completed. The height of these mountains is not knum, but it was comsilerably less than that of the highest part of the sierra levala tulay: the principal peaks may have stoud 6.000 to 7.0011 teret abova sea level but probably not mueh more.

During the disturban wes resting in the deformation of a geosindine into nountain. major changes gn within the lieart of the folled belt. Not only are the rocks bent amd broken by the stresses exerted upon them. but those at sone lepth below the surface are metammhosed: that in, they are partially or empletely recrytallized. and new minerals and - iruequres develop. Furthermote much irneous activity in intiated. The ignecus medhnion is extrandinarily compli(eated aml may be contained entirely below the surfare as appears to have been the ane during the deformatinn which produred the Jurassie mountains in cilifornia. There is no fiell evilence of far discovered that surface eruptions touk place luring this time. although there had been many befor the fuhing bewan. As has happened in so many similar settiners, an enormou bedy uf gmotoid rock developed a mile or more helow the surfian. The folded belt undoubtedly was invaded by liquid roek which evolvel at still greater depth, but considerable sections of the granitoit mass appear to have been formes by the remaking of other roms by roleanic wases and solutions into new material which eamot be distinguished from that formed during the erystallization of a molten mass. This proeess of remaking other irneous - ant selimentary rocks into rocks definitely of granitoid character is called granitization.

Igneous action. like deformation. was not continuous but rather oeeurred in a series of waves. for many bodies of granitold ruck have been differentiated in the Sierra Nevada. all apparenty belonging to the same rolcanic eycle. Some bodies transeress others. showing that they are slightly younger. In other words. the total bouly which is called a batholith or deep-seated ioneous intrusion, was formed over a considerable time and consists of many parts, only a few of which have so far been separated.

Granitoid rock like that composing the sierran batholith includes true granite and other rocks closely associated in chemical and mineral eomposition. They have been formed probably at depths of at least a mile below the surface. For this reason the growth of urystal grains has been relatively slow and the roeks are generally medium- to coarsegrainet. They are charaeteristically light colored, gray being the

\footnotetext{
- Ignewus rocks have solldified Irom molten masses sedimentary rucks have been formed chiefly from waste products of other rocks or from organic debris. or by
} $2-60455$ dominant shade. The rocks are male to a very large extent of two light-eolored minerals, one called quartz ani the otber feldspar. Quartz is a mineral of simple composition. always being composed of one part of silieon and two parts of oxyen; feldspar, on the other band, is represented by several varieties, each much more complex in composition than quartz. In most "ranitoid rock. there is a distinetly minor quantity of the dark-eolored mineral grains that give the roek its pepper-and-salt appearance. These dark-eolored minerals eontain various proportions of iron and magnesium while the light-colored varieties do not.

The voleanie eycle apparently started during the deformation in the late Jurassic and eontinued after it. possibly into the earlier part of the Cretaceous period When finished, a gigantic rock complex was evolved entirely under the surface. It probably extends throughout the folded belt and, in the Sierra Yevada at least. evidence derived from study of earthquake waves indicates that it is 10 to 12 miles thiek. Round about the margins of this great mass, the covering rocks were intensely metamorphosed into new types, the metamorphic effeets decreasing with distance from the batholith. The granitoid roek is very resistant as are most of the metamorphie rocks. Closer to the surface where the metamorphism did not reaeh and where the roeks of the geosyneline were less thoroughly eonsoli. dated, the materials were meaker and more easily weathered and eroded. The development of the granitoid core and its assoeiated zone or aureole of metamorphic roeks thus increased the strength of the heart of the deformed belt.

The Sierra Nevada of today is very different and mueb more majestic than the aneestral ranges of Jurassic time. Instead of being a series of elevated ridges separated by troughs and basins, it is now a grigantic tilted fanlt block so huge that within it are a number of minor ranges. each of considerable magnitude. The eastern face of this inmense block is a searp developed along a multitude of fractures called faults. A fault is a break in the outer earth along which the adjacent bloeks slip past eath wher. The mestern sile of the Sierra Nevada is a complex of landseapes evolved during the long interval since the birth of the original fold-fault system.

Inderstanding of the many changes which have oceurrel in sierran lambseape requises a brief analysis of what has transpired since the mountains first appeared. Because the size of the rang" is so great and its seology so complex. at present it is possible only to outline the primeipal steps in the story.

Between the end of the first rise of the srstem and the close of Cretaceous time. nearly 60 million years elapsed. but of this interval there is only the seantiest record. By the beginning of the last or Cenozoie era, another 60 million years atro. the ranues hat been so eroded that they were quite inconspicuous, and in places the ocean 
spread to their western base. The hand was so low that wind sweeping

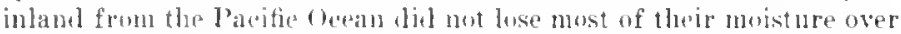
Sierran slojes as they do toma. lustan they provided enowh rain for loundreds of miles inland to permit the growth of a luxuriant vegetation which could not possibly axist over most of the region muler the arid anditions that now provail. This is proved by the eharaeter of fossil plants found in doposits belonging to that time.

During the Eocene, first "poch of the Cenozole Tertiary period, the region was bowed upward along an axis approximately thit of the present sierra-('ascade system. A low mountain barrier was created and fairly deep gorges were ent into the rising hills. The shore line still remained close to the present westem base of the Sirrra Nevada.

During Miscene time. lowerer, the mountains had been elevated suffieientig to ent off most of the moistures and thes remion to the east became arid.

Huch mope rigorous disturbances marked the end of the Hiocene and the begiming of the Pliocent epochs, for the Sierrat Nevada was elevated eonsiderably and became stronely unstmmetrical in form with a broad western and short eastern slope. There was much faulting and associated voleanic actirity. Faulting conspicuonsly inereased the boldness of the eastern slope, especially north of Mono Iake where several long range spurs were devoloped. Between one of thesp spurs, the Carson Range, and the main Sierra Nevada, a section sank, evolving the basin now partly oecupied by Lake Tahoe. Faults also broke the western fonthills, so that the long slope in places descends in a series of abrupt steps.

Then fullowed a period of relative ealm huring most of Plioeene time and erosion dominated over elevation by deformation. Considerable changes in the landscape of the range resulted. But the quieseence was not enduring, for at the end of the Plincente and continuing into the earlier part of lecistoeene, the deformation was vigor. ously renewe. These movements lifted the Sierra Nevada approximately to its present height and the country to the east also was elevated so that Owens Valley stond about 9,000 feet above sea level, considerably above its present maximum height. Nost of the alevation took place betore the beginning of the l'leistocene or Glacial epoch so that the snow and ice whinh remained year after year was bulky enongh to generate the slowly moving ice masses called glaciers. Reeords of profound glaciation reconized as belonging to the earliest part of lefistonm time have been found, hence the recoion must have been nearly as high as now for, even during the climaxes of the graciations. the snow line in the Sierra Newala apparently did not lie mueh below 11,000 feet

Most convineing evidenee left by an early glacier is provided by the debris deposited on the mountains west of Meree Canyon. The primipal gliciers on the east sidu of the Sipra Nevida, because of tho steepness of its slope, were ralley glaciors, that is they formed in valleys or canyons which alrudy lad been eroled by rivers. Moraines are erreat heaps of unassorted rock framments, some of which are very large. Valley glaciers leave two mincipal types, the more common sile moraines formed from debris frozen in the silles of the ice and "arried on its top, and trminal morains, composed of rocks and fine sediment pustsed in front of the ice and melted from its end.

The McGee moraine, which has been identified as belonging to the first of the four whacial stages, ends abruptly at the great eastern scarp. and stands about 3,000 feet above longr Valley at the base of the scarp. Stuly of the moraine shows that it shlacier followed a rather flat, shal. low valley ligh in the Sierra Nevala, proving that MeGee Canton and the searp intu which it has been "ut did not exist. Horeover the McGee moraine, in spite of some later damage, obvionsly was about as large as the moraines of the later glaciers. This, together with mueh other evidence, indicates that the Sirra Nevada had about as large an ice mantle during the early Pleistocene as it did later in the epoch.

Abundant evidence indicates that the eastern scarp does not owe its height to elevation along fanlts at the base of the range. Rather, long, narrow bloeks sank, developing Owens, Carson, and other valleys immediately east of the range. These depressed masses were broken into great numbers of fragnents by lesser faults and along them there has been much voleanic eruption. On the other hand there is not much evidence of shattering within the main mass of the Sierra Nevada at the time of the last disturbance.

Other proof that the depressed blocks have sunk is afforded by the slant of the lowlands toward relatively fresh fault scarps, it the base of the range and against these searps is either wet, swampy land or lakes, such as Owens Lake, which is deepest near its western shore against the highest section of the Sierran scarp; the wet neadows sloping to the range base near Bigpine; Mono lake, lying next to a stepe searp and deepent on its western sicle; the marshes in Carson Valley which lie direetly beneatl fresil fanlt elifis at the base of the Carson Range; and Jloney Jake at the far northern end of the searp.

The griant surp, without doubt the most magnificent example in Ameriea, thus is not mueh over 800,000 years ohd and has been increasing in majesty as the bordering, eastern blocks hav'te continned to sink. It has been considerably battered, for a multitude of deep gorges have been cut into it and the upper parts or even the entire length of many of these grorges have been glaeiated.

Faulting at the base of the range has oceurred internittently, some of it being very reent. Very probably there have been differential movements along the faults so that the Sierra Nevala has risen some. 
what but its height has not be'n greatly increased over that eleveloped

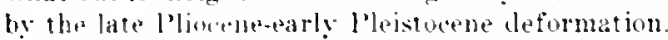

Farther east in the Basin-hanges provindes, similar faultine separated formerly continuous struthes of landseape. raising some to form ridges and ranges. and depresing others to form trourls and basins. Some of this fitulting to the east started as early as Hineene time, some is of much later. and some in gume on actively tolay of the blocks which were isolated by fanleinet the sinrra Nerala is by far the largest It must not be onglesed that the ereat fracture systems bounding the blucks were dovelnged quinkly or that the immense dis-

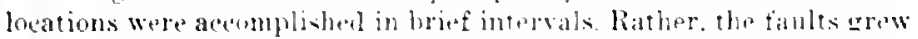
in length and complexity and the indivinul moxmonts along them were relatively small. a few feet to a finw seore of feet. Furthermure.

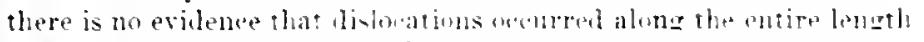
of a fault wstem at the ande tine.

There is much adthtimal information about the erwwet of the Sierra Nevala eontained in F. E. Math hes entertaining bunk. The Incomparable ralle!. ampiled after his death he Fritinf Fryxell. Wueh of the furecroing stury of the later history of the range is summarized from this rolume

As the up-arching of the siorran renion went on. the maximum elevation was attained in th. nurthern half of the sulthern sortion

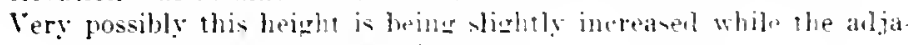
cent valley blocks are utill sinking.

\section{Eastern Fault Scarp}

In places, as along mont of the westem sile of Owens Valley, the prineipal fault bounding the eavern bave of the Sierra Nevala appears to be relatively simple anl most of the morement wis concentrated along it. Alone most wi the range. however. intersewting fraetures are indieated by salients and resentrante like these weyt ef Bishop near the head of owens Valley. Also. the are many faults parallot to the main system along whilh blucks have sunk loss than the valley blocks. promlucing a terraced frout. Siuth uf Mount Whituey. there seems to be no artual eridene of fanting along the base of the range. but its form definitely sugess that this pottinn as well is a tilted fault bloek. The fracture zone appear to have been completely buriel by great mases of sediment ramienl from eanyous worn into the fault searp. The faulting in this southern section appears simple for there is litile evinlene of the step-blocks that product a terraced fromt.

The freat warp is highent aml mont rearly defined from olancla

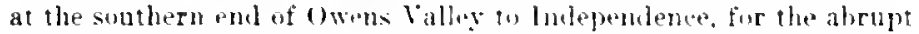
descent from the erest of the range in mut brokin by any finthills striking faceted spers. the trmucated whls of ridges broken by the

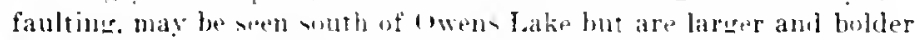
suthwent of Imlependence. The east slope of Monut Williamson. dominating peak of the sierra Sevala vioible from this part of Uwens
Valler, is a huge triangular facet into which have been ent three lesser facets. Each of the three rises to a height of 10,000 feet, below which the range slope shows the marked orer-steepening charaeteristie of recently develoned fault s'arps.

West of Indepentenee, the Sierrin scarp thanges in eontour. The hase exhibits salients and reentrants formed by uranite foothills protruling through the deposits at the base of the range and apparently lying axainst its main mass along the principal fault system. These foothills loubtless are step fault blocks which either have not sunk as far as the owens lalley graben or have not bitan el+vated as far as the main block.

Farther nurtl toward Bishop, fine triangular falots again appear indieating that the bimnlary fracture is a simple one. As far north as Hirch Hountain. the eastern side of the Sierra Cevada presents unmistakable proof that it has been developed by profound dislocation alone the faule srstem. but from there nurthwarl to Bishop Creek. the evilence is less convincing. Long, straggling fouthills projeet into Owens Valley and merge with the main momtain mass. In this section. there probably are a number of parallel faults, with the dislocation distributed more or less edually along them throuwh quite a wide zone. There has been sufficient erosion tu wheure most evidence of faulting. a common oceurence where this step structure is present.

In the ricinity of Bishop Creek, the fault srstem is offset to the west about s miles in a manner characteristic of the area farther north. The searp here shows the same abruptness and simplicity as near Owens Lake; the best development is the extraordinarily steep slope faeing Round Valley. The fanlt indicated by this dexlivity. if prolonged sonthward, would coineide with the canyon of the South Fork of Bishop Creek, which is conspicuous amone the canyons on the east sille of the sierra Nevala in having an approximately northward trend. There is good evidence that this canyon has been developed by faulting. The fact that an alraned erosion surface stamling 2.500 feet almos the river in the button of the canyon is at essentially the same "aleration on both siles of the eanyon indieates that this gorge. if evalreel by faulding. is a rift ralle!l: that is, its thoor is a block which han sunk berwent two fants. In ciled road leads up this valley from Bishop to the beantiful glatial lake country on the east side of the hiqh sijerra.

Multiple displarements alung beth sides of Truckee Healows have furmeal this amb n." which hav hill areas projecting above its surtace.

North of the Truckee liver. the faulting and therefore the Sitran front change notably. Misplatement alone the boumlary fault diminishes, the faulting apparenty is multiple in many places. and nurthwarel-trending rideses project from the main mas of the range

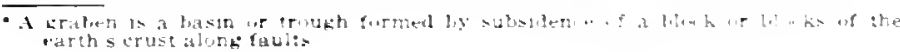




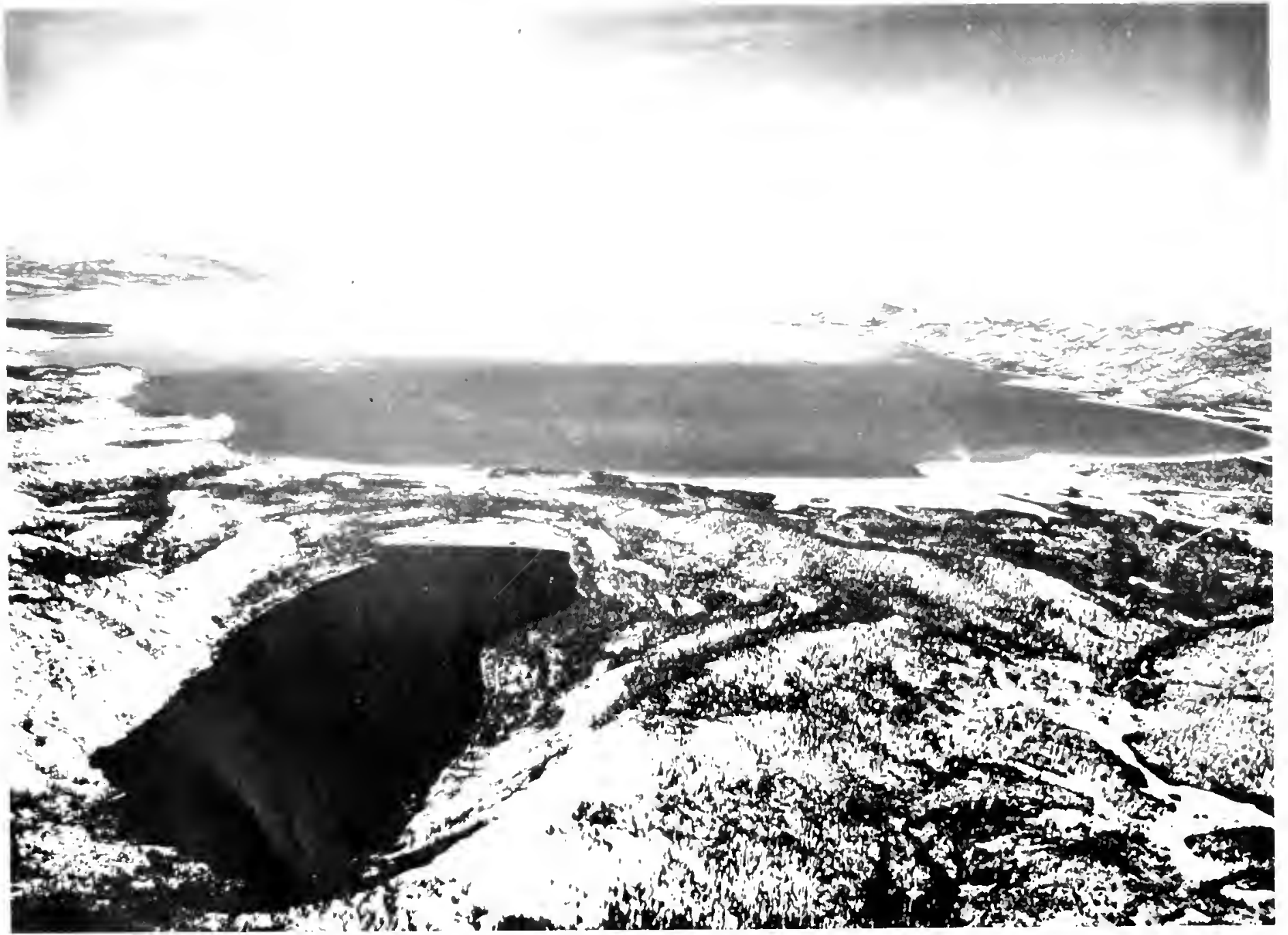

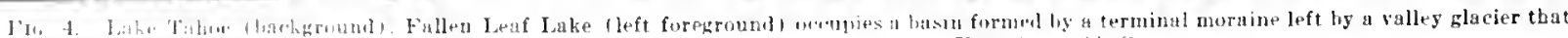

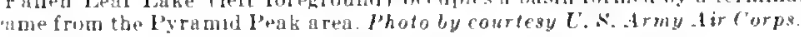




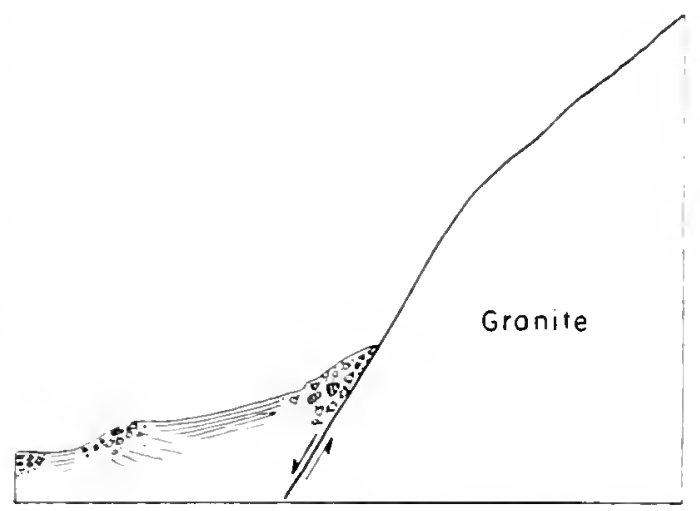

FIG. i. Section showing fault scarp north of Kern River.

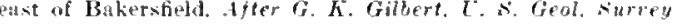
Prof. Paper 133, p. Ss.

\section{Tahoe Basin}

The outstanding example of the effect of faulting within the sierra Nevada is the Tahoe basin, which lies near the crest in the central part of the range and is partly oecupied by Lake Tahoe. This lake, by far the largest in the Sierra Sevada and the major borly of water in the state, is nearly 20 miles long. 12 miles acruss at its witest place, and has a depth of more than 1.600 feet. Its surface stamls a little over 6,200 feet above sea level. On the eastern and western sides of the basin are rugged mountains whose summits are from $8,0(10$ to 10,000 feet high; Rubicon Peak $(9.193 \mathrm{feet})$ and Iomt Tallac $(9,785$ feet) are the principal eminences on the western rim. In the ('alson Range on the east side. Mount Rose rises 10.800 feet and Genoa Peak 9,173 feet. This eastern range slopes less abruptly towarl the basin than does its western counterpart and therefore looks lower. lut it is not. The two ranges completely enclose the low reyion betwen.

It is the common belief of people living or visiting at Iake Tahoe that it is of voleanic origin, but such is not the ase. The general features of its evolution are well known. though many details remain to be supplied. The basin has been formed by disloutions oncurring at the time of the vimorous Miveene-l'liocene deformation. Two principral faults, one on the tast and one on the west side of the basin and both roughly parallel to the preat bonndary fault system at the eastern base of the range, evolved as the fijerran region bryau its upward movement. The Carson lange, forming the eastern rim of Tahoe basin. rose along the boundary lault while the mountains on the west were elevated along the fault on that sile. The intervening area slowly and unevenly settled evolving the Tahoe basin and sierra Valley farther north.
Because of the heary snows and rains in the romon, a lake puivily formed near the suuthern eml. or lowest part of the graben wince the passes through the borderine ramess stand at eonsilerable elevations above the basin floor. the lake grew to mucll greater size and lepth than it now is. Finally its water foumet an exit through a low spot in the Carson Ranere not far wast of the present ite of Truchee and the Truekee River was born. pouring down the wastern slope of the Sierra Nevada. This strum beran to excavate a gorere mustly in unconsolidated voleanie debris. Ilighwa 40 follows the course of the Truckee River in going fown the eastern side of the sierra levada.

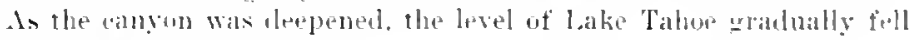
and its area diminished.

Somewhat later basalt flows wert erupted. flowing into Truchee Canyon and forming a dam extending to the prenent northern end of the lake whieh for a time broke the Truekee River. Finally the lake overflowed this barrier, eut a gurge through it, and the river was re-established; the Hows of lava wan be clearly seen in the walls of the gorge along the highway leading to Iake Taloe from the north.

The Truckee River Hows from its eanyon at the eastern base of the Sierra Nevada across desert tault basins until it empties into I'yramid Lake whicb oecupies one of these basins some 30 miles nurtleast of Reno, Nevada.

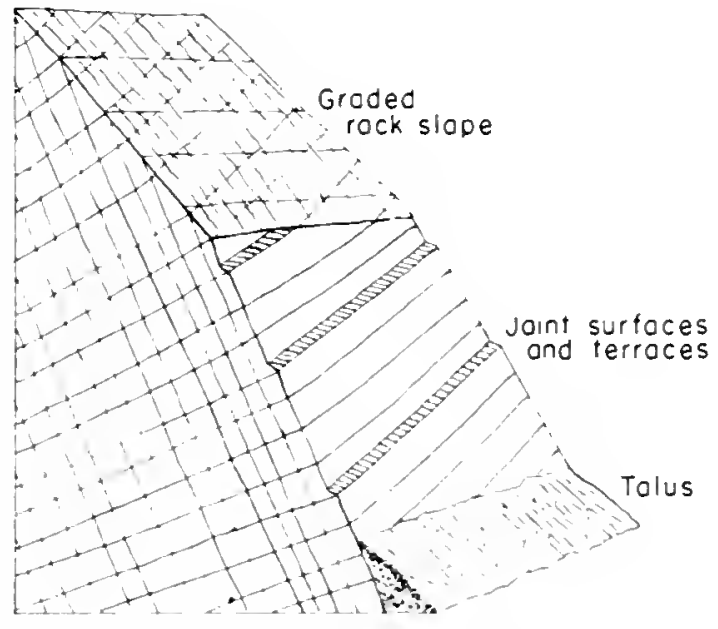

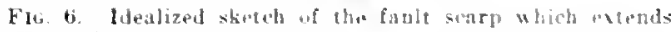
for about five miles nurth and wath of the Korn lower camsun

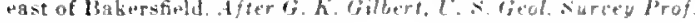
Paper 15, p. sit. 
The southwestern side of the Sierra Nivada is sharply contrasted in dimensions, slope and topougraply with the great scatrif fronting in the opposite direction. Only in one place for a llistance of alout 5 miles north ank south of the linn River canyon east of Bakersfield in the San Joayuin Valley is the western base defined by a fault. Elsewhere, exeept for minor effects produced by faulting, tlet southwestern side slopes araclually to its base where it passes under sedimentary deposits which in places in the Great Valley" to the west are very thick.

At the mouth of the Kern River eanyon, the base of the Sierra Nevada is a nearly straight fare of granitoid rock broken into triangular facets by young gorges which cut it. The scarp is about 400 feet high and 5 miles long. Actually it is not a single surface, but is male up of several steep declivities separated by narrow inelined terraces that evidently are controlled ly jointing which is prominent in the bedrock. The steep sections of the scarp exhibit little evidence of faulting for they have been too much weatlered. There does, however, appear to be a vertical grooving best seen at a little distance and many patches of small quartz veins are vertically fluted in harmony with the larger grooving. Probably the various elements composing the main searp were originally a single fracture surface, and have since been separated by slippage along the joints, developing a minor type of step faulting. In the north side of the Kern River eanyon. the lower part of the scarp is much steeper and smoother than the upper, indicating close approach to the slope of the actual fracture surface, the upper part having been more croded.

The narrow terraces which break the continuity of the scarp are roughly parallel and rise from north to south across it. They are covered to some extent by soil and waste which has fallen from above. At the base of the searp are considerable deposits from the face and brought out from the canyon of the Kern River. The fault evidently is recent but no movement is known to have oceurred along it in historic time.

This rift certainly does not mark the western bounlary of the Sierrat block, rather it is a local feature. Location of the western boundary is not known but possibly it may be against the Coast Ranges on the western side of the Great Valley. It has been proved that Sierran bedrock extends under deposits in the Great Valley which in places are very thick, but the bedrock has only been met where the overlay of sediment is much thinner. As more deep oil wells are trilled and particularly as more geophysical prospecting is done in the Great Valley, knowlectge of the extent of the Sierran block below the valley will be extended.

The foothills of the Sierra Nevada rise from the borter of the Great Valley as a series of low hills and ridges inereasing in altitule and elevation above their surroundings as the main range becomes higher.
The higher rjelges in the loothill belt are formed by the more resistant members of the Sierran bedrock complex while the weaker nembers form low hills having rather gentle contours. Between these eminences are narrow ridges and winding valleys. East of the foothill belt, the ridges and hills are more prominent and the canyons are deep and narrow.

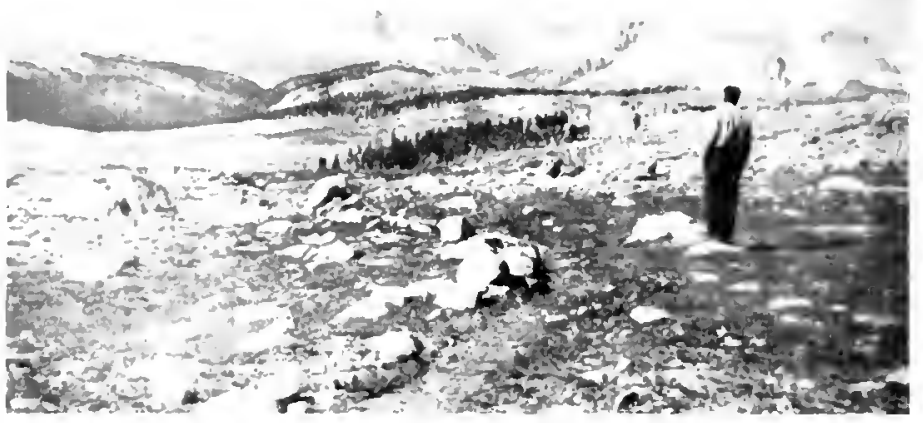

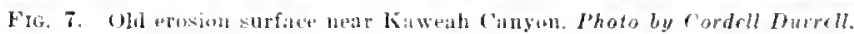

Between the great canyons which are such prominent features of the western side of the Sierra Nevada are extensive stretehes of rolling upland that become increasingly rugged in the higher parts of the range. In these uplancls remnants of two prineipal landscapes so far have been recognized.

To understand the development of this aneient relief, it is necessary to trace changes which have ocenrred since the Jurassic fold-faulting. When the Sierra Nevala was first built, it consisted of a series of ronghly parallel ridges separated by troughs or basins, all outlined by the deformation. The principa! rivers flowed through these troughs, here ant there breakin across or flowing around the riclges and cventually passing beyond the mountain belt. Minor streams descended the ridge slopes, either joining the trunk rivers within the range or flowing beyond the mountains to add themselves to other drainage. Such a stream pattern is founcl today in the Coast Ranges, which were formed by fold-faulting in mildle Pleistocene time.

By the end of the Cretaceous period, the Sierra Nevada had been worn down to relatively losw elevations so that its highest points were not much more than 2,000 or 2,500 feet above sea level. Early in the Eocene epoch, the range seems to have been gently upwarped along 
an axis roughly coineiding with its present crest; whether a corresponding slope inerease took place on the eastern side we do not know, for later events have obseured too much of the record. As a result. there was considerable rearrantement of drainage, for southwestwarlflowing streams grew at the expense of streams oriented in other directions, beeoming trunk lines which divided among themselves many rivulets that had been flowing parallel to the trend of the range. In the latest part of the Eocene and part of the following Oligocene epoebs. there was an alteration of erosion. deposition. and voleanic eruption which altered the landseape, but subsequent modifications have wiped out most of this reeord.

The Oligoeene activity was followed by a long interval of virtually uninterrupted erosion which developed toward the end of Miocene time the older of the two landscapes found in the rolling country between the great canyons of the western slope. The highest peaks had been reduced to elevations of little more than 6.000 feet above sea level and were loeated prineipally where the crests of the Sierra Nevada are today; most of the peaks were aligned in ronghly parallel rows as we now see them and these rows probably represented the greatly modifed riclges formed during the Jurassie fold-faulting. In the northern part of the Sierra Nevada there are enough remnants of the deformed bedroek in many places to indieate this elearly". In the southern two-thirds of the range. lowever, erosion had removed the bedrock and was working in the great granitoid batholith below; nevertheless, the rows of peaks clearly show that their position is controlled by structural ridges which unce lay above the batholithic mass.

The peaks of Miocene time were far from startling, rising only 1.500 to not nuch more than 2,000 feet above rather broadly flaring eanyons that separated them. Their tops were mostly Hattish or roumled and their slopes were only molerately steep. Farther down the westem slope of the Sierra Kevala the landscape was still more subdued. Ridges from 500 to a little more than 1.000 feet separated that valleys which increased in wilth toward the lower part of the range. The streams flowing in these valless bad reached maturity and had eroled terraces into the bedrock. Simme of the ringes rove quite abruptly from the outer margins of the terraces while those in less resistant rock ascemled with gentler slopes. Must of the streams flowed southwestward as they do tolay, but soms followed depressions hetween the rows of preats as they had done in the early stages of the devolopment of the range. An exanple is the upper part of the hern River which parallels the trend "f the ranet between the eastern and western crests before it fually breaks aeross the latter to descend the western slope.

This stage in the evolution in Sierran landstape has been called the broad valley stage; remnants are recognizable in many places, par-

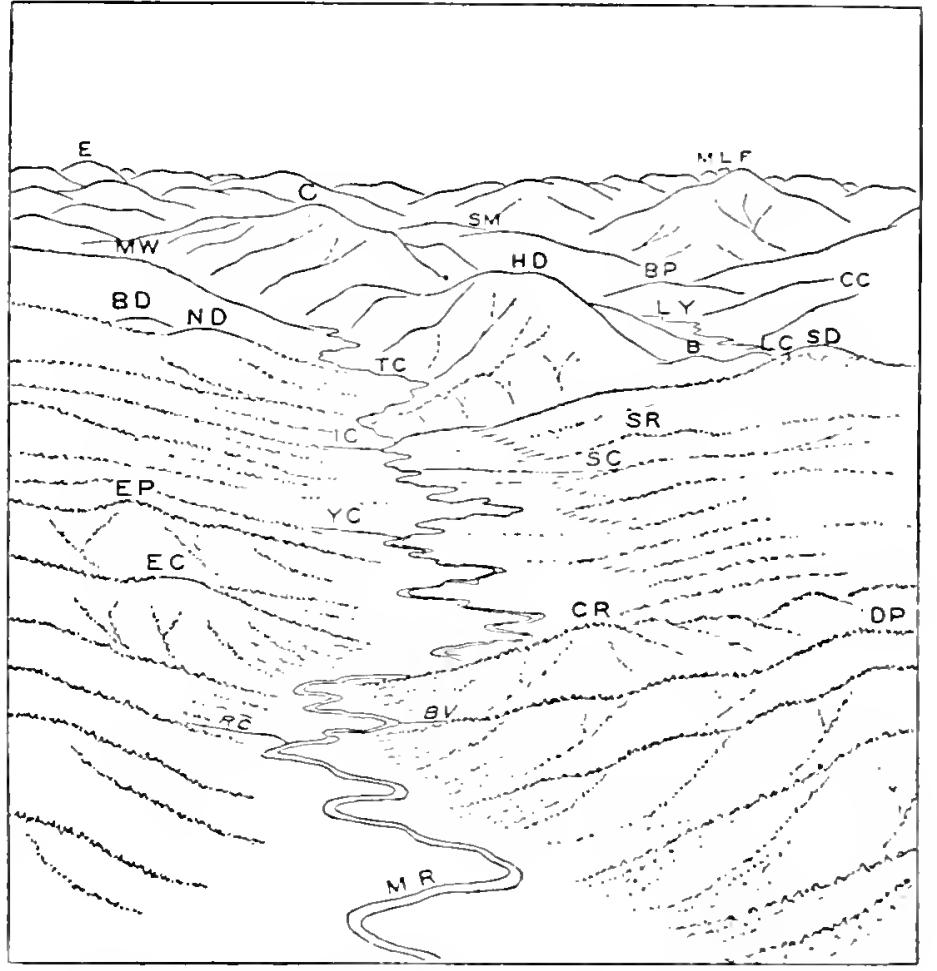

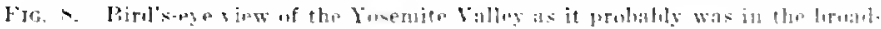

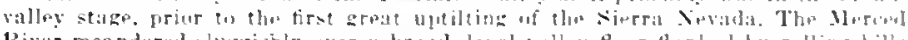

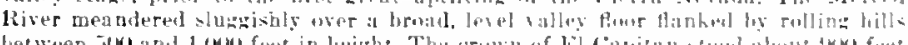

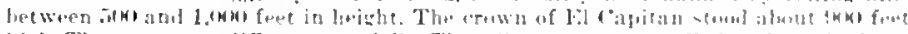

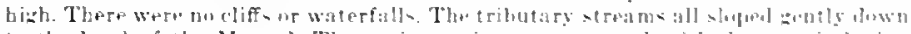

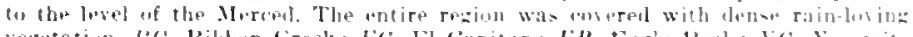

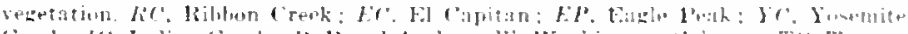

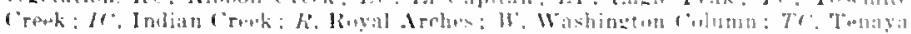

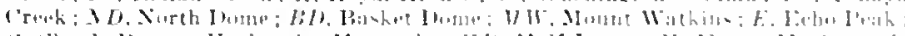

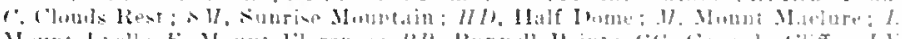

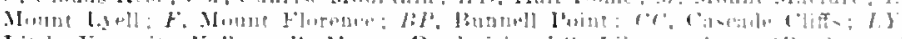

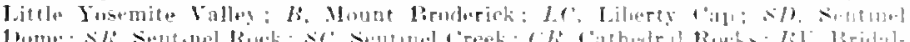

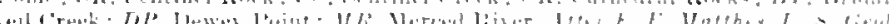
surley trof. Piner litio p. Bi. 


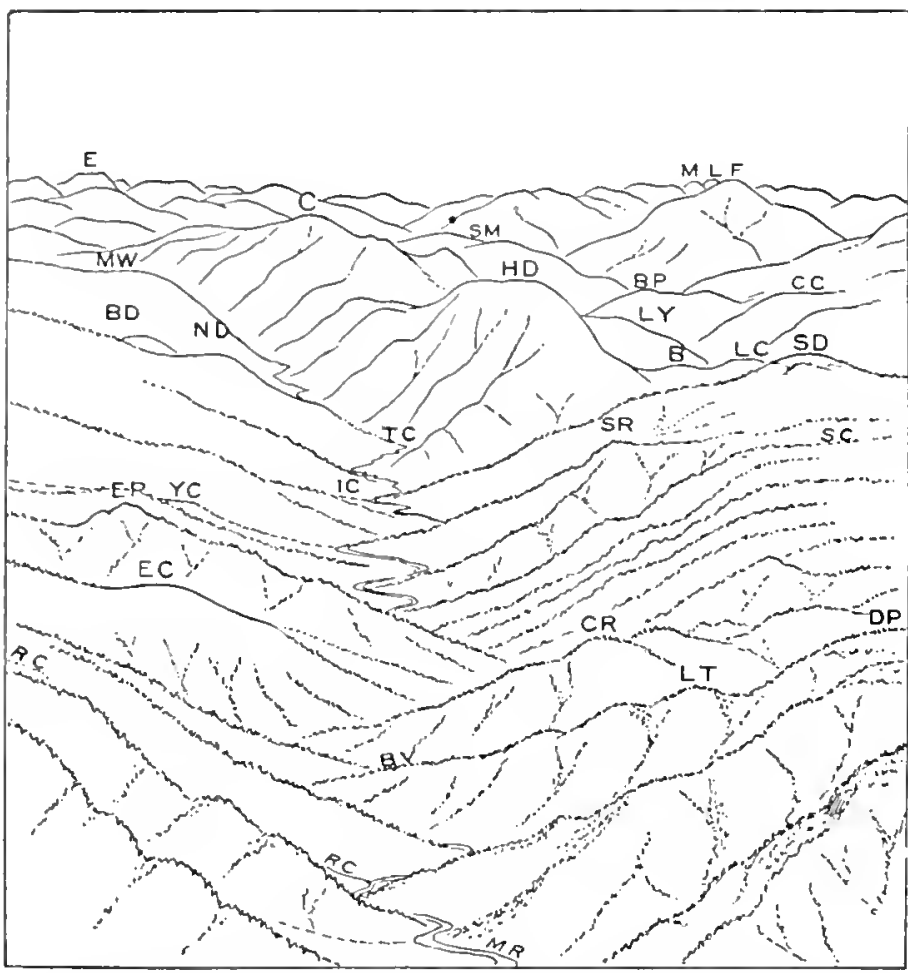

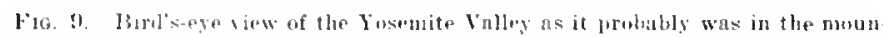

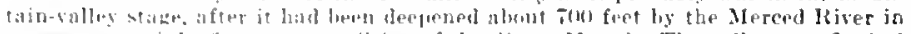

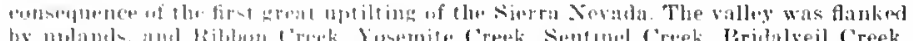

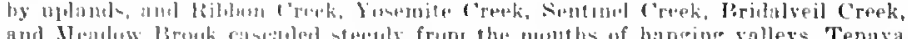

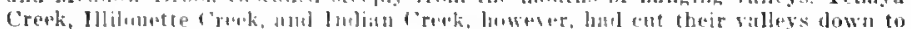

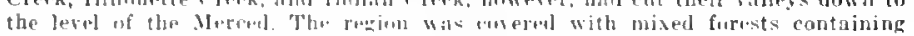

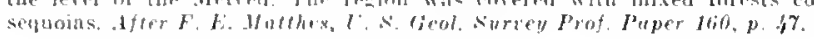

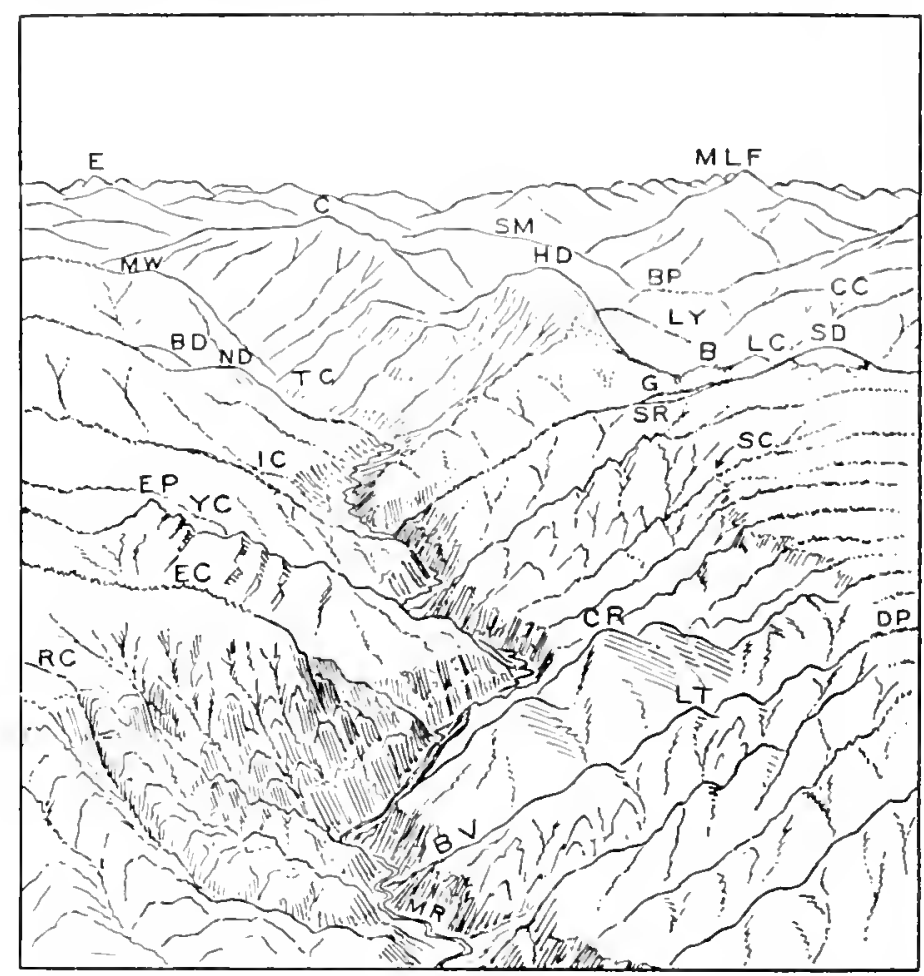

FIG. 10. 1sird'seye view of the Yospmite Valley as it probahly was in the canyon stige, junt by-fore it wns invaded by the glaciers of the ice age. The valley had been rut 1,314) fwet deejer by the Merced lRiver, in consequence of the second great uptilting of the Sierra Spvala, and had a Y-shaped inger gorge and two sets of hanging silfe-valleys. Illibunte ('reek and latian ('reek now also nale cascades, bat Tenaga

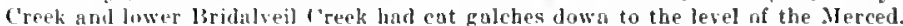
Thu regim was covered with coniferous forests a dapted to a temperate climate with

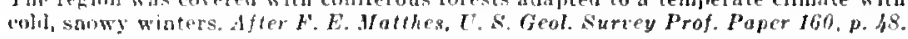


tieularly in the southern part of the range. Naturally they have sufferel much damage hy later erosion and in parts of the Siersa Nevada have not been deteeted. though more thorough study may reveal them.

In late Mioceue aud early Pliocene time, the northern third of the Sierra lievada at least became a great rolcanie field. Frequent explosions erupted great quantities of coarse and fine debris of andesitie lava and a cousiderable number of llows also were poured out. Most of the centers of this autivity lay east of the present Sierran crest but some have been recognized in the erest region. The fragmental deposits for reasons that we do not know became waterlogged and moved as great avalanehes down the valley's piling one upon another as the vol. canie eyele continued. Even after mueh erosion in the erest region there are sections of these voleanie mud flows 1,500 to 2.000 feet thick. In spite of the relatively low slope of the valleys. the mudtlows were liquid enough to move through them and in some eases passed the base of the Sierra, spreading onto the eastern side of the Great Valley. The valleys in the range were well filled and some of the lower ridges were over. whelmed but the higher eminenees projected above the volcanic surface. Apparently the mudflows formed a flat area with masses of bedroek protruding through it. Certainly th is landscape covered much of the northern third of the Sierra Sevada but how far south it extended cannot be determined as the amount of erosion which has sinee oceurred is difficult to estimate. The suggestion is strong. however, that most of the southern section of the range lay berond the limits of the voleanie aetivity.

After the elose of the rolcanie episode in the earlier part of Pliocene time, the Sierra Nevada which then probably was mueh broader than today was elevated about 3.000 feet. The deformation doubtless was not continuous, but was concentrated in eertain intervals with others of relative quiescence betreen. The elevation of course inereased the slopes of the range and the streams were correspondingly invigorated. Where they had started to flow on the roleanic surface, they eut through it into the bedroek, while others in the broad valleys eut soung gorges below the surfaces of the terraces which they had eroded prior to the elevation. These new eanyons were 1,200 to 1,500 feet deep by late Pliocene time. The upper part of the Kern River, flowing parallel to the erests of peaks, reached maturity while the streams descending the steeper western slope were still young. at least throughout most of their length. The Kern therefore began to widen its ralley, destroying much of the terrace which had been eut before the early Pliocene elevation. Remnants of the broad Miocene valley are preserved along the sides of the peaks of both eastern and western crests but are not partieularly conspicuous; none the less it is possible to reconstruet the valley approximately. Remunts of the Pliocene mature valley are finely preserved as flat areas in the Jount Whitney region. Thus there is striking eontrast between this longitulinal mature valley and the dominant!y young canyons of the same cyole on the restern slope.

The Plineene landsedpe, which is a much more vigorus one than the Mioeene, has been termed the mountain lalley landscapr. The highest peaks of the Sierra Nevada at this time spen to have stuon about 6.000 to 8.000 feet above sea level, but most of them had been evolved during the still earlier erosion eyele.

The late Pliocene and early Pleistocene elovation of the Sierra Nevada and the region to the east caused a sharp increase in the gradient of the streams and therefore in their downcutting power. They began the incision of the great canyons like the Iuba. the Ameriean, the King, and the Kern. Since the range probably is still rising to some extent, the cantons are still being deepened: they are narrow. V-shaped gorges with bold, ragged slopes rising abruntly from the sides of the streams. except where the canyon form has been modified by glaciation, as in Yosemite Valley. Although these great gashes have been speedily eroded because of the eonsiderable increase in slope of the restern Sierra Nevada and the abundance of water available, the elevation has been recent enough so that hroal stretches of the older landseape remain between them, making it posible to read at least part of the ehapters of later Sierran history. The eanyons naturally are deepest in the central. highest part of the range: to the north and the south they are less eonspicuous. but are nevertheless deep gorges.

This stage of landseape development, which starled on the western side of the range in late Plineene time is called the canyon stagc. Inlike the others. it is also represented on the eastern side, but there the gorges have been slashed into the great fault scarp. most of which was formed after the first glacial stage of the Pleistocene epoch. Remnants of the older landscapes are not present on the eastern sile of the Sierra Nevada except in a few places where they have been preserved on step-fault blocks. On the eastern sile the landscape is mostly a suceession of deep gorges separated by narrow crested ridces.

\section{GLACIATION}

Except for the great fault searp on the east side of the Sierra Nevada and Tahoe basin with its beautiful lake. the most starting features of the range are those which have been moteled in part at least by glaeial ice. snow avalanches, and frost wed crints with associated fall of blocks of rock.

To understand the extraordinary work of ice in seulpturing the high Sierra Nevada requires a brief discussion of the last chaneer of earth history, the Pleistocene epoch of Tertiary time or, as it is eom. monly ealled. the Glacial enoch.

During the last great marine periml of earth history, the Cretaceous. extensive seas prevailed, and the climate over nost parts of the earth 
was much more equable than today-a characteristic of the important marine intervals. Such elimate continued over sonewhat reduced areas and with some modifications for the next 15 or 20 million years; but, as the continents gradually enlarged, far-reaching elimatie ehanges set in. Climatic zones were more sharply defined and there was an inereasing differentiation of elimatie types. While intermediate latitudes were becoming cooler and drier, tropieal and subtropical regions which earlier had been so widespread were becoming confined to a relatively narrow belt north and south of the equator. In the extreme north and south and at high altitudes, cold blanketed larger and larger areas. In this progressive climatie change the rise of the continents to abnormal heights above sea level and the extensive building of mountains which hal charaeterized late geologieal time played an important role. (1) ther factors, not yet determined, were also undoubtedly involved.

When the Glacial epoch started a million or two years ago, the area over which polar climates prevailed rapidly expanded in high and moderately bigh latitudes both north and south of the equator and at higl altitudes. Where the climate was glacial, the cold was so intense that a lasting cover of snow and iee began to grow, since all of the sthe ancomulated luriner the colder months conld not be dissipated during the slightly warmer days and weeks. This blanket gradually inereased in thiekness, and from the margins of the larger masses, moving fronts or tongues of iee ealled glacicrs tere projected. Beyond the glacial areas and regions were stretches of the slightly less hostile tundra climate where snow and ice melted during a few warmer weeks of the year, and frozen ground was thawed to depths of a very few feet. Below this shallow melt-zone, ice extended for scores or even lundreds of feet, particularly in the higher latitudes of the northern hemisphere and there even today tundra regions are very extensive. Under the permanent ice, water also was frozen in the rocks and remained so throughout the year.

During the Glacial epoch, the elimate fluctuated notably over much of the world. Four times the glacial areas expanded, increasing the extent of the lasting mantle of snow and iee until the maximum coverage amounted to about 32 percent of the land above sea level. These four episodes are the glacial stages, in the last one of whieh we live. Then, for reasons as little known as are the causes of their expansion, the areas dominated by polar climate shrank, glaviers and other masses of ice receded or disappeared, and warmer cond itions developed over most of the land previously held in the grip of the ice. The magnitnle of ice recession during these interglacial stages is not known, but doubtless it was different in each as also was the magni. tude of advanee during the four glacial stages. It is quite probable that, at least during the longest (the second) of the interglacial stages, practically all of the ice disappeared from the earth. Areas outside of the polar regions were strikingly changed elimatically during both glacial and interglacial times.

The length of the Glaeial epoch has been extensively debated by many authorities, but evidence so far aceumulated does not permit an aceurate estimate, the range of opinion being from 1 to 5 million years. Probably the beginning of the epoch was not more than 2 million years back. The lengths of the glaeial and interglacial stages also are uncertain. Assuming that the epoeh started about 1 million years ago, the following ehronology has been suggested:
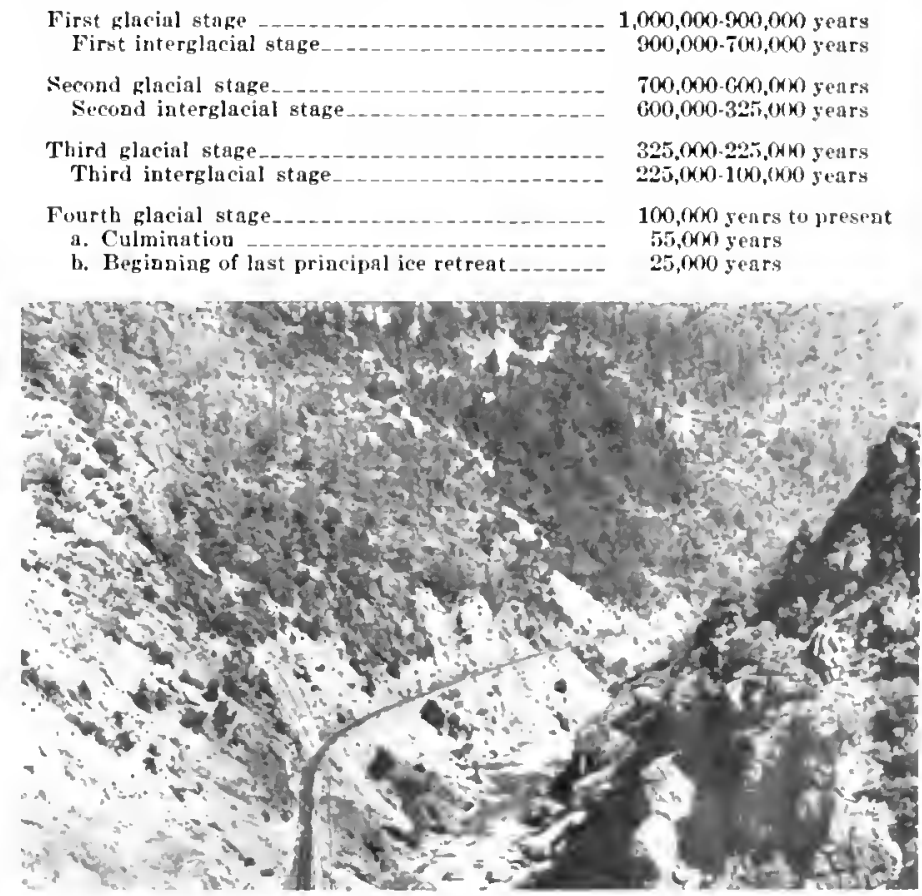

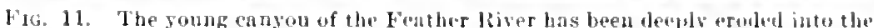
Sierran buldock as the result of invigoration of streams caused by the late loliocene

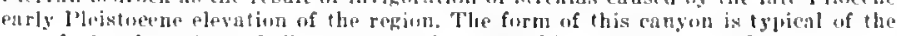
mon-gheratel portions of all eauyons iu the range. I"hoto courtesy of Western Pacific kioilroad.

If the Glaeial epoch includes more than 1 million vears, the figures given above must be proportionately increased; further studies also may revise the proportions between glacial and interglacial stages. 
Two facts, howerer, aro well establislond. The erlacial states are the outsanding features of the "pouth, but the intorglacial stages were of considerably srater length.

Considering the small amome of iep on the earth in protilavial and interplacial time, the "roation of the ralabers and other ire masses was rapid and on an enormous seals. As previously noted. the maxi-

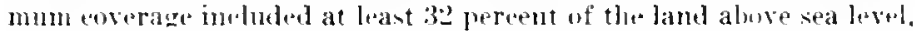
and in addition vast areas of the ocean were prozen to depthe of a fow fret or. in somle plates. as mueh as a fow humdred feet. The hast glacial stage, the one in which we live. witnessed the overwhelming of ahout 27 percent of the land, and ol this area nore than at thirt still lies beneath the snow-ice blanket. It is elear therefore that the present is a brief interval in the waning of a glacial state, a falet not only evidenced by the extent and rolume of snow and ice but also be the great areas over which climates still prevail which are not rey far

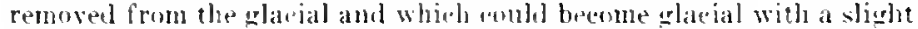
decrease in averate temperatura.

The formation of smow and ine fields which last for lonat perionds represents sturage on the earth of water evaporated into the atmosphere and later previpitated as smow. The prineipal evapratind basin is the oeean. thouml of eourse a dertain amount fores from the waters of the lands. As the ion mases arew during the glacial stants, the wolurue of the cuan arathally shrank. Sea leved was slowly lowered and the land wovered by shallow depths of ocean water anered. It is believed that the maximm fall of the oceans when the jee reached its greatest extent and thiekness was between 300 and 400 feet. whereas at the endmination of thr last alarial statre it amounted 10.50 or $: 300$ feet. This caused a small increase in the size of eontinents and islands and the joining of some large and many small islands to the continents or to eael other. For example. the water between Nlaska and Siberia is so shallow that the above-mentioned lowering of the ocean united tle two areas. The area of ('alifurnia in reased somewhat as the ocean went down, but the continental shelf off the California coast is narrow in most plates, hence the increase was not of much moment. The depression now oceupied by San Franeisen Bay had a very different appearance during the last glacial stage at least beanse the depth of water in the Golden Gate is about 381 feet and most of the hay is funite shallow. Therefore when the orean rearled its lowest stand, the bay luad largely disappeared and was not restured to material size until sea level had risen appreeiably thus bringing the development of the present bay down to the last few thousand years.

Four times during the Glacial epoch ocean level fell and four times it rose, though there appears to have been a slight drop in very recent time oeeasioned hy a moterate dilling of earth elimate and some increase of iee. A larıe volume of water is still loeked up in the Green-

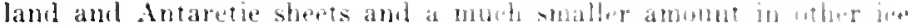

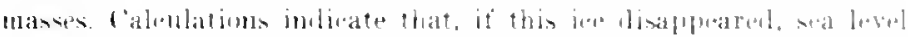

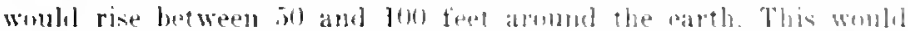

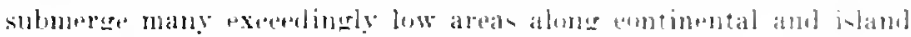

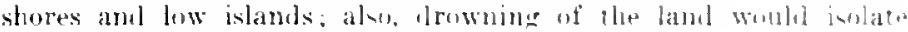
aertain hicher aroas as islaumls.

The profoumd elimatio haness whioh lormegt on and did away with the glacial stages naturally were folt far besuld the limits to which the ice expanded. In both hemispheres, though more comspinounsly in the northern because of its greater land acrease, the luele of antwal

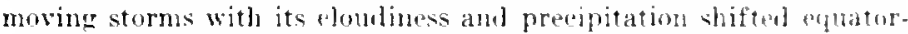
ward as the cracial stares alvinced towarl their olimax, spreadint over many remions which are semi-desent or desire tombay and hringiner greater precipitation over both Jowlands and hishlands, Ju nor northerly and southerly lowlands and particularly in adjacent mem tains, both rainfall and winter snow infreased. Sitrams multiplied or srew in volume: Jakes without untets expanded, wme loreloping ontlets: and great numbers of new lakes appeired The chandes were more notable in the poleward and libher parts of the recions arib] terday

It is elear that each maximum spread of ereater humidity orser the present ary repions eoincided with the culmination of and alarial stage. This climate prevailed ahmut 5.000 years azo, when the pumrth elaciation reached its heicht. The present aridity has evolved principally during the last 25,000 vears when the ice recession has been most rapid. Today desert dinate prevaids over abmut 35 percent uf the land above sea level and vast areas are semi-tlesert

The very dry parts of wostern lonited tiates present al splemdid reeord of this climatic edange. P'rofessor Flint of Yale Tniversity has shown that there are len elosed basins in this region where evideneo uf 98 formor lakes or expansinus of existine lates has been obtainol. Ond 8 basins have not viedded pusitive avdences of former lates amel 20 have been insufticiently stullied to slow whether bakes were prenent or not. The !s hasins antaineat it lakes, as some flomber more than one basin.

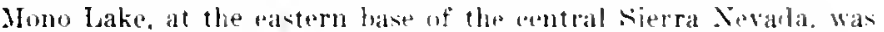
much lareer and during the third glacial stage attained a depth of nearly gon feet. (Wwens lake at the suth ond of owens lalley increased notably in size. In the dlojave besert seetion of the bavill. Ranges provinee there is reourd of many furmer lakes. somes of anduly.

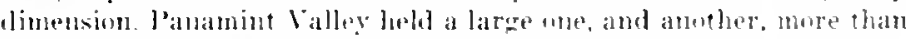

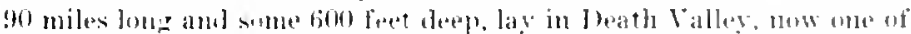
the most arid regions of the worlu. The evidendes of these furmer lakes and expanded existing lakes ineludes wase-ent eliffs and awseiated wave-ent terraces standine at rarions elevations alnut the sides of 


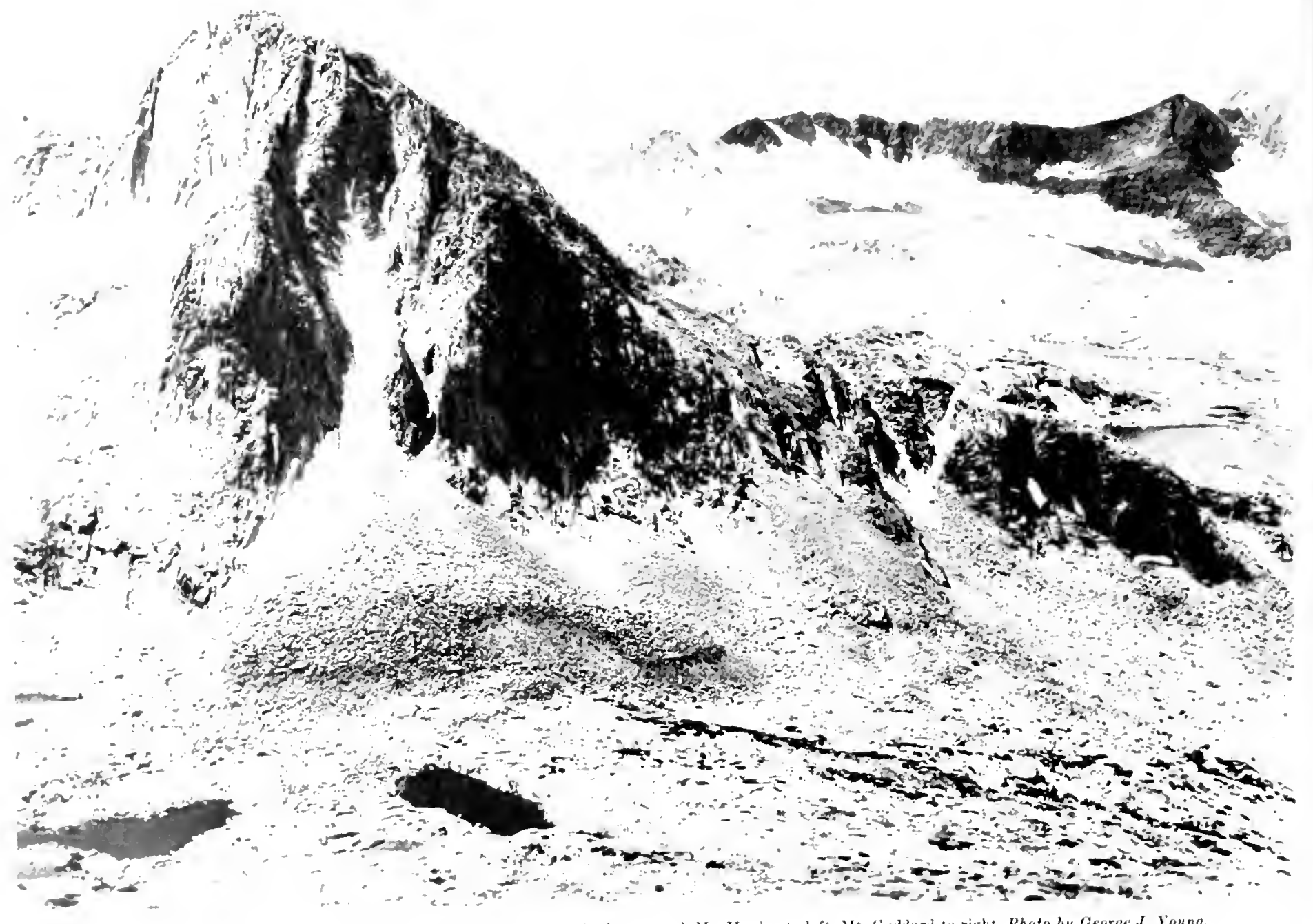

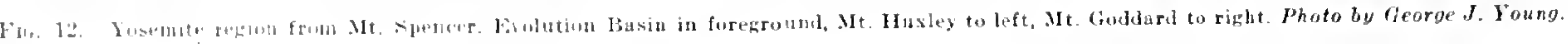


the monntains arainst which waves pounded, together with beach sedimens and onther deproits laiel down in quiet waters.

It is true that, since the culmination of the last glacial stage about 55,000 years aqo, the elimate of the earth has become warmer and Irier and the ice hlanket has notably diminished: but there have been thetuations both in the elinite and in the stand of the ice luring even this interval. Neither the advance to the climax of a clacial stage nor its recesion has continued unbroken. In very reeent times there is abundant evidence of one of these flutuations, for the greatest warmth and dryness of the fourth glatial stage was reached between 6.000 and 4.000 years ago. Since then, also with minor Huetuations, earth climate has become somewhat cooler and moister. Even as late as 500 B.C.. the general clinate was warmer than tolay. This warm, relatirely dry episode whilh began to wane so late in human history is termed the Climatic Optimum.

The proof of the elimatic change just referred to is both geologic and biologic. For example. in the Sierra Nesada it has been shown that the regional snow line was considerably higher than today, the averase summer temperature also was higher, and the summer season wan - mewhet longer. This means that none of the small ralley-head ur cirque glacier are renuant of former valley glaciers, as had long been believed, but are infants ennceived during the cooler interval which started about 4,000 vears ayo. To judge from the speed with which these glaciers are now wasting. it seems impossible tbat they muld have survived the areater warm th of the Climatie Optimum. The extreme youth of these glaciers also is shom by the freshness of the debris composing their moraines and by the fact that the moraines in some instances contain cores of clacier ice. Moraines of older glaeiers. those born during the fourth glacial stage, are somewhat weathered and eontain no ice eores.

Certain lakes, like wens in California, do not contain as much salt as they should if they were resilues of larger lakes evaporated to their present size. Therefore it is believed that these lakes disappeared during the climatic optimum and have been recreated in the last 4,000 years. It is pussible that most or all existing lakes in western Corth America may have lad similar histuries. but this has yet to be proved.

since the present sierra Lisada began to rise nnly a little befure the beginning of the Glarial epreth, it som felt the effect of the increasing cold. The climate became more wintry and the higher parts of the range were blanketed by snow and ice which did not disappear during the slightly warmer months. As the glacial stages advanced, the nnowiee piles became thicker and thicker until they generated glaciers, most of which moved down canyons alroady scored deep into the rneks by rivers. However, on the western sile. the rolling uplands between the canyons provided sites for the generation of small and not particularly

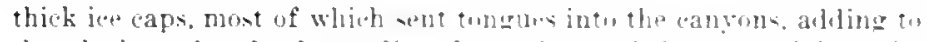

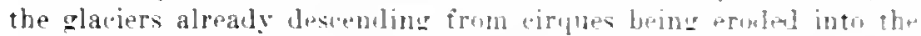
canyon heals. On the eastern sile, where the surfall was less, the valley glaciers were thimber am -horter and there was no renm for ice-cap formation. However. enume from extain capn on the wotern side found their way into the eavern canyons, a for example, in the Tioga l'ass section ahove Mono Lake.

In the relatively low, mothern section of the sierra Nevala. where the high peaks do nut much exced 6.1904 and 7,000 feet abure sea level, only eirque or valley-heal glaciers and short valley qlaciers were present. Sinee this portion of the range has received little geological stuly, ice effects are not well known. South of the hern River where acain the neaks are lower as they approach the terminus of the ranse at Tehachapi Pass, there was little or no glacial jee. The lones section between these two parts, lowper, is quite difierent.

Around Donner Pass, which is crossed by llighway $4^{n}$. glacjers of the last stage measured 10 to 15 miles in length and apparenty joined to form an ice field approximately 250 square miles in area. Donmer Pass was overwhelmed by ice during each of the four stages. long tongues projecting both to the east and west.

Toward the southern end of Lake Tahue, where the peaks on the western side are 9.000 to 10,000 feet high, the later glaciers on the west side of the main west were at least I) niles long. the earlier one: shorter, measuring only 5 to 10 niles. so bulky was the ice man that part of it was fored aurus the divide and this together with short valley glacier developing on the eastern sile descended into Lake Tahoe. Between Lake Tahoe and Fosemite National Park. the crest rise from 11,000 to 13,000 feet above sea level. so nuth snow fell in this section that. w the rolling uplands-remmants of the elevated ancient lanturapes-a dhmed ice wap formed which ran along tbe trend of the range for abunt on miles and had a width of about 40 miles

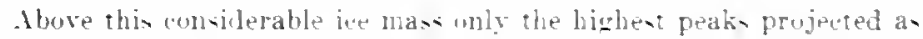
lonely nunatuks. From the cap, iongues thwed inte canyons alreanly. erolet by rivers. and its volume was sreat enuth to furce some ioe

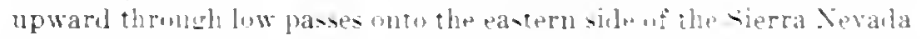
The largest glacier invaled Tuolnme caunon and in the earlier glacier stages had a leneth of about 60 miles. The leser ice of the last stave did wot desenel the canyon mor than 46 miles.

The Yosemite glaciers were the hortest of the tungues in the vectim under disussiun, for most of the iue formed in a relatively small basin and there was only a molesi contribution from the we cap.

Annther considerable ice maw about in miles long and 30 miles wile developed in the brual basin uf the upper san duapnin River

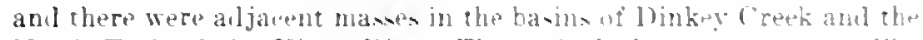
North Fork of the hings liver. The main broly was not a lap likw 


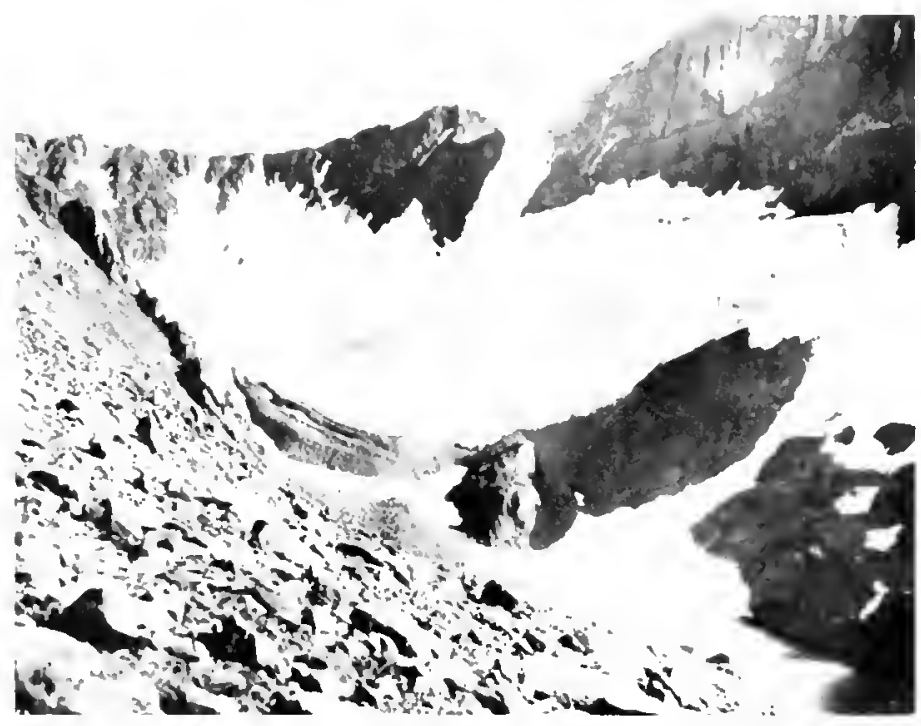

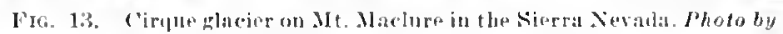
(?.K. Cillbert, courtesy L. S. Geological Survey.

that in the Yosemite-Tahoe region, for it appears to have been formed by the union of several valley glaeiers too thick to be eontained in the canyons where they originated. In the last glacial stage, there was not enoigh ice to ereate such a field and the glaciers were held within their eanyons. The principal ice tongnes in this area followed the Niddle and South Forks of the San Toaquin River, starting from Erolution Basin and joining into a short trunk stream at Balloon Dome.

In the kings kiver drainage area, the canyons were so deep that the iee was held in them. The Middle and South Fork glaeiers were the dief ones but the supply was insufficient to eause them to join so they remained separate streams.

In Kaweah Basin, eaeh tributary canyon barboret a vigorous glaeier 5 to 7 niles long. The main mass of jee in this region, however, lay in a seetion extending from Tokopah Valley to the head of the Marble Fork of Kaweah River.

The southernmost of the Sierran valley glaeiers lay in the Kern liver "antum. Muring the earlier glacial stages, the iee overflowed the eanyon onto the surrount ing beneh lands which are parts of old valleys generated before the last elevation of the range. The glatiers of the bast stage seem to have been confined to the Kern Canyon and its tributaries. The earlier iee was about 32 miles long, extending down to the vicinity of 1 Iocket Peak; the last iee was about 7 miles shorter.
Iloekett Peak appears to mark the southern limit of glaeiation in the Sierra Nevada.

Today, there are about 60 tiny glaciers in the high sierra, the best known being two on Mount lyell, a third on Mount MeChre, and a fourth, the Palisade glacier farther sonth at the head of lig l'ine Creek. All are true glaeiers, thongh they are now shrinking, and, because of their small size, they move very slowly. They are not remnants of earlier valley glaciers belonging to the culmination of the fourth glaeial stage, but have been ereated during the sljuht upswing of the "old, known as the "little ice age." From evidence at hand, it appears that these miniature rolaciers began to evolve alyout 4,000 years ago. Host of them lie in ligh peak cirques* faeing north and northeast though some are on the north and northeast slopes of narrow, comb ridcres. In all 'ases, they are loeated where abundant snow is drifted by the wind and where they are proteeted from the sun by the great roek walls above.

The upper part of the Mereed River eanyon in the Yosemite region was invaded by iee at least three times during the Glaeial epoch. The Fosemite glaciers were formed by two prineipal tributaries, one duscending Little Mereed eanyon south of 1 Ialf Dome and Liberty Cap while the other followed Tenaya Canyon on the north side. The two streans joined about where Camp Curry and the Awalınee Ilotel are now loeated and proeeeded down the main eanyon. The first two graeiers were much thieker and longer than the third; little evidenee remains of the initial stream but the seeond and third left a fine record. The Mereed River eanyon prior to the appearanee of the iee probably was 1,200 to 1,500 feet deep and possessed the usual $V$-shaped eontour of sueh gorges. When the glaeiers reaehed their maximum, they filled the eanyon which was being appreeiably deepened and widened by

- A cirque is a steep-walled, round-bottomed amphitheater evolved by glaclatlon of
the head of a nountaln canyon.

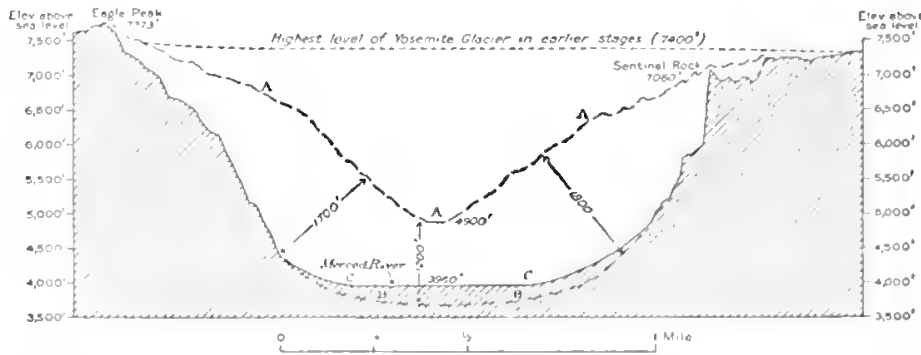

Fye. 14. Dotted line shows probable cross section of Yosemite valley before glaciation. Sulid line shows the present cross-section and figures indicate a monot of widening and deepening by the glaciers. After $F$. E. Mathes, $U$. S, Geol. Survey Prof. Poper 160, p. 8i;. 
their erosive action. The modifications annot be eorrectly" apportioned to the various ice tongues, but in total the canyon was deppened about 1,500 feet at its head where it was widened 1.800 feet on the north side and 1,700 feet on the south side. Exeavation deereased in amount downstream. Glacier loint along the rim at the upper end of Yosemite Valley was corered by about 700 feet of ice, but Sientinel Dome which stands a mile back from the rim, the upper 700 feet of llalf Dome, the top of El Capitan, and Eagle Peak, highest of the Three Brothers. were not overwhelmed. The lower limit of the jue projected perhaps 5 miles below El Portal where the typical glacial ["shaped eanyon berins; the lower few miles of the glaciers were thin and did not erode that part of the canyon to any extent.
The last glacier was mub thimer, measuring about 2.700 feet at the head of Yosemite Valley, instead of more than 4.000 foret as diul the third glacior, and extended only a short distance betow the great, bold promontory, El Capitan. This tongue of the fourth state left a terminal and a number of revessional noraines as its fluctuated after its maximum advance. Recessional moraines arp riluos of rebris comparable witl: a terninal moraine and roughly paralleling it. "They" are developed by temporary advanees of the ice after recession from the maximum derelopment has begnn. One of the recessional moraines lies a little below El Capitan and now appears as a high embankment well covered with trees and shrubs. It contains great numbers of wranitoid boulders embedded in finer debris. As the glacier receded

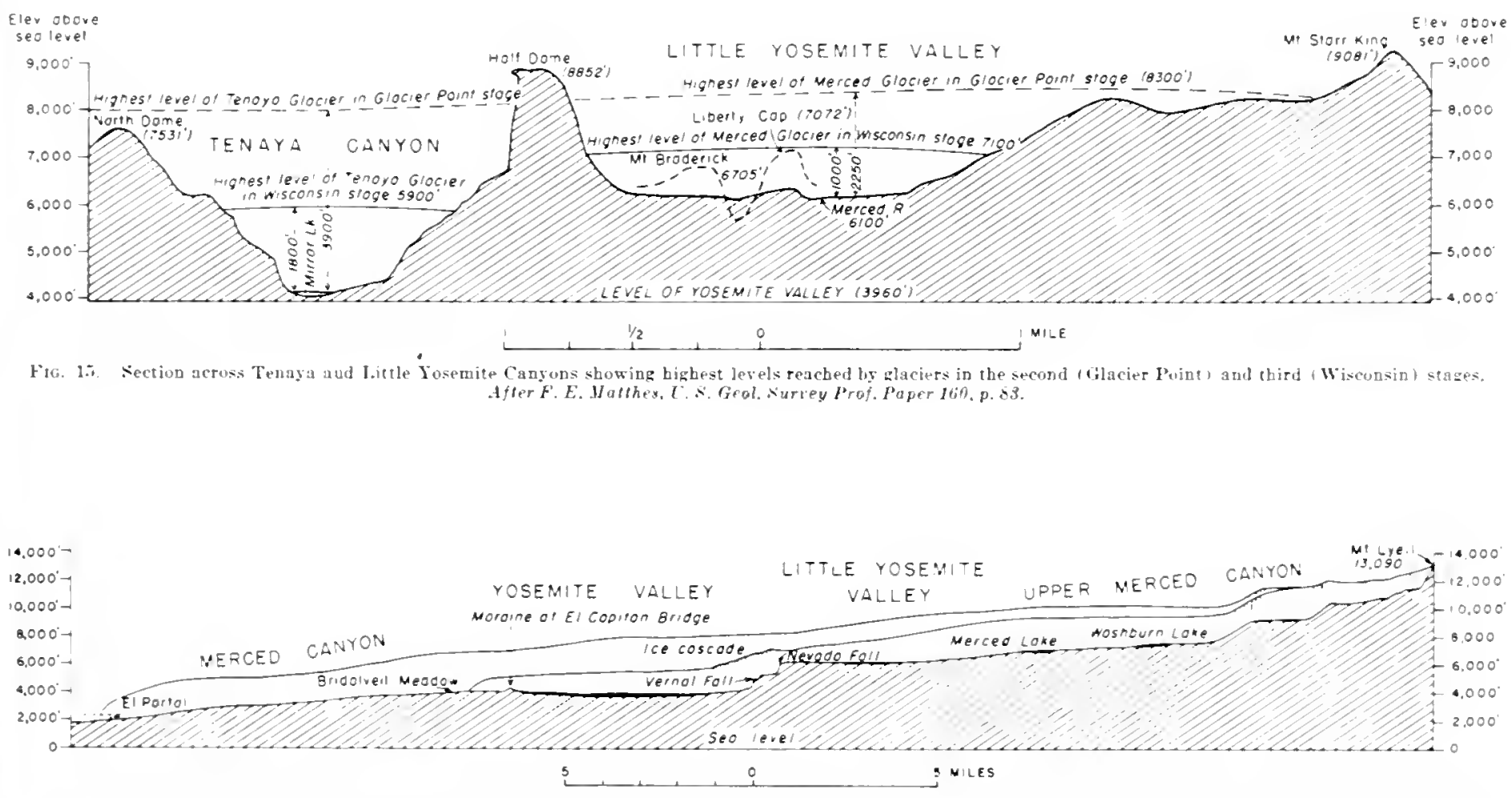

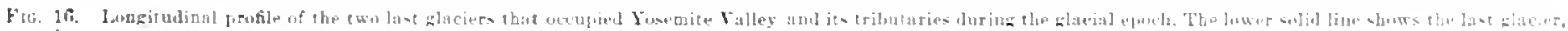

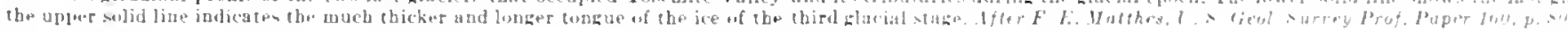




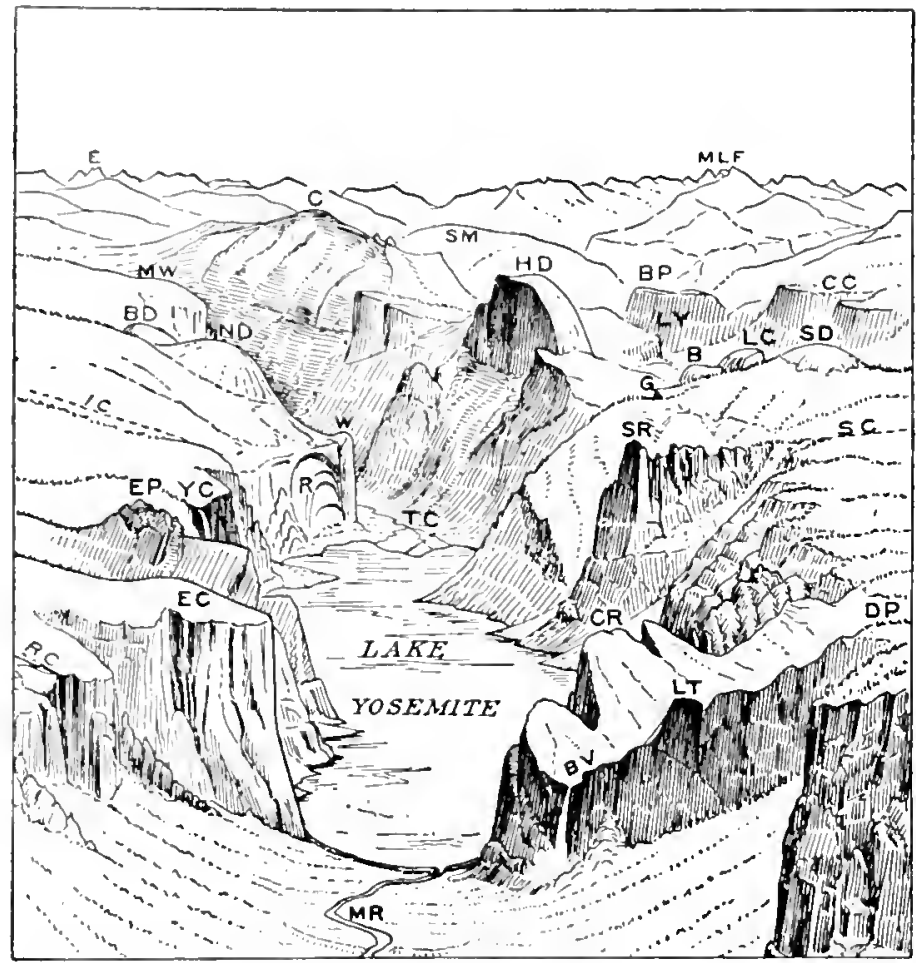

Fra, 17. Bird's-ere view of the Yosemite Valley as it probably was immediately after the ice age. The ralley had been brnadened and deepened to essentially its present proportions. The deepening accomplished by the ice ranged from 600 feet at the lower end to 1,500 feet at the upper end. A lake 51 miles long occupied a basin gouged into the rock floor of the valley and dammed in addition by a glacial moraine. After F. E. Hothes, U. S. Geol. Survey Prof. Poper 160, p. 49.

up the valley from this moraine, a short, wide lake formed between the ice front and the rock barrier. With continued withdrawal of the ice, the lake grew until it extended to the upper end of Yosemite Valley, then attaining a length of about 6 miles. Because of the greater amount of glacial erosion toward the head of the valley than farther down, a basin had been formed sloping in that direction from the lower section where erosion had been much less vigorous. The moraine therefore merely increased the depth of the basin and the lake was much deeper at its upper end than its lower end, measuring perhaps 300 feet. When the lake reached its greatest size, upper Yosemite Valley must have been a glorious sight with the great, deep blue body of water fringed by gray walls rising nearly vertically above it. But Lake Yosemite did not last long in terms of geological time for into it quantities of sediment were poured by streams coming from the waning ice; thus the basin was filled rather rapidly. At the upper end the delta, as such deposits are known, finally rose slightly above average water level, forming at first a small delta plain. This advaneed down the lake until it reached the erest of the dam, driving out the last of the water. The tribntary streams formed the post-rrlacial Merced River which developed a serpentine path over the even surface of the delta plain until it came to the morainal dam down whicls it plunged into the unfilled, lower section of the canyon. Thus, though the lower part of Yosemite Valley as far as El l'ortal is a ellaracteristic, trougl-shaped, glacial canyon, the upper part las a flat floor, covered with trees and other vegetation. Since the disappearance of the lake, the Merced River for some unknown reason seems to have rather suddenly developed a shallow breach in the dan, eut a trench about 15 feet deep into the sediments, and then proceeded to widen its valley into a flat floor over which the river lazily meanders.

Little Yosemite Valley, which was evacuated by the ice considerably later than the main Yosemite, had a rock-basin lake about 21 miles long and a mile wide. Since the basin does not appear to have bcen more than 50 feet deep, it was filled even before Lake Yosemite.

Mirror Lake in the mouth of Tenaya Canyon is not a glacial product but was impounded by landslides, particularly from a place on the west wall of the canyon behind the Washington Column. This lake is being rapidly filled with sediment, though steps are now being taken to prevent its destruction.

In no other Sierran canyon is there a lake history which matches that of upper Iosemite Valley. Small lakes, chiefly of the rock-basin type, are present and many have been filled, or nearly so, developing little meadows, but no large lake is known to have existed.

The deepening and widening of the valley together with the trim. ming off of spur ends between tributary gorges have given the bold, barren sides which stand so prominently above the valley floor. The excavation was greatly facilitated or hindered by the abundance or scarcity of joints, for where they were closely spaced removal by quarrying was easy, but where widely separated it was relatively ineffective and wear was accomplished by abrasion. The widest part of the valley, the upper half, therefore lies in closely jointed rock, but the lower part and the tributary gorges are in rock jointed less prominently. In the main valley, the widening decreases from about 1,800 feet on either side to a minimum of 500 feet on either side not far below El Capitan.

Ascent of the Yosemite, Tenaya, and Upper Merced canyons is accomplished by a series of steps, another characteristic of glaciated 


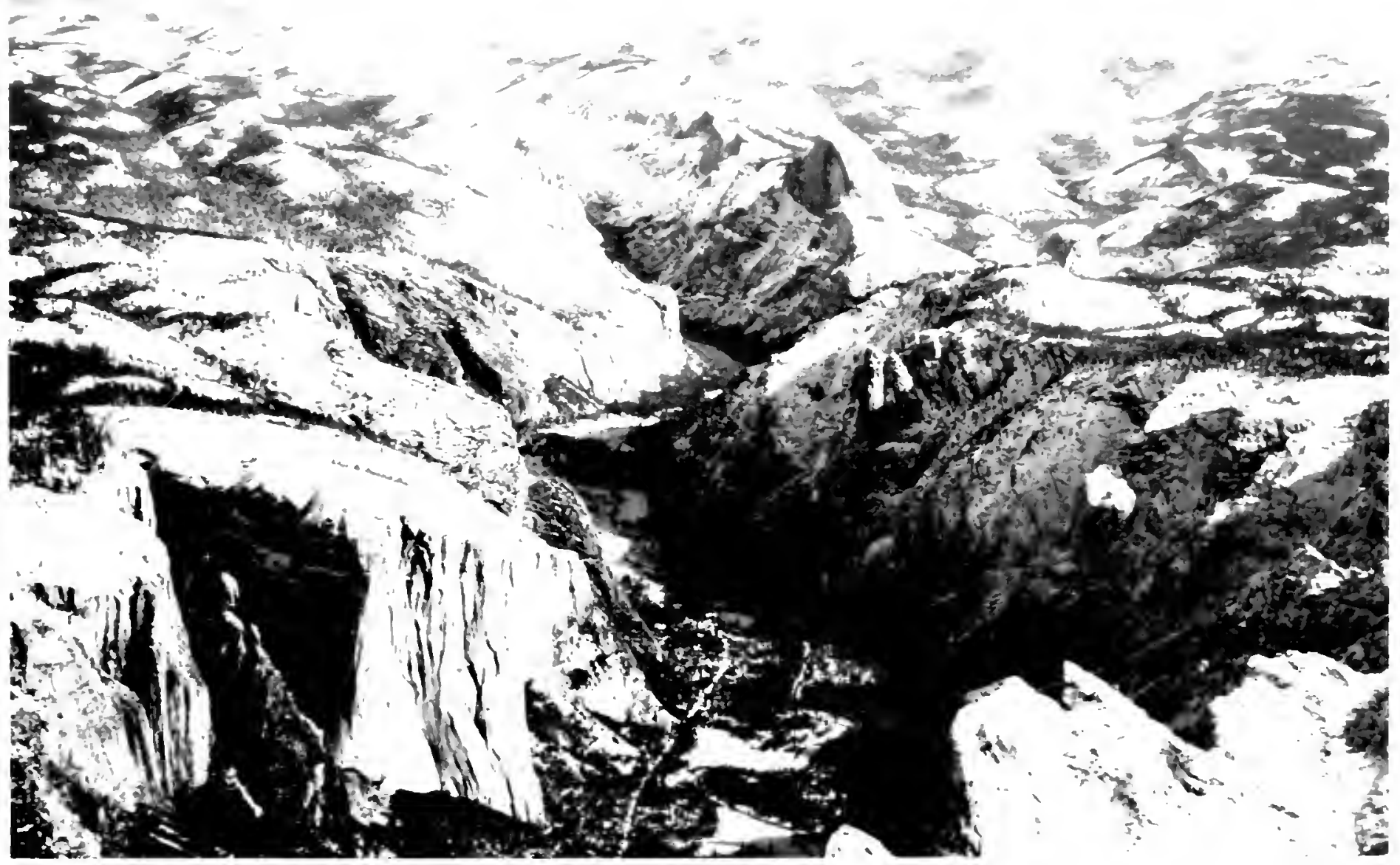




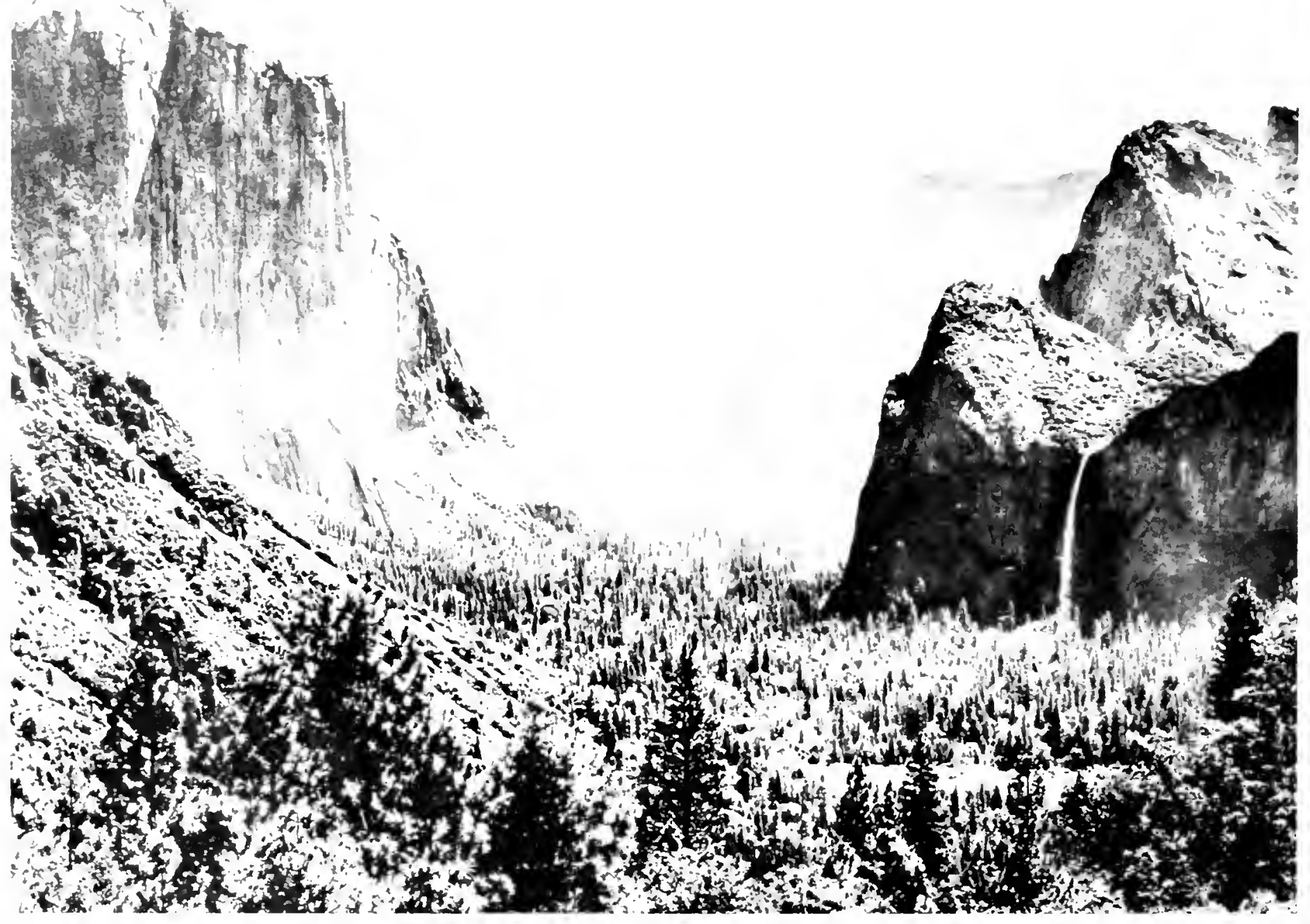

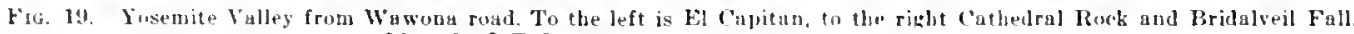




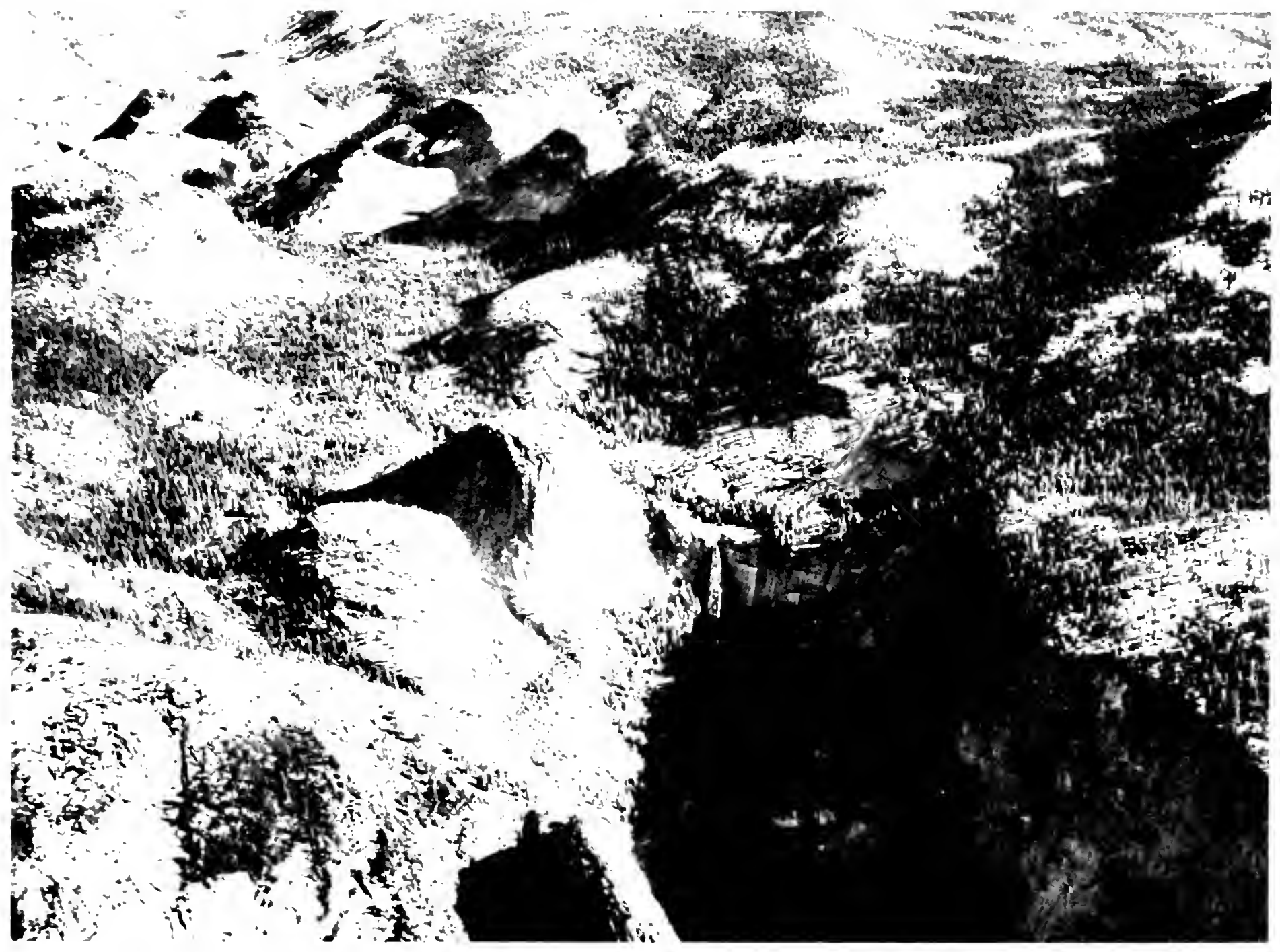




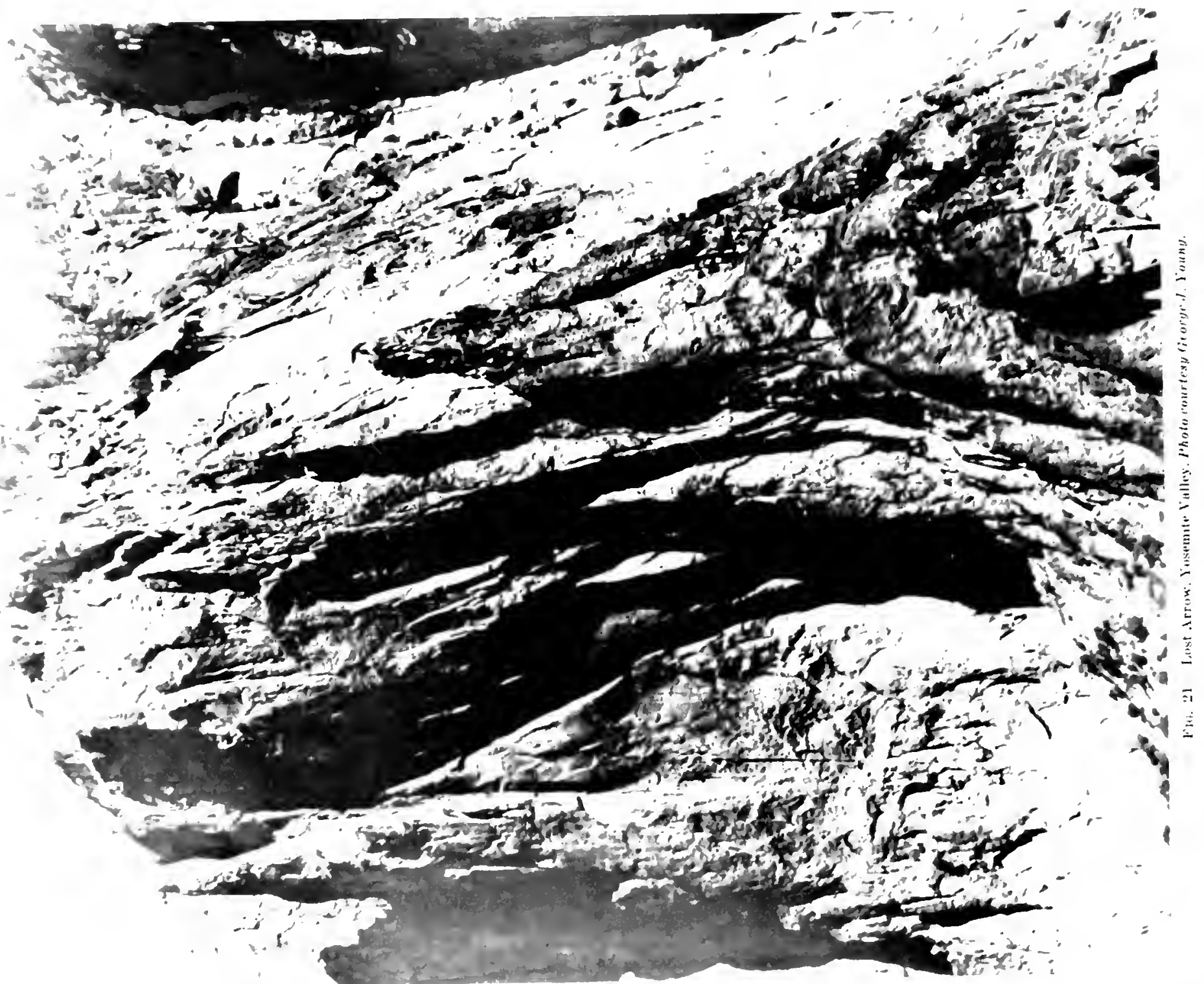




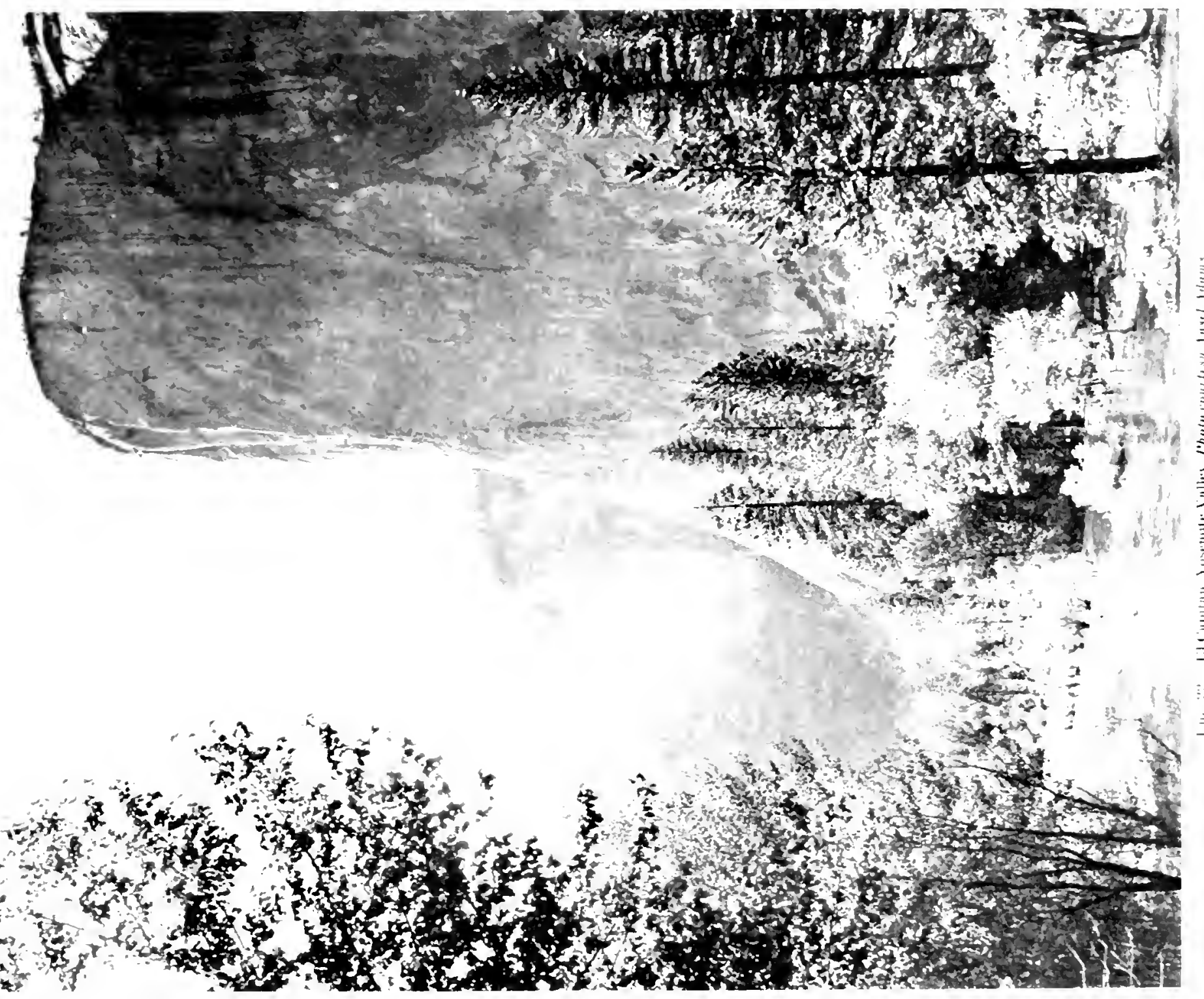




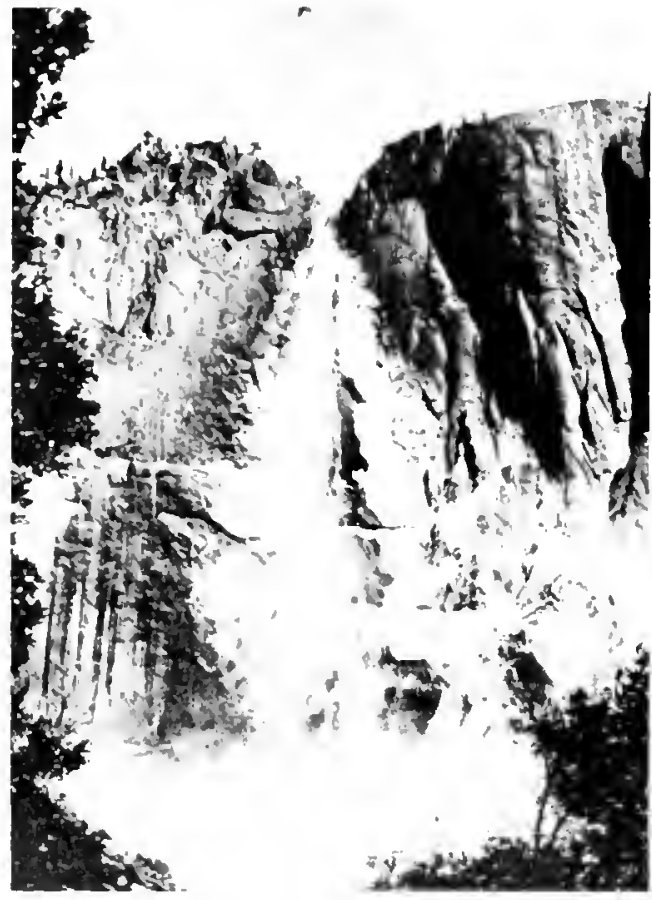

Fig. 23. Ipper drop of Yosemite Falls (about 1,430 f(rwt), as seen from Merced River. Norman $H$. A. Hinds, CEOMOKPJOLOGY (comuright 1943 by Prentice-Hall, lurr., Der lork). Reproduced by permission of the publisher.

canyons. The risers of the steps have been evolved in rock eut both by vertical and nearly horizontal joints where quarrying was easy; the edges of the steps and the treads between them are in relatively unbroken rock, which resisted this type of erosion. Each tread is essentially a basin, and the edges are barriers of virtually unquarryable rock, smoothed on the upstream side by abrasion and steepened on the downstream side by removal where more abundant jointing beuins. Exeavation took place most aetively at the head of each tread for there the ice exerted its greatest force because of its plunge downward from the step above.

Thus is explained the replacement of the steeply rising irregular preglacial eanyon bottom by a nearly level, basined rock floor, and also why the cxcaration by the ice was nearly three times as great at the upper end of Yosemite Valley as at the lower. The ice entered the valley not only by the great stairway from whose steps Vernal and Nevada Falls now plunge, and from Tenaya Canyon, but also by a gigantic eataract from a cap of moderate size on the rolling upland at the base of llalf Dome. The deep, walled-in heads of Little Yosemite and Tenaya canyons also were excavated by similar ice eataracts coming from the sheet ice on the upland.

Joints determined the level of each step in the valley. The high stand of the Little Yosemite above the main canyon resulted from the height of a very massive body of granite tbat forms the upper step of the great stairway in that canyon. The absence of such a step at the mouth of Tenaya canyon is explained by the presence there of jointed rock which greatly aided glacial exeavation.

Evolution of the minor features of the walls of Yosemite Valley also have been controlled by the jointing which has played a most significant part in the weathering that has taken place.

Vertical master joints have controlled the position and profile of most of the great cliff faces, including the sheer precipices over which the falls plunge. The smooth, sheer front of Sentinel Rock is bounded by such a joint. Where there is little fracturing, the relief features are massive, as for example the great promontory, El Capitan, which rises so boldly for 3,000 feet above the valley floor. Cathedral Rocks

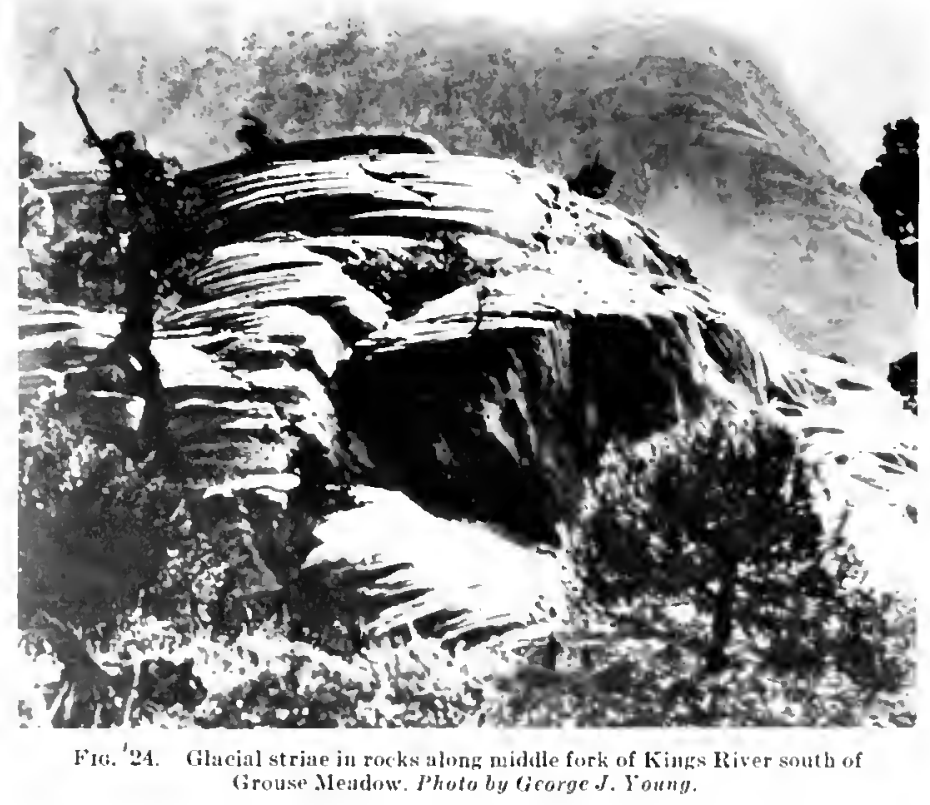




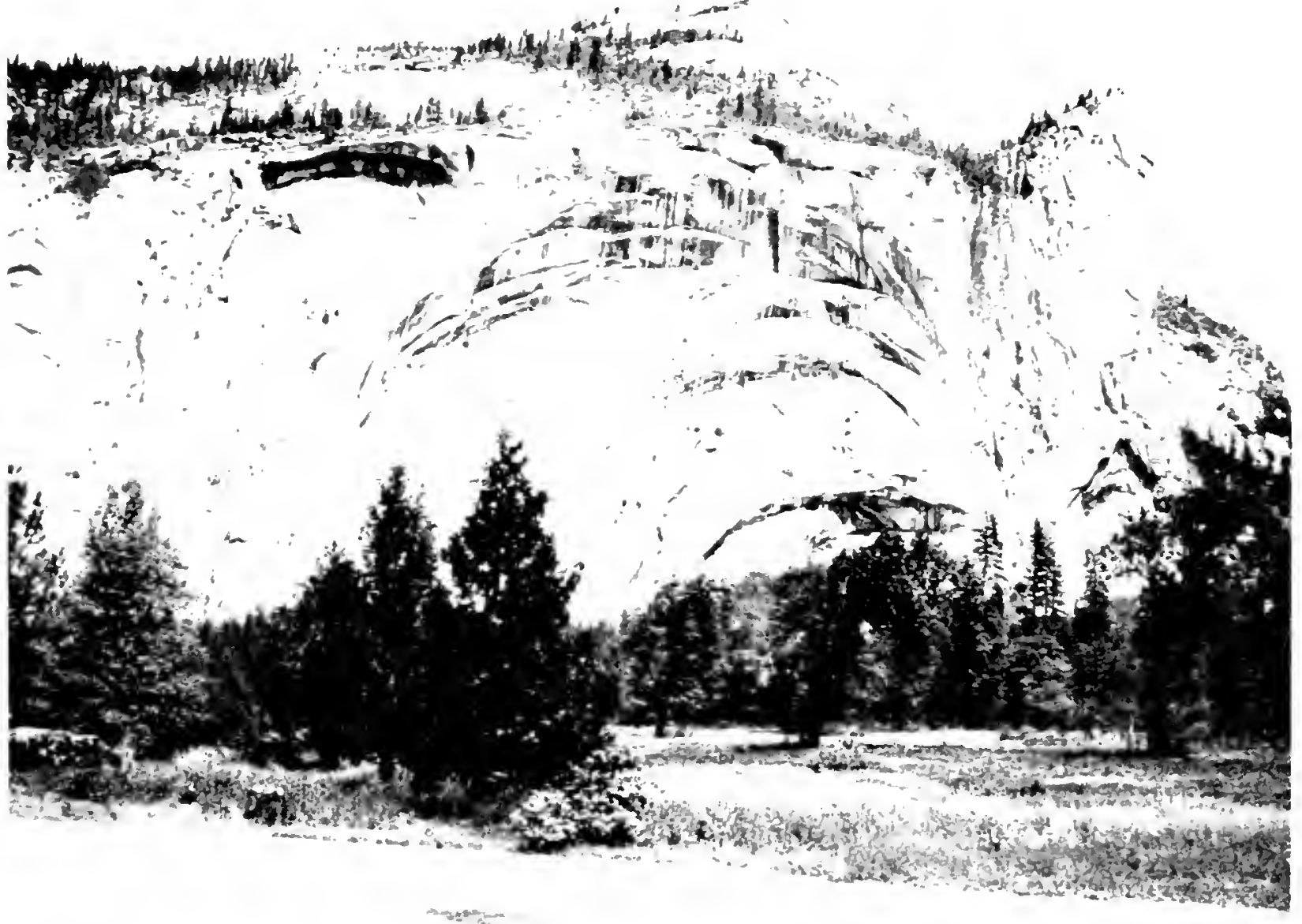


also have heen sculptured into some of the most massise rock in the entire valley. In contrast are frail Cathedral Spires where the jointing is more elosely spaced; elsewhere nany reesses which have been excavated along narrow, abundantly broken zones. The Royal Arches have been etched into a eomplexly jointed slanting eliff face about 1,500 feet high. Along highly inelined and eurved joints, frost wedging has pried loose blocks bounded by these fractures. The Washincrun Column standing just east of the arehes has been earved out of a less broken mass or roek.

Adding great beauty to Yosemite landseape when water is abundant are the many falls which plunge from hanging valleys standing at variotis elevations above the valley floor. Most waterfalls are broken in their deseent by projeeting ledges and should properly be called euscades; it is primarily in glaciated valleys that this less eommon, high, free-leaping type of waterfall is present, though some are formed in uther envirunments. The streams responsible for the Yosemite Falls are small and consequently they appear as veils or ribbons of water rather than as massive eataracts, except for those of the Merced which are somewhat heavier. During the dry season the streams decrease in volume, the falls become largely misty elouds, and some disappear.

Bridal Veil is one of the most perfect examples, emerging from the edge of a V-shaped guleh and plunging over a precipice 620 feet high. In the spring and early summer when the snow is melting the torrent is of considerable size, but during the rest of the year it is flmy and veil-like. Direetly opposite on the other side of the valley, Ribbon Falls drop 1,612 feet from the edge of the upland; it is the highest of all, but does not make a free deseent throughout for it is held in a narrow, sheer-walled reeess in the side of the valley. Even

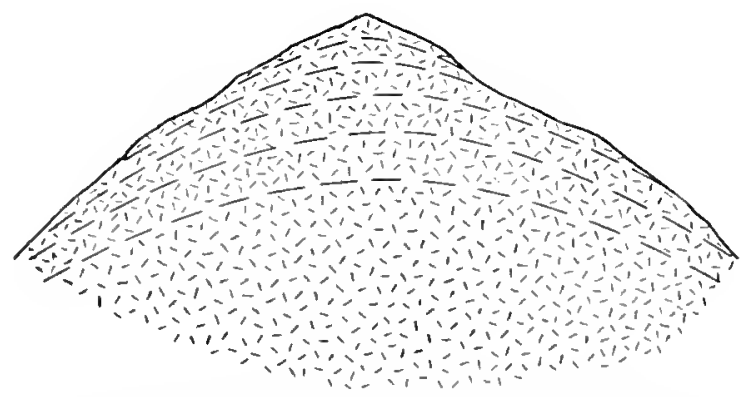

Fuc 21;. I lagram showing how, by progressive exfoliation, the original angularities of a rock mass are replicesl by smooth curves, -lfer $E$. E. Wathes, $t$. S. Heol. survey l'rof. Paper 100, p. 115 though they are produeed by a stream of modest size, Yosemite Falls are the supreme speetacle of the valley. They are in three sections, the upper dropping over a cliff 1,430 feet high and heing one of the highest if not the highest free-leaping fall in the world, though it does not clear quite this entire distance in a free plunge. Then the water seatters over several aeres, collecting into sheets and rivulets that eonverge toward a half-bowl of polished granite from which the remade stream raees through a narrow winding gorge. After this tortrous deseent of 815 feet, the water again plunges over a 320 -foot eliff to the floor of the valley.

In the short stretch of the Merced Canyon that eonnects the Little Yosemite with the main valley, there is an abundance of falling water, for the river deseends 2,000 feet in a mile and a half. In the upper part the stream drops over the risers of the giant stairway produeing Vernal and Nevada Falls, the former 317 and the latter 594 feet high, and farther down races in a series of raging easeades and rapids.

A rival of Yosemite Falls is the Tueeulala in Iletch Iletehy Valley whieh has a total drop of about 1,000 feet, but a free leap of only about 600 feet.

Morainal deposits inelude the terminal and recessional barriers whieh impounded the lake that lay so lately in the upper part of Yosemite Valley, and side moraines along the valley walls which have been added to by boulder fall and avalanches from the precipitous eliffs after the ice went away.

One of the features charaeteristic of a glaciated region is polished, seratehed or striated, and grooved bedrock, a product of the abrasive action of the moving ice. Partieularly in resistant rock like granite, the polish is often remarkable. The seratehes apparently are made by sand ilagred along by the ice; the grooves, which may reach a yard or more in depth, are formed by resistant boulders grinding into the rock. Such features ean be produced in other ways, but, where present orer eonsiderable areas and associated with other features of glaciation, ean be interpreted only as the product of ice action.

The famous domes of the Yosemite upland have been evolved from giant, joint-bounded cohmns of granite by long-continned exfoliation. This hreaking off of shells of roek along more or less eoneentrie fractures apparently has been eaused by expansion of the roek as the load upon it has been relieved by erosion. Some of these domes in the Yosemite region were ice covered, others were not. The breaking off of shells of roek has also been aided by the prying action which results when water freezes in the joints. The Half Dome has an exceptional form beeause its steep northwestern side, a sheer drop of more than 2,000 feet, has been exposed only recently as the result of glaeial modifieations of the eanyon below and the exposure of a nearly vertical 


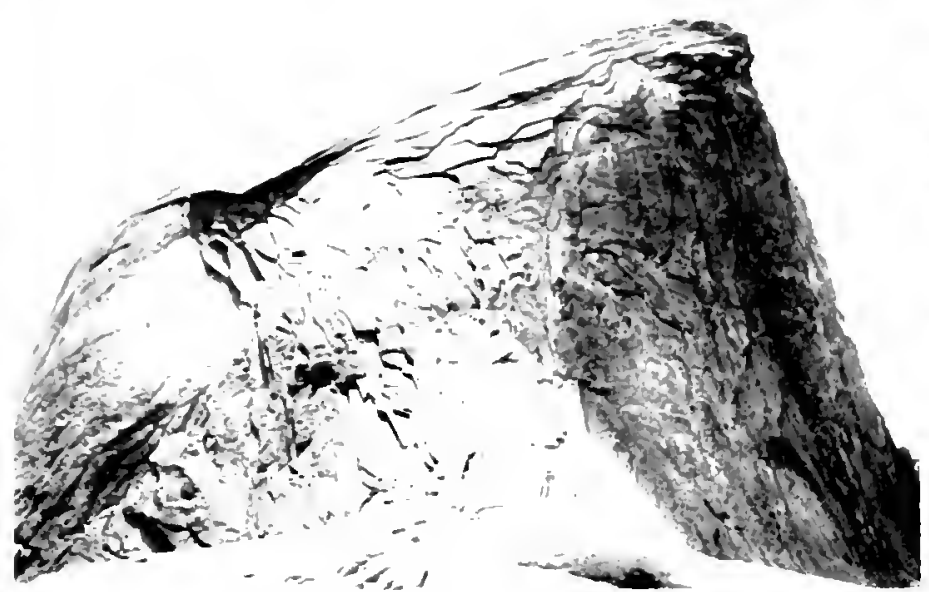

FIg. 27. Northeast side of IIalf Dome in Vosemite Valles. Frost wedging of joint hiens along n system of eured joints has produced shells that are several feet thick. Photo by F. C. Culkins, courfesy t. S. Geologieal surcey.

sistem of joints which eontrols the prexipitons face. The form of the southern site is controlled by concontrie curved joints along which front wedging has pried loose shell after shell.

\section{Tahoe Region}

In the vicinity of Lake Tahoe, the western mountains range from 8,000 to 10,000 feet in elevation, are broken by deep valless which have been much ice worn and have prominent cirques at their heads. In the valleys are many rock basins and the charaeteristic stairway topograply already deseribed from the Iusemite section. The moun. tains in part are narrow ridges but rertain areas like the Tallac-Dick"s laak rang have brual, that summits. The higher parts were not cov ered by ice and eonsequently have topography characteristie of vigorous mechanical weathering, gravity transfer, and snow avalanching above the limit to which the ive extended. In the mountain canyons there are few morainal deposits. Ice-abraded surfaees prevail, but suth features as grooving, striation, ant polishing have been extensively destroyod by rock weathering which las followed tisappearanee of the crlaciers. In some places there is considerable burial by talus.

When the ice reahed its maximum thickness. it covered all but the himhest ridges and flat summits, moving principally from a large area uf arumulation in lesolation Valley. Tongues trawled north, east. and south. Other glaciers came from cirque heads of vallys tributary to the main ones. While the main movement was down the valleys, several of the lower divides betwen them also were covered. This

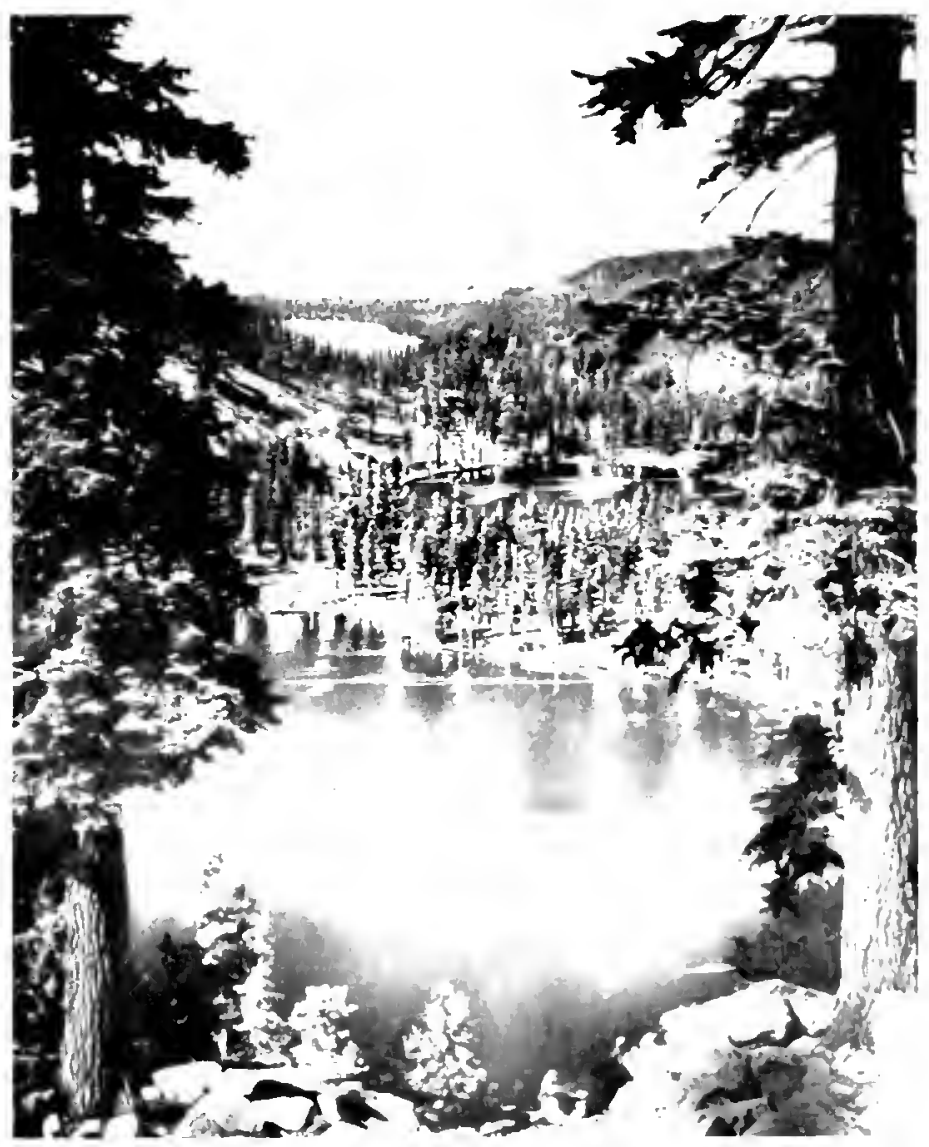

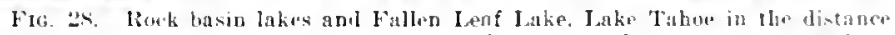
oecupifs the subthern part of a long. narrus fault basin. Fhopo courtery siouthern Pacific hailraat.

zone of virorous elaciation possesses the willest, most spectacular seenery to be fouml about lake Taloe.

Toward the lake is a zone of momainal ridges and irreqular hills in which there are a number of lakes behind morainal barriers. The landseape is far different from that of the montainus soction pro sentine litthe that is startling but mode that is beatiful. In thic zone

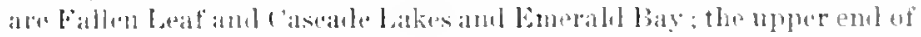

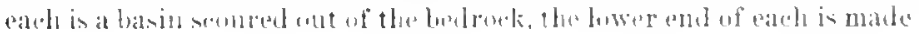




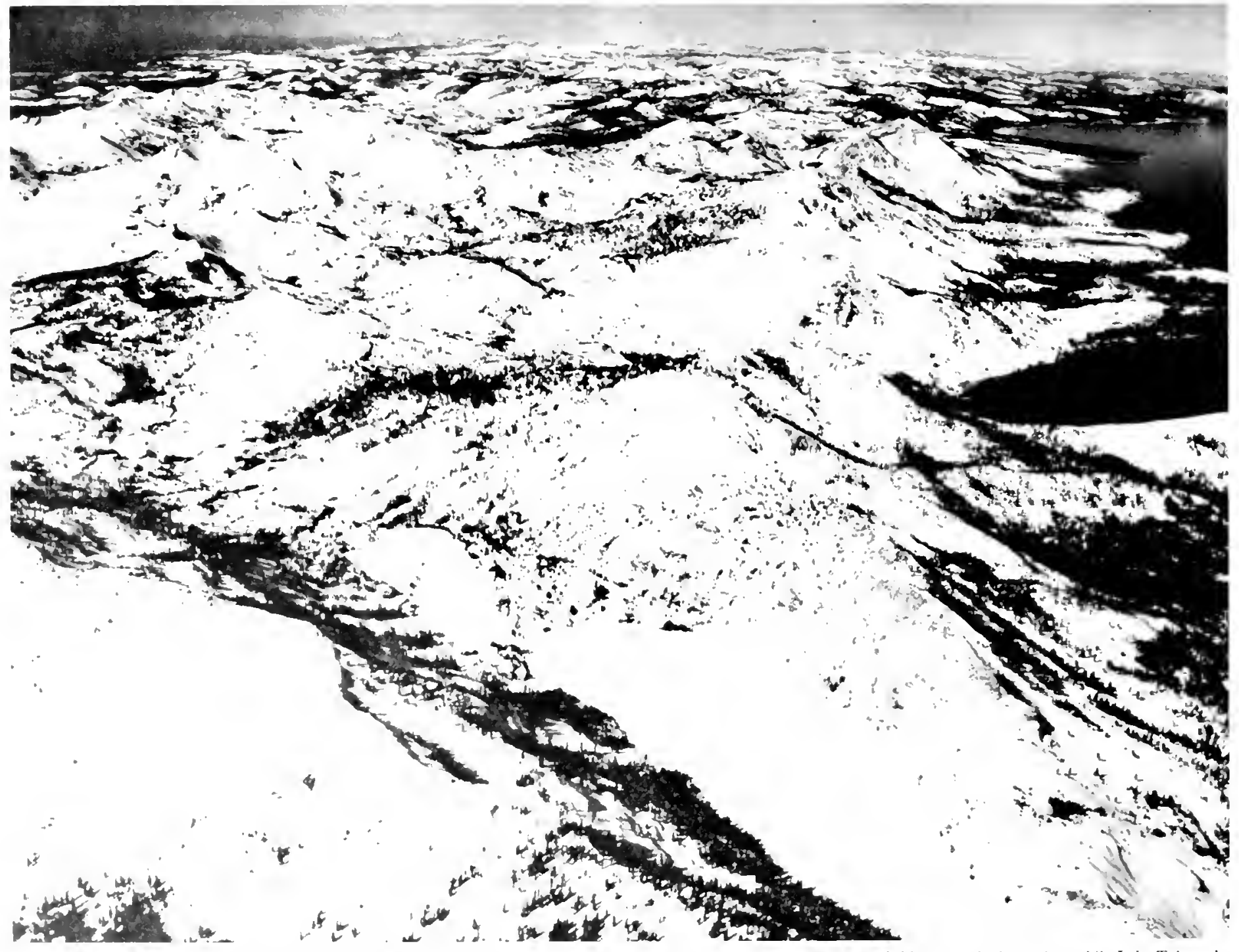

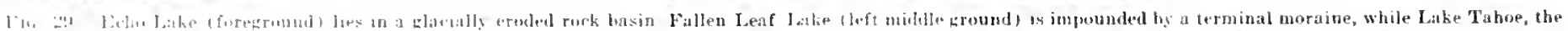

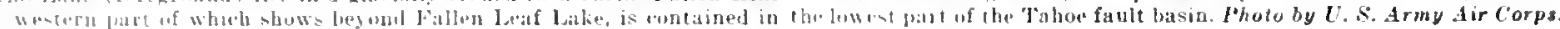


by a combination of lateral and terminal moraines. At the southern end of the lake plain extending south from lake Tahoe there is an extrusive area of morainal hills and rilges left by a combined piedmont glacial mass formed by tongues moving northward in the upper Truekee Valley and eastward through Eeho I akes basin.

At the southern end of the Tahoe fault basin is a series of flat plains standing at three levels. The most extensive of the three was formed by outwash left by subglaeial streams coming from glaeiers which lay to the west and south. About 20 feet below this outwash plain is a lower, mueh less extensive series of terraces eroded by the Upper Truekee River sinee the iee receded. About 20 feet above the out wash deposit is the third section of the plain; its origin is mneertain but it very possibly represents deposits of the larger Lake Tahoe before its maters developed the outlet eastward by erosion of Truekee River Canyon.

In the heart of the western mountain areas is Desolation Valley, or, as it is ealled on eertain maps, Devil's Basin. On its southwestern border rise the bold slopes of a range dominated by Pyramid Peak (elevation 10,200 feet) which constitutes a barrier between the basin and a group of westward oriented valleys. The Craeked Crags separate Desolation Valley from Glen Alpine and Eeho Lakes valleys, and north. direeted spurs from the Pyramid Peak Range and Jack's Peak unite at Mosquito Pass and form a divide beyond whieh is Roekbound Basin. Southward a group of low hills partly isolate Desolation Valley from the steep gorge down which its drainage flows to the South Fork of the American River.

During at least some of the glacial stages, ice so filled Desolation Valley that it overflowed northward into Roekbound Valley, eastward into Gilen Alpine and Echo Lakes valleys, and southward into the eanyon of the South Fork of the Ameriean River. The relatively low eleration of the divides erossed by the glaeiers in part has resulted from the heary wear by the advaneing iee.

Largest and most complex of the valleys in this region and perhaps the most attraetive seenieally is Glen Alpine. In it lies Ifeather, Susie, IIalf Moon, and Grass lakes, which oceupy roek basins, and Gilmore Lake which is held in by a morainal dam. There are prominent eirques, particularly at the hearl of Ilalf Moon Valley, and the eanyon sides exhibit eridenee of vigorous glaeial erosion. The rounded rock knobs ealled roches moutonnces are fairly abundant in the valley bottoms.

Echo Lakes valley is similar to, but is not hranched like Glen Alpine. lower Echo Lake is unique in that it oecupies a roek basin on the southeastern rim of which is a low morainal ridge. The remainder of the eastern rim is bedroek, from which the re is a long, steep. ice-worn slope deseending to the lake plain. Down this slope Echo Lakes ylacier must have plunged as a gigantic iee caseade.
In the northern part of this mountain section the valleys trilutary to Cascade Lake and Emerald Bay sluw alacial fratures similar to those in the Desolation area, but they were developed hy glaciers whith grew in the valley heads.

Roekbound Valley also was deeply eroled by iee flowing in from Desolation Basin.

The longest valley heading in this glaeiated mountain region is that of the South Fork of the American River. In the upper part are abundant morainal deposits and assoeiated marshy flats, douhtless fills of small lakes lying between the morainal ridges. This morainal cover extends down the valler about a mile southwest of Phillips. heyond which glaeially eroded features are prominent as far as Lovers Leap, about $3 \frac{1}{2}$ miles to the southwest.

\section{Mount Whitney Region}

The Mount Whitney region of the Sierra Nevada lies a little south of the middle of the range and is the highest part of the fanlt block. Mount Whitney, 14,496 feet above sea level, is its enlminating summit.

Normally the higher part of a mountain range of great altitude whieh has been powerfully eroded consists of an alternation of deep narrow eanyons separated by high and narrow crested ridges surmounted by sharp pointed peaks. If suelı a landscape has been intensely glaeiated, the boldness and ragredness of the topograply is greatly inereased. Mount Whitney and many other peaks in this and other seetions of the Sierra Nevada, however, have gently sloping. table-like summits which eould not have been formed by initial erosion; rather they are gradually being destroyed by weathering and removal of debris. Therefore these mountains must belong to an earlier cycle of erosion when the landseape looked quite different from that of tolay. Beeause of the long time which has elapsed since the first bnilding of the range, 120 to 130 million rears, we see none of the landsiape developed by the deformation, but we do see relies which have been carved from it. The great folded and faulted ridges brought into beints by the eompression of the regrion are gone, but fortunately in plates their roots are still preserved showing the struetures which were evolved. In the sonthern two-thirds of the range, eroxion has gone deeper into the granitoid batholith which formed in the heart of the mountains as they were nriginally elevated. None the less, there are scattered remnants of folded and fanlted enver which hat projeoted farther than the average into the intrusive mass. After the ancentral Sierra Nerada hal been eroded for about 60 million years. it hat been so worn down that there remained only rows of hilk probilhy marking the sites of the original deformation ridges; betond were lowlands sloping gently westward towarl the opean aml for an unknown distance to the east. Between the rilleses, the stroms flemwel mostly in northwesterly and southeasterly direetions as they had done 


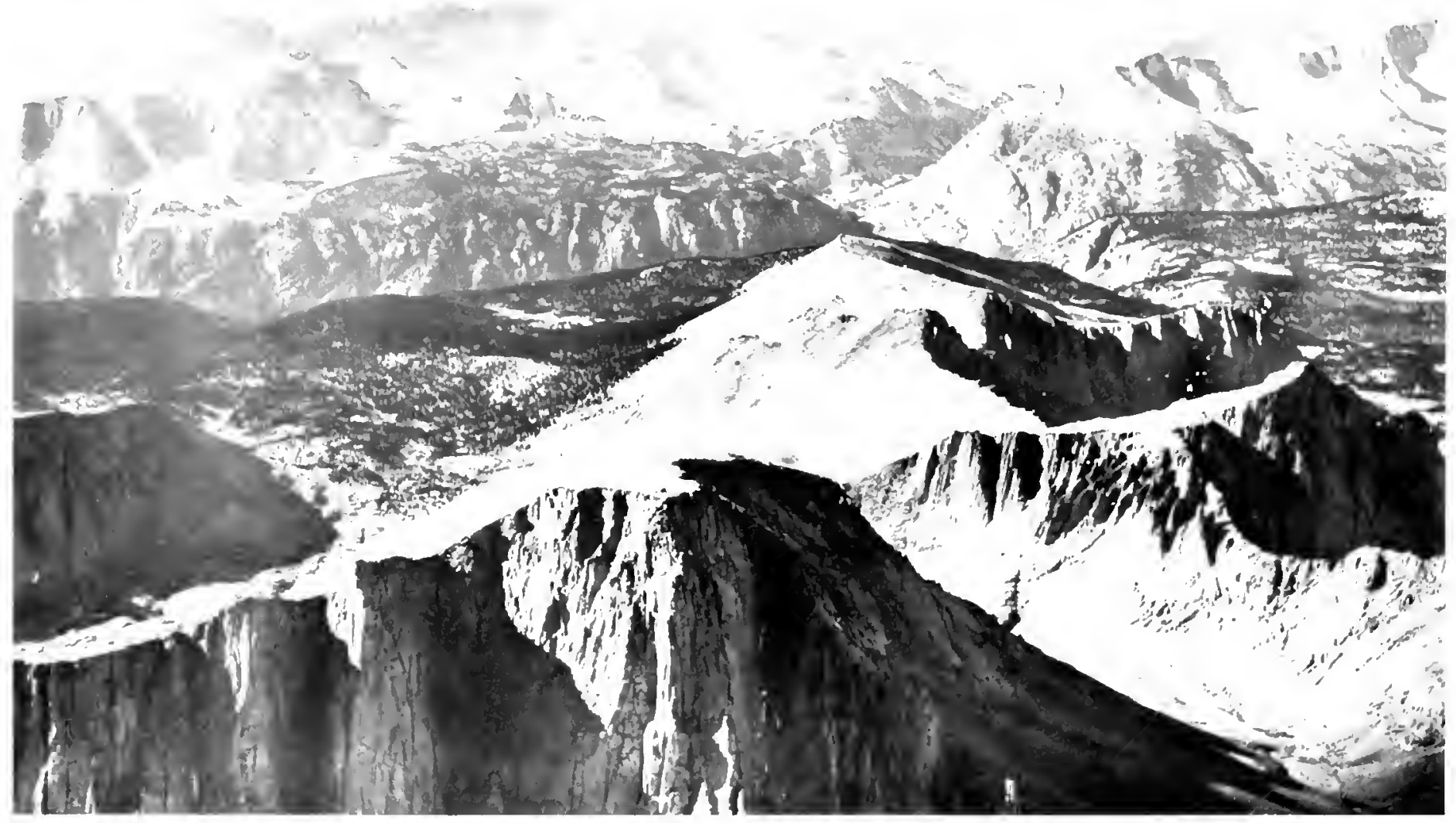

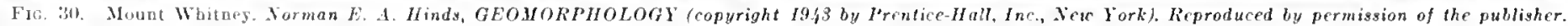

from the early dias of the range, with less important drainare direeted toward the southwest and northeast.

Possibly to or 50 million years ago began the first of a series of uplifts which eventually led to the development of the present Sierra Nevada. The Sierra and the eountry east of it seems to have been tilted to the southwest so that new master streams flowing in that direction were created. However, lesser streams between the rilges were unable to change direction and continued in their previous courses parallel to the trend of the range. As each uplift oecurred all of the streams were invigorated and cut young eanyons deeper into the roeks of the range, the principal ones directed to the southwest, lesser ones to the northwest and southeast.

In the evolution of present Sierran relief the northwesterly-southeasterly erests roughly paralleling the principal erest along the eastern marrin are of prime sirnificance. They are among the oldest features of the landsape and are inheritances from the oricrinal ridges of the foldfault range. Sone of these longitudinal erests have been carved into folded and faulted roek, as for example the Ritter Range. The sonth. 


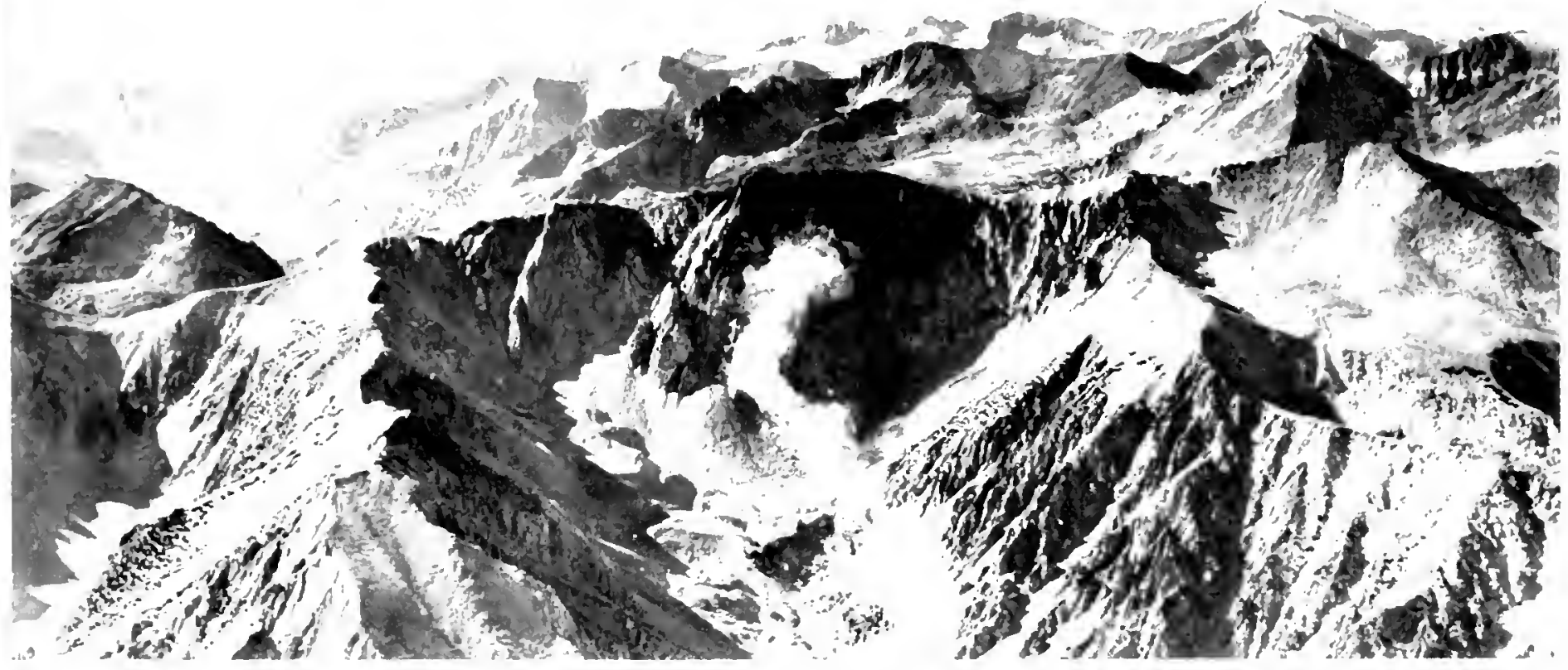

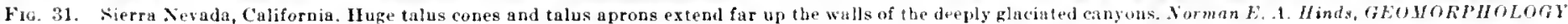
(copyriuht 1:93 by Prentice-IIall. Inc. Xew Fork). Leproduced by permission of the publisher.

eastward-trending upper canyon of the Hiddle Fork of the San Joaquin River, paralleling the Ritter Range as far south as l'umiee Flat, has been eroded into the same mass of rock and follows the direetion of the folds. Le Conte Divide is another example. On the other hand, the South Fork of San Joaquin River has cut its northwestwardtrending canyon in the rock of the batholith.

Farther south in the headwaters of the Kings River and in Sequoia National Park, where the folded structures of the Sierra Nevada bend farther south and southeastward, the principal erests and valleys follow them but are carved mostly in granituid rock. The Great Western Divide contains folded rocks in the vicinity of Mineral King and in the Kaweah group. The upper Kern River cangon is eut entirely" in the batholithic rock; Mount Whitney itself is composed of the same material.

The erest of which Whitney is a part and for which the name Muir has been appropriately suggested, runs south-southeastward for about 17 niles from Shepherd Pass on the north to Cottonwood l'ass on the south. It contains seven of eleven peaks in the Sierra Nevada whose 


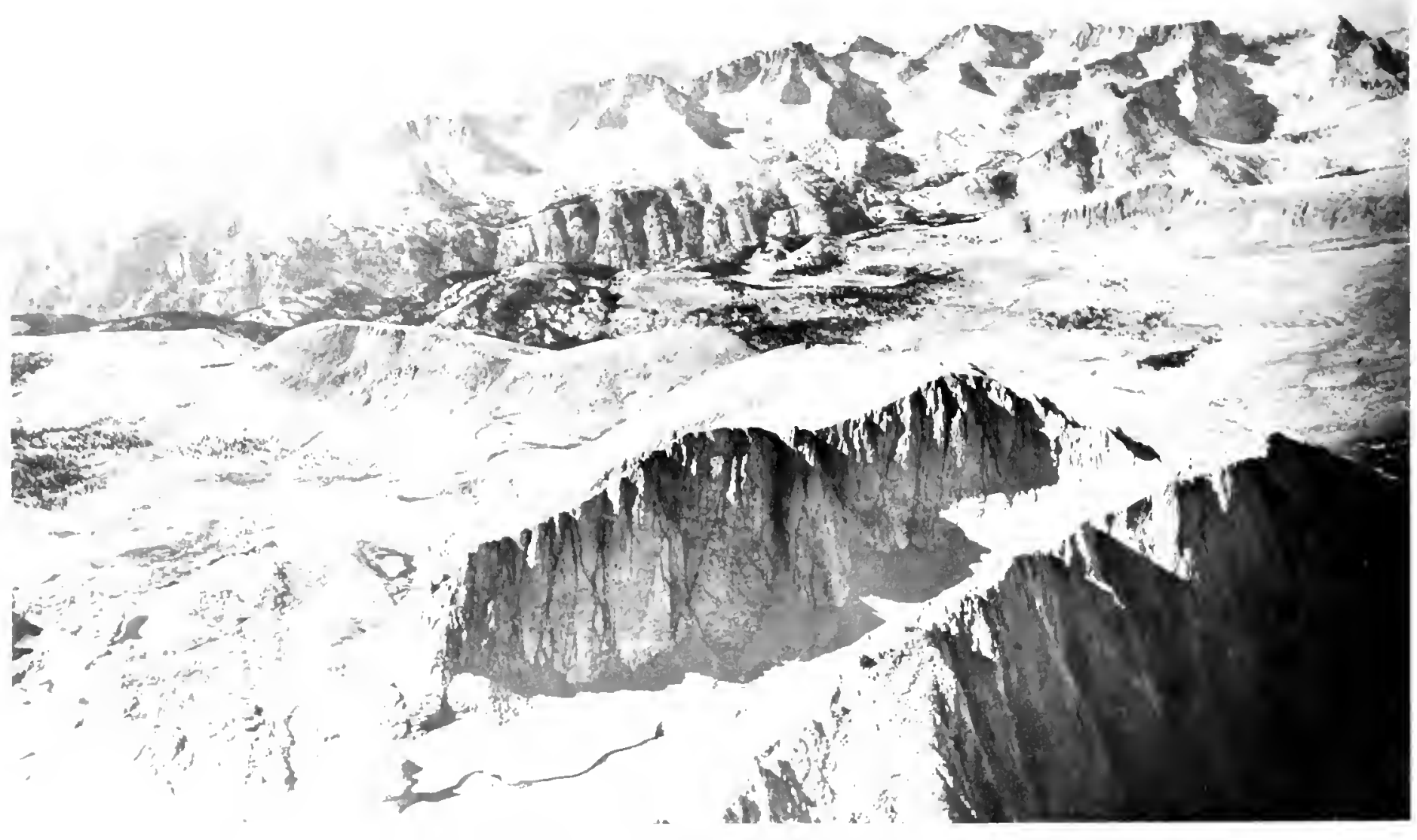

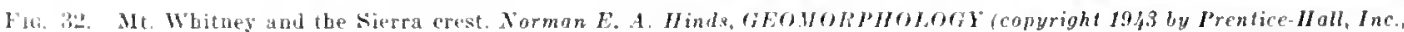
lete lork). Reproduced by permission of the publisher.

elerations exceed 14,000 feet-Tyndall, Williamson, Iarnard, Russell, Whitney, Huir, and Landey - as well as several which are only slightly under that elevation. West of this crest is the upper part of the kern River anyn. The river's position may lave been determined

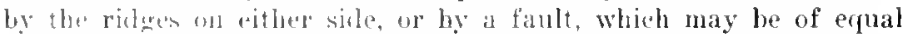
antiquity and which was easier to erode than the unbroken rock on either side.

There are features on the east side of the Minir erest which suggest that another longitudinal valley of great age lay in that direction, a valley generated long before the late elevation of the Sierran region and the depression of Owens Valley. The erest appears to have been more sharply outlined by valley deepening east and west of it during the episole of elevation, perlaps 40 or 50 million years ago. Many of the peaks in the various crests show a summit platform similar to that of Whitney and some of them slope downward on one or more sides to what evidently were at one time broad valleys. $\Lambda$ t this time Mount Whitney was a dome-like hill which rose about 1,500 feet above the adjacent valley floors. The distance from the sea coast was 


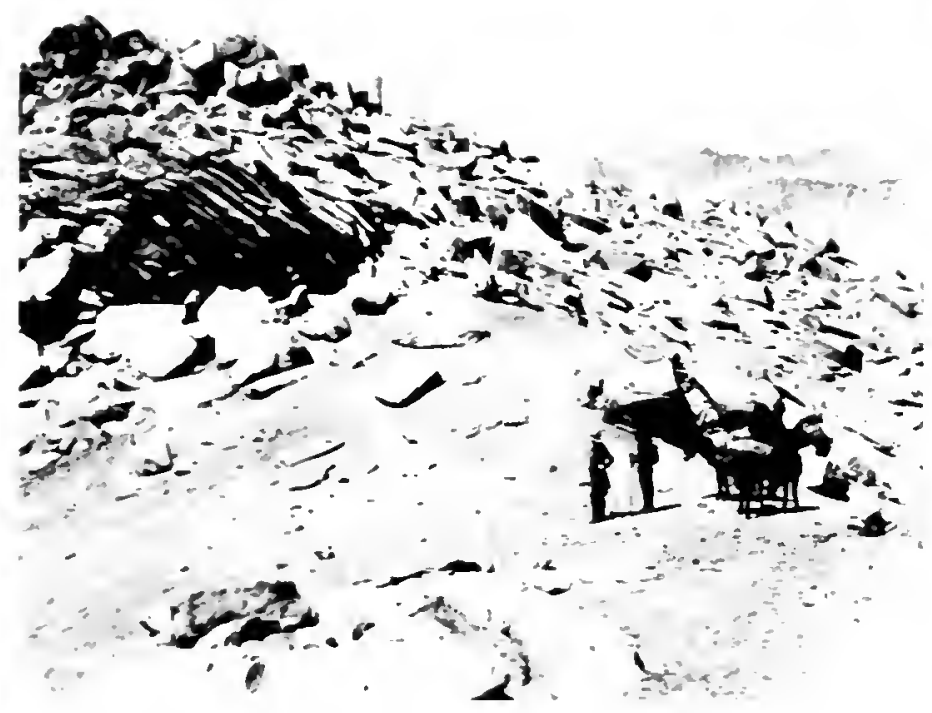

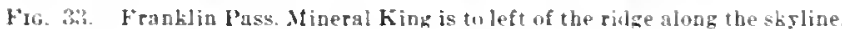
Photo by Georged. Joung.

less than tomay, for the ucean cosered much of the region now oceupied by the Coast hanges and the Great Valley, but the peak must have stomd at least 50 miles inland. Comparing this with other regions, it has been concluded that the elevation at the base of the "Whitney" Ifill" was perhaps 500 feet, so its summit stood approsimately 2,1100 teet above sea level.

The many flat-topped peaks in the high Sierra similar to Whitney evidently are of the same origin. Perhaps most striking is Table Mountain (13.464 feet) in the Great Western Divide on the opposite side of the Kern River Canyon from Hount Whitney, but thare are others in the vieinity. These peaks are about 1,000 feet lower than Whitney, but they are 10 to 15 niles farther west where the general slope of the range carries them to lower elevation. Farther nurth in the range are I)arwin, which has two separated platforms standing at altitudes of 13,841 and 13,701 feet, respentively : lima. Koip, and Blaektop in Yosemite National Park which tugether form a continuous platform about $3 \frac{1}{2}$ miles long and between $] 3.000$ and 13,000 fert in

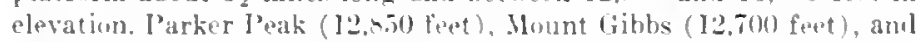
Mount Dana (13,050 feet) are other examples. The lower elovation of

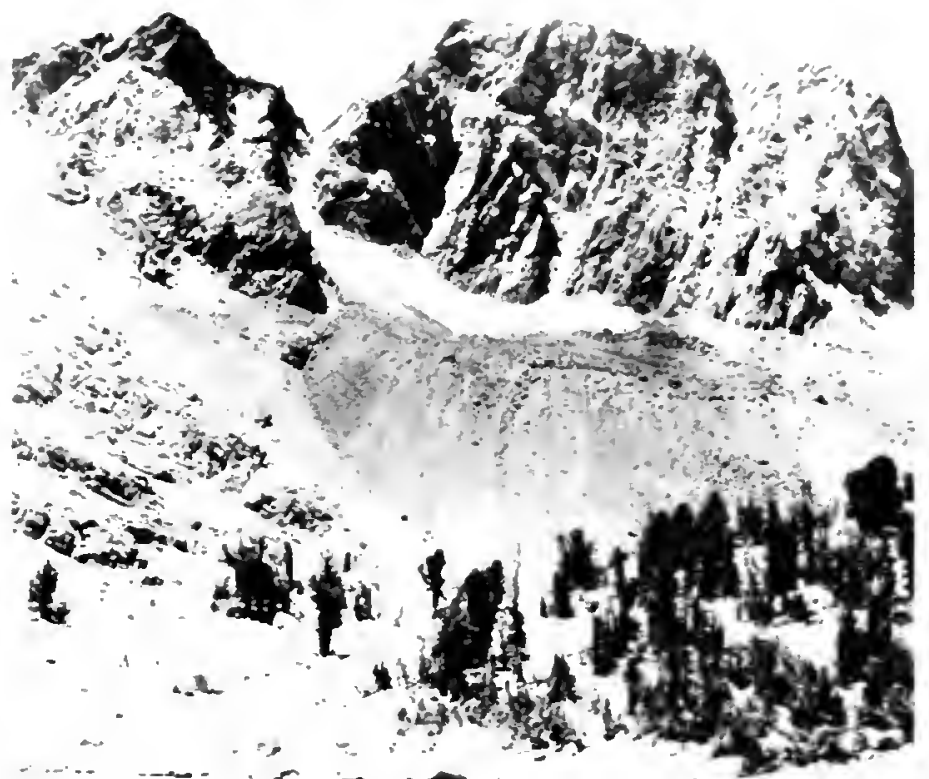

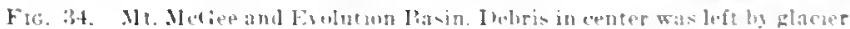

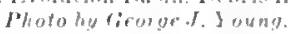

these more northerly peaks is consonant with the slope of the erest of the fault bloek in that direction from the .hount Whitney region.

Iount Whitney is about I.000 feet higher than other peaks in the immediate vionity which have rounded or enently sloping summits sueh as Young. Ilitehook. Lone J'ine, and Cirque. Nhmnt Langley (I4.042 feet) also exceels by a similar amount summits in its neiglibor hood. Furthermore the smouthly anving slopes of these lower moun tains deseend to levels at about I2.000 foet and seem to have besn evolved with referene to lower valley floors than either Whitney or Langley, whose slepes deseenl to remnints of a former valley which

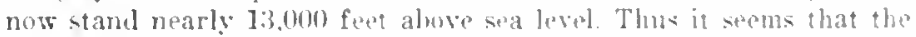

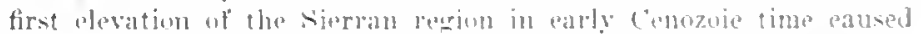

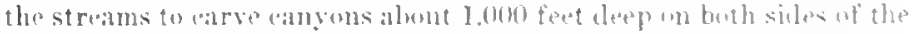

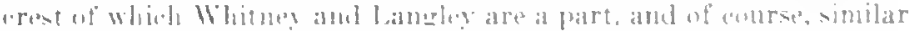
erosion oecu"red elsewhere in the ranere. During the wuint that followed this cisturbance the streams pasid from youth to maturitg.

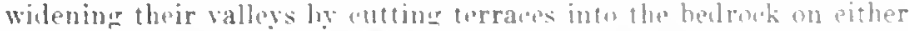
side of thair centres. At the sime time the monmtain slopes were worn back to rather erentle angles. This unliti increaled the elevation of 


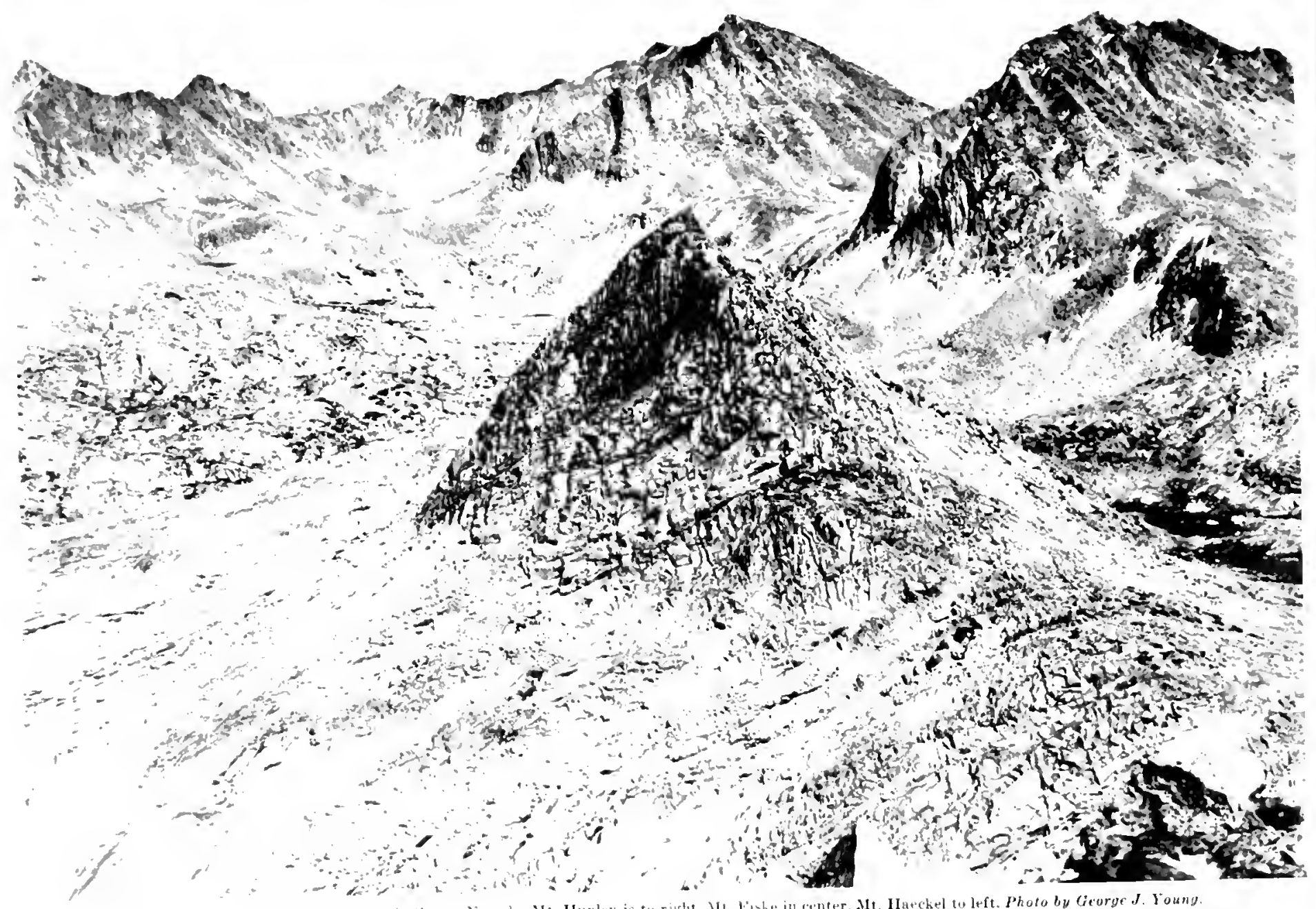

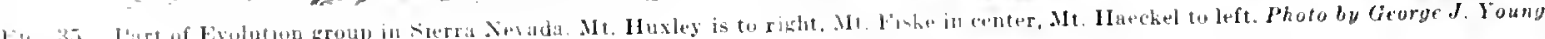




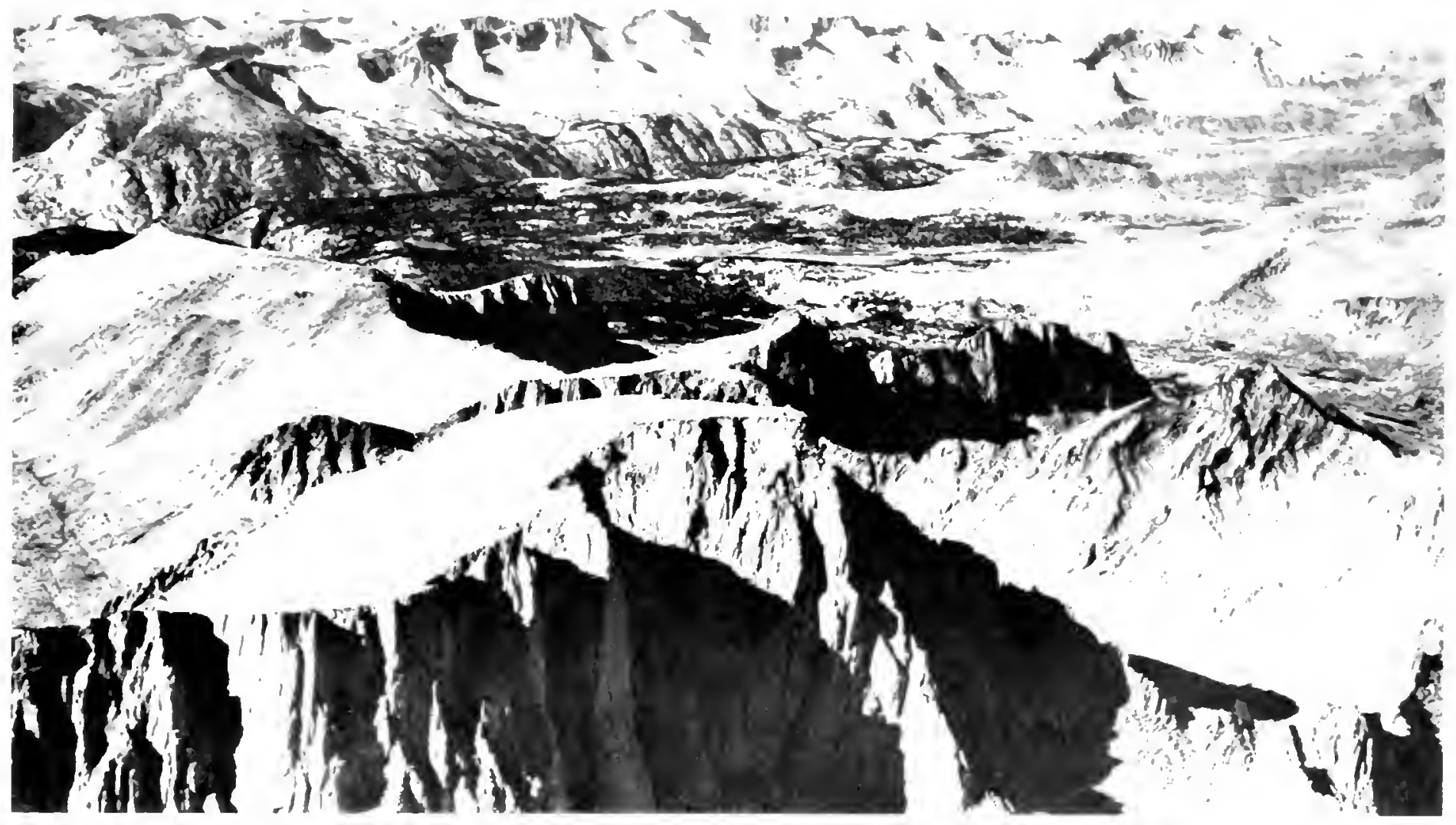

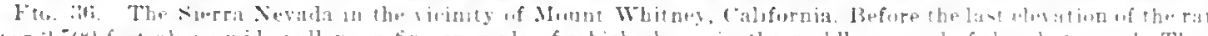

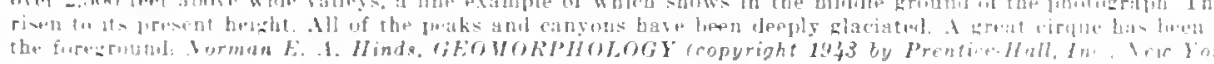

Mount Whitney to about 4.000 feet. and, because of the valley orosion. caused it to stand another 500 to 6010 feet higher above its immediate baun. Alwo lung spurs were carved on both siles of the erest, which are representeal by lluunt Young (13.493 feet) and Lone Pine leak $12.4,1$ feet

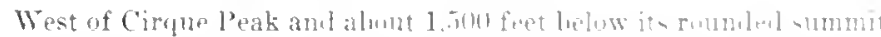
is a gently undulatine platean that patemls unbroken for 7 miles to

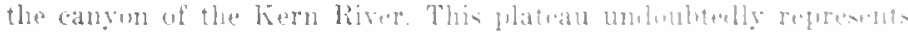

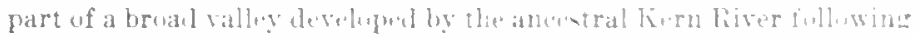

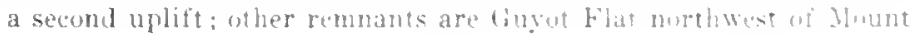




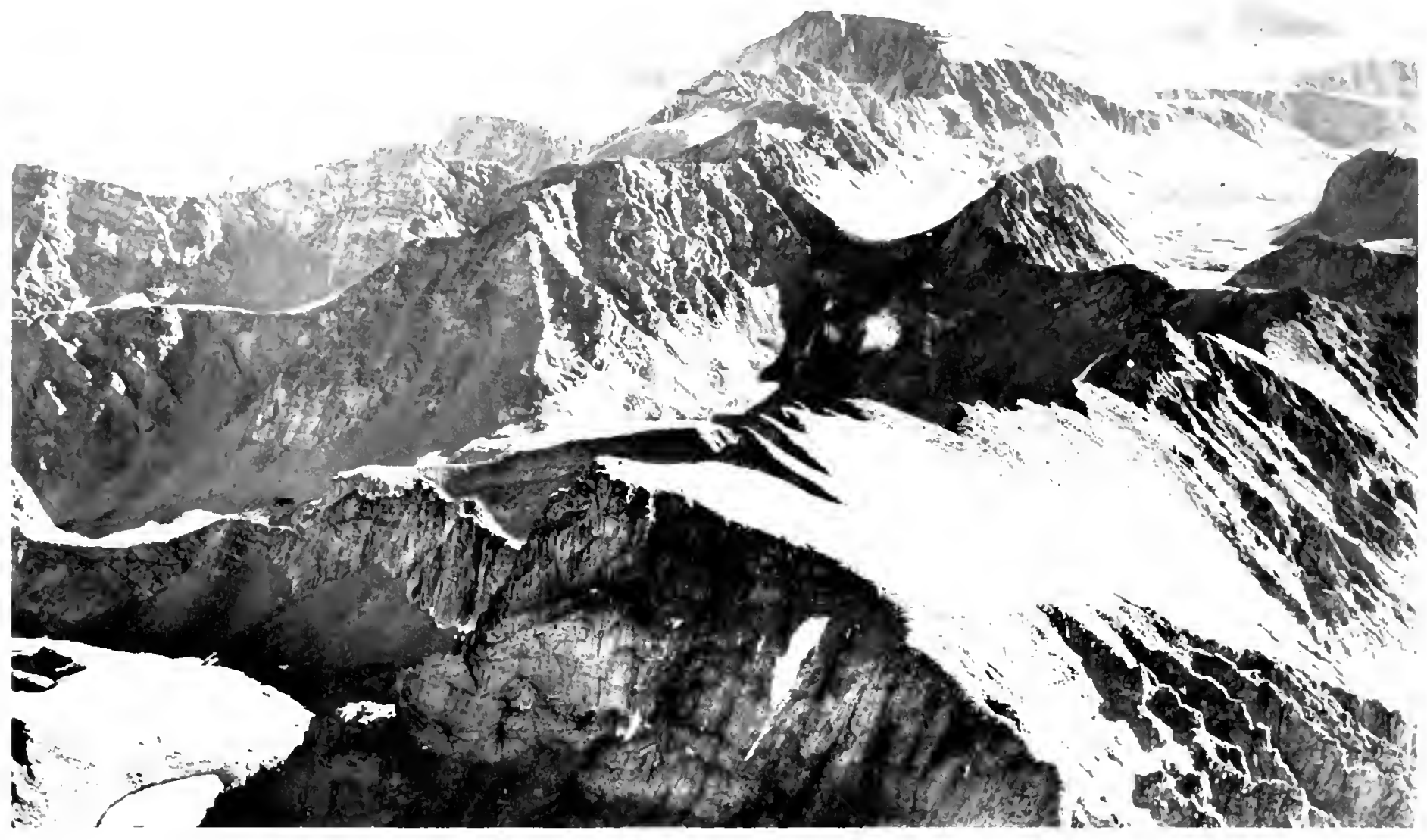

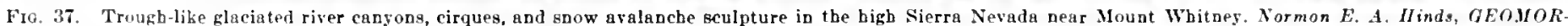
PIIOLOOY (copyright 1949 by Prentice-IIall, Inc., New York). Reproduced by permission of the publisher.

Guyot and Bighorn Plateau between Wallace Crcek and Tyndall Creek. Apparently this second deformation, which oceurred in late Mioeene and atry Plincente time, athed ahout 3,000 feet to the elevation of Mount Whitney, so that it stood 7,000 feet above sea level. Its height above its western base resulting from this further valley eutting was about 2,000 feet as compared with the 500 feet of the "Whitney IIIll" first deseribed.

A bout 1,500 feet below the terrace remnants just deseribed hie broad, gintly sloping rock benches that flank the deep Kern River canyon. One of these is the Chagoopa Plateau which rises from an elevation of about 8,600 feet at the canyon rim to about 10,500 feet at the base of the mountains. These benehes are elearly remnants of a former broad valley of the Kern River eroded after a third period of uplift which seems to bave added about 2,000 feet to the elevation of the Sierra Nevada, thus raising the summit of Mount Whitney to about 9,000 feet. Probably this was part of the Aincene-Pliocene deformation.

The present Kern River eanyon, like other deep canyons in the Sierra Nevada, is the produet of vigorous stream erosion aceompany- 
ing the clevation of the region which started just before the beginning of the Glacial epoch and has continued with notably decreased intensity until the present. The part of the Kern River canyon in the Mount Whitney region is 2,000 to 2,500 feet deep and has been strongly glaciated.

The U-shaped form of the upper part of the Kern River eanyon is the product of glacial nodification of a normal $V$-shaped river canyon. There were at least three invasions by the ice and further study nay reveal a fourth. Tributary to the master gorge are the canyons of Wallace, Whitner, Rock, and other creeks. Because of the recency of eleration in the Sierran region, these tributaries have eroded gorges only about a mile in length, at the mouths of which water plunges precipitously into the main canyon. Thus they are hanging valleys such as are present in the Yosemite and other sections of the Sierra Nevada. The glaciation of the valley of Whitney Creek differs materially in its rarious parts. In the lower section, the ice was never more than 600 feet thick and wrought only moderate changes; but, near the base of Mount Thitney, where two tributary glaciers joined, the comhined tongue exceeded 1,000 feet in depth and the glacier remained longer than it did far down the valley, altering the original form of the river-eut gorge to greater degree.

On the eastern side of the Muir Crest, vigorous ice attack profoundly modified the canyon heads by eroding large cirques which worked back, destroying pre-glacial slopes and spurs and even carrying away part of the main divide as between Mount Whitney and Whitney Pass, where only the western slope now remains. In some places, as south of Ilount Le Conte, the divide was attacked from botb sides, and was reduced to a narrow, ragged, comb ridge; in others, as between Mounts Whitney and Russell, the growth of opposing cirques was so extensive as to leave only a thin rock wall. In a few localities, as between Mounts McAdie and Mallory, the divide was destroyed and replaced by a saddle.

Mount Whitney must have been a dome of considerable bulk, even if not of grcat height ahove its surroundings, or it would have been reduced to a thin spire like its neighbor, Mount Russell. Even so, the entire eastern half has been cut away by small, but long-lived glaciers which lay upon its slopes until comparatively recent times. Destruetion still goes on vigorously because of frost wedging and the fall of multitudes of loosened blocks down the steep slopes. A considerable section of the north side of the peak was removed by the glacial widening of a eanyon between it and Mount Russell, and on the west, the lower pre-glacial slope has been destroyed by the enlargement of Whitney Canyon while occupied by ice. The southeast side also lost a small slice by the incision of a narrow cleft, the northernmost of a similar series that break the crestline at intervals of more than a mile to the south of Mount Whitney and through which oecasional views may be obtained to the castward from the trail up the muntain. These clefts are not glacial features but have resulted from active frost wedging aicled by snow sliding along vertical zones where the pranite appears to have been sheared by ancient faulting into thin, rather easily removable vertical plates. Only on the southwestern side does Whitney retain its original pre-glacial slope which connects it with the equally unglaciated slope of the main divide.

The upper slopes of Mount Whitney and the entire length of the Muir Crest show no evidence of glacial attack, in striking contrast with the abundant evidence of such action in the upper San Joaquin and Tuolumne drainage areas and in the Kaweah, Kings, and Kern basins. This probably results from the close proximity of the Muir Crest to the southern limit of Sierran glaciation and also to the effect of the Great Western Divide upon which the rising air currents delivered most of their moisture as they do today, thus keeping a greater share from the Wuir Crest. Such topographic barriers produce striking climatic contrasts within short distances.

Above the level of the ancient glaciers, the sides of Mount Whitney are furrowed by parallel or converging snow or alalanche chutes developed by powerful erosion as the great snow eancades swept down the steep slopes. Some of the chntes are 50 to 100 feet deep. and. where close together, are separated by narrow rock ribs which give the cliffs a fluted appearance. The hottoms of the chutes have been worn smoothly concave by the abrasive action of rock carried along by the snow slides. Avalanche chutes are best developed on the west side of Mount Whitner: though they also show well on the north side. Even more perfect, though not so deep, are those on the north side of Mount Hiteheock and in the cirque at the head of Whitney Canyon. The Whitney region is especially rich in this type of sculpture becanse of rather regular joint and fault structure in the granitoid rock which makes for easy erosion. In other parts, where the joints are more widely spaced or irrenular, the chutes are sparse and not well developed.

Studies indicate that snow conditions prevailing on the flattish summit of Nount Whitney are closely related to evolution of the chutes. The avalanches produeing them come largely from snow blown to the east as great "snow banners" by terrifie winds sweeping across the top of the mountain. Although most of the snow goes astward, con. siderable amounts are driven in other direetions, accumulating as massive cornices at the edge of plat furrus, with the snow now and then collapsing to produce the avaldanelses.

Today in the winter the flat tops of the Sierran peaks are covered only with a thin mante of snow because of alde powerful winds which sweep aeross them; this condition secms to have prevailed during the 
glacial stages. Therefore these summits have eseaped the ice attaek which has been so effeetive at lower elevations. Not only this, but there also has been little stream erosion to modify their contour. IIeavy showers are rare at such high elevations and snow melts too slowly to produce streams of water. In fact, most of the water sinks into the rocks where it freezes during both summer and winter, eraeking the roc:: to produce the great multitude of blocks which cover the tops of the flat peaks and have fallen down the slopes to form huge talus cones and oprons.

Thus we have in Mount Whitney and most of the other peaks of the high Sierra, hills and low mountains belonging to a time when the highest stood not more than 2,000 feet above sea level and the Sierra Nevada was anything but an imposing region. This perhaps was 60 million years ago. The changes which have followed bave produced the remarkable multiple landscape, of which extensive remnants have been preserved because the vigorous erosion accompanying the late elevation of the range has not had time to destroy them.

\section{Glacial Lakes}

In the glaciated seetions of the Sierra Nevada are hundreds of small, very beautiful lakes which add immensely to the glory of a landseape undoubtedly almost lakeless prior to invasion by the ice. Although there may have been a good many lakes and swamps when the Sierran region was worn down to its lowest stand 60 million years ago, it is certain that few existed as the mountains rose; the normal proeesses of mountain erosion are against their formation as the land is too much broken up by active streams. A few basins may be evolved by faulting, landsliding, or voleanic aetion but their total is far short of the number present in those scetions of all mountain ranges remodeled by iee.

The present lakes were produced by the latest glaciers though undoubtedly many were formed as the earlier sheets and tongues left the range. Perhaps in many eases the thinner and weaker glaciers of the last stage merely eleaned out debris-filled basins excavated by the earlier, more powerful ice masses, but without douht they dug additional basins. In the high Sierra, where the reservoir ice supplying the slaciers evolved in eanyon heads and eroded eirques, it etched depressions into the bedrock in whieh lie hundreds of cirque lakes. In this part of the range, and also in the lower northern and southern sections, eirque lakes are most abundant on northeast slopes where the snow was drifted by the prevailing westerly winds and where melting was least effective. The peaks above such lakes are typically unsymmetrieal, being steeply cliffed on the northeast side, where the cirques have been incised, and more rounded on the southwest. The rounded slopes are remnants of the ancient hills and low mountains whieh had been evolved prior to the late elevation of the region.
Cirques not oeeupied by the last ice have been considerably modified by erosion, their bottoms filled with great masses of talus, and lakes that were present have been eonverted to meadows. In cirques where the last ice grew, the rock is generally so bare as to indicate that the glaciers have very recently left. Where several cirques are being eroded opposite each other in valleys radiating from a dome-shaped peak like most of those in the pre-glacial Sierra Nevada, the cirque lakes are separated by high ridges commonly having exceedingly ragged crests and the peak itself has been reduced to a steeply sloping spire. On the other hand, if several pre-glacial valleys headed in a group of mountains and converged into a trunk eanyon, the cirques have a similar converging pattern, the smaller ones hanging above the canyon. The cirque lakes of sueh a group therefore are closely associated.

In the Sierra Nevada there are many cirque lakes in basins developed under one of the two conditions described above. In the higher middle seetion they are present by the hundreds but farther north and south where the glaciation was less intense there are not so many. Gold Lake, at the head of a tributary of the Middle Fork of the Feather River, has a length of about 2 miles and is one of the largest eirque lakes. Somewhat farther south below Sierra Buttes near the North Fork of the Yuba River and a round Fall Creek Mountain near the South Fork of the same river, are two groups of lakes. $A$ number of small cirque lakes lie at the beadwaters of the Kaweah River in Sequoia National Forest, and fourteen of them, more or less completely eonverted to marshes, are elustered around the head of the Stanislaus River.

In some of the U-shaped valleys, basins have been excavated below the cirques. The lakes filling them, starting with those in the cirques, are eonnected by a stream flowing in and out and from a distance look like beads of turquoise or sapphire on a chain. The basins are in plaees partieularly suseeptible to erosion where the rock was closely jointed, or where it was slightly less resistant than the immediately adjacent rock. Such chains of lakes are found in the headwaters of Illilonet te Creek, 16 miles southeast of Yosemite Valley, between Mammoth Mountain and Mammoth Crest high on the eastern slope of the Sierra Nevada 22 miles south of Mono Lake, and farther south in the Sixty-Lake basin at the headraters of the Kings River below Mount King.

Garnet Lake and Thousand Island Lake, whish have a roundabout drainage to the Middle Fork of the San Joaquin River, stand ont among cirque lakes beeause of the many roeky islands rising above their surfaces.

$\Lambda$ few lakes like Silver, Loon, and Pleasant in glaeiated branches of the South Fork of the American River appear to lie in the lowest parts of unevenly eroded valley floor. Where the valleys are narrow and steep walled, such lakes are long and oval in plan, being larger 


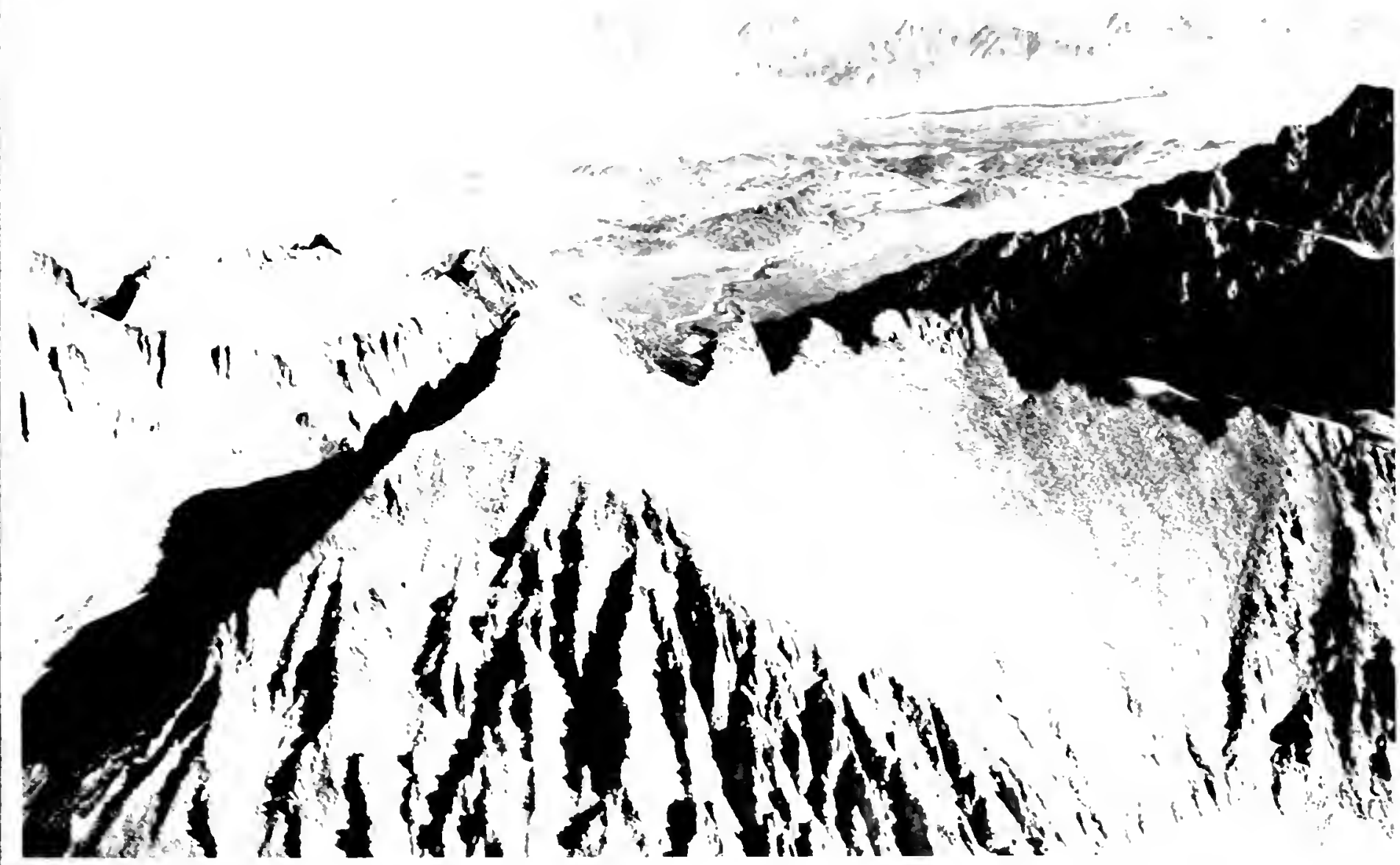

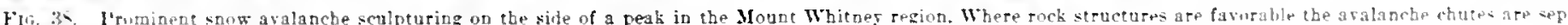

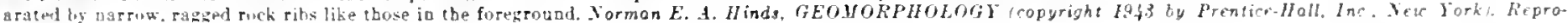
dured by permisgion of the publisher.

than the normal rock-basin lakes; but if the glacial trough is wider, the lakes are broader, irregular in outline, and commonly have roeky islets projecting from them.

In the barren. wind-swept, rolling upland toward the higher part of the range, where remnants of the ancient landseape are preserved

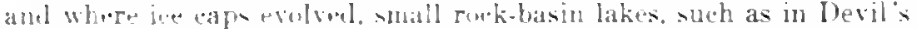
Basin, a wide area at about 8,200 feet at the head of the South Fork of the Ineriean River, alw are present. IInphres Basin, at abut
11.000 feet at the head of the Sonth Fork of the San Joaquin liver. is another example. In this area is Desolation Lake, about I nite in length.

Certain lakes lie at or toward the end of the glaviated s..etion of a canyon and are partly impounded by a barrier of morainal material. The most familiar example is Doniner Lake (elevation $6 . t(n)$ feet) about 3 miles long, on Highway 40 on the east slle of I lonner l'ass In the same drainage basin. but less often snen betane it lin ligher in the mountains to the northeast is Imlemendence lake elesaion 


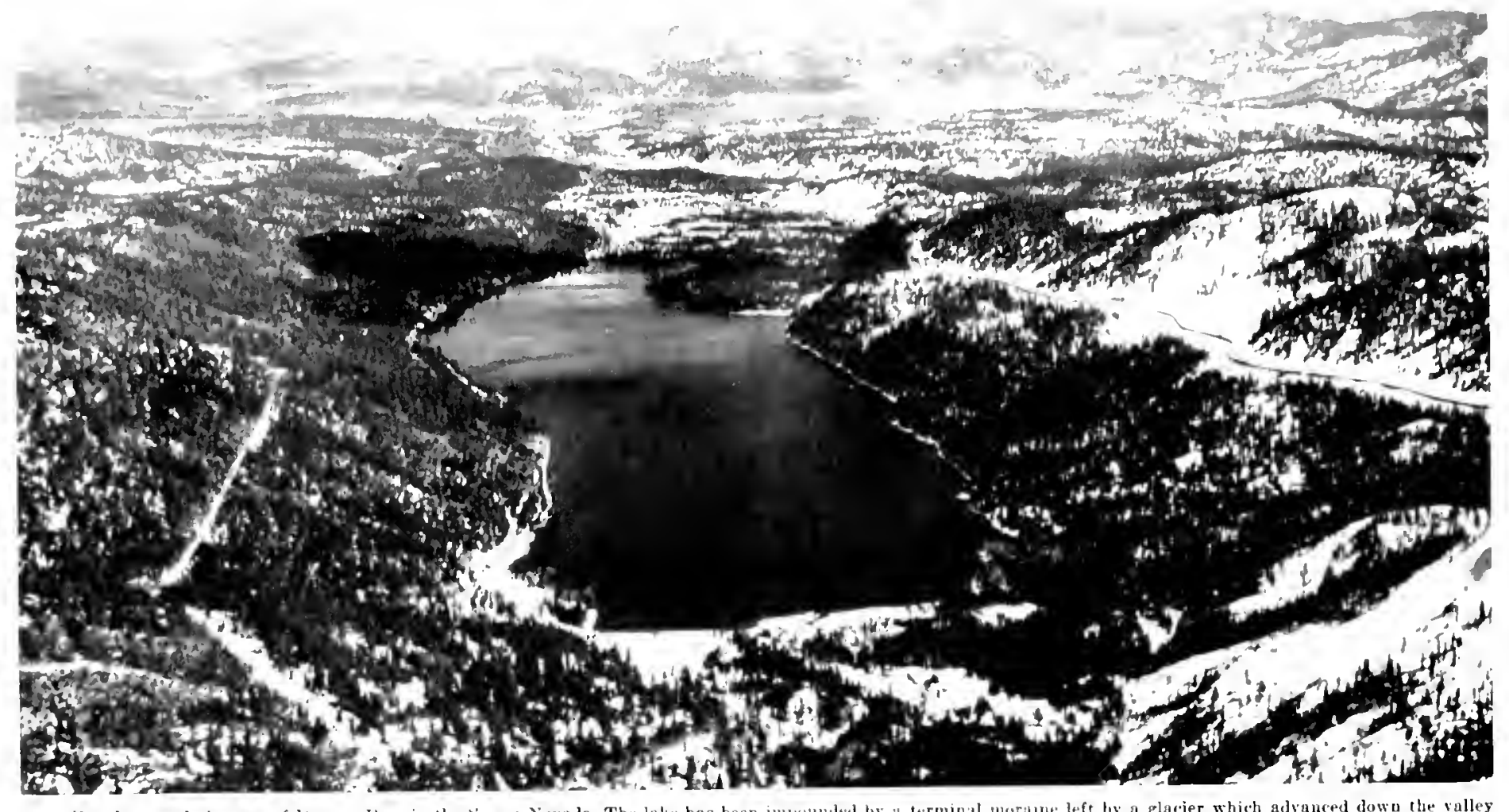

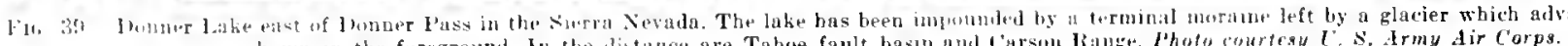

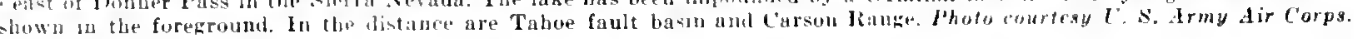


7,000 feet), which is 2 miles in length. Well-known Falten I,eaf Lake (about 6.400 feet) on the southwest side of lake Tahoe is about the same size as Donner Lake and its barrier is a relatively low moraine of the last glacial stage. However. beyond this deposit are huge moraines of the preceling stage: one southeast of Fallon Leaf Lake in about 3 miles long and rises abruptly for 900 feet above its surroundings. Caseade Lake, 3 miles northwest of Fallen Leaf and of about the same size and altitude. lies behind a eompound loop of morainal deposits. Twin I akes, having a enmbined length of 3 miles, and more than 7,000 feet high on a fork of the Walker River 15 miles southwest of Nono lake, also lise behind a moraine and have been separated by the growth of delta plain denosits near the middle.

Many of the Sierran lakes have been filled or nearly filled with sediment and now are meadows covered either with small vegetation or trees: these meadows are some of the most delightful spots in the Sierran eanyons. The best kuown is that in Yosemite Valley. Another ocenpies the lower part of Tenaya Canyon, northern tributary of the Yosemite, and is the fill of a rock-basin lake. Still a third of larger size oecupies part of Little losemite Canyon. One of the longest filled areas is Tuolunne Meadows whin apparently represents the filling of several closely spacenl rock-basin lakes.

Most of the meadow are larger than the lakes were, for the deposits generally have spread in some or all directions beyond the margins of the basins.

Numerous lakes impounded by landslicles from steep canyon walls are present in the Sierra Nevada. Mirror lake in Yosemite Valley is one of these. Another is Kern Lake in Kern River canyon.

\section{Artificial Lakes}

Ilany reserwirs have been estallished in the Sierra Nevada for food protection, water storage for irrigation and other uses, and power generation. Some of the principal examples are Almanor near the intersection of Highways 36 and 89 at the north end of the Sierra Vevada, a group in the Inkelumne basin which supplies water for cities on the east side of San Fran iseo Bay and another. prineipally Hetch Hetchy Reservoir, whieh is the principal snurce of tan Francisco's water supply. Still other artificial lakes of considerable size are the Pardee Reservoir near Jackson, the Calaveras Reservoir near San Andreas. Near the mouth of the canyon of the San Joaquin River is the Friant Dam which impounds. Millerton Lake; this is the second most important element in the great Central Valley Project which is so vital to the Sacramento and San Joaquin Valleys. The priueipal unit in this project is the huge Shata Dam in the Kiamath Jountains of California. Water is to be exported to various partin of the eastern

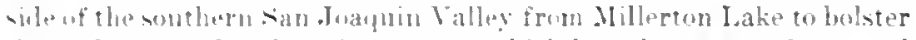
the underground and surface waters which have been soverely tapped
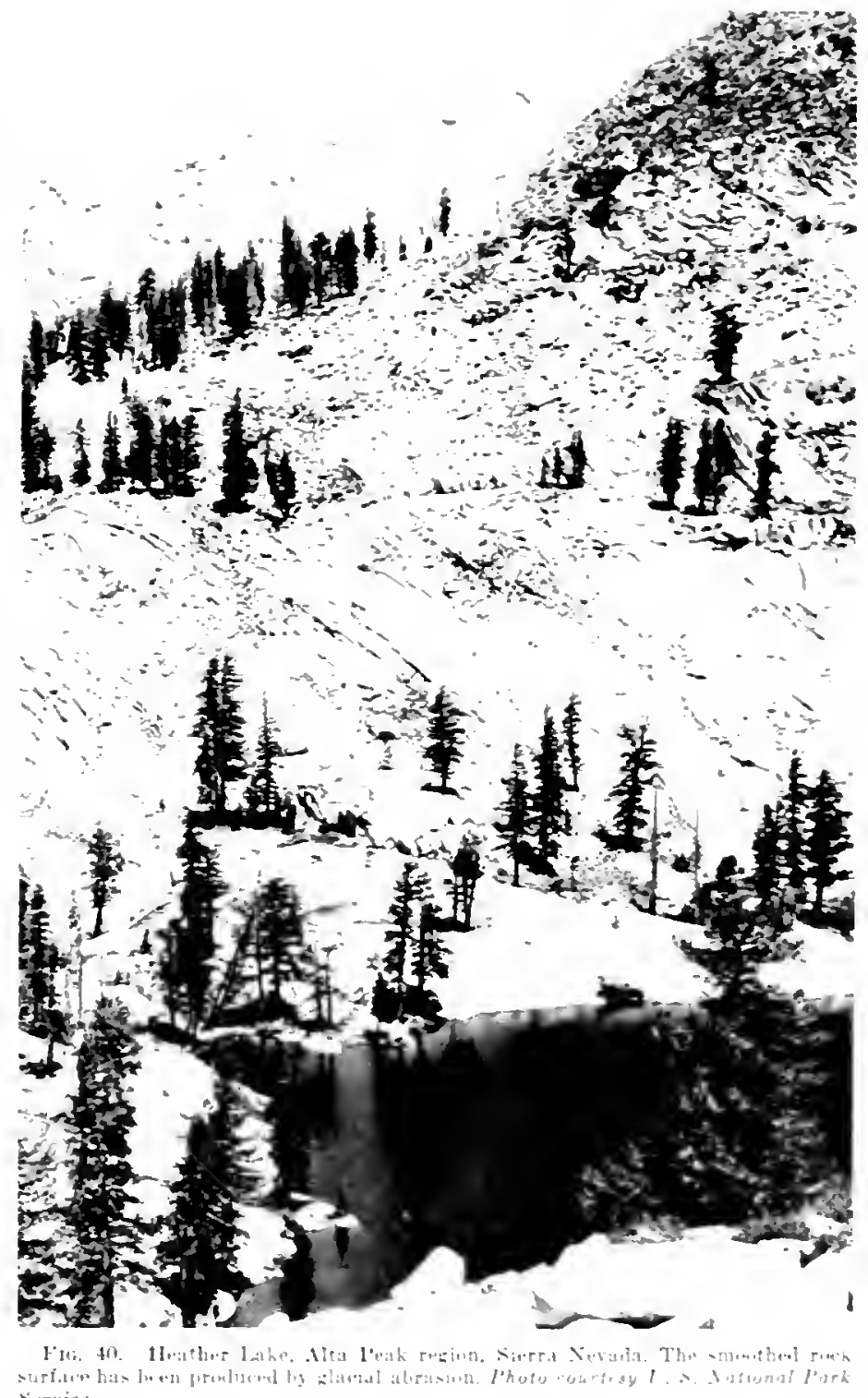

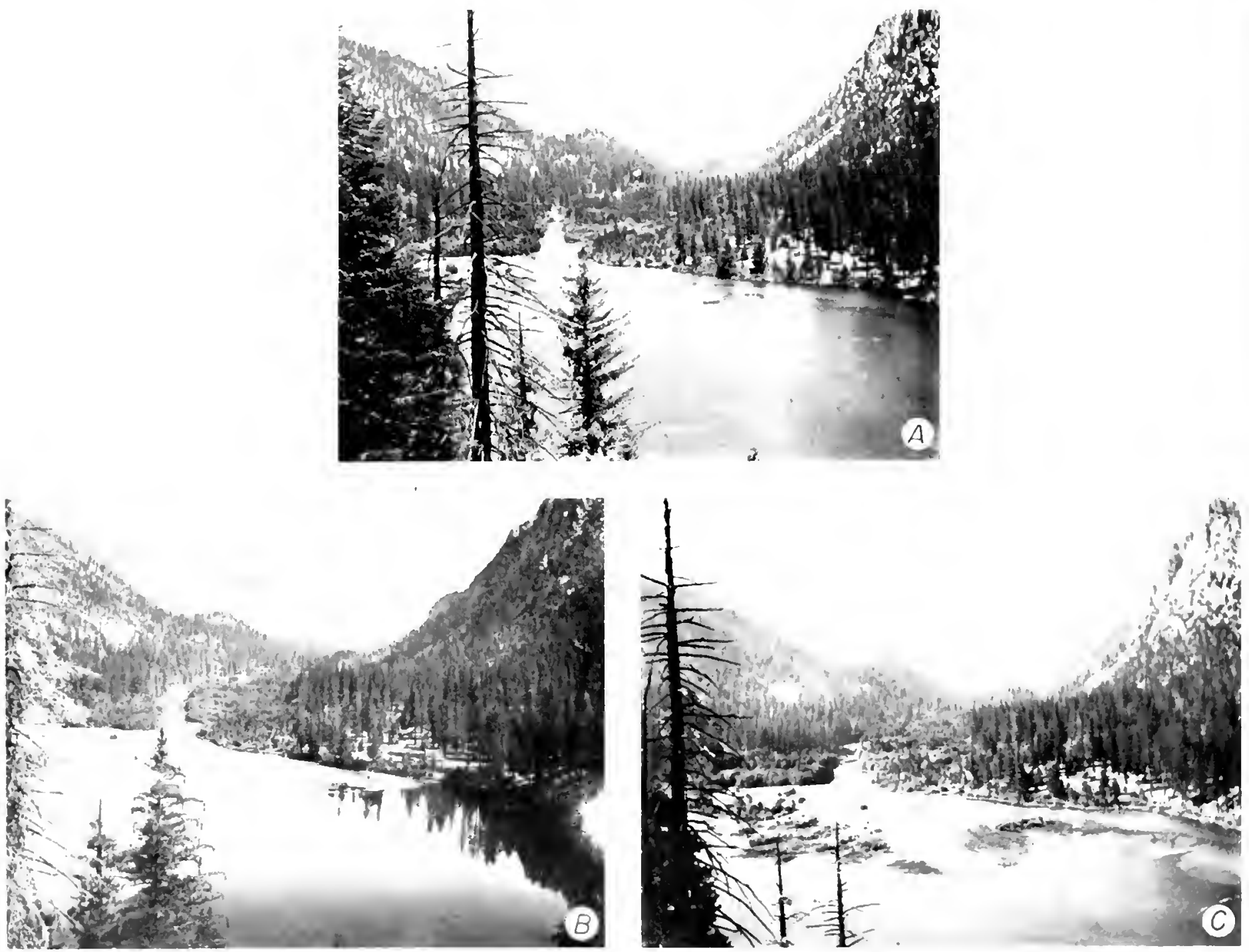

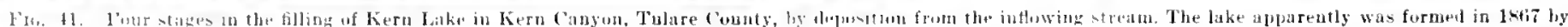

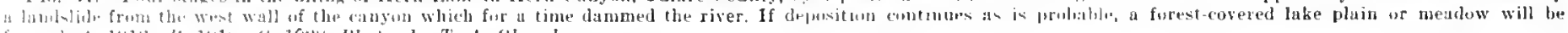

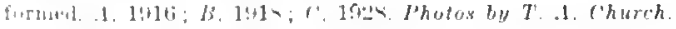


by wrowing population, agrieulture, and industry. Many of these reservoirs have become pleasure resorts to which hundreds of people go for outings of various types.

\section{VOLCANISM}

Along part of the Kern and Little Kern canyons are the l'alisades. part of a lava field that shows at least four distinet fows, each of which possesses rather crudely developel columnar jointing perpendicular to the flow surface. This jointing developed as the lava cooled and eontracted. In other places in the field there are more flows, but thin, weathered zonus betwen them makes separation difficult as the lavas are similar in composition. The total thickness of the lava in remnants that are left exceeds 400 feet; how much has been removed by erosion cannot be determined.

In the Toowa Valley below Toowa Range-a high ralley drained to the west by a stream known variously as Godel. Trout. Yolcano, or Little Whitney creek, and to the east by the Sonth Fork of the Middle Kern Rirer-there is another volcanie field which covers an area about a half mile wide and $t$ to $i$ miles long. This field contains flows and cinder cones. Cinder cones are small rolcanoes, generally less than 1,000 feet high, composed entirely of lara fragments. Host of them are built during brief eruptive cycles lasting a few days. weeks, or months.

Toowa Valley is broad and open and stands at an elevation of about 8,600 feet. The cones rise from 400 to 600 feet above the veneer of flows which corers the bedrock. The latest aetivity blocked drainage, as two prominent eones lie along the axis of the ralley-South Fork Cone where Golden Trout Creek enters Toowa Valley, and Groundlog Cone $2 \frac{1}{2}$ miles farther east. Two other volcanie centers are in the valley, one at the head of Little Whitney Meadow and one at the Tunnel, north of South Fork Cone. The activity has been so recent that soil is seanty and therefore regetation is sparse. Sereral stages in the total eruptive cycle are recorded. It is evident that these eruptions occurred long after the major faults outlining the eastern base of the Sierra Nevada had been evolved.

Earlier basalt apparently of pre-glacial age poured from rents in the canyon of the North Fork of Oak Creek and spread over an alluvial cone formed by the stream issuing from its mouth. Later this lava was partly eroded and eovered by debris of the first glacial stage. Basalt flows, probably of the same age. form a number of isolated patches on the south side of Bishop Creek which issues from the Sierra Nevala.

Another considerable volcanic area is located in the headwaters of the Middle Fork of the San Joaquin River to the east of the towering range which has Mount Ritter, Banner l'eak, and The Minarets as its principal peaks. The summit of the range is somewhat over 13.000 feet above sea level; Mount Ritter rises abruptly more than a nile above an area of much gentler relief which fually ascends to the lower main eastern divide of the Sierra Nevala, a crest much less imponing than those to the north and south. The rolling area between the two mountainous barriers probably was part of one of the flat valleys belonging to a landsape evolved prior to the last elevation of the Sierra Nevada. The section described has been extensively cuvered hy pumice and lava which is believed to he at least 2.000 feet thick in places. The frothy pumice fragments were exploded from a series of cones at least 30 in number lying mostly east of the Sierra Nevalla and extending from Manmoth Mountain to Mono Lake, and includ. ing the Mono voleanic range. Most of the pumice came down around the voleanic pipes forming the voleanoes but finer debris was carried far by the wind and is found sprinkling a considerable part of this seetion of the range. Mammoth Pass and the divile for several miles north are most liearily mantled, and Pumice Flat. as the name indieates, has a goodly cover. Eren at Reds Meadow and farther south along the Middle Fork of the San Joaquin River, there is a thin reneer of pumice.

From the alignment of the cones, it is erident that they are located along some of the faults evolved during the great landscape changes in the eastern part of the Sierra Nevada. Certain of these fractures apparently penetrate into the range for some distance as is indicated by the fact that Mammoth Mountain, a greatly worn old rolcano, the Little Red Cones on the east side of the Middle Fork. and Pumice Butte north of Fish Creek stand in line with them. The well-known hot spring near Reds Meadow, though somewhat to the west of the line of cones, probably rises along a branch of this fracture system.

Volcanic eruptions occurred along these faults at different times. Mammoth Jountain, a modest eminence which belies its name. was built prior to the beginning of the Glacial epoch and therefore is more than a million years old. So nuch time las elapsed since activity ceased at this vent that the original form of the cone has been destroved and there remains only a shapeless mass of voleanic debris. The pumice outbursts are the latest chapter in the recurrent eruptions along the faults, having begun late in the fourth glacial stage and continuing until quite recent time, though not within the historie period

During the third interglacial stage, more than 100.000 years ago, a fiscure opened in Mammoth Pass and from it spilled a fon? of hasaltic lava most of which streamed into the enyyon of the San Joaquin's Middle Fork, spreading out as a tongue from the head of l'umice Flat

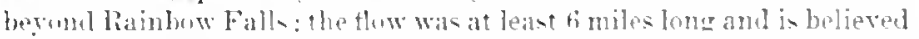
to have ranged from 100 to 700 feet in thitkness. A the rmok cooled

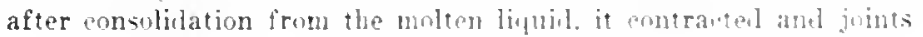
formed whicl broke it into rather asily removable colums. 


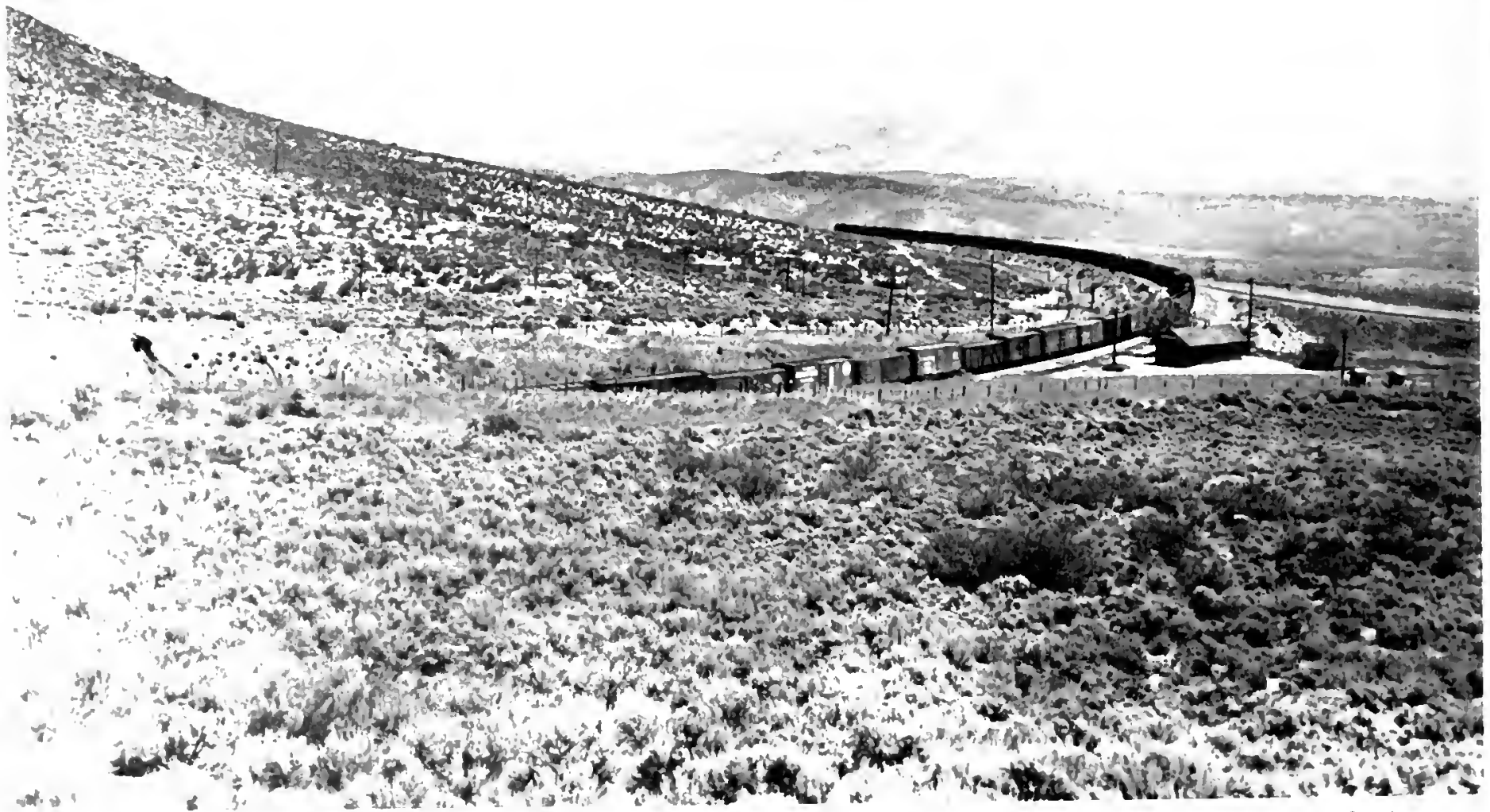

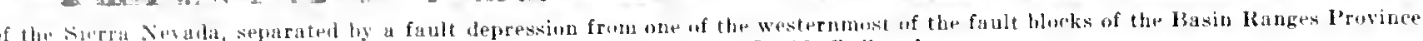




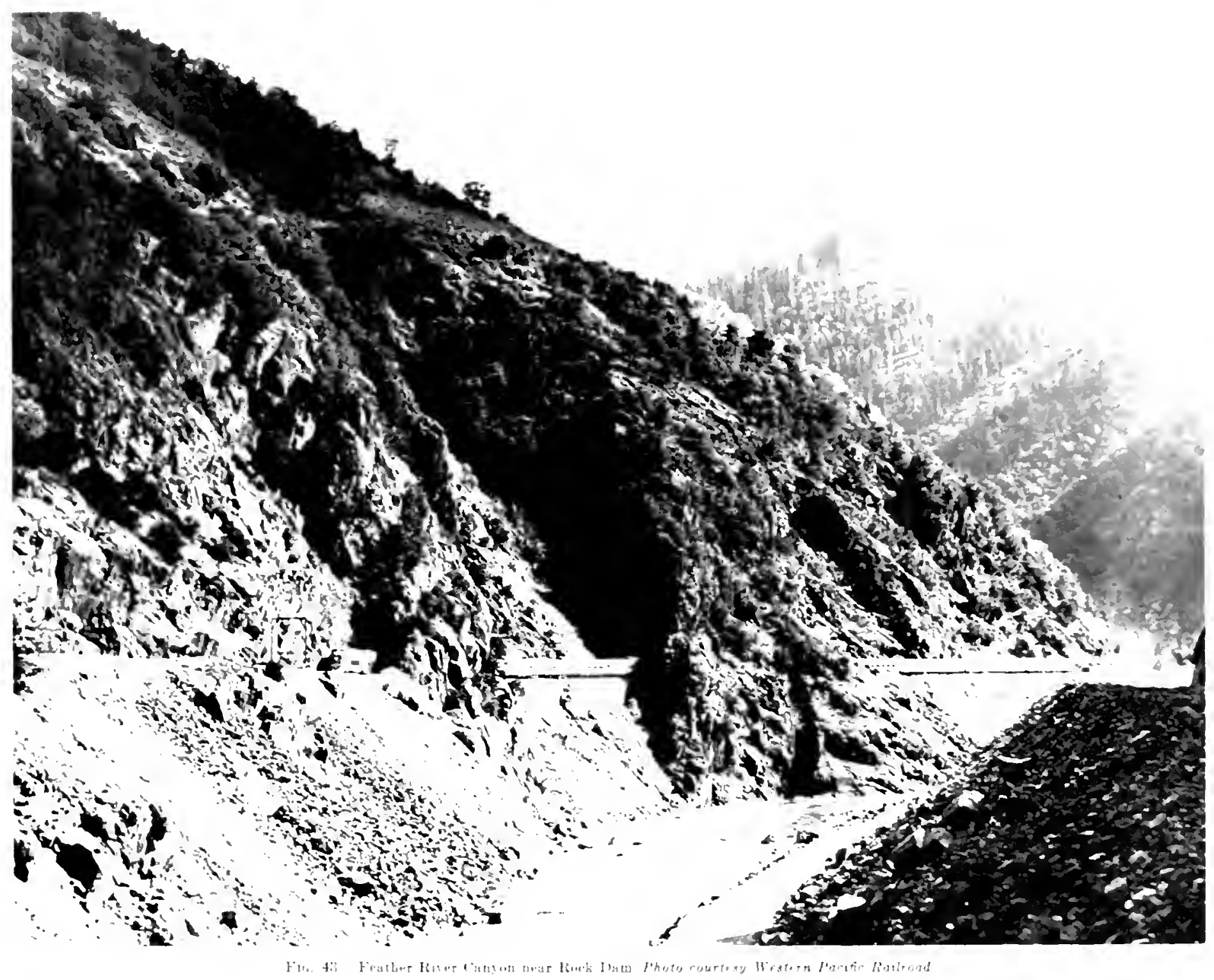


When the last glacier descended the Middle Fork canyon, the lava flow formed an obstruction in its path; but the ire was about 1,000 fect thick and therefore overrode the barrier. The prominent jointing made possible easy quarrying by the glacier which was present long enongh to remove most of the lava and re-exeavate the canyon down to the granitoid roek beneath. Only the most resistant parts of the flow escaped destruction. The largest remnant is a hump in the middle of the canyon which is about 300 yards long and 200 feet high. Because of the resimblance of its tall, straight columns to stacked posts, it has been called the Devil's Postpile, and a National Monument has been ereated to protect it.

The columns forming the steep western front of the Postpile are high, straight, and very clearly outlined, but those at the sonthern end are even more remarkable for their curvature and radial arrangement with respect to a center at the top of the pile. On this upper surface may be seen the five-or six-sided ends of the columns, in places still possessing the polish and striations given to them by the overriding glacier.

\section{REFERENCES}

Atwood, W. W., Jr., Crater Lake and Yosemite through the ages: National Geographic Nagazine, vol. 71 , mp. 326-343, 1937.

Beatty, M. F.. A brief story of the geology of Fosemite Valley : Nature Notes, Special Number, Natiogal l'ark Service, 1943.

Blackwelder, Eliot, Pleistocene glaciation in the Sierra Nevada and Bagia

Ranges: Geol. Snc. America Bull., rol, 42, pp. 86r.-891, 1937.

Blackwelder, Fliot. Supplementary notes on Pleistocone glaciation in the Great Basin: Wash. Acad. Sci. Jour., vol. 24, pr. $21 \mathrm{~T}-222,1934$.

Daris, W. M., The lakes of California: California Jour. Mines aod Geology, rol. 29. pp. 175-236, 1933.

Flint, R. F., Glacial geology aod the Pleistocene enoch, John Wiley and Sons, Inc., 1947.
IIIls, T. M., Glacintion of the upper Fero ad its tributaries: Sierra Clab Ibull., rol. 12, pp. 17.19, 1928 .

Jones, W. I., Cincial laud forms io the Sierra Nevada south of Iake Taboe: Univ, California l'ub. Geog., vol, 3. Jp. 137-157, 1929.

KFesseli, J. 1., Situdies in the l'leistucene glaciation of the Sirra Nevada: ["aiv. California l'ub. Geog., vol. 6, np. 315-361, J941.

Knopf, $A$, and lirk, $\mathbf{E}$, A geologic reconmissance of the Inro kange and the eastera slope of the southero Sierra Nevada, Calilornia: $U$. S. Genl. Sarvey, I'rof. Paper 110. 1918.

Lawson, A. C. The geomorphology of the upper Kern Basin, Califoraia: Uaiv. Califorsin Dept. Feolugs Bull., vol. 3, pp. 291-376, 1904.

Lawson, A. C., The giomorphologic features of the Midjle Keru: C'niv. Califoraia Dept. Geology Bull., vol. 4, mp. 397-409, 1906.

Iouderhack, G. D., Lake Taboe, Califoroia-Nevada: Jour. Geograpby, vol. 9 pp. $277-279,1911$.

Toaderback, C. D., Morphologic leatures of Basin Range clisplacoments in the Great Basia: [air. Califoraia Dept. Geol. Sci. Bull., rol. 16, 11p. 1-42, 1926.

Intthes, F. F., Kings River and Yosemite Valley : Sierra Clab Rull., rol. 12, pp. 224-236, 1226.

Matthes, F. F., Devil's Postpile in the Sierra Nevada and its stragne setting: Sierra Club Bull., vol. 15, np. 1.S, 1930.

Tatthes, F. E., Geologic history of Fosemite Valles: I. S. Geol. Surrey Prot. Paper 160, 1930.

Natthes, F. F., Geography and guidebook of the Sierra Nevada; 16th Internat. Geol. Cong., Guidelook 16, pp. 26-40, 1933.

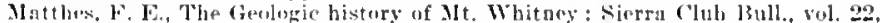
p. 1-18, 1937.

Matthes, F. E., Avalanche seulpture in the Sierrn Nevala of California : Internat. Assne. IJydrology Ball. 23, pp. 631-637, 1938.

Matthes, F. E.. The incomparable valley, Caiv, Califormia Press, 160 pp., 1930. Matthes, F. E., Sequoia National Park, Caiv, California J'ress, 1:36 pp., 1950 Miller, W. J., Feologic sections across the southern Sierra Nevada of California Univ. California Dept. Geol. Sci. Bull., rol. 20, pp. 331-360, 1931.

Putan. W C. Quateraars geology of the Juge Lake district, California : Geol. Soc. Amprica Bull., vol. 60, pr. 1281-1302, 1949

Reid, J. A., The geomorphogeny of the Sierra Nevada antheast of Lake Taboe: Univ. California Dept. Feol. Sci. Ball., vol. 6. pp. 89-161, 1911.

Webh, R. W., Kern Canyon fault, south Sierra Nevada : Jour. Geology, vol. 44 pp. 631-638, I936.

Wehb, R. W. Genmorphology of the middle Kern River hasin, soutbera Sierra Nevada, Califoroia: Geol. Soc. America Bull., vol. 57 , np. 355-362, 1946. 
BASIN-RANGES 


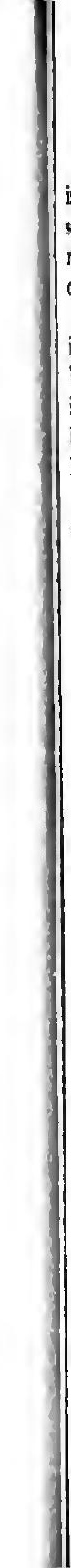




\section{BASIN-RANGES}

Margining much of the eastern boundary of California and including a considerable part of the southeastern section of the state is a section of the Basin-Ranges provinee which eonsists of north-trending ranges separated either by conpletely enelosed basins or by troughs open at one or both ends.

In northeastern California, the forces evolving this provinee invaded the Modoc seetion of the great Columbia lava platean; the Warner Mountains, which mark the western boundary of the province in this seetion are composed entirely of lava. On its western side the Basin-Ranges provinee abuts against the eastern base of the Sierra Nevala: its southern boundary adjoins the Mojave Desert provinee.

The portion of the Basin-Ranges province lying in California includes part of the belt folded into mountains by the deformation in Jurassic time. During the Cretaceous and earlier part of the Tertiary, this region, like the Sierra Nevada, underwent long erosion together with eertain re-elerations, the details of which are little known at present. In the later part of the Tertiary period, the region was subjected to further deformation, mostly large- and small-seale faulting. though some local folling took place. Along the faults certain blocks were elevated to form a new generation of ranges, while intervening bloeks were depressed in similar fashion. developing basins or troughs ealled graben. The result has been the evolution of many discontinuous mountainous areas. most of which are relatively small and not particularly high. Some, like the White-Inyo and Panamint ranges, are mueb more bulky and tower thonsands of feet above the bordering lowlands. None of the blocks approaches the Sierra Nevada in size or maximum elevation.

Throughout the Basin-Ranges provinee, elevation and depression have been mostly rotational, giving tilted range and graben blocks, though some horsts (vertically elevated blocks) are present. However, many ranges have been so deeply eroded that their original form eannot be determined.

Most of the basin ranges have been examined in reconnaissance fashion, but very fer have been studied in detail; more is known abont certain of the grabens. So aetually there is relatively little information about this vast region, though its general history can be partly outlined.

In general the province is arid, much of it highly so; the dryness inereases from north to south and is more intense in lower than in higher basins. Precipitation in Death Valley, one of the lowest spots, averages about 1.4 inches annually. Independence, in southern Owens Valley (3,957 feet) receives 4.83 inches, Bishop at the north end $(4,450$ feet $), 6.05$ incbes. Over the ranges, particularly the ligher ones, more moisture falls, but there is very little reeord of this. There is snow on the higher ranges during the colder months, heary falls on the more northerly and higher ranges, lighter on the lower and more southerly ranges. There also is considerable snow over the northern and higher basins, little or none over those at lower elevation and farther south. The rains are principally summer thunder storms which concentrate over the mountains.

Many of the basins contain lakes; some are permanent, others eontain water only part of the year or during intervals separated by more than a year. II of of the likes are saline or alkaline. On the east and west sides of the Warner Mountains in northeastern California are Goose and Middle Lakes. Mono Lake is at the eastern base of the Sierra Nevada below Tioga Pass. Owens Lake in the soutbeastern part of the valley of that name formerly was fairly large, but the Los Angeles aqueduet which takes water from the head of Owens River has materially reduced its size and will do the same to Mono Lake. Honey Lake, about 70 miles northeast of Reno, Nevada, and just inside the Cali. fornia border, is dry during the summer.

The Truckee River, flowing from the north end of Lake Tahoe, empties into Pyramid Lake about 35 miles northeast of Reno. Farther south, some streams flowing down the eastern side of the Sierra Nevada empty into Mono Lake. The Owens River, also supplied from the Sierra Nevada, ends in Owens Lake.

Springs emerge at many places in the mountains and basins. Ifost of the ones in the mountains provide good water, as do some in the basins ; but many of the latter have taken up sueh quantities of salts as their waters have traveled underwround that they are anything but potable. Since good springs are of such importance to desert travelers. signs noting their location or the distance to them have been posted at many places, and the government has published various bulletins giving much information about them.

Travel off the main highways in the Basin-Ranges province should not be undertaken without first making eareful inquiries about watering plaees and condition of roads; also proper equipment for a region in general quite hostile, but wonderfully interesting, is essential.

The eoncept that the ranges and basins of this geomorphic province oricrinated from disloeations along faults was first arlvanced in 1873 by G. K. Gilbert of the Inited States Geologieal Survey. Another member of the same survey, J. E. Spurr, later attempted to aceount for them as eroded folded monntains since he was unable to find positive evidenee of faulting along the marcins of many of the ranges. It is recognized that the elevation and depression of the blocks started at different times in different parts of the province and that it con. 
tinued longer in some areas than in others. Ranges whose elevation started earlier and ended sooner naturally have elianged more than those elevated in very late time or those in which elevation still continues. Along the older ranges evidence of fault control has been largely or wholly wiped out, but in the more recent ones it is clearly defined. Between the two extremes are intermediate stages which can be recognized when tlue province is studied as a whole. Therefore the absence of clear-cut fault-controlled land forms by no means proves that such were not once present.

The size of the fault blocks varies greatly; low ones that make distinct ridges are only a few miles long and a mile or so wide. The length of the largest blocks is several tens of miles or even more than 100 miles, and their highest peaks rise several thousand fcet above the basins. The width of these major ranges may be only a few miles or may reach a few tens of miles.

In the Basin-Ranges province, the fault basins and trougbs between the ranges, such as Owens Valley, Panamint Valley, and Death Valley, are narrow compared with the width of the ranges. The boundary fault systems outlining one or both sides of a range can be reeognized easily in most places where elcvation still goes on or has recently ceased. In older ranges, the fracture systems have been buried by debris from the ranges, which is piled along their bases as alluvial fans and aprons. These deposits come from streams swollen by flood water, carrying coarse sediment down the canyons through which they flow, and depositing it quickly when their velocity is checked as the water emerges onto the low land at the base of a range. Where several fans unite into a single mass, the deposit is called an alluvial apron.

Along some ranges like the White-Inyo on the east side of Owens Valley, the west side of the Panamint Range on the eastern side of the valley of that name, and the Black Range at the southern end of Death Valley, the fans are small and discontinuous, indicating that vigorous recent uplift has interfered with the accumulation of debris at the canyon moutlis. Elsewhere the fans have joined to form alluvial aprons which border more or less the entire mountain fronts. Small knobs or ridges of lower ends of divides between canyons may project through the mantle of unconsolidated debris. The heads of fans forming the great aprons may extend far back into the canyons, in some places to the divides which separate them from those on the other side of the range. Alluvial aprons may eventually join in the middle part of fault troughs or basins with valley-like depressions between them down rbich flash floods from torrential rains occasionally flow.

One of the best known and most spectacular sections of the BasinRanges province in California is that included between the eastern base of the Sierra Nevada and the ranges on the eastern side of Death
Valley, 250 miles away. In this region there are three depressed fault bloeks, Owens Valley, 'Manamint Valley, and Death Valley, which are separated by tilted fault-block ranges. The White-Inyo, Coso, and Argus ranges lie between $O$ wens and Panamint valleys; Panamint and Last Chance mountains separate Panamint Valley from Death Valley; and on the east side of Death Valley are the Grapevine, Funeral, and Black Ranges.

The region exhibits great differences of relief: the elevated blocks have peaks ranging from 8,000 to more than 14,000 feet above sea lerel, but part of Death Valley is more than 270 feet lower than the level of the ocean. The mountains are newly elevated and therefore rugged; the valleys, on the other hand, have rather even floors.

Owens Valley is a long basin whose floor is between 2 and 8 miles wide; the distance between the crests of the bordering Sierra Nevada and White-Inyo Mountains ranges from 15 miles between Bishop and Bigpine to 40 miles at the north end and 25 miles at $O$ mens I ake near the south end. The floor of the graben slopes gently from an elevation of about 3,600 feet at Owens Lake to about 8,000 feet at the northern extremity of the valley. South of $O$ wens Lake the land rises to a broad, low divide at an elevation of 3,670 feet, which separates Owens Valley from Rose Valley to the sonth.

The I'overty, Tungsten, and Alabama Hills are isolated low eminences standing above the floor of the valley, but are quite inconspicuous because of the cnormous height and bulk of the great bordering ranges. The hills very likely are small, fault-bounded blocks thongh they may possibly be bedrock remnants left by erosion. Southwest of Bigpine there is a well-preserved volcanic field comprised of explosion cones and lava flows, consisting predominantly of basaltic material, although slightly older rhyolitic roeks, including glassy rocks of various types, are present. Crater Mountain, the highest point in the field, is a cone with crater in the top which rises about 2,000 feet above the floor of Owens Valley.

All evidence points to the subsidence of the Orens Valley block along a series of parallel boundary faults, one at the base of the Sierra Nevada and the other at the base of the Inyo-White Mountains. The graben bedrock in turn is broken by minor faults some paralleling and some lying transverse to the boundary faults. The subsidence of $O$ wens Valley has not been uniform. Partial rotation has oceurred and undoubtedly the lesser blocks have moved within the main one. For example the basin holding Owens Lake seems to have been evolved by this uneven sinking and partial rotation of one of the blocks com. posing the graben.

The rocks composing the Alabama IIils are Triassic or Jurassic volcanics which are intruded by granitoid rock unquestionably of the same age as that of the batholithic complex in the Sierra Nevada- 

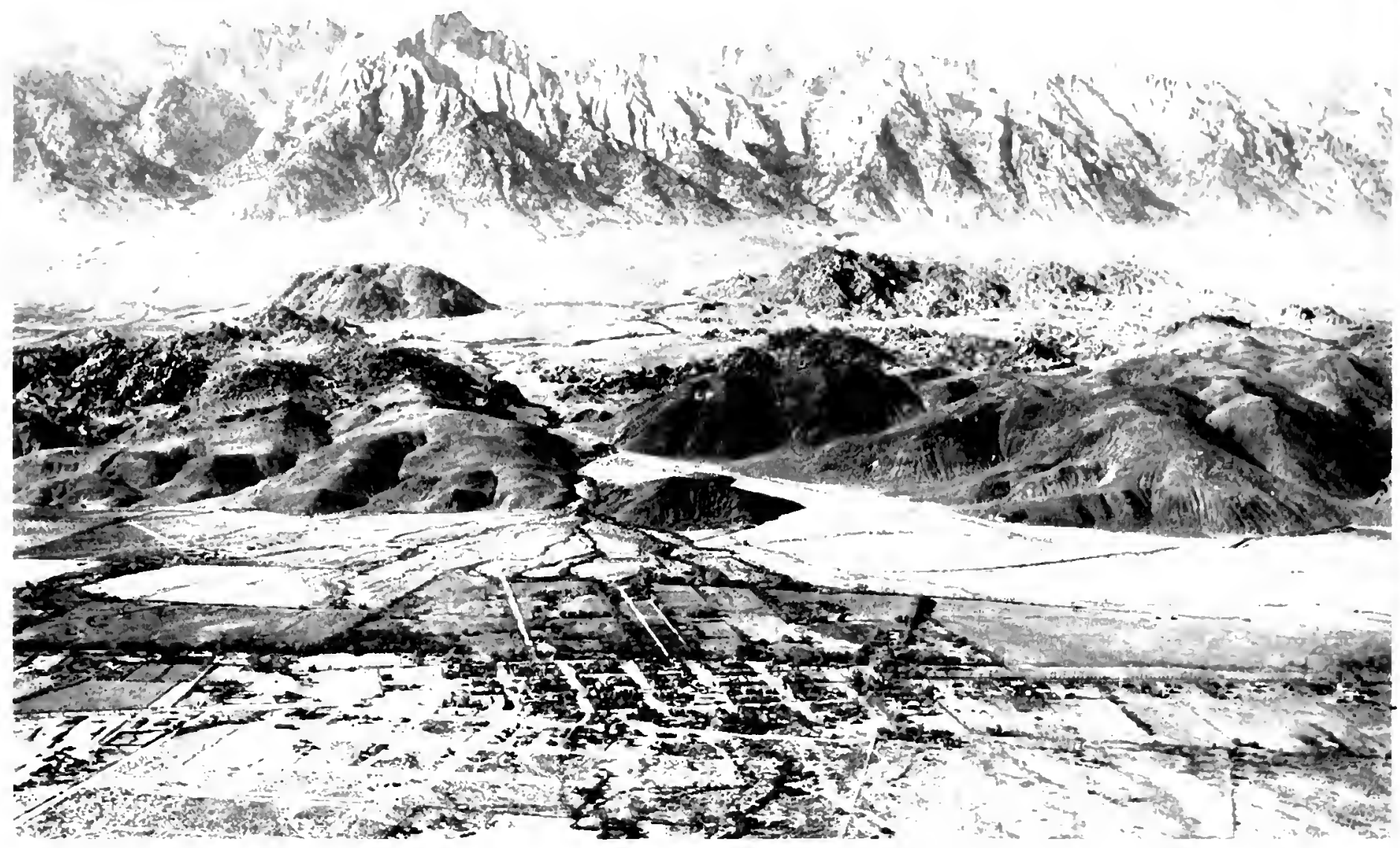

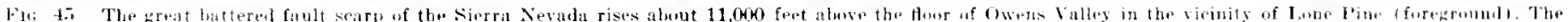

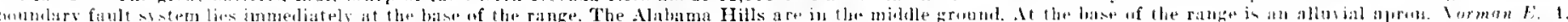

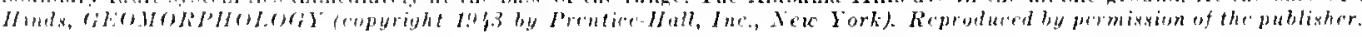

which the streams carry, especially during time of llwou, when the most adetive addition to the fans oundrs, is marse: whe the slope flattens abruptly, mostly fine framments are carried. (m the easteru side of the valley, the fans along the White-Inyo Range are isolated from each other and are comparatively small.

Viry resent, low fault scarps are present in (owens valley indicating movement pither along the sierran bomalary lault system or along faults roumhly parallel to it. Near Lone l'ine siveral suall starps cut late stream deposits and were evolved by dislocations at the time of the very severe earthquake in 1572 which resulted in much loss of life and damage in the town. Becanse the searps are in unconsolidited debris, they have been considerably eroded; in heichlit they rillue from a few feet to about 25 feet. liecent scarps may lie sern west of Bigpine also, ane at least being the product of the 1872 disturbance. 


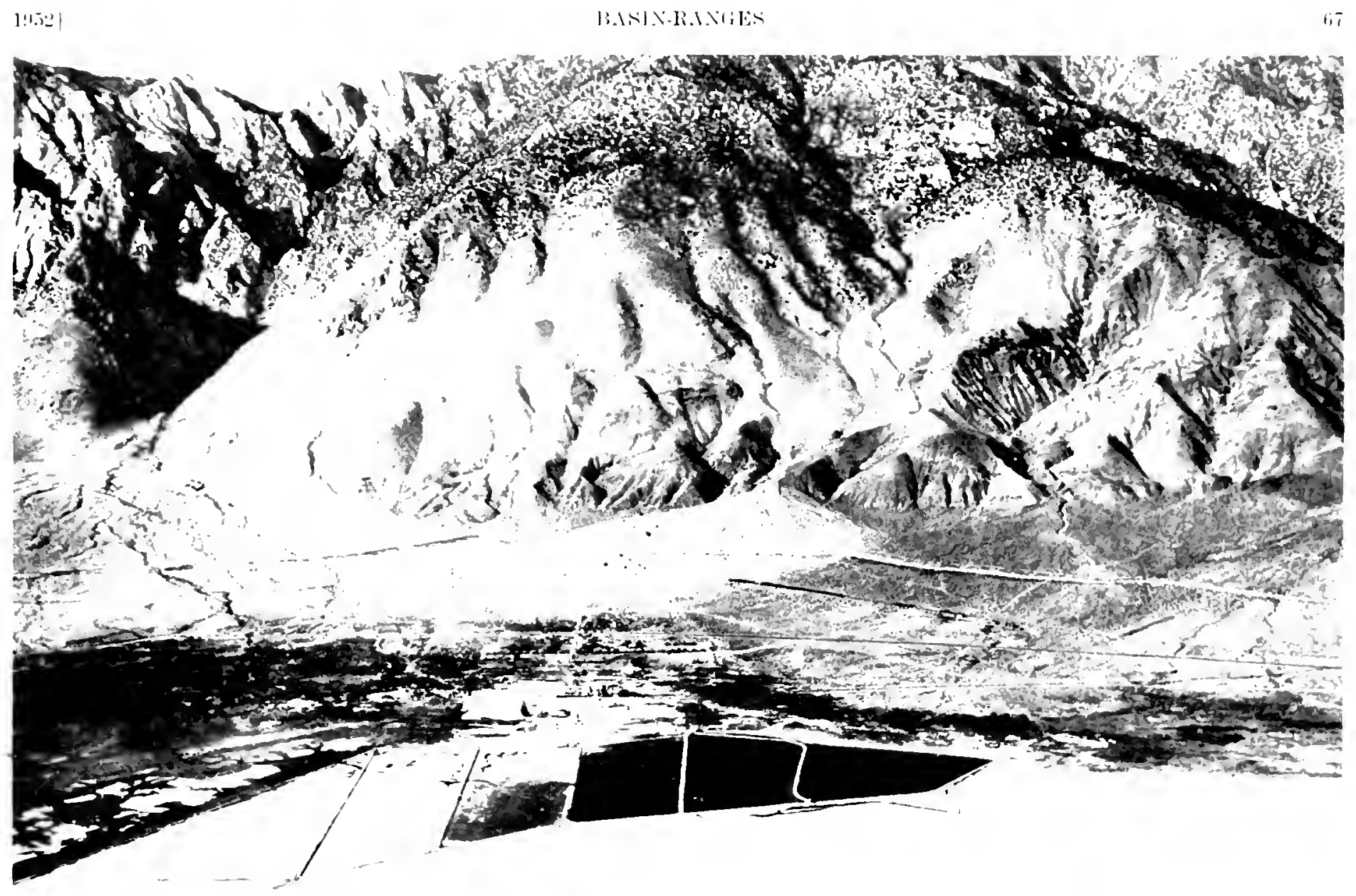

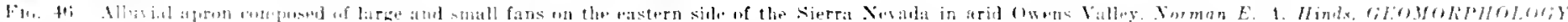

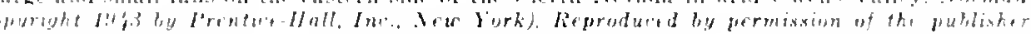

There are many uthers on the went side of owas Valley most of them

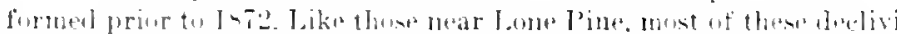

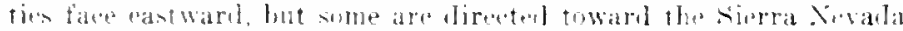

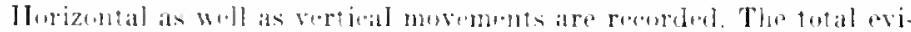

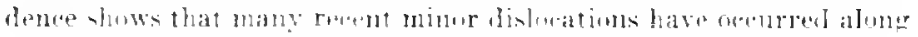

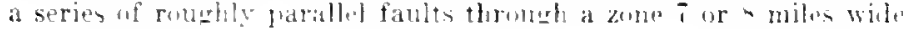

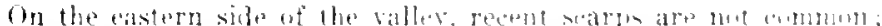

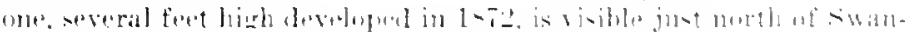

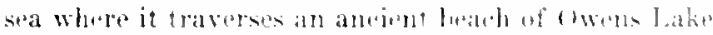

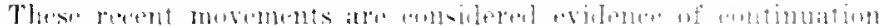

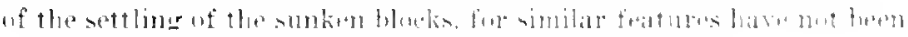

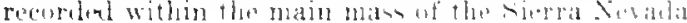




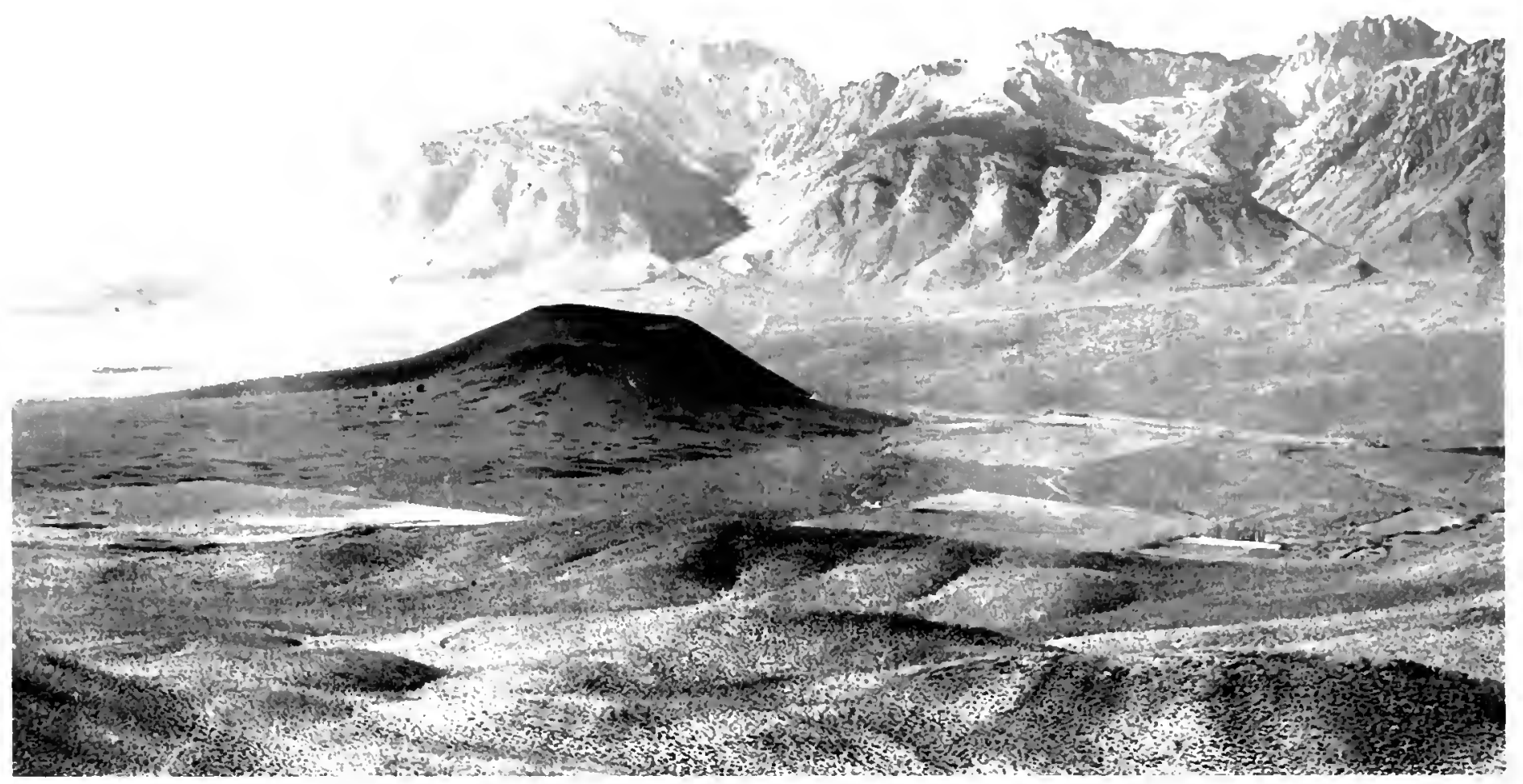

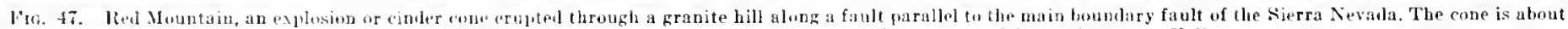

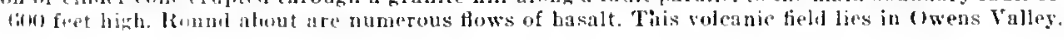

Ihetween IBigline and Independence near the eastern hase of the Sierra Nevada there is a volcanie field comprised of a considerable number of cinder cones and associatenl lava flows. Some of the eones are on fanlts along which there was movement as late as 1872 . Crater Monntain, linghest of the group, stands about 2,000 feet ahove the floor of Owens Valley, bnt this consiclerable elevation results prineipally from the fact that the explosions burst through a granite hill rising nearly 1,400 feet above the valley, hence the cone itself is not particularly imposing.

Most of the cones are on the alluvial apron projecting in to Owens Valley from the base of the Sierra Nevada, but some lie along the lower luedrock slope of the range. The most intense voleanic activity ocenrred between Taboose and Sawmill Creeks where large flows of basalt spread far over the valley floor. The flows are extremely rontrh, 
the surfaees being wild jumbles of elinkery blocks. The lower ends of the tlows have been partly eovered by later alluvium, but because of inequalities in their surfaces basaltic eminenees project through the deposits.

The most perfectly formed cone is Red Mountain which rises about 600 feet above the alluvial apron. An extensive basalt flow poured from the vent, but the erater rim extends unbroken over the head of the flow indieating that the last phase of aetivity at this center was explosive. The eone is built largely of reddish fragments of lava, hence its name; most of the debris is angular and individual chunks reach an average maximum diameter of about 6 inches, but some bombs which were erupted measured at least 4 feet aeross. Red Mountain has suffered some erosion and also burial of part of its lower slopes by alluvium, but at first glanee it looks as though it were exceedingly recent.

A large but rather imperfeetly formed cone stands on the upper end of the alluvial apron between Division and Sawmill Creeks; seattered over its top are many large granite boulders evidently derived from debris of the apron as the eruptions blasted through it.

At an elevation of about 7,000 feet on Sawmill Creek explosive cruptions oeeurred and basaltie lava flowed from the vent to the mouth of the canyon.

Considerable basalt is present near the base of the Inyo Mountains near Aberdeen on the east side of Owens Valley. Explosions also took place formint a number of inperfeet cinder cones. elosing the rolcanie eyele-one that was probably eontemporaneous with that on the west side of the valley.

Red Mountain, previously referred to, stands at the south end of a elearly defined scarp in the allurium developed at the time of the 1872 earthquake. A short distance to the north along the same scarp there is a minor quantity of exploded debris which did not form a eomplete cone. Still farther north on the projection of the same fracture is Crater Mountain. Thus three centers of eruption are located along this fault, which evidently is still active.

A large cinder cone west of Fish Springs School was broken by a recent fault along which the displacenent amounted to about 50 feet; before it oceurred the lower slope of the roleano had been partially: buried by alluvium.

On the eastern side of most of Owens Valley is a massive bloek 110 miles long, with one or two of its highest peaks elosely approaching the maximum elevations in the Sierra Nevida. White Mountain l'eak stands 14,242 feet above sea level. The range is a continuous mass though there is a depression in the central part culminating in Westgaard Pass (elevation 7.276 feet) which lies east of Bigpine. It is generally known as the White Mountains, though the southern end may still be referred to as the Inyo Ilountains. Although there is no real demareation between the two parts, in consileration of loeal preference, the tern White-Inyo is used in this description.

On the north, the White-Inyo Mountains terminate quite abruptly at Mount Montgomery; at the sonthern end there is a broad depres. sion separating them from the Coso Mountains which borler the southern part of Owens Valley on the eastern side. The south end of the White-Inyo block therefore is nuch less clearly defined than the northern. Althotgh the average elevation of the range crest is high, more than 10,000 feet, it is considerably less than that of the corres. ponding part of the Sierra Nerada on the west side of Owens Valley, hence it is somewhat dwarfed by its greater nejghbor.

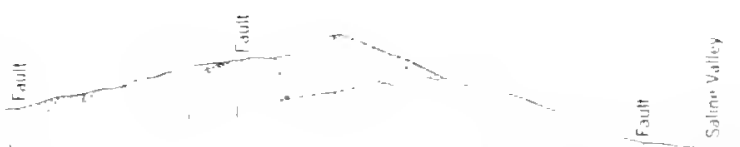

F16. 4h. The Inso Mountains are a tilted fault block in tbe Basin Ranges Province. Rocks in the Inyo. Iountains have heen intensely folded and are broken hy great faults, as sbown on the cross section. A large mass of intrusive granite shows to the west of Saline Valley. After $K$ nopf and $h$ ir $h$.

The west side of the White-Inyo range slopes abruptly to the floor of Owens Valley and is only little less spectaeular than the east Sierran front. The western base against Owens Valley is sharply defined, but its eastern margin is much less elear. The northern part of the eastern side is marked by the edge of Fish Lake Valler. Between this graben and Saline Valley farther south, there is an irreqular mountainous area not elearly separated from the Inyo Range on the west and the mountains to the east. Saline Valley is an elliptieal depression whose floor is about 2,500 feet lower than that of Owens Valley. The eastern face of the Inyo Ilountains fronting on this valley is quite as abrupt and majestic as the eastern side of the Sierra Nevada.

The White-Inyo Range is a gigantie fault bloek, but the evidenee of the disloeations producing it is most clearly shown at the two extremities. At the northern end, the inter-eanyon spurs projecting into Owens Valley are terminated by remarkably large, clearly defined triangular facets whose sharp edges and geometric jerfeetion make them extraordinarily fine illustrations of this inportant feature of recently uplifted fanlt bloeks. At the southern end. which is almont eompletely covered by a thilek mass of basaltic lava flows averlying an exceedingly even elevated erosion surface actual dislocations of the flows are visible. Between the two ends of the range the evilence is less conspicuous, probably because the dislocation has been distributed along parallel fractures and this has prevented the development of prominent triangular facets. Sucl morements as have oceurred in the 


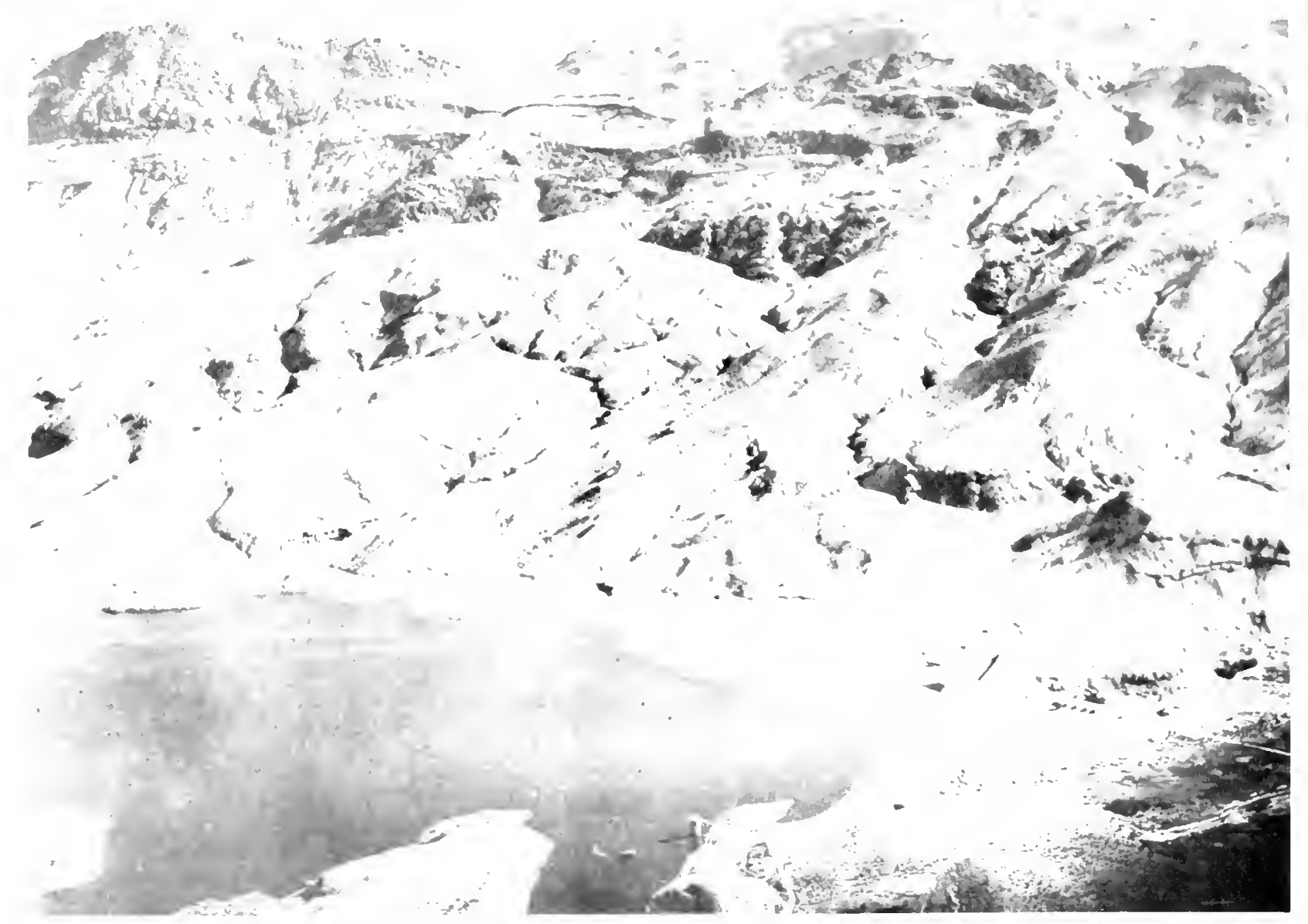

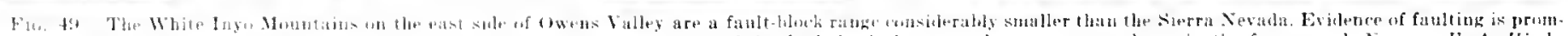

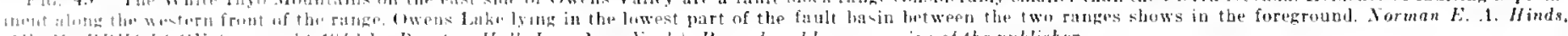

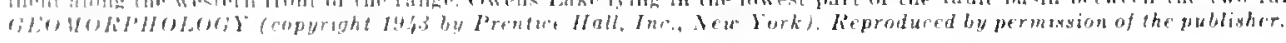


midelle section appear to have taken places alonte faults which parallel the butudary fanlt for a distance and then run into the bouly of the range.

Other evidence of the fanlt block origin of the White-Inyo Mountains is the straightness of the western front and its independence of the belrook. for the front transinesses the trent of the rock layers as is commonly the case in fault block ranews. The eastern front loes not provide so straight a base as the western side. Howeser, the topog-

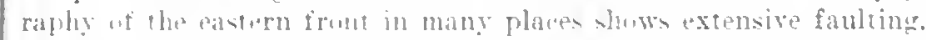
especially in the great escarpment margining saline Valley where very prominent triangular facets are present. Further evilence in the same place is the badly erushed rock along this escarpment which could only have been protuced during dislocation along a major fault system.

The slopes of the west sile of the Arus Range. and the east and west sides of the Cosn. Panamint, and Black Rangex are all exceed. in rly steep, not areatly batterel fault scarps. The west sides of the Coso, Argus, and Panamint Ranges also include minor searps known to have been dereloped by step-faulting, for in many places traces of these lesser faults can be observed. as well as displacements along them. Highway 190 erosses both the Coso and Panamint Ranges on its way to Deatly Valley.

Perhaps the most conspicuous fault zone bounds the east side of Panamint Valley and marks the base of the Panamint Range, for the dislocation here has been very great. There are evidences of recent movement, partieularly south of Wildrose Canyon wbere the range front is extremely high and abrupt and the alluvial fans at the mouths of the canyons are feebly developel. For this reason the lowest part of Panamint Talley is near the base of the range rather than near the center of the valley as is normally the ease. IIowever, because the volume of debris in the present fans is only a small proportion of the total removed from the Panamint Range in the erosion of the canyons on its western side. Tanamint Valley must have sunk as the range was elevated and older fans have been buried by those growing from the eastern side of the Arrus Range on the opposite sile of Panamint Valley. Even some of the new fans alntw the Pananint Range have been broken by recent faulting and parts of them elevated. In some places, the beilroek scarp. which rises to a height of 2,000 and 3.000 feet, slopes as mucl as 35 degrees; apparently it is the montinuous footwall of the fault so recently exposed by dislocatiuns. The roek in which the fasets are cut is greatly eruslued, sheared, and discolored, additional evidence of the presence of the surface of the fault.

One of the must striking bits of evilene favoring the recency of the faulting along the west sille of the Panamint Ranup is a large northtrending graben in the alluvium just south of Wildrese Canyon. This

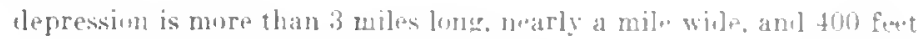
deep in its deepest part.

Between the Coso and Irous lianges is a hilly area of low peliof which is a somewhat deformed and eroled portion of an oll limelape found in the higher parts of the ranges. This section inclulm (isol Valley and the hills immed lately to the east, the Darwin IIills, and also Darwin Wash. Lower Marwin Wash, east of the Darwin llills. is an alluriated area in which white lake beds indicate the presence of a former water body. Hoalward erusion of Darsin Canyon, a narrow gnrge which empties into Panamint Valleg. has recently draind the lake; as a result the hase of erosion for most of the intermittant streams draining Darwin Hills and the west slope of the Arius Range has been lowered about $2.00 n$ feet. causing onnsilerable diswation of the lake beds and the alluvium in Darwin Wash.

Remunts of the ancient arocion surface are fouml elsewhere in the mountain ranges, and are being progressively eut to pieces hy hear. ward erosion of eanyons which have been cut durime the late uplift of the fault blocks. At one time this surfaee appears to have been very widespread oser the region and probably was continuous with remnants found in the Sierra Nevala. In the western part of the section under present discussion. thin flows of basalt spreal across the prosional plain completely burving mush of it, but. in places, hills several bundred feet high rose above the general level and were partially or completely surrouncled but not covered by the flows. The age of this erosion surface which shows in the Sierra Ciprala, the Cosi, the Arms. and Pananint Ranges at least. is of interest and some information is given by geological features in the Coso Range and in the Mojave Desert farther south which indicates that the surface had been evolved

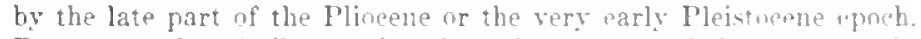
Remnants of a similar surface have heen repnrted frum ranges in snuthwestern Nevala and posihly from the San Bernaritinn Momtains of southern California. If all are pare of a one continuous landseape, a large area had been relucel to most molost relief when the late faulting occurred

Death Valley, one of California's nost interpsting and spectactalar scenic areas, is a completely enelowe grahen abun 1:30 miles lone and from 6 to 14 miles wide. On the western side. l'anamint Monmains rise to a highest elevation of more than 11.000 feet : the last Thane Range to the north is somewhat lower. Along the paleprn marerin. three ranges, the Grapevine at the north, the Funeral. and the Black at the sutut complete the enclosure. Fach of these is distinuty lower than the Panamint.

Death Valloy basin and the burdering ranges owe their origin to such profound fracturing as has been destribed in areas farther wert The deepest part of Death Valley, lying between the l'anamint and 
B]ack Mountains, has been lowered below sea level, though the region as we see it today has not been invaded by the ocean. However, in the past, before development of the present relief, the sea invaded this part of California several times, as is proved by the wealth of marine fussils contained in many rock layers exposed in the ranges.
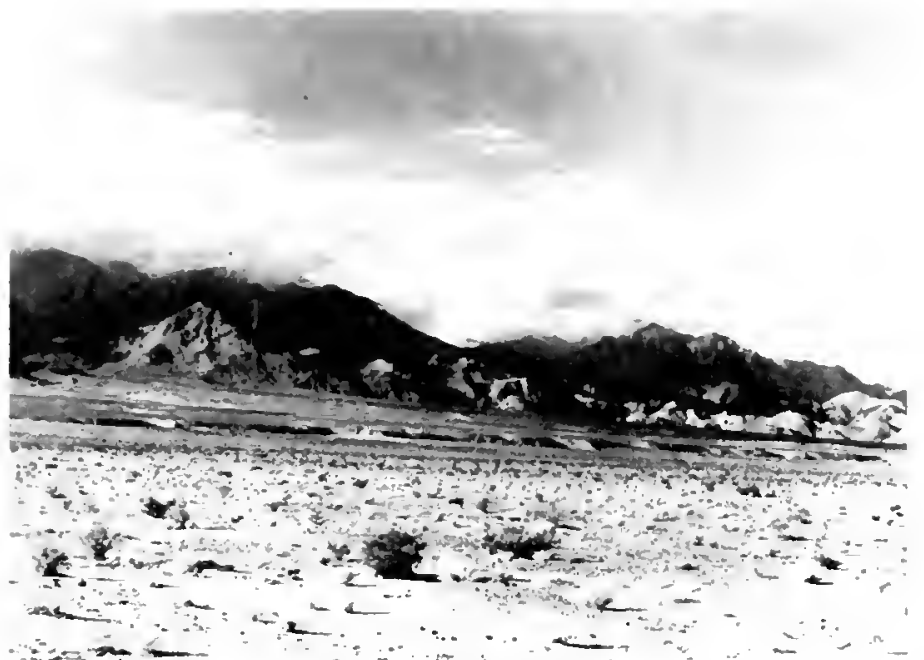

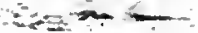

Fro. 5o. The lous cliff in the allusium at the base of the Panamint Range in 1 hath Valler is a fault scarn formed hy recent movement ulong one of the fractures rluse to the las of the range. Photo courtesy. National Park Serrice.

The faulting, which started in the late part of the Plioeene epoch anl is still going on, is extremely eomplex. Its effects show best along the eastern face of the Black Range where the most recent and most active movements have oecurred. The lower slope of this range is extremely steep; although it has suffered some crosion, it is one of the best preserved fault suarps in the Inited States. The road along the east side of Death Valley from Furnace Creek south runs close to the searp and affords easy aceess. For 15 miles below Furnace Creek, the boundary full sistem ents aeross Tertiary rocks, but, farther soutb, ther. are preeipitous slopes in aneient, resistant formations which roughly outline the surface of the fautt. Three miles north of Badwater. the deepest point in the valley ( 270 feet below sea level), a fault between the Tertiary and the very old rocks is clearly exposed for many thousands of feet where it extends upward into the range. and the fault surface is continuous with the valleyward slope of the ancient roek farther to the south.
Because of the height of the ranges around Death Valley and their

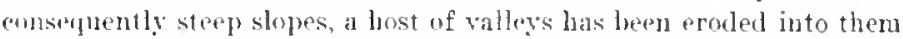
and the streams have carried great quantities of debris into the basin forming alluvial fans and aprons. Along the Black Range, the fans are small and diseontinuous and much of the lower part of the range front is abnormally steep, both part of the evidenee that this bloek has been recently elevated to a considerable pxtent on that the valley has sunk. Elsewhere the fans luave united to form aprons having moderately steep slopes from the toe of the deposit to its upper end which may be miles up the eanyons. This is notably true along the west front of the Panamint Range where the fan heads extend far back into the mountains. The steep slopes of the fans and the coarse lebris composing them testifies to their speedy formation. In plaees the fans are broken by low scarps, indicating the presence of active faults beneath then. A very good example may be seen about a mile south of Furnate Creek Inn where a scarp lies just east of the hirtway and extends parallel to it for some distance; another is at the base of the Panamint Range.

The floor of a considerable portion of southern Death Valley is made of rock salt formed by the evaporation of a large lake. $\Lambda$ s shown previously, during the elimases of the glacial stages, more snow fell on the California mountains and in most places over the lowlands more rain than does today. At various places around Death Valley, there are wave-eut terraces and deposits as much as 600 feet above the valley floor. These terraces, although faintly outlined, ean be distinguished,

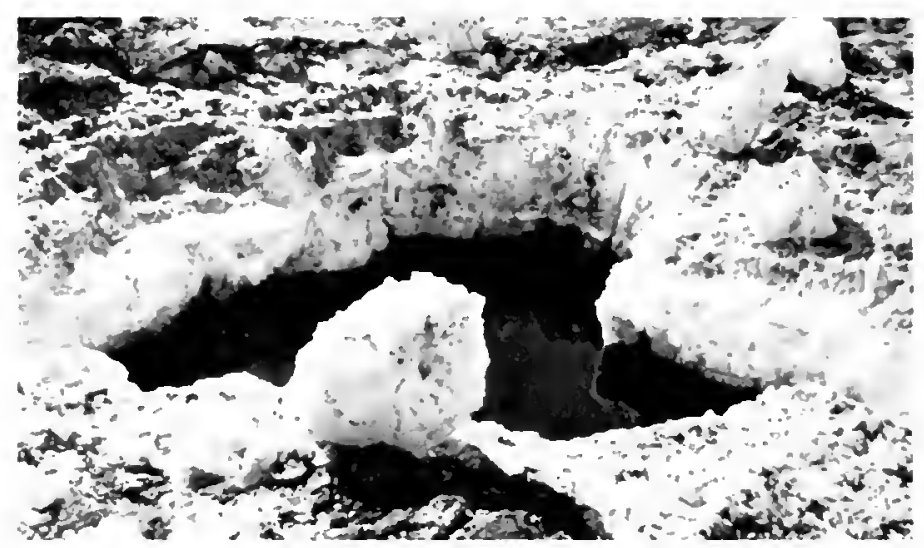

Fig. il sialt left by evaporation af lake in leath folles is brisg dissolved by water falling on the valley floor and hy water miprating down ward from the adjarent ranges. The wnter is nn excedingly biter brine. Photo by Willard. 


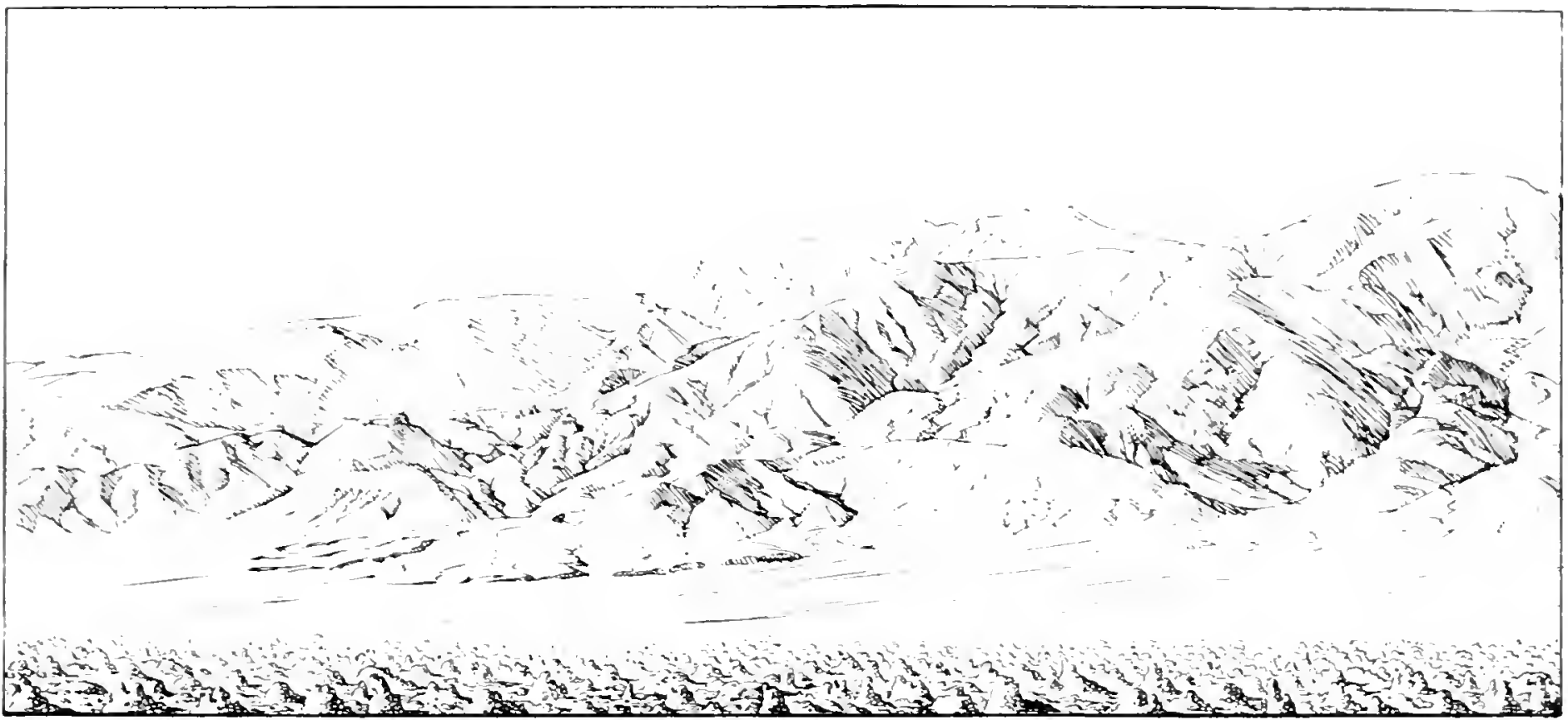

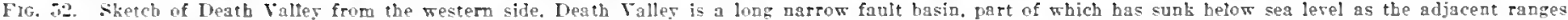

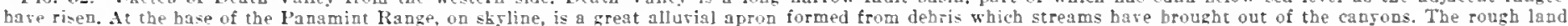
in the foreground is weathered salt left when the large lake that formerly flled the basin evaporated. Photo courtesy $R$. $I$. Th

as for example at Mormon Point and on Shore Line Butte, which is a hill of black basaltic lava rising above the valley floor, a mile northwest of Ashford Mill. This ancient lake has been given the name of Ianly. for one of the early explorers in this region.

Eridences of other lakes which oceupied the valley at earlier times lias been gained from borings into the sediments. A well 1,000 feet deep along the road across the Devil's Golf Course, passed through alternate beds of clay and salt without reaching bedrock. Each pair of salt and clay layers represents the evaporation of a lake, the salt representing the final product as the water disappeared.

In the middle part of Death Valley, principally north of the road leading to Stovepipe Wells, is a small group of sand dunes made up largely of quartz sand.

Considerably north of the sand dunes and only a few miles from the famous Death Valley- Scotty"s Castle are the Ubebebe Craters, a group of small cones built by explosive eruption of fragments of basaltic lava. Probably these cones overlie one of the faults traversing the graben bedrock, and were erupted only a few hundred years ago. The craters in the tops of the cones are well preserved and in their walls the various lavers of fragments blown ont by the difierent explosions are well marked. The volcanic eycle seems to have been a brief one, as is normally the case with rolcanoes built solely by explosion. In the southern part of Death Valley there bas been liberal outpouring of basaltic lava along the faults.

Cenozoic deposits present in the ralley are especially notable for their bigh coloring, as for example along the base of the Black Range south of Furnace Creck Inn, where a striking badland area has been develuned by the reasional torrential storns. Becaue the rocks are quite unproterted by veswation and surtace slupes are steen, the sheet and Aash foods are literally ripping the deposit to pieces. A labyrinth 


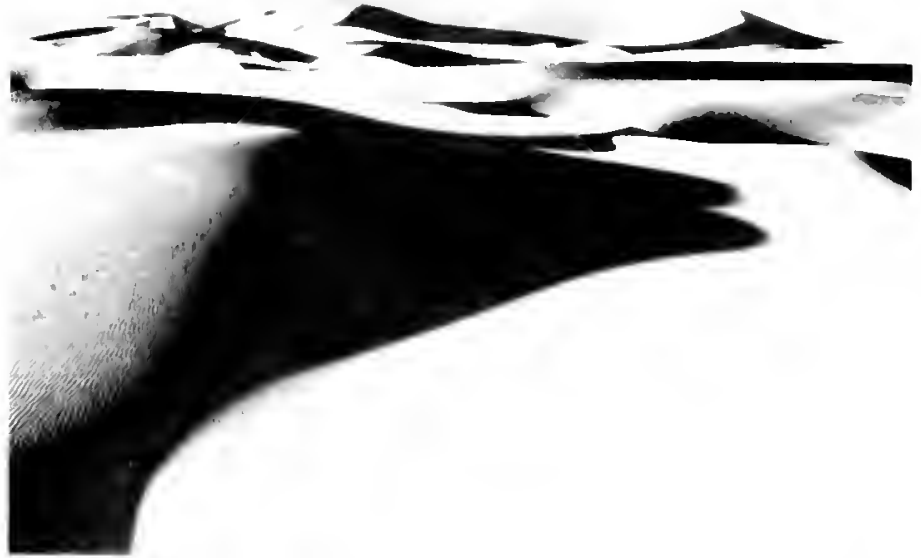

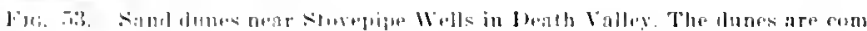

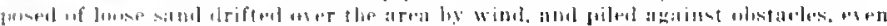

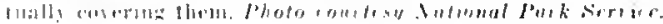

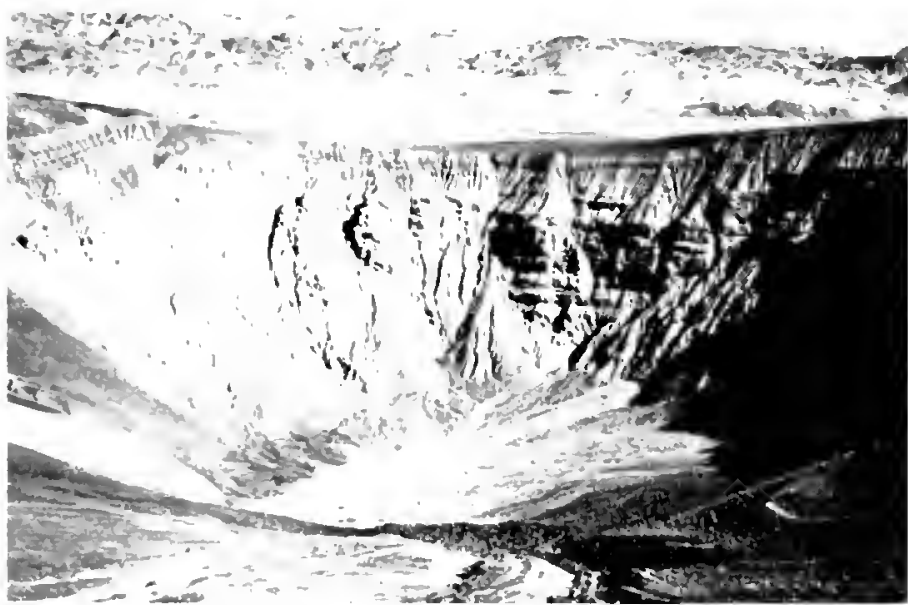

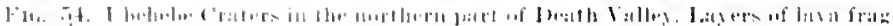

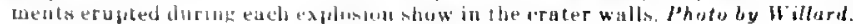

of deep, narow golges lies between high, sharp-erested ridges. Most "if the secliments are brilliant rellow in color but there are many other shardes.

In the Tertiary deposits ar the famous borax minerals mined long ago and transputed by the giant wagons drawn by the twenty-mule teams.

Janamint Valley is a natrow fanlt hasin about 60 mites lone lying beyoud the montains bordering the west side of Jeath Valley. About 15 miles from the northern ent, alluvial fans built on from the ranges on the two sides have coalesed, dividine the basin into two parts separated by an alluvial rilge. Al the solithern end, this graben is narrow, Jess than a mile across near the San bernarilino (ounty line. and not more than 2 miles wide for some distane to the nortl. The alluvial slopes rise streply to the monntains on both sides. Farther north, near Ballarat, Panamint Valley widens to about 10 miles and maintains this approximate width for a considerable distance, beyond which it again narrows.

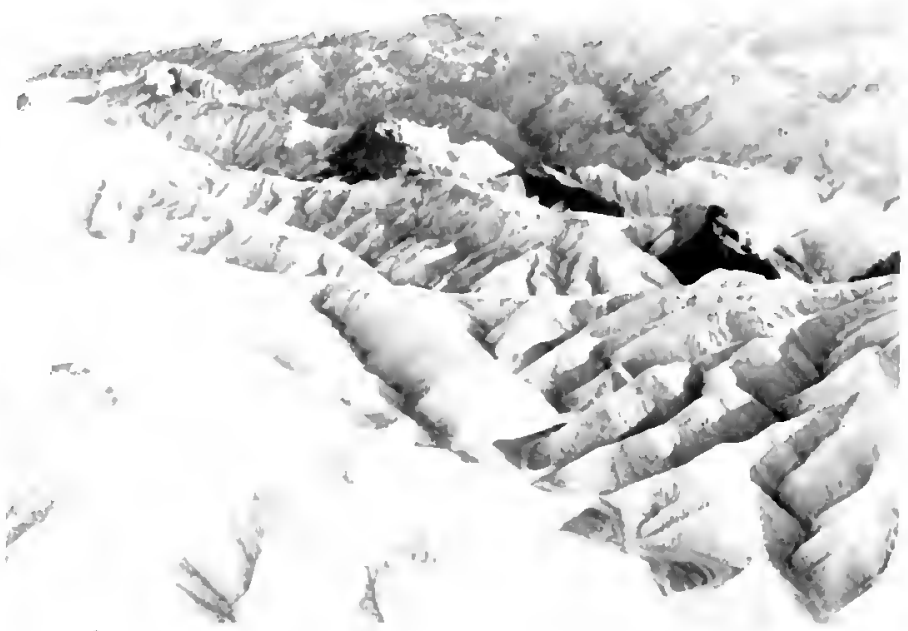

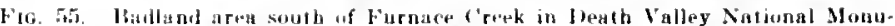

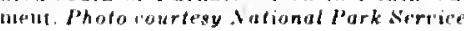

At the south, the west borter of the valley is the Slate Range which farther north (abeut latituele $36^{\circ}$ ) mereres witl the Arerus Mountains. At the sonthern end the eastern border is formed by Brown Hountain which gives way to Wingate lass s miles northward This is a low, nearly level valley about 2 miles wide which slopes gently eastward for several miles and then drops rather sharply into Death Valley. 
The summit of the pass is less than 300 feet above the Panamint Valley floor, but the mountains to the north and south rise several thousand feet higher. North of Wingate Pass, the eastern side of the valley abuts against the great l'anamint Range, whose high point, Telescope Peak, is 11.045 feet above sea level.

The lowest part of l'anamint Valley is a playa or intermittent lake about 17 miles long and 3 miles wide at its widest part. This flat is nearly a thousand feet lower than the lowest part of the valley at its south end and about 600 feet below the alluvial divide whieh separates the valley into two parts. During the glacial stages a large lake was present in Panamint Valley. There are wave-eut terraces and deposits of tufa standing several hundred feet above the valley floor. Panamint Lake was contemporaneous with Searles, the greater Owens. and other lakes in the western desert eonntry. Searles Lake at one time apparently overflowed into Panamint Lake and was in part responsible for the notable size and depth of the latter. However, there is a considerable area of mountainous eountry tributary to Panamint Valley and the inereased rainfall and snowfall over these heights during the moister episodes must also have provided sufficient water for a lake of moderate size. The uppermost terraces eut by the waves are not distinet, hence it has not been possible to determine just how high the water rose on the mountain slopes. Tufa has been found at elevations as high as 1,980 feet, whieh is praetieally that of the summit of Wingate Pass, and it is possible that for a time water did flow through this break in the monntain barrier into Death Valley. If the maximum depth of Panamint Lake was governed by this overflow area into Death Valley, the depth of water was about 930 feet and the area ronghly 272 square miles. Not only was the southern part of Panamint Valley covered, but the water overtopped by about 300 feet the alluvial divide which now isolates the northern from the southern seetion. This great body of water evidently existed for a considerable time in what is now desert land.

No saline deposits eomparable with those of Searles Lake hare been found in Panamint Yalley, the deposits formed in it being fine elay and sand.

One exceedingly interesting section of the Basin-Ranges is Searles Lake Valley, a rather narrow, elongate depression almost completely enelosed by mountains. The boundary of the northern half is the Slate Range which rises 3,000 to 4,000 feet above Searles Lake and attains a maximum altitude of 5.565 feet above sea level. South of this range, the border of the valley bends to the southwest and is eomposed of high hills extending as far as Klinker Mountain. These hills are along the Garloek fault and undoubtedly have been evolved by movements along this zone. The western border of the valley as far south as Salt Wells Canyon is formed by the Argus Range, and south of this there is a lower unnamed range.
In Searles Valley there was a large lake or series of laks during the glacial stages of the Glacial epoeh, while today there are only a few incles of water during the rainy season, hence present searles lake is an intermittent lake or playa. Evidenes of the greater water body is provided ehiefly by wave-nt benches on the mountain sides up to 640 feet above the valley foor, at an elevation of 2.262 feet above sea level. When the lake reaehed its highest level, it extended westward through Salt Wells Valley and covered a large area in Indian Wells Talley. The lake at this time overflowed southeastward also into Pilot Knob Valley and thence into Panamint Valley.

Other evidence of the expanded lake is provided by deposits of the porous lime rock, ealled calcarcous iufa, which was preeipitated from the waters. In places the tnfa merely coated other rock, but in some loealities it aceumulated to eonsiderable thiekness. It is especially well developed at the Pinnacles which are steep-sided knobs rising about 100 feet above their surroundings some 15 miles south of Trona, near where the railroad turns to the sonthwest. Similar masses also show $1 \frac{1}{2}$ miles sonthwest of Salt Wells, a short distance east of the eanyon road to Randsburg.

Unique features associated with ancient Searles Lake are the saline deposits underlying part of the area : they are outstanding both in the purity of the salt beds and also in the variety of minerals eomposing them. Also, there is an unusually high content of potash, for which the deposits are worked. The salt body extends to depths of 60 to 100 feet in the central part of the playa. Laterally it grades into elay and sand eontaining less and less salt, which, in turn, pass in to the coarser allurial sediments along the margin of the vallev.

When largest, aneient Searles Lake eovered an area of about 285 square miles. It was one of a sistem that existed in Owens Valler and farther south during the moister elimates eoineiding with the enlmination of the glaeial stages. MIost of the water came from the east side of the Sierra Nevada, forming Owens River, whieh ran to the lower end of Owens Valley where it was imponnded to form a lake much larger than present Owens Lake. The water funally overflowed southward making a stream whieh ran into Indian Wells Valley where it in turn was backed up behind a low barrier forming a small lake. This overflowed into Salt Wells Valley and thenee into Searles Valley. As previously noted, Searles Lake became too high for its barrier. spilling into Panamint Valley where it contributed to a lake that for a time was 930 feet deep. At this stage, Searles Lake water also tlowed into Salt Wells and Indian Wolls vallers. Over large areas the surface of the Searles playa is characterized by the remarkahle self-rising ground produeed by the formation of salt erystals from water evap. orating in the sediment. Alkali erusts are present in places on this ground, increasing in continuity toward the center of the playa 


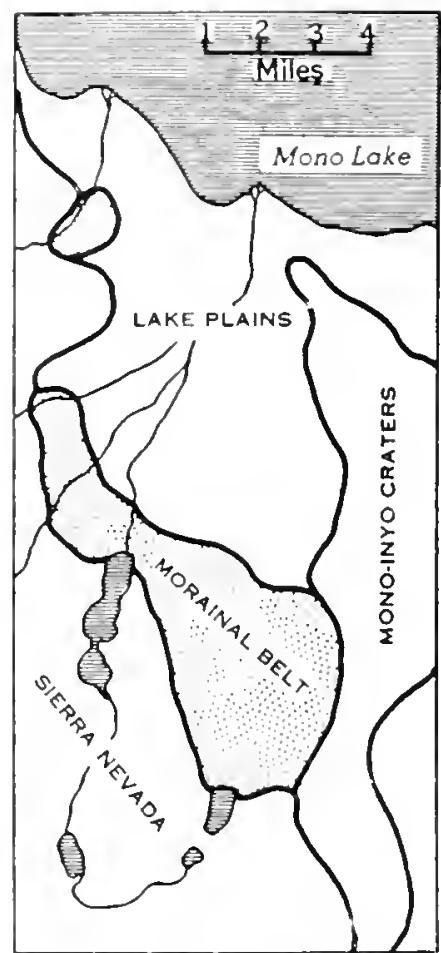

Fug. 56. Map showing principal physical divisions of the district south of Mono Lake on the east side of the Sierra Nevada. After W. C. Putnom.

\section{Mono Basin}

One of the most interesting and spectacular parts of California is that in the vicinity of Nono Lake which lies in a fault basin at the base of the east central part of the Sierra Nevada. This area is about 360 miles north of Los Angeles and 180 miles east of San Francisco. It is traversed by Ilighway 395 from which three roads branch off. One leads across the desert basin to join Highway 6 at Benton Station near the Nerada border; the second ascends the Sierra Nevada through Leevining Canyon reaching the erest of the range at Tioga P'ass and then goes down the western slope through Yosemite National Park; the third is a short stretch going past June Lake and back to Highway 395 through Reversed Valley.
The relief of this section is striking, for on the west the great battered fault searp forming the eastern face of the Sierra Nevada rises more than 6,000 feet above the desert basin. The searp is broken by deep canyons which are separated by narrow, ragged ridges. In contrast, the relatively flat basin stretehes for miles to the cast where it abuts sharply against various ranges of the Basin-Ranges province. In this fault basin three divisions may be recognized: Mono Lake and the associated lake plain, the morainal belt, and the Mono-Inyo craters.

The present Mono Lake is fairly large, measuring 14 miles in length by 10 in width, the greater dimension being in the east west direction. The greatest known depth, recorded in 1889, was 152 feet between Paoha Island and the Mono Craters to the south. The present depth probably is somewhat greater, though the lake level is falling and probably will continue to fall heeause of withdrawal of water from tributary Rush and Leevining Creeks for the aqueduct supplying the City of Los Angeles. The lake water which contains sufficient concen. tration of various salts to make its taste unpleasant, has a foul odor.

Clearly defined beyond Mono Lake are old shore lines which show its much greater size and depth during the culmination of at least two glacial stages. In 1947 the surface of the lake stood 6.416 feet above sea level; easily reeognized older shore lines stand as much as 654 feet above this elevation and a fainter one, less certainly identified, is about 100 feet higher (between 7,170 and 7,180 feet). When at its largest size, this greater Mono Lake, which is called Russell after the geologist who first worked out its history, was about 900 feet deep. The shoreline at 7,000 feet appears to mark the stand of the lake during the later part of the last glacial stage; the higher, less distinet one belongs to an earlier part of the same stage.

Field evidence indicates that Lake Russell overflowed into Adobe Valley when it reached its greatest size, but not during the last rise. The outlet cut a channel in hasalt across the Mono Basin divide at approximate elevation of 8,150 feet, east of the now abandoned Benton-Bodie stage road, and this channel conneets with Adobe Val. ley by a number of linking, shallow basins and finally by a deep, narrow canyon also eroded in basalt. In the eastern part of Adobe Valley there is a chain of lakes which appears to be part of a once-connected drainage system. Adobe Valley is linked with Owens Valley farther south by a narrow channel in the Benton Range, west of Benton, Nevada. Thus it appears that, during the highest rise of Mono Lake waters, Lake Russell was the nortlern end of a chain that extended through Owens Valley by way of Searles and Panamint lakes to that in Death Valley (Manly) which has already been described.

As the waters of Lake Russell receded to their present position, they left a broad area covered by deposits which had been accumulated on the floor of the lake. This area is ealled the lake plain, but actually it is a succession of terraces which are clearly defined to an elevation of 


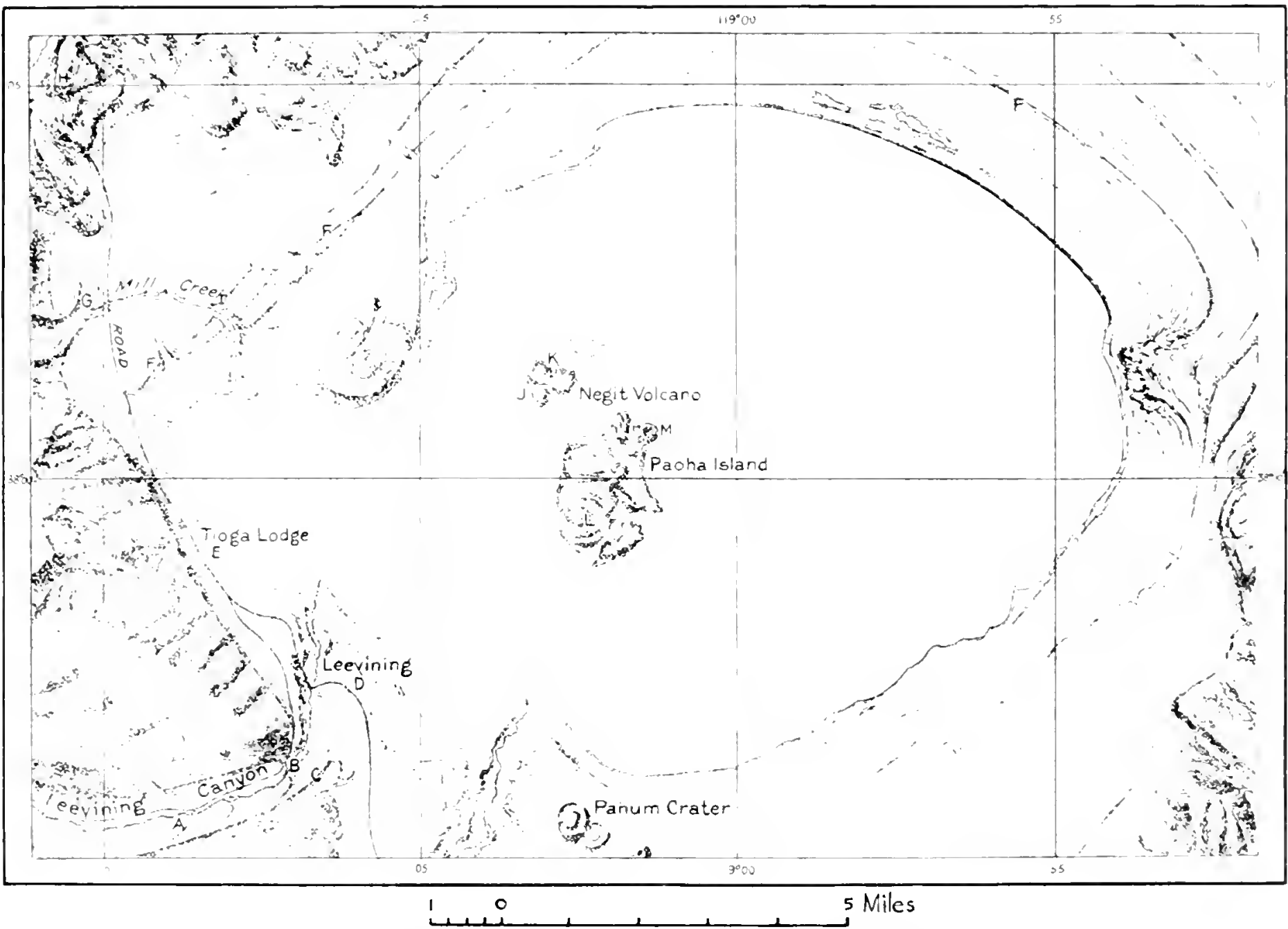

Fig. ni. Mono Iake on the east side of the sierra Nevada below Tinga 1ass. Aprund the lake are

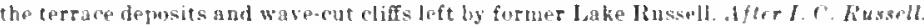


about 650 feet above the present surlace of Dono Latke. In places the terraces were eroded by waves into the sierran belrock or into mo. raines which had been left by orlaciers descending from the great range; clsewhere they were constructed of sediment deponited while for a time the lake stood at various levels and then were exposed as the waters fell to lower positions. Most of the debris which tributary streams carried into the lake is silt (very finely diviled roek fragments), the remainler being sand and gravel. There is almost no clay in the deposits. The lake terrices now are a rather desolate area cuvered principally by sage brush.

The small tomn of Leevining at the junction of the Tioga I'ass road and IIighway 385 stands on one of these terraces, a widlo one, 380 feet above Mono Lake and the same terrace makes the broal expanse of Pumice Valley farther south.

Streams flowing from the Sierra Nevada into Mono Lake, sueh as Rush and Leevining, have eut gorges 300 feet deep into the terrace deposits since the recession of the valley glaciers evolved during the fourth glacial stage.

In the Hono Lake region on the Sierran side four glacial stages have been recognized by moraines left as the various glaciers receded. Reeords of the last two, the Tahoe and sueeeding Tioga, are far better preserved than those of the earlier pair, for the later glaciers destroyed or greatly modified the earlier deposits.

Lateral moraines project from the mouths of the larger canyons, extending beyond the base of the Sierra Nevada as a series of erescentie riclges whose slopes are broad and culminate in narrow erests. Some ot the embankments rise at least 800 feet above the lake terraces whieh they nearly surround. There are also terminal moraines belonging to the last wlacial stage but they are small as contrasted with the lateral banks. The moraines are chiefly granitoid debris, ineluding great boulders embedded in masses of sand and gravel. The extent of the morainal belt and the volume of debris included in it is striking testimony of the vigor of glacial erosion.

One of the most remarkable topographie features of this area is the anamolous horseshoe valley of Reversed and Rush "reeks, which is partly oceupied by four lakes, June, Gull, Silver, and Grant. The name Reversed ('reek is appropriate, for the creek tows from Gull lake toward the mountains rather than toward the low country as does the normal Irainare; it joins Rush Creek at the bend of the horseshoe, and Lush Creek flows to Grant Lake in the western arm of the loop. June Lake has no outlet exeept a small drainage canal cut auross the marshy ground separating it from Gull Iake.

The origin of this strange valley pattern has been explained in varions ways. Two principal fault systems eross the area, an outer one which is the main boundary system along the eastern base of the Sierra
Nevala and an inner one which runs along the escarpments of Mount larker, Mount Wood, and San Joaquin Mountain, and under the trough oecupind by Silver Lake. This second system probably has been the more important in the evolution of heversed Creek-Rush Creek eanyon. It is assumed that $t$ wo east ward flowing streams erossed the area and were separated by a low divide near the south end of present Silver Lake. A tributary of one of these streams, e roding liead. warl along the weak eruslsed zone of the inner fault system, diverted the other stream into itself. The probability is that Rush ('reek (the western stream) captured Reversed Creek which lies to the east beeause it had the advantage of working in less resistant roek. Whether or not

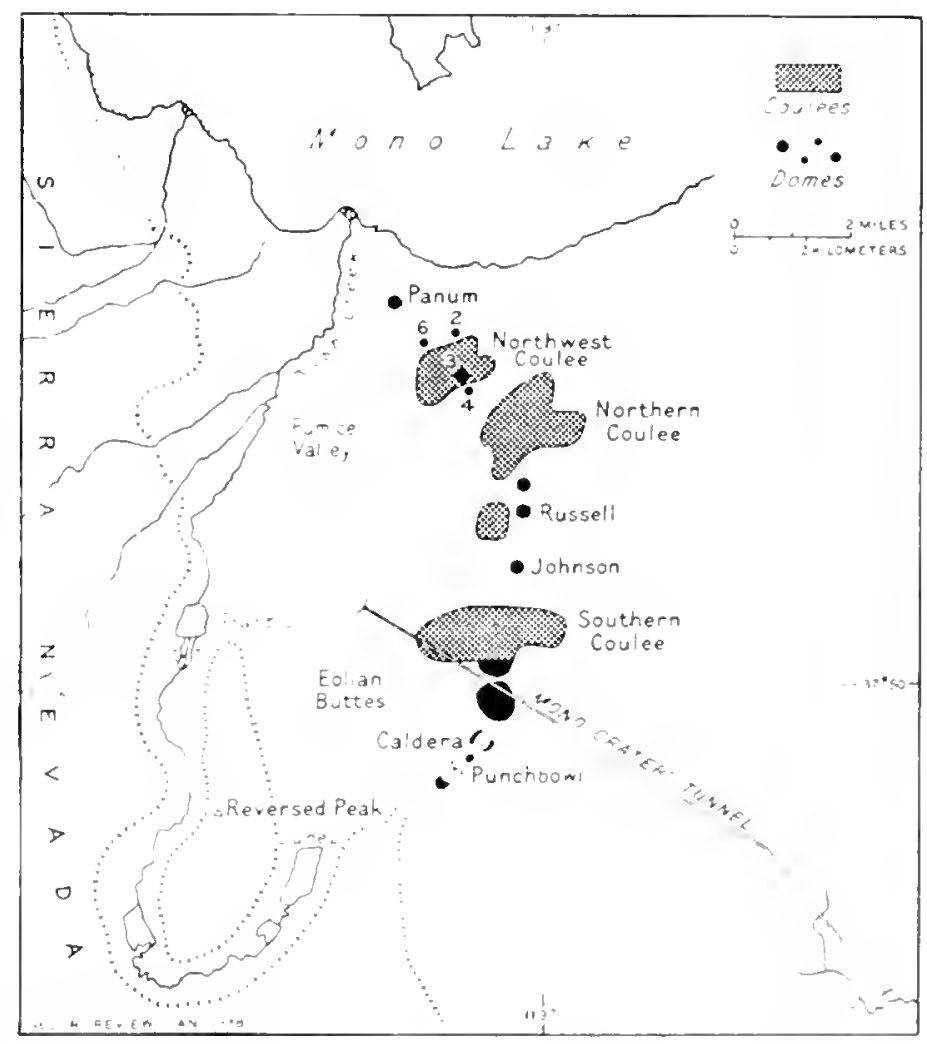

Fur. is. Maj of Mono cones und surrinuding area. lfer W. C. Putnam. 
the eapture was made before the end of the next to the last (Tahoe) glacial stage has not yet been determined.

The problem of the reversal of drainage direction appears to be related to the relative resistanee of the bedrock in the area and the relative erosional efficieney of the two branches of the Rush Creek glacier. Rocks in the June Lake area are more resistant than those about Grant Iake, henee glacial attack upon the former was less effective than on the latter. The June Lake branch of the Rush Creek glacier averaged abont 2.2 miles in length, as compared with the Grant Lake arm which was only 1 mile; the latter not only was thicker $(1,800$ feet as compared with 1,300 feet), but bad the advantage of being concentrated in a narrow, well-defined channel. Therefore glacial erosion was more successful in the Grant Lake than in the June Lake branch of the glacicr. The depth of glacial crosion also is closely related to the fracturing of the rock, the trough at Silver Lake being deeper where the faulting and jointing has been most intense and shallower where the ice traveled orer rock in which the joints are widely spaced, as immediately west of Gnll Lake. Thus the valley was deepened less in the June lake area and more around Grant Lake, causing the present Reversed Creek to flow in an abnormal direction as compared with other streams in the region.

Perhaps the most unique feature of the IIono Lake region is the range of voleanic mountains called the Hono Craters, extending from the south sile of the lake for about 10 miles southward, and clearly visible from Higl way 395 . The highest of the mountains stands about 2,700 feet above the surrounding rolling plain and the range as a whole would be quite conspicuous were it not dwarfed by the enormous bulk and heirht of the Sierra Nevada a few miles to the west.

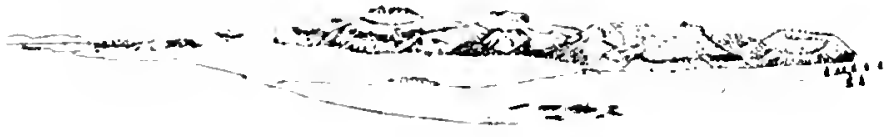

Fio. 5i, l'anoramic sketch of the west side of the Mono cones, showing cones, domes, and coulees. After IV, C. Putram.

The IIono Craters are a group of pumice cones in most of which have risten domes of ohidian (voleanie glase of granitio composition), some so bulky that they flowed over the eone walls, advancing upon the adjacent plain as short, steep-fronted and steep-sided flows, ealled coulecs. The range, which is erescentic in groundplan bending toward the cast, is divided into three nearly equal parts by the projection of

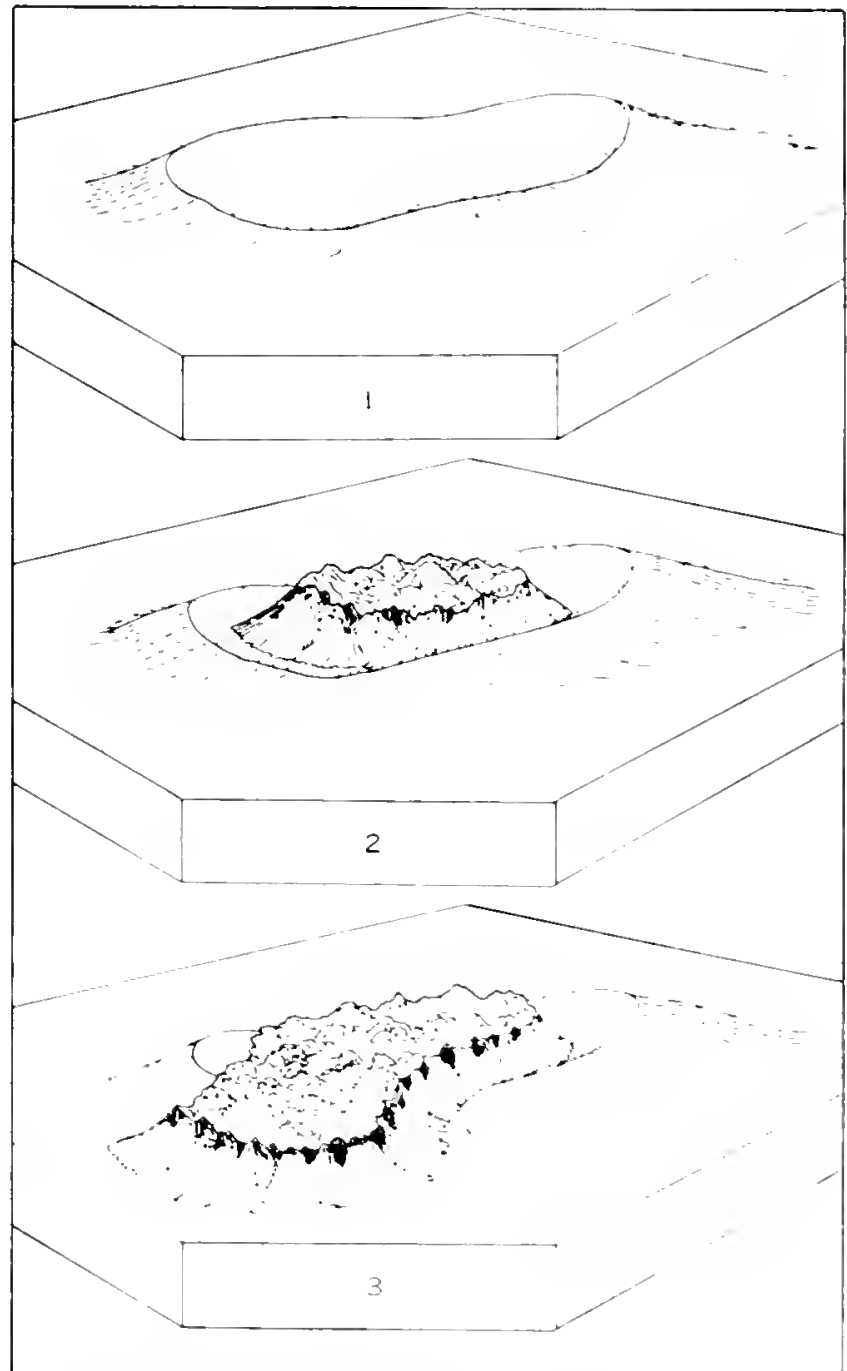

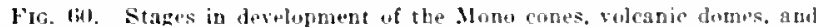

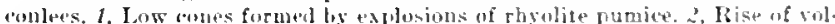

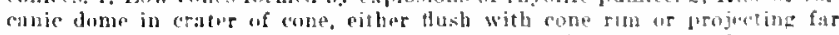
almse it. 3. Too high dome elesiation taused fart of mass to cosertlew crater

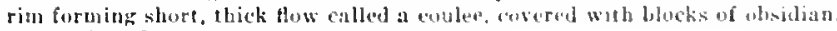
lifer H. ('. Putram. 
the two largest coulees nearly at right angles to the trend of the range. The northern of these two prineipal conlees shows only on the eastern side of the mountains, but the southern is divided nearly equally between the two sides.

The Mono Range rises highest near its eentral part, where three turret-shaped domes of nearly equal size are present, the middle one forming the highest peak.

North of the northern eoulee, there are five domes and two smaller eoulees; south of the southern eoulee are six domes and four large explosion pits. The northernmost dome is isolated from the rest of the range, standing about a mile from it and just south of Mono Lake. This eone and dome, which is ealled Panum Crater, is low, the dome rising about to the level of the erater wall, from which it is separated by a treneh or moat.

The generation of most of the volcanie forms of the MLono Range has followed a definite sequence. At first explosions of moderate violence formed shallow, bowl-shaped depressions much resembling large shell holes. Highly gas-eharged lava was blasted out building low explosion cones made of pumice fragments. Following the explosive episode, largely solid, cylindrieal columns of obsidian rose in the eraters, forming domes of various heights. If the domes were sufficiently elerated, they eontained enough liquid-though very sticky-. lava to eause the rising mass to spill over the rim of the cone, generating the eoulees which in their outer parts are chaotic jumbles of angular boulders. In the north and south major coulees separate outpourings coalesced to form more extensive flows. When the domes ceased rising in the craters, most of the eonduits were sealed. There was but one ease of renewed explosive activity whieh produeed the deep pit ealled the Calflera at the south ond of the ehain. This is a steep-sided double erater oceupying the eenter of an obsidian dome extensively destroyed by explosion.

Great streams of talus coming from the higher domes liave almost completely masked the pumice cones in which they rose. The obsidian boulders forming the talus were generated by fragmentation of the steep domes as they eooled and eontracted and also by later frost wedging which has further disrupted them.

Two nearly complete pumice eones may be seen near the summit of the Mono Range between the southernmost of the three eentral domes and the south major eoulee. The Devil's Punchbowl, near II ighway 395 , is a small but rell-preserved explosion eone whose crater is ahout $\mathrm{I}, 200$ feet in diameter and $\mathbf{1 4 0}$ feet deep; in the bottom is a small obsidian plug about 250 feet across, rising about 40 feet above the erater floor. Panum Crater, just south of Mono Lake, illustrates a somewhat more adraneed stage of dome derelopment. The eone is low, but stands out distinetly from the rolling plain round about. Separated from its rim by a deep treneh or moat is a steep-sided obsidian dome whieh rose after the preliminary explosions had formed the cone. The top of the dome, like that of others, is a wild jumble of spires, erags, and loosely piled bloeks of obsidian.

The Caldera at the south end of the range, as previously noted, is the product of explosion at the end instead of the beginning of the voleanie eyele. This crater is eomprised of a large, flat-floored bowl open at the west and a small, deep pit blown throngh the north wall of the main depression. Originally it was believed that eollanse of the dome had developed the depressions, henee the name Caldera; bnt later studies indieate that explosions were responsible. The tops of the obsidian eliffs forming the walls of the Caldera are covered by 30 to 50 feet of voleanie ash and the seeondary pit is clearly of explosive origin, differing from the larger one only in size. There is no evidence of faulting, whieh should be present if the basins had been formed by collapse.

The voleanic eycle which built the Mono Craters started in late Pleistocene time. Explosive activity began during the last high stand of Lake Russell for pumice is interlayered with lake sediments, but no lake shore lines eut the more recent cones, notably Panum Crater whicb is elose to the lake and stands only 150 fect above its level. The explosion eones at the southwest end of the range were erupted through the floor of one of the small late Pleistocene lakes lying mainly to the east of the range. I'umiee blasted out by the explosions mantles moraines of the last glaeial stage, but there is no sign of aetivity today anywhere in the range.

\section{Warner Mountains}

A splendid example of a fault bloek range in northeastern California is the Warner Range, a narrow, rugged mountainous mass about 87 miles long which extends from southern Oregon across Modoe Connty, California, into Lassen County. On the east it projects slightly into Nevada. At the northern ent, the range merges into a ligh plateau between Abert Lake and Warner Valley and does the same at the opposite extremity just cast of the Madeline Plains in Lassen County. The width of the Warner Mountains ranges from 8 to 20 miles, the narrowest part being slightly north of Alturas, eounty seat of Modoe County. The highest peaks, located southeast of Alturas, are nearly 11,000 feet, but most are eloser to 8,000 feet.

The eastern front of the range, rising abruptly from arid Surprise Valley, is a speetacular, battered fanlt searp along the base of which runs the road leading north and south of Cedarville. The northern half of the western side, as far south as Fandango Valley, closely resembles the eastern front. Fandango Valley is a major embayment which almost euts the range in two, but has no counterpart on the eastern side. South of this valley, the western front is mueh less imposing, sinee the faulting is eomplex and the mountains rise in a 


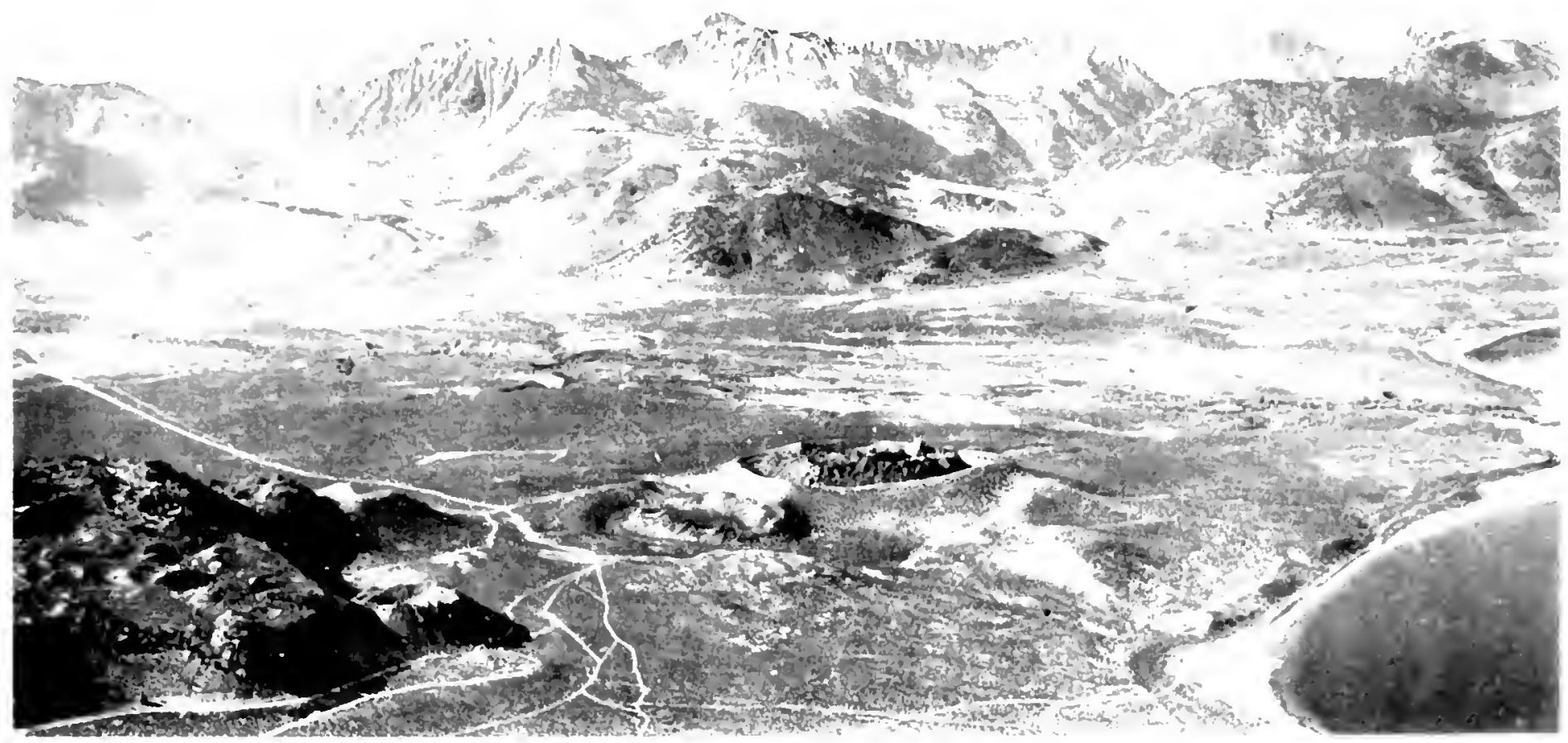

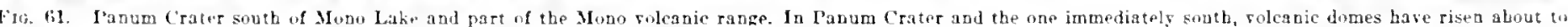
the level of the crater rim from which thes are separated by a narrow trench or moat.

series of stepk, each representing a hlock bounded by faults. A splendid view of the western part of the Warner Mountains may be obtained along Highway 395 leading north and south of Alturas.

The southern half of the western front of the Warner Mountains differs widely from the northern. There is no eonspicuous escarpment, only a long unbroken slope from the base to the erest of the range. The surface of this slope for the most part coineides with the uppermost layer of lava eomposing the mountains.
From the pieture just drawn, it is evident that the northern end of the Warner Mountains is a horst or vertically elevated fault block bounded by battered scarps on both siles; also that the southern seetion is a tilted fault bloek with the great searp on the eastern side. The ehange from the one to the ot her is gradual. The uplands of the horst are comparatively smooth lava-eapped areas, little modified by erosion, whieh are being destroyed by eanyous being eroded headwarl into them from both sides of the range. 


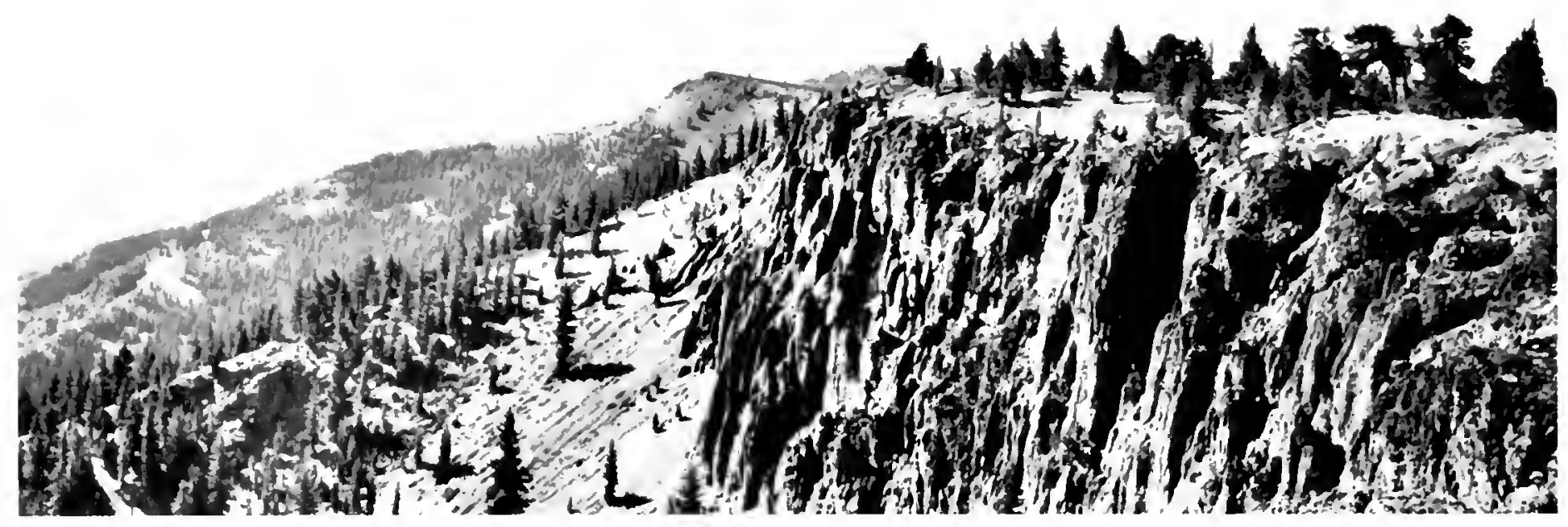

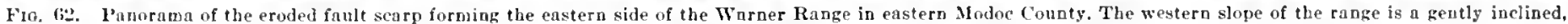
nut greatly dissected erosion surface. Showing at the base of the rante is part of surprise Valley. Photo by C. W. Chesterman.

West of Goose Lake Valley and the north part of Pit River Valley is an extensive plateau known as The Gardens. Most of its surface is a smooth lava cap but locally small domes of rhyolite and obsidian rise above it. Still farther west, toward the boundary of Modoc County, there has been much recent volcanic activity and large areas of the plateau are covered hy lava flows, explosion cones, and other extrusive inrms. This sertion is known as the Mrolow lad bea Beds or the Burnt Lava Country.

Surprise Valley east of the Warner Mountains is a larger trough than that on the western side. Along its eastern margin rises the Iays Canyon Range, which is bounded by a battered fanlt scarp, but one far less striking than the eastern declivity of the Warner Range.

The rocks composing the Warner Mountains are principally lava flows and fragmental deposits which lay in essentially borizontal position at the time of the elevation of the fault block. These volcanies were erupted during a long but intermittent eyele which saw a liuge section of northeastern California and still greater territory in Oregon, Washington, Idaho, and Nevada tnrned into one of the most gigantic volcanie ficlds of the earth.
It is believed that prior to the deformation which produced the ranges and grabens of this region, an extensive rather even-surfaced plain existed. Below this plain the lava flows and fragmental deposits were essentially parallel with its surface. Over some scetions very late basalt flows were erupted, covering them in places to deptls of 600 feet.

Deformation, starting toward the pnd of the Plineene or in the early past of the l'leistocene epord. prouluced a bond dome with it, crest in the Warner block; as it evolved the dome fractured. The Warner and IIays Canyon ranges rose, while Goose Lake, Surprise Valley, Long Valley, and other grabens moved downward. There does not appear to have been much compression outside of the broad doming, the principal deformation being the differential vertical dislocations. The cvidence for the development of this breaking dome comes from the increase in elevation from the Gardens to the snmmit of the Warner Range and the decrease eastward from the summit of Hays Canyon Range to its base. In a north-south direction, the greatest height of the Warner Range is in its central part with decrease toward both ends. The arch in this direction, however, quite certainly resulted from differential elcvation of blocks bounded by faults and not from 
eompression. The Warner Range, therefore, is a mosale of fault. bounded masses which have behaved in different fashions as the deformation proceeded.

Indication of continued sinking of the arrabens comes from the location of lakes against the base of the steepest escarpments, where apparently the movement is most active. If this dislocation were not still going on, erosional waste from the ranges whicb forms alluvial fans and aprons at their bases would long since have forced the lakes farther outward and the deepest parts of the grabens would be toward their centers. The broad playas of Surprise Valley, deposits formed in a lake which formerly lay against the base of the Warner Range, Lake Annia in Jess Valley, Alkali Lake in Long Valley. IJigh Rocky Lake in Iligh Roeky lalley, Abert Iake, and others hug the steep escarpments. All of this evidenee testifies to the recener of evolution of the major features of this remarkable landscape.

Surprise Valley, the graben between the Warner Range and fault bloek mountains to the east, starts 7 miles south of the Oregon border on the east side of the Warner Mountains and estends for about $\overline{5}$ miles southward. An average width of about 8 miles is maintained over this distance, though there is narrowing at the northern and southern ends. At present there is no outlet from the valley.

Perhaps the most notable feature is evidence of series of large lakes ealled Surprise Lake, which existed during one or more of the recent glacial stages. These great bodies of water whieh reached a maximum depth of 550 feet not only filled practically all of Surprise Valley but overfowed a narrow divide at its southern end, covering

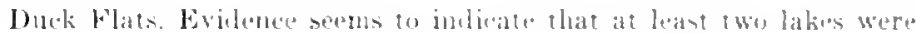
separate? hy a time of aridits when the valley beame very dry and probably al of the water was evaporated. The oh slore lines are indicated by wave-cut cliffs and terraces, and by delta and other deposits. The highest shoreline is particularly well marked and pxtends around the valley in virtually undamaged condition.

The Duck Flat extension spread mostly over a surface of basalt which probably already had on it a growing lake, for this area also is an enolumb ham. In l)uck lolat the highest level shore line is best developed, indicating that at this stape the lake remained relatively stable for a considerable period. Whether the water overtlowed barriers into other basins is not known, though this is quite possible.

As the water of Lake Surprise Jowered, the Duck Flat section was isolated from the main body as is shown by an outlet rorge cut between the two with the slope toward Duck Flat. For a time two lakes existed with that in Duck Flat standing about 200 feet below that in surprise Valley. Lut whes lake Surprise was still 200 feet deep. overflow through the gorge into Duck Flat ended and its lake probably dis. appeared rather soon beeause it seems to have been maintained principally by water from the larger body. Finally the main lake itself was eompletely evaporated.

On many maps of Surprise Valley, three large lakes are shown which are called by some Alkali Lakes and by others Lpper, Middle, and Lower Lakes. The northern or Cpper Lake when filled is a unit. Middle Lake also was a unit wheu it contained water, but, some vears ago, it was divided by the construction of a causeway east from Cedar-

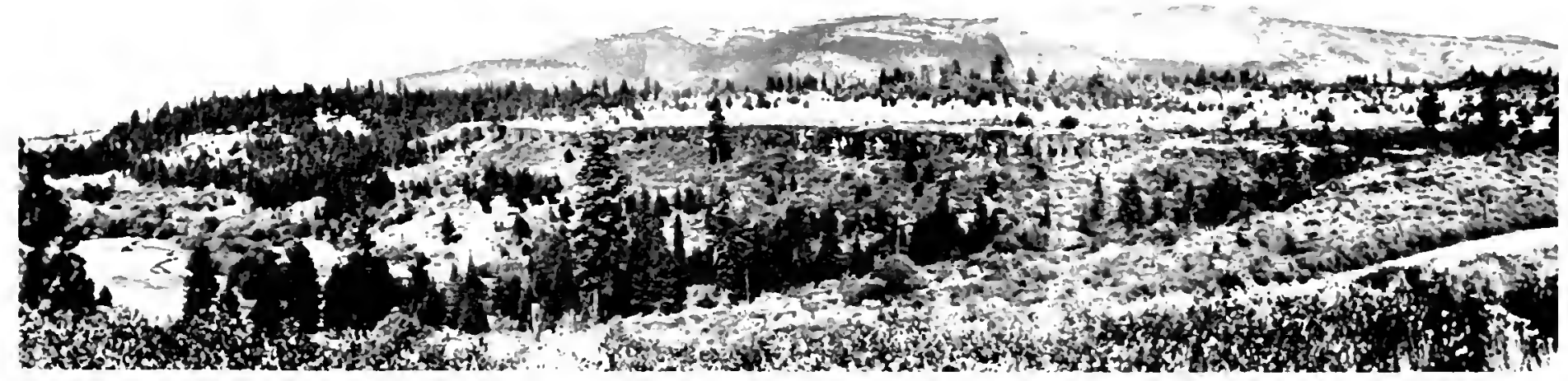

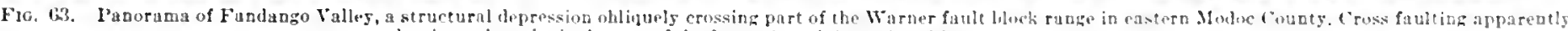
has been the principal cuuse of the formation of the valley. Photo by C. IV. Chesterman. 


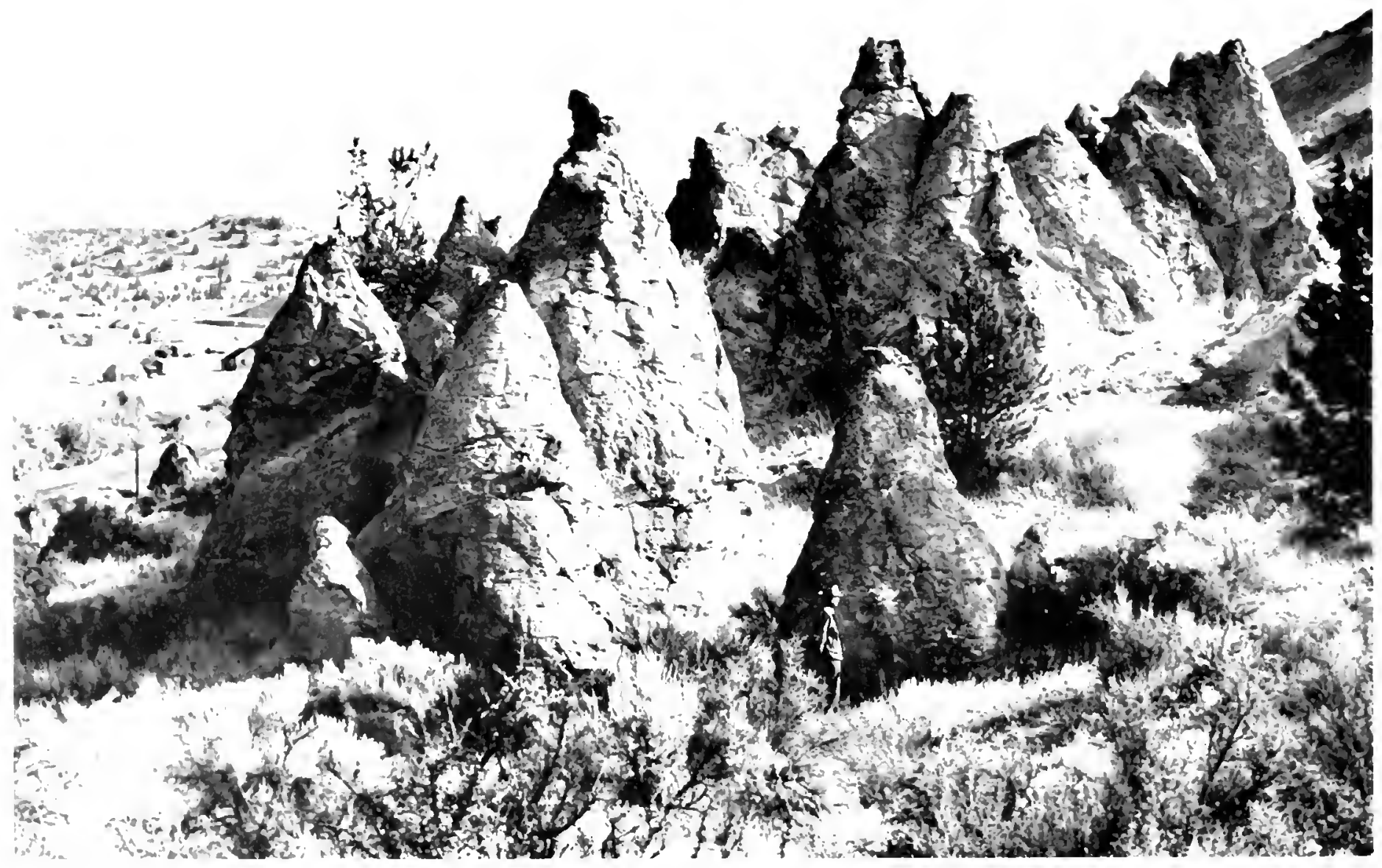

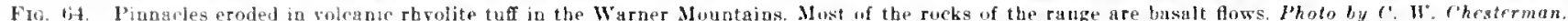




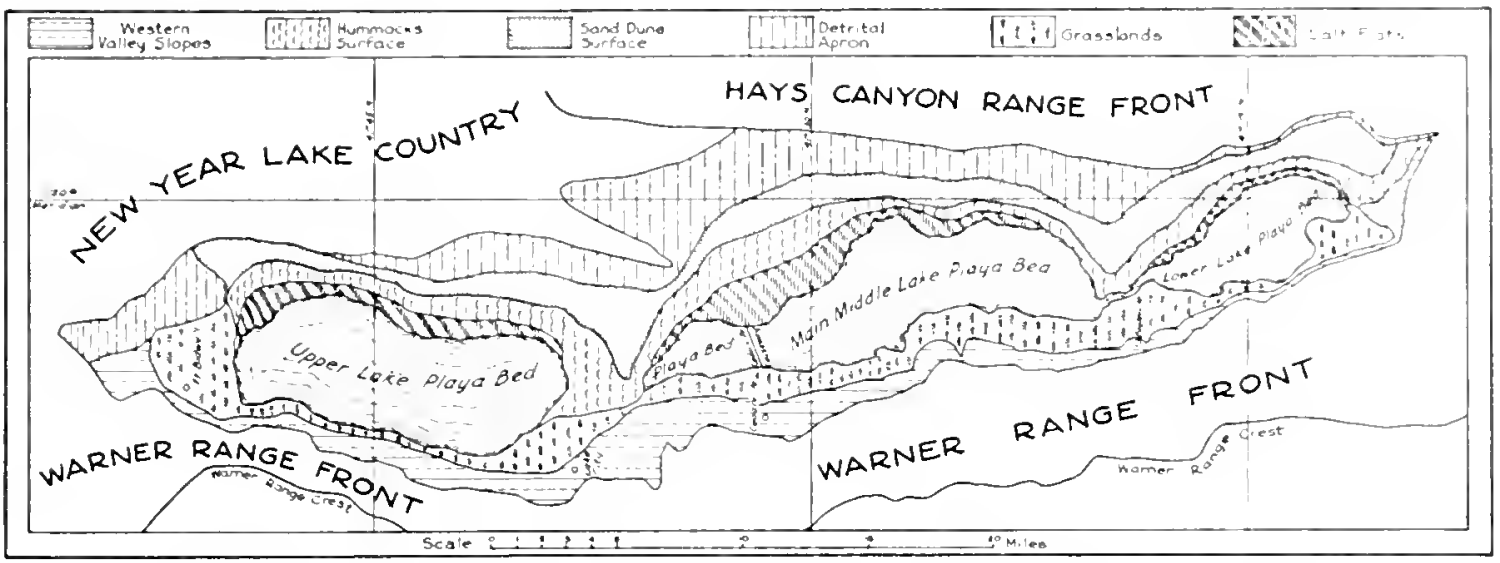

Flg, 6.i. Map of Surprise Valley and the adjacent Warner and Hays Canyon Ranges, After R. J. Russell.

ville, the principal town in Surprise Valley. The southern or Lower Lake, in contrast, is an aggregate of smaller lakes, each of which is a playa but does not become dry simultaneously with the others. Since the waters of the larger lakes evaporate so that only isolated depres. sions are filled, it has been "umtomary to grive names to the small residuals. Thus the term Eagleville Take is much more simnificant in Surprise balley than Lower hake and refers to a small portion near the town of Eargleville. This lake is sait to have drietl up only unce in the memory of many of the oldest intiabitants.

Cpper lake when filled is about 13 miles Joner and 4 miles wille, an overtlow vannel into Middle lake preventing further growth. In normally wet years. it decreases to about half its major size during the ary season, but in dry years it disappears. In the winter the frozen surfare of this lake offon serwes as a highway betwen lake City and Fist lid well. When (ampletely dry, the playa surface is also used for traffic. l'pper Lake normally does not become as completely dry as the two lower ones

Midule lake is nearly as widle as the ujper one and is $1 \mathrm{~m}$ miles long. The northern 4 miles have been isrlated by the Cedarville eansway and is dry mont of the time during the summer. The main bower part trenerally contains water until early summer and onte or two pools usually romain altmo its western marern.

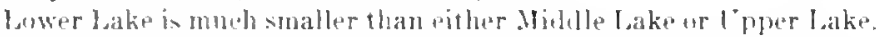
Toward the south is a hroad. nontinums playa but northward this is broken, whisfly beanse of wint-blown accmmulations which form isolated basins. X゙early every year water overflows from Hidlle into the Lower lakes, but during the summer most of the basins are dry llowever. even in the driest years, a fow depressions in the western side of the larest playa contain water coming from nearly hot sprines.

Evaporation uf the lakss is ancompaniel by wat ward movement of the eastern shoreline until finally mo water is left. When the play bets are exposel, they crack into blocks having an irresular hexagonal pattern. In the summer frepuent wind whorls carry dust to heirhts of 1.000 to 3.000 abose the flaya surfawe and moro violent blows eause dust storms which cobsure the landscape to elevations of 2.000 to 3.000 feet above the valley

East of the play hels salt and alkali coiting are abumbant; plspwhere there are none, Along the eastern side of these salt thats there art hummoky areis whith appear to be wind-hown ateumulations of sand and dust with degesition startine mostly around saure bruh. small, atetivaly migratiug sam dunes are found east of this hummoeky area. Ther do not pxiend 311 foept in height, and their northeast-south.

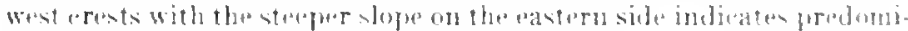
matly soutlatastolowing wimls.

On the west side of the llays Canyon Range there is a prominent alluvial apron having a slope in the steeper parts of at least 10 dewrees Reant fault scarps break the continuty of the apron in a number of plares. Above the alluvial slope rises the eroled llays Cancon fault scarp which is steeper, more barren, and more subject to (onnsiberablye roekslides than is the Warner Range across the valley. Then' nutable slumps and sears appear to be a product of the deficiency of rearta. tion over the upper slopes of the range which receive much less snow 
and rain than do the Warner Mountans. The elevation of the two ranges is approximately the same and the rock formations are alike. At the ends of the Warner lange where the elevation is less and there. fore veretation not so prevalent, slide features are more "ommon than in the higher part.

Along the Warner Monntains across Surprise Valley there also is a considerable alluvial apron, with steep slopes (up to 10 degrees) at and near the canton mouths but decrasing farther out until they seem almost flat.

It varions places in the Warner Nomntains there are a number of landslide lakes which have been formed by the collapse of lava rim rocks overlying more easily weathered and eroded material. Under proper eonditions where there is not too much proteeting talus, the eanyon walls are sufficiently exposed so that the resistant rims are undermined and masses eventually break loose, easeading into the bottom of eanyons where they may form dams suffieiently durable to impound lakes for eonsiderable periods.

One example, Clear Lake, loeated in Mill Creek Canyon 2 miles northust of Jess Valley in the southeastern part of the Warmer Range, is small and not over 90 feet deep. It has been formed by $t$ wo slides, one from each side of the eanyon a thousand feet deep. The slide sears are so fresh and the delta formed by the stream flowing into the lake is so small that the barrier probably was not formed more than 100 years agro. Blue Lake, 10 miles farther south, is similar in origin and very reeent, but its waters are impounded by a single slide. Both Clear and Jess lakes drain to the Pit River. On the eastern side of the range, 7,400 feet above sea level, is Lost Lake, also in a deep canyon; the sear of the slide whieh holds baek its waters is mueh less distinct than those of the lakes previously mentioned and the delta plain formed by the stream supplying the lake is half again as large as the water surfaee, hence it is considerably older.

Jess Valley is believed to be a filled, drained, older, and larger landslide lake in the valley of the Pit River between Clear and Blue Jakes, where the river flowing from the west base of the Warner Range cuts a gorge througl another up-faulted lava bed block of lower altitude. The nearly even surface of the valley is about 6 miles long and more than 2 miles wide. The slide which dammed up the river is of enormous size.

Eagle Lake, 30 miles northwest of Honey Iake and therefore south of the Warner Mountains, stands about 5,100 feet above sea level, is
12 miles long and 2 to 1 miles wide. The barrier forming it appears to be a landslide on the sontheast side. The level of the lake rises and falls without regard to rainfall and when it sinks streams flow from the outer slope of the barrier and are tributary to streams entering IIoney lake. This indieates the porous nature of the dam, a feature characteristie of landslide jumbles, but it also shows that the passages through which the water emerges are alternately opened and closed.

\section{REFERENCES}

Baker, C. L., l'hysiography and structure of the western El Poso Range and the southern Sierri Nevadn: Univ. Californiu Dept. Geol. Sci. Bull., vol. 6. pr. 11T-142, 1912.

BInekwelder, Elint, Lnke Monly, nn extinet Lake of Death Valley: Gegg. Rev. vol. 23, vp. 464-471, 1933.

Blackwelder, Eliot, Yardangs: Geol. Soc. America Bull., vol. 45, pp. 159.166, 1934.

Gale, 11. S. Notes on the Qnaternary lakes of the Grent Basin with special reference to the deposition of potnsh and other snlines: U. S. Geol. Survey Bull. vol. 540, pp. $540,2 \mathrm{p} .3949-406,1914$.

Kesseli, J. E. The origin of Jnne, Gull, and Silver lake vallezs, Moao County, Californin: Jour. Geolory, vol. 40, wy. 7236-734, 1932.

Kuoplf, A., and Kirk, E., A geologieal reeonuaissnace of the layo Rnnge and the eastern slope of the Sierra Nevudn, California: U. S. Geol. Survey Prof, Paper $110,1918$.

Lee, $C 11$. An intensire study of the anter resonrces of part of Oweos Valles. Californin: U. S. Geol. Survey Wnter-Supply Paper $294,1913$.

Londerback, G. D., Jeriod of scarn production in the Great Basin: Univ. Catifornia Dept. (ieol. Sei. Bull., vol, 15, pp. 1-44, 1924.

Inouderback, G. 1). Morphologic features of Pasin Rnnge displncements in the Great Basin: Univ. Culifornin Dept. Geol. Sei. Bnli., vol. 16, pp. 142, 1926.

II aso, E. I3, nnd others, Southern extension of the Mono Craters, Cnlifornin: Am. Jonr. Sei., 5th ser., vol. 32, pp. 81-97, 1936.

Noble, 1. F. Structurnl fentures of the Virgin Spring area, Death Vnlley. California: Geul. Soc. Anerie日 Bull., rol. 52, pp. 941-1000, 1941.

Pntnam, IV. C. Quateruary geologs of the June Luke District, California : Geol. Soc. America Bull., vol. s0, pp. 1281-1302, 1949.

Russell, I. C.., Qunteruary history of Mono Valley, Cnlifornia : L. S. (ieal. Survey Eigbth Anunal Report, pp. 26-394, 1360.

Rnssell, R. J Lnadslide lnkes of the northwestern Great Basin: Univ. Californin Publ. in Geography, vol. 2, pl. 231-254, 1927.

Russell, R. J., The land forms of Surprise Vulley : Univ. California Puhl. in Geography, np. 323-358, 1927.

Russell, R. J., Ihusin range structure nad stratigraphy of the Waruer Rnage, northeastern Californin: Univ. Califoruia Dept. Geol. Sci. Bull., rol. 17, pp. 357$496,1928$.

Ton Tugeln, O. D., Ubebebe Craters and explosions breccias in Denth Valley. Californin: Jour. Geology, vol. 40, pp. 726-734, 1932. 
MOJAVE DESERT 


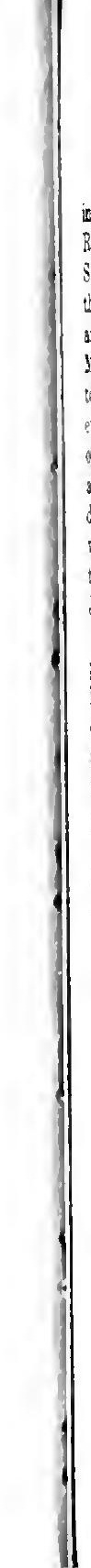




\section{MOJAVE DESERT}

As used herein the term Mojave Desert province applies to the area in southern California which has the following boundaries: the BasinRanges province on the north (see pl. 2); the southern end of the Sicrra Nevada and the Tehachapi Mountains on the northwest; on the southwest the Sawmill and Liebre Mountains, the Sierra Pelona, and the San Gabriel Mountains; on the south the San Bernardino Mountains and the Colorado Desert. The northern margin is difficult to determine, as the Mojave Desert merges into the Great Basin. How. ever, an approximate line has been (hosen between the southern part of the Great Basin where the mountain ranges are markedly parallel and the region to the south where the ranges are lower, more deeply dissected, and lacking in conspicuous parallel arrangement. This eastwest line falls between the Nopah and Kingston Ranges and runs west to El Paso Mountains north of the mining camps of Randsburg and Johannesburg (see pl. 2).

The Mojave Desert is charaeterized by a small amount of annual precipitation and low humidity. The temperatures are moderately high in the winter and extremely high in the summer, with notable daily range. At certain times of the year strong winds blow across the region. Precipitation increases with altitude, but the inerease is far from uniform, the known differences in part at least resulting from position of a locality with respect to the rain-bearing winds.

Faulting has been conspicuous in the Mojave Desert province and bas been the prime control of separation of high-and low-standing areas. MIost notable of the fault systems is the San Andreas which lies along the north base of the San Gabriel Mountains. It shows conspicuously from the air as an almost continuous suceession of long, narrow basins separated by elevated areas which undoubtedly are small fault blocks that have risen as the basins have subsided. The last known dislocation along this section of the rift occurred in 1857.

Another prominent fault system, the Garlock, is found along the southcast face of El Paso Mountains. Near the town of Garlock, it cuts a large alluvial fan; 5 or 6 miles to the northeast, near Goler Well, there are large depressions formed by dropping of blocks of ground along the fracture zone. The scarps are so fresh that the dislocation must be ratber recent. Northeast of El Paso Nountains, the Garlock fault shows along low hills on the south border of Searles Valley. East of the Slate Range, a long, narrow valley-with Leach Point Mountains rising steeply on the southern side and a more gentle slope on the northern-suggests the same fault, which may continure as far as the Avawatz Mountains. However, the faults in the Avawatz Mountains may belong to another series. Southwest of El Paso Mountains there is a marked escarpment on the southeast side of the Tehachapi Moun. tains which is in almost perfect alignment with the southeast side of El l'uso Mountains, containing sag pouls and other features showing that the Garlock fault continues in that direction.

The San Andreas rift and the fault along the front of Fl Paso and Telıachapi ranges bound a conspicuous area having the form of an arrowhead, whose point is at the western edge of the desert. This area has within it only low, seattered hills but no large mountains.

South of the Garlock fault, the strikingly parallel ranges and basins so characteristic of most of the Basin-Ranges province are less appar. ent, and the arrangement in most of the Mojave Desert is much less clearly defined. However, there is abundant evidence of faulting in many places, and major landseape features liave heen evolved by movements along the faults, many of which seem to be rather short, but have been zones of much displacement.

Areas where faulting seems to have exerted notable control in landscape evolution are Lane Mountain and the connected hills abont 15 miles north of Daggett; the basins containing the playas known as Soda, Silver, and Silurian dry lakes, with the adjacent mountains extending from the Soda Lake IIountains north to A rawatz Mountain and the New York-Providence Mlountains. Others are a series of northwest ward trending, short, parallel ridges north of Bagdad and Amboy. the lighest of which is Old Dad Mountains, and a more or less con. tinuous range south of the Atchison, Topeka \& Santa Fe Railway, extending from near Daggett for many miles southeastward and including the Bullion and Sheep IJole Mountains.

Evidence is insufficient to determine the age of much of the faulting but some certainly is of very late date and some faults are still active.

Because most of the Mojave Desert has not been studied geologically, the history of its landscape is imperfectly known.

The Afton Basin is an enlargement of the valley of the Nojave River about 40 miles east of Barstow in the Mojave Desert. This arca is one of rather even-surfaced alluvial deposits-both low sloping alluvial fans and basin sediments-above which rise isolated mountains of moderate elevation. The basin appears at one time to have been undrained, and this condition probably continued into middle Pleistocene time. Later the Mojave River, flowing from the San Bernardino Mountains, advanced into the region where its waters were impounded to form Lake Manix, named for a station on the Cinion Pacific Railroad. An almost completely enclosed cmbayment of this lake occupied the $\Lambda$ fton Basin. Later on, probably becainse of erosion by its outlet, this lake was drained and the sediments deposited therein have been eroded rapidly by the Mojave River and its tributaries. 


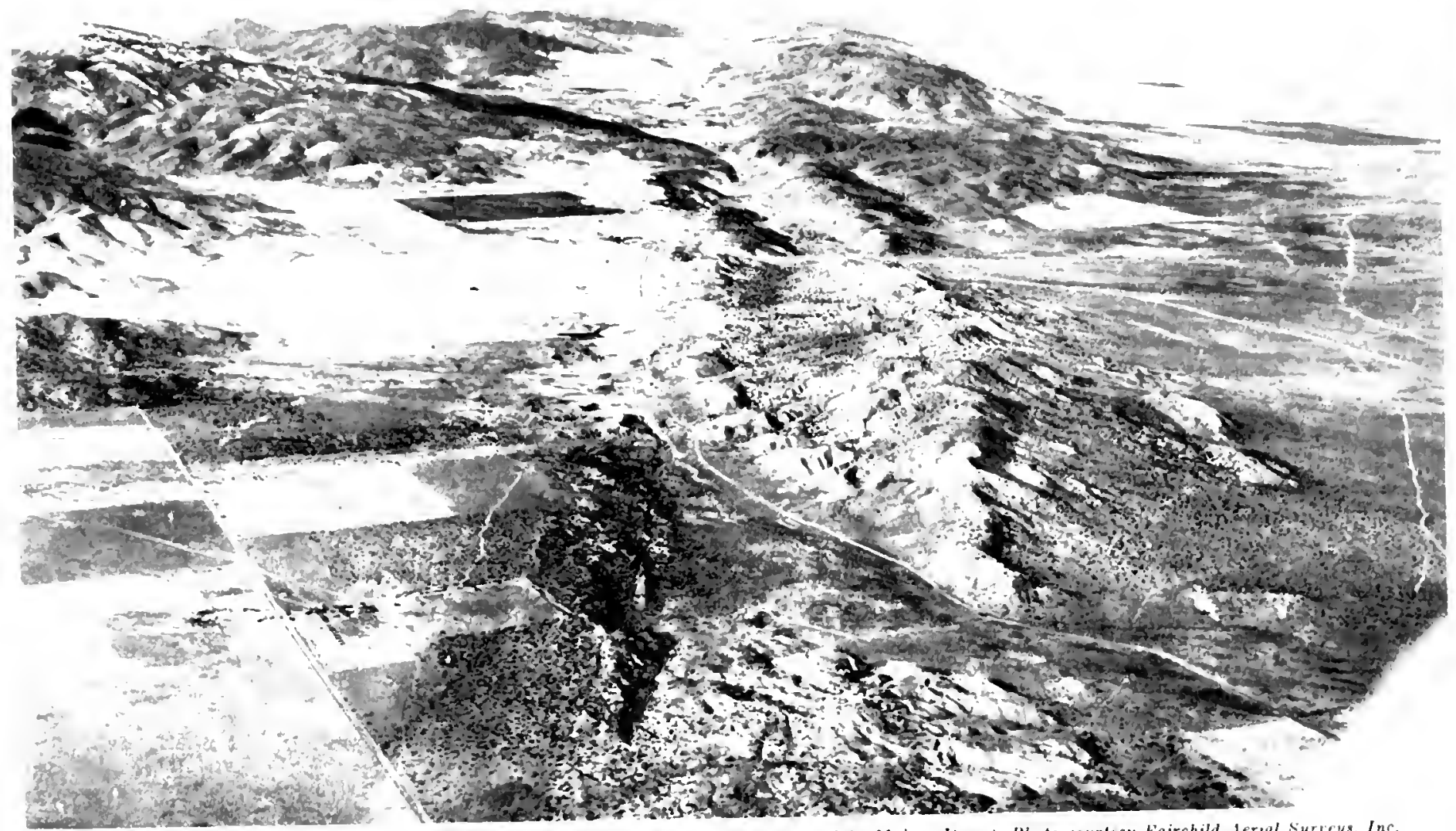

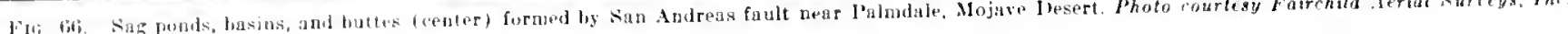




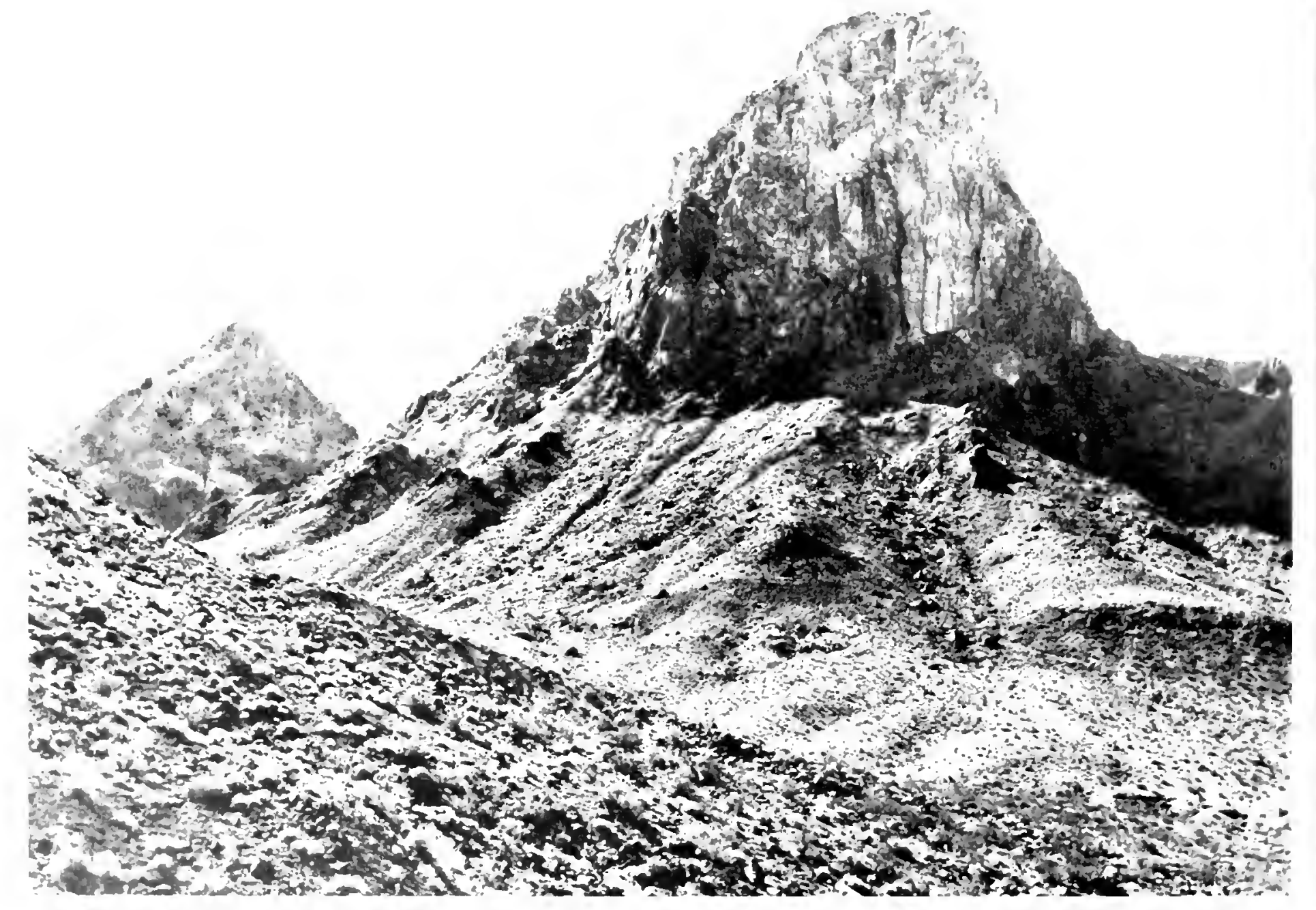

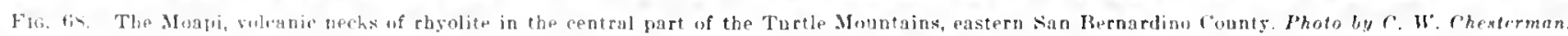




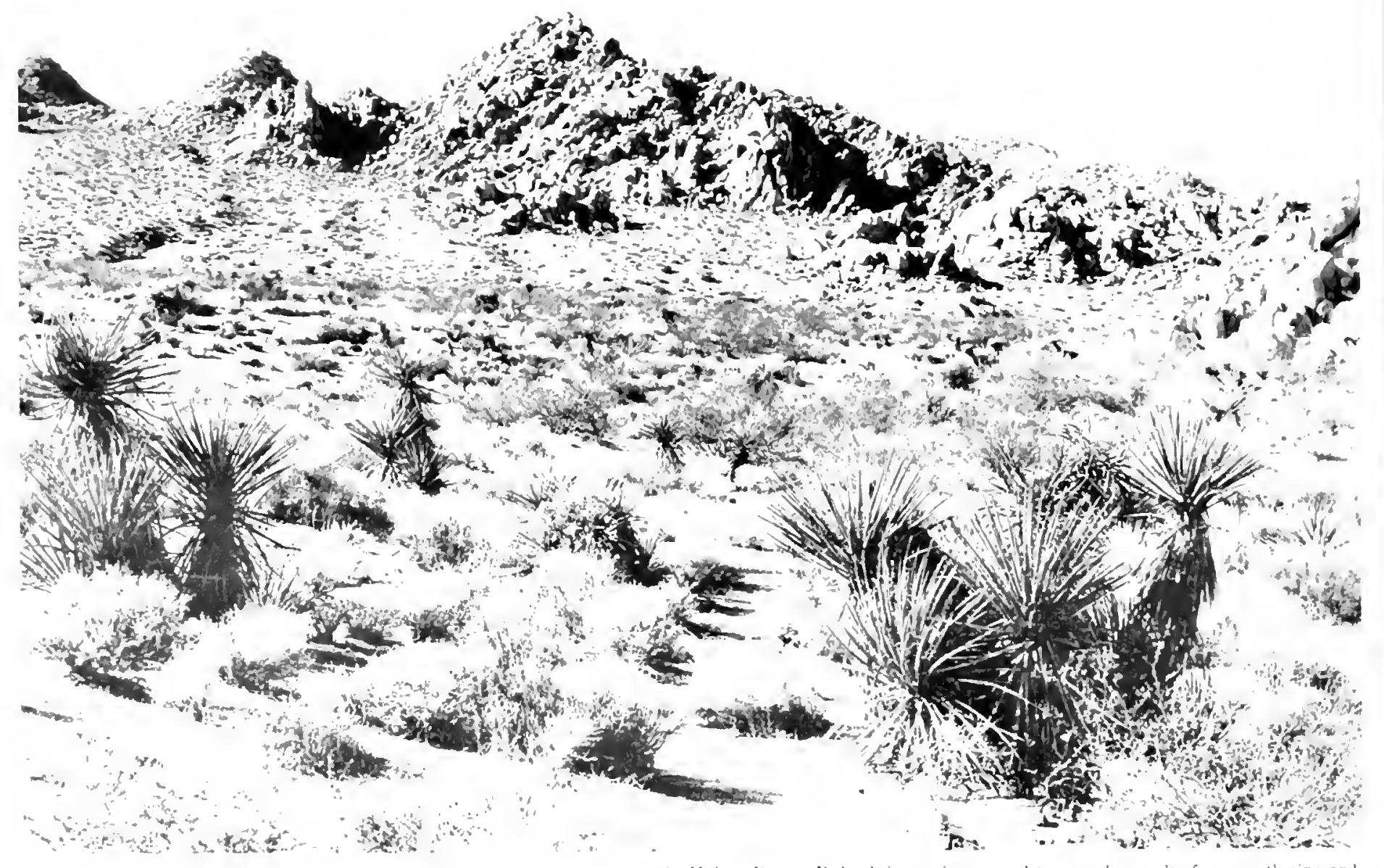

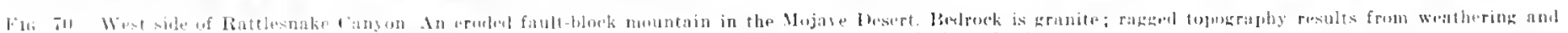

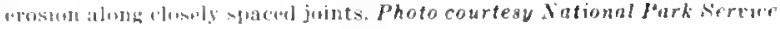




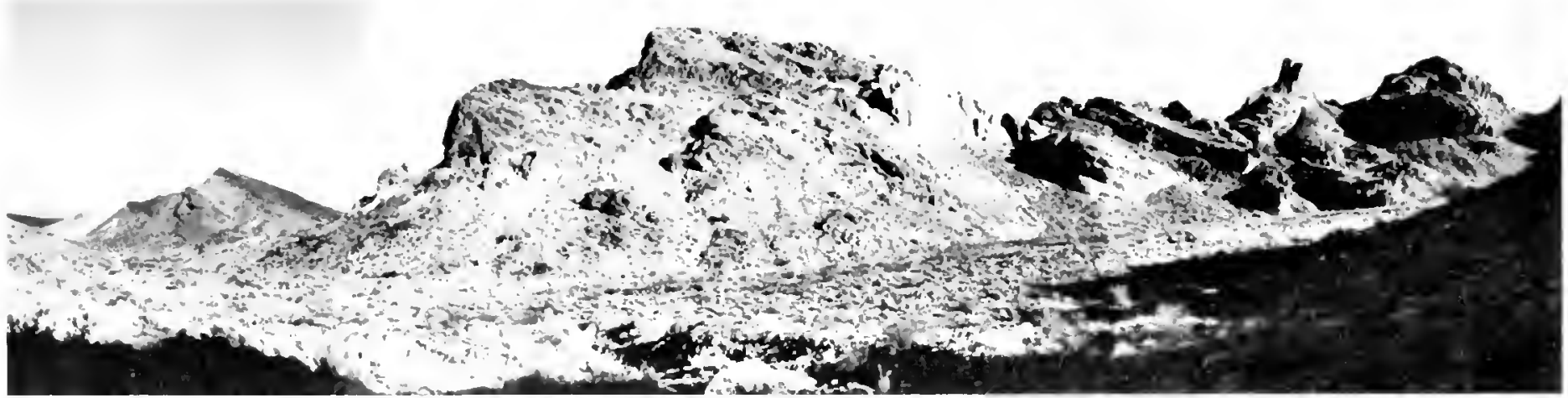

Fro. T2. Panorama of the north part of the Turtle Mountaina, eastera San Bernardina County. Photo by C. W. Chesterman.

Along the California border with Nevada a large man-made lake lies behind Parker Dam situated in one of the canyons of the Colorado River about 16 miles north of the town of Parker on the Arizona side of the river. The great stream has excavated this canyon through one of the fault-block ranges of the Mojave Desert, apparently keeping pace with the elevation of the block as it has done in crossing various other ranges. The dam which rises about 300 feet above the surface of the water has impounded a long, narrow lake-a beautiful sight in an otherwise desert land. From this reservoir water is hoisted by electric power brought from the great generating plant at Hoover Dam. Five lifts are necessary to carry it over a divide about 1,600 feet above the reservoir surface. From this point, a transporting system, the Colorado Aqueduct, earries the water down slope aeross desert basins and by tunnels through mountain ranges to a main storage reservoir about
7 miles southeast of Riverside. From the reservoir, mains and canals lead to various parts of the Los Angeles region and also to San Diego. Parker Dam can be reached by an oiled road which branches off from Highway 95 ahout half way between Needles and Blythe.

\section{REFERENCES}

Baker, C. L., Notes on the later Cenozoic hiatory of the Ifojave Iesert region in southeastern California : Univ. California Dept. Geol. Sci. Bull., vol. 6, pp. 333. $383,1911$.

Blackwelder, Eliot, and Ellaworth, E. W. I'leiatocene lakeg of the Afton Bagin, California : Am. Jour. Sci., vol. 31. pp. 453-463, 1936.

Davis, W. M., Granitic domes of the Mojare Desert: San Diego Soc. Nat. Hiat. Trans., rol. 7 , pp. 211-258, 1933.

Foghag, W. F., Saline lakes, Mojave Desert, California : Econ, Geology, vol. 21, pp. 56-64, 1926 .

Thompson, D. C., The Mojare Desert region: L. S. Geol. Surrey Water-Supply Paper 578, 1929. 


\section{COLORADO DESERT}




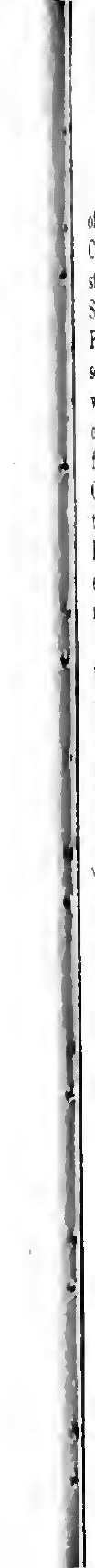




\section{COLORADO DESERT}

The Imperial and Coachella valleys are parts of a great depression of roughly V-shaped groundplan oceupying a section of southeastern California known as the Colorado Desert province. This immense structural trough has its apex to the north not far from where the San Jacinto and San Bernardino Mountains meet at San Gorgonio Pass through which goes Highway 60 on its way eastward and then southeastward from Banning. The trough opens to the southeast where it is continuous with the larger and much deeper depression occupied by the Gulf of Lower California. Rising more or less abruptly from the southwestern and northeastern sides of the Imperial and Coachella valley's are bold mountains : the l'eninsular Ranges border the soutbwestern margin while the soutbeastern portion of the San Bernardino Mountains of the Transverse Ranges province and various elevated blocks belonging to the Hojave Desert province lie along the northeastern side.

The climate over the depressed area is desert, being characterized by extremes of heat and dryness, for the Imperial Valley section is the hottest part of the United States and one of the hottest in the world. Ranges of temperature also are extreme as is characteristic of all such regions. The highest recorded temperature was $130^{\circ} \mathrm{F}$., the lowest $22^{\circ} \mathrm{F}$. Rainfall ranges from 1.10 inches annually at Ogilby, a small settlement in the far southeastern corner of the Imperial Valley, about 16 miles northwest of Yuma, Arizona, to 3.53 inches at Palm Springs near the northwestern end of the Coachella section. Most of the moisture falls in December, January, and February; in the Salton Sea region the month of June is practically rainless.

The Salton Basin is the southeasternmost section of the ImperialCoachella trough and, though now separated, it is continuous with the depression under the Gulf of Lower California. At one time the gulf extended about 125 miles north of its present limit and one arm projected into the present Imperial Valley, a considerable section of which lies below sea level. The Colorado River diseharged into this expanded gulf head north of the Hexican border as today it does into the shortened gulf south of this boundary. Near the border between the United States and Mexico, the river built a buge delta, the landward part of which finally rose above water level as a delta plain that eventually extended across the gulf isolating the northern part and impounding its waters as a lake having no connection with the ocean. As in most of southern and southeastern California, the climate in recent time has become increasingly arid causing the drying up of the lake and the conversion of the whole of the Imperial-Coachella depression into a desert.
The area of the Imperial-Coachella trough is considerably grcater than that of other similar areas in California but the major features of the landscape are quite similar. The central part of the Salton Basin is rather flat. In a number of places bedrock masses project above the sedimentary fill, as for example Borego, Superstition, Carrizo, and Cargo Muchacho Mountains, Indio Hills, l'ilot Knob, and a number of volcanic buttes 100 to 200 feet high south of Salton Sea.

Along the borders of the Salton Basin, there are extensive balland areas, as for example in the Hecea and Indio Hills near the two towns of those names on the east side and south of the Santa Rosa Mountains, around Seventeen Palms, and in the valley of Carrizo Creek on the west side. Smaller areas are numerous.

Badlands are areas characterized by a labyrinth of gorges separated either by round-crested or sharp-erested ridges. They are a product of the various phases of sheet and flash flood erosion in weak rock or rock mantle unprotected or insufficiently protected by regetation. While best developed in arid lands, they are found also in humid places where for one reason or another the plant cover has been removed or seriously depleted. Badlands are among the most intricately sculptured landseapes.

The arroyos or dry washes generally are $V$-shaped in cross section, though some of the larger are flat-bottomed. The walls may rise almost vertically or may flare outward at various angles. In this region, where such landscape has been developed in nearly horizontal strata, vertically walled, flat-bottomed gorges predominate, and between them are nearly flat-topped divides rather than the more normal rounded or sharp-crested ridges. It is believed that this shape results from the speedy erosion by infrequent flash floods which represent the accumulation in brief time of great volumes of run-off. The torrential rain falls too fast for any great volume to sink into the ground, hence landsliding of water-logged masses from the walls rarely occurs.

In folded rocks, as in the Indio and southwest part of the Mecca Hills, the dry washes follow the outcrops of weak layers in which narrow, $V$-shaped gorges have been eut while in between are narrow ridges developed in resistant strata.

Wind erosion and deposition in this and other desert regions of California are no match for the effects of running water, but many sections show evidences of both.

Sand dunes are rather abundant in the Imperial and Coachella Valleys, particularly in the Salton Basin. The Sand Irills, running from past the Mexican border northward for 40 miles somewhat beyond the little settlement of Amos is the largest dune pateh in 


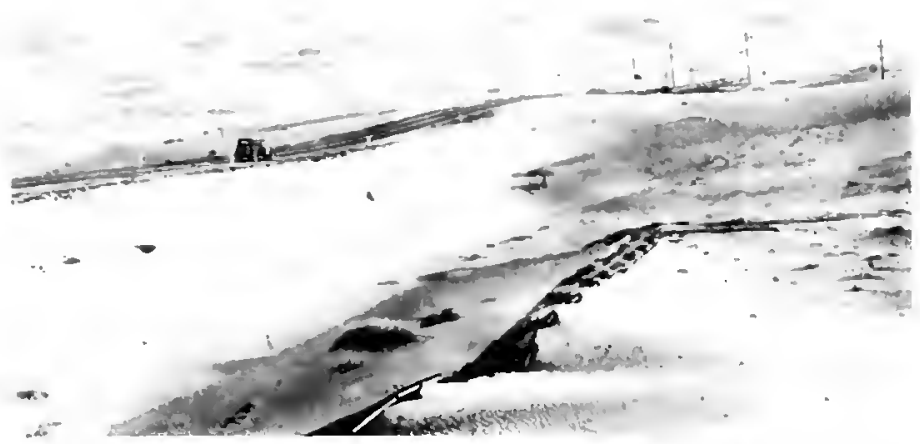

Fis. 73. Lew bighway and old plank road crossing the sand sea in the soutb. eastern part of the Imperinl Valley. The main bighwa is sometimes blocked by drifting sand. Fancher's Fotos.

California and one of the largest in the United States. The belt ranges from 2 to 6 miles in width, forming a prominent barrier roughly paralleling the trend of the great trough. The crests of some of the dunes rise 200 to 300 feet above their surroundings. IJighway 80 crosses this most interesting area and is blocked on numerons oceasions by the drifting sand and an old, now abandoned corduroy road has been extensively buried.

Dunes are built principally by violent winds such as are common in desert areas and are best developed where the direction of blow is more or less uniform. Study of the Sand IIills shows that the winds responsible for their formation have come clicfly from the sonthwest, irest, and northwest. West of the Sand llills there is a nearly level plain 3 to 20 miles wide covered practically everywhere with sand which in places has piled into small dunes. However, over most of the plain is a thin coating of gravel consisting of fragments about the size of peas and evidently too heary for the wind to move. This entire deposit is a beach formed when the lake was present in the Salton Basin. Probably the Sand Jills began to derelop as the beach was formed and the supply of sand was being constantly increased. The dunes lave migrated to their present position as the wind continned to blow over them driving the sand east warl, leaving the larger fragments behind. When this migration ocenrred is uncertain but land surveys made in 1856 show very little difference in form and position of the dumes from the present. There does, however, seem to be some movement of the hills tawards the southeast.

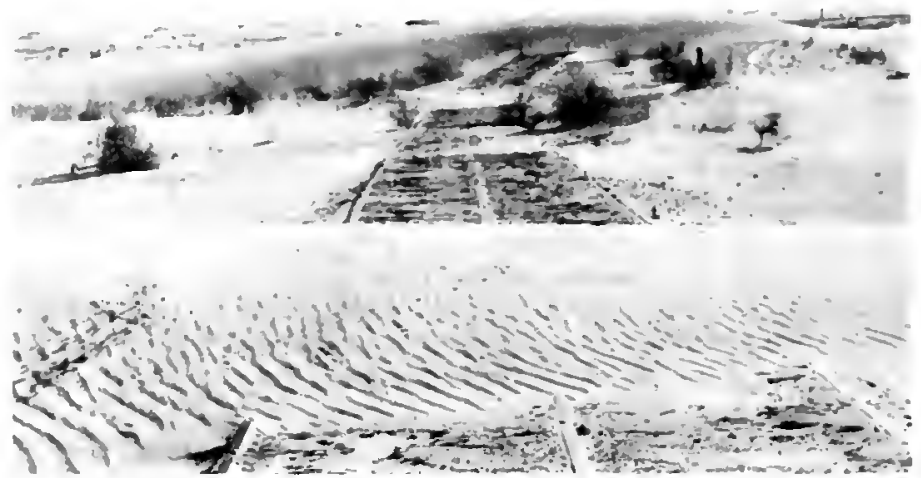

Fig. 74. Old plant road in southeastern part of Imperial Valleg. Sand has partly bucked the road. Funcher's Fotos.

In the Coachella Valley, north of Indio, there are extensive arcas of shifting sand which are called drifts, but only around Indian Wells are there large dunes, which are formed by strong winds blowing from the northwest down San Gorgonio Pass into the heated lowland. In the pass itsclf there are great drifts of sand piled on the east sides of all rocky spurs projecting from the San Jacinto Mountains. Drifts are distinguished from dunes by being less sharply defined land forms.

Southwest of the Salton Sea, between MeCain and hane Springs, there is an area where small erescentic dunes ealled barchanes are well developed. These sand hills appear to evolve where the wind blows quite constantly from one direction and the supply of sand is rather meager. The barchanes are strongly unsymmetrical in cross section, with the gentle slope oriented in the direction from which the wind blows. The horns of the erescent, like the steep side, lic in the opposite direction. The sand forming the dunes apparently comes from an old beach, practically all of the sand having been used up in making the dunes. Some of the barclianes are not more than 300 feet from point to point of the horns, others measure about 1,000 feet. Hany of these dunes travel in the direction toward which the wind blows, others have been essentially stationary for considerable periods of time. Those in the Imperial Valley have not changed position materially for the last 10 or 15 years, but this is quite a bricf interval.

In San Felipe Valley in the same general region where the barchanes oceur, there are spring-formed dunes. These develop in sandy areas where rising seep water allows growth of vegetation on accunulating 
0000

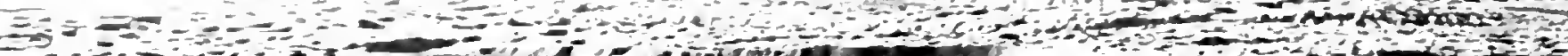

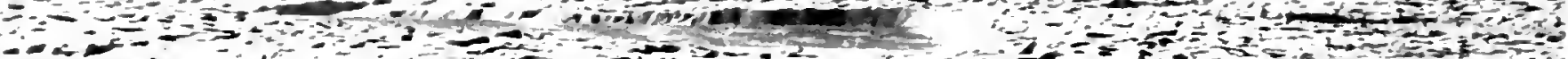

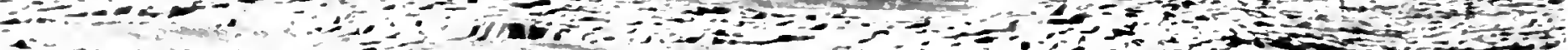

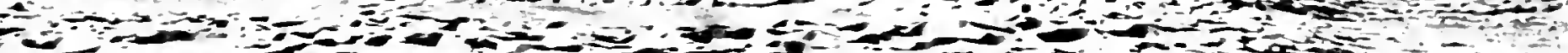
-

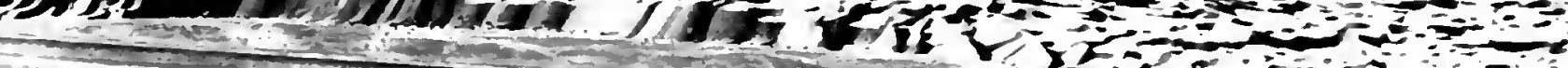

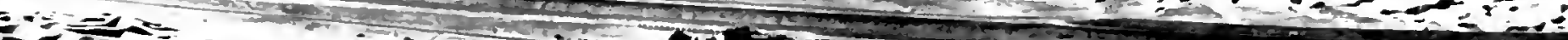

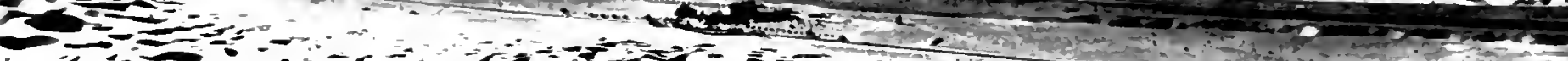

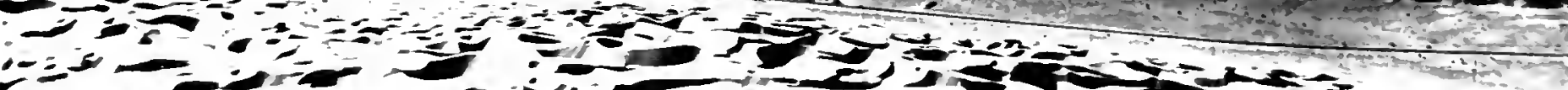
二E

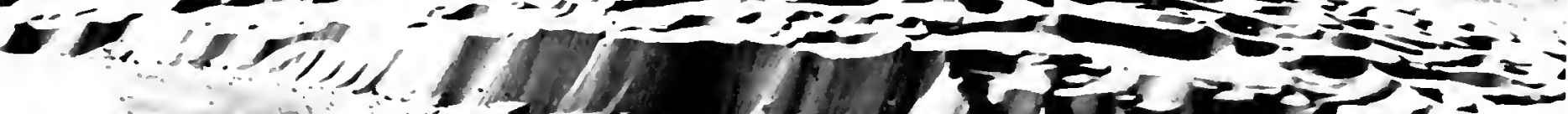

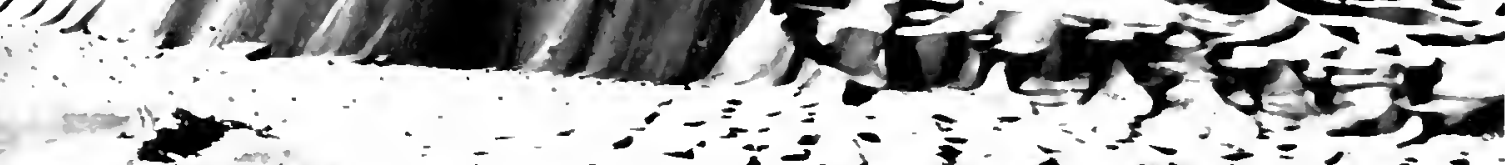

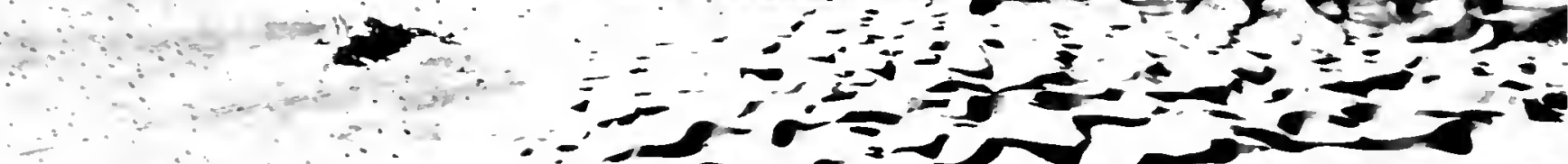

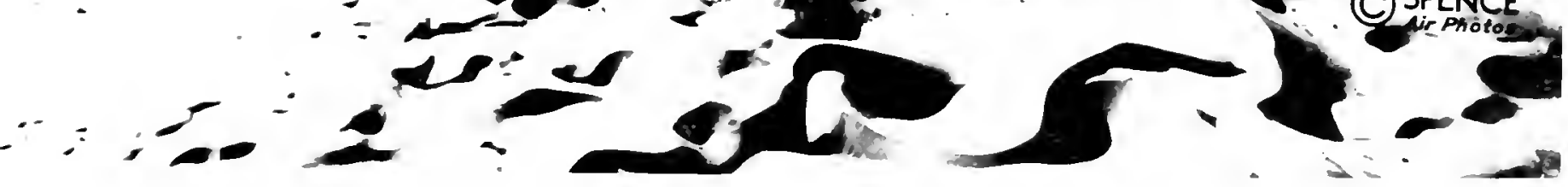




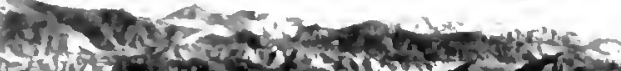

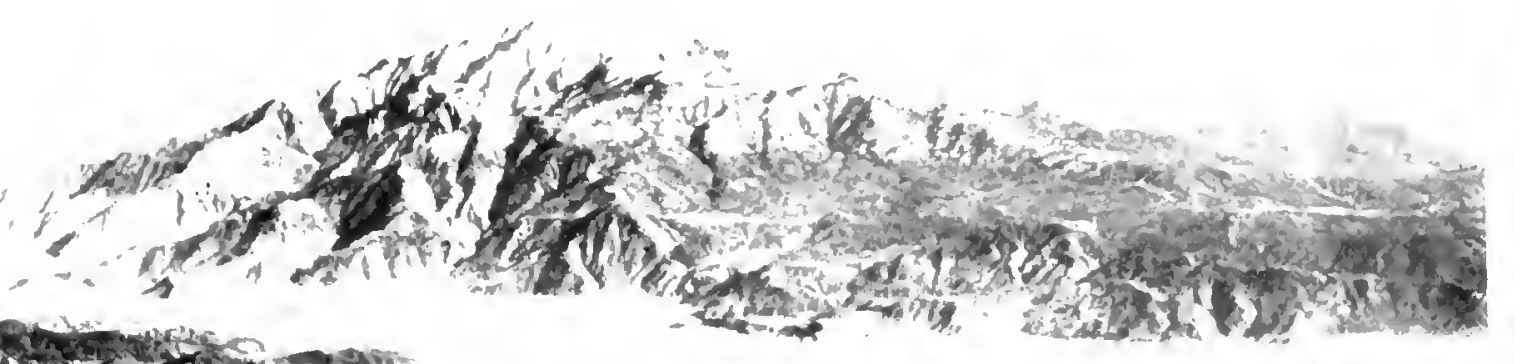

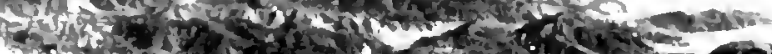

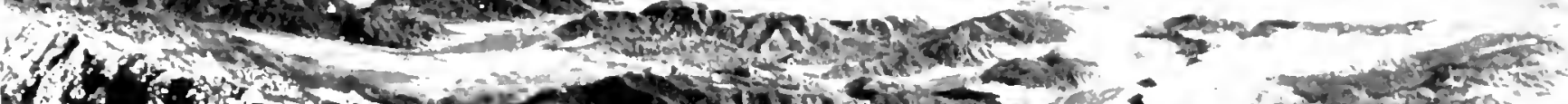

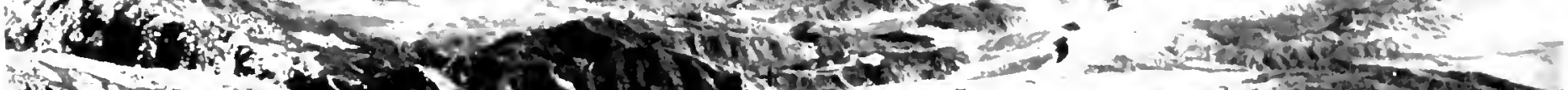
6.

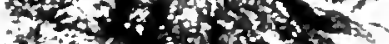

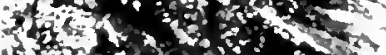

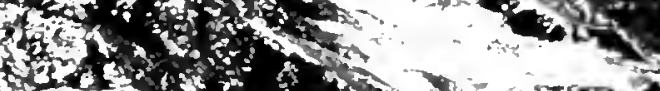
$3320 \times 1+7$

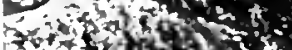

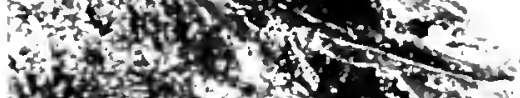

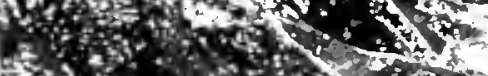

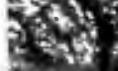

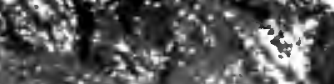

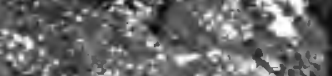

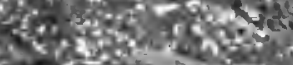

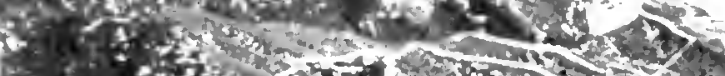
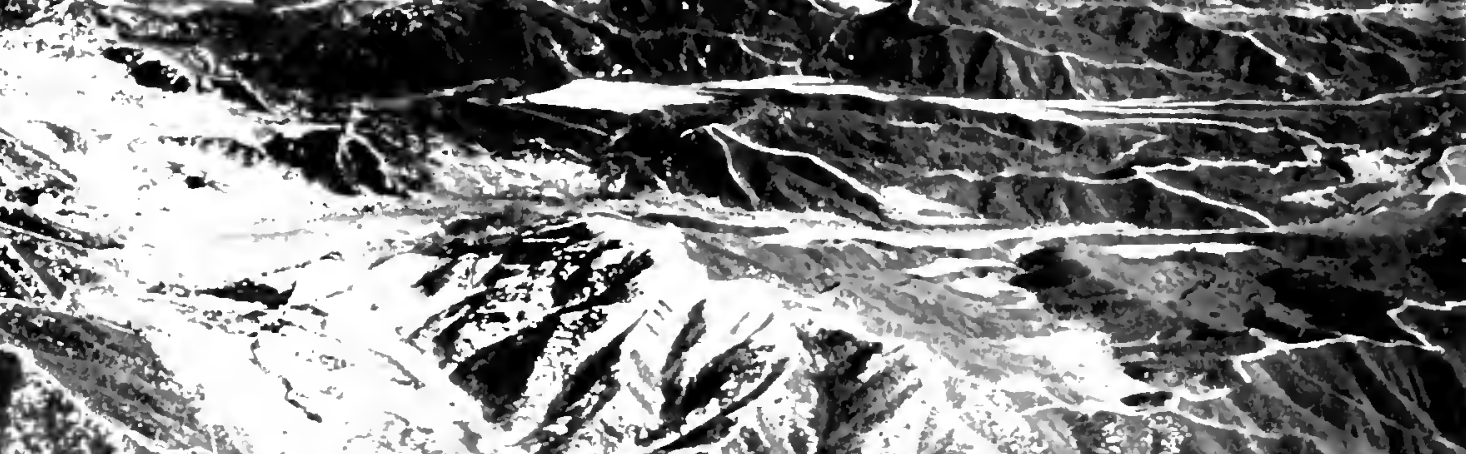
$x-2$

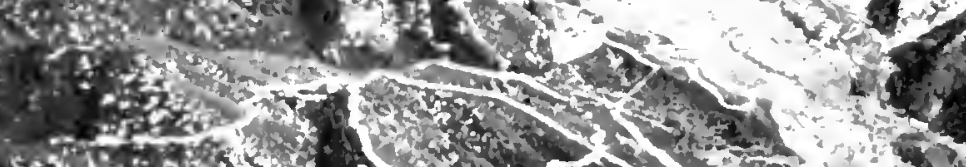

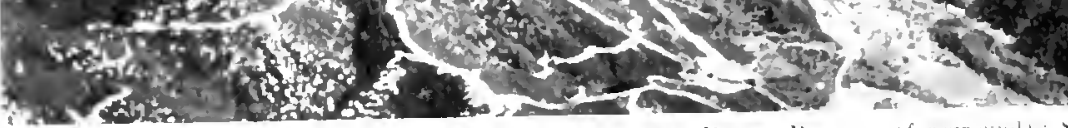
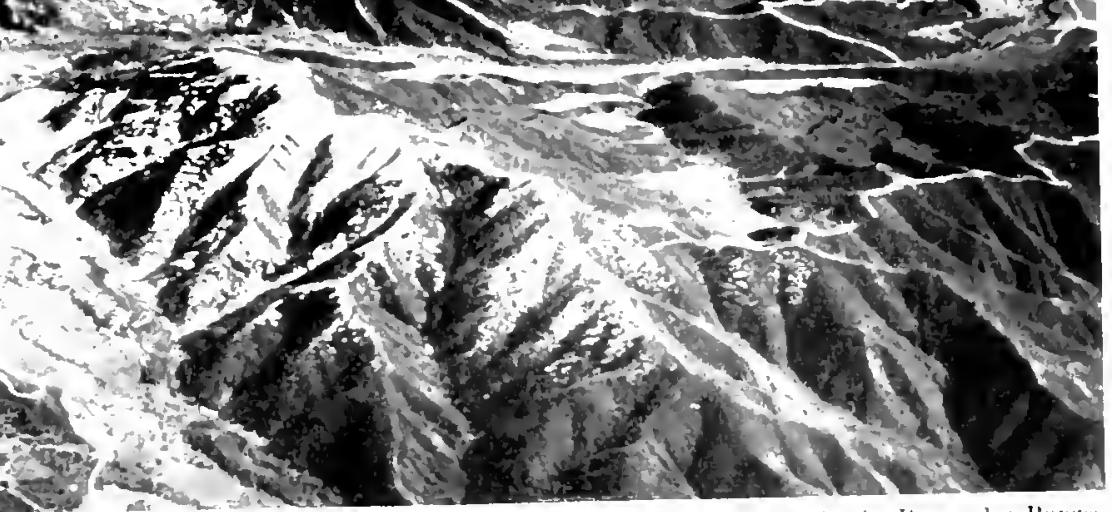

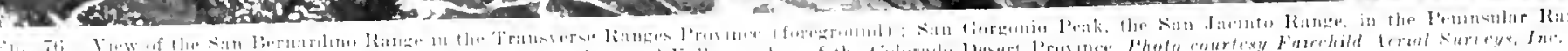

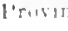


sands. The sand may pile so high that the water cannot rise throngh it and the spring is completely sealed. The core of the dune is a black, mucky mass of soil and deaved regetation. Kane Spring, which oceupies a mound about 30 feet high and sereral hundred feet in diameter, is an example. At the top is a sunken marshy area an acre or two in extent from which water seeps eastward.

Peculiar dunes having a serpentine pattern ocur on Superstition Hountain west of Westmorland on llighway 99 and are elongated parallel to the long axis of the mountain. They are found on botin sides and apparently shift back and forth over its crest as wind direction changes. Frequently they blockade canyons. forming temporary basins behind them.

In various parts of the Imperial and Coachella Valleys, great numbers of irregular sand drifts have formed about chmps of regetation, rock piles, and other obstructions.

One of the notable features of the Salton Basin is an old shore line which stands 40 to 50 feet above sea level, encircling the Imperial Valley including the Salton Sea, that part of the Coachella Valley south of Indio, and extending south of the border into Mexico. On the west side of the Salton Basin and throughout the Coachella Valley, the beach at most places consists of a sand ridge a few feet high. though its character varies somewhat with the rocks on which it was formed. In the sand are found many small. well preserved fresh-water shells. Near Fish Springs the slore line of the lake was granitoid rock and there is no beach deposit like that just described. Instead the shoreline is marked by an encrustation of the massive. limy rock ealled trevertine whieh in places is several feet thick. This deposit, formed from the evaporation lake water, makes a white zone con. spicuous from a considerable distance.

On the east side of Imperial Valley and as far north as Frink Spring. there is an almost continuons wave-eut cliff 10 to 30 feet hirh, with various amounts of sand forming the beach at the base of the elifts.

All of these features show the presence of a large lake as one of the very recent features of this now descrt basin. The shells indicate that the water was fresh or nearly so, hence the lake nust have been supplied by the Colorado River which at that time apparently disehared into it rather than into the Gulf of lower California, though overflow from the lake sery likely went into that arm of the ocean. This lake. Lako Cahuilla, may have represented the gradual freshening hy the Colorado of the arm of the Gulf of Lower California "ut off by the building of the river's delta plain. On the ot her hand, the salt water may have dried up and the hasin later supplied with fresh water from the river. Whatever is true, Lake ('ahuilla lasted until very late time: its waters may have remained until 300 or 400 years ago. There also is some evidence that the basin may have been oeempied by fluctuating lakes for a long time and that on some oxasions the water disappenaped hy exalporation. later to be replaced hy overbow from the river.

The basin is known to have been comparatively dry from the time of the spanish discoreries to the time of the wreat floods of the coloridu (1904.07) which ereated the present salton Sea

As the acrientural value of murh land in the Imperial vallev became increasingly apparent, the problem of supplying sufticient water for irrigation besame a pressing ont. In 1900 work was anmenced on a canal system to bring water from the Coloritlo liver into the basin, and at that time the name Imperial Valley was chosen to lure settlers to this desert land.

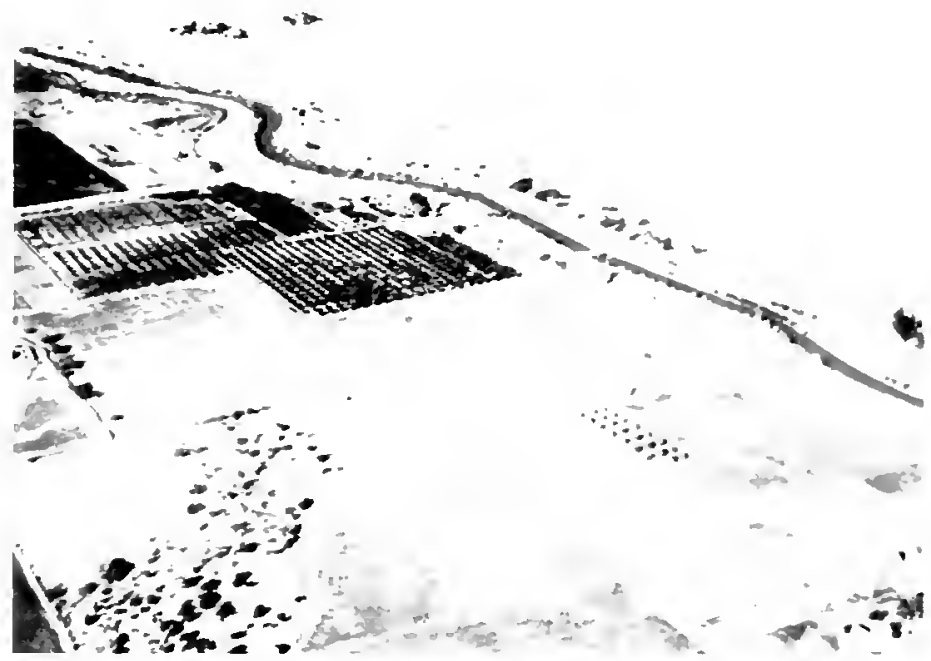

Fig. 7T. View of Inperial Valles, stowing the prolife cropk whoh can the

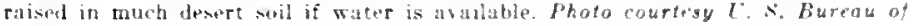
Reclamation.

The transfer of water from the great river to the salton Basin seemed quite simple. For years the Colorato had spillet] its thwn waters into the basin throngh two rather well-tefinm lolanuedi. Alamo and New Rivers. The slope from the river down the dela plain into the Salton Basin is greater than that toward the Gulf of lower California. The California Development Company, which built the irrigation system, construeted its intake near Pilot Knob. an isolaton mountain projecting above the alluvium of the delta plain about 10 miles west of Iuma. Arizona. The water was diverted thromgh a gap excavated along the side of the river, and was led throuph a canal 


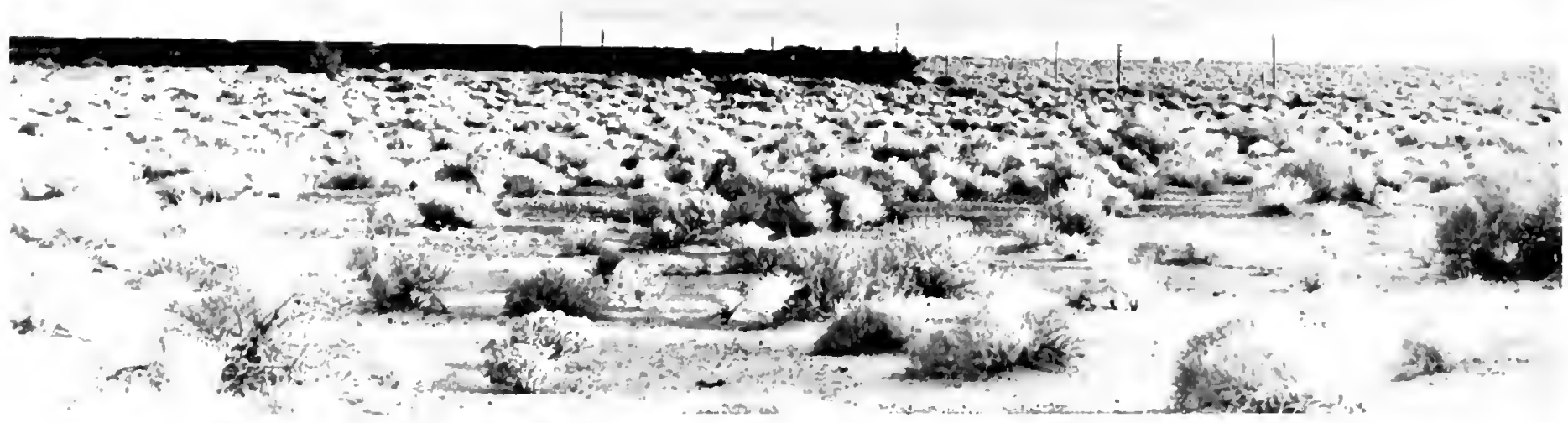

Fis. TS. Imperial valles and sulton Sea. The Salton Sea has attained its present size primarily as the result of great tows from the Colorado River in 190.' and 1966. Photo courtesy Southern Pacific Railroul.

which crossed the Mexican border and then went back into the Salton Basin some distance away. Hater, because of too rapid silting in the eanal, another intake was eut on the Hexican side of the border.

The flood danger from the colorado was then not well understood aml no proper preparation was male to take eare of the river at high water. In the spring of 1905 several musually high floods materially

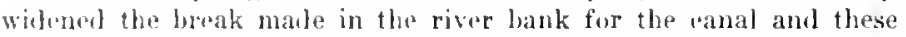
fluods also carried a wily dams built to seal off this intake. By summer time when the higrhest water stare is reached, too much water was being diverted toward the Imperial Valley through the canal and spilling over its lranks, where it wasted and began the formation of the Salton Sea. The irrigation company, involved in fuaneial diftieul- ties, har placed itself under obligation to the Southern l'acific Raitroad whieh finally took eharge of the river control. Efforts were made to dam up the intakes, but suecessive floods arried these struetures away.

Growth of the Salton sea foreed the railroad to move its main line to higher ground a dozen times and threatened to engulf all of the irrirable land of the Imperial Valley. The water sweeping into the basin eroded wide gorges into the soft al\}uvinm, in which are the present ehannels of New and Alamo Rivers.

Alter most strenuous effort and great expenditure, the Southern Pacific sueeceded in elosing the break in November 1906, but a flood in the following montl destroyed the repairs and the work had to be 


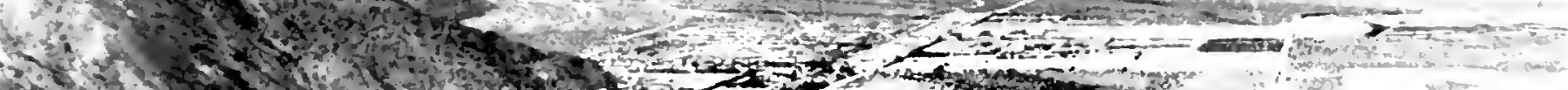

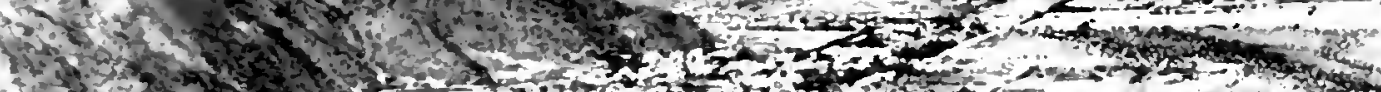

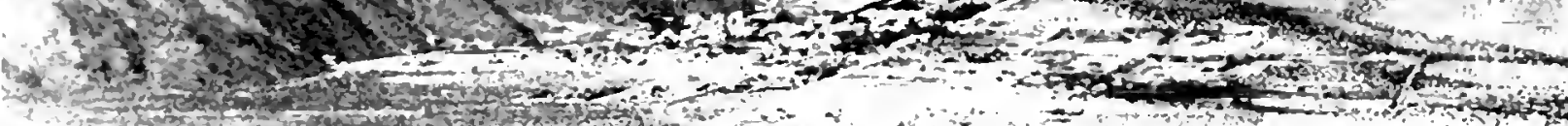

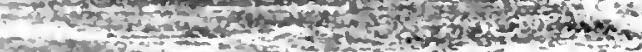
T.

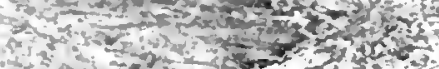

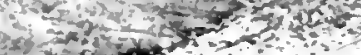

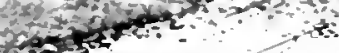

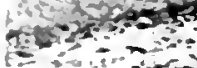

I-

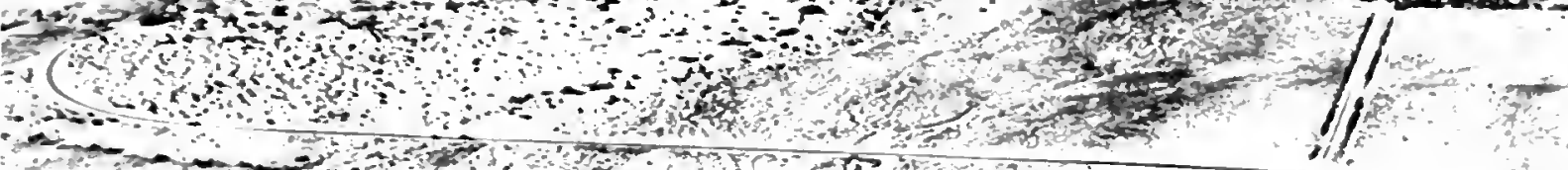

20.6 and

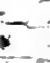
$\therefore$. $\therefore$

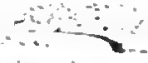

$+x^{2}-10$

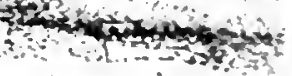
(1) a 


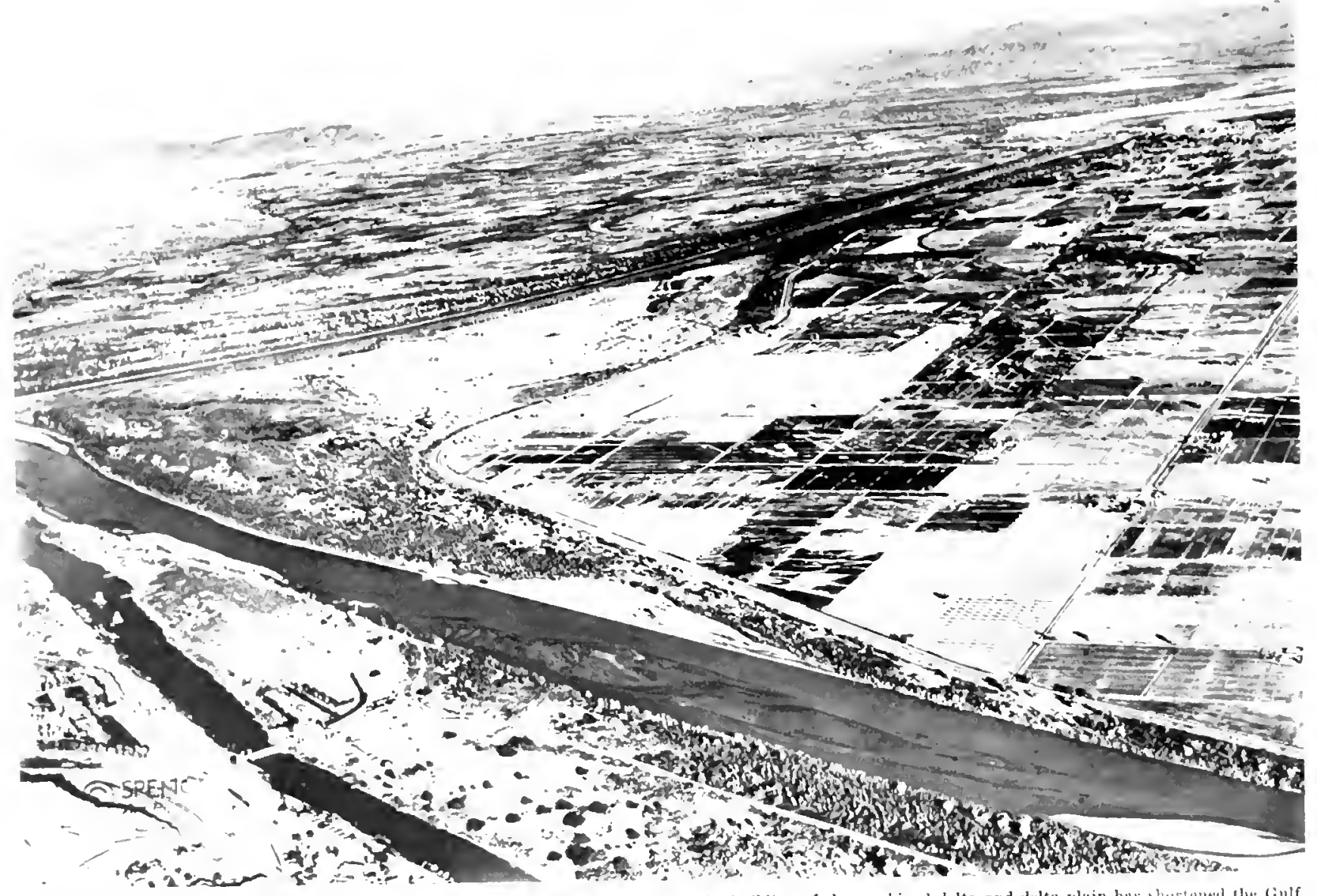

f.u f lir thotes.

done arain. Finally, anded hy reduetion of the flood waters, the river was sealed oft and the valley remlered temporalily safe. Inwever, what the river had clone many times it could repeat, hence agitation started for the levelopment of a flood-eontrol project farther up the Coraco, This tinally was nudertaken ant lloover Dam now holds in cheek by far the greater part of the Colorado's floods. Relatively little water comes in below this barrier

In the evolntion of the Imperial-Coachella trough and the bordering rances, faulting has played a paramount role. The depression is part of a very large graben which extends sontheastward begonel the 
bemulary of the Imperial Valley, while the ranges horderine on the east and west quite evidently have been elevated at the graben hav sunk. Along the north side of san Gorennio Paxs and extemling suth eastward into the basin is the sin . Indreas rift. It probably is continums with a frawture zone extending along the northeant siche of the Indio and Meeca llills, buth of which apparently hase besen clevated by movements along this section of the fanlt. These low hills rise from the basin floor and are separated from the higher mountains to the northeast by a series of vallevs and saddles. Corth of Indio the northeast side of the Indio llills is quite steep, though not more than $\mathbf{2 0 0}$ or 300 feet high, and is the most clearly defined fault scarn in this seetion. West of Dos l"almas the searp is merely a low bluff. The fault probably passes north of low hills near Palm siprings Station: to the southeast it appears to pxtend at least as far as a low hill mear Durmid which probably was uplifted in manner similar to the hills farther north. The same rift may continue as far as the Ind Voleanoes southeast of Salton Sea, and on past the Jexiean border. Wuch of this is speeulation because of the cover of sediment which nakes positive identification virtually imposible.

On the southwest side of the basin there are faults of two arees trend. ing in sonewbat different directions. The intersection of these srstem. has caused the irregularities in the outline of the western border in which ureat mountain salients like the Santa Rosa Mountains, the Vallecito and Fish IIountain spur, and the mountainou, projections along the Mexican border are separated by deeply re-entrant valley: like those of San Felipe and Carrizo Creeks.

If this structural picture is correct, the older of the two fault systems tremls about 10 degrees north of west and is responsible for three spectacular escarpments, one forming the east base of the san Jacinto Jountains and passing up Palm Canyon, the seend on the west side of Porewo Valley and the thirl extending from Arua Caliente springs sonthward up Carrizo Gorge along the east face of laguna Mountains.

cuttine across this older system, a second system trends approximately 45 dewres north of west and is represented by several prom. inent faults. The most northerly is the San Jaeinto. trending west and south uf San lacinto Mountain and extending throurh llemet Valley, down coyote Canyon, and for several miles along the northeast sibe of Burego Valley. The uplift along this fault has been on the northeastern sile anil Coyote Mountain, nurtheast of linrego Valley is part of a prominent spur elesated along the fault and havine a prominent sarp on the sontlawestern sille

Several faults have been recunized nar. Warner Valley and axtend sutheastward in this part of the region: apparently developed by them are a number of so-ealled valleres such as lburego, san Falipe. Jasun, Vallecito, Collins, and a small nue ist Banner. Fach of these valleys has for its northeastern wall a strep fale which is a moderately

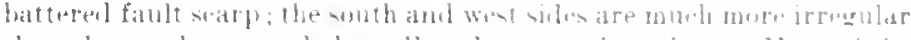

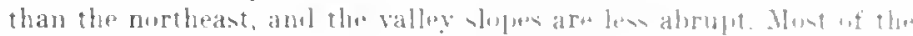

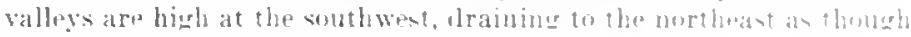
the lault blocks lad been tilted on the whthwent.

The faults have compelled the streanu in mos of the wallex aftor

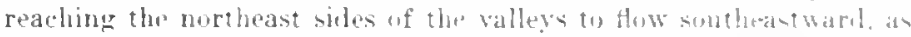

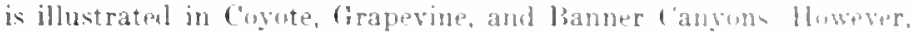

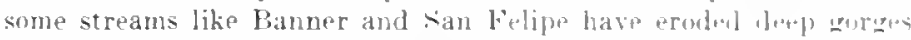
cutting auross the faults, surgesting that the streams wore present before the faults wer developell and that moxement alome the fran tures was slow enoush so that the streams cut downward as rapidly as the rocks were elevatod across their paths.

Fortheast of the Salton Bain well-definml fanlts are dificult to make out because of the erosion of the range lolorks and the ereat amount of alluvinm which has been spreal around their martins.

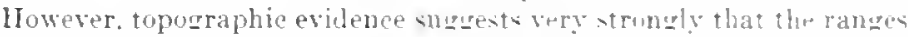
have been elevated along fractures. The steep south from uf the Cottonwoul and Easle rangen northeant of Hirhway Gll ill and a prominent warp at the south side of the Iaria Mountains are examples. At the north end of the Palen Jountain ean of Demert fenter on Ilighway 60 70, there is definite evidence of faulting.

About 16 miles north of Fuma. Arizna, a lone luw lan, the lmperial, has been construeted acruss the Coloradn liver impundine a lare. shallow resersoir. Great canals carry water from the mervir. one to the califurnia side to supply the Imperial and Coachella Valleys. the other to the southwestern corner of Arizoma where thare is rich land in the Gila River basin. The California canal has been comstruted across the sand IIills. The main branch gives water fo the Imperial section: a smaller one leads north into the ("nachella Valley. The denert soils in many places yield splentid trops if water can be suplipl. In this highly arid region, the Culorado River is the only wnthipnt supply. C"sed since the early part uf ihe century, its water is nuw being

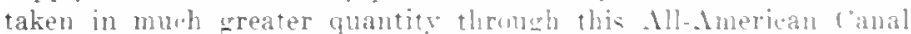
system.

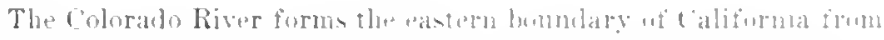

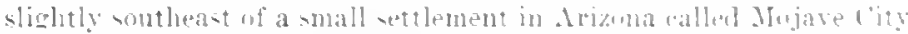

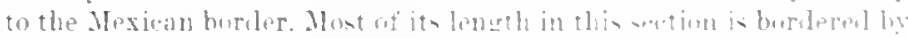
mountain ranges, the larient un the ('alifornia side beinge the Maria

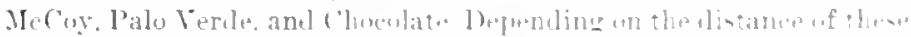

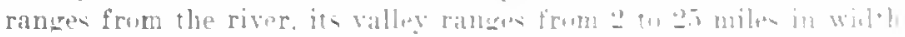

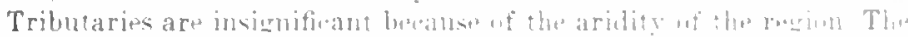

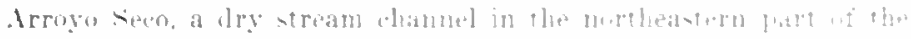

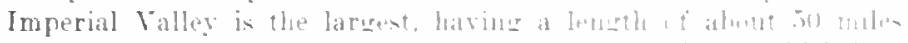
Elsewhere the mountains are connected ly allurial diviolo which form enclosed basins that to not drain inte the folurate. 
Throughout virtualy its antire length alone the Califormia border, the Colorado Valley is terraced into two parts sparated by a prominent bluff 50 to 100 feet high. The lower terrace is that being developed by the ribr and covred with its sediment when overbank thools oceur, tie other represents a former level at which the river fowed. The lower terrace, which is called Palo Verde Valley, has a slight slope away from the river because of the formation of natural levees along its hanks, the eharacteristie feature developed especially by a large strean flowing through a lowland region. The surface soil is fine textured, and is added to almost every summer by floods except where artificial levees have been constructed to contain the waters in the normal ehannel. Numerous old channels and oxbow lakes show the usual wandering of the river from plaee to place over its flood plain. The Palo Verde Valley in places is 7 to 8 miles wide, but where the monntains come close to the river, as with the Clocolate Mountains near Laguna Dam north of Yuma, it is greatly constrieted in width or even absent.

The higher terraee, called the Palo Ferde Mesa, is a narrow almost level plain a few miles in width. In some places, the palo Verde Mesa is broken by bluffs which divide it into a series of terraees standing at rarious levels. West of Blythe, for example, there is a second terraee 30 or 40 feet higher than the first part of the mesa. The surface of the terrace in most places is sandy or gravelly, but beneath there appears to be finer sediment. However, where good exposures show in the esearpment separating the Palo Verde Mesa from the flood plain below, sand and gravel predominate. Near nountain brrders, the tarare rises abruptly and grades into alluvial fans at the montlis of eanyons. The surface material in such places is eoarse sand, pebbles. ani boulders

The esearpment separating the Palo Verle Mesa from the present floot plain of the Colorado is quite straiglıt and has an abrupt slope. thungh it has heen eonsiderably notehed by sheet-flood and flash-flood erosion. On the Arizona side, the terraes bluff is mollified by the Gila River which joins the Colorado near the Mexisan horder. The bluff along the Coloralo mermes with a similar one whieh extends up the Gila Valley for at least 50 miles. This would indirate that the esearpments along the two rivers are similar in age and origix

A particularly notable feature of the bluft on the* California side is that it bends west ward at l'ilot knob, near the international bonndary, passing south of the Sand lills on the Mexican sicle, and then turns northward, morering into the old shore of lake cahuila which is marked by a prominent wave-eut cliff for many miles northward.

There is striking similarity between the esarpment alons tho colo-

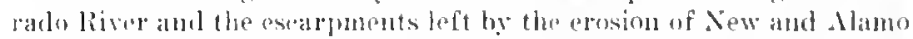
hivers as the result of the overflow into the lmperial Valley in l!)0 and 1906. For many miles, the grorges eut by these two streams are about 50 feet deep and nearly a guarter of a mile wille. The bluts along these two channels are similar to those along the Colorado. Also there is sueh marked similarity between the river hluffs and the old lake shore line east of Imperial Valley that it is impossible to tell where one leaves off and the other begins. The suggestion is strong that both river and lake terraces may have originated at approximately. the sanse time, the explanation possibly being the diversion of the river into the Salton Basin and the formation of ancient lake Cahuila.

The Colorado River flows down a gently sloping delta plain, whose surface is inclined both toward the Salton. Sea and the Gulf of Lower California. The construction of this delta plain of eourse las been the prime factor in isolating the Salton Basin from the gulf, the delta plain having been built above sea level aeross the great graben to the Cocopa Mountains on its west side in Mexieo. It is well known that at various times the river las distharged into the Salton Basin, which stands as much as 275 feet below sea level. The slope of the delta plain in that direction is greater than toward the gulf, henee, if the river broke througl its bank discharging into the basin, its fall would be temporarily increased by 275 feet, and rapid erosion would occur such as happened during the overflow in 1905 and 1906. Furthermore, the basin was then deper than now by the amonnt of sediment which was deposited in Lake Cahuila. If the Salton Basin did not fill too rapidty. time nimht be suffieient for erosion of the Palo Verde Talley to its present depth and width below the Palo Verde Nesa. Climatic fluctuations which unquestionably have affeeted this entire region during the glacial stages also may have been a factor in the terrace development. There does not seem to be evidenee of elevation of the region which would aeeount for the terrace development, hence the two factors mentioned above and possibly otbers have been involved in their development.

\section{REFERENCES}

Brown, J. S., Fault features of the Salton Basin, California: Jour. Geology, vol. 30 , yp. $217-226,1922$.

Brown. J. S., The Salton Sea region, California: U. S. Geol. Survey WaterSupply Fauer $497,1923$. 
MODOC PLATEAU 



\section{MODOC PLATEAU}

Between the Warner Mountains and the Caseade Range far to the west is a high, semi-arid platean whieh is part of the great voleanic field known as the Columbia Platean that covers a huge area in Washington, Oregon, and southern Idaho. Actually the Warner Mountains and the Ilays Canyon Rantre on the Nevada side were once part of this region, having been elevated into mountains by movements along great faults which broke up that section of the vast tableland in relatively recent geological time. Surprise Valley between the two ranges is a depressed bloek bounded by faults.

To the Califoruia portion of the Columbia Plateau the name Modoc is generally given because it lies very largely within the connty of that name, thoueh it is also partly in Siskiyou, Shasta, and l assen Counties. The elevation of the region averages about 4,500 feet above sea level, but there are many peaks and ridges projecting well above the general level. The main highway crossing the Modoc Plateau is No. 299 leading from Redding to Alturas, and part of No. 89 traverses the soutbwestern section. A third road, which is oiled, leads from Canby on Ilighway 299 to Klamath Falls in southern Oregon. There also are a number of dirt roads, mostly of quite uncertain quality, but considerable areas are not reached by road. The geology of the Modoc coutry is little known, most information relating to that area con. cerns the vicinity of the Lava Beds National Monument.

The most aneient features in the Modoc Plateau are hills of tuff and lava in the south, southeast, and north. The rocks are dominantly basalt whether flows or fragmental, but interlayered with them are various kinds of water-laid sediments. The hills form wide areas rising from 500 to 1,500 feet above the general plateau level, and tbey also are present as single prominent blocks surrounded by younger formations in Timber Monntain, Double Head, Indian Butte, and the prominent ridge bounding the west side of Tule Lake basin. Most of the eminenees are rounded because of the great proportion of fragmental rocks composing them, and the long time during whicb they have been subjeet to weathering and erosion. In places, however, resistant rocks interlayered with the exploded debris form eliffs both above and below which are slopes, thereby evolving a terraced landscape. These volcanic and sedimentary formations quite evidently are part of a onee-extensive sequence whieh has been deeply eroded and also buried by later eruptions. After the volcanic cycle, probably not later than Miocene in age, the region was broken by faults along whieh there was elevation and depression of blocks. The slope of the layers in the visible remnants shows that the blocks were tilted to some extent in the course of the deformation. Because of the long time which has elapsed sinee the close of this cyele, the fault searps have been greatly eroded and undoubtedly their bases have recded somewhat from the fault zones. The present hill fronts therefore are erosional products of land forms once prominently controlled by fanlting.

It is clear that this first volmine aetion in the Modve region was mainly explosive and was related to central openings about which voleanoes were constructed. The activity was interrupted on various occasions and, during the intervals of quiescence, sediments, mainly lake beds, were laid down. Some of these deposits nere covered by subsequent outbursts belonging to the same cycle.

The main part of the Modoe l'latean has been built principally in Pleistocene time, the oldest lavas of this sequence being definitely later than those of the decply eroded l'lioeene volcanoes of the adjacent Caseade Range. The youngest flows are so fresh that they eannot have been erupted more than a few centuries agro. These late volcanics are divisible into three groups, the oldest being by far the thiekest and most extensive. These lavas were apparently highly liguid, forming thin, rather even surfaced flows, were erupted from fissures rather than from central openings, and flooded the region to build a plain of gently undulating surface. The second group is comprised of generally mueh rougher surfaced flows, mostly erupted from central vents about which were constructed broad, low shield volcanoes. Explosive eruptions also oceurred forming a eonsiderable number of small cinder cones.

The third group includes the most recent flows such as the Callahan on the northern edge of the Medicine Lake Highland, an eastward. projecting promontory of the Caseade Range and the Burnt Lava at the southern margin of the same area. The flow surfaces are chaotic jumbles of great blocks. Rising from their surfaces are cinder cones whose craters and outer slopes are almost perfectly preserved, testifying to the recency of the activity; in fact, this suggests the definite possibility of further eruptions. Evidence given by the voleanies of the Modoc group shows that, as the eyele waned, the eruptions became more and more localized and more explosive.

As the plateau was being formed by the eruption of the Modoe lavas, it was broken by numerous faults. The results of movements along the faults are conspicuously expressed in the landseape. The northern part of the region, especially around the basins of Lower Klamath, Tule, and Clear Lakes, shows a series of fault searps trending mostly northward. A few. however, are nearly at rimht angles to this trend. Some of the dechivities are low and deeply worn, others are bold, steep eliffs ranging in height from 200 to more than 400 feet Immediately to the west of Tule Lake basin, fresh scarps are especially well defined. Four of the more prominent ones ean be traeed for 6 to lis 


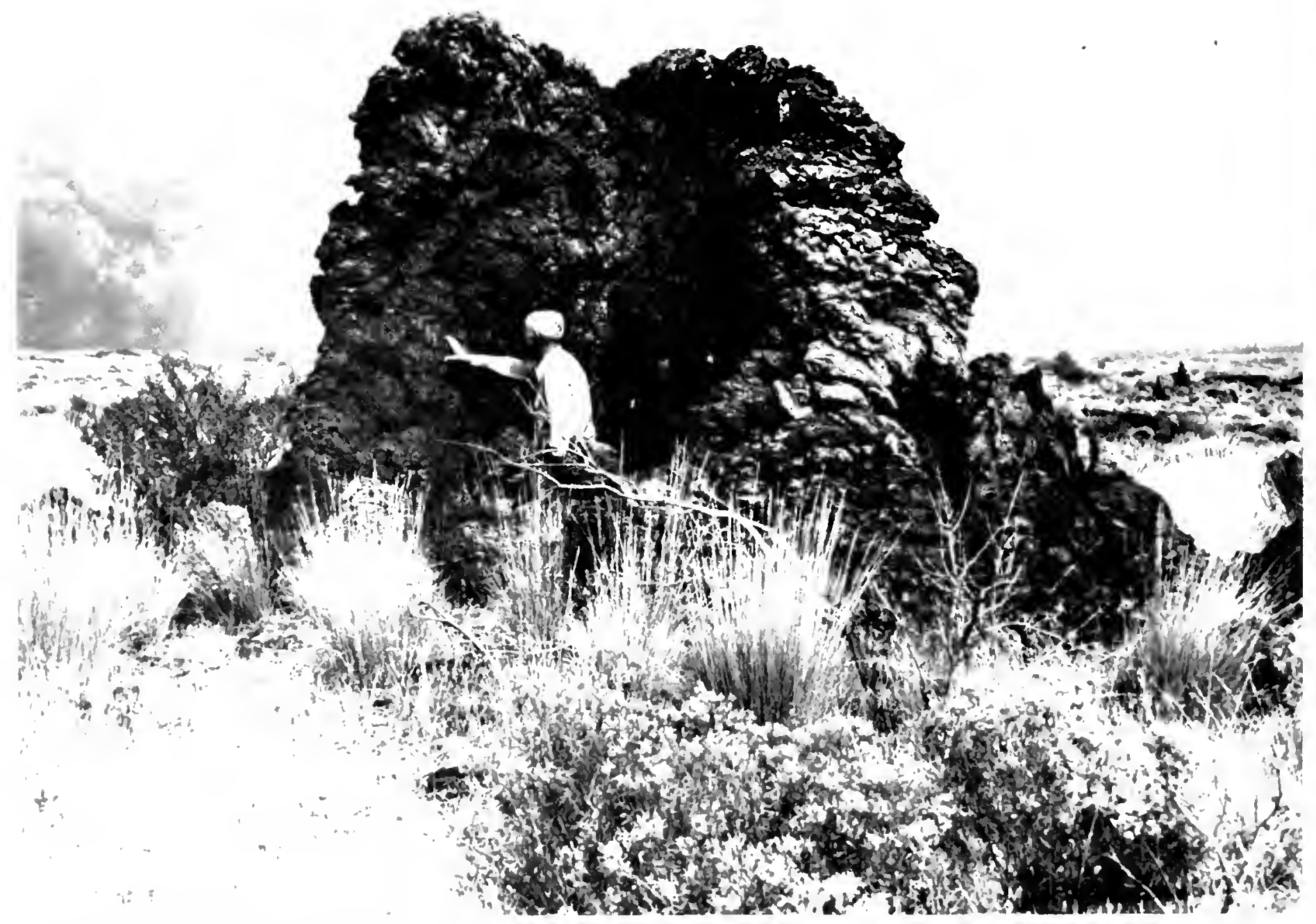

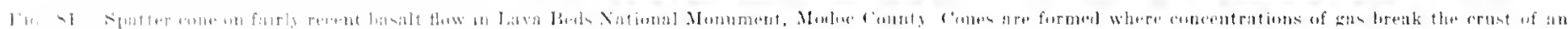

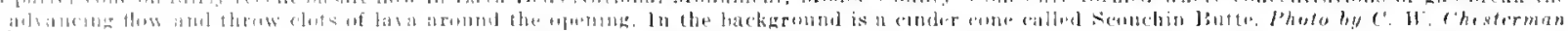




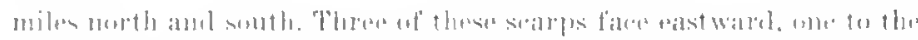

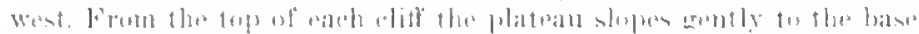

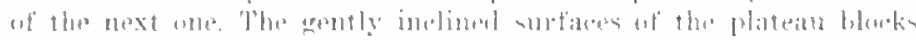

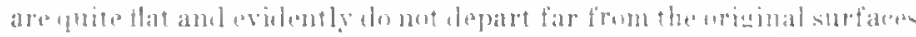

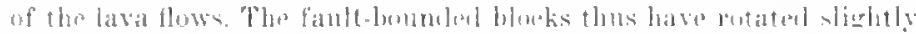

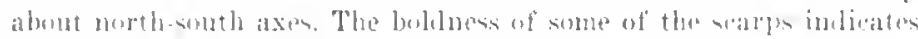
puite recont development.

latin and smow uxer the Iodoe Platean are relatively light and many of the latals are extremely permeable, henoe streams and lakes are lew and are rastricted th the extrome borth and extreme south patts of tha" legim, learing the antral sectim quite destitute ot water. The Whef rivers are the l'it, Meroud. Fall, and Lost. (Hhl maps show

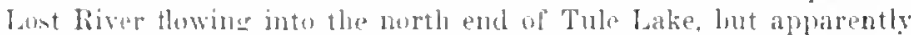
the small volume of water which the river arries now is entirely used for irrigation.

Tule Lake, ompealled Rhett lake, hat an area of abont 150 sifuare miles in 1ont; by 1924 it had slirunk to half that size, and by 1930 was represented by at small, shallow pond whioh has since ceased to exist as a permanent feature. Similar reeent shrinkage has taken place in Lower Klamath Lake which lies west of Tule Lake. Clear Lake in contrast has been enlarged by construetion of an irrigation dan.

Lake sediments are known over eonsiderable sections of the Notoc Platean which evidently were covered by water in quite late time, possibly during the climax of the fourth glacial stare. Inder the Holoe lavas are older lake beds indieating the presenee of goodly bolles of water at still earlier times.

It appears that toward the done of the epoch when the ollest roteanic rocks in the region were erupted, probably near the end of the Miocene, north-trending faults leveloped along which blocks were elevatod and depresserl. The high areas were vigorously eruled and the debris areumulated in the interrening basins, heing mostly de. positel in lakes. Later the Hotop lavas wet" pourel out over conparatively level sedimentary plain between th' high hodks, expntually urerwhelmine some of the more deeply erotos resituals and leaving

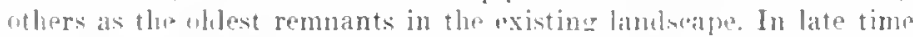

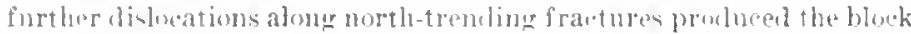
structure of the present platealu and in the lower-standing areas the morkeru lakes gretri.

The rapis shrinkage of the lakes in recent time is noteworthy A small amount is the result of therelopment uf recianation urojerts

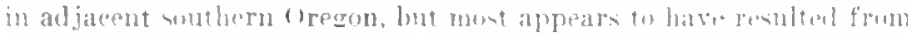

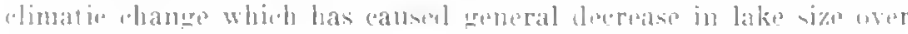
this rewion and beromel

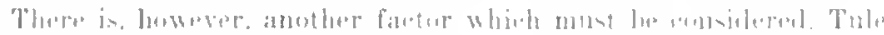

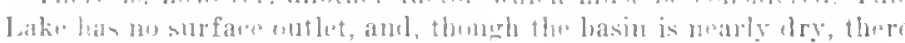

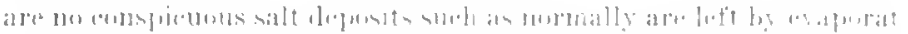

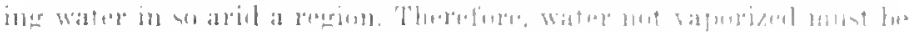

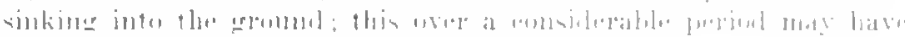

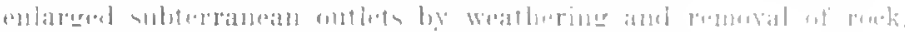

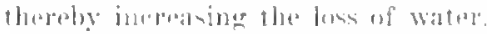

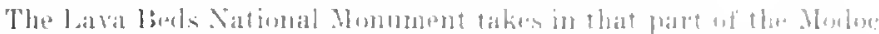

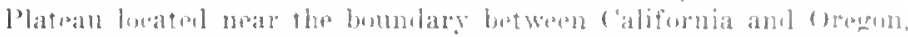

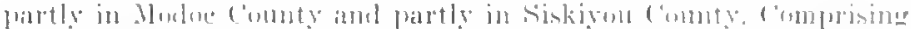

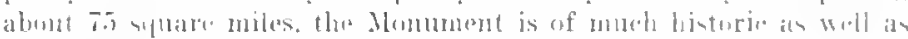

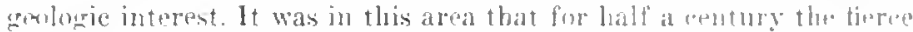

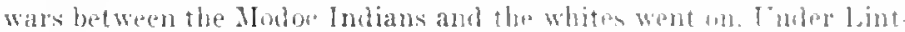

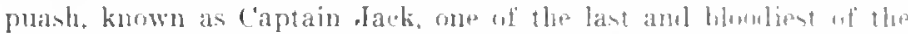

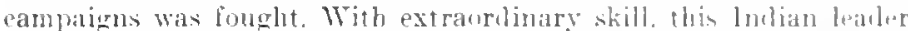
and a small band, entrenched in stone forts, the remnants of whin may still he seen, and in lava caves. fonght a muh largor purop of white sothers during $1872-79$, wntil they were funally killod or Hute evilence of the bitter strugele may be seen in many places about the nonument tolay-battlo scarreal trees, splintered rock, bonew ref eatth and horses, and the stone forts which gave the helearuerol warriors part of their slefter. Of eourse it was a losine fight, as oventually were all of the contests between the fewer thefulers and the more numerons invaders.

Bearpaw or Bearfoot Cave near the enter of the Monumpnt ivabut 4.j miles from Klamath Falls, Oreson. am 6.5 miles from Alturas, enunty seat of Modoe County in California. The pavel ruinl trom

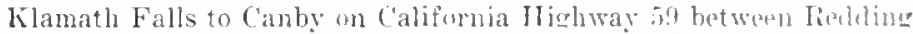
and Nituras passes a few miles from the Mommment in eantan bommlary. but the only roads into the area are of lirt and nut tor gom quality. for, althom they are in fair contlition in plases, in mher there are numerous lava boulders whith makw traveling sluw and difficult.

It the south end, toward Meling Lake llighlint. the elevation is about 5.200 foot ; but this deoreases northward to about 4.140 fret at an whl slure line of Tule lake which forms the morthern boundary

The lavas uf the Momument, whinh werer also a mull more eonsiderable area in the Mudue l'latean. rablate fome fanlts in the

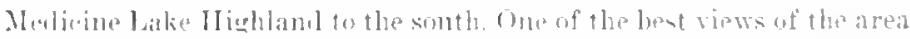

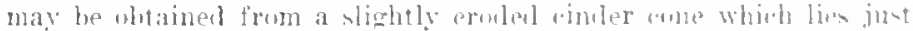

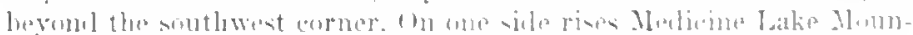

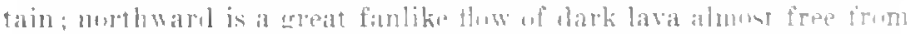

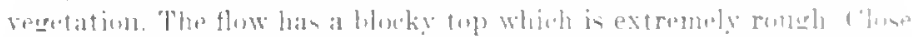

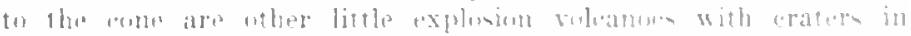

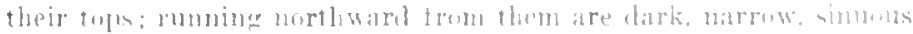

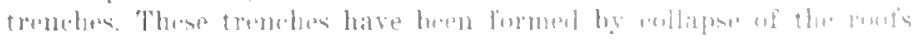

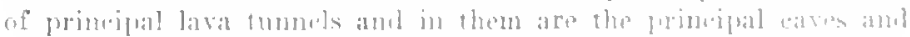
waterbols which phyol su important a part in pho lulian wars. 


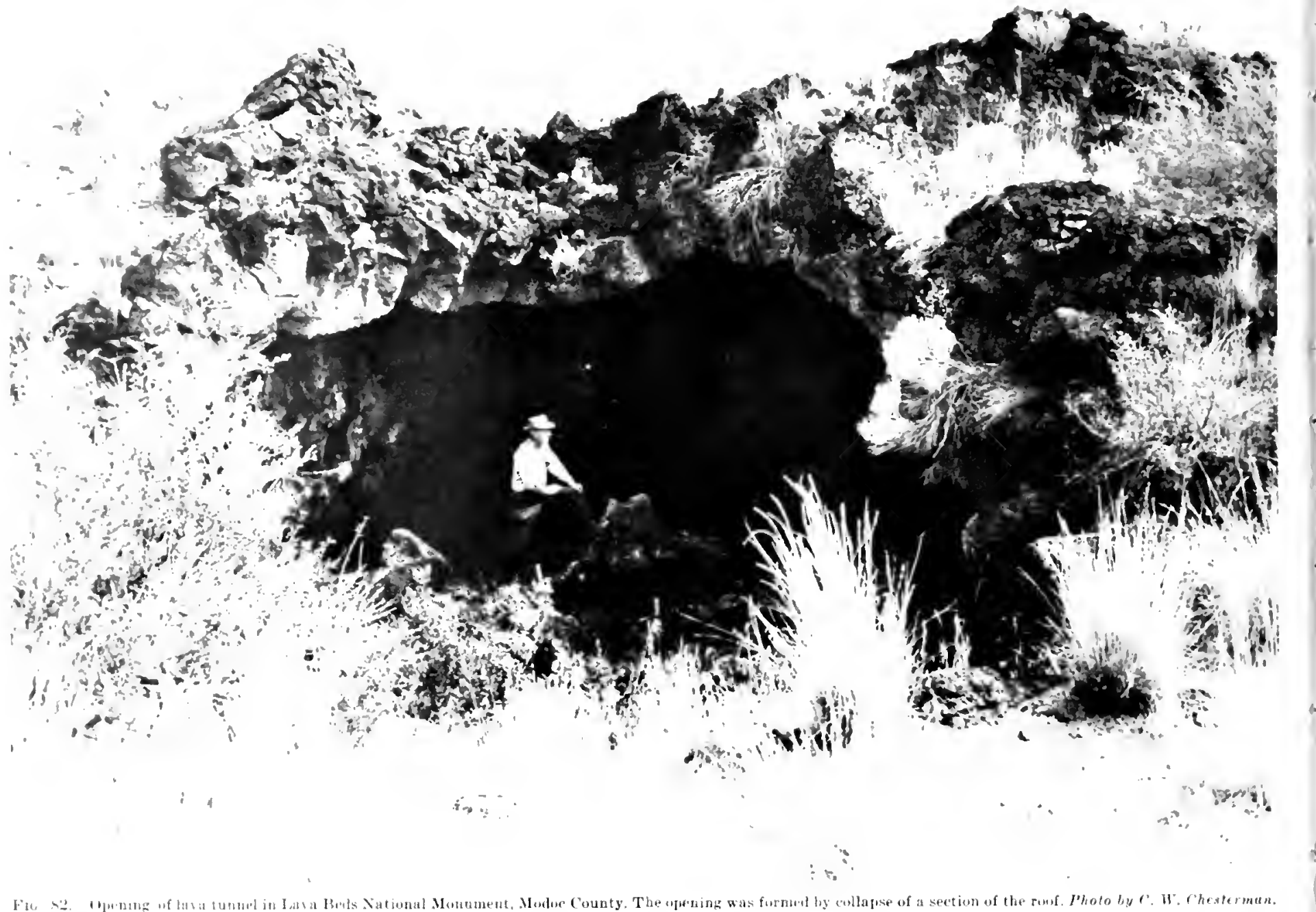


Warther north are three long, lastwarl-fileing, parallel eliffs of morderate height. spaced about a mile apart. These are some of the fault sarps refurred to in the foregoing destription of the Modot l'lateau. Ac the low of the eantern eliff is the smatl remnant of the once great Tula bake: the clift, an almost sheer previpice and therefore a quite recent searp. rises abont 1.000 feet; its back is smooth and slopes arenty tuward the base of the next eliff to the west.

The most conspicuous landmarks in the area are cinder cones rising from 100 to 3100 feet above the surface of the Hows. The newer ones are little damaged by erosion, the older are somewhat worn; others have been breached by Hows that have poured frum the rents. In all there are 11 of these little mountains, most of them lying toward the southern side of the Monument.

Less conspicuous are lines of spatter cones or chimneys which mark the thation of fissures from which lava quietly poured; they were formet by small fuundations of gas-rich lava thrown above the general level of the flow. In may of them are tubes extending down ward for 50 feet or more, erolved by the settling of the lava column inside an already hardened walt of rock. Some tubes were developed by gas anel lava spatter from loles in the roofs of advancing Hows.

Much of the lava lias a smooth ropy surface, but some is broken into chantic jumbles of jagged blocks.

The lavin caves and tunnels are found only in the ropy lava, and were formet as the roof and sicles solidified leaving a cavity below through which the molten liquid continued to stream. The main tube branches so that, as the How moved forward, little or no molten lava showel. it having been eonducted through a sort of subway from the liswure to the end of the stream. Then through fraetures in the sides or frunt of the How, the lava eseaped leaving the undercround passageways. Becaus, the rock jointed as it cooled and contracted, sections of the rufs foll in forming many short caves, humtreds of them being present in the Monument. In length they range from a few feet to

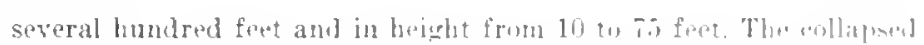
sections make long, narrow trenches fillet with broken ronk sume ob

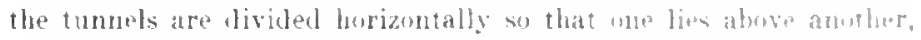
even thourh in the same How. In places the rouf has follagnem in whe manner as to have sections forming natural britwes.

Bearfoot or liearpaw (ave in the central part of the Alonument has several stories: the approach is a decp trench with almont bertical walls; descent into it is by means of a ladder.

From the roof of many of these tunnels hang lava stalartites. a testimony to the tremendous heat of the liquid strom which was able to melt solit rock. On the floors of a few eaves are stalamiter furmed by the drip of the molten lava from pendants in the roof.

Berause of the high porosity of the lava resulting from abundant joints and other openings, there are no surface streams in the Monument; all of the water goes underground. It is found as fuckls and as ice. for the temperature in some of these tubes is so low that water remains frozen even during the summer when it is very warm on the surface. In others, the ice melts during the warmer months but the eare temperatures are rarely more than $40^{\circ} \mathrm{F}$., and the water is elose to the freezing point all of the time. Caldwell Cave in the sontheast corner of the Monument is one of the largest showing abundant winter" ice which forms on the Hoor. In summer this is replaced by a pool of water. Crystal Cave, about 2 miles north of the one just mentioner? has great icicles hanging from its roof and ice stalagmites rising from the floor. During the summer the stalagnites and most of the pendants melt but some of the ice remains.

\section{REFERENCES}

Peamek, M. A., The Modoc lara field, north California: Geng. Review, rul. 21. pp. $259-27 \overline{1}, 1931$.

stearns. I1. T., Lava Reds National Ilomument, California: Geog. Soc. I'hila delp bia, "rol. 26, yp. 239-253, 1928. 

CASCADE RANGE 


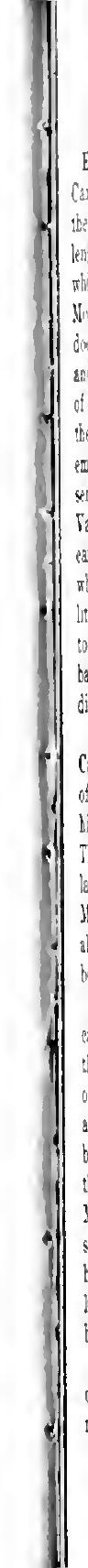




\section{CASCADE RANGE}

Extenthe from the north end of the siorra Nevatia virtually to the Canalian burnler is the Cascalo Raruge which is aspevially noted for

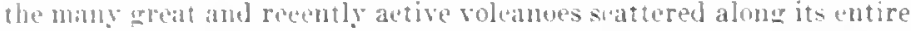
lengh. In California, the southernmost conspicuous peak is lassen whinll erupted explosively between 1914 and 1!17. From this point to Mhunt thanta, the range is not partienlarly well defined though it lows enntain some eones as large as Crater Mountains ( $7 . \pm 1$ feet) aud Burney Mountain ( $7,-71$ feet $)$. Mount Shasta is the supreme peak of the rance in the state standing 14,161 feet above sea level, one of the outstanding scenic views in North Ameriea. North of this mighty eminence. the "ascade Range is better lefined, being comnosed of a series of giant volcanoes which stand conspicnously above Shasta Valley on the west and Putte Valley on the east. Some of the rol. eanoes, such as Miller and Eacle Rock, have been eonsilerably eroded whereas others, such as Goosenest and Whalebaek, are so young that little change has been wrought in the voleanic form. These neaks rise to leights of 7,000 to 8,500 feet above sea level; the eones made of basalt have broad gontle slopes; those formed of andesite lava are distinetly steener.

During Pliocene and early Pleistoeene times in the southern high Caseales of California and southern Orewon, a morth-trending chain of large, gently sloping shield roleanoes was built by outpourings of bighly liquid basaltie lava interrupted by a few explosive intervals. The chief of thes are Niller Mountain. nartly buried under the later lavas of Willow Creek Mountain, and the Gowenest, Ball, and Poeky Monntain. Muravin l'ak, and Secret spring Mountain. East of these along Bnte Valley ar several contemporaneous shields which have been much modified by faulting

The eones were simultaneously active and there is no positive indication of the order in which they began to grow. Miller Mountain is the most deeply eroded and may be the oldest whereas flows probably of bate leistocene age were erupted from Ball Wountain, Ihes Peak, and Eagle Rock Homnain. The craters of all of these volcanoes have been destroyed although relies of former summit cones are on some of them wuch ar. Ball Mountain. None of the shields was claciated, as were Mount Shasta and the ereat peaks of the Oregon and 17 ashington seetions of the Caseade Range, but the marewins have been driven back by sapping action of springs and sireams which lave cut easily into less resistant rocks below the Caseade lavas and therefore lave caused breaklown of the margins of the shields.

Most of these voleanoes are elliptieal in groundplan and their orientation suggests gruwth over two sets of faults, one set roughly nortli-south and the other $\mathbb{1} 30^{\circ}-45^{\circ} \mathrm{W}$.

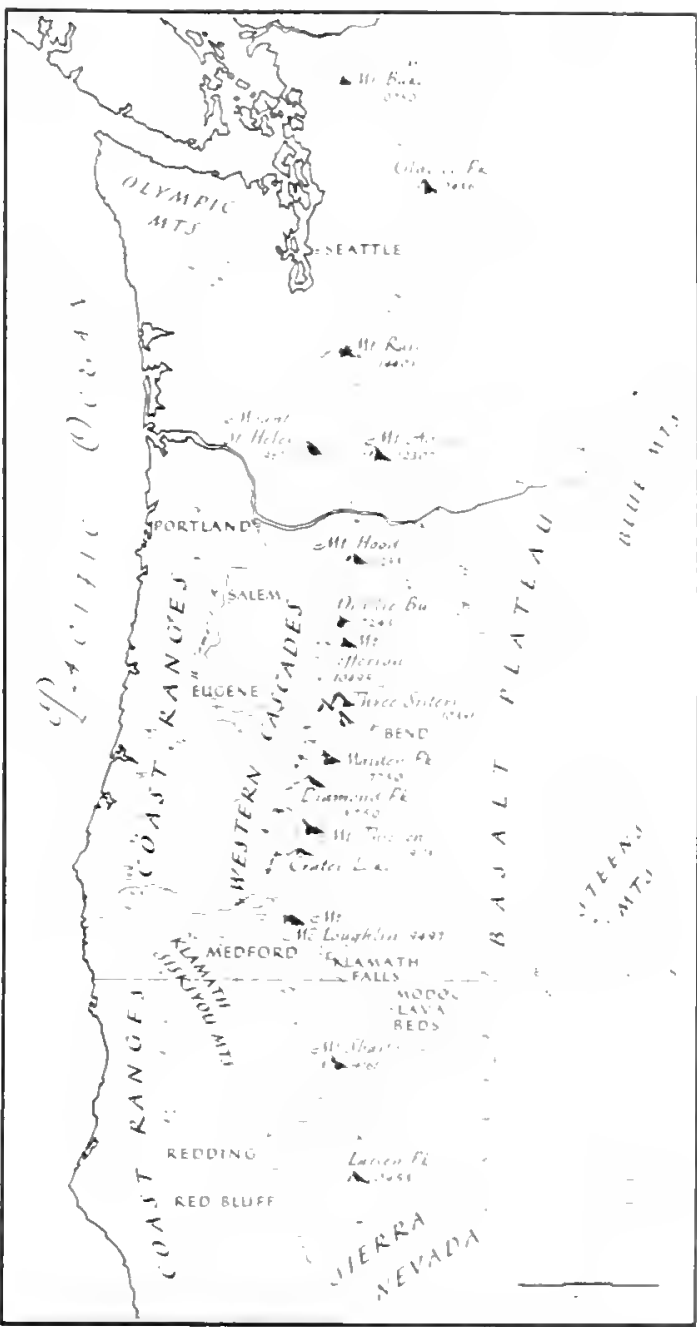

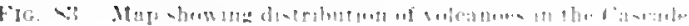

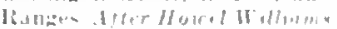


The eastern shields never extendel much beyond thir present limits, but the larer vestern ones nust bave been much more extensive as remnants of their lavas extend far down the Klamath River Valley and also into Shasta Valley.

Much later than the eruptions just eseribed are those which have ocenreal sinco the Shasta glaciers beran to retreat as the last glacial stage wand. There aro flows and cones, some of which are so fresh that they must have been erupted within the last thousand years or so.

Jeer Mountain (7,007 feet), for example, eonsists of five lava cones built over two nearly north-south-trendind faults. Four of the eones are llattish shields of basaltie lava or lava closely approaching basalt in eomposition. The fifth cone, the summit of tho monntain, is steeper. No craters are visible; they have either been destroyed by erosion or filled with later extrusions. Each of the fire eones is heavily mantled with basaltic lebris blown from nearby vents and all have a thin veneer of the pumiee which was blasted from Momt Shasta in $\mathbf{1 7 8 6 .}$

Nen. liolan and Jellow Butte is a consilerable area of flows having a distinet hummocky surfaee whieh at the sonthern end is covered by patehes of noraines, but farther north has on top only sediment left by subrlacial streams. It is believel that these lavas were erupted from fissures near the base of Hownt shasta early in the main retreat of the glaciors on that momntain.

The largest of the late voleanoes north of Mount Shasta is the Whaleback which rises 3,000 to 4,000 feet above the adjaeent lowlands. The mountain is a steep cone which has been modified by erosion. It the top there are two mounds of exploded debris; the larger, about 500 feet high, has a well-preserved erater in the top.

Kenur, Sionle Fiutte, and llorsethief Ranch eones are older than the Iittle Deer Nountain voleano. The first two have been largely llastrugel by quarrying, but both evidently were composed of exploded debris, Jlorsethief Butte is made by two explosion cones whose adjacont sides orerlapped as eruptions went on.

little Deer Munntain is a cinder eone between 500 and 600 feet hich hreacled on the south sicle. Surromuling it is a field of reeent lavit unge than lo sfuare miles in area which seems to have been epropted luring the waning stages of the voltrano.

lerlages the most comspieucus peak in this part of the Cascade Rampis the Goosenest, the top of whirh rises more than 5,000 feet abuve the end of its lonerest flow. The mountain was built on top of a

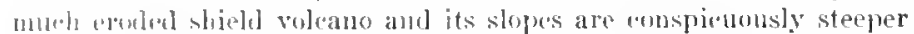

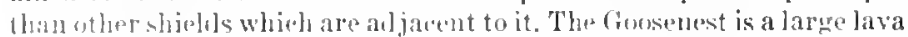

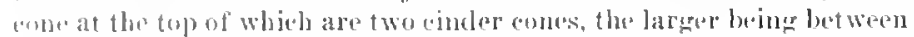

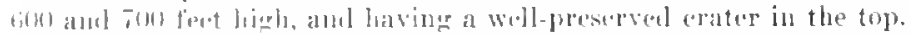

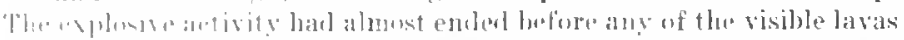
labl beroll pruptel, thongh luriol streams may hase been emitted as the outlutests were going on.
Most of the lavas from the Goosenest voleano flowed to the west the last issued from fissures at the hase of the summit cinder conc jobably less than a thousand years ago.

The eastern half of Shasta Valley is ocoupied by a great flow of basalt which has heen called l'luto's Cave Jow altor the larro lava tumel near its southern end. This flow covers more than 50 square miles and exveeds 20 miles in leugth; it seems to lud comm from faults elose to the northeast base of Monnt Shasta. Before eruption of this lava, Shasta Valley was a broad depression containing low libls of andesite some of which still rise as islands above the later basalt. Almost certainly Shasta River and l'arks Creek flowel through the valley before being diverted to their present ehannels by the eruption. The maximum thickness of this immense stream may be elose to 500 feet near Jluto's Cave but in Little Shasta Valley it deereases to a fews tens of feet.

Toward the head of the flow where it is rather narrow, there is a prominent median ridge and over it there are oval domelike eminenees ealled schollcnilomics formed by the hylrostatie pressure of the lava nnder the solid erust. In the lower part of the flow there also are pressure ritges and eollapse depressions.

The largest of the lava tumnels is l'luto's Cave diseovered in 1863 which onee could be traced for a mile and a half or two miles. Now probably half a mile is as far as it ean be followed, aecess being easy in places where the roof has collapsed. Most of the accussible part of the tumnel has a diameter of 30 to 50 feet but in places it reaches 80 feet. The floor is heavily eovered by bloeks which have fallen from the roof and by sand drifted in from dumes on the smrface. The walls show that there are three and in places four superimposed flows with clinkery tops and bottoms, whicl, were not separate units, but lobes extruded througl the front of the adrancing lava.

(bva] solublemblumes, a few up to 20 feet high, are seattered over the lower part of the flow and marginal pressure ridges. some with gaping fissures in their erests, are common along the eastern margin. Collapse depressions are seattered, but are most numerous near the margins of the lower part. Mnst were formed by collapse of tube roofs, but some are bein producen today by nornal weathering processes. In groumdplan they are elongated, cirmular, or irresular. Many are oesupied by ponds and marshes.

In the southern ent of Butte Valley is a basalt flow very similar in vinarater to the l'uto Cave stream. and similar hasalts probably of the sam" ay are exteusively exposel near Bray. All seem to have come from fissures on the east sich of the Caseale liance. A narrow flow of black basilt pouren from a fissure located about 6,000 feet high on the east wall of Pinte Canyon, trarelel for about 10 miles, and ended ciose to Sonle. Runch at an elevation of about 4,600 feet. 'The upper part is almost eompletely concealed by marshes and meadows 
while the lower part is buried by out wash of sulgglacial streams and by exploflow cinders. The best exposures are below Mount Slasta Vimbls where Butte Creek has eroted a narrow gorge luetween the eastorn sile of the flow and a ghatial moraine. Most of the lava, which ranges from 10 to 150 feet in thickness, moved through tubes beneath a smonth. memlating erust.

Another flow issued from a fissure near the top of the bold northern wall of Alder Creek eanyon, easeaded down this declivity, ant continued for about 2 miles, ending with an abrupt front as it spread wer the liutte Creek basalt. The surfile features are so well preserved that, in spite of the forest upon it, eruptions must have necurred not much over a thousand years ago.

Arain within the last one or two thousand years, the Klamath River was bloeked by basalt flows forming a lake 35 feet deeper than present Copeo lake at its lighest level. The shore lines of this expanded lake are markel by eonspicuous benches of diatomite above the present water level. Diatomite is a remarkable roek that eontains myriads of the beantiful shells of the minute single-celled plants ealled diatoms which live abuntantly in fresh waters but more prolifieally in the oeean. Beranse the shells are made of silica, a very hard substance, this roek if pure is quarried for use as an abrasive.

The Copeo activity hegan with the eruption of three einter eones rangine from 200 to 300 feet in beight ; then flows. at least nine in numher, issued from the base of the lones, the lougest moving lown the valley of the Klamath River for about 2 miles. The flow erusts are bloeky, lunt the lava beneath shows prominent columnar jointing. Most of the enlumns are vertieal, but some are strongly eurved like those of the Devil 's Postpile in the Sierra Nevada. In part the eurved columns developed where younger flows traveled along the channels in the older ones. while others resulted from the intrusion of a later flow into cracks of one already emplaced.

Two reent flows have erupted from the sides of Shasta and Shastina. The older one may be seen a short distance east of Dwinnel Reservoir. Along its eastem side it has ridden over glacial moraines, but its surface is barren of whacial features, being mantled only with a thin veneer of einders. The younger flow, probably the last from Shastina, came from fissures at elevations of 9,000 to 9.500 feet ant covered approximately 20 square miles. Ilimhway 95 goes aromd its margin. Find evidence inticates that the Shasta glatier's had shrunk to about their present size before these lavas were erupted, one tlood issuing from the ent moraine of Whitney glaeier only a short distanep be]ow the present front of the iee. These flows are quite perfectly preserval, have very steep fronts, and litthe forest cover, all testimony of their extreme youtli.

From the preeding aceonnt it is evident that this remarkable area in comparatively recent time was one of the worlel's great volcanic

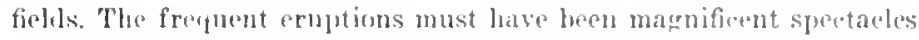
comparable to these which mon have witnessed at many voleanie areas roumd about the world. The reeney of many of the lavas strongly suggests dormaney ratler than extinetion for parts of the area at least.

Older voleanic features also are present, hut are much less speetacular. For example, six volcanje necks which unce sepved as fenters for flows stand elose to the Kilamath kiver near Copen Dam, and there are various others in the same area. Some are found in shasta Valley.

On the eastern side of the Cascade Range and separating it from the Kilamath Nomntains to the west is Shasta Valley, a roughly oval basin measuring alrout 30 miles north-sonth ant 15 miles east-west. Most of it stands between 2,400 and 2,800 feet abuve sea hevel, hence the Caseade Range rises very eonspicuously above it. The eastern half of the ralley is ocupied by a huge flow recently erupted from the side of Mount Shasta, while the western part consists of older voleanies which have been erodet into a multitude of hills rangincr in height from a few feet to 200 and rarely 300 feet. Most of these hills are lomes or cones, but some are mesas or ridges. They look much like little einder cones of fairly reeent origin, but actually they are older lavas whielı have been deeply eroded. Between the hills lie small ponts and marshes and the alluvial flats of winding streams, rhief of which are Shasta River and its tributary Parks Creek. In the northern half of Shasta Valley, there are fow streams because of the porous character of the lavas and most of the underground water empties into the ponds and meadows of the lower southern end.

On the east side of the Caseade Range is Butte ralley, the bed of an ancient lake, standing approximately 4,200 feet above sea level. Neiss Lake is all that remains of a former mueh lareer body of water that drained througl, Sam's Neck into the Klamath River. As with Shasta Valley, this depression is a large struetural basin, lut the faults which bound it are mueh younger than those margining the western basin. Several that-floored grabens like Sam 's Neck and l'leasant Talley extent beynd the margin of the basin between elevated linult bloeks.

When the last grlaciers on Hount Shasta reached their maximum about 25000 or mure years ago, those descending its nor thwest slopes spreat into. Shasta Valley leaving end moraines along the shores of present Dwinnel Reservor and rewssional barriers senthwari as far as the town of Wood. Tolany thase glaciers have heren reduced to a leneth of ahout 2 miles amel none deserent loelow 10.000 feet. A larape

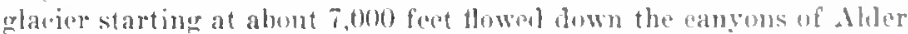
and Butte Crecks renching an elevation of about 4,800 foet near houle Raneh. It overflowed the western rim of the eanyon near (iranilla Banch, flough its thickness was only 400 or 500 fort, and arossidl the opposite rim near Mount Shasta Wouls, leaving buge lateral moraines.

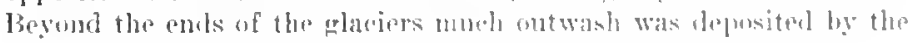
streams flowing from them. 


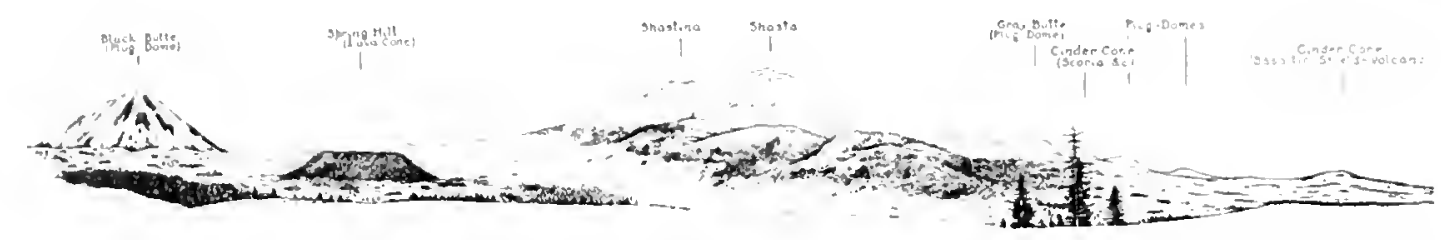

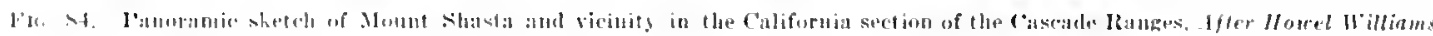

\section{Mount Shasta}

Mount Shasta is one of the most spectacular of a great galaxy of roleanoes seattered along the Caseade Mountains from Lassen Peak on the south to Mount Baker 500 miles northward in Washington. Shasta is an isolated mountain rising about 10,000 feet above its base and 14,16I feet above sea level. In majesty and beauty it is exceeled among the Caseade volcanoes only by the higher Monnt Rainier, prime feature of the National Park of that name in Washington, but others like Jood in Oregon, Baker, St. Helens, and Glacier Peak in Washington are superb stmutures, standing like wreat temples above their surroundings.

How old Shasta is we cannot determine, but there are suggestions that the first eruptions began toward the close of Pliocene time. The latest products certainly are not nore than a few hundred years old and a lot spring near the summit may indicate that fresh lava still exists beneath the monntain.

Shasta, while not the highest of the Caseacle voleanoes, probably is the largest, for it rises from surroundings about 4,500 feet above sea level while Mount Rainier is built on an elevated platform whose surface stands about 8,000 feet above the sea. Some hold that there lias been considerable erosion from the top of Rainier, even as much as 2,000 feet of the top being gone, while the summit of Shasta probably has not been lowered more than 200 or 300 feet. Even if removal from Rainier is as great as indicated above, the Shasta cone exceeds it in bulk and height.

Viewed from the east, Shasta appears to be a single mountain, but from other positions it has the form of a double cone, for a small vol. cano, Shastina, rises boldly from its western side. Shasta, like many voleanic giants similarly constructed, has rather gentle slopes near the base while its upper part becomes increasingly steep. This slope change is eaused primarily by the difference in fluidity of the earlier and later lavas; the later lavas being much more sticky when erupted than were the earlier formed shorter, thicker flows which piled up around the central vent making terraces ending in steep, high steps. Furthermore river and glacial action have added their effects, for above 8,000 feet there has been deep erosion while below 5,000 feet much deposition by streams, gravity streaming, and glaciers has aided in reducing the slope.

Besides the two main eones, there is a line of small einder cones and plug domes located along a north-sonth fracture traversing the summit of Shasta and a very prominent plug dome, Black Butte, which rises more than 2,500 feet above the western base of the mountain. Lava flows of rather late date have been erupted along the base of the voleano.

The lower 5,000 feet of Shasta are mantled with thiek brush, while between 5,000 and 8,000 feet there is a belt of dense pine and fir forest which gradually merges into the treeless alpine top of the mountain. This alpine section is normally clad with snow from October to June and this greatly enhances the beauty of the peak. Five valley glaciers are fed from as many valley heads in the treeless upper reaches, the largest of these ice tongues being located on the northern side of the mountain where they descend to about 9,000 feet.

Although the main voleano appears to be deeply searred by erosion, actually it has been marred very little for the deepest canyon, that of Mud Creek, euts only 1,500 feet into it. Thus a small part of the structure of the cone is visible. That part is composed very largely of lava flows, layers of exploded fragments being relatively few. Of the latter, the most abundant exposures are in the walls of Mud Creck canyon. The last explosions of Shasta came from the summit vent and produced the Red Banks, a deposit of pumice mantling the cirque heads on the south side of the peak.

The erater of the rolcano lies beneatl a snowfield about 200 yards across. At the margin of the snowfield is a small hot spring.

Evidence indicates that all but the latest blocky lava flows on the northeast side of Shasta and the final deposits of pumice had been erupted when a north-south fracture broke through the summit of the volcano. No displacement of the surface slows along the fissure and little or none may have oceurred, but its direction is clearly indicated by the linear arrangement of five plug domes, two cinder cones, and one lava cone. The largest dome is Gray Butte, about 4 miles south of Shasta, which rises about 1.500 feet above its surroundings; the 


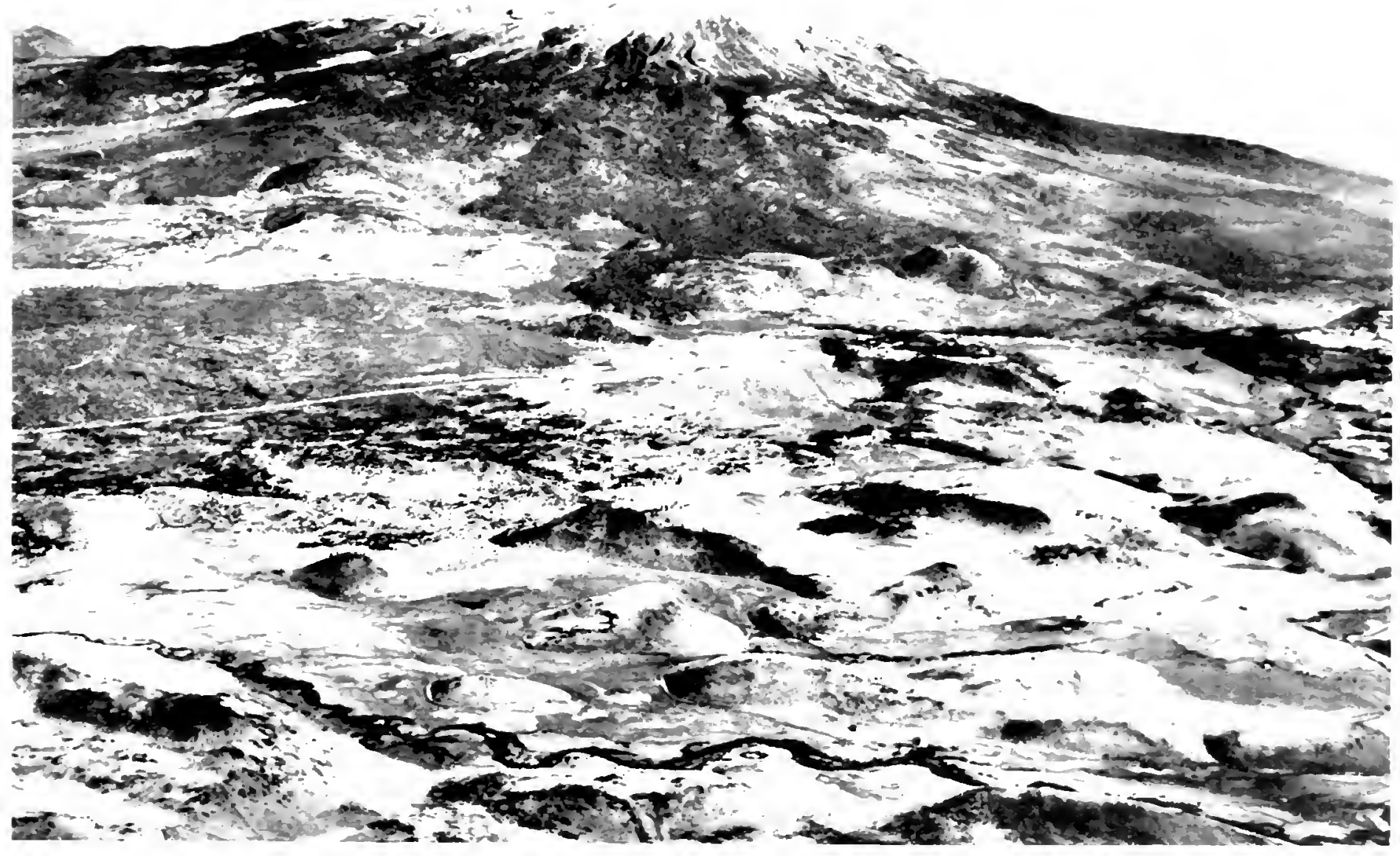




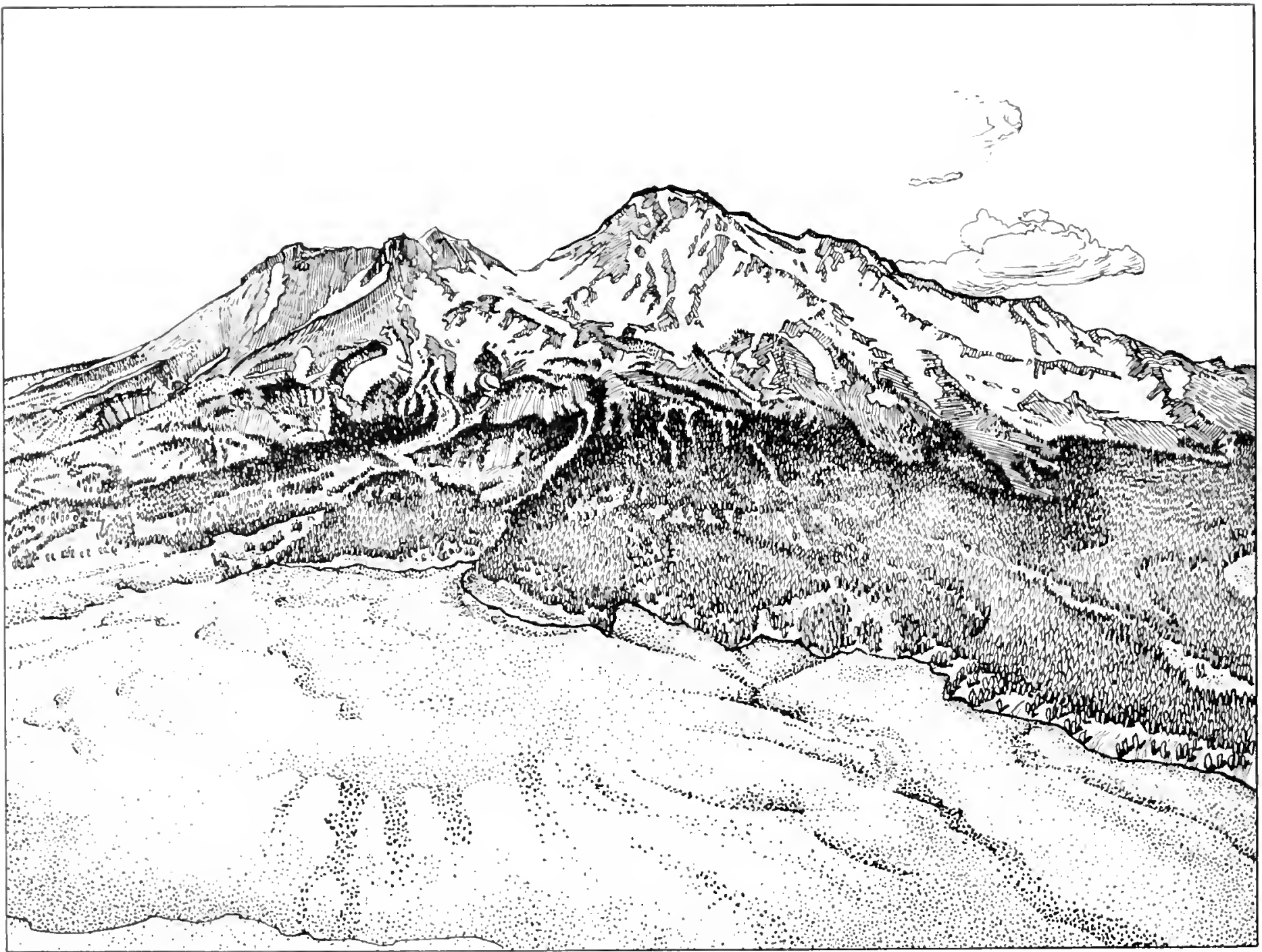

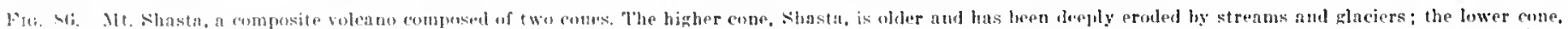

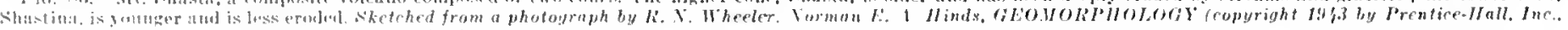

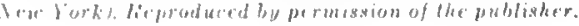




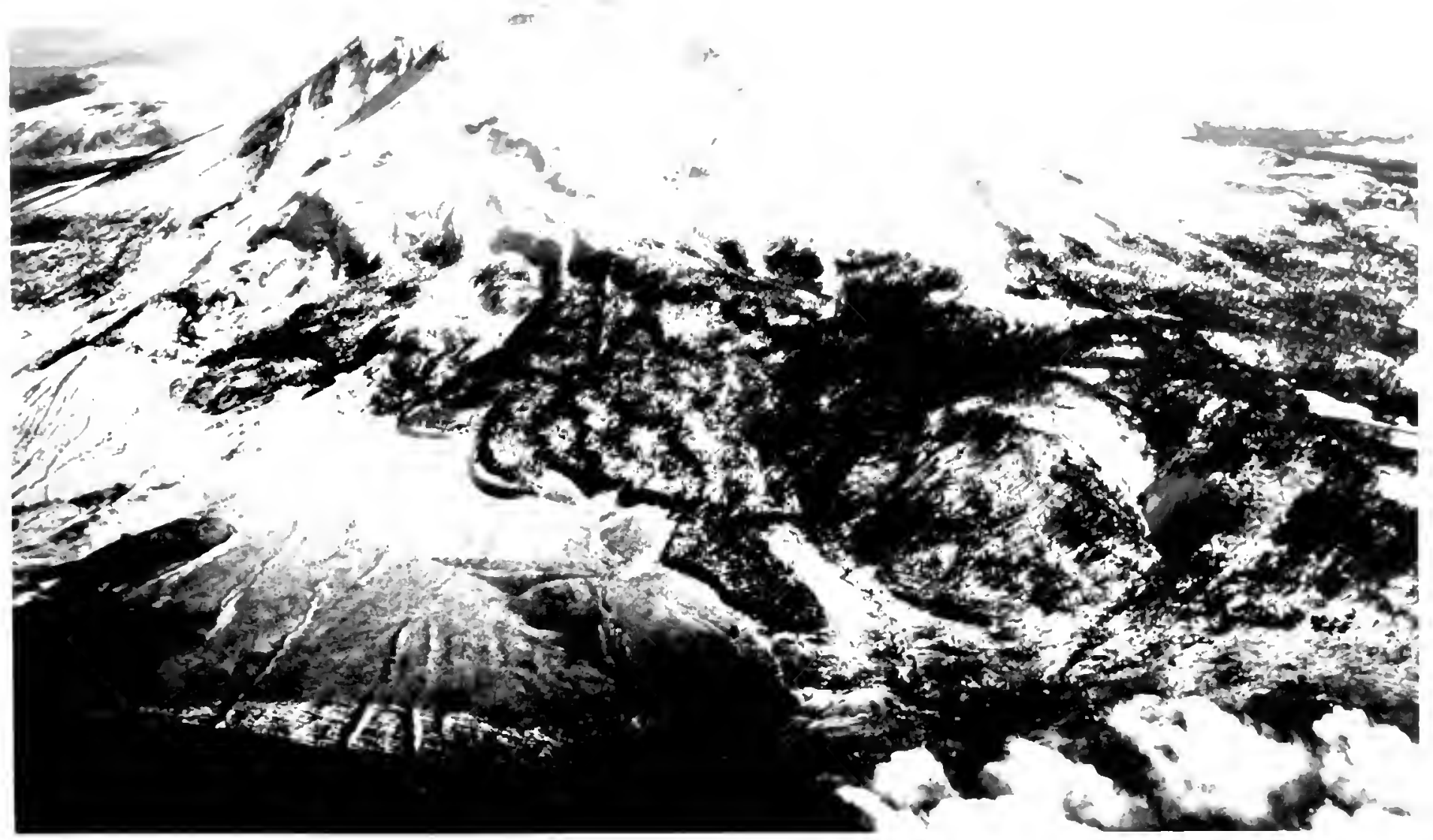

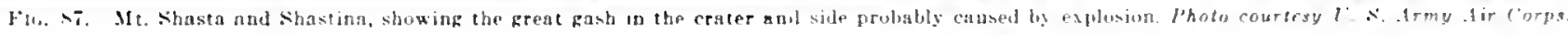




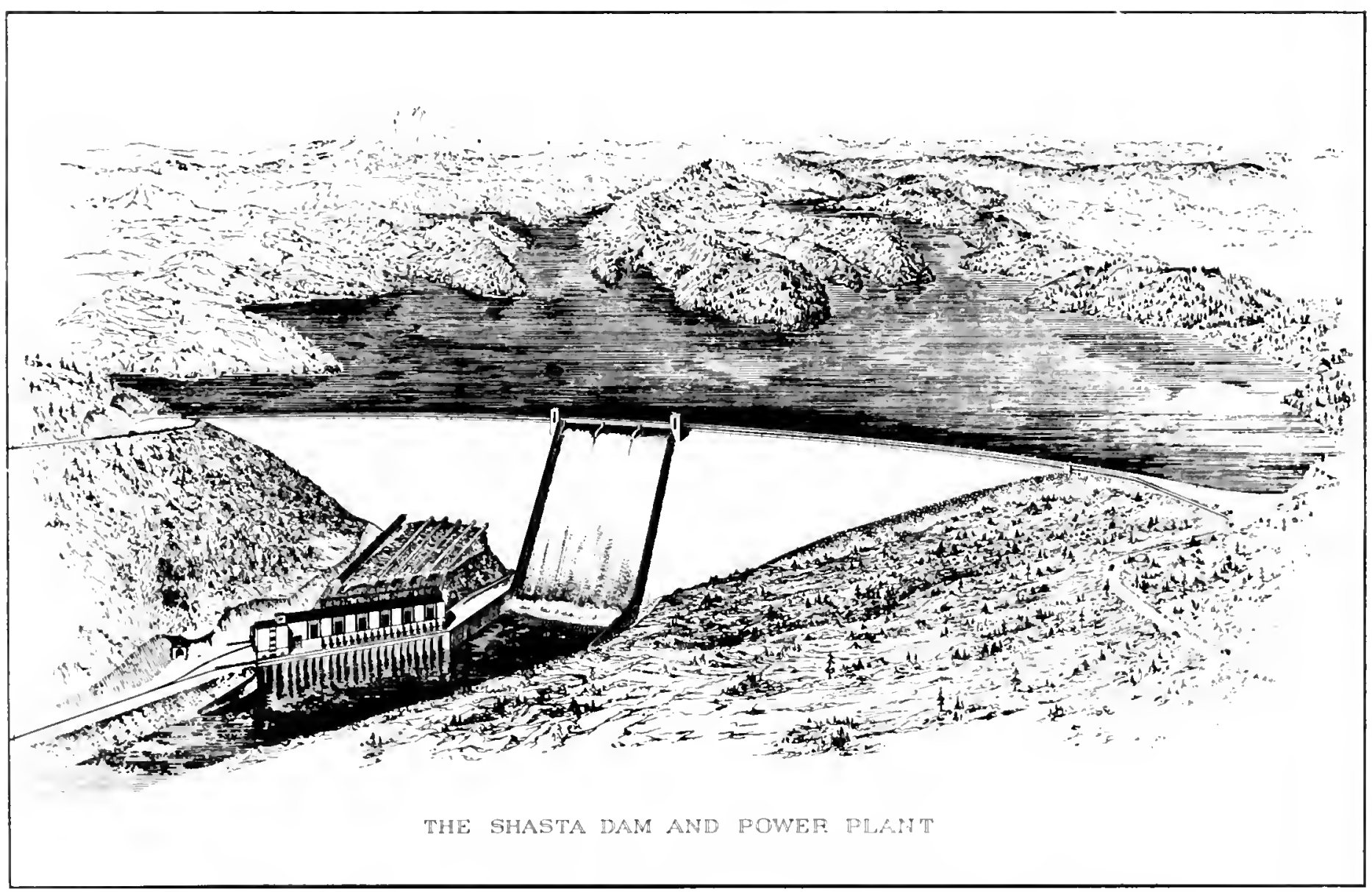

Frc. st. Sketch of Shasta Dam on the Sacramento River ahout 16 miles nurth of Redding, Courtesy $C$.s. Burcou of Reclomofion. 
leneth of this dome is nearly 2 miles, lut the rock core beneath may not be more than half that, the remainder being the great eovering of talus blocks. The cinder cones are small, the northern being only 200 feet limbl and the sonthern sno feet; their summits have been smoothed and the craters destroyed by glacial action. At the south end of the fissure about '2 miles from the town of MeCloud is Bear Butte, a small, steep-sided lill composed of dark lava.

A view of Slasta from the west shows a broad low cone rising from its lone southern slope. This appears to he a miniature shield roleano of the lIawainan type, surmounted by remnants of a einder cone. The lavas composing the main part of this voleano were very liquic] when crupted and spread over a wille area even thongh the slopes they traversed were quite gentle. Host of the flows went southward. though one was partly diverted to the north and changed the course of l'anther Creek, Others traveled eastward and eneireled Bear Butte. the small lavia eone previously deseribed. The longest outpourings from the shiphl volcano descended the canyon of the Sacramento River for more than 40 miles as long, narrow tongues. The river has cut throngl the flows, exposing in sone places gravels that lay in the botton of the canyon when the lava invaded and in others the bedroek into which the Sacramento had cut its eanyou. Excellent sections of these flows may be seen at Shasta Springs where Mossbrae Falls pours out in great volume much of the underground water eoming from Mount Shasta and at other places farther down the canyou. This water is heavily charged with mineral salts.

The main eone of Shasta seems to have attained its present elevation before the large minor cone. Shastina, began to form. It is possible that an east-west fissure developed about the same time as the northsouth one earlier described, the two intersecting at the top of the voleano. The first eruptions along this east-west fracture built a small cone about a mile and a half west of the summit of Shasta and somewhat later Shastina began at a second vent a lialf mile farther west. lintil late in its bistory. Shastina was construeted from short, quite viscous flows which issued from a single vent, but the last principal cruptions came from fissures which opened on the west side of the cone.

The almost perfectly preserved summit crater of Shastina is a bowl-shaped depression about 300 feet deep and half a mile in diameter. Within it are two more or less conical mounds which may be plug domes with much broken tops. In the western side of the erater is a deep breach and below this lies a huge $V$-shaped gash; possibly both of these features resulted from violent downwarl directed explosions accompanying the elevation of the domes within the crater, a not uneommon feature at voleanie mountains.

Later explosive cruptions oeeurred at lower elevations, most of them centering about 3.000 feet below the rim of the Shastina erater, though activity progressed westwarl so that some orourred Jono ferat brow or at an elevation of about 5,000 feet above sea level. 1)ark thow of

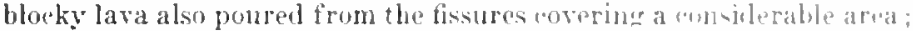
the longest descended almost to the present site of the town of 11 ind on IIighway 99. These recent flows cannot be more than 200 years ohl

Rising eonspicuously near IIigluwa 9.9 not far from the town of Weed is the prominent eminence known as IBlack lintte whose mumuit stands about 2.500 feet above its surroundings. From some plaw. the the Butte appears to be an almost perfectly conioul momtain, but we where this form is seen to be modified by a serine of arcuate ridene from 200 to 1,000 feet below the top and located on the northwest side. The diameter of Black Butte is about a mile and a half. The whole of it appears to be made of great blocks of lava whicll bevome larger towaril the top, only a few crags of coherent rock being visible.

The common belief is that this mountain is a roleano like Cimler Cone of Lassen Park and varions others. but actually it is a plus dome very heavily mantled with talus. The core nat be cylindrical in form with a diameter of little less than a mile. As the mass rose. eorl. ing and coutracting, it was heavily fractured and the great banks of talus formed. Ficld evidence shows that prior to the protrusion of this dome, explosive eruptions oeenrred, but whether a small cone was built has not been determined. Black Butte is one of the latest products of Shastan activity and its completion very likely took place in a few years, a striking contrast with the many thousands of years requirel for the building of Shasta.

Glaciers today cover a very small area on Mount Shasta, about 3 square miles, whereas not far back in Pleistocene time ice apparent? blanketed the entire peak. Of the valley glaciers, the Hotlum on the northeastern side is bo far the largest, accounting for almost half the total extent of the ice. Bolam and Whitney to the west of llotlum aml Konwakiton on the south side of the mountain are the others. IJotum glacier descends to an elevation of about 9,000 feet, the lowest point reached by any of the ice tongues; in the early days of exploring 1 ount Shasta, this ice mass was thought to be about 2.500 feet thick, but now we know that actually it measures only 300 feet which is a maximum for any on the peak. Konwakiton, also known as Mud Creek glacier. has been especially conspicuous at times because of the great mul] flows which have descended from it. A few tens of years ago, this glacier was about 5 miles long but since there has been comsiderable recession. Near its head, the slope of the iee is steep. while farther down, it flattens out, the glacier ending on the brink of a eliff in Mut Creek Canyon. During dry seasons, the run-off from melting snow, which in wetter rears is more gradual and sinks into tle ground. becomes torrential. Great streams find their way down the erevass in the ice and emerge on the floor of the ralley at the end of the alacier. 
The water, earrying large blocks of jee broken from the snout of the glarier, races througl a narrow eanyon, undermining the weak walls matle of tuff and breceia. At times part of the undereut eastern wall collapses into the bot tom of the gonde forming temporary dams. Rather quickly suftieient water is impound d behind the barrier either to flow over it or to break through and sweep it on down the eanyon. This debris-laden flood after following the canyon for about 6 miles comes out onto dlatter land, spills over the banks of the stream, and spreads thick sheets of sand and mud in which are embedded great boulders. Much of the finer letritus is earried into the McCloud River, from there into the l'it, and finally into the Sacramento, at times rendering that stream turbid for 200 miles below the junetion with the Pit. These great mul flows were partieularly well illustrated during the lry seasons of 1924,1926 , and 1931 .

Below Wintun and llotlum glaeiers, other mud flows may be seen, particularly along the banks of Ineonstance Creek, but much of the eanyons which these tongues follow is eut in lava flows and therefore less debris is available.

Evidence of the fairly late eoverage of the entire volcano by ice is provided by the abundance of morainal deposits around the base. Ilowever, the glacial history is not well enough known to determine whether there were various stages, though very likely such was the case as may be inferred from their existence farther north in the Casiade Nountains of Oregon, in the nearby Klamatb Nountains, and in the Sierra Nevada.

When the glaciers reached their maximum, they descended into Shasta Valley west of the peak, crossed it, and rose to a height of about 4,000 leet along the mountain slopes on the western side. On the southwest, the ice covered Quail Mountain and probably was joined by other glaciers coming eastward from the Klamath Mountains. In the prineipal valley on the north side of Mount Shasta, the ice was prohably at least 1,000 feet thick, while on the south it rose within 100 feet of the top of Red Butte as is proved by polished and striated roek. All hut the highest points of Gray Butte were overwhelmed, as were the cincler conts, lava domes, shielt rolcano, and probably Bear Butte farther south.

Espeeially fine glacial features are the great cirques on the southwest sile of Mount Shasta and some of lesser magnitude on the east. The most perfert of the lot is that at the head of Caseade Gulch between Shasta and shastina. There are well-preserved zuoraines in the eirque. Elsewhere high on the mountain good moraines are searee except at the ends of existing glaciers, but there are some examples on the plateau southwest of IIorse Camp. The road to the town of MeCloud along the south base of the mountain cuts through a group of side moraines, whil" in the catyon of Whitney and Bolam Creeks these deposits lie beneath recent flows of blocky lava.
In spite of the abundance of snow and iee on Mount Shasta, there are few large streams and these cease to flow during the winter; most of them are restricted to the north and east sides of the mountain. The eause of the searcity of water is the porosity of the lawas and the glacial debris. The water sinks below the surface flowing undererround to the base of the cone where it comes ont in many good sized springs, notably on the sonth and sonthwest sides. The finest display is at Mossbrae Falls in the Saeramento Canton.

Traces of avalanches are numerous especially at elevations of about 8,000 feet where the steep upper slopes gradually flatten out toward the mouths of eirques. Frost wedging apparently dislodges large masses from the highest ridges; in some eases they race over snowbanks increasing in volume as they go. One by the sile of the trail up Mount Shasta near IIorse Camp, occurring probably not more than 50 or 60 years ago, plowell a path half a mile long through tall timber.

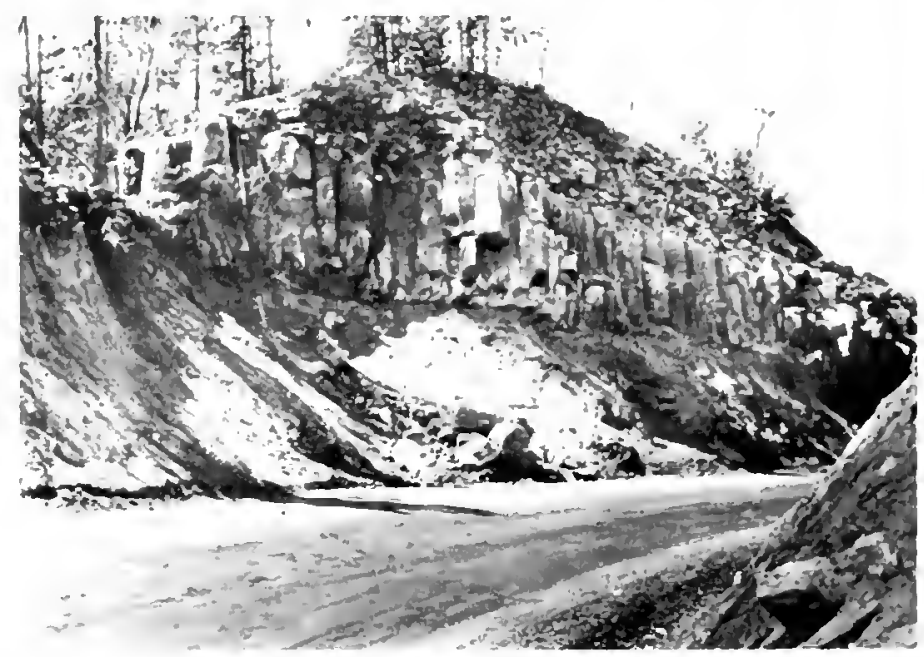

Fia. 89. Flow of basalt that descended the upper part of the Sacramenta Canyon for about 40 miles from a rent on the lower, southern slope of Mit. Shnsta. The Sacramento Rirer bas cut through the flow into much older rocks of the underlying Cormations. Photo by Olof P. Jenkins.

\section{Pliocene (7) Cascade Volcanoes}

Between the Mount Shasta and the Medicine Lake Mighland is a broad, irregular mountainous belt wbose lavas appear at a few places under the voleanic rocks near the midlle of the Ilighland. Their principal display is an areuate outerop around its eastern margin from whieh they extend westward and merge into the base of Mount Shasta. 
This area is composed principally of masive, deeply oroded, wratish.

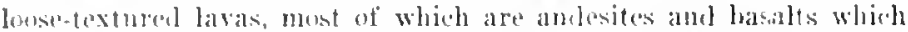
appear to have boen erupted from voleanoes of the Shast a type. In fact

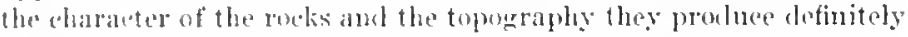
relate them to that sort of voleano, hemen they are 100 it rasted with the olhest lavas of the mearhy. Ifoloc Plateau which are darker in color and were poured out as fissure flows.

The reliet ot the area neenpien by this belt of iray lavas reaches a maximum of tiono feet. Ilaight dlountain, near the western margin extereds 8,000 leet; Garner Mountain and 110 rse l'eak each are more than 7.000 feet. Grizzly I'eak and several other conspienous summits stankl over 6,000 feet. On the other hand, the l'it liver, which "rosses the southern part of the area, has ent a gorge below the 2,000-foot mark into the lavas.

Iost of the landscape is the product of erosion, being determined by the I'it and Ilecloud rivers together with their tributaries. However, the major forms seem to be dependent upon original peaks which had been developed during a considerable voleanic eyele. These lieights are leeply eroded conical or pyramidal mountains so similar in form to Mount Shasta itself that they are far more likely the eroded products of like volcanoes than dissected remnants of a lava plateau.

The lavas weather easily and have produced a thick soil which supports a heary forest growth; this results in scareity of outerops of fresh rock and makes study of the area a matter of much difficulty.

The volcanoes from which these gray lavas were erupted are believed to have been active in Pliocene time, though the evidence is ratber meager.

\section{Medicine Lake Highland}

About $3 \overline{5}$ miles east of Mount Shasta and somewbat to the south of the Lava lieds National Monument is the Medicine Lake Ilighland, a roleanic center roughly 20 miles in diameter which marks the eastern boundary of the Cascade Range in this section of California. On the north, east, and south, the lighland is surrounded by the nndulating surface of the Modoe Lava P'lateau which in part is broken into small, fault block mountains.

The hiphland is described as "converging upward to a roughly clliptical rampart of cones and domes," + by 6 miles across, on which the highest point is Nount IIoffman, 7,928 feet. This rampart enclosed an elongated basin. the western side of which is occupied by shallow Menlicine ] alke whose surface stands about 6,500 feet above sea level The lake has no outhet, but its water is fresh probably because of suffeient seepage into the rocks below to prevent concentration of salts brought into it by feeding streams.

The basement rocks of the hightand are basaltie and andesitic lavas like those of the Ifodoe P'lateau immediately adjacent. The growth of the Nedicine Iake eminence was started by eruption of rather fluid andesitic lavas which huilt a broat shielel voleano ahout of miles in diameder. It is believel that the eentral part of the shisole later andlapsed forming a basin or caldera about ti miles long and 1 miles in wilth. As this was going on, more viseons lava was foredel up alomer the fractures lorming rim voleanoses. Ermpetions continnel pumbiner

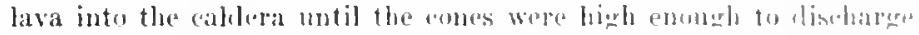
flows down the sicle of the orieginal shield roleano. As a result the fractures were setaled, the walls of the caldera were hidden, and the basin was silrromblet ly the rampart of cones.

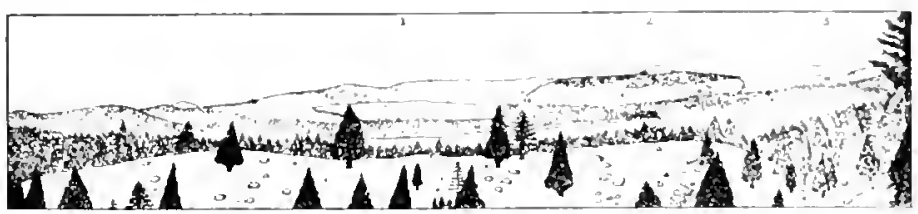

Fic. 90. Panoramic sketch fron the top of Medicine Mountain, showing part of the ellintical rampart enclosing Medicine Lake basin. 1. Recent lava flow loetween Medicine Lake and the northern ridge; 2, Mt. IIoffman; 3, Glass Mountain. After C. A. Anderson.

New vents then opened giving forth sticky, lighter colored lavas of composition similar to or approaching that of granite. The floor of the summit basin is partly covered by a quite recent flow of this type. During this late eycle, more openings were developed on the lower flanks of the old shield voleano, flooding all but the western side with flows of basalt. Many small cinder cones also were formed by mild explosions. On the southeastern side of the shield, a number of cinder cones have coalesced to form a broad ridge. The Modoe Lava Beds are the northermost expression of the basaltic flows discharged from the fissures along that flank of the Medicine Lake shield voleano.

Recent fanlting has developed small scarps and some of the recent voleanic activity las centered along these fractures forming cinder cones and lava cones.

The number of small cinder cones seattered over the highland exceeds a hundred and the latest of them probably have heen formed within the last 500 years.

The last basalt flows are very differently distributed for none of them are present in the summit basin or the elliptienl rampart surrounding it. All came from vents on the northern, eastern, and southern sides of the shield voleano mostly loeated between 5.000 and 6.000 feet above sea level. Soils are poorly developed. showing the receney of the eruptions which probably ranged from culmination of the last glacial stage to the last few conturies.

Flows of eomposition approachine that of granite are limited with exception of those of Little (ilass MIountain on the rest side to the 


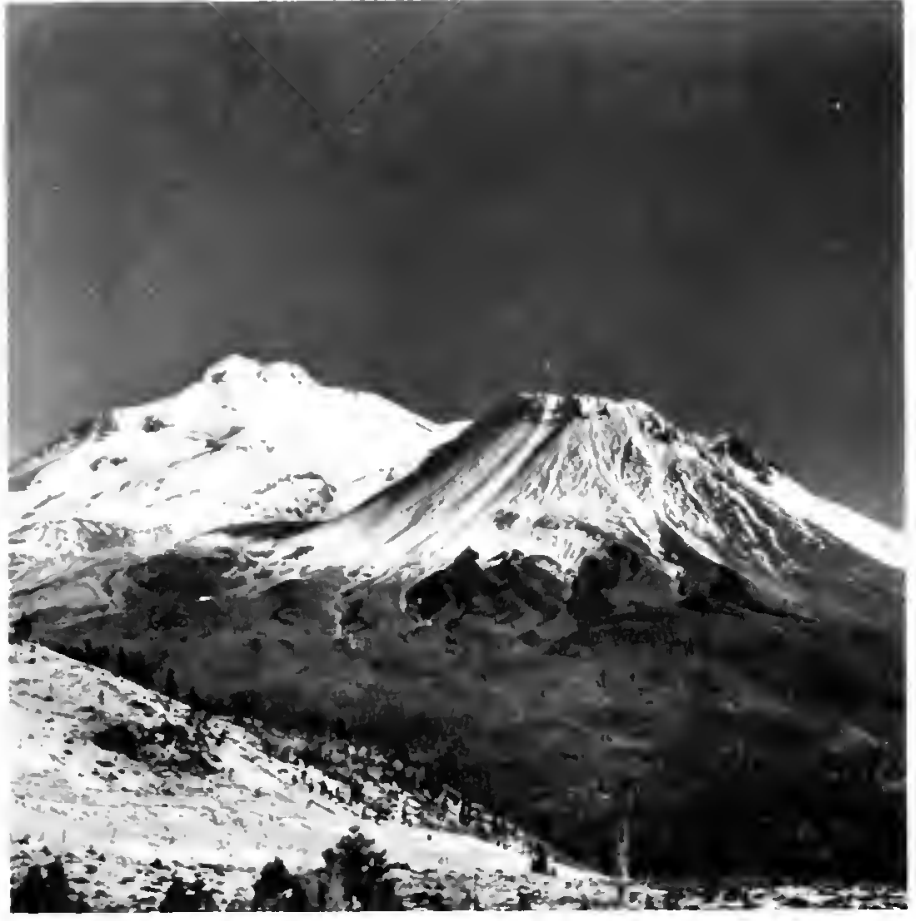

F16. 30a. Mt. Sbasta and Sllastina. Thotoby G. D. Manna.

center and the rampart of Medicine T,ake llighland; some are partly glassy while others are obsilian, the latter representing some of the most recent eruptions in this area. In addition there was considerable explosive eruption of pumice. At both Glass Mountain and Iittle Glass IIomtain, the rolcanic cycle was initiated by outbursts of pumice which built up steep sided cones, while later mueh obsilian was erupted at both roleanoes. Pumice and obsidian also were erupted at still other eenters.

\section{Lassen Volcanic National Park}

Very close to the southern end of the Cascade Mountains where they adjoin the sierra Nevada lies a must interesting area which has been set aprart as l.assen Volcanic National l'ark. The best approach is Hichwar 47 which goes from Iied Bluft in the Sacramento Valley to Mineral and Chester ant eventually across the Sierra Nevada. At Nineral a road turns north which grves the traveler a splendid view of

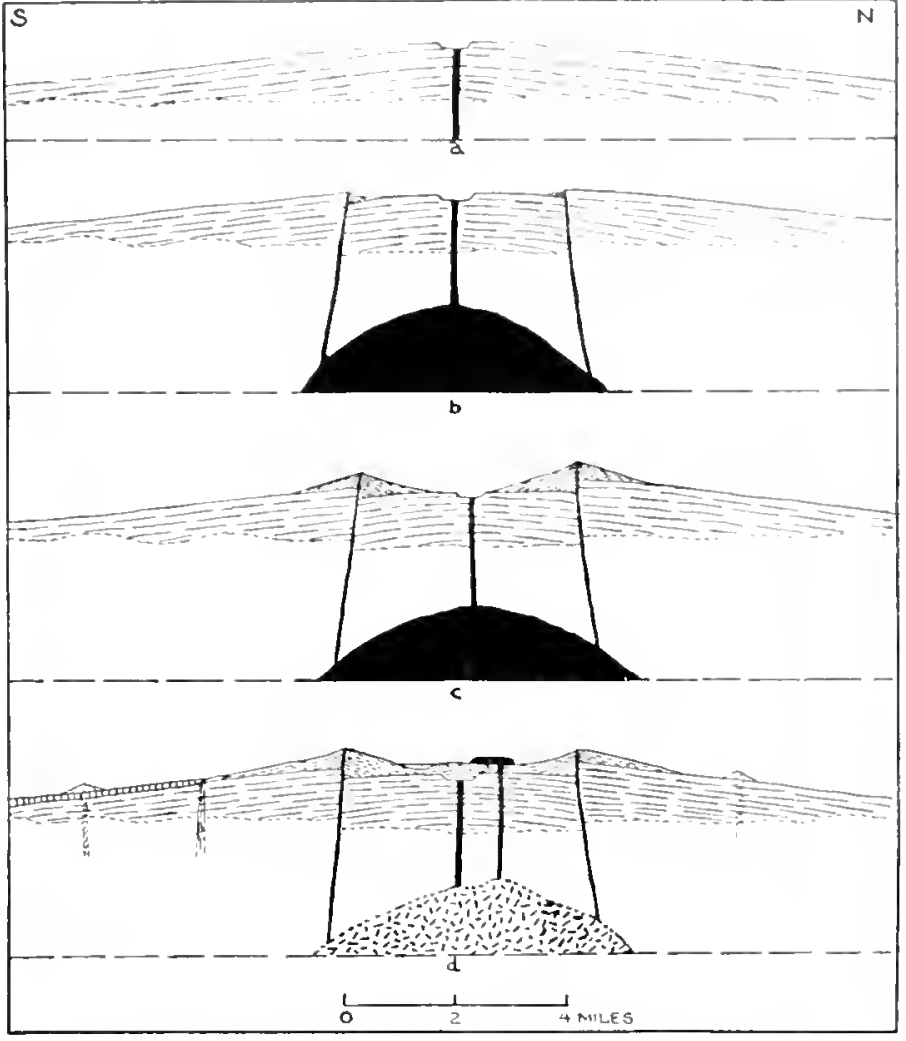

F10. 91. Cross-section illustrating the origin of Medicine Lake caldern and rim volcanoes. $a$, Shield volmno made of flows of andesite lava. $b$, Collapse of central lock along faults. Lava was squerzed up along frictures and poured out on caldera floor. Solid black aren is lava chamber. c, Continued growth of rim volcanoes discharging lavas down outer slopes of original shicld voleano as well as into ealdera. $d$. Cross section of present highland showing basaltic cinder cones (stipuled) and basalt flows (vertical lines) on nuter flantis of shield volcano. Black area in central basin is a recent Iava flow. After C.A. Andersan.

the principal seenic features of the lassen Park. Hiwhway 47 from Redding and 37, taking off from the Redding-Alturas roal (No. 299) about 5 miles east of 13urney, enter the Park at Manzanita Lake on the north side. Unpaved roads lead from immediately west of Chester and reach sections of the park not accessible by the paved highway; one groes up Warner Valley into a region of hot springs, ineluding the 


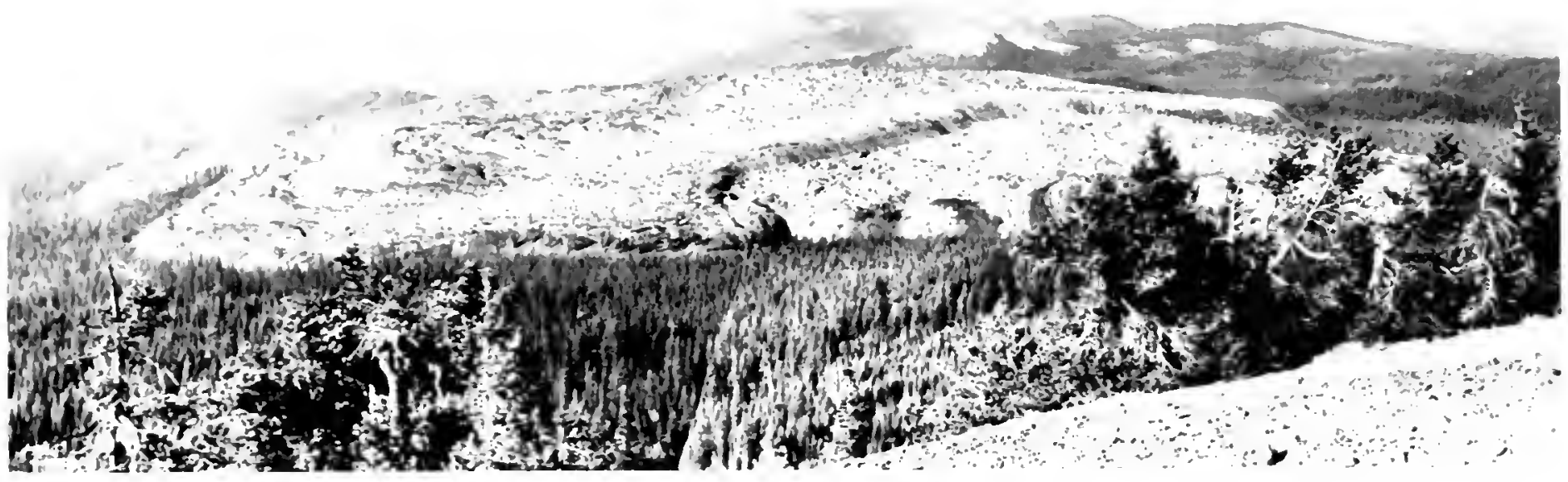

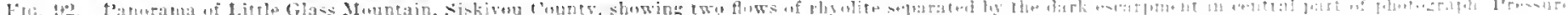

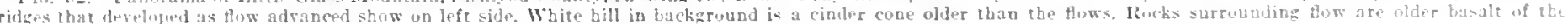
Modoc tlatesu. Photo ty $\mathrm{C}$. W. Chestermon.

Geysers, Boiling Lake, and the Devil 's Kitchen, centered near Drakesbal, the second passes along the eastern side of IIarkness Voluno to Juniper lake. Features to be seen along the principal highway throunh l,assen l'ark are many. This road leats thrungh Mill Valley. across the ancient, mueh faulted erater of Brokeoff Volcano which is dotted with hut springs. Then, after passing close to the fumaroles (hot gas springs and boiling springs of limmpass IIoll and glacial lakes Emerald and Ilelen, jt ascends the southeast shonler of basin leak, where good views of the many volcanie domes. principal features of the l'ark, and of eartier Hows from the original I awen water may be oltainel. Fullowing the upper part of Kings C're'k Valley, the highway goes arount the side of bold, talus-mantled White sountain. and crosses the valleys of llat and Jost creeks where the mal-tlows of 1915 caused much devastation.

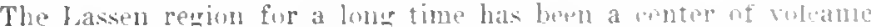
action. older lavas and explosion prolucts showing at many platees.

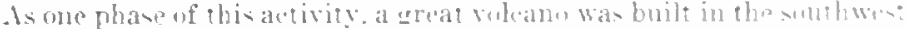

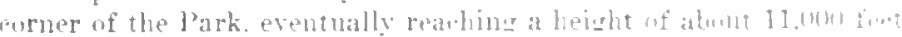

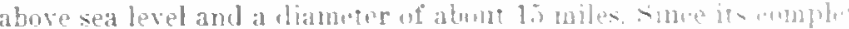

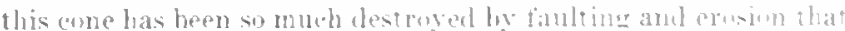

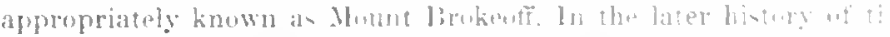

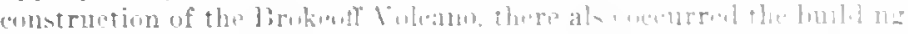

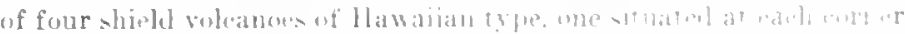

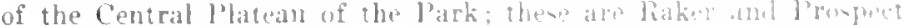


peaks, lied Mountain and Mount llarkness. Fach of these mountains is surnounted by well-preserved explosion or cinder eones which rise within the more or less nearly circular fault basins calted calderas at the tops of the mountains.

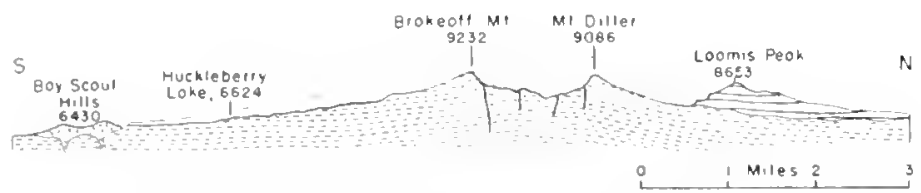

FIG. 93. Section across the Ibrokeof Volcano showing by dashed line the approximate original form. Present surface is indicated by soliul line. The top of the mountain cullapsed ulong faults, producing caldera in the top. The Boy Scout Hills are ling domes erupted through conduits opened in the lower southern flank of the volcano. After Horel Williams.

The eruption of Red Mountain had ceased when an irregular body of rhyolite was intruded into the cone at its northern base. Also after the completion of Raker Peak, a steep-sided dome of lava was protruded through its southern flank. About the same time, a new orifice opened on the northeast slope of the Brokeoff voleano, probably close to if not immediately beneath the present Lassen Peak. From this erater streams of fluid lava flowed radially though principally to the nortl piling up to a greatest thickness of 1,500 feet. These flows are the black, glassy, beautifully columnar streams that eompletely encirele the base of Lassen Peak.

Lassen Peak represents a erater filling of the voleano just deseribed. Gas-rich lava had poured out as llows making the mountain just described. Then partly solid, partly liquid gas-poor lava rose to form the lassen voleanic dome; its sides were abraded as they ground against the walls of the rent and its surface broke apart into blocks which slid down the slopes forming great piles of talus.

Smaller domes rose to the south of Lassen Peak forming Bumpass Mountain, Mount Helen, Eagle Peak, and Vulean's Castle, and some of these were connected by short, thiek flows of evidently sticky lava. l'ossibly at about the same time the domes forming Morgan and Boy Seout IJills were forced through the southern base of the Brokeoff voleano and that of White Mlountain was elevated tlirough vents from which lavas had been poured long before. The domes that border Lost Creek may also belong to this episode. It is evident that all of the domes were rapidly construeted as compared with the much slower building of the older voleanoes from layers of lava and exploded fragments.

This phase of the voleanic action was followed by the collapse of the summit of llount Brokeoff along a series of nearly vertical faults producing a caldera having an area of about $2 \frac{1}{2}$ square mites. lls origin is similat to that of the Crater lake basin in Orewon and many other basins in rolcanie mountains. The cause of eollapse mav lave been the large amount of withdrawal of lava from below the area in the formation of the domes above lescribed thongl very likely underground migration of lava also played a part.

Lassen I'eak appears to have risen to abuut its present height when a vent, Crescent Crater, opened on its northeastern side and erupted flows of lava. Then, ahout 200 years ago, a line of cones developel at the northwest base of Lassen throwing out clouds of tuff and pumice. Two rather eylindrival domes of highly viseous lava were elevated through these cones to form the Chaos Crags. The latter and northern of the two domes hat risen about 1,800 feet when stcam explosions burst from its northern base causing that sirle to colla pse and sending a great avalanche of angular blocks over about 21 square miles imme. diately adjacent forming the wilderness of boulders called Chaos Jumbles.

In the northeastern part of Lassen Park is Cinder Cone, a finely preserved, very young explosion cone built perlaps ahout 500 A.D. Not only was the cone formed by the explosions, but the area roundabout, more than 30 square miles in extent, was mantled with the

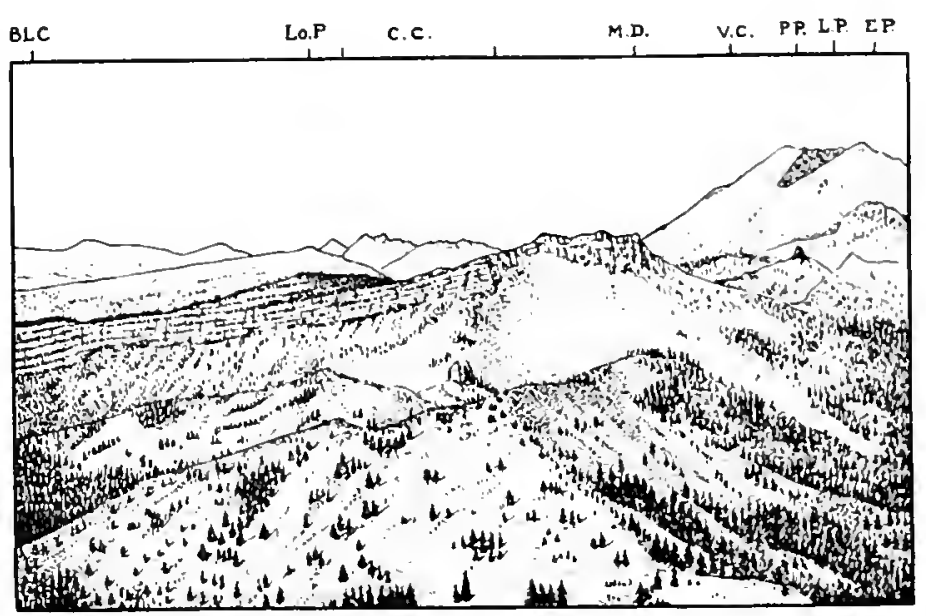

Fig. 94. View north from Brokenf Monutain across the downfiultid callera

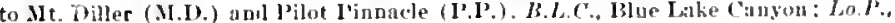

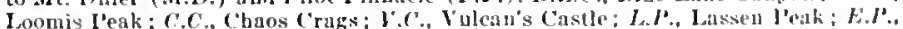
Eagle Peak. Dark Tongue on Lassen" I'eak is the 1!nj lava flow. Alter Hored IVilliams. 


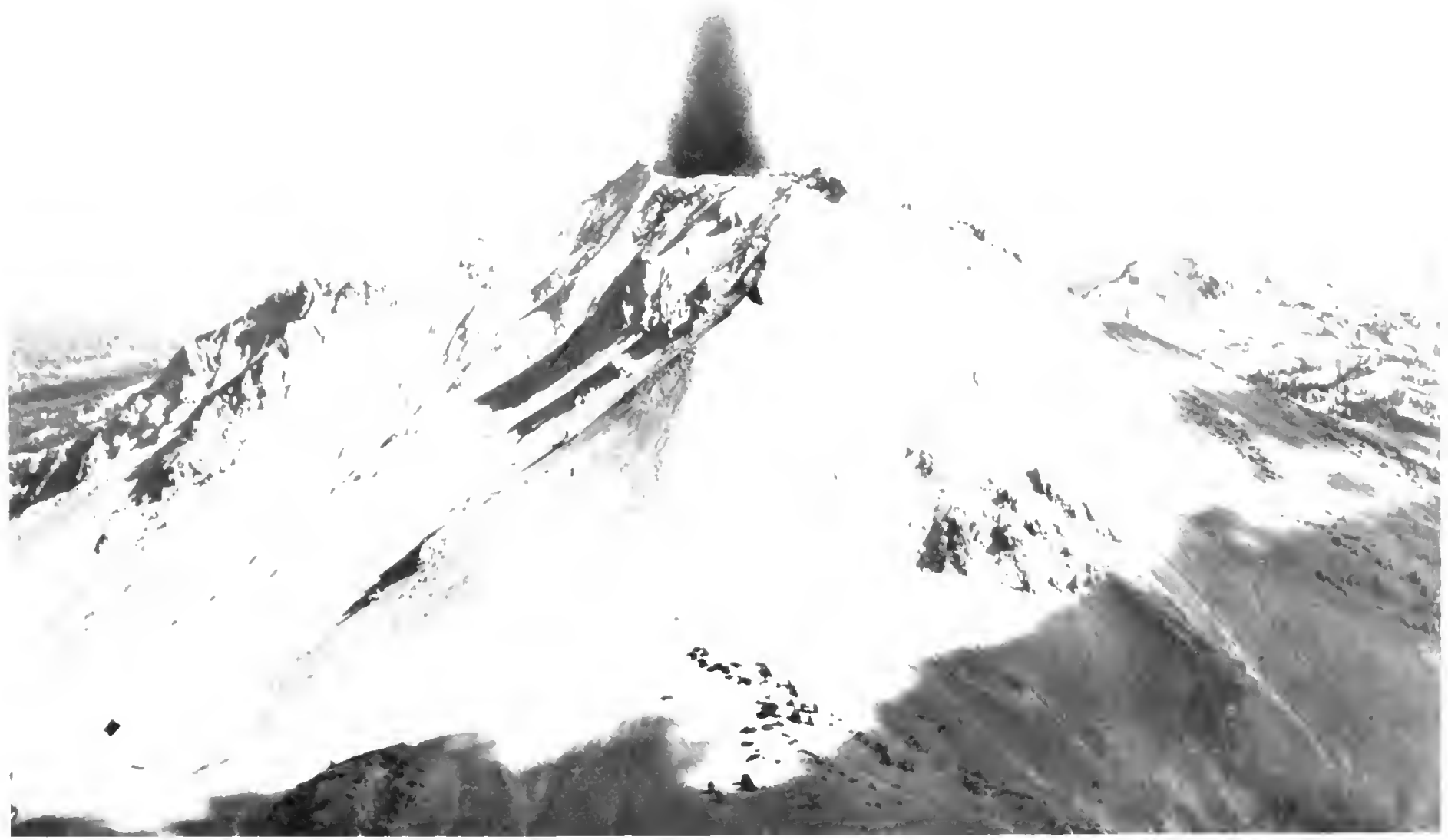

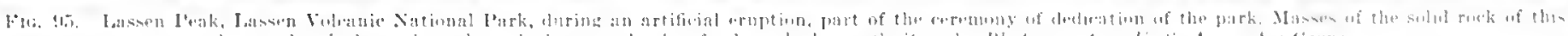

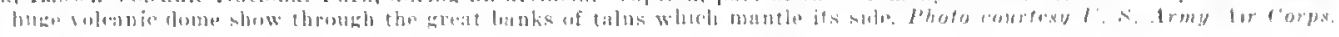




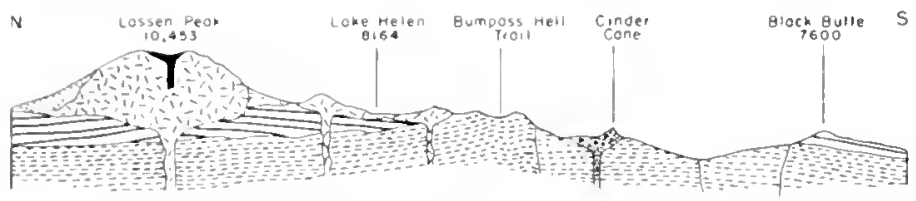

Fio. 90. North-south cross section through Iassen Peak, Lassen Volcanic National Purk. After Hotel Williams.

debris. Cinder Cone is almost undamaged by erosion and has a perfeetly preserved crater in the top. The layered strueture of the little monntain, representing the deposits of the rarious explosions, ean be seen in the erater walls. Round about the base are many of the larger framents hurled from the vent. some of them measuring 4 and 5 feet in diameter. At a later time flows of basalt were erupted from fraetures at the base of the momtain, am then these were partly covered by exploded fragments. Finally two very late flows appeared, the second quite reliably dated about 1851.

As late as $\mathbf{1} 857$ steam rose from the domes of Chaos Crars. In May, 1914, Lassen Peak beeame aetive, and, for a year, explosions occurred at irregular intervals. In May, 1915, lava rose in the summit erater spilling over the rim on its northeast and northwest sides, melting snow and eausing extensive mudflows. On the 2 ind of the same month, a horizontally direeted blast was loosed from the northeast sile of the crater, causing more damage along the headwaters of 11 at and Lost Creeks. Afterward the aetivity beame less vigorous and died out in the summer of 1917 with no later recurrence.

The Lassen Dome is by far the largest and lidrhest of these eurjous but common voleanie features in Lassen l'ark; it rises about 3.000 feet above its surroundings, standiner conspicuousty above the smaller domes on its south and northwest sides. The mountain has the form of a truncated pyramid. The steep-sided solicl rock eore probably meanures about a square mile in extent, but enormous masses of talus spread ont from it and cover at least twice that muel acreacre. Espeeially on the sonth and east fanks. hirh rugged "raes of the core stand out. hut in most plaees the mantle of debris eompletely covers it. The great boukler banks were almost entirely developed by the fraturing of the core as it rose, cooled, and contraeted, for hot rock shrinks in volume as it eools.

The activity which started in 1914 materially changed the form of the summit arater which before had been a smonth bowl about 360 feet in maximm depth and lloored with volcanie sand. No fumaroles (hot gas sprines) or other signs of activity were known within the memory of those fiving nearby. Snow commonly aeenmulated to depths of at least 40 liet within the crater. "lhe new voleanic evele emmenced ou Nay 30, 1914, with a short, mild explosion. 1)uring the first year more than 150 other outbursts took place enlargine the crater 60 a diameter of about 1,000 feet. Durinu 1914-15, snow aecumnlation on lassen l'eak was mnsually heary and this nay have becn responsible for the aetivity of 1915 as the meltwater seeped into the carth and came in contaet with hot lava. Between May 16 and 18 a mass of black lara rose in the notch in the western part of the crater rim and on the 19 th spilled out in thr form of a tongue about 1.000 feet long. What hap. pened on the eastern side of the mountain during this time is not clear, but on llay 19 a derastating mud flow pourod down Ilat and Lost Creek valleys carrying 20-ton boulders for a distance of 5 or 6 miles. Three days later a second mud flow vecurred in the same plaee with minor ones of similar sort on the north and west silles of the monntain. At the same time on the eastern side there came a terrifie horizontal blast which felled trees for miles around so that their trunks were aligned in the direction of the on rushing cloud of gas and rock framents. Clouls of steam and ash rose vertically above the erater to a height of more than 5 miles.

Following the vigorous activity of 1915 , the energy of the roleano seens to lave been largely exhausted. Explosions continued for 2 rears at irregular intervals, culminating in violent outbursts of May and June, 1917. There hal been insiderable snow during the previous winter and this apparently made more underoronnd water available to be turned into steam. After 1917 no eruptions have oecurred. The prinuipal eflect of the explosions of the last two rears was to still further modify the form of the crater. The temperatures generated during the 1914-17 cyele and the type of explosions indicate that Lasmen is a waning voleano far on the road to complete extinction

The voleanie domes called chas Cracs and the huge aralanehe deposit named Chan Jumbles are the most startling leatures of Iassen l'ark outside of Lassen Peak itself. It appears that before the domes were plevated, a north-south fissure probably opened at the northern base of Lassen l'eak and explosion cones were built aloner it. Only part of on come now shows, but arilnee indieates that there were at least two uthers. The exploded framents corer a molest area, but bombs and framents up to :3 feet in lemth ale fund at lean 3 miles from the cones while abmulant bombs 6 feet lon are embechat in the deposits 2 miles away. Probably not more than a few reeks or montlis after the formation of the consis. two great domes were protruded in the eone area. Each was about a mile in diameter at the base and the northern one rose 1,800 fort ahuse its surroumlines. lluge banks of tahus composed of angular blocks blanket the sides of the domes and many of them are $1,(10)$ feet high. Thronth the talus and above it rise ragred pinnaeles and peaks of more solid roek. 


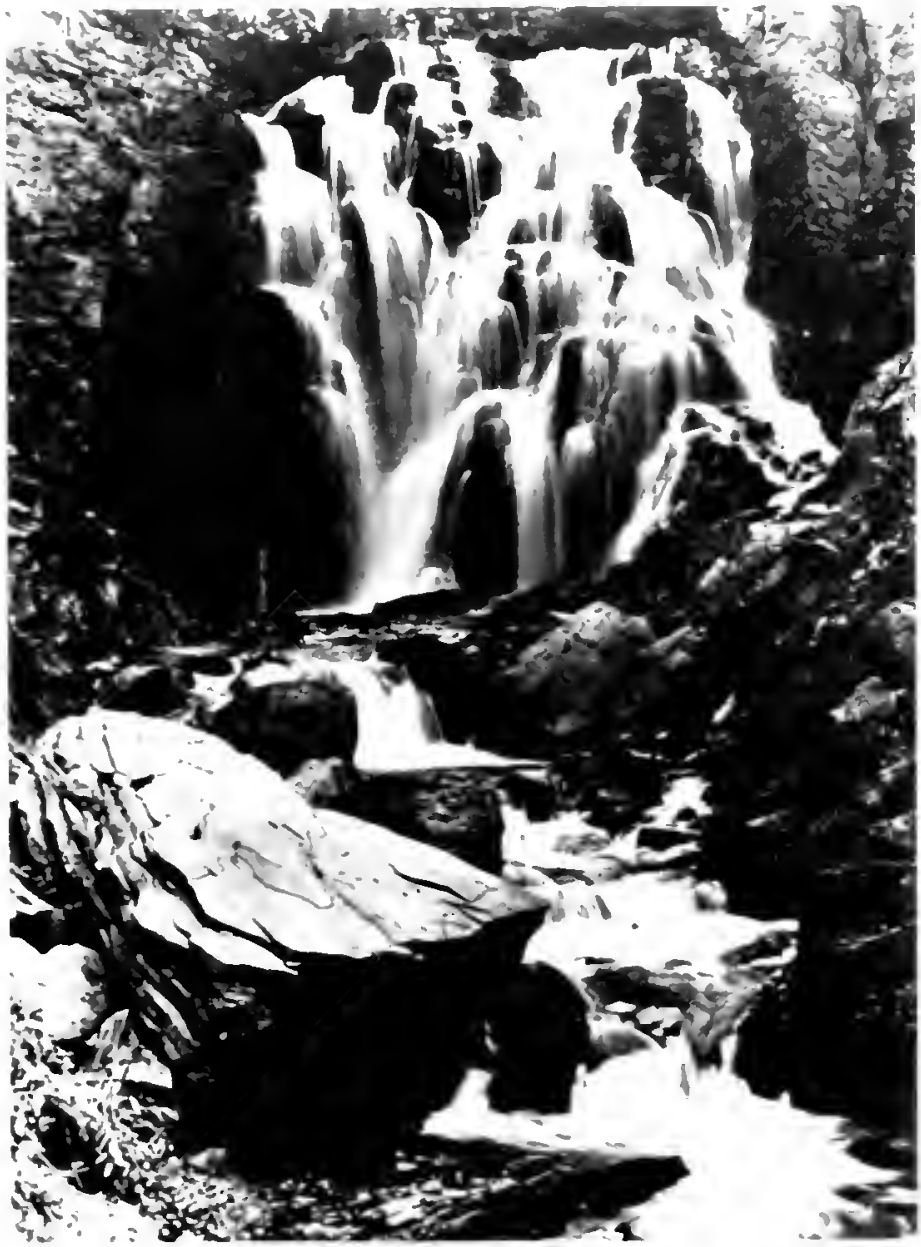

Fl: Kines Fults in Iasen Vulcanic National Jark. Many lava flows con-

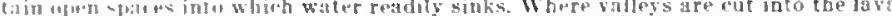
larian, linatiful waterfalls may deselog. Phato caurtesy Western Pacific Railroad.
"The later nomthern dome was manle of grpatly frowtirnt low and

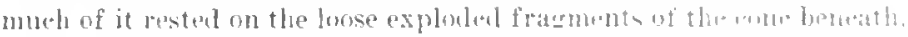

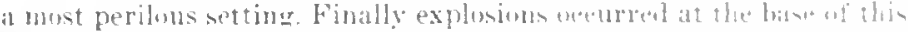

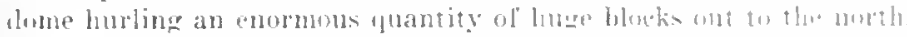

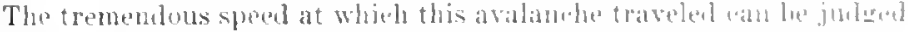

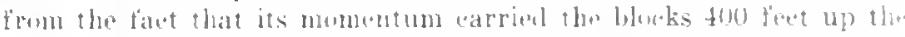

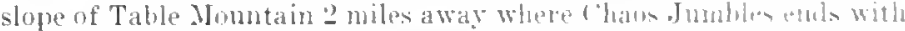
a precipitous front. The sharpnens of the bumntaries of the aralanche mass is nutable for alume everywhere its manins are stere momm. in places more than 1011 fieet high. It is believent that the hias which destroyed this part of the dome tid not oeetre more than 200 yeats ago.

The explosive autivity at cinder Cons in the northenst enrmer of Lassen I'ark formed a vileano about halt' a mile across at the base and 600 feet high. The eone was not forment during a single crele of activity as are many such mountains, as is proted hy the presence of two crater rims, ant there are two otleer rim remnants on the nurthwest side of the cone. Furthermore remants of small cones are present on the soutliwes side of the main munntain. Thus it is evilent that activity contimed over a conciderable perind possibly with interruptions of varions lengths between the minor erves. Then followet the eruption of a basaltic lava flow from the south base of the ene and further explusions which parly mantlet the flow. Later two or more flows poured out, the yomest of which advanepd town a depression in the prepeling Hows nntil it spreat into the northern end of Butte I ake. This flow is quite reliably lated as laving been erupted in $7-51$. On the surface of these last tlows are several small cinter cones.

Ifat Creek Valley, which starts abunt 10 miles northeast of Lascen

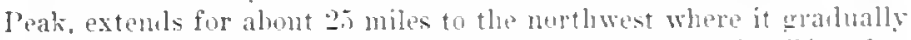
merges into the Molve Lava Platean thengh which the I'it River has cut its anyon. The valley ranges in wilth from 1 mile to 4 miles. West of it are three prominent volanic cones. Maspe and Burney mountains and stoney l'eak, which rise above a complex uf smatler roleanoes, all being part of the Caseade Ringe which ends sonth of lassen l'eak.

The eastern margin of 11 at ('reek Valley is a prominemt and only slightly ermed fault soarp. the displanent in part being montly alone a sinele fracture ant in part being distributel alome a seldes

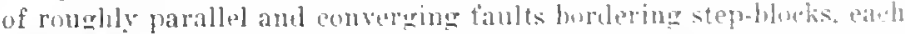
tilted eastward. At the south end of the valley the searp in alwout 7 (no

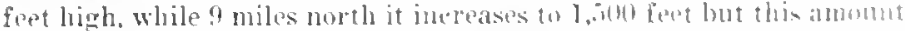
of dislocation is distributed along three fault blecks. eateh bommlet

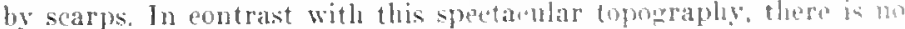
evidence that the west silde of 11 at Creek Valley was formed by fondting. It is true that two faults are present on this side, but the displice ment is small and the blones are dowmelropped to the west an on the 
oppesite sile of the valley. Jlat crek lalley miy be a large block tilted eastward at a genlli anerte or a number of smiller blocks similarly tilted and covered by later lava.

In the valley is a large thow of basaltie lava, probably erupted within the last 2000 years though exact uating is impossible. This flow was discharged from nortl-sonth fissures loeated near Oll Sta. tion along the highway leating throngh Jassen Voleanie National Park at the hase of Sugurloal Momutain. This peak is a lava cone eapped by a einder ene, both erupted aftur the distoeation along the faults above deseribed had hem largely completed. At the head of the flow is a series of spatter or driblet cones ranging from 3 to 30 feet high and having depressions in the top which reach as much as 40 feet in depth. Evidently these' (ones represent accumulation of lava thrown from a series of lava fountains spared along fissures from which the magma was heing erupted, a feature observed in some recent flows. Tongues of basalt lead from the spatter cones and merge with the main lava stream, showing that the principal source of the marma was that rising along the fractures. These tongues are described as having corrugated surfaces, the small rickes covering lava tubes 1 foot to 2 feet higls and 3 to 4 feet wide through whieh the molten rock moved after a crust hat formed above.

Some of the lava from the spatter cones fiowed west ward surrouml. ing several oller basaltic cones, but most traveled northward joining the main part of the flow near Ola Station. The flow near Old Station swept eastwart lrom the source vents, then north down Ilat Creek Valley for a distance of about 16 mile.

Lava tubes are eommon throughout the tlow but most are small. The best known and one to which travelers through the park of ten go,

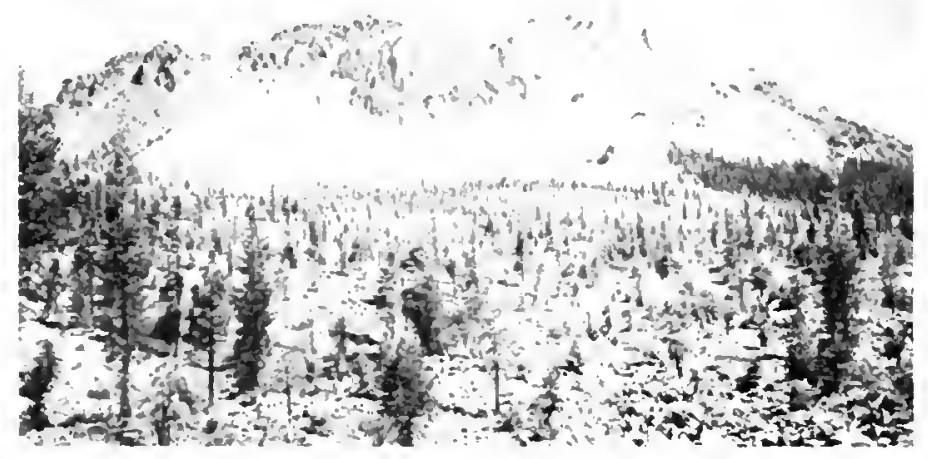

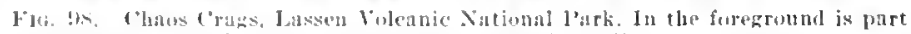

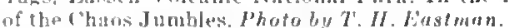

[alled Subway Cav", is about a mile northeast of Old Station. It has a height of 12 ti 15 reet and can be followed for a distance of half a mile. ('ollapse of joint blowks trom the rock has made possible entrance to the tube.

The lava is much jointed and these fractures together with the numerous tubes make the flow highly pervious to water. Hat Creek is the only stream which flows continually over the flow. On the east side of the valley a stream eoming from the plateau flows northward for a distance of 5 miles before disappearing into the pervious lava. At the lower end of the flow, the water tahle is close to the surface of the lava so that pools of water fill depressions in its surface and these gradually merge into a stream, Rising River.

\section{REFERENCES}

Anderson, C. A., Voleanic history of Glass Mountain, nortbera California: Am. Iour. Fici, vol. 26, pp. 485-506, 1933.

Anderson. C. A., Voleanoes of the Irdicine Lake IIiphland, California: Univ.

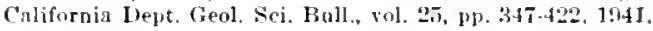

Williams, Iowel, A Reent volcanie eruntion nenr Inssen I'ark, California: [nis. California Dept. (;eol. Sici. Jul]. rol. 17, pp. 241-263, 1!28

Williams, II wel, The history and elaracter of volcanie domes: Iniv. Callifornit Itelt, Geol. Nei. Rull, vol, 21, pp. 51-14ti, I932.

Willinms, Ilomel, Gerulogy of the Lassen Folmanic National Parti, ('alifurnia

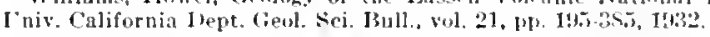

Williams. Ilowel, Mount Shasta, a Cuscude voleanu: Jour. Geol., rol. 40 pp. $417-420,1932$.

Willians, 1 Iowel, Geology of the Nacdoel qualrangle, Califurnia: california Hiv. Jines I'ull. 151, 1649.

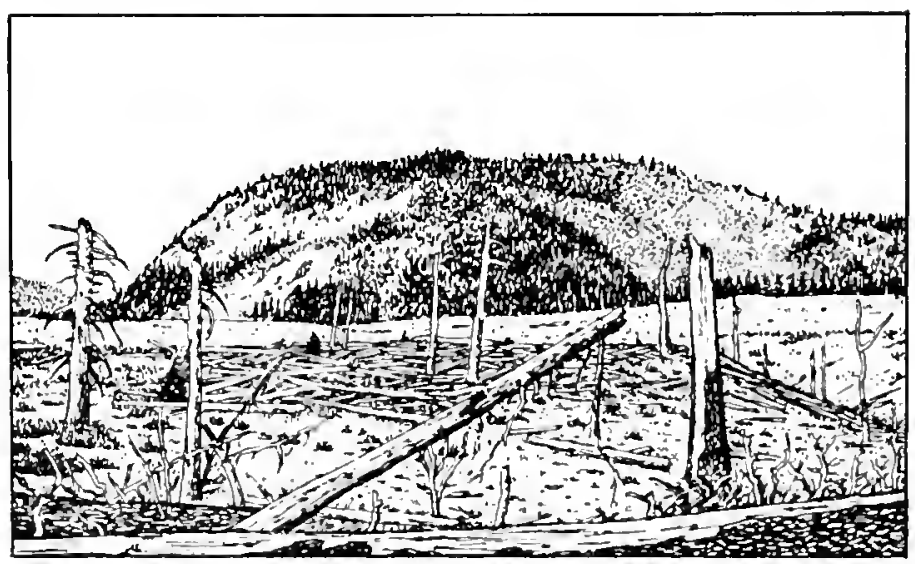

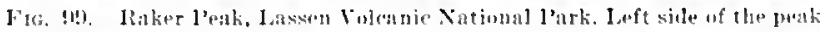

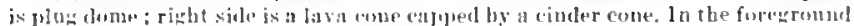

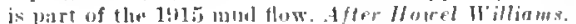


KLAMATH MOUNTAINS 


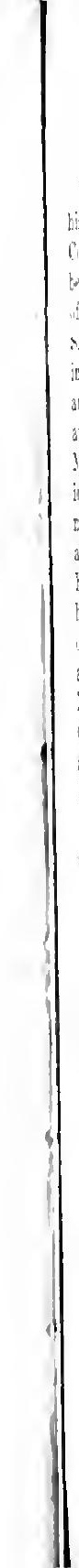




\section{KLAMATH MOUNTAINS}

The Kilamath Mountains include a rugged though not particularly ligh region lying west of the Cascalle Momntains, somth of the Oremon (wast limes, and north of the California Coast lianges, being divided betwen the southwestern part of (1rean and the northwestern part of California. Many local names are applied to various ranges such as Siskiyou, Klamath, Marble. Seott Bar. Trinity Alps, and others, but in the ensuing description the term lilamath is applied to the entire area. Within the California section there are many magnificent scenic areas, buth alung the coast and within the mountains themselves. Nuch of the coast is boldly cliffed, the eanyons are deep and narrow in most places, and the peaks and ridiges rise boldly above. The higher mountains have been ylaciated giving them partieularly bold contours and in these areas are beautiful rock basin lakes. Fortunately the Klamath eountry has not been so extensively penetrated by roads as have some other mountainous sections of the state so that the primitive eharacter of the region is largely preserved. Some of the bigh points are Conlrey Mountain ( 7,116 feet ), Red Mountain ( 8,317 feet). China Mountain (8.051 feet) and liussian Peak (8.163 feet) in Siskiyou County; Thompson Peak (8,936 feet), Caibour Mountain ( 8,563 feet) and Gibson Peak (8.375 feet) in Trinity County; and South Yolla Bolly $(8,053$ fret $)$ in Tehama County.

The principal drainage sustem is the Klamath River which starts east of the muntains in the Modoc I'lateau and Cascade Range. eventually flowing into the ocean about 15 miles south of Crescent City or 30 miles south of the Oregon border. At the settlement of Tieitehpee between 30 and 35 miles from its mouth. the klanath is joined by its principal tributary the Trinity, the South Fork of which flows for a long distance through a great struetural depression whose origin has not yet been worked out. Some other minor streams drain west into the l'acifu and some eastward into the sacramento River which bas its source in a small lake on the eastern side of the Klamath region. The Sacramento River. together with the Pit and HeCloud Rivers, which flow through the area, are the principal drainage lines in the eastern part of the Klamath Iountains. The picture has been altered some. what by the construction of Shasta Dam located on the Sacramento River a short distance below its junction with the Pit. This giant coneroto barrier, principal element in the great Central Valley Project for floul control, irrigation, and other purposes. impounds a large reservoir extending up the canyons of the Sacramento, the l'it, and the HeCloud The last two rivers now enter this large artificial lake.

Geolorically the Klamath Mountains are sharply eontrasted with the bordering rantes, for they are comprised largely of pre-Paleozoic and l'aleozoie sedimentary rooks, voleanio rocks, and nany meruedve bohlies. Along the eastern side Triassie and olurassite strata are expmed

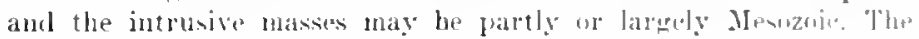
Klamath formations have been wreatly deformol am many of thom consilerably motamorphosed. In contrast, the California sention of

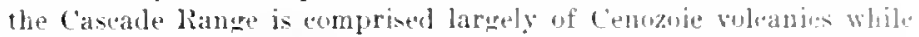
the California Coast lianges consist almost entirely of Mesozuic and

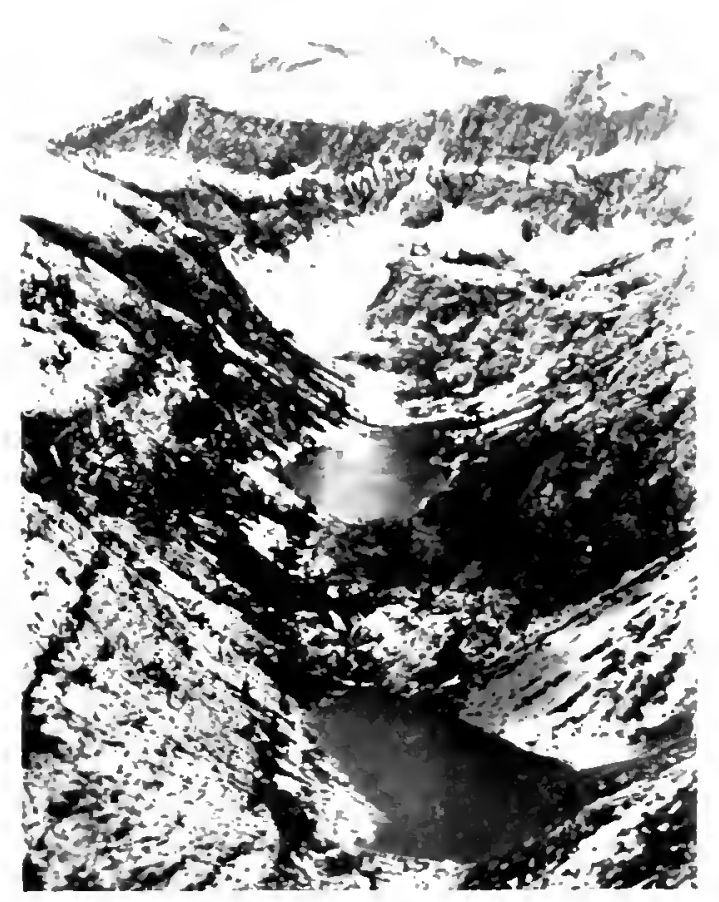

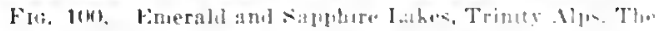

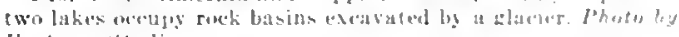
Enstmanstudio. 


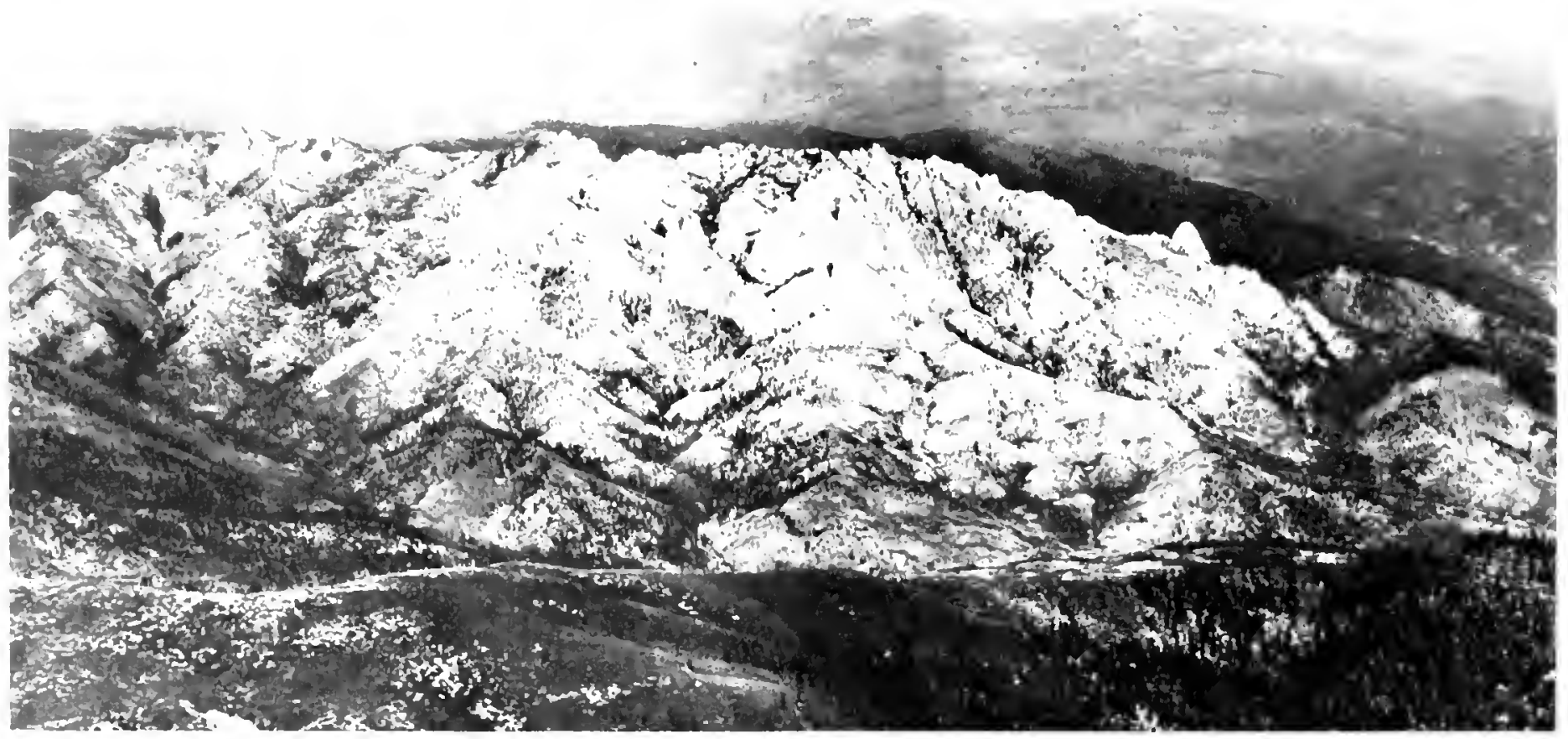

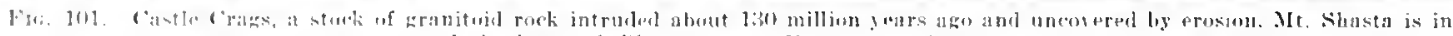

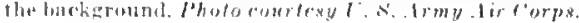


Cenozole sediments and voleanies, with the oldest Hewozoic formations helonging to the lath part of the olurassic perriol. The ereat bulk of

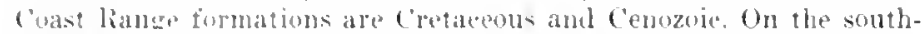
west sille of the hlanath Mountains, the natural bunntary with the Coast Ranges wenlul appear to be the south Fork of the Trinity River, but the sontl fork liange on its sonthwest side is comprised of Flamath formations ant the refore must be ineluded in that provinee.

The Klamatl In Mutains are slarply distinguished also from the Coast Ranges in the character of thejr lrainage systems. Fold-faulting of the Tlamath area mobably oecurred in the late Jurassie when the Sicra Levala and various other California ranges were created. The Coast lauges are infant mountains now in proeess of derelopment by fold-faulting which started in very late lliocente and Pleistocene time. In the Klanath recrion, beeause of erosion which has gone on sinee Jurawic time. control of drainage by folded and fanlted features evolved when the mountains first appeared has long sinee been wiped out, hence the streams do not follow structural trends. In the Coast Rances, on the other hand, folded and faulted ridges, troughs, and basins are eonspiellons, and the streams to a notable extent are directed by them.

The Klamath. Muntains lie in the path of the moisture lalen winds which sweep east warl from the Pacific. Along the coast rather equable elimate prevails. though the extremes are greater than in the Coast Rance belt and farther south.

I'redipitation along the coast is moderately heary. averaging 39 inches annually at both Eureka and Creseent City, a few miles north. Within the mountains at Monumental (2.550 feet) there is an aston. ishing increase to $109 . t$ inehes, but at other stations at the same or eren lipher elevations, the figures are much lower ranging between 28 and 32 inches with the higher figures at higher elevations. Measurements are made at so few places that a very inconplete picture of precipitation nser the Klamath area is available. [ndonbtedly orer the higher ridges particnlarly in the western part precipitation approaches or may exceed that at Munumental. Along the eastern base of the mountains there is sharp dereave, with annual averaues of 17 to 20 inches at three stations. Hornbrook. Ireka. and Edgewood whose wevations rante from 2.154 to 2.933 feet. It equivalent elevations somewhat farther west, average annual precipitation ranges between 36 ant 52 inches. Snowfall in the winter montlis in places is heavy reaching a measured maximum of 126 inches at Nonumental and 10 - in hes at Gilta (3.300) feet). 611 miles to the southwest. At Yreka on the eastern border, the annual average leereases to 16 inches.

The abundanee of rain and snw gives many permanent streams through the region though there is material fuctuation in their volume beeause of the heary concentration of precipitation during the winter months.

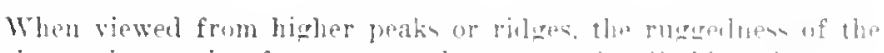

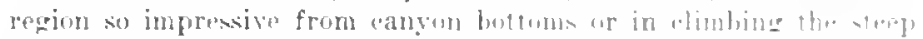

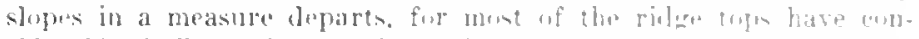

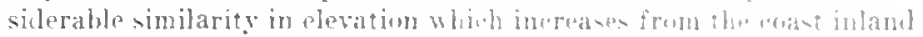

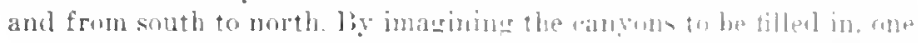

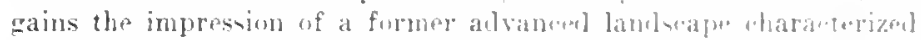

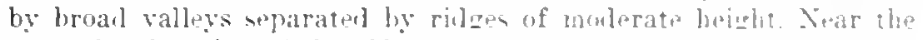
coast the devation of the rilge tops ralugs from 1.500 to 2.500 foep increasine to 4.500 feet 50 miles ind and: in places, a in qhe toutl fork.

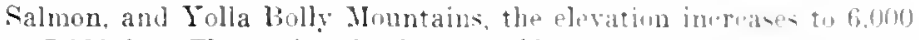
or 7,000 feet. The ancient landscape evilenty was warpen and prob-

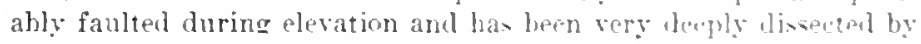
the invigorated streams.

Ahove the general level made by mont of the ridgev artain resilual peaks rise for 1.000 to 5,000 feet and lower ones from 100 to 600 feet in height arecommon. Some of the hicher artas undoubtedly represent erosion remnants but others may have reached their present position because of movements along faults. Amone the highes - wetions in the California part of the Kilamath Mountains are the Sixkigon Mountains between the Klamath and Rogue river hasins, the Sontt, Salmon, am Trinity Mromtains which make the heal warl parts of liviles leetween three large forks of the Klamath River flowing into it from the nortbeast.

The Bullychoop Mountains in Shanta County mark the divide between the Trinity and the Sacramento rivers and the Folla Bolly Mountains between the Sacramento amt the stream of the California Coast Ranges.

When the oldest and lighest erosion surface was being developed at an elevation nuch lower than its remnants now possess, the streams ran transwerse to the dominant structural trends of the reurion just as they do now. Apparently the ourassie mountains had been suficiently worn down so that the control of stream direetion by fuldm ant fanlted ridges and depressions and other parallel structures had heen largely wiped out. This surface must lave heen eqolvel hy Mineene or early Pliocene time. Sinne then there have been varions rejuwenations with streans returning to youth. later adwancine to maturity and dewhoping termes below the level of the oldest lankeane. Varions terrace levels have been rowonized. but they du not represent so continuous a landscape as that repesentw by the high level rem. nants. In late l'lioene and Pleistoen time, the principlal uplift of

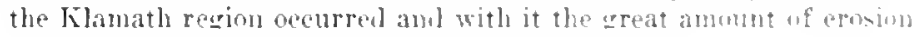
which has owlved the rugeed lamksape of tomay.

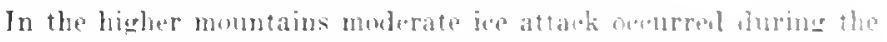

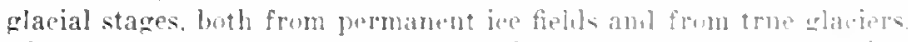

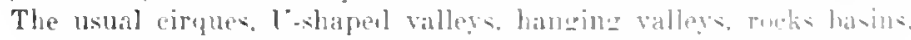
and moraines are present. thom on a relitively limited wall The 


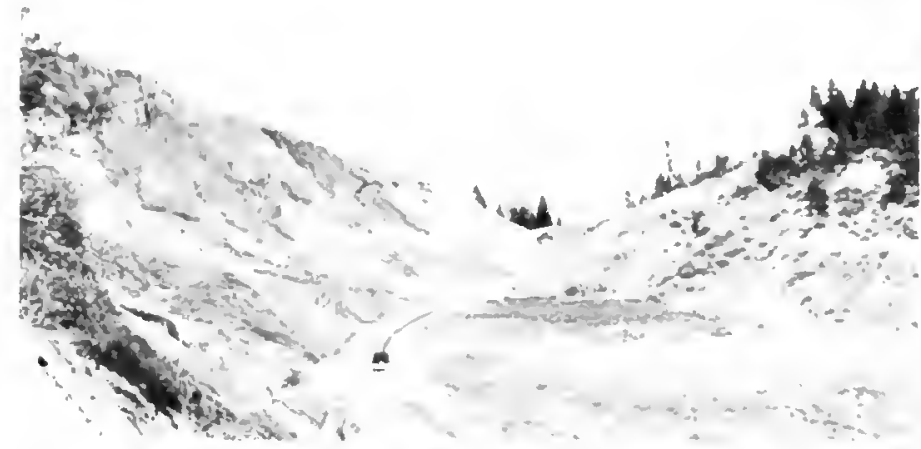

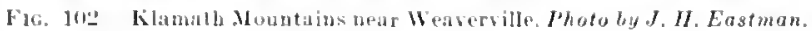

listory and extent of the ordaciation has not been worked ont, but it definitely was no matroh for that in the Sierra Nevada.

One of the best known sections of the Klamath Monntains is the

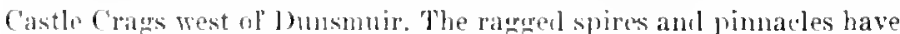
been eroded into a much juinted stock of gray granitoil rock whieh was probahly intruded at the time of the Jurassie folding which built the first monntains in this reurion. The stock has been exposed by the deep erosion which has followed the fold-faulting of this distant time. Another mucl more scente area is the Trinity Mlps, one of the hichest and most rumeal parts of this proviner. located about 15 miles north of Wearrille. Thre peaks and valleys in part have been moderately graciated and endsentently their contoms are bolder than the average for the recrion. A number of beantiful little lakes lie himh up in the deep. narrow eanyoms.

In a number of places in the Kinnath Nountains sueh as near Warerville and Ilyampon there are basins containing moderate thicknesses uf seliments ant some voleanic rokks principally of Eocene arre. These deposits are notable, as Tertiary sediments are rate in the entire province. l'robably the basins have been evolved by faulting which rery likely occurred after the deposits were laid down, motecting them from extensive eposion.

At variuns places along the coast there are elevated shore foatures-battered ware-cut clifs, erosion and deposition terraees and eminenees that once were ishands. One terraee has been reported at an elwation of 1,500 leet, another prominent one at loast a mile wirle in places at 1,000 feet, and a third at 500 feet. There are others less slarply defined. Infortunately stmdies of the coast line in this part of California go back many years and l'uture investigations undoubtedly will alter the photure we now have of the uplift and erosion that proluced these features. Whether the libest standing surfaces mentioned above actually are marine terraces remains to be cons. firmed; that there are some at lower elevations is certain. I'rominent clifis with the usmal attendant features are now being eroded along most of the coast in the Klamath region giving a bold shore landscape which in places is magnificent.

A nutable man-made feature is the huge, three-pronged artifieial lake impounded behind the huge Shasta dam which luas been eonstructed on the upper Saeramento River near the site of the former copper smelting ant mining town of Kennet some 16 miles north of the eity of Rolding. This immense concrete barrier is 560 feet high and 3,500 feet long across the erest. When the water is in the reservoir the vast lake is a beantiful sight, but when it falls there is an unly strip along the shore littered with sediment and dead regrtation. The reservir is part of the giant Contral Valley J'roject, a combined flood control, water supply, and power cenerating system which will be of growing importance to the Great Valley as acrienlture and industry of that region dovelop.

Oiled ruarl access to the Klamatlu Iountains is limited aud even dirt roads a re none too numerous. Jighway fot rums along the eoast and 299 leads from Eureka, principal city of the nortluren ('alifornia

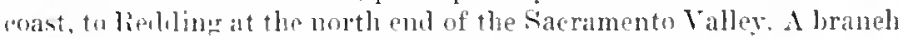
taking off at Willow Creek goes into IJoopa Valloy. Ilierhway 199 leaves 101 at Crescent ('ity and crosses the northwest part of California's Klamath Mountains on its way to Grants Pass in Orexron. An oiled roat follows the Klamath liver for many miles, and another also branching from Liphway 99 goes to Etna. On the cistern side Ilighway 99 traverses the Klamath Momtains from the Oregon border to their jumetion with the Sacramento Valley. By bridge this hierhway twice erosses the immense reservoir hehim Shasta Dam.

\section{REFERENCES}

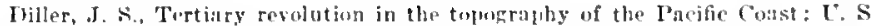
Geol. Surver Fourtienth Annual Reyort, 1s:2

Diller. J. S., Toungraphic development of the Klamath Mountans: L. S. Geol. Survey Buil. I' 16,1002 . 
GREAT VALLEY 


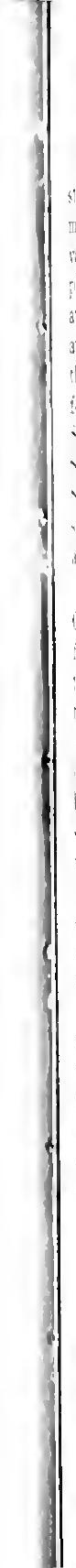




\section{GREAT VALLEY}

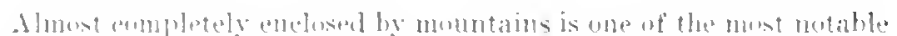

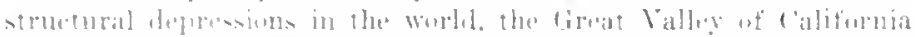

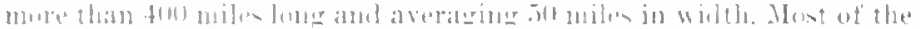

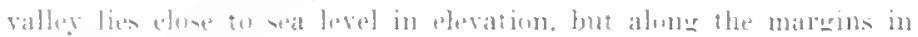

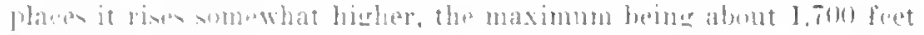

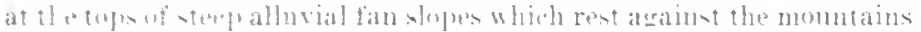

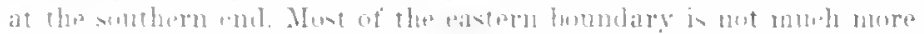

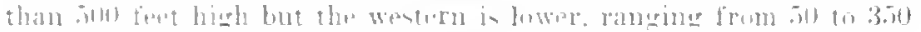

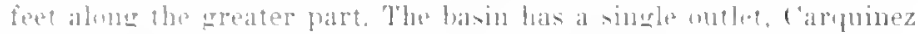

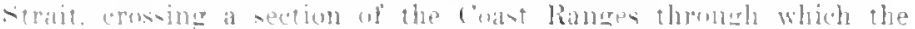

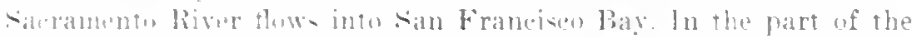

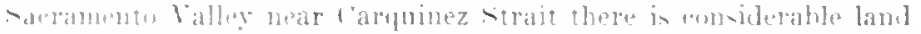

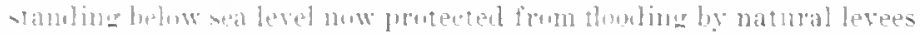
and artificial dikes

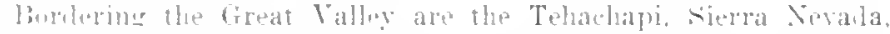

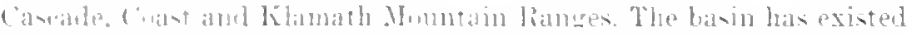

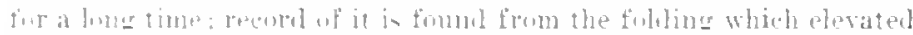

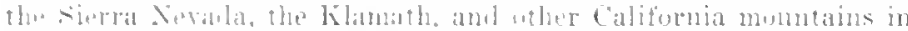

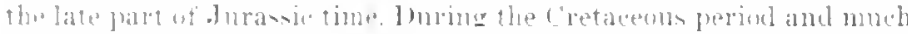

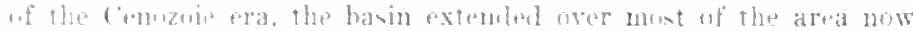

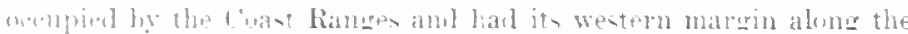

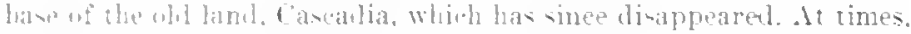

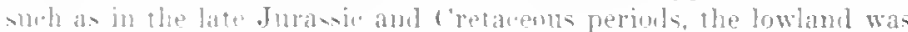

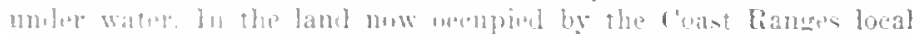

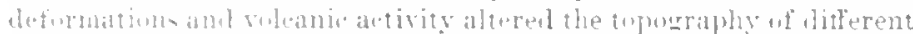

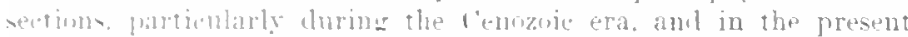

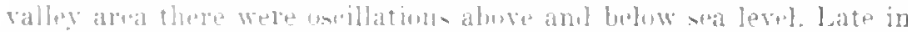

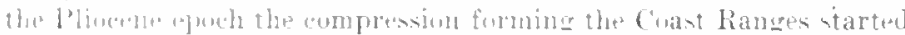

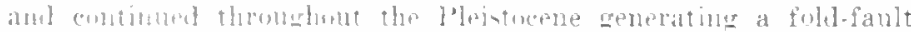

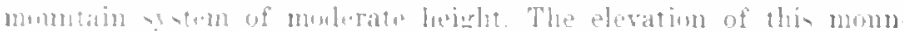

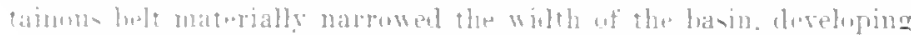

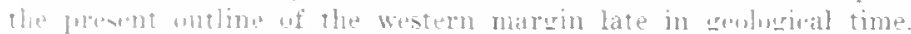

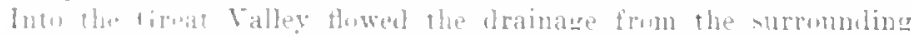

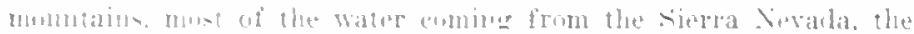

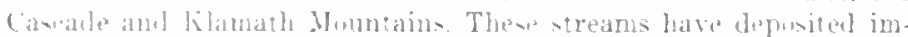

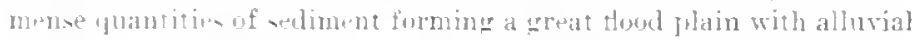
fans around the mountain base. Most of the streams joinet two trunk rivers. the Sis ramente in the north and the san Joaluin to the sonth. The Kine liber whinh enters the freat valley from the sierra

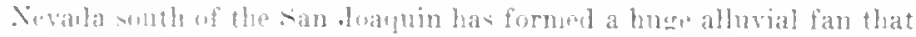

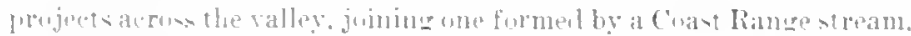
low Ciater fresk. shuttine uff the part of the valley le the smuth as an interior basin. Furmerly this seetion was oecupied by shallew laties.

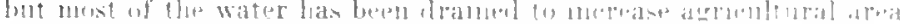

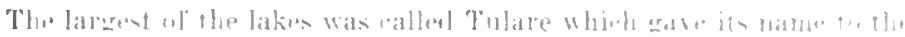

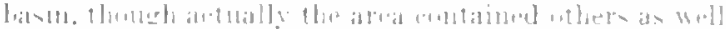

\section{Sacramento Valley}

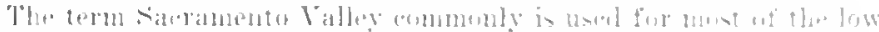

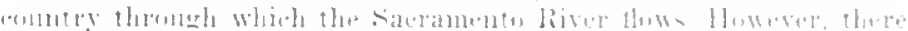

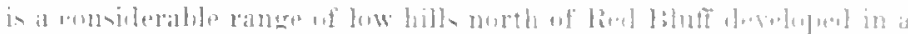

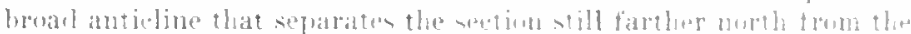

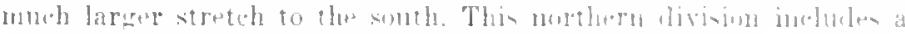

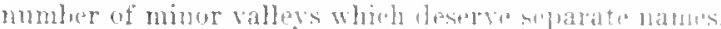

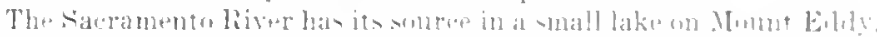

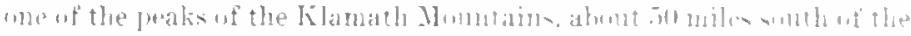

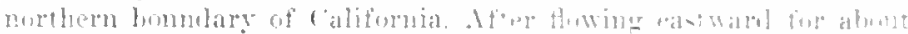

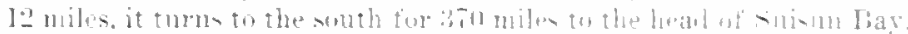

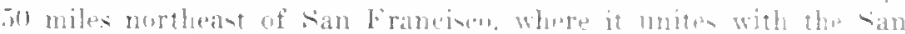

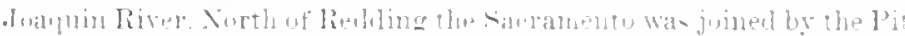

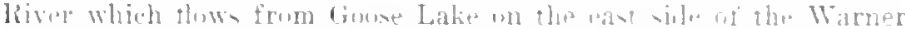

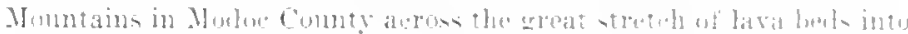

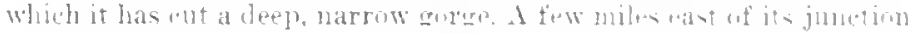

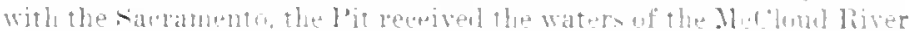

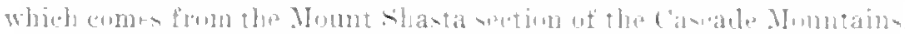

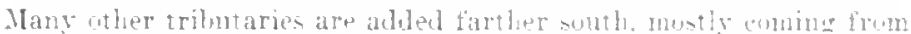
the vierra Jesalat.

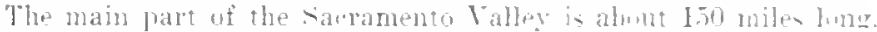

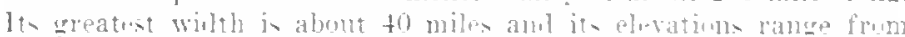

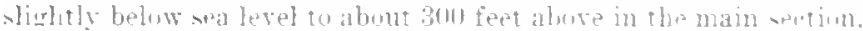

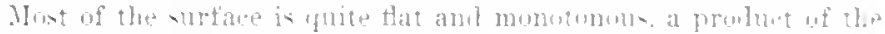

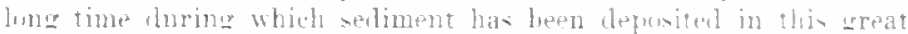

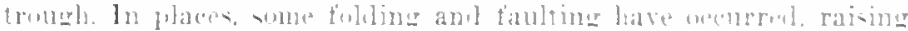

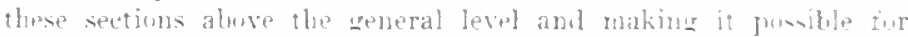

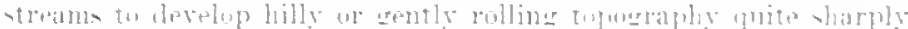

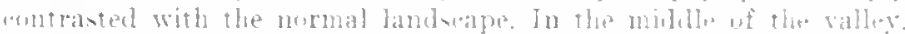

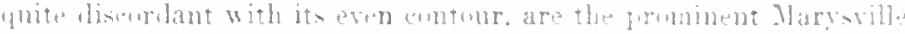

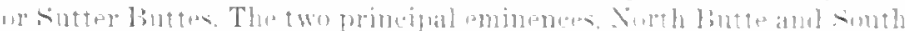

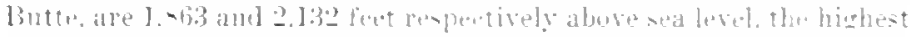
mints in the entive havin.

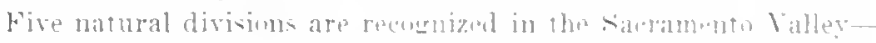

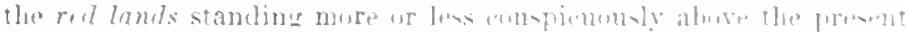

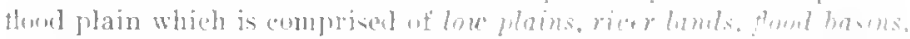
and I islanls

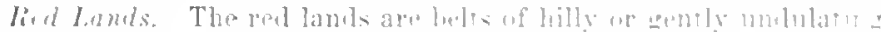

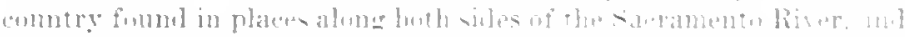

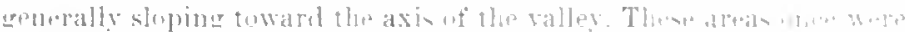

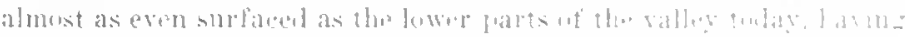


bon constructed by the various stroms coming from adjaeent mountaius and representing a flood plain and alluvial fan level higher than the present one. Later this plain was delormed by gentle folding or fauling which male it possible for the stroms that built them to cruele instead of deposit.

In the northern part of the Sacramento Valley, the red lands extend almost to the mithle of the valley and the siteramento River flows through a wilde, shallow trench bordered by discontinuous bluffs which it has eroded through them. On the east sile of the river, the red lands are narrow and not sharply separated from the low plains in the vicinity of Red Bluff, but farther south their width and definiteness increase until at Vina they are about 4 miles wicle and are separated from the low plains by bluffs about 50 feet high. In this section they are cut by streams coming from the Caseale Mountains whieh have eroded narrow, terraced valleys. South of Vina, the red lands are lower and disappear before reaching Chico.

West of the Sacramento River, the bolder of the red lands is a conspicuous bluff which extends from Red Bluff sonthward to Tehama, while south of that eity to the Glem County line, the boundary is poor'y defined with more or less detached hills and knobs extending down to the river.

From Chico southward to the Yuba River, the red lands oceupy a considerable area on eacl side of the deep, terraced gorge of the Feather River. From Chico southward and from the Iuba River northward. the red lands increase from seattered higher patches surrounded by the low plains to wider and wider tracts of highland, until on each side of the Feather River they form broal bench lands standing from 325 to 425 feet above sea level. In the recion south of the Fuha River, east of the Feather River and the American basin, the red hands are only slightly elevated above the present level of the streams. They rise gradually to an elevation of 100 to 300 feet but merge into the low plains so that a definite boundary eannot be drawn between the two.

On the west side of the Saeramento River, the red lands are less extensive than on the east, but are much more sharply defined, because uplift has made a sharper break between them and the low plains and because the soil in the low plain is yellowish. This eolor difference is not so conspicuous on the east side of the Saeramento River, as the redish color of the upland areas is not strongly developed. The reddish color has been produced by oxidation of iron moleeules contained in the sediment. From Stony Creek south to Williams, the red lands oceupy small areas flanking the foothils of the Coast Ranges and rise about 100 to 200 feet above the streams flowing through them. Their much dissected surface slopes abruptly from the foothills to the low plains. I3etween Willows and Williams the red lands increase in width and rugracdness.
The most extensive area on the west side of the Sacmento liver runs from Willians southeastward to Cache Creek. The soulleru part is called the Ilunery IIollow IIills but this term is applied by some to the whole area. This section is a platean 100 to $4.50 \mathrm{fer}$ alove sea fevel, bounded on the northeast by a remarkably strairht and uniform thougl, somewhat erodod fault scarp. The southeru part has beren greatly dissected into lill-valley landseape, but farther north there are remnants of the flat-topped platean.

South of Cache Creck, but offset to the west, is another tract of red lands also apparently bounded by a lault scarp, which fringes the foothills increasing in width until near Wiuters it is a lati mile to 2 miles aeross.

On the north end of the narrow throat through which the San - Joapuin and Sacramento Rivers find their way to Suisun liay are the Nontezuma IIils, circular in groundplan and about 12 miles in diameter with their west side joining somewhat detached foothils of the Coast Ranges. This is a much eroded remnant of red lands sloping from elevations of 250 to 300 feet above sea level on the southwest to only 25 fect on the northeast where it merges with the surface of the low plains and of the Yolo Basin. On the south and southwest, the Montezuma Hills are bounded by sharp bluffs rising above the Sacramento River or above narrow plains bordering the salt marshes of Suisun Bay.

River Terraces. Streams tributary to the Sacramento liver have terraced valleys in the edges of the foothills and in the red lands. The terraces vary in width and height in different valleys, but in a given valley, they are eonstant in their relative position above the stream; they generally are detaclied remnants alond the valley sides. There are two prineipal terrace levels, the upper level being 20 to 50 feet below the general surface of the rea lands, the lower 10 to 20 feet below that and 5 to 20 feet above the floor plains now in process of development.

Only streams rising in the mountains and crossing the valley border have terraces. Their bistory indicates three stages of valley cutting. widening, and filling with sedinent, the last being now in proeess. Causes of the evalution of the terraces include intermittent uplift with eonsequent linited downeutting by the streans until their downeutting power became so small that they began to widen the valleys producing erosion terraces later covered with flood sediment. The known elimatic changes of the Pleistocene also may have played a part. The history of the region is not sufticiently well known to determine the factors involved.

Low Plains. The low plains lic between the red lands and the river lands, but where the red lands are absent they streteh to the base of the monntains. They stand somewhat lower than the red lands and their surface is almost level. The plains have been built by the streams 
coming from the mountains which lave eroded the red lands and the evenness of their surface results from sedimentation which is still going on. They are the highest portion of the flood deposits being formed by the streams.

The low plains are comprised partly of alluvial fan and partly of ordinary thond plain deposits. The fans are eharaeteristie of the mouths of intermittent streams which have earried large quantities of debrix from the mountains, depositing very rapidly as they emerge from eanyon mouths. The two most notable examples are the fans of Stony and chilo Creeks, both broad and rather gently sloping. In sonte places clisely spaced fans have ealested into alluvial aprons as at the foot of llungry flollow Ihills in the vieinity of Arbuchle.

On the west side of the Sacramento Valley from Williams south to the Montezuma IIills, intermittent streams issuing from the hills earrying fine sediment have leveloped raised banks on either side which are natural levees rather than fans: they stand from 3 to 20 feet above the bottoms of the channels and range in width on each side of the "hannel from 510 sards to 3 miles depending on the size of the strean which has produced them.

The streams forming these levees not only build up their banks but ako deposit silt in their channels, thus raising their level and lowering the shope over which they flow. Bed and banks together slowly gain in alevation forming inconspicuous double crested ridges standing 710 to 25 feet above the bowland on either side. Thes show prin"ipally at time of thoul since the lower adjacent areas are uniler water while the lome sinuous rideses stand above. Sot infrequently flood waters burst through a levee startinu a new channel with banks built up along it similar to the olu. learing abandoned channels helow the point of diversion and giving a series of forking ridges. The levees along these intermittent streams are similar in eharacter to those along the permanent rivers like the saveramento, but are much smaller.

Toward the sides of the Siaramento Valley the low plains merge into and are represented ly the more actively forming flom plains of tributary rivers, which are of two trpes-ihose of permanent and those of intermittent streams.

In the first aroup are the flood plains of the Mokelumne, the Cosumnes, and the Ameriean livers, which are a half mile to 2 miles wile and rise frum a few feet $t 020$ fert above the rivers. Through the plains the rivers run with sinuous but not strongly meandering courses. Iluman activities have so changed conditions alume the Bear and Yuba Rivers that they no longer have their original appearance.

River lands. The river lands are yuite narrow belts rising 5 to 20 feet above adjacent land and extending along botl sides of the two principal streams in this portion of the valley, the Saeramento and the Feather. They are natural levees which have very gentle slopes toward the flood basins or adjacent low plains, and have been built in recent time by overflow from the rivers. The levees do not stand very light above their surronndines. but their elevation is enomeh to make them habitable. their soil arable. and thus to separate them from the swampy and frequently submerged lanels thromel which they run for many miles.

Flond Basins. On botl sides of the Sacramento River between the natural levees or river lands and the low plains are broal. sluallow basins locally hnown as tules because of the heary growth of tules or rushes which they formerly supported. There are five principal basins-Butte, Colusa. Sutter. Ameriean. Yolo, and two smaller ones-Marysrille and Sacramento.

These areas are dry most of the year or sometimes for whole seasons. but during major floods. ther are inumdated forming shallow lakes. Before reclamation had been undertaken along the river. abont 60 percent of the valley was subjeet to overflow, including the basins, the river lands, and a considerable portion of the low plains.

The flool basins are broml. shallow troughs filled during floods by the side streams whieh sweep across the low plains in broad sheets and by rivers discharging into them through definite channels. or overtopping the natural levees and the river lands. Deposition in the basins comes primarily from standing rather than from running water. hence their surfaces are almost ideally even, though there is a gentle supe toward the eenter and the downstream end of the basin. The soils are heayy, less satisfactory for nrlinary agriculture. but suceessfully used for arowing of rice.

Islinds. At Clarksburg. minor channels break away from the Sac. ramento River. flowing for a distance. then joining other ehannels or the main river. These many channels therefore are interconnected and also are eonnected with similar channels of the San Joaruin River. Both the Sacramento and the San Joaruin enter Suisun Bay by separate courses in a gap about 4 miles wide between the Ionte. zuma Ilills and the Diablo section of the Coast Ranges. On aceount of the various channels above the river mouths part of the disiliare of the Sarramento may enter Suisun Biat throuch the San Joaquin River and vice versa.

Retween the channels are islands bommled by natural levees formed by these minnr brancluss of the Saramento and therefore basin shaped fuder natural conditions the islands were party covered with water durine mudh of the sear and were almost completely overwhelmed dur. ing high flome. Tho tide raised and linered the level of water nver laree areas, thus helping to srour out and kerp open the minor channels. The natural levees therefore are amposed of silt and loam deperitel durine the overthow while the centml part of the islands enntain peaty material formed from decaying ventation whily orew in them when covered by water. Artificial levees have been built on top of the 


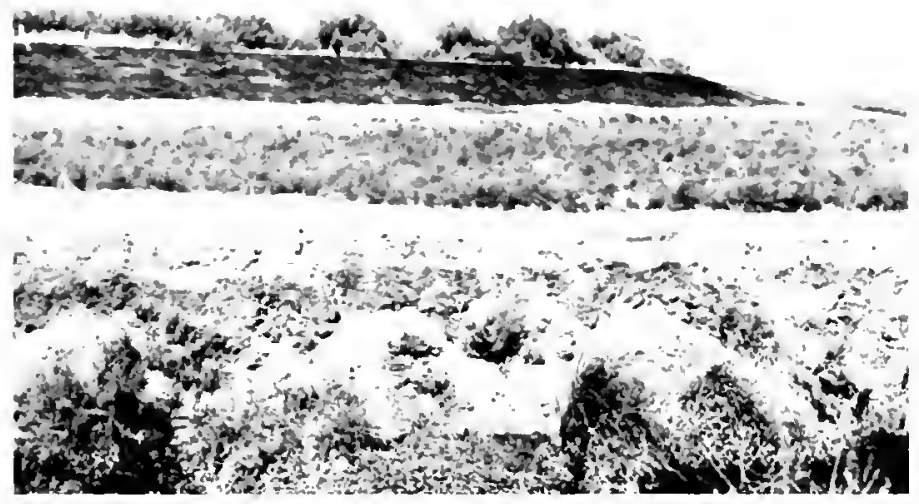

Fra. 103. Wilie along sateramento Kiver. Woolland Istanl in foregromal. Material used to build dike was obtained ty drulging the river. Photo by Mary'lae Mill.

natural preventing the fooding of formes yesus. Rainwater and seselage from the river are drined by a canal ent through the eentral flat of ads island leakling to jts lower part, and pumping stations an mantanel to lift the water over the river banks. I) nring the dry seasus, water is pumped from the river for irrigation and the surplus runs to the lowest end of the island where it is pumpal back into the risire.

\section{Marysville or Sutter Buttes}

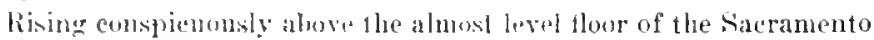
Valley about sumiles northwest of the eity of Marysille are the Matrovilla linttes or as they are locally known the sutter Buttes. (Menpong an almost circular area abunt 10 miles in diameter, their lighest point stancls 2,132 feet above sea level and almost that amount aloos the surrounding lowland. In any view from a distance two "listinct features stand ont-peripheral slopes extenting in a long.

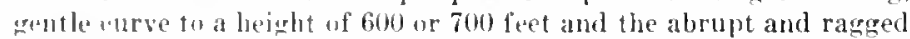
fuaks and domes making the entral part of the mass. With almost. featureless platins extending for miles rouml about, the buttes make a starting lamelmark visible for lone distances.

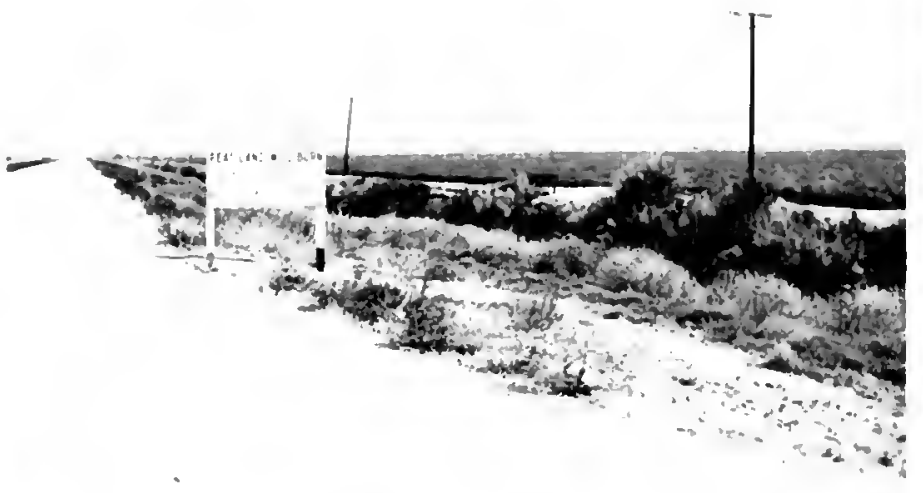

Fig. 104. Vietoria Island in Narramento River. Asparagus fuld in background. lhoto by Mary live IIill.

The Marysulle Buttes are a voleanie mass, principally a laceolithis intrusion which is a boughly mushroom-slaped looly of small size that deformed the wovering strata into an anticlinal dome as it was being emplated below the surface. During and after the intrusion of the igneous mass, the overlying layers were larpely stripped away. Then steam explosions developed a central arater by blasting through the eore of the laccolith and construeted a voleanie cone. Other minor voleanic eruptions also oxtarred.

l'rior to the intrusion of the laceolith, the present site of the butes seems to have ben a pain like the rest of the sacramento Valley and

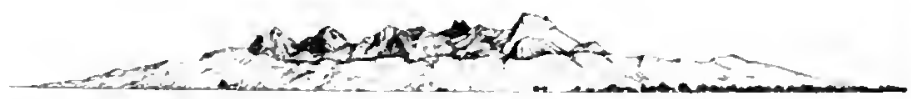

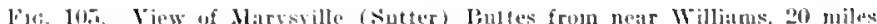

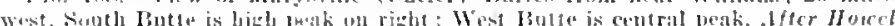
Hillism. 
is brow 1 $E$
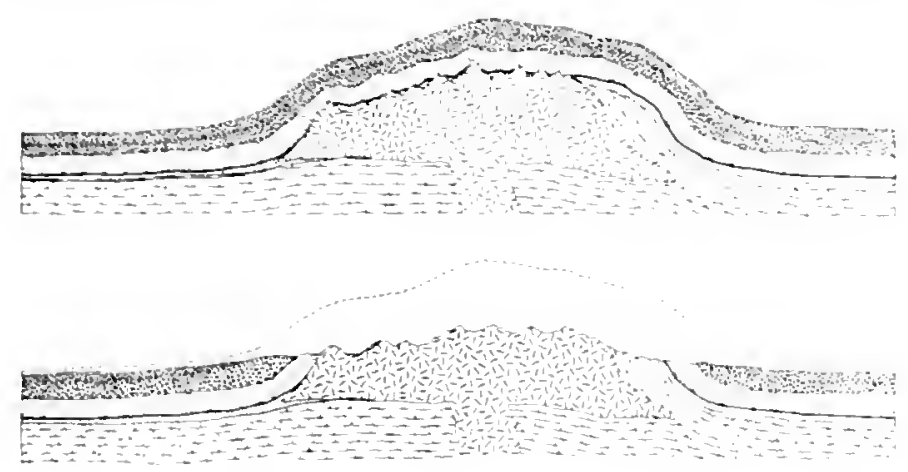

4
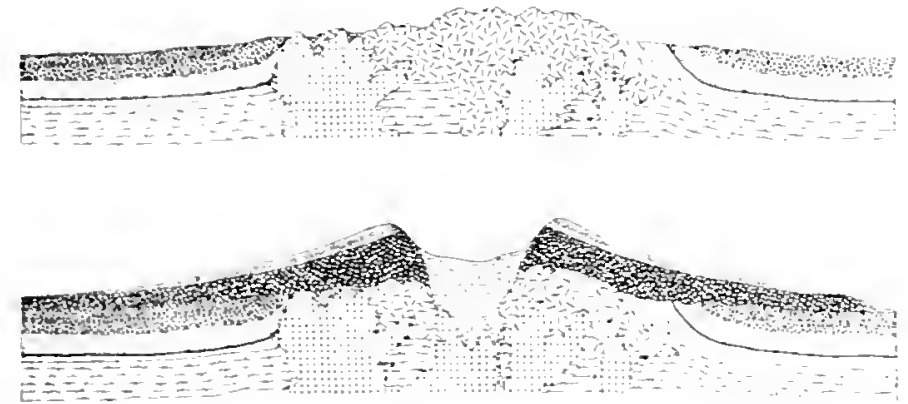

6

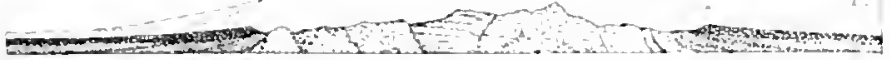

$-\cdots$

Fis. Jot. Stages in the development of Marssille (Sutter) Ruttes. $t$, Original structure of nulliments under Sacramento Valley. 2. Intrusion of laceulith nod chusing of welliments. 3. Erusiun of the sedimenting cover and laccolith. A. Intrusion of rhyolitw dentes. 3 , Furcher intrusion of rbyolite and explosions forming volcanic

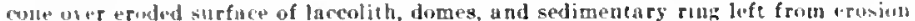
of uriginal easer of laccolith. b. Jroduction of existing topograply by erosion. After Hoarll llilliams. was underlin by nearly dat-lying sediments such as are being laid down in many places today ly the streams whieh flow throurh the valley. The rise of the mayma was forceful enough to arch the strata above it nutil the eover could vield no further to this type of lofur. mation: it then was broken apart by a series of faults part of which are radial to and part eoncentric with the narerin of the lacoslith. The blocks thus produed were tiled ontward at various angles.

The intrusive body apparently has steep sides toward the top and flattens out irregularly near the margins. The top of the body was eovered by an meven blanket of sediments; how much rock has been eroded from the blanket and intrusion is uncerlain but evidence rather strongly indicates that the tops of the buttes are not far below the original surface of the hody. Also how high a done was originally produced cannot be determined because the roof was being eroded while deformation was proceding under the inpetus of the risin: magma. Field evidence indicates that when the later volcanic explo. sions occurred, the sedimentary cover had been stripped off about as it is today, showing that it has only recently been denuded of the cover of voleanie debris imposed upon it.

Following emplacement of the laceolith but before most of the explosive eruptions oceurred, necks or stoeks of rhyolitie composition were intruded both into the marenin laceolith and the surrounding sediments.

When the sedimentary cover had heen largely removed from the laceolith. riolent steam explosions wolved a central crater and minor eraters near the margins. No frenl magna was erupted, the prodncts being fragments of previously consolidated rocks erupted at relatively low tenperatures. The first outbursts were vigorous, indicating lone aeeumulation of ras pressure under the mountain, but the intensity decreased and intervals between the various explosive eycles were long enough to permit drep erosion of debris which had been pre. viously blasted out. This would indicate that magma, still being intruded at depth, was crystallizing and expelling gas which aceumulated until the explosions beran.

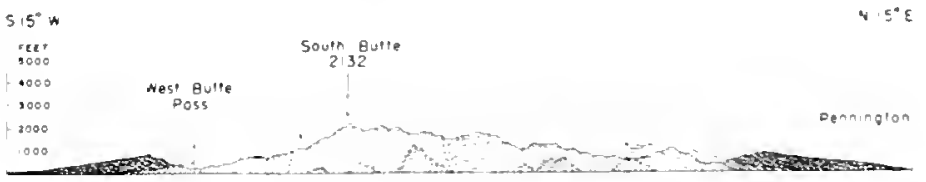

$\therefore$ is

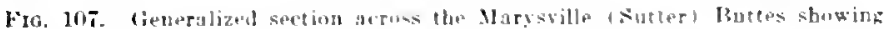

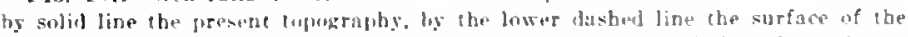

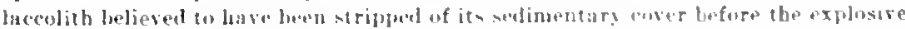

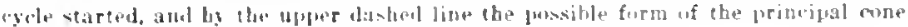
buile hy explosinows. H/ter Houral Williuma. 
Before the explosive phase commenced, the mountain was a more or less eone-shaped eminence with high points standing about 3,000 feet above sea level. The explosions opened a roughly cylindrical vent in the central part of the laceolith which is now filled with the produets of the last eruptions. The violence of the eruptions varied, for some threw ont angular boulders up to 15 feet long while others emitted only fine-testured debris.

The more forceful outbursts erupted great masses of coarse as well as fine fragments which apparently swept down the sicles of the cones in avalanche fastrion. When the eruptions were less intense, the produets were finer and formed well-bedded deposits which eontrast with the chaotic nature of the avalanche debris. Also there are other deposits formed by streams which flowed down the slopes of the voleano both during the explosive plases and episodes of quieseence. The cone which was formed above the laceolith probably had an elevation of about 5,000 feet.

Besides the major eruptions, there were many minor ones fron the principal erater and from smaller openings along and near the margins of the laccolith. The explosions of the subsidiary rents doubtless built small cones.

The final explosive products are fine tuffs which seem to have filled the crater of the volcano; in some exposures they are more tlian 1,000 feet thick. From their field relations it appears that they were erupted from a long, narrow fissure located near a crescentic valley in the soutluwestern crater wall.

For a time, the voleanic cone must llave been an imposing edifice in this very flat region, but now most of it has been removed so that the resistant rock of the laceolith now makes up the prineipal mass of the buttes.

\section{San Joaquin Valley}

The larger part of the Great Valley, extending southward from the Cosummes River and Suisum Bay is called the San Joaquin Valley, althougl its entire area is not drained by the San Joaquin River and its tributaries. The southern, more arid third, extending from the lings River to the base of the Teliachapi Mountains, has no surface outlet mder normal conditions, and the surface waters accumulate in Tulare Lake and Buena Vista Reservoir. Tulare Lake formerly recoiven a portion of the excess flow of the Kerm liver, but by means of a restraining dike, water is kept out exeept when floods break through. The original lake botfom has been converted principally to wheat-growing land.

The streams draining from the Sierra Nevala bring practically all of the water reaching the San Joaquin Valley, hence their volume is many times preater than that of streams coming from the other bordering highlands and their flow is much less erratic.
This strong dominance of drainage from the eastem side has griven the valley an unsymmetrical form, for the axis or line of lowest clevation is much closer to the Coast Ranges than to the Sierra Nevada. In places the axis even lies along the base of the western ranges, but in other localities the western slopes may reach half the width of the eastern as between I,os Gatos and Cantua ereeks. The slopes of the western side are somewhat steeper than those of the eastern.

This unsymmetrical eross section, which in most places is not characteristic of the Sacramento section, results from the greater aridity of climate. The streams, overloaded with sediment because of decreasing volume as they reach the lower, drier mountain slopes have formed conspicuous athvial fans, the larger, of course, growing at the mouths of the eastern streanis.

Over the fans the streams discharge in numerous channels fowing from the apes at the mouth of the canyon in different directions down the slope. Most of these distributarics as they are called travel outward on the sediment of the fan into which they have cut fairly deep trenches, but some from the San.Joaquin River northward have eroded into the bed roek below the fan to a depth not exeeeling 100 feet, the result either of recent elevation of the Sierra block or change in stream volume, the actual cause not yet boing known.

The west side l'ans, palticularly near the middle and sonthern parts, are steep and symmetrical, features characteristic of areas of slight rainfall quite nnevenly distribnted where the streams are smaller and have greater fluctuations in volume. The eastern fans, on the other hand, are mueh larger, more gently stoping, and less clearly defined.

On the eastern side the Kern River fan has grown westward against the Melittriek Jills isolating the Buena Vista basin somth of it Originally slallow Buena Vista Lake oceupied part of the basin and during umsually rainy seasons there was overflow northward into Tulare Lake. I ater on dams were built changing the natural conditions, impounding the waters of Buena Vista reservoir. Northward, the effeet of aridity has been expressed by the building of the great Iings River fan which has joined one from Los Gatos Creek flowing from the Coast Ranges forming a low ridge behind whieh is the Tulare basin. I'art of the water from the streams sontl of the barrier was imponuded to form Tulare Lake which, when present, was very shallow. Breause of this and the fluctuating water supply, the lalie varied notably in extent from year to year. There is no evidence that overtlow from Tulare Lake ever went northward into the San Joaquin drainage.

North of Tulare basin, discharce from the streams is great and con. stant enough to prevent formation of such dams and an open channel is maintained by the San .Joaruin River to Suisun Bay. The trunk river meanders slugerishly tlirourh its flood plain.

Along the lower course of the San Joaquin, the topographic picture in general is similar to that along the Sacramento as it is developed 
E:

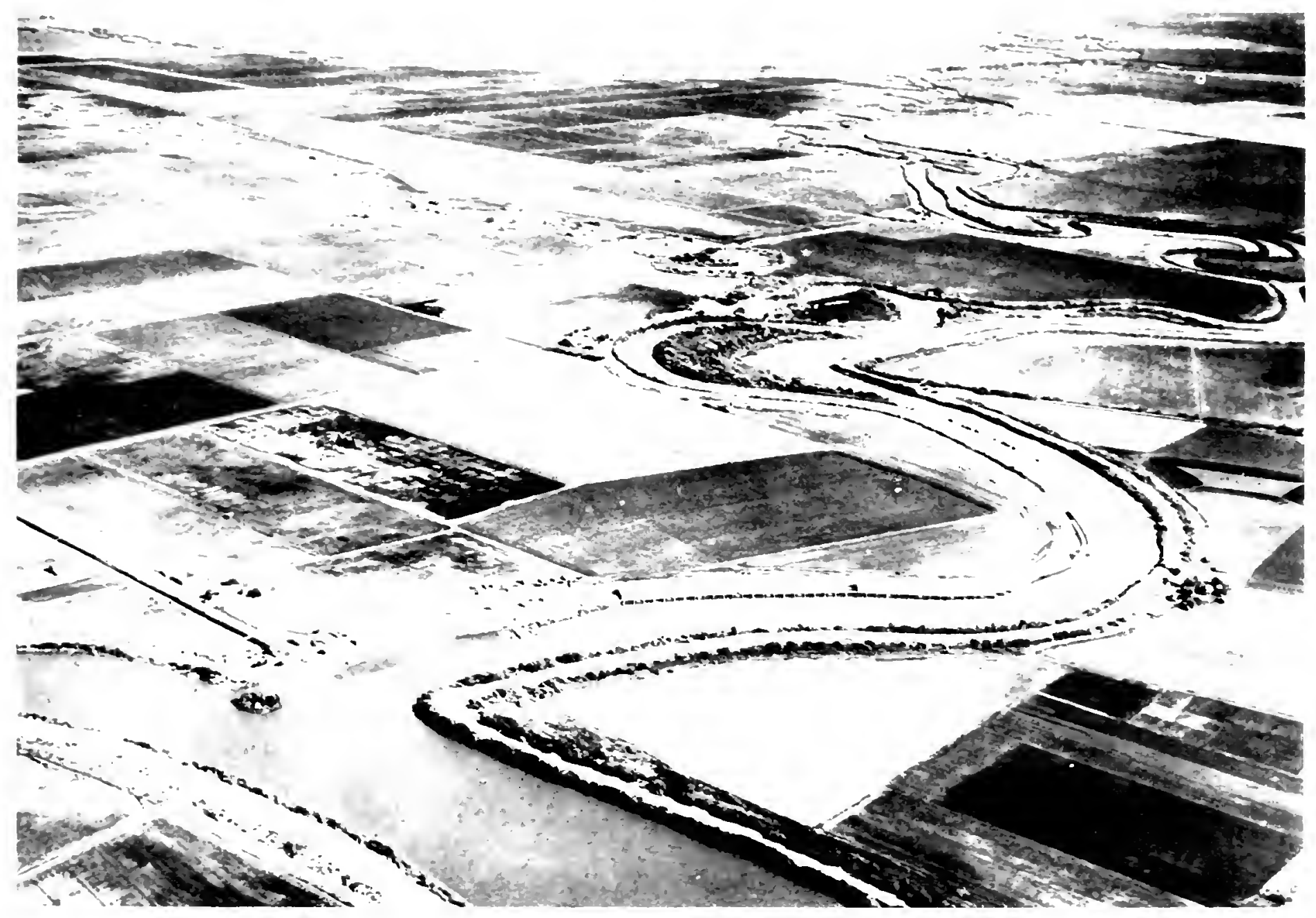

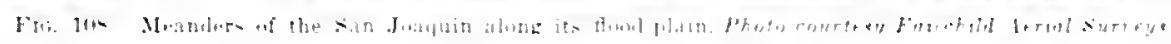


umder somewhat more humid comditions. Laripe areas along the river are annually inmated by tlood waters except where protected by artificial additions to the natural levees. The major floods oecur when both the San Joaquin and the Saeramento are in flood at the same time. North of the mouth of the Stanistaus River, 20 miles south of Stockton, numerous channels diverge from the San Joaquin as from the Sacramento, isolating islands similar in topograply to those already deseribed.

The great contrast between the two major sections of the Great Valley is found in the southern. arid San Joaquin portion where the surface is a combination of alluvial fan surfaces with intervening shallow basins of the playa type, the Tulare and the Bnena Vista. Farther north and throughout the Sacramento seetion, fans are less striking because of the areater anount of rainfall, and althongh they are present along the valley margins, the main feature of the valley is the flood plain.

The Kettleman IIils lie elose to the eastern base of the California Coast Janges about 10 miles southeast of Coalinga in the San Joaquin Valley. They form a slightly areuate low range having a northwesterly trend, a length of abont 30 miles, and an average width of 4 to 5 miles. The hills rise rather abruptly several hundred feet above the San Joaruin Valley to the east and are separated from the Coast Ranges by the almost flat Kettleman l'lain which is 3 to 5 miles wide. The greatest elevation of 1,366 feet above sea level is at the northern end, from which there is a deerease southward until the hills merge almost imperecptibly with the even surface of the San Joaquin Valley. The Kettleman Ilills are the main part of the isolated outermost foothills of the Coast Ranges which extend southrastward from the mountain front along the axis of the large Coatinga anticline. Three major anticlines comprise the Kettleman Jills, named respeetively North, Middle, and Sonth domes; they have edbelon alimment and a re offset. North and Middle domes are doubly phuring antiches, that is their axes are inclined in two direetions whereas South Dome plunges northwestward and is overlapped on the south by the alluvinm of the San Juarnin Valtey. The whole line of folds of which the Ketteman Hills are a part extends from Anticline Ridge to Lost Hills, a distance of about 70 miles.

South and Middle domes are separated by $\Lambda$ venal Gap, an alluviumHoorel depression extending from the Kettleman Plain to the San Juaruin Valtey. No similar feature lies between North and Middle domes, the boindary between them being marked by deerease in pluggehness and ehange in trend. North Dome is the highest of the three and is most deeply eroded. Its cuminating point, la Cima, vamls abmut fon fept ahove the lietteman Plain and 900 feet above llo. Sinn . Thayuin Valley.
The Kettleman liths have been developed by deformation of a surface of very low relief which had been etched into sedimentary beds of Cenozoic are and apparently extended far beyond the limits of the area. The deformation is believed to have resulted from renewed fold. ing along the already existing Coalinga anticlinal belt. The erosion surface elevated by the deformation has been largely destroyed within the area of the hills. The domes contain two concentric rows of hills separated by shallow valteys exeavated in weaker strata, an cscarpment-cucsta topography common in such structural settings. The erests of the hilts in some plaees may represent frarts of the old surface somewhat modified by erosion. One nearly flat remnant of the surface about a mile long and a quarter of a mile wicte shows near El Prado at the north end of the Kettleman llits, and other smaller remnants are present elsewhere. $\Lambda$ lower erosion surface evidently formed by trenching of the older snrface and broadening of the new valleys shows in some places. The deformation which gently folded and elevated this erosion landseape eertainly occurred during Pleistocene time and probably rather late in the epoch.

The entire liettleman llills area is eharacterized by rounded hills, but, in most of North Dome and on the west side of Middle Dome, the lower parts of the stream valleys are relatively narrow and steep sided. Loeally the hill slopes are gullied into badlands, sinee the weak rocks are insuffieiently proteeted by vegetation from the attack of torrential rains. The drainage is all intermittent, but, when it flows, transports enourh sediment to add to alluvial fans which have formed at the mouths of the goraes where they open onto the adjacent plains. The headwater streams of North Dome have relatively deep, narrow valleys, but the lower parts of some of them have reaehed maturity, are widening their valleys, and are depositing sediment over the terraces they have eut.

Small patches of sand dunes are found here and there. In the San Joaquin Valley immediately adjacent to the Kettleman IIils, there are lone northwestward-trending ridges of sandy material which some have surgested as eminences resulting from reent faulting but which actually may be old sand dunes of considerable size modified by later erosion.

\section{REFERENCES}

Bryan, Kirk, Geologs and water resources of the Sacrameato Valley, Cuhfornia U. S. Gerol. Surrey Water-Supply Pnper 495, 1923.

Mendenhall, $\mathbb{W}^{*}$. C., and athers, Groind water ia San Joaquin Valley, Culifornia: [T. S. Geol. Survey Water-Suphly laper 398, 1916.

Woodrias. W. P., and others, Geology of the Kettleman Hills ail field, Califurni: [. S. Geol. Surves Prof. Paper 195, 1940. 


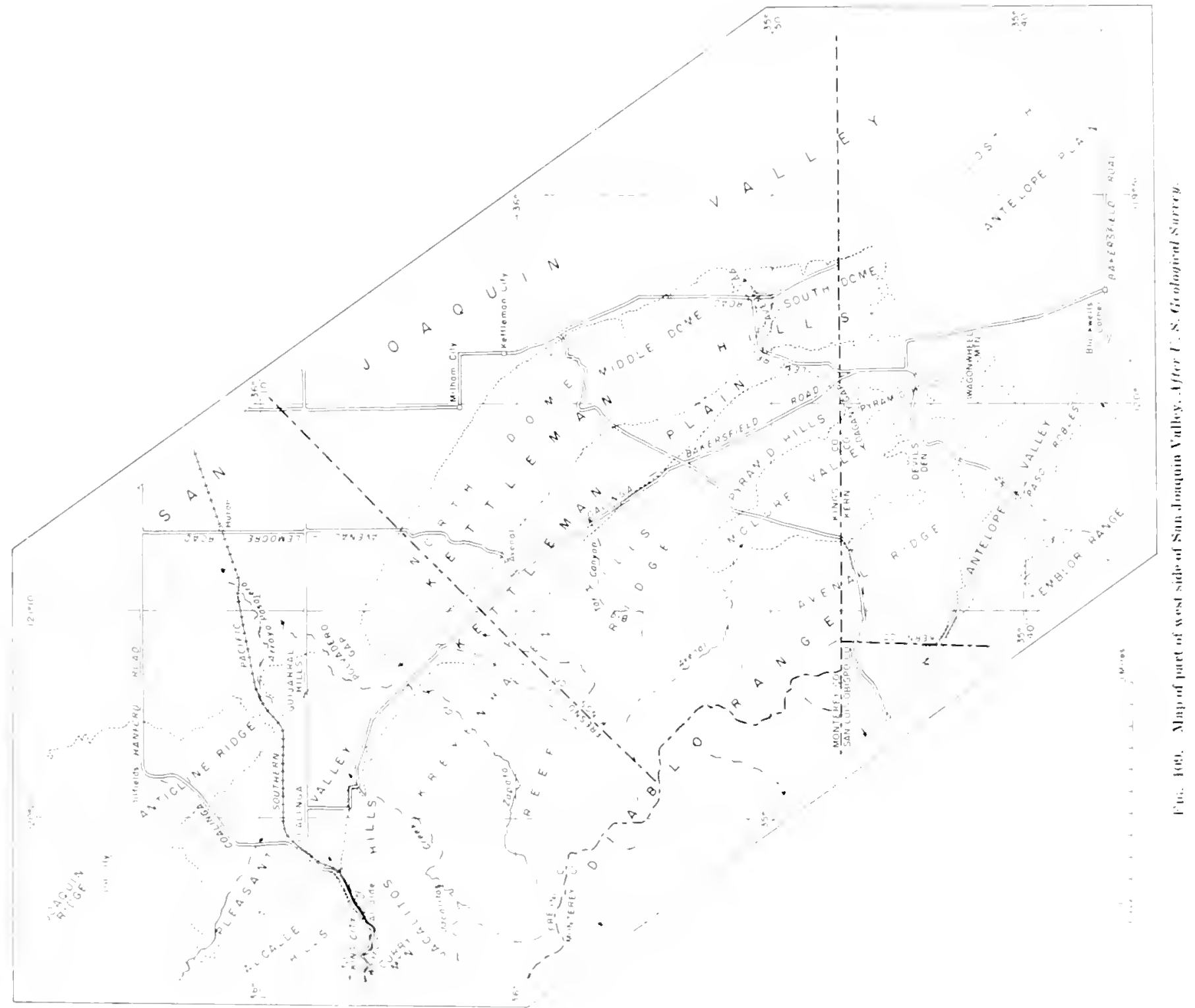




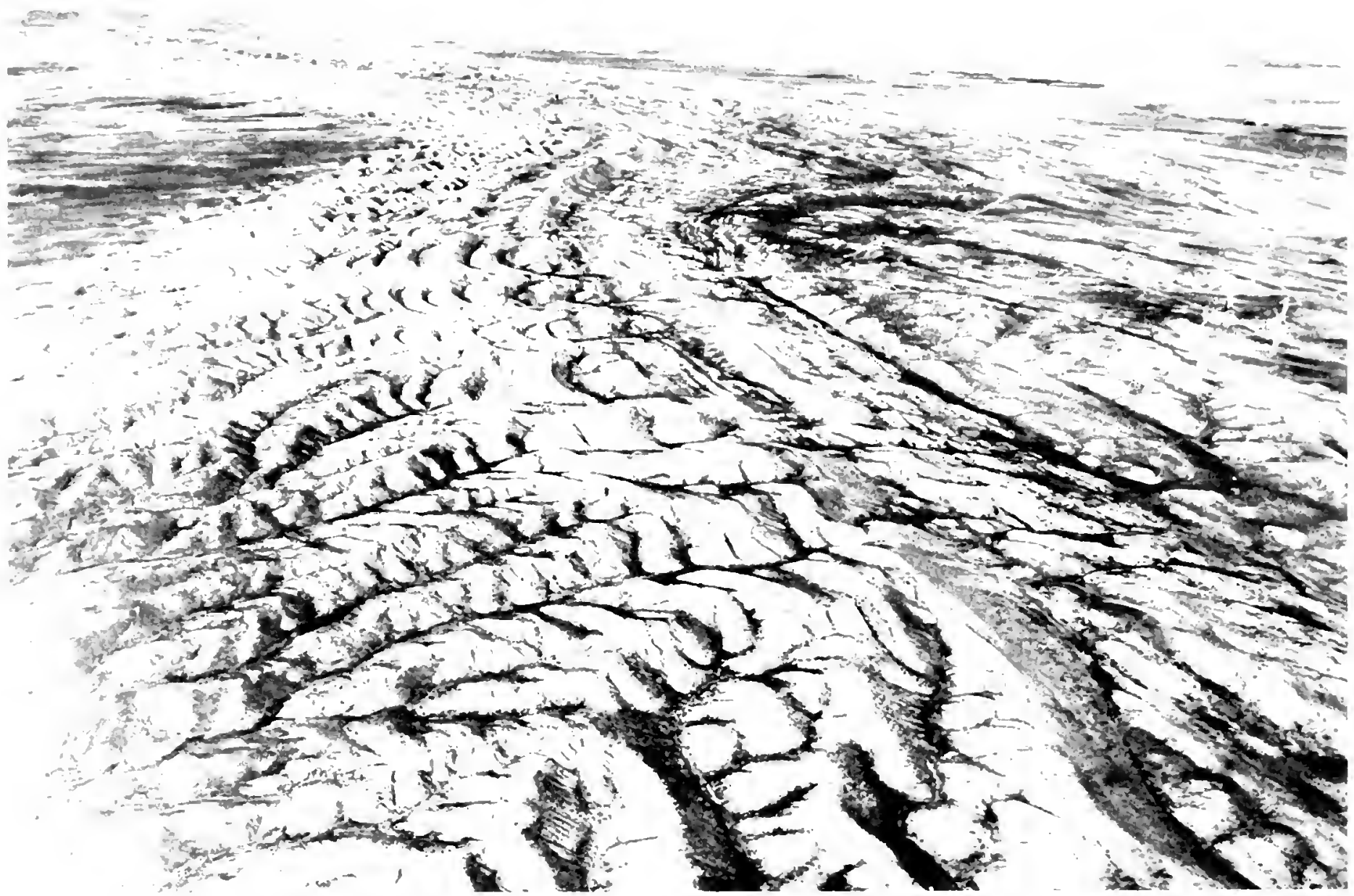

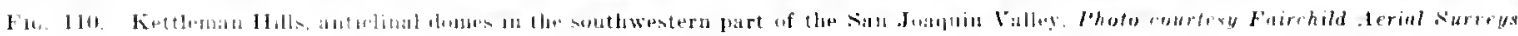




\section{COAST RANGES}




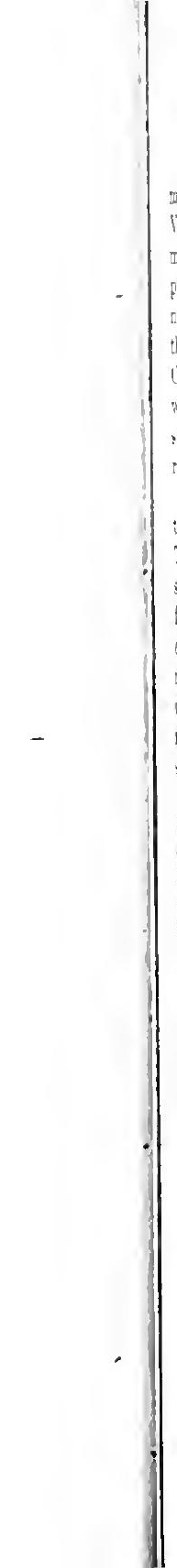




\section{COAST RANGES}

The california coast liames form a physical provinee about 400 miles long aml 50 miles wide between the lacitic Ocean and Great Valley. They are composed chietly of late Iurassic and younger lormations. and their topography is eontrolled by folds and faults. The provine contrasts sharply with the older Klamath Mountains to the north. The Coast Ranges adjoin the Transwerse Ranges to the south, the Sian Ralial Ilountains being the sonthermmost coast range. The foast lianges in most places rise abruptly from the shore line, their western marain being markel by prominent sea clitls. On the eastern sirle, the lireak betwen the mountains and the Great Valley is generally rather abrupt.

Along the coast the climate of the Coast Ranges is controlled by the the moisture laden winds sweeping on shore from the Pacific Ocean. The temperature variations between day and night are normally small, summers are cool, winters moderately warm, and there is considerable fog. From south to north in the province, temperature variations in. crease, there is greater contrast between summer and winter, fog is more frequent and lasts longer, and rainfall increases. Snowfall is unconmon at low elevations except in the far northern part but the uneuntains, especially from San Francisco north, receive not infrequent s)1 1 i.

The part of the Coast Ranges that is best known extends from the San Franeisco Bay region to Santa Barbara County. The first deci. pherel chapter of the history begins with the formation of a comparatively small geosyneline lying between the ancestral Jurassic Ironutains, particularly the Klamath. Sierra Navada, and Transverse Ranue sections, and a land mass called Caseadia, which lay west of the presest shore lime. During the latest part of the Jurassic and most of the Cretaceous periods, dominantly elastie sediment was deposited in the basin. the debris being derived principally from the western land. There were interruptions when the land rose above sea level, especially at the end of Cretaceous time when there was some folding and laulting. Throughout the Cenozoic down to the last epoch the basin oscillated above and below sea level, thourh the influxes of the ocan were not so extensive as in the two preceding periods; in addition the land was less stable as shown by folding and faulting and by the products of volcanic activity. When above the ocean the relief of much of the Coast Range belt was similar to that of the Great Valley torlay, with which it was then eoestensive.

In the middle part of the Miocene epoch, eompressive deformation began and gradually became stronger causing part of the Coast Range rewion to rise as ridges above sea level while other parts remained below and reeeived sedimentary deposits. IIow much of the bedt became land to be erodecl we do not yet know. The rather weak compressive movements contimed at intervals through the earlier part of the Pliocene epoch and became very much intensified in the later part of that time when the entire Coast Range belt seems to have been strongly folded and faulted, with the leformation being strongest near the coast and less pronounced east ward. A still more important deformation of similar type started in the middle Pleistocesus. stamp. ing the general features of the present landscape on the Coast Ranges and establishing the main features of the drainage. Snbsequent ehanges along the coast and inland seem to have been of less significance. The formation of the Coast Ranges therefore bas been a complex process spread over a considerable interval from the midalle part of Hiocene time to the middle of the Pleistocene, the compression increasing in severity and reaching its climax in the last deformation. Hovements since the middle Pleistocene apparently have been predominantly vertical, either upward or downward.

The mid.Pleistocene folding aceentuated Pliocene folds and faults and formed new structures of the same sort which deformed strata laid down both below sea level and above during later Pliocene and early I'le istocene time.

The mid-Pleistocene uplift was rather rapid, greatly steepening the mountain fronts from which great and small masses of slide rock broke loose. That these slides occurred some time back is proved by the amount many of them have been eroded. At numerous places there are hills and ridges along the mountain fronts that are eovered with slide debris derived from the searp of the principal ridge belind the bordering hills. In some loealities there is a sequence of slides with the later being snialler because of deerease in the slope of the mountains as erosion gradually subdned them. These huge jumbles of rock in many places completely hide the searps, giving an erroneons impression of the distribution of the roek formations and structures.

Along the coast and in the valleys there are many finely developed marine and river terraces shown to be later in origin than the midI'leistocene deformation beeause they commonly transeress structures formed at that time. The terraces testify to the spasmodic eharacter of the uplift of the various blocks, having been evolved during episodes of quiescence and raised cluring times of increased intensity of deformation. In eertain places there uay be definite intervals between terraees, but farther along these intervals change, indicating difference in rate of uplift which warped the terraces as they rose above the sea.

Coastal terraees do not seem to correspond very elosely with those developed along river valleys within the ranges, probably the result of more rapid uplift along the west side of the provinue since middle Pleistocene time than has oneured farther past 
sing

(n)

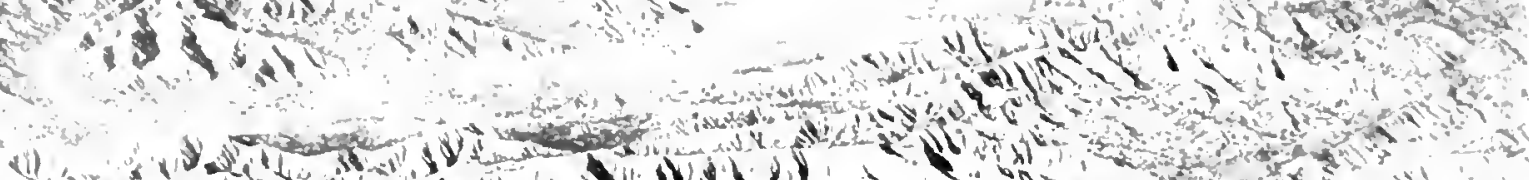
3.

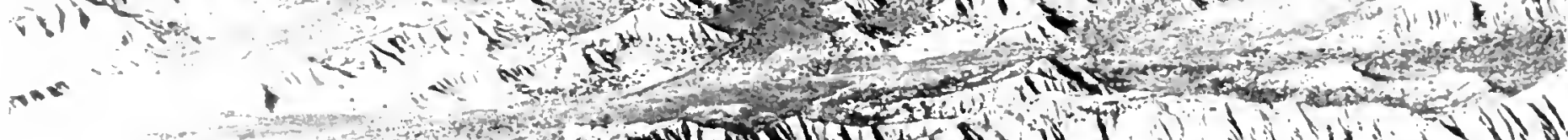

م.

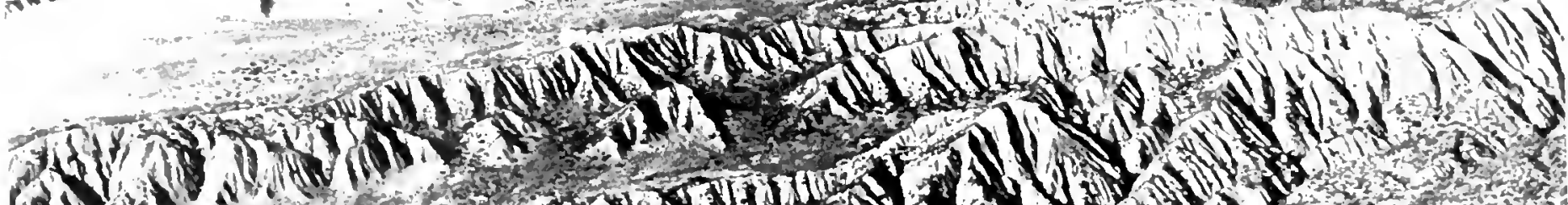

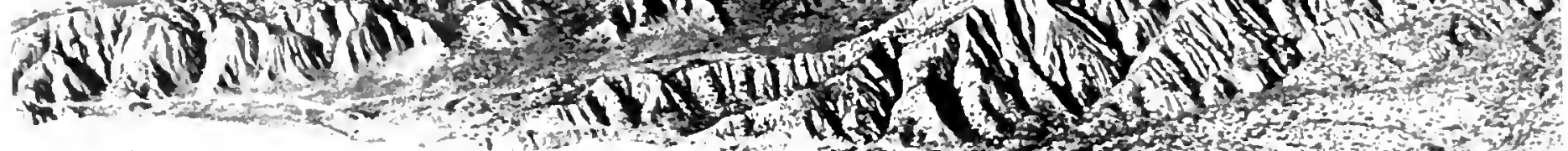

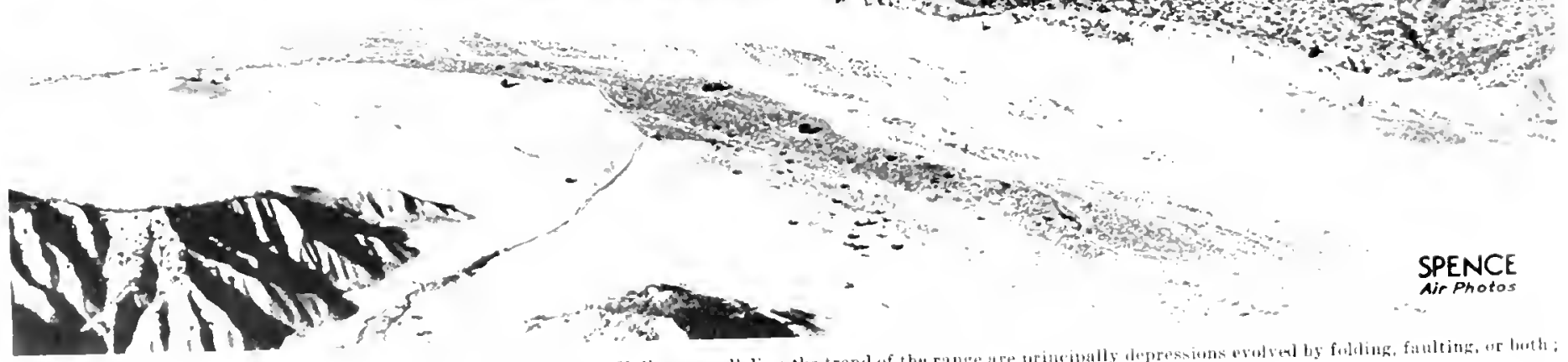

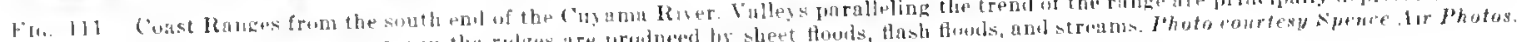




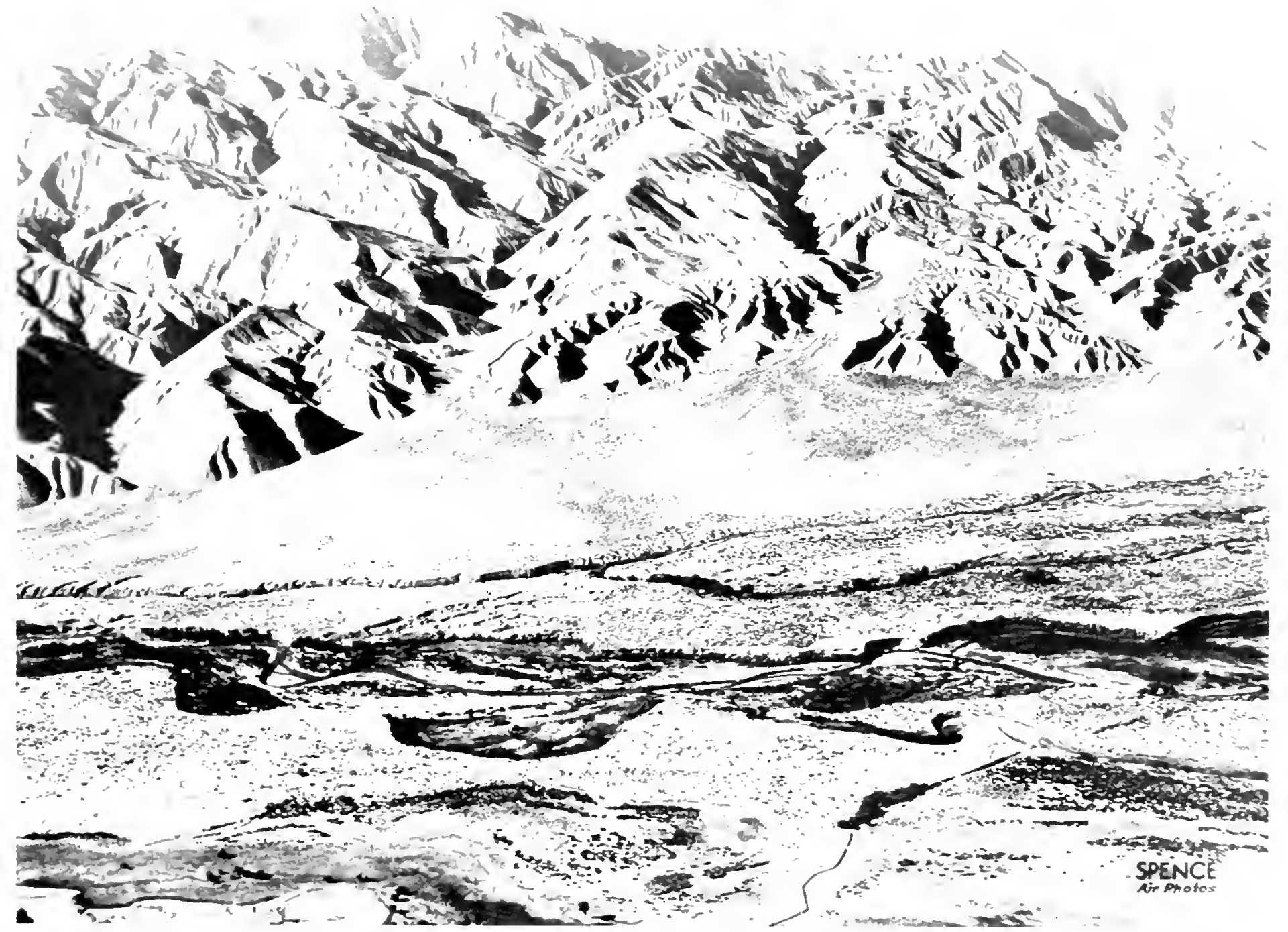


1

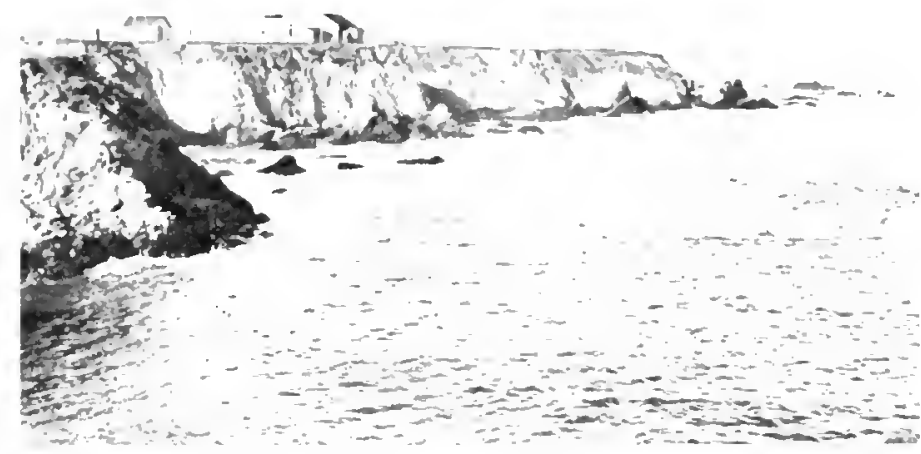

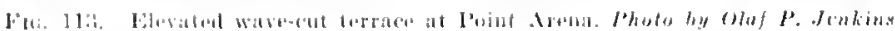

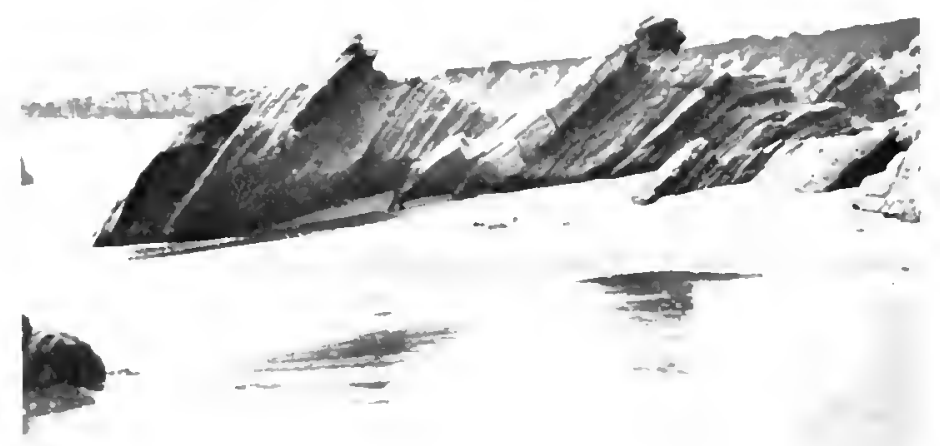

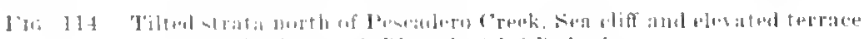

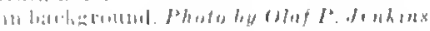

The best known and porhaps the mont important fault or rift

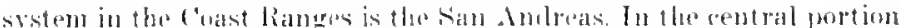

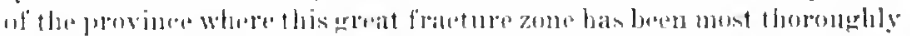

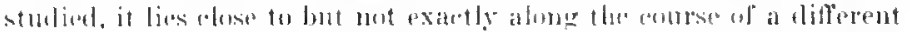
type of fanlt lorment in kinerme time. What the relationships are in

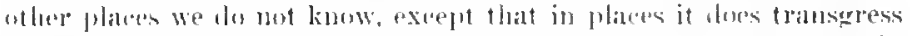

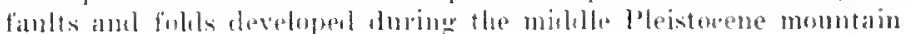
molling, and therefore is gommer than they are; it also lratures

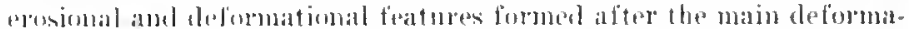

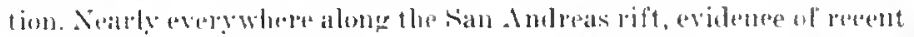

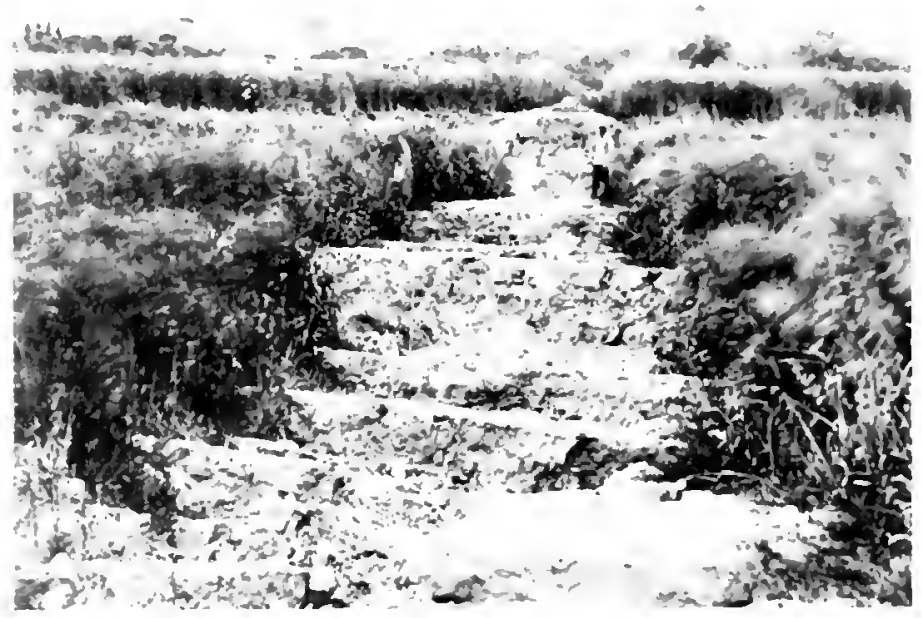

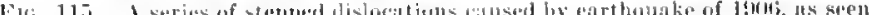

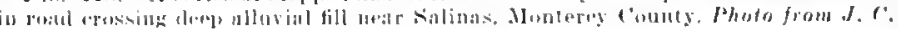

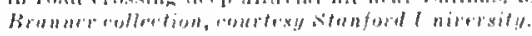

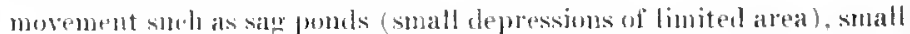

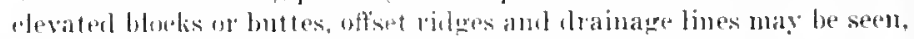

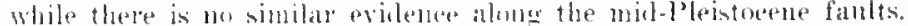

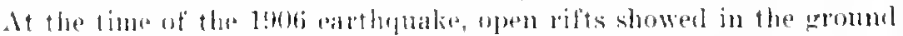

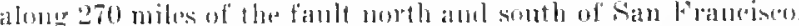

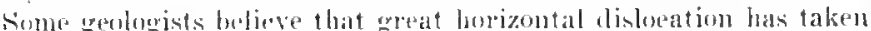
pliner alome tho sin .Mulreas rift, most of the movement having taken flate in that direetion, and that the utfiset is measurable in miles ur

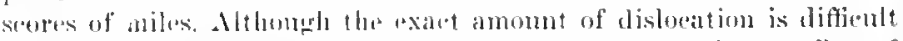
to determine, it apprars to be lexs than a mile. The maximum offset of clrainage lines calsed ly the repeaterl breaks along the fault is about 3.1001 feet. Thus, in spite of the 600-mile or more length of the rift, 


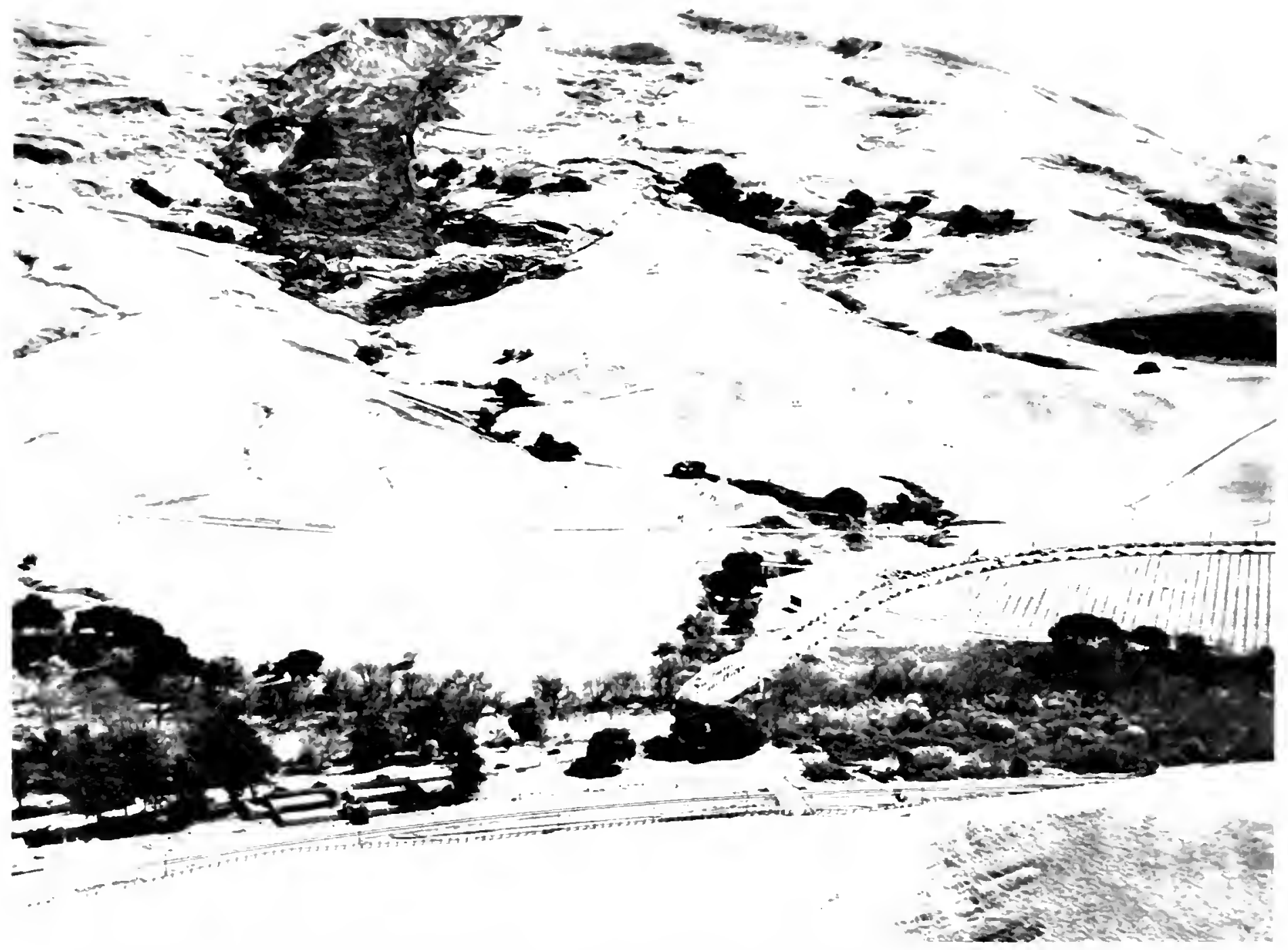

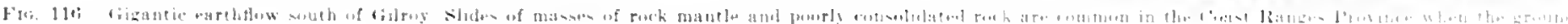




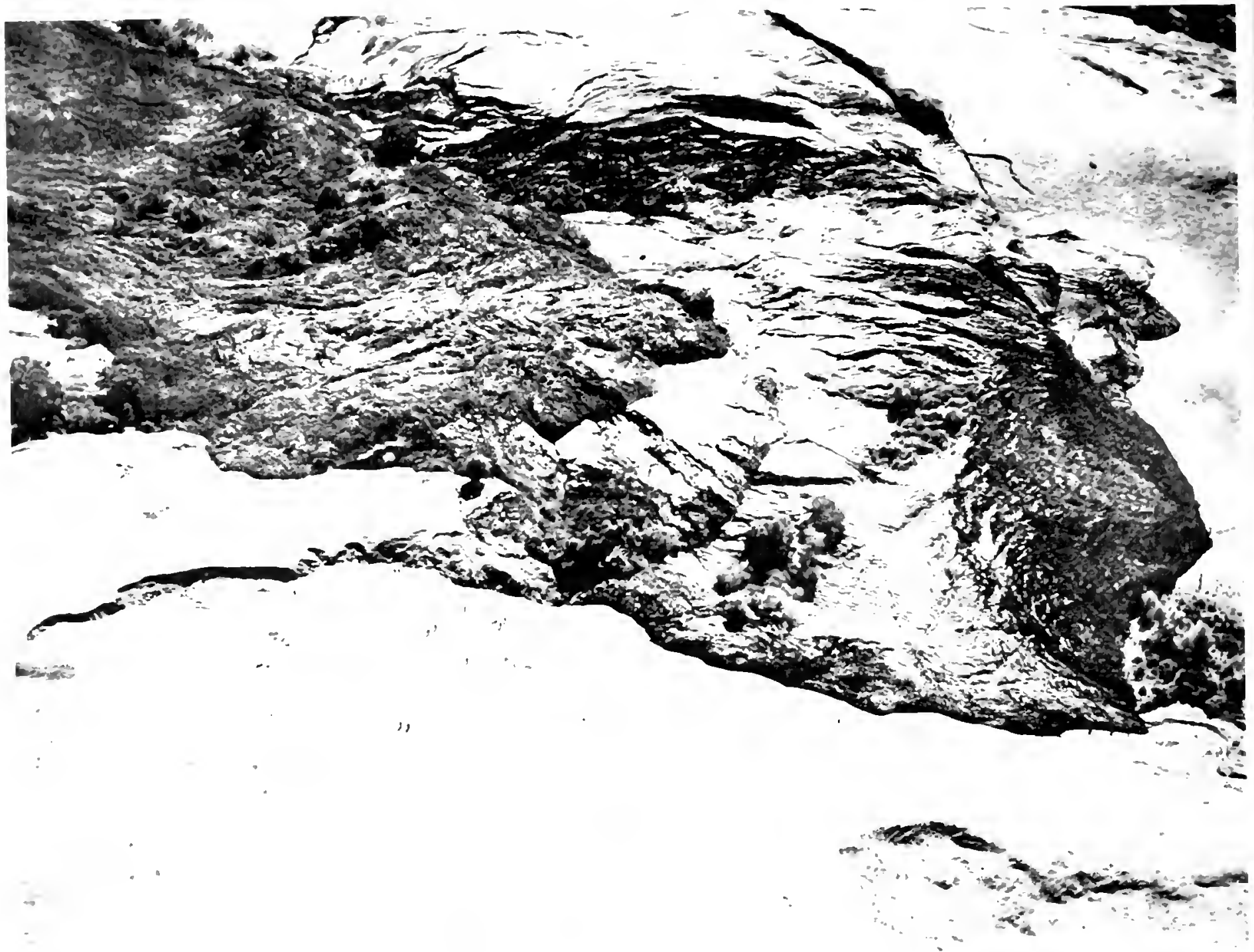




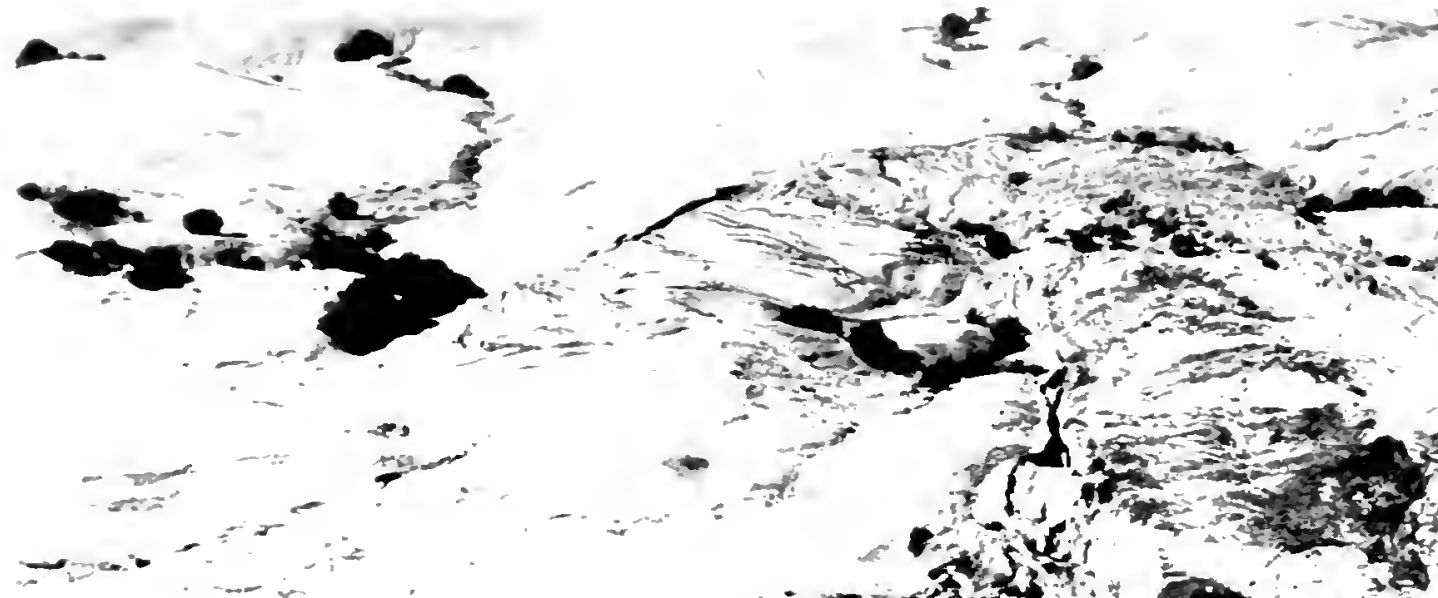

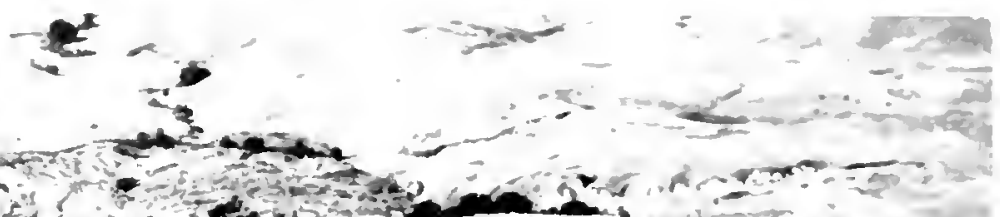
$2=-2$

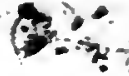

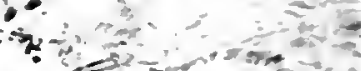

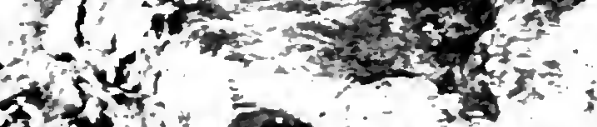
$\therefore$ or

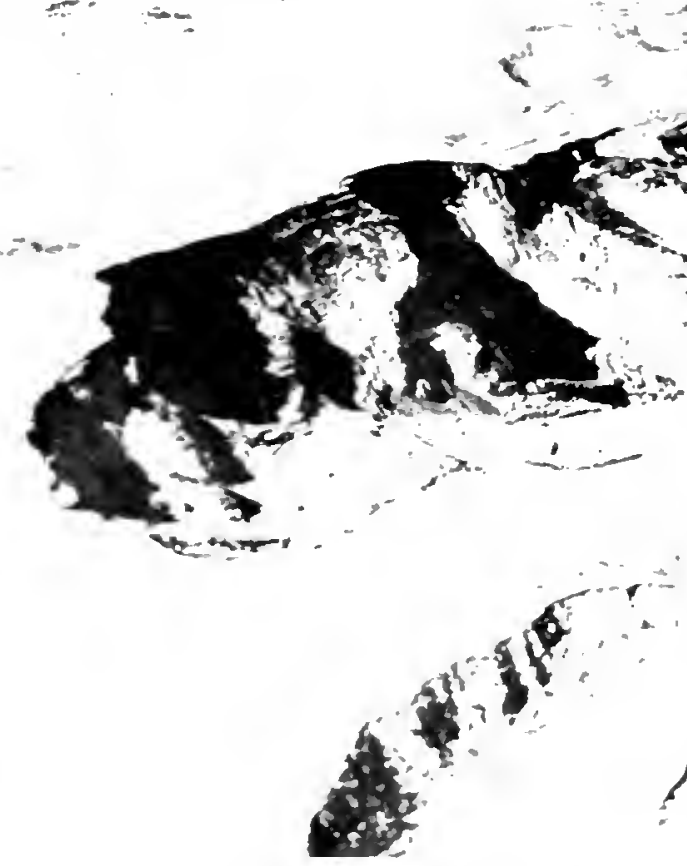

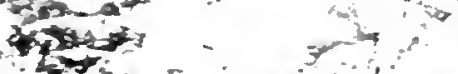
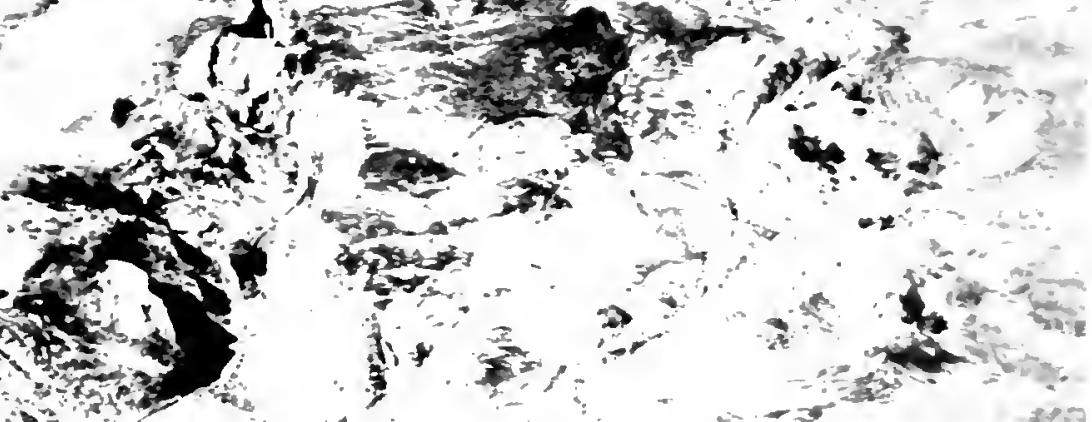
$\therefore$ tक
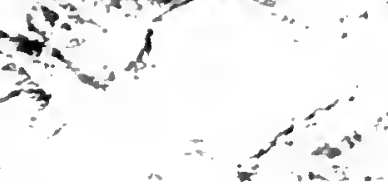

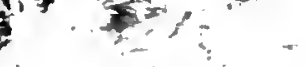
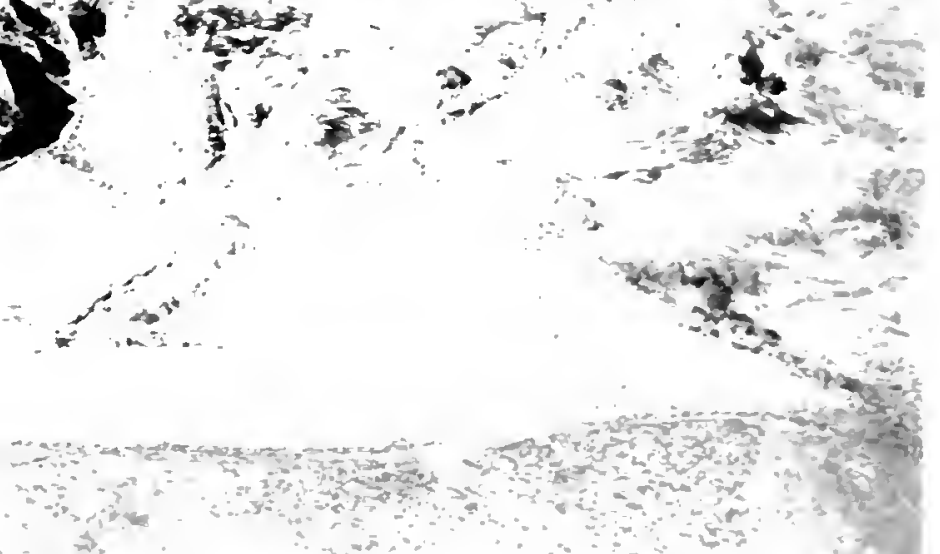


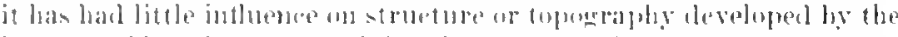

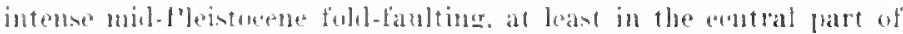
the loist liangex

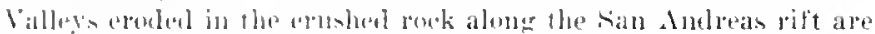
ancmir the gumerest lamb forms in the province.

\section{San Francisco Bay Region}

'l"he hills and mountains lying west of Sim franeisco Bay are divided into a northern and a whthern sertion ly the Golden Gate:

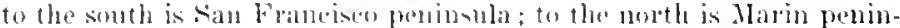
sula with its cromning point, llount lamalpais. Whese two summits

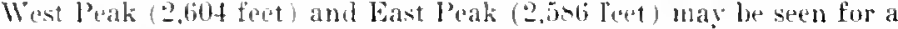
long distanoe.

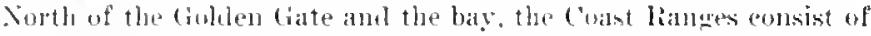
varinns ritges oriented somewhat west al north. There is little arreement on the names of most of 1 lus so palleges on the atrea to which the

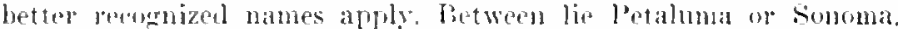
Nitpa, Clear lake, and Berryessa balleys, named from west to east: racly is a major structural elepression shapply contrasted with the lessere eanyons and ralless earved into the gandes by streans. About 50 miles nortlo of the bay, all but the fonoma liange merre into a much

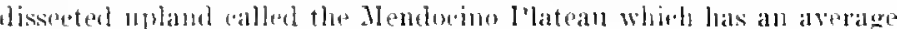

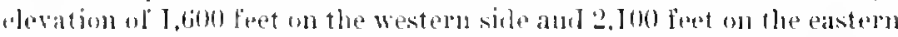

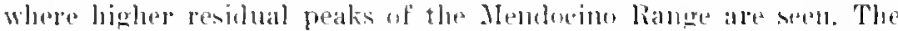
npland withont question is a subluet eresion shetale developed at fower elevation in past time. later ralised. and now in process of fortuction. of the najor struetural depressions, only the Petaluma and its extension along the Rousian liver project as far morth as the Memelocino Platean.

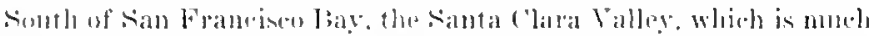
larerer than any on the northern side. reparates the ("oast hanges into an eastern division often called pollettively the biablo liange and a

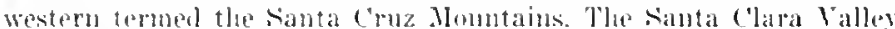
is the largest structural depression of the central section of the Coast fianges, laving a length of about 100 miles and a width of 1.5 miles

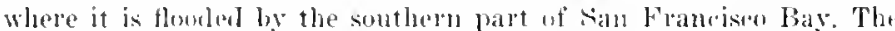
lower thiles of this valley are drained by coyote Creek into the bay

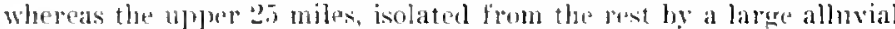
fan, sends its water's first into Llatgo Crest and lhence into the Pajaro River which empties into Monterey Bay

The Diablo Ranere, the montainous belt past of San Franeisen Bay and soluth of the sideramento River. is divited into several smalles northwest trenting rideres separated hy valleys larwaly eontrolled by prominent fanlts. The highest peak in the northeru part is the promi-

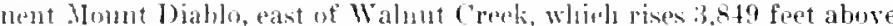
sat level. Sintle of the Livermore Valley, the Diablo liande. Ineally known as the Wount Jlamilton liange, has a wiltlo ol more than 30 miles and some praks exording 4.000 feet high. The lierlseley llills,

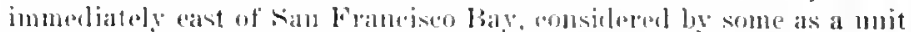

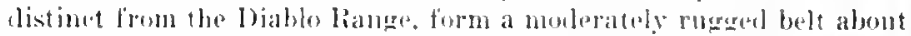
15 miles lone and 10 miles wile with a prominent westepn-faring searp. Betweren the maju portion of the Pertoleg Hills and the main portion uf the Diablo Raner lies San Ranon Valley, a struetural depression.

Went of San Francisen Bay, the Santa Cruz Momutains extend for nearly s.5 miles southward from the folden fate to the l'ajaro hiver. This section of the C'oast kanges is narrowest and lowest in the San Franciseo Peninsula, wiclens and grows ligrler leyemel, but again narrows motably at its southern extremity. The higlest praks stand ahout 3,700 foret alme sea level. Northwest-tremlinar struetural val-

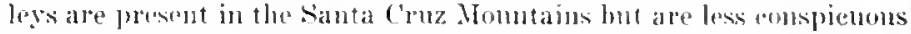
than in the Dialsu liancre.

The crests of many ol the Coast linures buth north and south of San

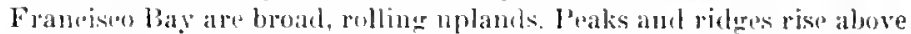
the upland both in the south and the north. In the Santa Cruz Moun. tains two orosinn surfaces are present, ons at 600 feot and the other letwern 1.100 and $1: 200$ feet, but it is nucertain whether they are two distiunt erosion lopels or parts of one separated by falts. Elsewhere there is a single well allwanced landseape now being deeply trenched by rentiz cantous ant because of the elevation of the rancres.

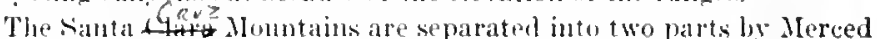

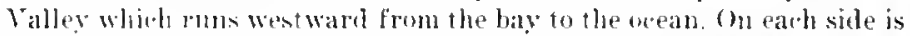

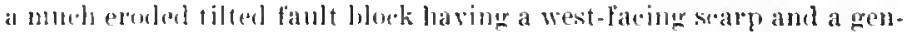

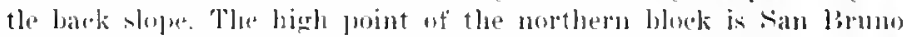
Momntain (1.315 feet). While that of the southern blonek is Nontara

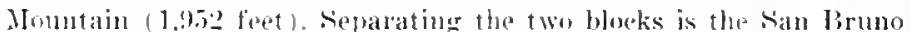
fault lying at the base of the steep smothwestern liont of San lirumo Xlumtain.

The nothern block is irrenularly hilly, and exerpt in san brumo Iomntain, there is little parallelism between hills and ralleys and the trenl ol" the bloek. "The topography is generally' sublud though certain rugrel arrac of resistant ehert stand out. C'hert is a roek romprosel of almest pure silina On the other hand. in the southern Montara section, rewh and ralleys run parallel to the lone axis of

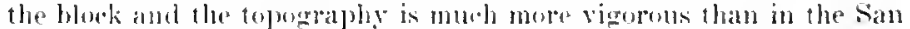
Brmo llills. The most notable leature of the Jontarat block is the valley containing san Antleas and (rystal springs lakes and through which rums a portion of the ereat saln And peas rift. This valley has been partly formed by earth movements along the fault but more important has been the easw aromon of baully cruslied rork in the fraeture zone. Nontleant of this valley lies liuriburi liblge which slopes to

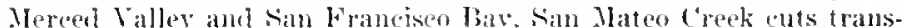
versely acous this rider araining the san indreas rift valley and flowing through a narrow grore to the Bay. 


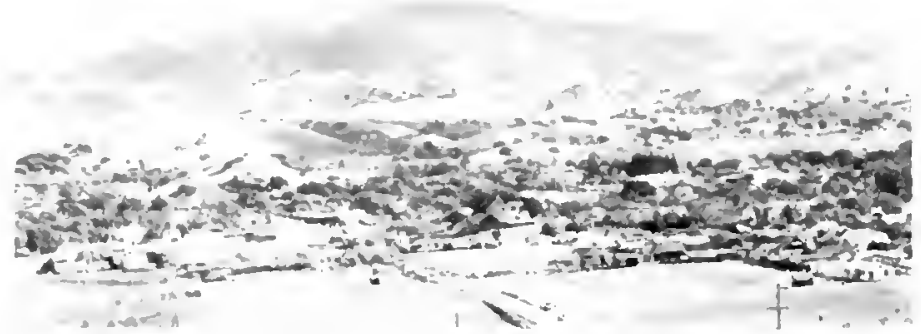

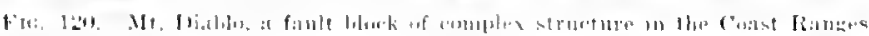

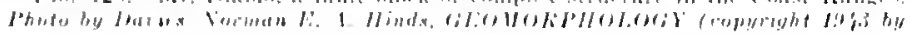

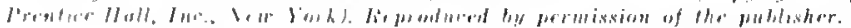

The slope of the Mentara blark southwest of the rift valley is broken by a series of narlew ranyens and ridges which are in large part remnimts of the oriminal trusion surface tilted upward as the block rose.

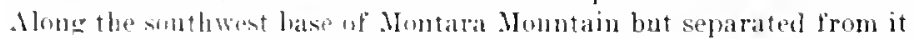
ly an alluviated valley is a low ridere known as Miramontes which

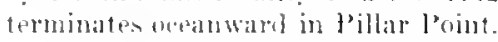

Tho slorelines of the two sides of san Franciso feninsula are

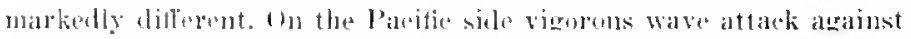

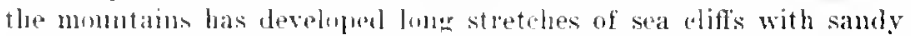

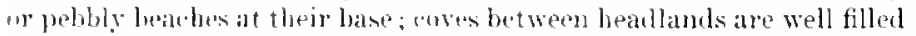
with sediments brought in by rivers, waws, and enrents. There are

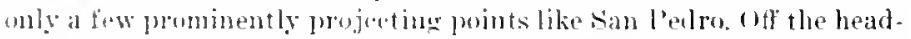
lanth stamel rouky islanck, like the heal liowks ur the south side of

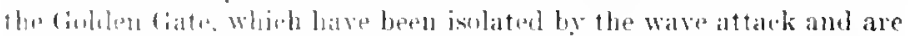
wadually hing destroyed. In contrast the bay-side shoreline is highly

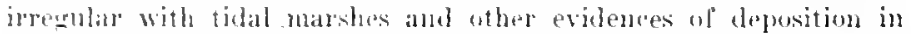

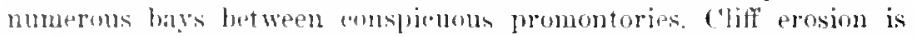
forble ind there atre no "lean samly or pebbly heaches. The shore

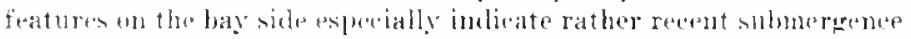
of a considerably eroled lanel mass. Similar submergenee also is incli-

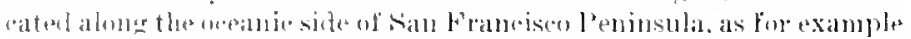
at lakn Jercul, which betore it was molitied for use as a reservoir, was a drownal valley ont aff from the ocean by a har of drifting sand. The Golden tiate is anotlan illustration: there the onean has invarled

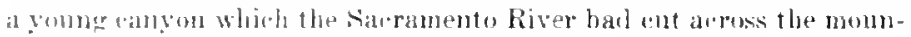
taimms barrier

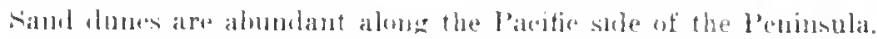

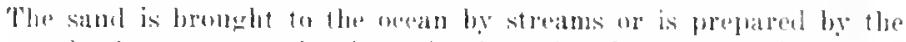

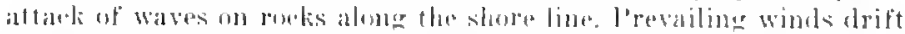

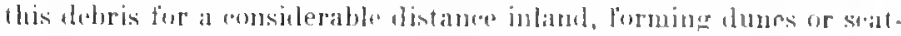

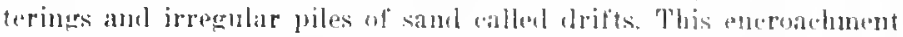

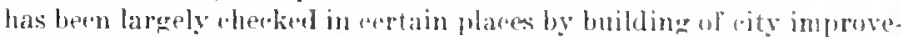
monts or planting regetation. This was one of the prine purposes of the establishment of Golion Gate ['ark.

Harin Peninsula, morth of the folden (iate, is a continuation of the mountainums seetion to the sonth and is separated from it by the narrow wannel thromph which the weran lats spread to lom sin linneisco Bay. The mouths of stram valleys descending to the ocoan from the highlands have been embarel indieating either that the lenimsula has sumk or that the ocean, rising as the ice of the fonrth oracial stare melted, has invaded the lowest parts. from the highest point, Hount Tamalpais, a ridge "xtends west and northwest for a eonsiderable distance. The slope's from the praks and from the rilire are steep in all diretions and are broken by deep gorges bet we wh wh lic narrow rilges. Howerer, where these eanyons approarh the shoreline, they widen and their floors are flat, mestly salty marshes, al produet of sedimentation in the embayments. This is notably trus on the bay siefe of the pronsula, where Tiburom l'eninsulal ant sim Quentin l'oint separate three nain bays rearling fur inland to the base of the moun. tains. Each of these indentations has a wide sellimentary fill, the elelta plain of the strenm which carven the valley. (1n the western side of Honnt Tamalpais, ridgess and valleys either descend to the sten or to a longr valley separating the pealk from the loint lieyes l'oninsula.

besides the Golken Gate. Elk Valley crosses Marin l'eninsula from the head of Richardson Bay to the head of Tennesse' Cove. "l'his valley, while possessed of rather low hottom shpe, has steep walls and ties almost at right angles to the trom of the Marin block. Its origin is not yot fully mulerstoul. The bottom is alluriated to some extent by wash from the walls.

loint Reyes Peninsula is generaphieally distinet from the main part of Marin lenimsula to the cast and is separated from it by a tome narrow valley throngl which gasses a section of the san . Ambeas rift.

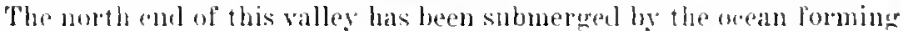
Tomales Bay, while the south end lerminates in bolinas latgoun which is separated from the sea t:y a wave-built samt spit. "l'he formation of the valley, like a similar one previonsly deseribed in the Montara fault blok south of the Golden Gate, has been pirtly the result of earth movements alone the great liault but more important has been the atsy prosion of crushed rock alome this fracture zome. The quite

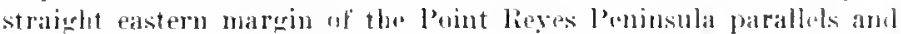

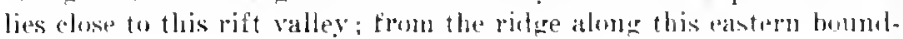




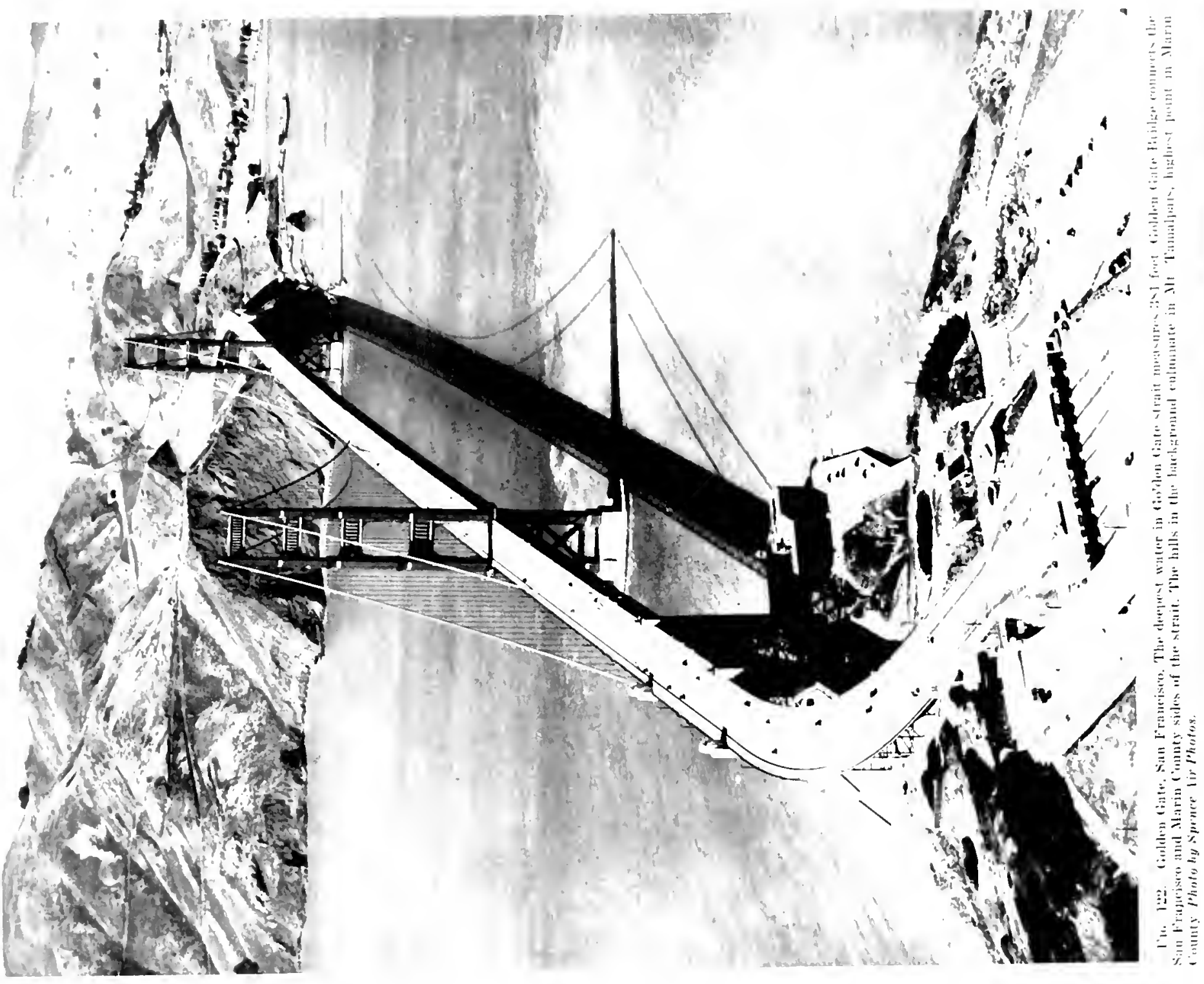




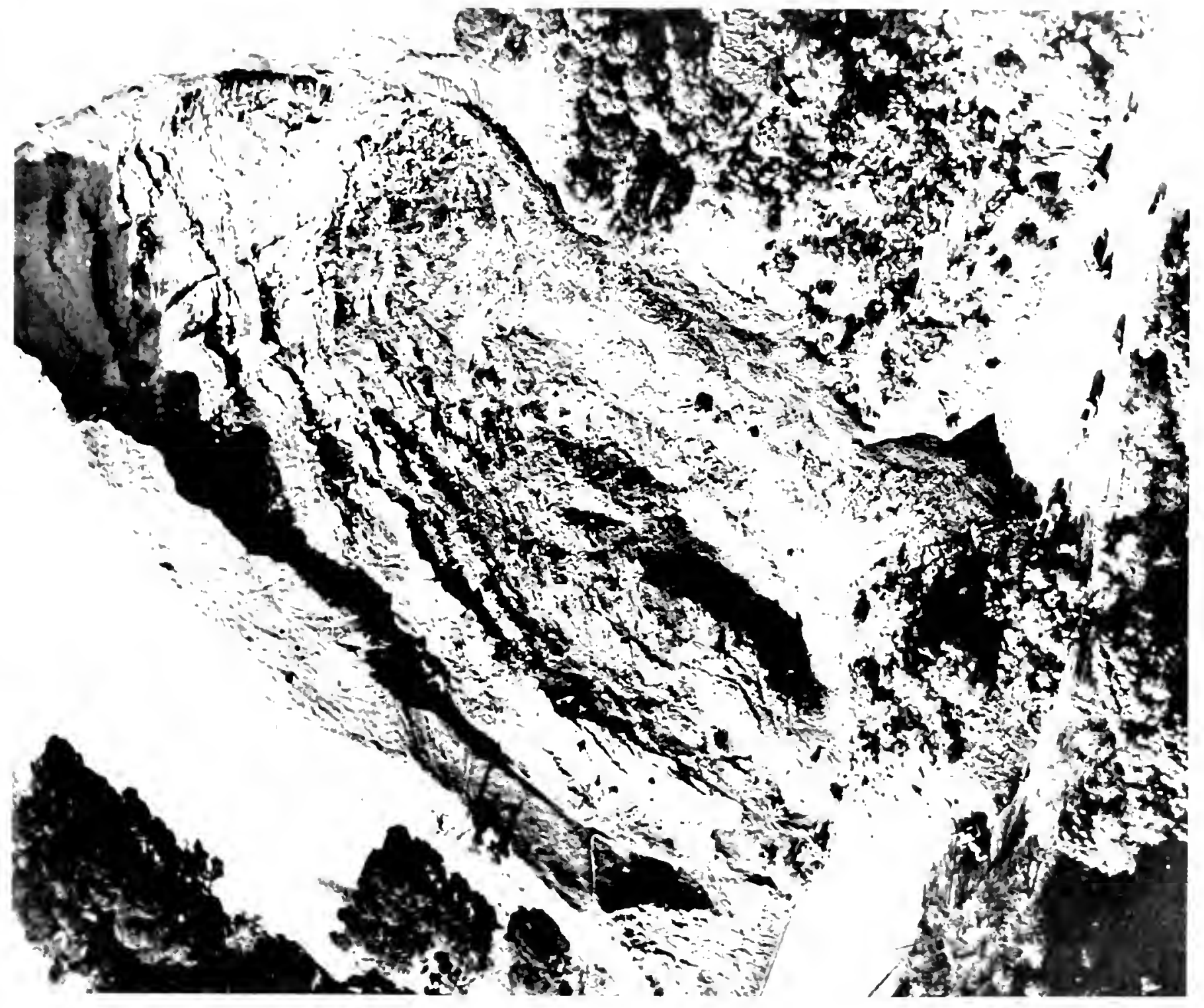




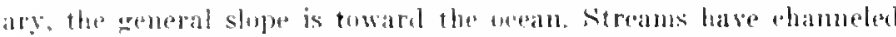

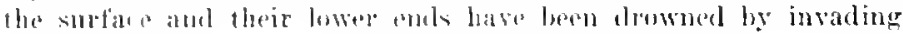
sea water.

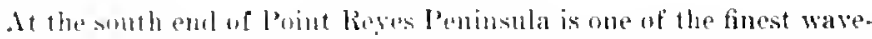

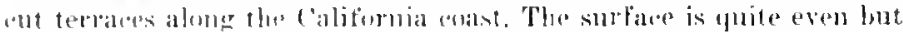

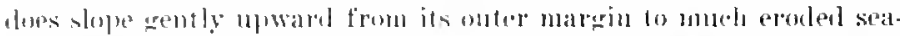

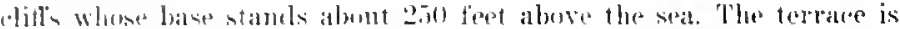

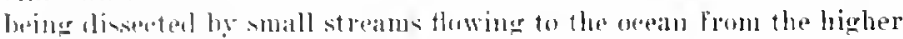

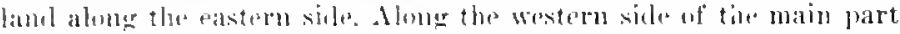

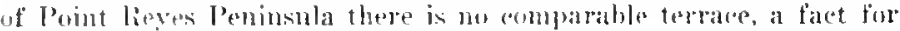
whioh we have no explanation.

As wht must of the chast lianges province, landscape evolution in

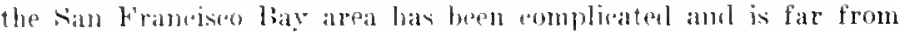

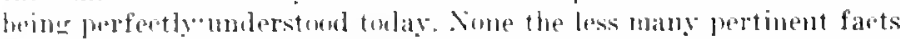
are known which arive at least some molelstandine ot the history of

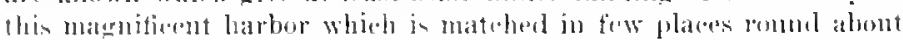
the worlel. The bay wenpies part of a lome valley lying between and

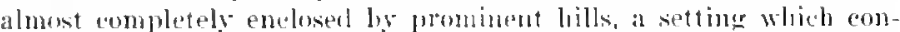
tributes to its beanty. Along the western shore, headlands and peuin

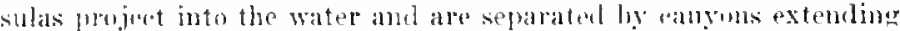
fal into the hills. In eontrast about fo miles of the eastern sible is lowlered by a low plain which slopes arently to lhe hase of the Berkeley

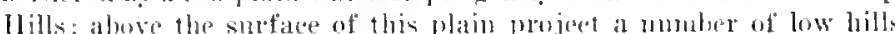

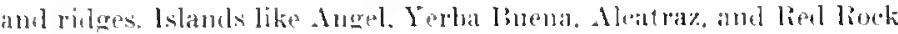

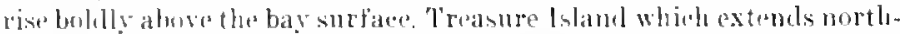

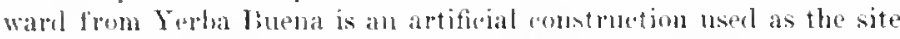

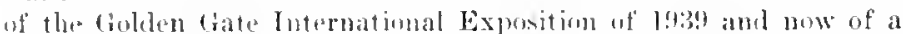
erreat manal fistablishment. There also has bern comsiderable addition fo the lamel alomg both eastern and wastorn shores of the bay by man-male fills.

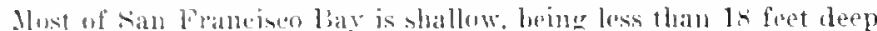

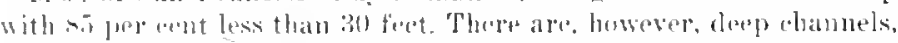

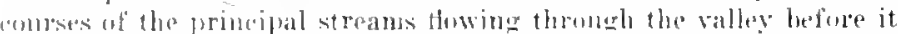

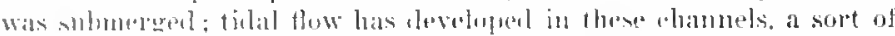

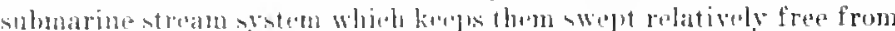

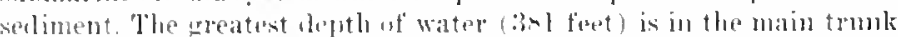

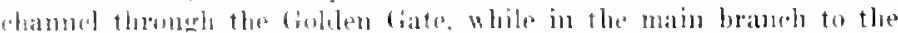

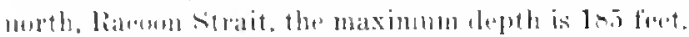

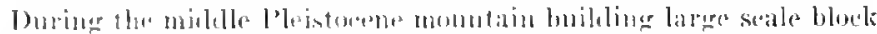

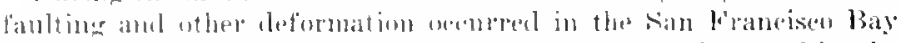

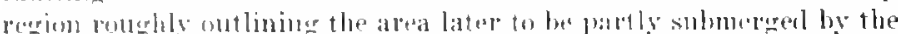

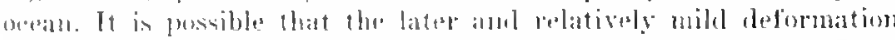

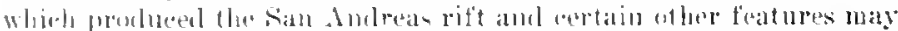

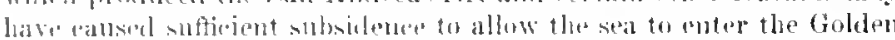

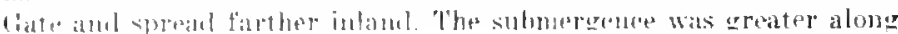

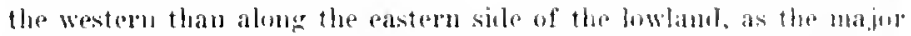

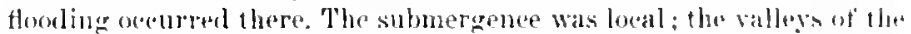
Rusian River 50 miles north of the hay and the l'ajaro River soluiles soutl were not drowned. Bolinas and Tomales bays wore antablishol

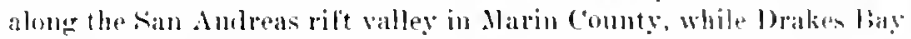

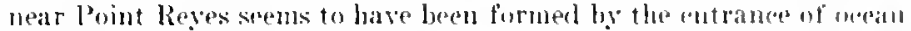
water into the hoal of a valley system which drained suththard tuwal

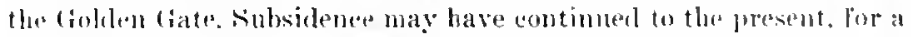
large whell mumd on the east side of San Francisoo Pay near limery. vill. stambs mowe than 2 feet below sea level amd similar situations exist thewhere. Ilowever, another explanation of the bas "s oridrin must be considered

It is mut defintely known when the drainage from the fireat talley hegan to reach the sea in the vieinity of San Franeisoo. but reptainly there is no evidence of surch a sistem prior to the late fliocene deturmation. Sonc have thought that the Sacramento River dicl not Hew to the l'aritix (hean through the Golden Gate but rather was direrted southwarl throngh santa Clara Valley to Monterey liay. The purfonderance of evidence now at hand opposes the latter combept.

The depression partly occupied by the bay has long ben rearated as being primarily the problut of deformation thouerh it is also wall known that its routour has been molifed by erosion and cleposition before the bay appeared. Early explanations called for the tiltime of

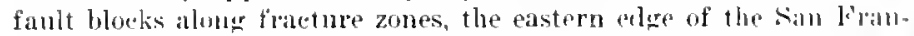
"isco-Jarin blork lying against the base of the Berkeley Jills. liut the Iravward fault, the wreat structural boundary at the westorn bay" of the Berkelyy llills, is not loeated where such a marin shmul be under the teriss of the forecoing explanation. The boundary of the sonthern part of the bay had been thought to he the Montara block which was tiltal up to the west alone the San Linno fanlt. Iluwever. it is diffinult to fit the distribution of land masses auct topoumbly into any definit" adjustment of major fault bloeks. The bay valley ansos supposed boumbary laults on both sides and transeresses ablomim bluks. Th" ralley passes at various augles over all mmlium to laraw faults in its vicinity and auts across other structures botly youme aurl

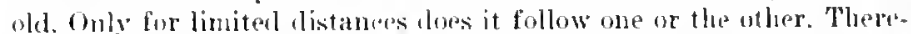
fure the most rasumable origin of the depressed area seens to be awnwarping with some slopes formed by normal open folds white others are the product of faulting distributed along zones of various widtls.

The elivation of the Berkeley Ilills seems to have been a prime event in the evolution of the bay distriet and the hrst rise of this block at tha time of the late fliocene deformation may have eoincided with the initiation of the depression now partially flonded by ocean water. Duriug the midlle l'leistoesne mountain building, the re-elesation of the lerkeley IIills was slow enongh so that the Sacramento liver 
maintained its course across them, eroding Carquinez Canyon, now Careluinez Strait, to a depth of 800 or 900 feet. Possibly simultaneous elevation occurred on the west sile of the bay and at slow enough rate so that the river kept its ehamel and cut Golden Gate Canyon, now Folden Gate Strait, to a depth of mor's than 700 feet. The lower course of the Russian River north of the bay and of Alameda Creek on the south sicle also seem to coineide with their position before the elevation of the ranges. On the other hand, most drainage was obstructed by the rise of ridges athwart their paths and the former stream eourses are now represented by abandoned channels called wind gaps of which Racoon Pass, Liberty Gap, and Elk Valley are examples.

A number of streams tributary to the Saeramento River before advent of the bay entered the main valley through open. Y'shaped vallers whose bottoms are now 150 to 200 leet below sea level. Borings have shown that these streams were flowing on bedrock and therefore were downentting instead of wandering over broad alluvial fills as they lo today on their way to the bay.

Most of the bay valley hat considerably more diverse topography than the part immediately along the main river, being traversed by hills trending in directions somewhat diagonal to the main axis of the valley. Examples of these are the l'otrero San Pablo west of Richmond, Coyote IIills west of Newark, San Mateo l'oint, and El Cerrito Hill. Other pronounced eminences are the various islatnds. while lower hills and ridges now snbmerged by oeean water have been revealed by borings.

Very late in earth history eame the flooding of the eanyons and associated lower parts of the valley region, developing the first stages of the drowned valley which was to expand into the present large-sized bay. such embayments in many eases are the product of deformation, vet evidence has been obtained in the San Francisco Bay region showing that for some time prior to the invasion by the ocean, the rivers were actually eroling rising ground. This is particularly true north of the bay and aloner Carcuinez Strait.

We are now aware that many bays have been evolved by the rise as the great ice sheets and other irlaciers of the last glacial stage melted or receded. However. in most cases it is not possible to tell whether all of the submergenee resulted from inerease in the volume of the ocean or whether deformation also played a part. Evolution of San Francisco Bay by rise of sea level is eonsonant with much evidence which has been accumulated regarding the recency of its appearance, for the flood spread not only over the depressed area but also over some that was rising.

The ocean first enteresl the month of Golden Gate Canyon which was being eroded in bedrock. Sea level has probably risen about 350 feet since the beginning of the submergence. Most of the ice appears to have melted cluring the last 25,000 gears of earth history henee the main devolopment of present-day San Franeiseo Bay must have acenred durine that interval.

The growth of the bay of course was slow. At first the streams retained their way to the ocean by way of the trunk channel through the Golden Gate, though ticlal markiges gradually developed along their margins. $A$ s the ocean eontinned to rise, it drove the mouth of the Saeramento River baek, progressively isolating tributary streams. Some hold that 10,000 or 15,000 years probably clapsed before Carquinez Canyon was invaded and the ocean rolled into the lowlands of the Great Valley forming Suisun Bay. In faet the growth of the bay may have eome very much closer to our time than the date just indieated.

From recent studies of sea level changes during the last glacial stage, some authorities believe that the lowering of ocean level did not amount to more than 250 feet. If this is eorreet, the picture just drawn must be modified somewhat. The bay may have existed on sunken land prior to the beginning of the last glacial stage, then grew very much smaller as sea level fell, and funally assumed its existing dimensions as the orean rose in exceelingly late geological time.

With increase in the depths of the bay, it beeame a basin in which settled great volumes of seliment transported by the Sacramento River and its former tributaries. Advent of man to the recrion eontributing sediment has greatly aceelerated the rate of deposition, mostly from livdraulie mining, but also the result of ever inereasing farming. overgrazing. improper lumbering, forest fires ot human setting, and other activities. The great bulk of sedimentation is at the north end of the hay, but the sonthern end also gets a eonsiderable volume. Deltas have been eonstructed at many of the stream mouths and their inner parts lave grown above sea level as delta plains like those of Napa and Petaluma Creeks. Sedimentation is sufficient!y rapid so that the bay will be filled in a relatively short geological interval unless deformation intervenes to deepen it.

Beyond the Golden Gate and extending past the Faralton Islands lies the continental shelf which is wider in this seetion than along most of the California coast. The shelf prohably represents in part the delta of the Sacramento River when it flowed into the Paeifie Ocean through the narrow gorge of the Golden Gate, but it has been added to by sediment earried from the bay during the flood season and dropped beyond this strait.

Rising above the low plain bordering the west side of San Franciseo Bay or from the bay itself is the rather rugged, low, hilly block known as the Berkeley Hills. Some hold that this mit is part of the Diablo Range while others consider it a separate mass. The principal rilges in the Berkeley Ilills are direeted sontheast ward and the valleys between them have heen etched by streams either into weak layers 


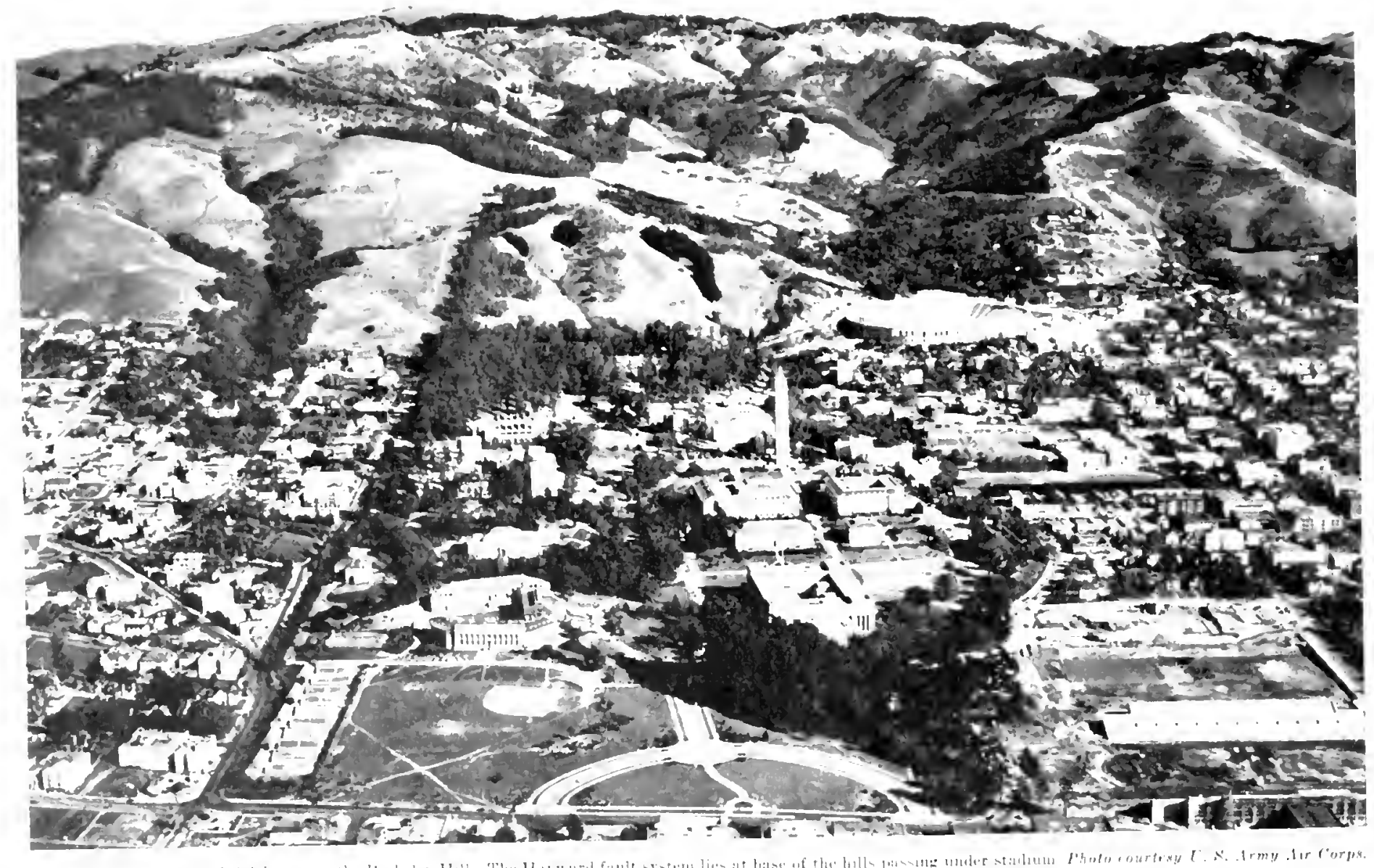




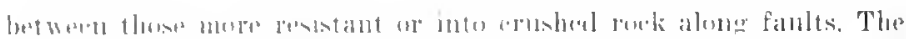

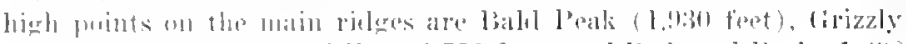

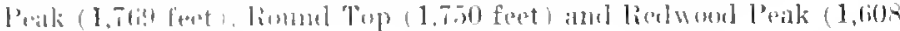
intiol

Tho lBerkeley Hills block is bounded on the somthwest ly a zone of intense deformation in which the prineipal foature is the atetive IIayward fault. It is quite wertain that the zone of wakness eonsiderably antedates in oriwin the fault just refered to, a situation comparable to that found along part of the San Andreas rilt. It is possible that the Halward and San Andreas systems join sonthward nl'ar IIollister, though this las not been positively demonstrated.

Alone the Ilayward fault there are basins and buttes similar to those along the San Anclreas rift. One particularly well developed basin contains the southernmost green of the Berkelay Country Club; this may be seen just east of Ardmore hoad whind leals from Berkeley to Richmond. Perbaps the most striking feature along the rift is a lone, narrow, interrupted valley between Clarenont Creek and the vieinity of Hayward. As the western searp of the Rerkeley Hills grew in height, consequent streams began to flow down it and earve young canyons: this drainare is directed southwest watrol. Thus the valley following the Hay warl rift and paralleling the trend of the Berkeley Ilills is ont of aecord with the normal trend of valley development. In this section between Claremont Creek and lfayward, most of the trainage has been diverted for short distances along the rilt ralley before it refurns to a normal southwesterly direction throunh bregehes in the rift valley walls. The western slop drainacre of the Berkeley Ilills therefore appears to be older than the rift valley, where erosion has been made easy by the abundance of crushed rock developed as adjacent blocks have moved along the fault. Thus it appears that the Hayward fault is younger than the main lrature zone separating tlue Berkeley Ilills and the San Francisom Marin blocks, just as the San Andreas fault is younger than that along which the San Franeiseo and Marin County" and the Marin blocks are displaced.

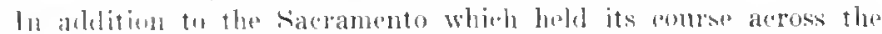

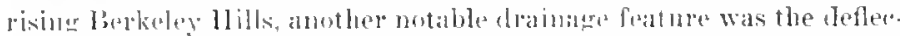

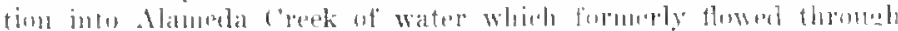

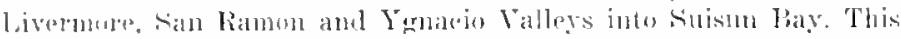

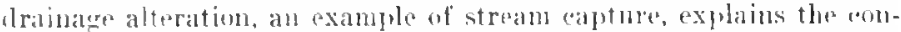

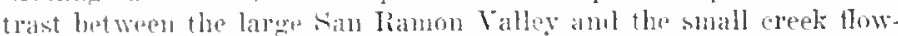

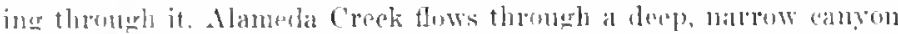

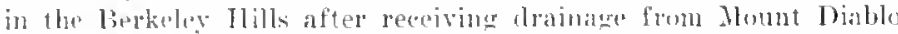
and the Afount blamilton range and flowing thrusch broad valleys east of the Berkely. IIIlls. Its numse botween sinnol and Niles evidently was establishad before the glevation of the hills. whosi rate of uplift was such that the stream was able (o mately it, emoling the "anyon which it now oecupies. Such streams, of which the lower courses

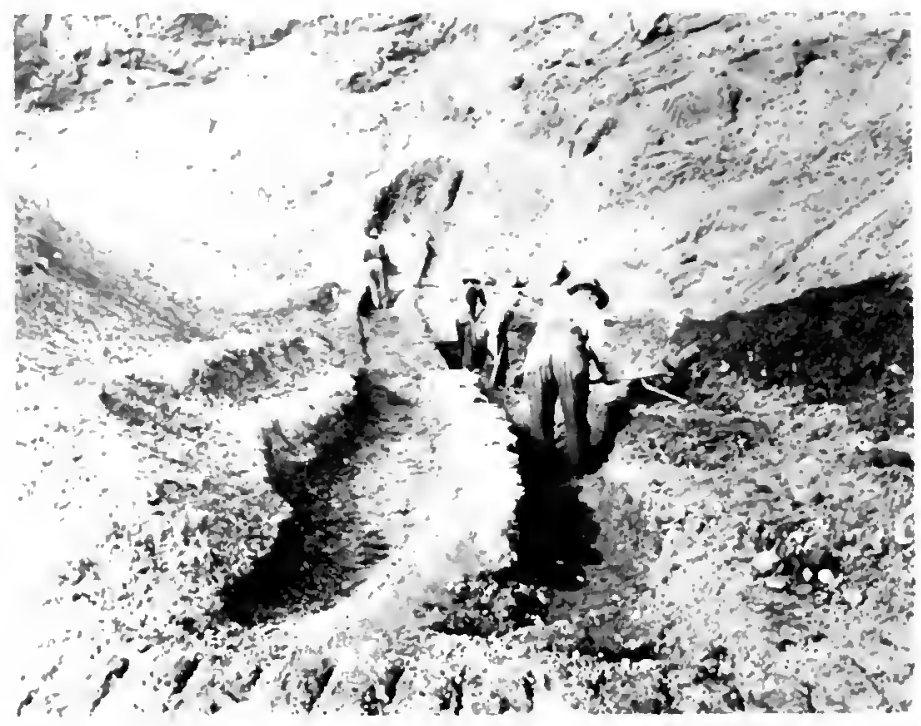

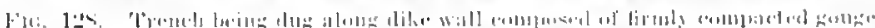

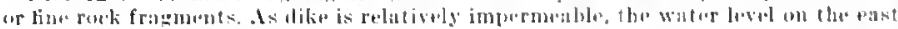

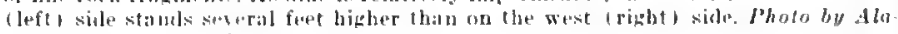
meda rounde llinter listrict.

of the Sacramentu and the liussian liver are axmples, exist before the appearance of a mountain rance, continue to How aress it thronert deep canyons, and thus are said to be antecent nt to the uplitt.

In excavations along the llayward rift framented row of the crushod zone has hern exposed. Well iblustrated at many places are the polished, seratched, and grooved surfaces produeed by the grind. ing of rouk masses arainst each other.

This zone of delormation atso is marled by a series of step-faults which produce at teraleed front in the hills like that paticularly well shown between strawbery and condenices Creeks. North of Cordonices Creek such fanlts, although present, have had little effeet on the toporraphy.

Many ot her faults are present in the lerkeley lfills but topowraplie features lik' those deseribed along the llayward rift do not show aloner most of them, indieating that they are of treater age.

The structurally controlled rides in the block have been abundantly somptured by streams so that there is a myriad of deep, young gorges trending ronghly at right andes to the courses of the principal ridges. The spanmdi" nature of the elevation of the block is illustrated by a surcession of river cut terraces in many of the eanyons. 


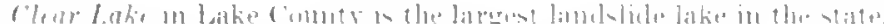
The basin is a former plain 25 miles hy 1.5 miles in sim, which wa trained by two outtlowing streams. (bne of the strams, Cohl creek. had eut a deep gorge westwarl to the Russian liver : the wher vitam, Cache Creek, proted a still deeper anyon through the range an the eastern side of the basin and erentually joimed tho sat ramentu River The eastern stream was later hroken or had its comroe displarenl mar

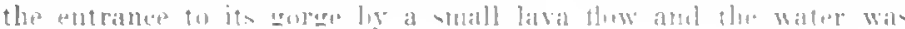
diverted into tohlel creteli.

Only a few centuries ago a large lanklide. luetaking lowe frem the midtle part of the sonthern side of the wentern grortes. filled it up for a mile or more to a higher lovel than that of the surface of the lavis flow on the other side of the basin. This lam backed uy water from the streams flowing into the (lear lake hasin until the finally urer Howed to the east through a sat ju the lava flow at the month of cache

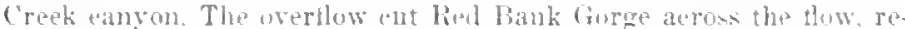
established the drainage intu ('alle (reek canwon, and reduced the lake level abont of feet. If this eastern outlet had mat developed. the lake level wold hare riven until it overtoppent the landside barrier. which would probably have been ermled si that most or ever all of the basin would have been drained. But becaluse of the eastern ontlet surface rills and leakage throngh the slile can do it little damage on aceount of its great size.

Since the parly lays of the lake, the narrow embaymut that oncupied the western rarate back of the landslide dam has been isolated from the main part by the broad delta of Niddle creek eoming in from the north and has been further hortened by another delta, that of seott Crest entering from the south. The remainder is diridet into the two little lilue Lakes by conbined delta plaits of two wet-weather streams.

('lear Lake was artificially modified more than 30 years ayo by wonstruction of a $30-$ foot dam at the entrance to the eastern gorge and by blating a rocky harrier to a slightly greator dapth near tbe entraned ol" the eastern witlet stream through the lava harripr. This male? possible the sturing of a greater rolume of water from the winter rains and of withdrawing it to lower than normal lake bel for irri. gation of rice fields in the Yolo Basin of the saeramento liven luring the summer time. As a result the lake level now usually sramo a fos feet abuve shore beaches furmed bufure these alterations were mate. However, the 25 to 30 inches of anmual rainfall orer tho ("lear lake basin does not supply" the inflowine streams with muth anore water than is lost by evaporation from the lake, honita the anmunt avalable for irrieation is small.

Recent fielel work may alter to some extent ilpas ennerning the

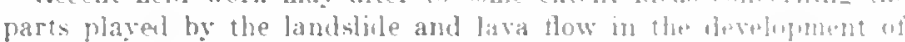
the lake. The study indieates that the doformation basin probably was

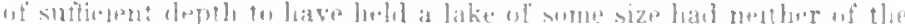

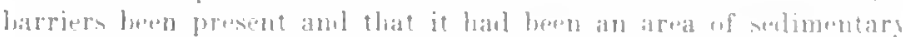

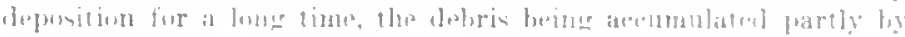
rivers amb furnly in lakm

\section{Volcanic Activity}

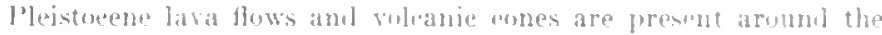
somthern marein of clear lakn latront natural boly of water in the

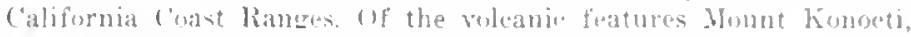

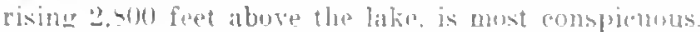

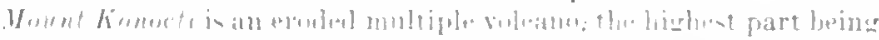

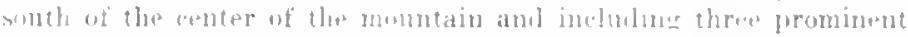
peaks, one of which apparmtly is the remuant of a sew mory cone.

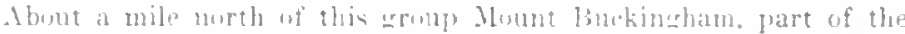
voleane, vamb at wmewhat lumer oldevation and there are other small sepondary peak

In the visible part of the bulandn. lava flom are most common, thongh fragmental deposits shww on flu lower western flanks and at other scattered areas. Konocti therefore is a composite cone.

There are remnants of several craters. the best example being Sonthern Peak, which has a shallow summit deprensin: anuther. apparently lareer example lies farther north and includes 11 ward l'eak. highest point on the roleano. Snall cinter cones dut the tlanks as is so common in cumpoite and sheld voleanoes.

The amount of erosion infirates considerable antiguty, the main a "tivity having ended in midhe or rather well back in late I"leistoeme time. It the summit of Buckinghan l'sak. there is newer lookine frat. mental material indicating pusibly more recent cruptions from this northern summit.

Siontheast of lielseyville on the western side of Clear Lake are sereral sifuare miles of pumice-tulf and breceia which appear to be the ohlest roleanics of Mount livnocti. Most of the monntain, huwerer.

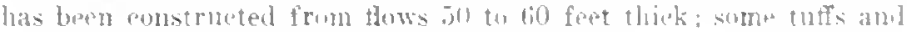
brecejas are foland between the lava flown

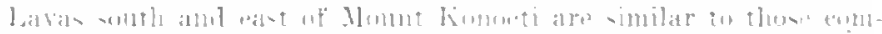

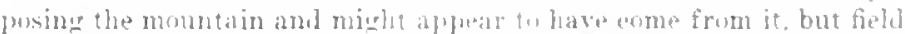

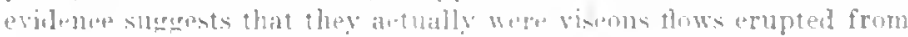
a number of local wats This is illutrated b. Thurstun late havin

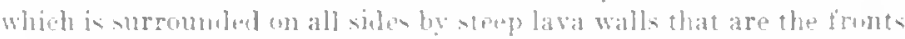
uf lava Hows. the hasin being formad beatuse the Hows coming from

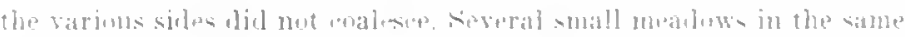
area probibly are fillet lake hasins furmol in similar fabhon The "levation of Thurston lake is about that of ('lear Lake. hut it level

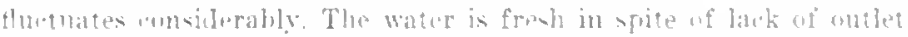

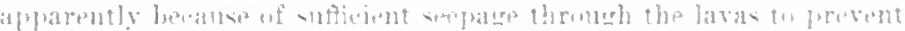

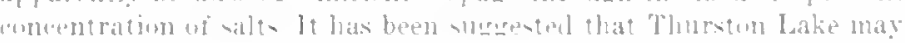

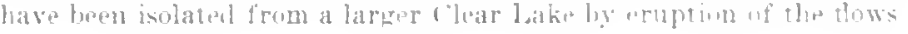



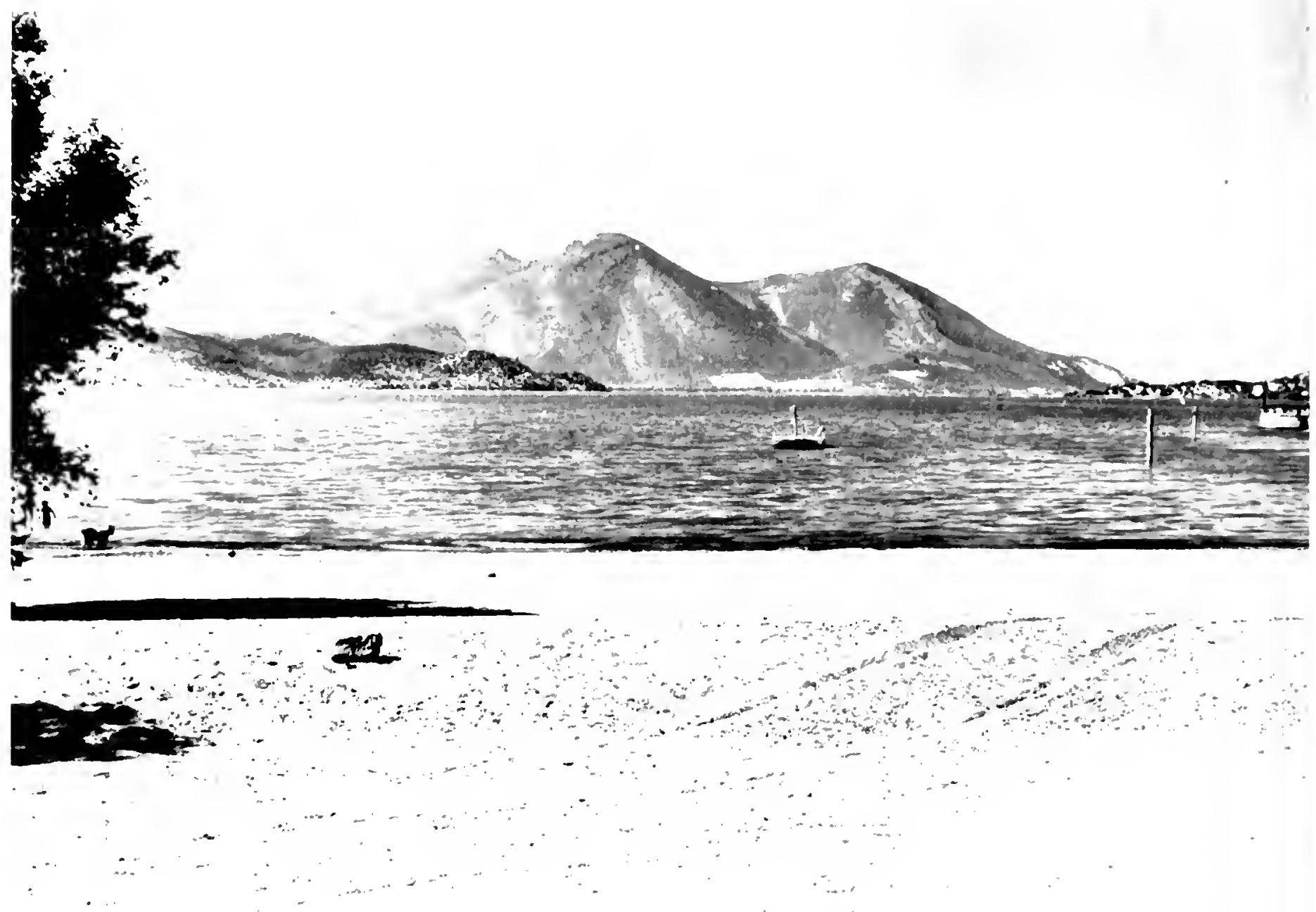

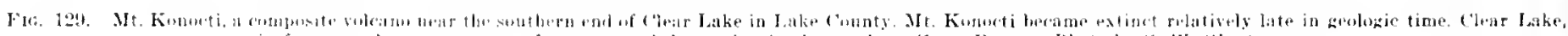

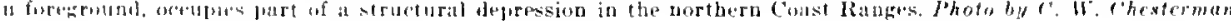




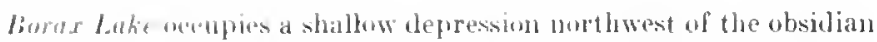
flow. Oceasionally it dries up. The source of the borax appears to be the northeast end of the obsidian flow where some solfataric artion has revently oceurred. Some sulphur is present but the obsidian is not badly decomposed. The soltataric action is now weak, though the ground is moist and warm and a faint odor of hydrogen sulphide pervades.

The most southerly of the recent cinder cones surmounts recent flows hess than a mile southeast of Thurston hake. Ijke the Sulplur bank eones it is breached, opening to the northeast. A flow of hasalt 2xtends to the east of the cone and probably is of later clate.

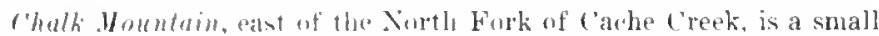
eonical hill about 400 feet high. The lava has been altered giving a hrilliant white eolor which makes the hill a prominent landmark easily visible from the Williams-Clear lake hirhwa (No. 20), whieh runs 4 miles to the south. Chalk Mountain apparently is a plug dome, extensively bleached and deeomposed by later solfataric action. There is some discharge of eold water eontaining hydrogen sulphicte on the western side of the dome, and the same gas ean be detected at the top. Otherwise the vents are inaetive. Stream terraces at the western base have been eoated with white spring deposits testifying to the reeeney of the gas action. It is thought that the Chalk Mountain dome was elevated within the last few thousand years.

Little Borax Lake oceupies a shallow erater at the base of steep slopes descending from Buekingham Peak. This erater apparently was produced by a gaseons eruption without ejection of fresh lava for none of the fragments appears to have been liquid when blasted out.

The water of the lake is saline and is said to deposit borate and earbonate minerals. Some lime deposits are above water level alonir the south sibe, but there is no hot spring action now.

South of Mount lionouti are several isolated patehes of basalt which have been partly eroded. They evidently were erupted after the development of the inajoy lanciseape fuatures in this section, lut probably are older than the other voleanic rocks belonging to the last eycele.

\section{Pinnacles National Monument}

Pimnacles National Monmment is betwen Salinas and Sian Benito valleys in the Gubilan Mountains, a division of the ('alifornia Coast Ranges. It is 3.5 miles south of llollister and about an equal clistance north of ling City. The area, because of its reuarkable topography. was sef apart as a National Monument by l'resiant Thumlore Roose.

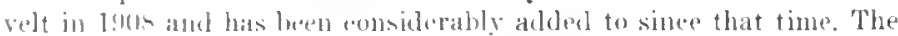
momument is most accessible from tle astern side by a branch of a road leading south from Jollister. Good trails have hen construeted so that the prineipal soenic featuresare within reach of hikers.
As the name storests, the nonument is an astonishing galaxy of rocky crags, spires, and pinuades which uake a most bizarre landsuape.

Tho area is not particularly high. Chalout Valley las an elovation of about $\mathbf{1 , 0 0 0}$ feet, while nearby North Chaloue l'eak, lijerlest point

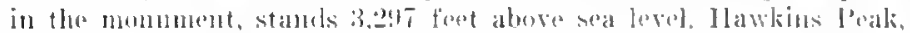

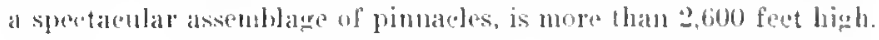

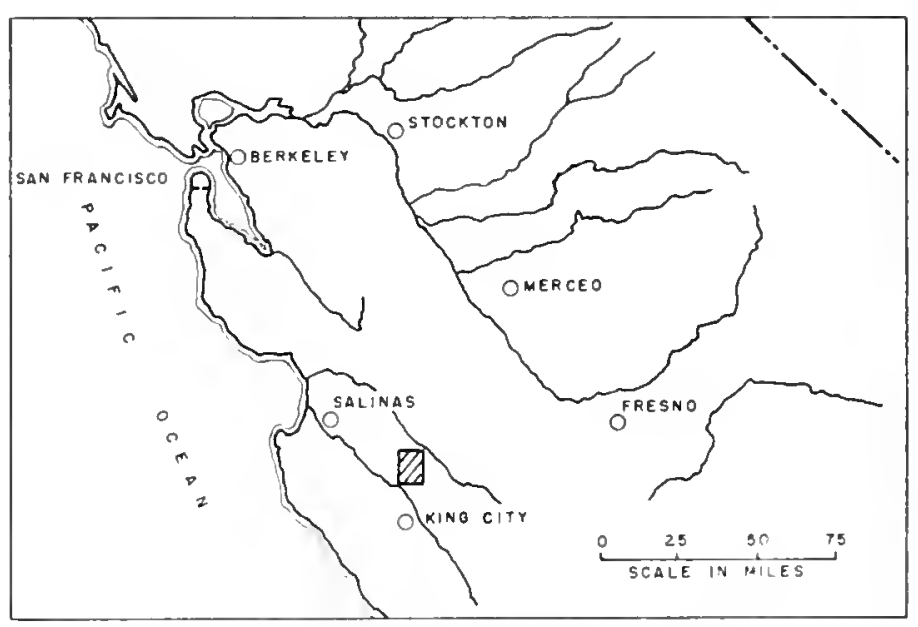

Fig. 131. Map showing lantion of l'intates National Monument. ifter Phillip indrews.

Millions of years aro, this section of Califormia was a vigorous volcanic field. Many lava tows were erupted and still yrater thicknesses of exploled products which were eemented tugether into vol. eanie breecias. In the brecoias the principal erosional foutures were sculptured after the rock had been bruken by great numbers of prominent joints. Weathering along these fraetures loosened fraquents whieh have been removed by gravity and running water, perhaps a ninor number by wind, thus enlarering the joints and evolving a wedra comples of land forms. Deposition of silin lrom water nirrating through the brewas has greatly hardened certain parts, allowing them to stand out from adjacent more easily erodable material. The lava flows also have been abundantly jointed in places so that they have behaved much like the fragmental loposits in the formation of pinnacles.

Natural ances of rather lares size are prenent alomer botla branulues of Chalone Creck, principal stream of the moniment, which has under"ut beds of massive breeid. In scouring out bess resistant material, tho 
exwation las been so extensive in plates that large. unsupported masses have slumped down. A short distane from the loumales Ranger Station, a subterranean ehamber nearly 100 font across and in total darkness exeept when artifie ially illuminated, lats benn formed by a single bluke of massive lnercia supported aromel the edgas by smaller blocks. Larape juint blocks also have rolled down the steep canyon slopes aiding the formation of the caverns

Exapt for ('halone (reek, streams thow through the monument only during and aftere heary rains. The distinctly arid elimate helps to preserve the angular outlines of the landecape and presents the formation of a heily whil entor.

Prior to the beginning of the voleanite misole, long erosion hat reched this section of California to a lowlind of wery suludned relief etched in various kinds of rocks witl granite being the chief type in the monument. The resistant granite basement was hroken by numerous fractures probably during a later deformation and along these rose masses of rhyolitite magma which solidified as sills and dikes, some of which were undoubtedly feeders for the flows poured out on the surface. The ogrliest surface eruptions were rholite flows which piled one upon another in considerable thickness. though somewhat later andesitie and basaltie magmas also were poured out. In the last stages of this flow episule, the lava apparently became quite viscous and a large, steep-siled mass was elevated along one of the fractures form. ing a voleanic dome having an elongate pattern fontrasting with the mor or less nearly eircular examples in Lassen Voleanie National lark, Mount Shasta, and the Mono Cones on the east side of the Sierra Nevada.

Then from five nearly cireular vents and possibly more, explosive eruptions blasted out great puantities of solid and liquid fragments. The largest center was that of South Chalone; the others definitely known follow a roughly north trend. The centers ean be identified beeause explosions filled them with layered masses of rhyolitio tuff while round about is massive rhyolite. In these rent-fillings, as they are called, contical pinnaeles have been earved by erosion.

The eruptions occurred during Miocene time, the third epoch of the Cenozoie era, consequently much evidence regarding them has been destroyed by erosion. I'robably the massive breceia deposits were formed by several agencies including various types of violent voleanie explosion and the erumbling of the walls of the steep rhyolitio dome which formed a deep mantle of talus. Many flows followed

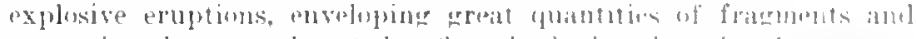

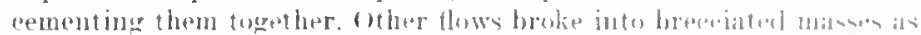

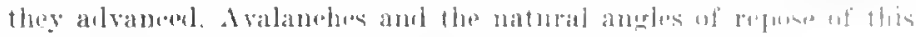

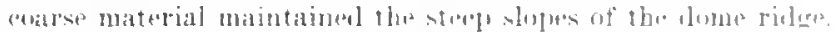

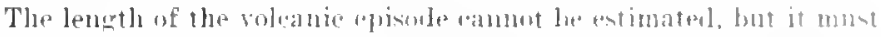

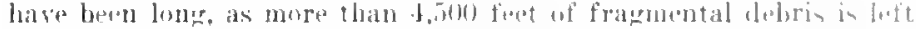

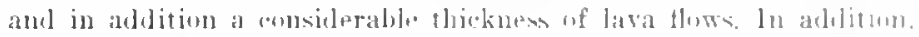
both explosisa and flow eruptions were repeated after interruphions

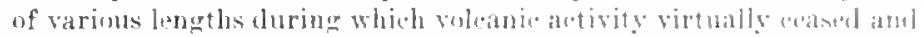
weathering and erosion of the coleanic loposits touk plan.

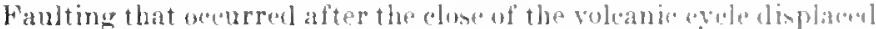
rocks along the fractures consulprably. Three girincipal faults are present in the Pinnarles National Momument, all of them being roughly parallel to the san Andreas fault which lies a few miles to the west. Erosion has removed voleanie rock from areas elesated aloug thin fractures so that the orierinal extent of the depusits camot be letermined, but it certainly has been considerably redueed. In "puit" late time the elevation of the region has eaused conspicuous crosion by invigorated drainage.

\section{REFERENCES}

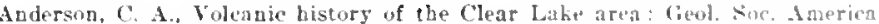
Bull., rol. 4i, n1) 6:T-tit, 1936 .

Andrews, Phillip, Gealogy of the Pinuades Nationnl Munumnt: Init. ("ali fornia Trent Gesl. Sici. Rull., rol. 24, plp. 1-3s, 1930.

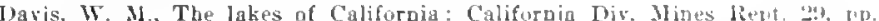
$17.1-236,1933$

Inward. A. W., Invelonment of the landseape of the San Francisen liag eunntus:

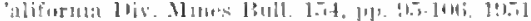

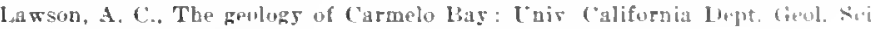

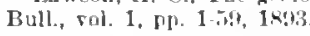

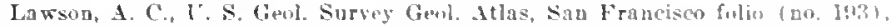
1914.

Lawson. A. C.. and Palache, Charles, The berkeley Jills, a detail of ('abist

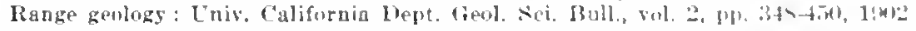

Louderback, G. D, Characteristics of active faults in the central ("onst lianges of chlifornin witb upplication to the safety of dams: Seispon. Soc. America Bull. sol. 2 T, гp. 1-27, 1237 .

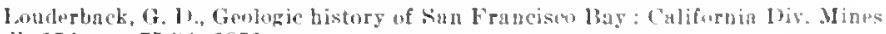
Bull. 1it, pp. 7.t-44, 1931

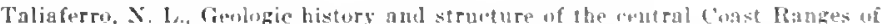
California: California Div. Mines Bull. 118. Jp. 11! 14: 1!18.

Weaver, C. E. (ieology and mineral demesits of an area netb of san Francisoo Bay, California: Culifornia Dir, Mines Bull. 14!4, 144! 


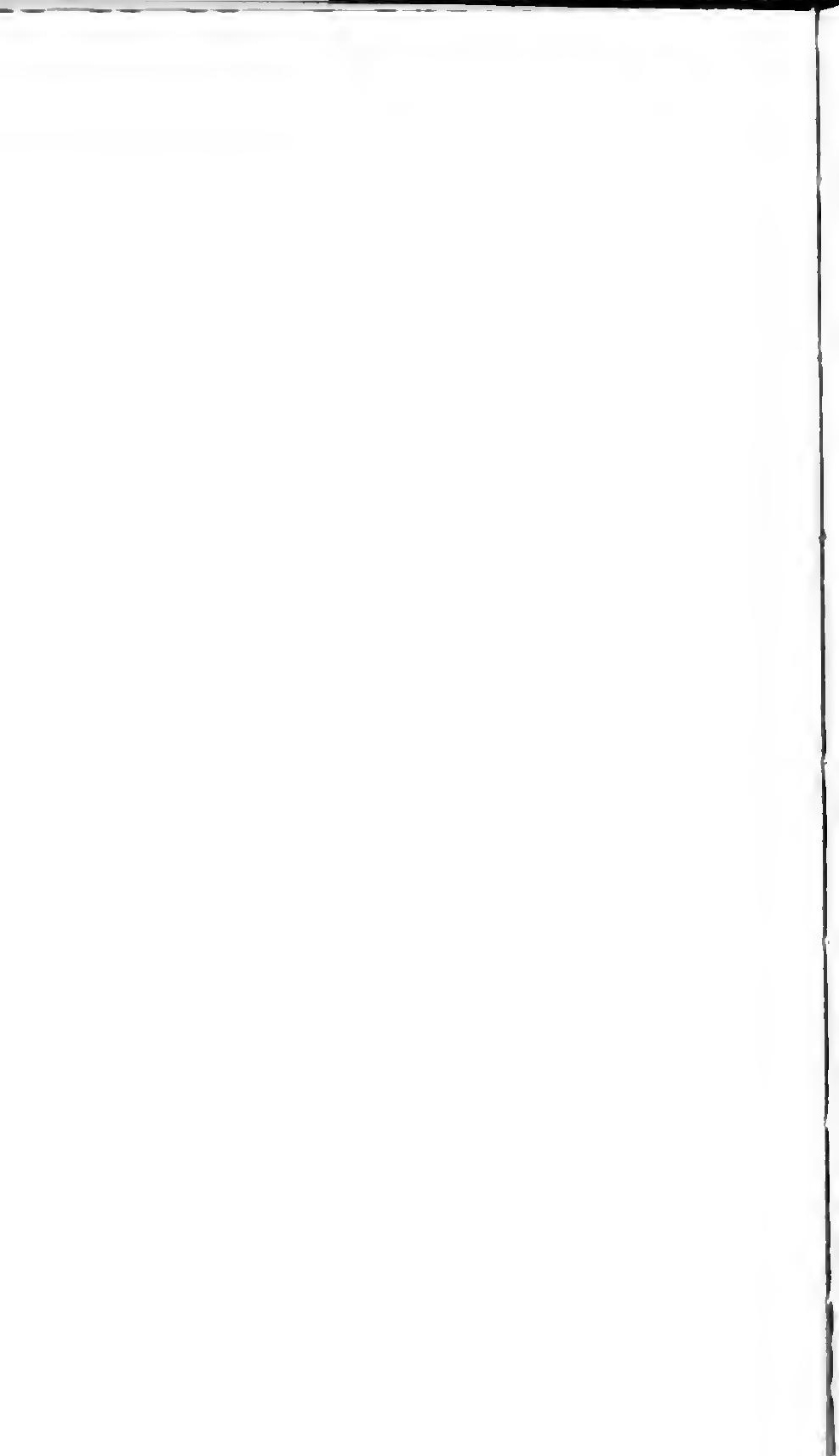


TRANSVERSE RANGES 



\section{TRANSVERSE RANGES}

Wilum flu Transwerse hanges, an east-west system in sonthern california, is a structural a leprosion extenting eastwart foum the coast and reaching soutl of the Mexican borter. The basin is the most

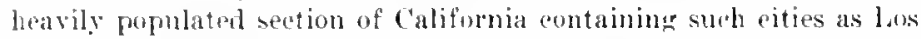
Aneros, Jong Beach, Lan Djecr, l'asadena, San Bernardino, Riverside, lixllands, and many others. It is a great arrienltural region and is beoming incrasingly intustrialized. The Transverse lianges consist of the sianta linez and other low monntain groups and intervening vallexs swoh as the Ojai and that of the Ventura River and the Santa Monica Mountains farther south which extend from los Angeles to the eoast. Separatel strueturally but a part of the transyerse systen and undoubte?ly once conneeted with it above sea level are the Channel

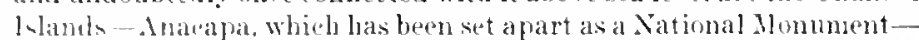
Santa Cruz, Sianta Rosa, and San Mirnel, named in order from east to west. Farther east and rising very abupty above the plains are the San Gabriel Mountuins which extend as far as Cajon Pass where the San Burnaralinn Rance, the seend high member of the Transierse system starts. The sunthern front ol the San Gabriel Mountains forms the northern bondary of Sian Fernando. San Gabriel, and Santa Ana valleys, all of which lie to the west of Cajon l'ass.

The l' ntura listrict, about 70 milen mortlowest of Las Augeles, is ehiefly hilly and mountainous. It is comprised of a number of stotions, the hicrlands being the Santa Ynez Rangre, an east-west tronuling ehain on the nortle side; the kulphur Mountain Cpland, a diseontimuous bierhland in the central part formed by Siuphur, Red, and Rineon mountains; and the Coastal llills, a low billy reorion adjuent to the const and extending inland parallel to the santa clara liver east of Sauta Paula. The chief lowlands are the Ojat liasin betwen the Santa lnéz Mountains and the Sulphur Mountain I pland, the Ventura River Valley, and tle Santa Clara Valley alunor the south boundary of the distriet.

In the arta is a nearly complete record of cenozojo hintory of coastal soutboru California, for an immense thiokness ol foposits. aloont 47,000 feet, were accumulated partly when the land lay loclow sea

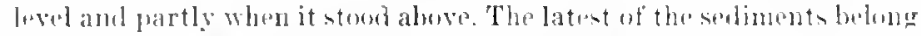

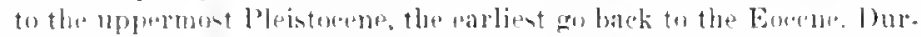
ind the mildle part of Plestome time. the entime mass was fuldul and faulted, then was beveled off with the evolution of a rather alvancel landseape. Still later, differential vertical uplift has invinurated the streams, developins the present erosion eycle.

The older landseape, hest presirved on the summit of sulphur Mountain, is called the Sulphur Mountain erosion snrtace. It was characterized by broad valleys with bills and low nountains rising

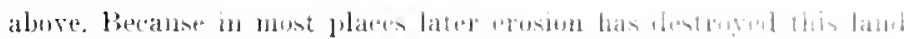

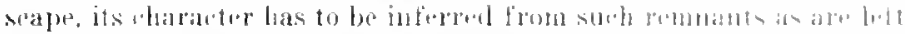

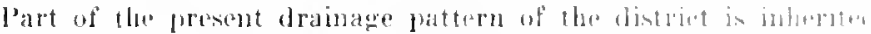

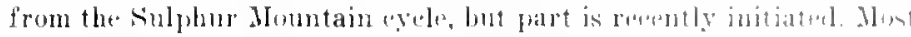

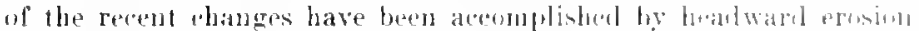

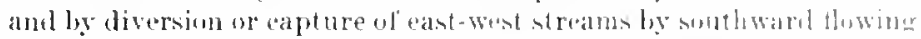

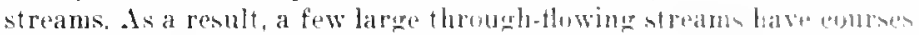

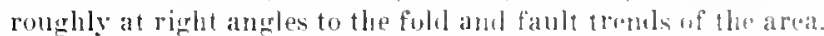

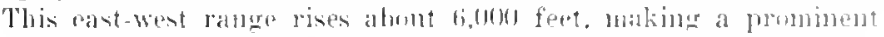

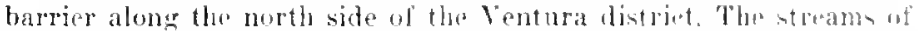
the southem part ol this range aro tributary to th. Vintura litior of tu Santa Panla Creek. They How lown steep endes and have ineind deep, uarrow rorese into the mountain tlanks. Sine these principal tributaries flow noarly at risht angres to the trend uf the lighls and faults, minor branehes have excavifed valless into the waker bed and hence parallel the structural trents. These lesser streams, havinir rached maturity, broadened their valleys and developed an almont continuous lowland paralleling the front of the Santa Yus Jlomenins This lowland, oroled in shale botween two resistant samdstone ridess. slows most prominently north of ojai Valley aud west of the Ventura River in fiennedy c'anyon.

The Ojai lowland is divisible into three parts, the santa And Valluy or western section. Jong Valley in the center, aml the eastern part which does not have a name. The sauta Ana Valley is principally a brdrock surfaro ecrered with thin rosilual soil, whila in long Valley, this bedrock is covered by river termaces. The eastern part of the lojis lowland is filled with alluvium and at the pastern end are the wo larer alluvial fans ol' Semor and llorn Canyons.

In the sumta Ana section, the two prineipal stroms are Santa dua

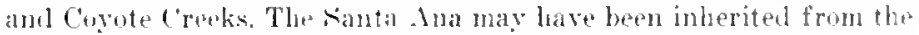

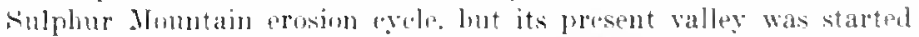

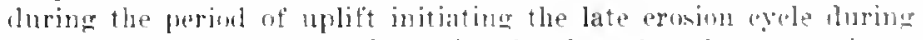

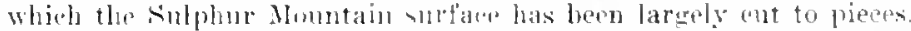

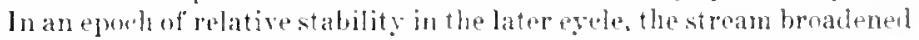
its yalley by the erosion of a wile torrace and then incised a natrow

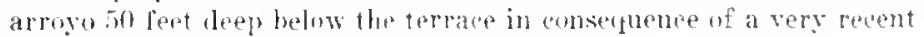
uplift invigurating the power of the streats.

Coyote Crok was establiklad hater than Santa Ina Cropk by headwall promon and hiversion of easthwing tributarios ut the santa Ina drainate.

East of Sinta . Ina Cropk, the lustory of the valley is uneptain. The

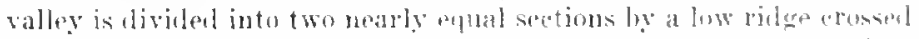
both by Santa Ana and Coyote C'retss. The two halres of the ralley 
in the area east of the Santa Ana Creek may have been exeavated by tributaries of the Ventura River when it flowed at a eonsiderably higher level than at present.

The upper Ojai Valley is a small, lens-shaped basin about 5 miles long and 1 mile wide, ranging in altitucle from 1,250 feet at the west to 1.550 feet at the east and separated from the main part of Ojai Valley by a ridere 50 to 150 feet hirh at the southern end and 300 to 500 feet high farther north. Westward the same ridge rises to 1.035 feet at Lion Mountain. The difference in elevation between the two parts of Ojai Valley probably results from erosion by San Antonio Creek along the eastern part of the Santa Ana fault which erosses the northern base of the dividing ridge. Because the south side of the fault has moved upward bringing resistant and less resistant rocks in contact, erusion has been slower on the sonthern, more resistant sicle, which now stands higher.

This neary continuous ridge, conves to the south, runs through the center of the Ventura district and is breached by only two streams, the Ventura River and Santa Paula Creek. It consists of Sulphur Mountain east of the Ventura River and Red and Rincon mountains to the nest.

The eonspicuous feature of Sulphur Mountain is the sharp contrast between the advanced mature landseape of the summit, the elerated erosion surface of earlier tine, and the bold soutbern faee. Some have interpreted this declivity as a fault scarp, but actually it has been evolved by rapid stream removal of easily eroded sbale.

Red Mountain, west of the Ventura River, is an elongate dome. In the reak rocks exposed during erosion of the dome, valleys have bien evolved parallel to the strueture and are separated by ridues of nore resistant strata. These valleys are tributary to the drainare flowins down the slopes of the dome. Such a eircular or elliptical valley and ridge pattern is often called race-track or anmular topography.

On the summit of Red Mountain are numerous undrained depressions formed by morement of masses of sandstone down the slope. The hollows range from 100 to $\$ 00$ feet long and 20 to 60 feet deep. Many eontain permanent ponds while others are partly filled or converted to grassy flats. Most of the undrained hollows are at the east end of the nountain north of a lare, now inactive slide at the head of Canada del Diablo. A large slide in Padre Juan Canyon has projeeted the amplitheater-shaped head of this valley tbrough the original erest, so that its stream is now attacking the north side of the mountain where it las beheaded several northward flowing streams.

Is is common, the slide blocks have rotated backward as they have mored, and the undrained depressions lie between the rotated bloeks and the sear left on the hillside as the masses broke away.
Rineon Mountain resembles Sulphur Mountain in its general topographie form and much of its geology. The erest is a rounded ridge falling of ubruptly to thr north and south, but rising praukually east. ward to the domelike summit orerlooking Jos Siaures Creek. This rounded erest is a remnant of the silphur Mountain erosion surlace and is the most prominent feature in the coastal area, standing "2,16.5 feet above sea level. On the south side of Rincon Mountain are 9 levels of marine terraces, the lighest being between 1.250 and 1,300 feet above sea level. The terraces have been warped in proeess of elevation and increase in altitude east ward. All of the terraee surfaees are buried by bater detritus which obscures a thin layer of older fossiliferous marine sand and gravel overlying wave-cut platform.

The Coastal Jills include the area between Sulphur Mountain and the Santa Clara Talley and inland from the evast to the eastern boundary of the regrion. The hills range in elevation from 1.000 to 1.950 fort. The Sublur Monntain erosion surlace undoubtedly extencled arous this section, but has beon alynost completely destroyed. heing replaced by a hill and valley toporraphy.

Landslides are abundant and even nore so are masses of dehris ealled earthflows that were water-lowed when they started to slide. The landslides have moved down favorable surfaces of resistant sirata whiln earthflows have occurred generally thronghont the hilly belt.

The Ventura River flows from the Santa Ynez Mountains for 12 miles before enterine the l'acific Ocean a mile west of the city of Ventura. It las a narrow flood plain in no place reaching a mile in width and in few places more than half a mile. In the lower part of its course the river meanders shightly, but in most places has an anastomosing channel, especially north of Ojai Valley. The last 2 miles of the valley seem to be underlain by deep alluvium. indicatine that there was excavation in this section probably when the sea stuod lower cluring the glacial stages of J'leistocene time.

Along the Ventura kiver are terraces which provide important information reqarding the extent and nature of deformation since erosion of the Sulphur Mountain surface. The highest terrace stands at 1,180 feet on the west end of Sulphur Jountain where it merres with the Sulphur Hountain erosion surface, indicating that the Ventura River liad evolved before the late Pleistocene uplift while the erosion of Sulphur Mountain surfaee was going on. The river probably established its course by headward growth and eapture of an earlier drainage system, mucb as Santa Paula Creek has done in diverting west-flowing drainage of the upper Ojai Valley.

Deepening of the Ventura Valley kept paee with uplift, guing on most aetively when elevation was most vigorous. Then during episoles of greater stability, the valley widened out by the development of a lower terraee. This proeess has been repeated giving a sueeession of 
terraces. As the deformation prowressed. the terraces were bent into a broad areb wheh reachel its maximum elevation at the hed Houn. tain fault.

\section{Marine Terraces}

At the base of the methern sea "diffs along the coast, there is a low waspont platform. Flevated terraces are restricted to two sections.

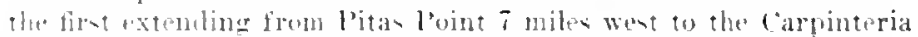
Flain and the secomel foum Pentura east to the Santa clara River. Wot uf l'itas Juint. teraten are prominent and best developed on kincon .Mnntain "here they have been recognizent as high as 1.300 fort aluse sa level. Filsewhere their number and altitule are difficult to amortain. Near linen Muntain the terraces have been tilted so

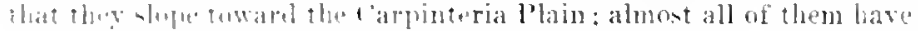

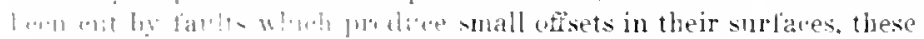

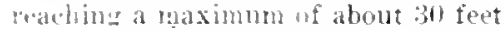

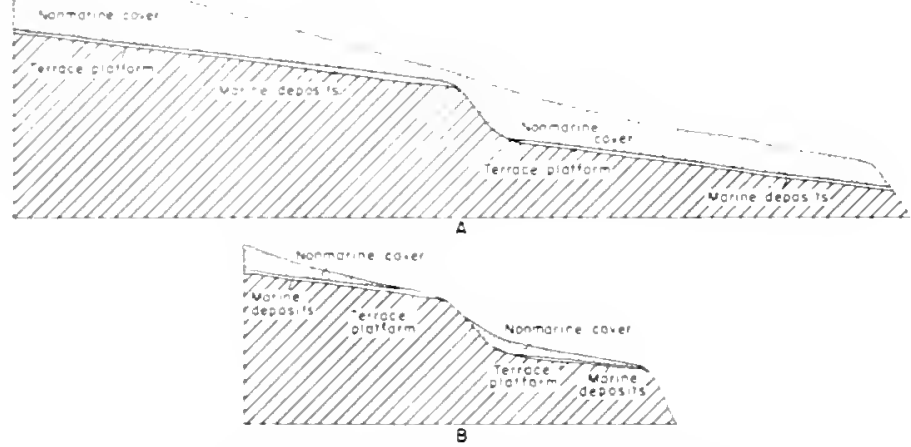

Fri. 13:. Wave-cut terraces povered by benew of marine degusits and then lurient or parially buried hy nonmeine corer of sediment aftor tebation of the lerracs. I. Conmarint iver concaling ctif between successive terraces. $B$. Xonmarine cun wher terraces hut not concealing cliff between thera. After $I$. S. Gealog. scalsurecy

Behind Ventura, marine terraces have been eroded but are diffieult to recognize because the bedrock and the terrace gravels are quite similar. Terrave form is best preserved on the lower ones and virtually liwappars abuve 500 feet; evilenee for their presence above this mevation is prineipally travel remuants whieh may or may not be arrectly identifiel as having been forned on a wave-ut surface. The best preserved terraces near Ventura are on the ridge immediately "ast of the Ventura flool plain. J'raetically the entire business district

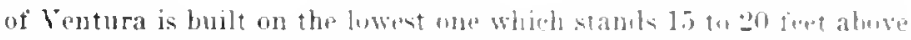

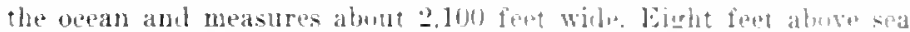
level there is a secont comsunemons bench at the past marein of the

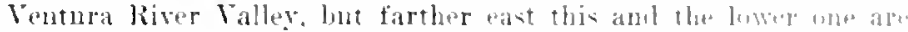
largely buried by an alluvial fan whioh has furmed at the musth ef the first canyn went of Jiall Canyon.

At 350 or 400 feet abne sia level is the Hattenet ridge, al w a marine terrace, on which stands the Serra ('rus. Butween this and a lower

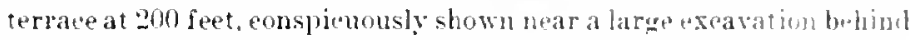
the Ventura County Courthouse, are four mime ones indicatine that the emergence of the land was broken by intervals of relative siability. sme lunger. as that when the main terraces werpe chit. and others

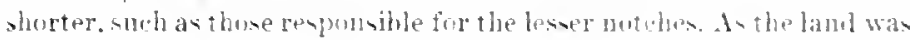
elevated. there was snme fraturing with displacenents of a few feet showing in some of the terraces.

The evolution of the present shore line has been controlled by the direetion of prevailing winds and currents and by inequalities in the resistance of rocks under attack by the waves. The unsymetrical major heallands have a Jong northern sile and are smparated by short northeast-trending embayments. The sea breezes are crenerally strmi. est in the summer when the Santa Clara and Ventura valleys connect highly heated inland with the coast. Ocean currents fluw east want al a result: the waves assoeiated with them paraltel the lonter streques of the beach and approach the shorter side of each headtand obliquly. the ande between the headland shore and wave front being between 20 and 30 degrees. Active erosion goes on along those parts of the shere attacked by this oblitgue wave approach.

Between Rinton Point and the Ventura River. the beach is a thin veneer of sand with bedrock eropping out for eonsilerable distance's. The widest beach is at P'ierpont lay sontheat of the Ventura livirer. a shallow enharment between the Ventnra and Santa Clara livers supplied with sand printeipally by the Ventura liver. The beath is not being built outward, the shorehne in places cianding as much an 2.500 feet from the base of the seaclitis, a reoult of the northwart migration of the santa Clara liver over its flom and delta plain.

The Jast event in the hintory of this section of the euant has been slight emerence, shown by a wave-ut terrate exposed along the

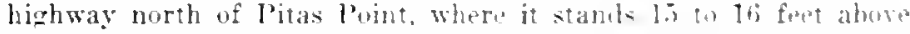

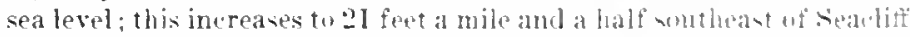

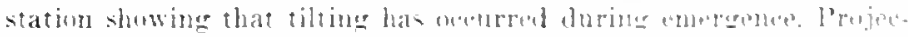

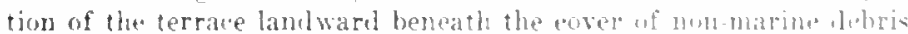

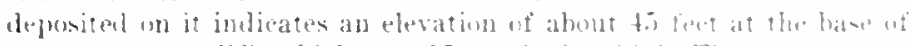

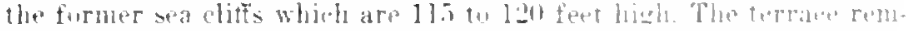

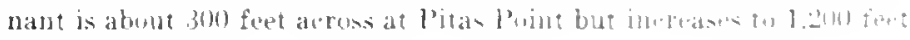
at Seaclifi station 

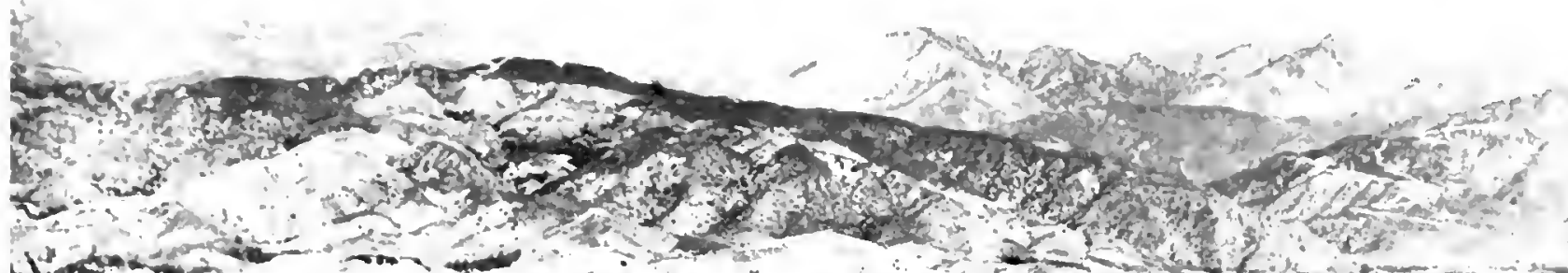

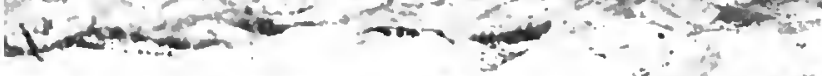

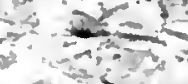

2.

$-1 x-1=0$

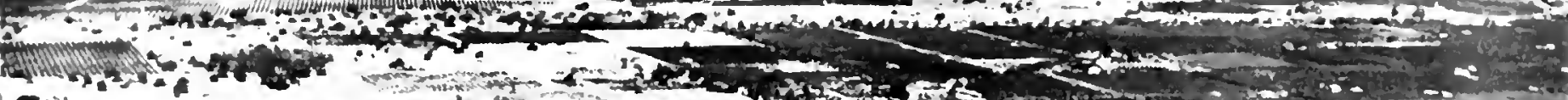

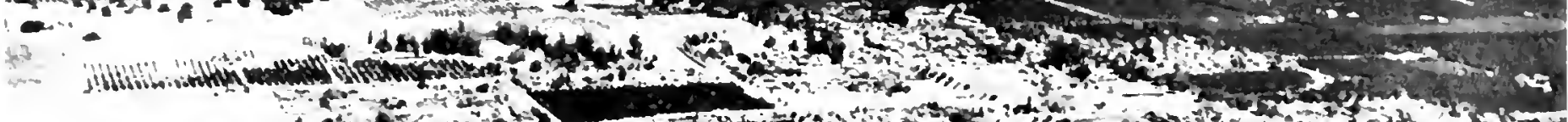
for

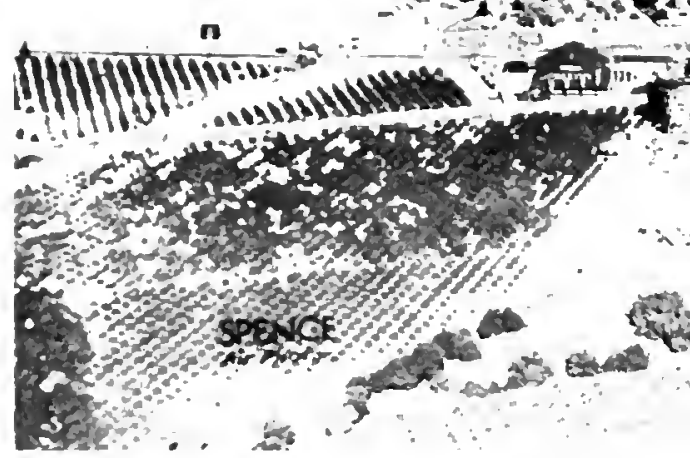
(a)

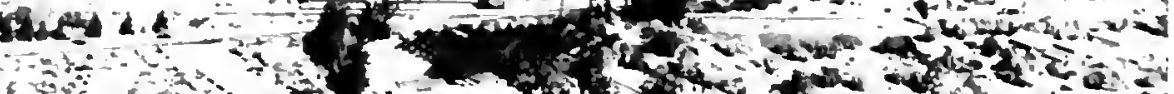

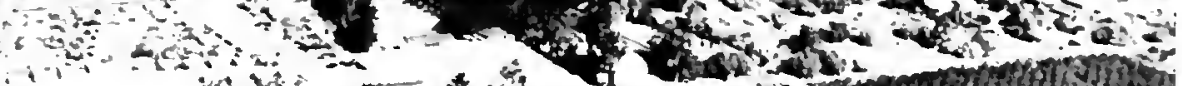
C. * +

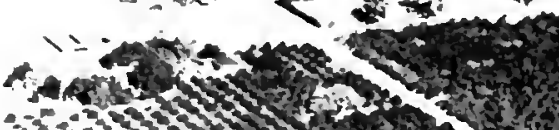

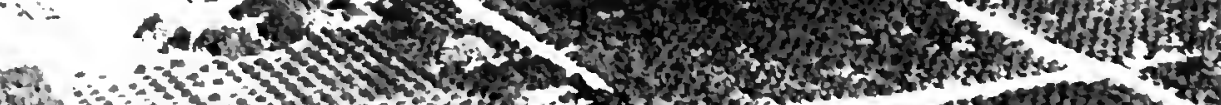
1. $\rightarrow$ H.

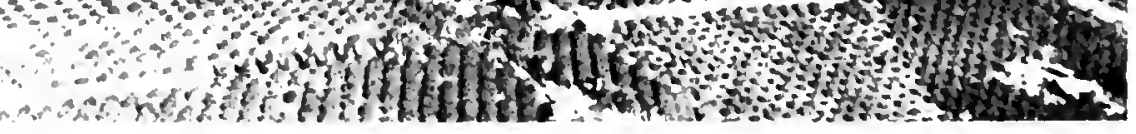

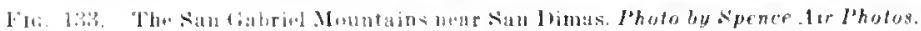




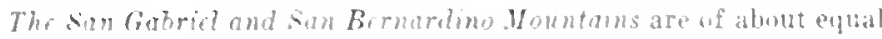
size ant form an imposing barrier extending many wiles north atu? east of Pasadena and Glendale. Both ranges are composed of a series of faulted blocks thrust upward from a region of rather low relief and elevatel to their present height during l'bistoene time.

The sonthern front of the San Gabriel Range is a bold. cunsiderably dissected slope marked by a complex srstem of faults whose base forms a sharp but irregular hine separating the low alluvial plain to the south from the mountain bloek. West of San Antonio Canyon near Claremont and south of east-west Tujunga and San Gabriel Canyons, the summits of the range are from 3.0100 to 6.000 feet in elevation. while north of this area, they rise to 8.000 and 10.000 feet, the highest point being . Iount san Intonio or Old Baldy (10,080 feet . The ridges of this portion of the Transverse Ranges are sharp and the canyons leep. hence there are few remnants of the adranced lands'ape which was elevated as this fault bloek rose.

like the San Gabriel, the San Bernartino Mountain are abont 60 miles long in an east-west direction: they widen from a point at the summit of Cajun Pass (eleration 4.250 feet to nearly 30 miles at their eastern end. The erest line of the western seetion is renarkably even and forms the drainage divide between the Mojave desert. which is part of the Basin-and-Range Provinee, and the coast. The crest begins near the summit of Cajon Pass at an elevation of about 5,000 feet ant rises irradually for about 25 miles to the southeast where it reaches 7.500 feet above sea level. Then it is broken by Bear Crete Canyon. Beyond this narrow gorge. which is more than 3.000 feet deep, the erest again rises for more than 12 miles to 9.500 fept. hut is no Jonper the Jrainage divide it eulminates in Sugarloaf Monntain. 9.500 feet high. Sullerast of the Santa Ana Fiver into which Bear C'reek enpties. the range is mont rugged and reaches its highest elevation. with San Gorgonio l'eak. 11.t-j feet above sea level, as its supreme summit

In the vicinity of San Bernardino, the south front of the san Bernardino Mruntains is a steep, battered fault searp that faces the santa Ina valley and makes a clearly defined straight boundary with this alluvial plain.

The summit region to the north of the crestline referred] to alnove is a gently rolling plateau whose high points do not rise more than 1.500 fret abure the bottoms of the valley's between them. The platean is a remant the same advanced erosion surface that is much more damareul by later erosion in the San Gabriel Mountains. I'rior to the uplift of these blocks, this tlat surface seems to have nceupied a large part of southern California, though its linits eannot be determined bevane of the ereat amomt of later deformation. The features of this "dur mpoeraphy in the San Bernardino Mountaina are sharply contrasted with the nuch more rugged topography developect as the range

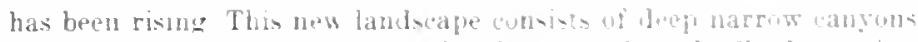

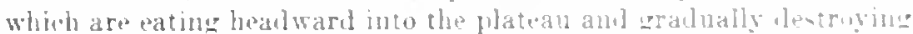

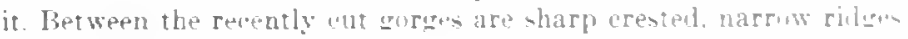
The western part of the platean ifrains into the Hujave IRver and th. eastern part into the sianta . Ina River

There appear to be wo principal fracture betts on the southern ide of the San Gabriel seation alone which this mass has riom, one lying at the foot of the range and the other sumewhat farther back within it The fault system along the front of the monutains is called the sierra Wadre: the total displacement which has oecurret along this fracturp zone is probably about 5 , on feet. juxtgine by the position of the bedroek floor at the base of the range and the elevation at the top of the searp. East of Dalton Canyon, this fault zone diverges frum the ranep front and runs along the base of foothills south of the main searp: this section is called the Curamonga fault, along which displacement ranges from a few feet to 1.000 feet west of San Antonio Canyon.

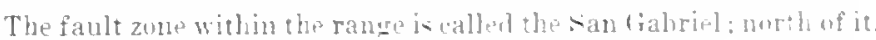
the range rises in elevation neary 3.900 feet, a change that may be due to movements along the fault.

()ther fractures that have caused less displacenent include the San Indreas, which euts the san Gabriel Ranee near its northeast margin. and has moved horizontally.

Most of the sonthrest margin of the San Bernarlino Mountains is bounded by the great San Inutras fault, the major fracture syotem in California. The several faults that diverge from the san Indreas zoue. swinging eastwarel into the range, are probably responsible for most of the uplift along the south and west sides. The western san

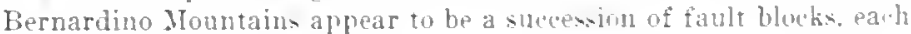
tilted to the north.

Sorth of the San Andreas zone. five important faults run eastwarl into the range and appear to have heen the zomes along which the soutlumestern part of the mass has been clevateal

The cumulative effect of the uplift which has taken place along the cast-west faults in the san Bernardino Monntains is partly we we by the tilting of the bloks northward as they have risen. However. the

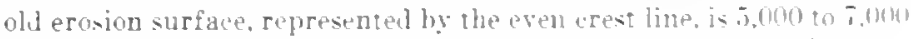
feet above the bedrock sourl of the san Anjreas fant where the sume surface shows.

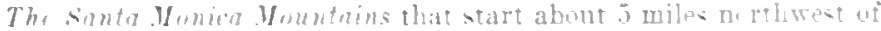

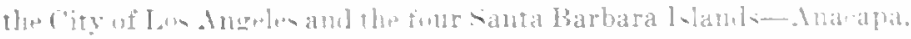

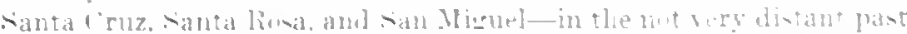

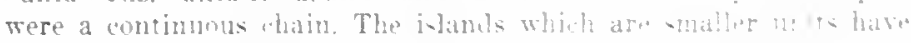

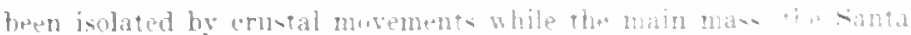
Ioniea IFountains, is locked to the land by the Veritura lasin which 


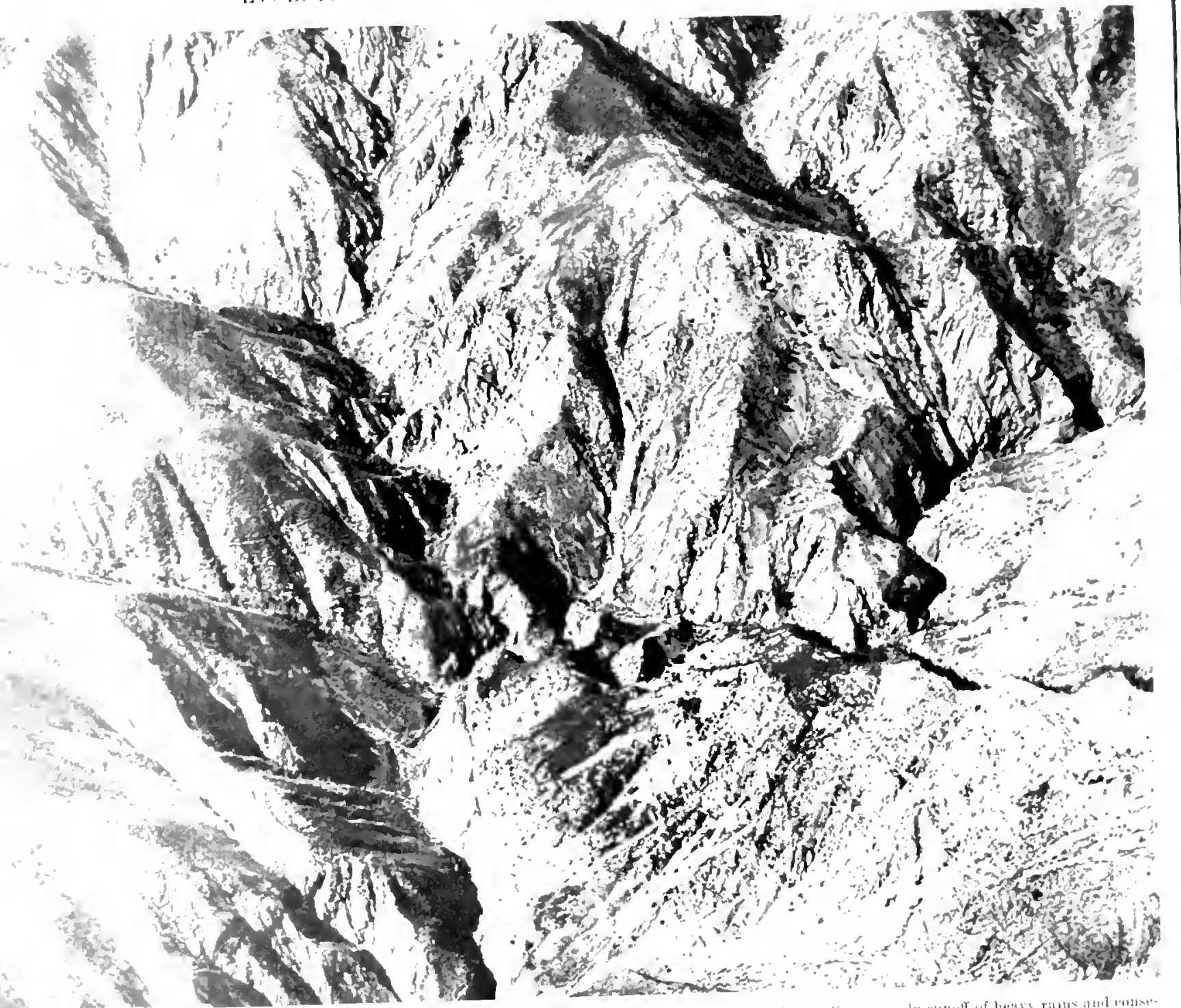




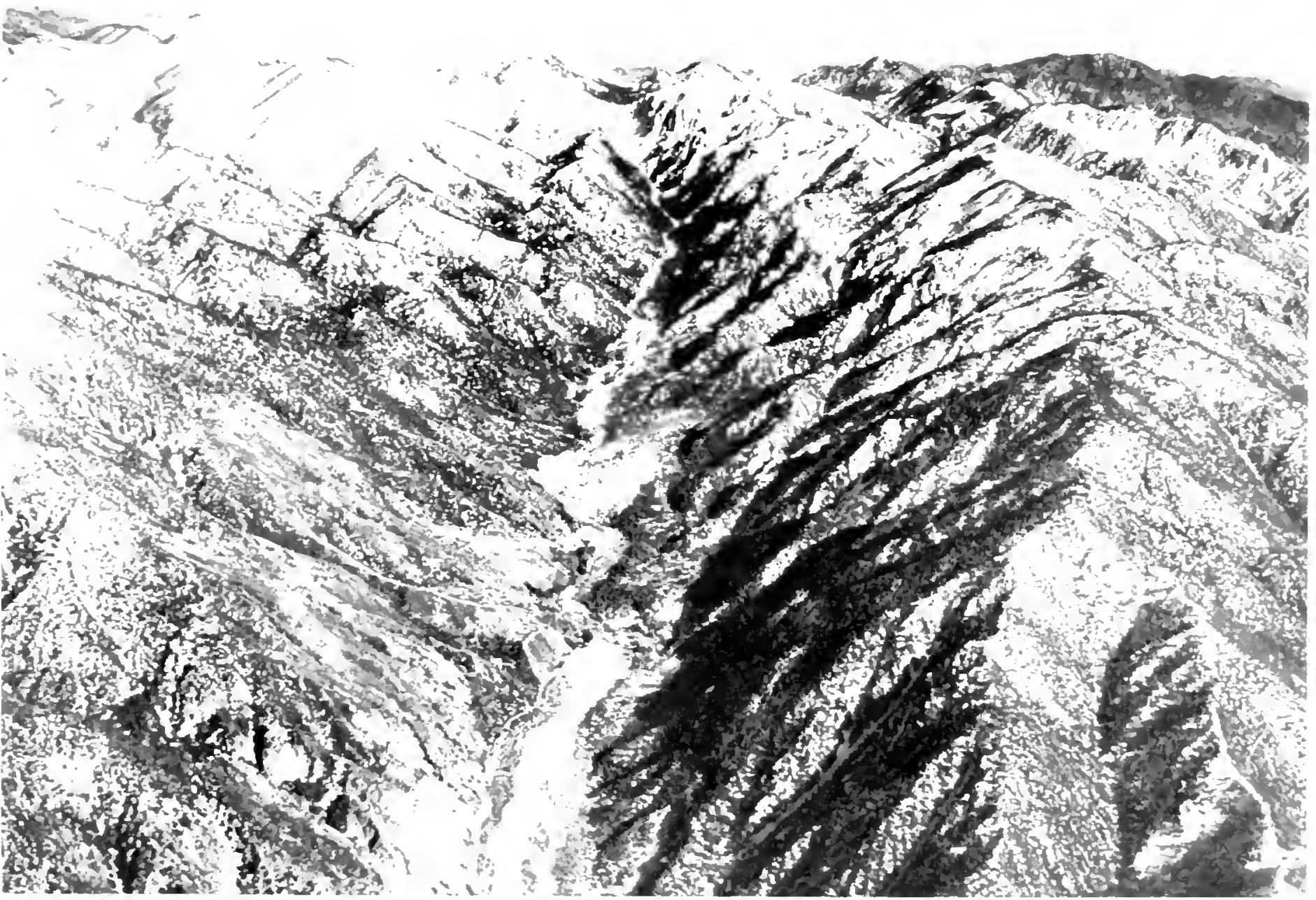




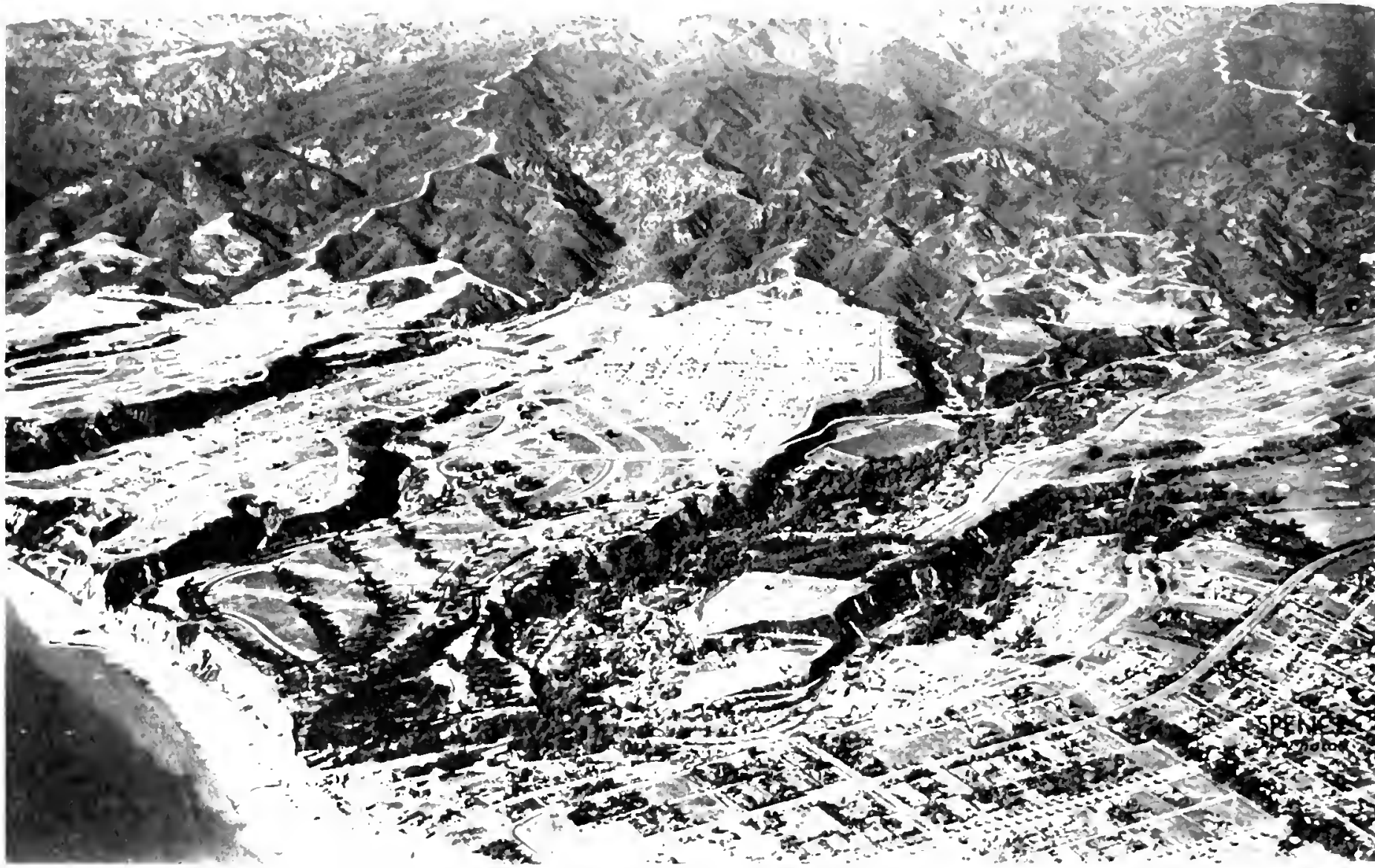

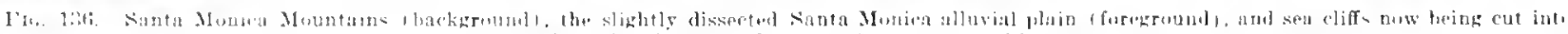

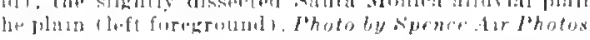




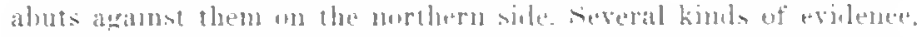

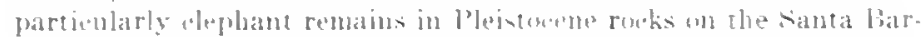
bara hamis comparable witl types fomm in rocks of the same and an the mainland, indleate strengly that the ehain was formerly com.

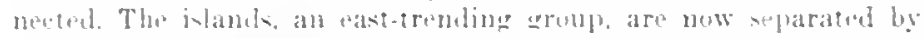
deep submarine troughts, a plan charateristie of the rather broial continental whelf offshore from the lass Angetes Basin. Studies sug-

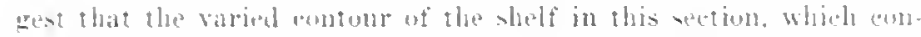

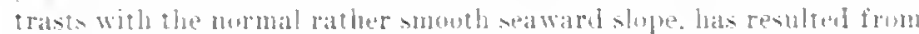
fanlting wheth developed at number of small, nearly rectangular bleks whin lave movet upwart and hownward. wiving a rather leetern-

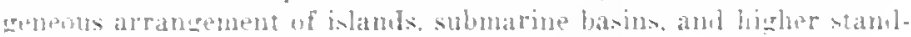
ing unlerwater areas. This faulting is ascigned to the late part of l'leistorene time.

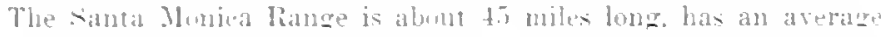

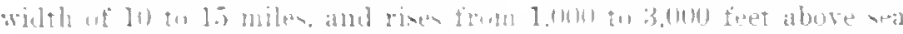

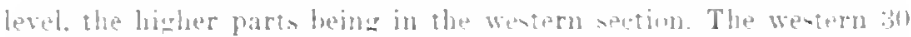
miles front on the pautic Ocan. where strong wase erosion low

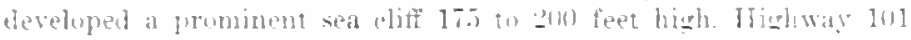

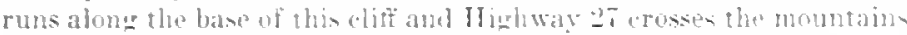

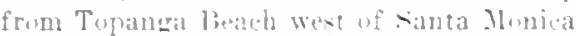

The easters part uf the sima Monica Momntains las quite sub-

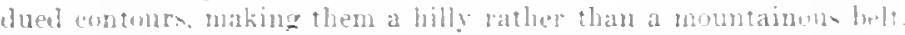

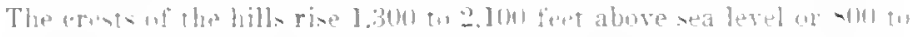
I.

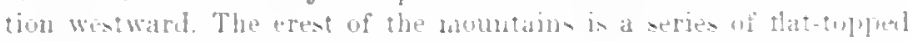
ridgen of alume the same elevation. The that tugs aplear to he rembant

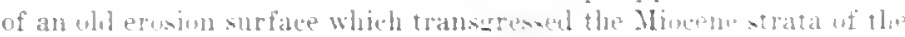

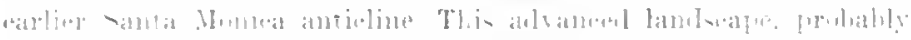

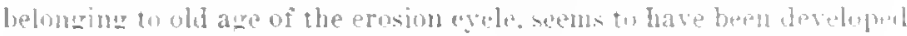

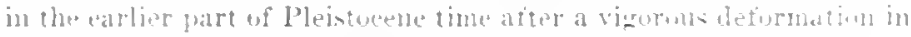

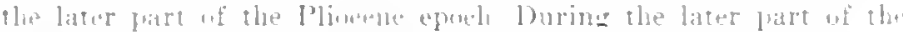

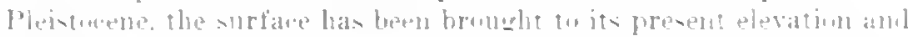

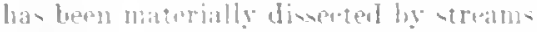

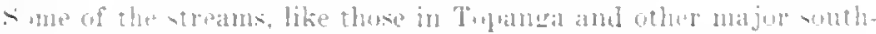
ward direted angms. are fed by ofring am therefore permanent

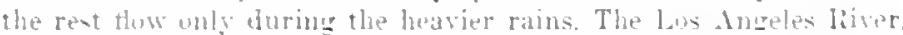

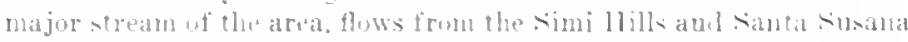

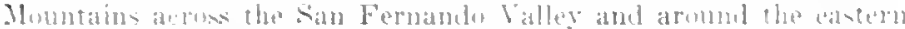

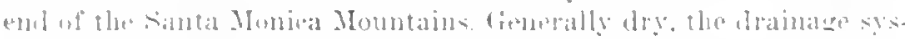
twh of ten atries wild torrents diring heary" rains

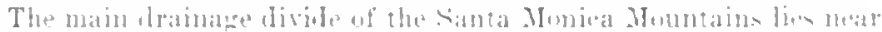

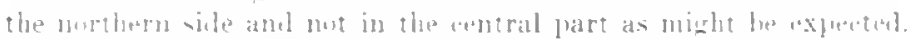
This very likely resulte from the hisher olevation of the platin an the nerth araimat the base of the mountains and the longer bivtame which the stream must flow to reach the ir lowost level of ermion.

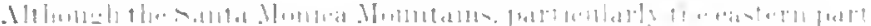

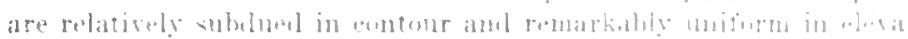

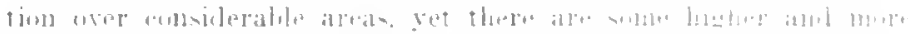

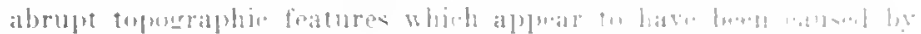

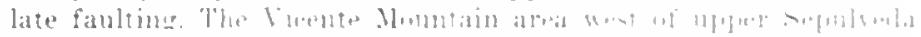

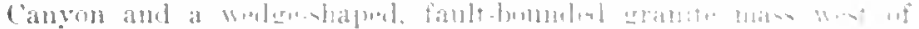

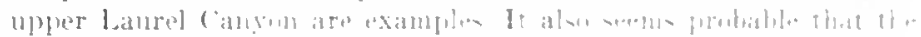

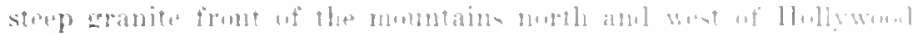

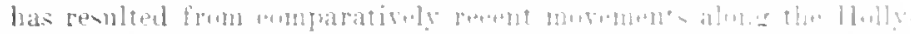

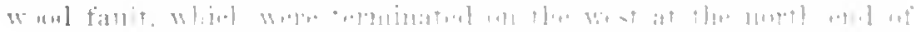

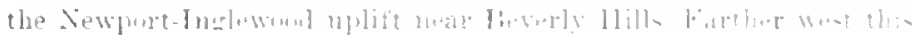

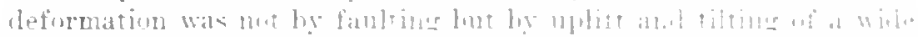

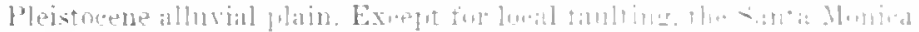

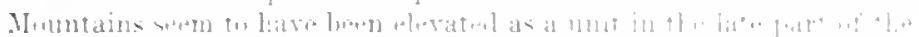

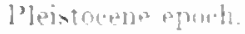

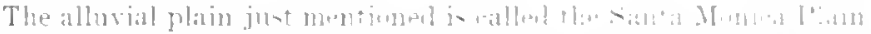

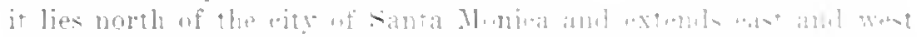

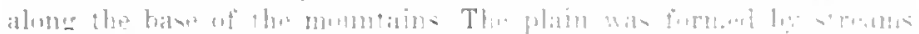

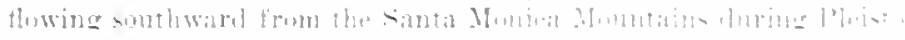

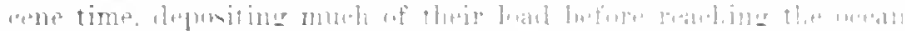

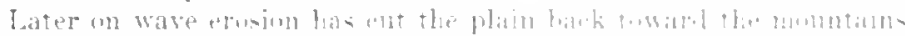

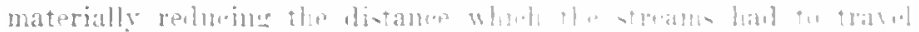

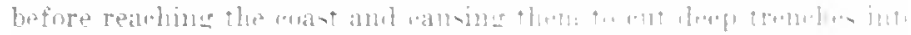

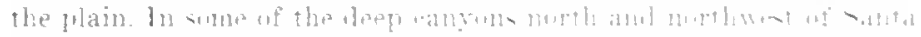

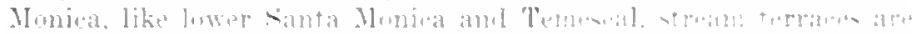

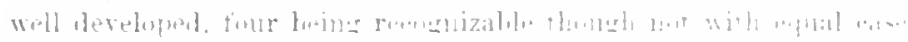

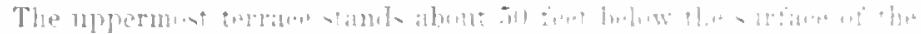

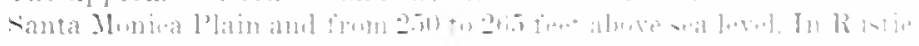

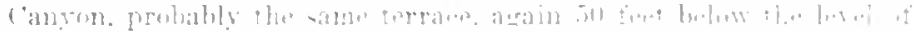

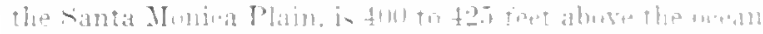

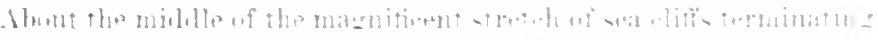

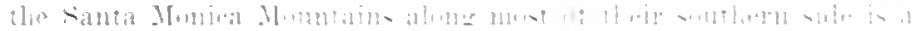

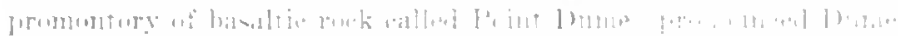

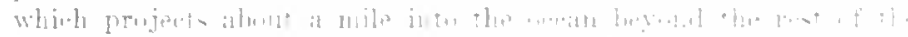

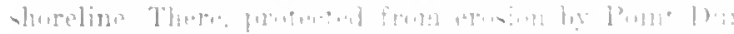

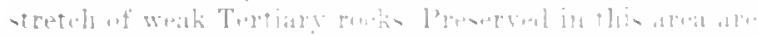

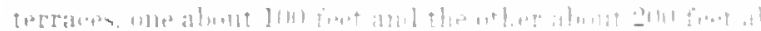

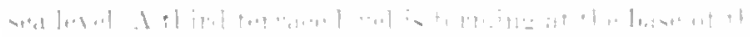

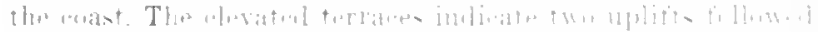

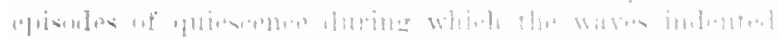

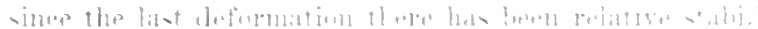

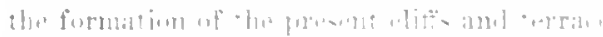

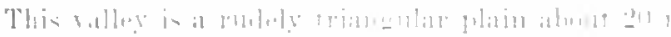

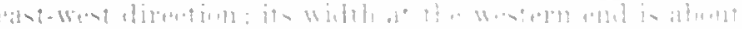

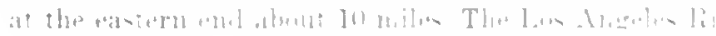

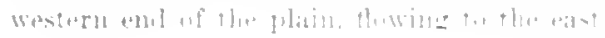


and ont through hills at the extreme sontheast corner. Almost all of the salley is a cunter of active deposition. The eastern half is covered by the lighly pervious fans male laredy of granitio grasel which have ben deposited by Big and hitth Tujunga Rivers and l'acoima Creck: the western half is coverel by less pervious cones of smaller streams draining from adjaent hills which are composed largely of sedimentary roeks.

lievend the coast, the Channel Islumets, ineluding Anaeapa, Santa Cruz, Šanta Rosa, and son Niguel, extend far enough westuard so that San Mignel lies due south of Point (onception east of Santa Barbara but is separated from it by about 30 miles of ocean. These islands evidently were once part of the Santa Nonica Mountains, westernmost member of the Transverse linges, and have been separated by the deformations which have profoundly affected this part of the California coast in quite late time. To the southeast are Catalina, San Clemente, San Nicolas, and Santa Barbara islands, not part of the first group, but all members of the little galaxy eollectively ealled the Channel Islands.

San Clemente, typical of the Chamel Islands, hes ahout 50 miles south of the Palos Verdes Ilith, the nearest point on the mainland. The Palos Verdes IJills themselves were unce an island hut have been muesed to the mainland by sedimentation. Between Catalina and San Clemente is a 25 -mile stretch of ocean. San Clemente is about 21 miles long, 4 miles in maximum width, narrowing to about 1 mile at its northwestern end. The greatest elevation, 1,964 feet, lies just a little east of the eenter of the island. From the crest, the descent on the northern side is very abrupt, dropping in one place 1.800 feet in half a mile. The southern slope is more gratual, broken prineipally hy a remarkable series of elevated marine tirraces. The bohl northern face is broken here and there by deep gorores.

san Clenente is a simple tilted fault block not greatly modified by erosion, the northern side therefore being a somewbat battered fault searp. The contrast in slope between the northern and southern side is andinnal bedow sea bevel, for 2 miles from the northern shore depthe

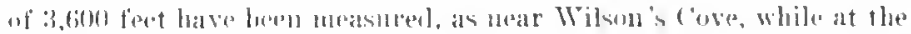
same listanter from the coast on the opposite side, the water is only 300 linet deeps.

There are minor faults paralleling the trend of the bounlary system, and low searps have been observed along them.

The outstanding features of the landseape, developed largely on the sonthern side are marine terraces, which are described as outstanding for their size, continuity, and distinetness.

As high as 1,320 feet above sea level, the terracus are so well preserved that they can be tracel for miles: more than 20 have been recognized. It is evident that the deformation which caused the chesation of San Clemente to its present height was interruptel by times of relative quiescence during which the terraces and sea elifis behind them were evolved.

\section{REFERENCES}

Bailey, T. L. Iata Peistocene coast Range orogenesis in southern Cullifornin:

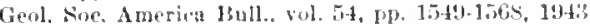

Davis, W. M., Gharial morhs of the Santa Moniea Mountains, Califarnia : (imol Sue. Anerical Bull., vol. $4+1,11,1041-1133,1133$

Eckis, Rollin, south cuastal hasin investgation: gowlogy and water sturage of valley fill: California [niv. Water Kesulures Bull. 45, 193\%4.

Jouts, II. W. Feology of the eastern part of the Santa Monica Monntains, Los

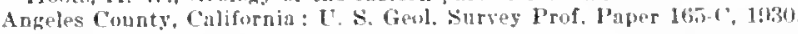

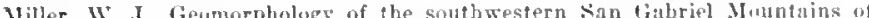
California: Univ, California Dept. (jeol. Sci, Bull, vol. 17, pp. 1913-240, 1926.

Putnam, W. C. Cienlog of the Ventura region, Califormia : Geol. Soc. America Bull., vol. 53, po. tient-754, 1942.

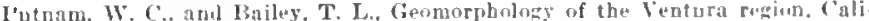
fornja: Geol. Soc. America Bull, vol, 53, pp. tol-65t, 194:.

Reed, R. D., and Jlollister, J. S., Structural ewhution of southern California:

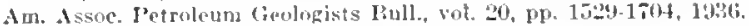

Russell, R. J. Land forms of san Gorgonio ['ass, soutbrn California: Lnis Californis Puh. in Geography, vol. 6, nT, $23-121,1932$ 
PENINSULAR RANGES 



\section{PENINSULAR RANGES}

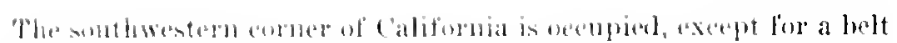

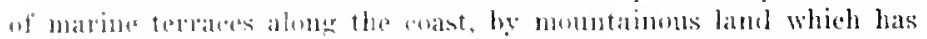

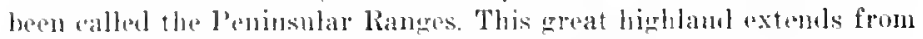
the vicinity of Los Angetes and hiversite nearly to San Fermando at about latitule $30^{\circ}$ in lower (alifornia, a distanre of mearly 300 miles with two-thide of it being south of the dlexiean horder. North of the landers lies the Transwerse Ranges l'rowine; at the sonthern end is the desert of tian lingra. "The average whlth of the Peninsular system is albunt in miles: on the California sille of the borter it includes the santal Ana Monutains which are betaehed from the main body.

'The eastern side of the provine is strikingly definet, for there a

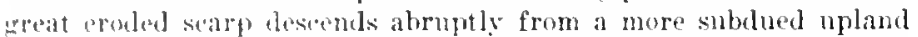

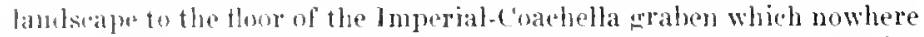
in the statestands more than a few hundred leet above sea level. With few rexptions the hirlest elevations in the loninsular hanges are locatisl alose to this scarp while the western side slopes much more grallually, In ('alifornia the highest point is Mount San Jaeinto (10.3018 feet), a short distanoe west of Palm Sinrings. Santa Rosa Hountain farther to the sonthast rises 8.046 feet above seal level.

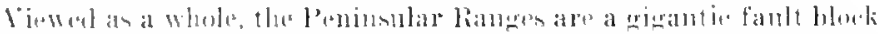
which has has raisad with tilting upward on the eastrom side like the sierra Vevala. Artually. however, this block is divided into minor mits alone subsidiary fractures which either he parallet to the boundary system or at high angles thereto. Earh blowk has had a more or less distinct landseape evolution which has depended upon the nature and marnitude of movements affectine it. The great eastern scarp, simple in places and in others developed by interseeting faults, along the lront of the San lacinto aml sinta kosa sections is comparabe in majesty with that of the sirerat Nevala frouting on cwens Valley; it is expecially ponspieuons west and sonth of l'alm Syrings. At this eity, the elevation is 45.5 fert abuse sea tovel, while San Javinto Slountain, at little more than 7 miles distant is more than 10.000 feet higher. Fur a thousand feet above the coachella Valley,

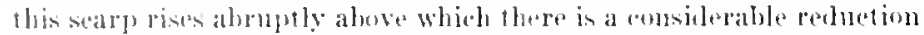
in sherse. 'l'his indivates recency of murement werating a block which had andrancul to sprater age in the soheme of bundseape evolution, and

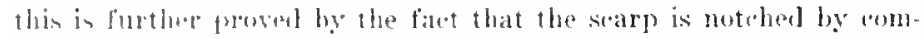

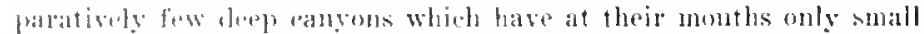

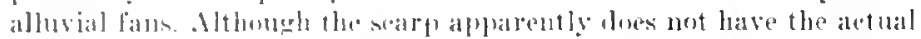

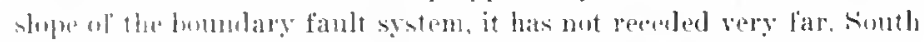

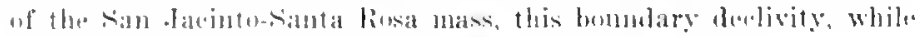

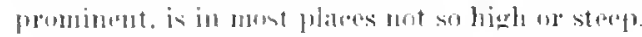

The Peninsular Range resembles the Sierra Nevala also in distribu. tien of precipitation, most falling over the broal western slepe. "lho" dominant wints come from the oceatl, rise over the hiphland, and hose most of their moisture beform raching its crest.

Descending the eastorn slope, the air is warmed, ahsorbs motstur. most of the time, and the climate becomes increasingly arit fowath the base of the range where it aljuins the desert Imperial-comblalla basin. On the western sick rain and snow are much less than at equisalent elevations over most of' the Sierra Nevada. 'The broal western sloje of the great Peninsular hlock together with the distribution of preeipitation has eaused the devalopment of numerous thourl not very lare streams thowing towart the Pacific Ocean. Becalsse of the abrupt descent of the eastem scarp and the less moisture available, the streams are short and small; they very unickly disappear after reachim the mouths of their canyons by evaporation and by sinkiny of their water in to the highly pervious alluvial fans. Only the larger flowls transport debris beyond the margins of the fins onto the flatter floor of the desert basin.

Above the searp the ehange in landseape is conspicuous, for muth of the range shows an advanced toporraphy into whill the western shop streams have eroded corres and wayous 500 to more than 1 .ino fent deep. In places this upland is gently rohling, in other's hills or mutntains of irregular pattern rise above its yeneral level. erosion residnals which had not been worn away bifore the rreat block began to rise in recent time. Also partieularly near the eastern searp. there are short detached summit ranges, some oriented parallel to the treml of the range but most directed more narly east-west. In California the more prominent of these isolated ranges are the San Jarinto west of Palm Springs, the Agua Caliente and Cuyamaca farther south; heyond the dlexican border there is the endminating range of san Peitro Martir and at the sonthern extremity of the peninsular block, the Sierra San Juan de Dios. In the western part, this broad seawal slope increases from ahout 1,500 foet in elevation to more than 3.500 feet as in Cowles, San Mipnol, and otay monntains, It rises to more than 4,000 feet in Mc('ains Platean am over 6,000 feet in the langma Momntains alonin the eastern escarpmant. Tho increase in elevation is by no means gralual or uniform, for the range has been fractured into large and small blonks which have moved more or less independently of eath other. Many of these borks stand out ats molerately well definet plateau areas, while othres, less uplifted and usually smaller form basins or valleys and valles as they are ealled. Some of the dishorated remants of a once antinuons eposion surface thave heon little atlected by the strean invigroration which has accompaniel ele 


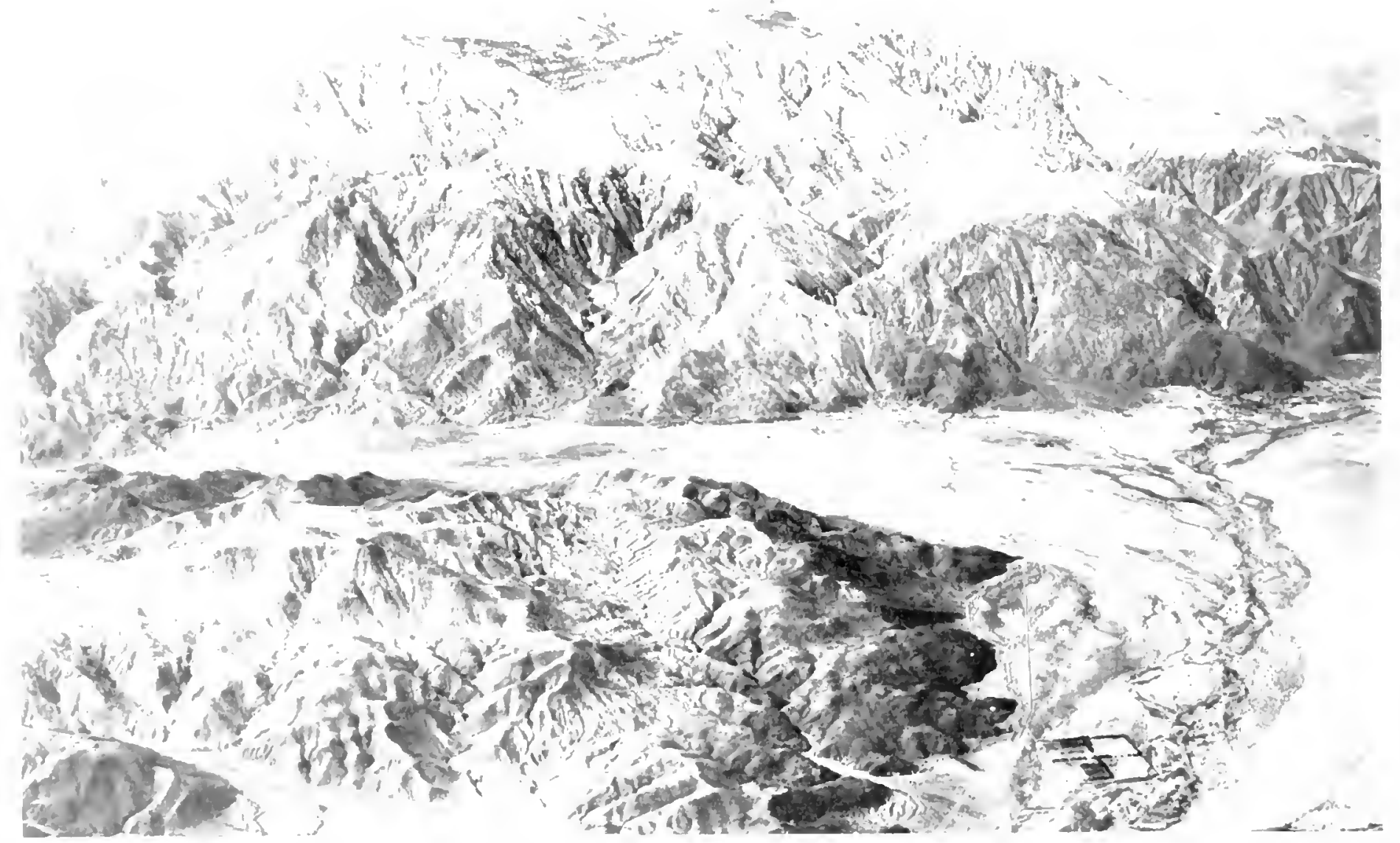

live 10- S

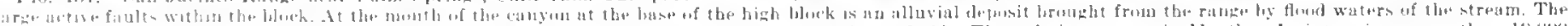

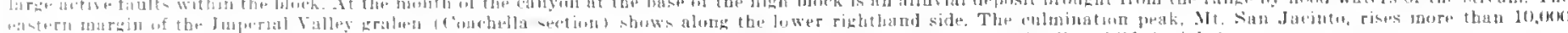

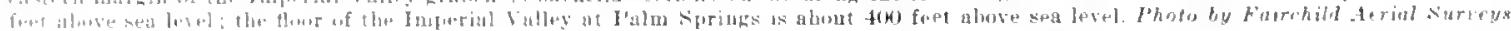



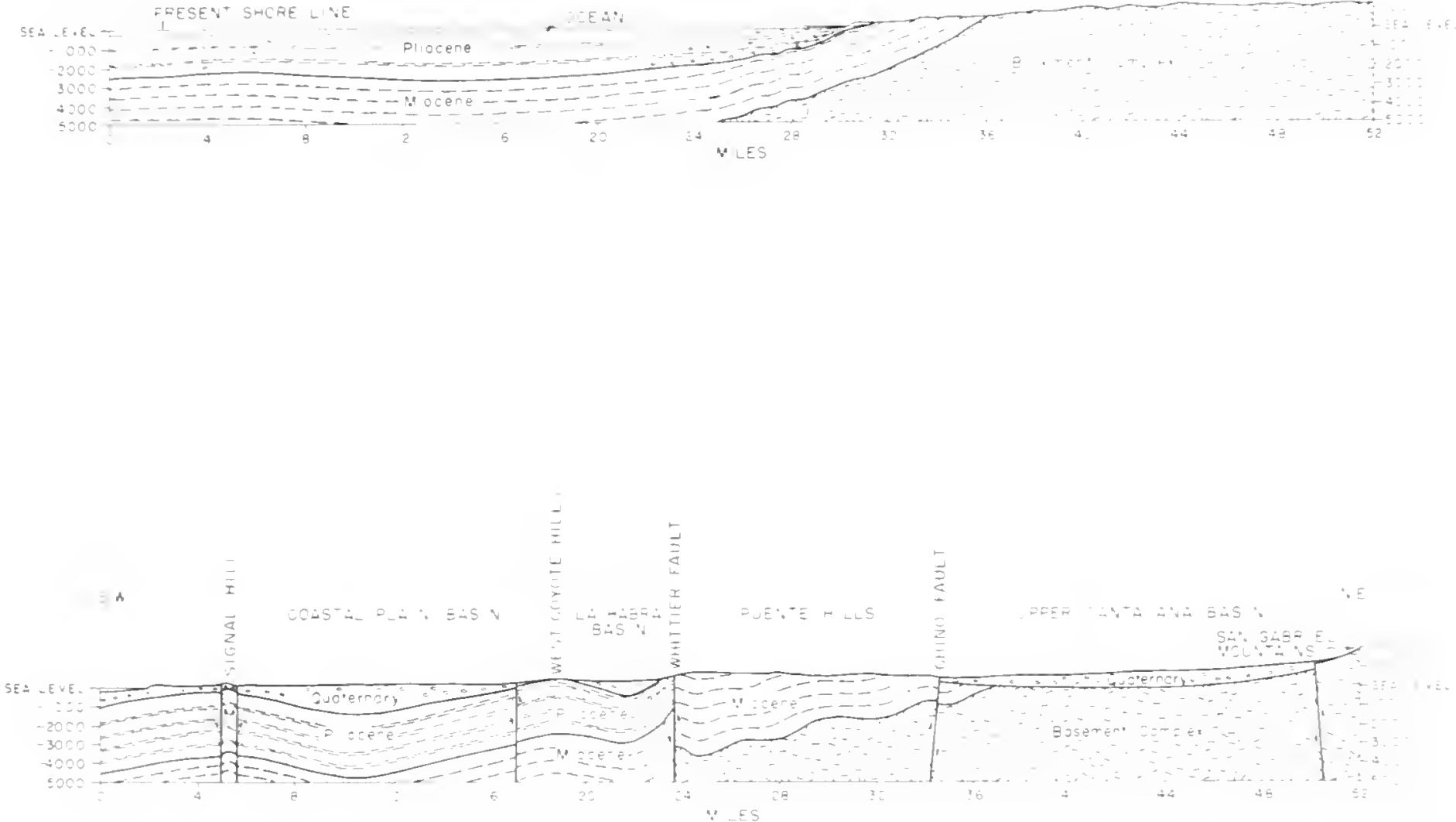

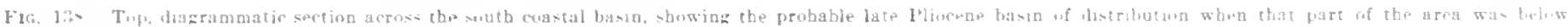

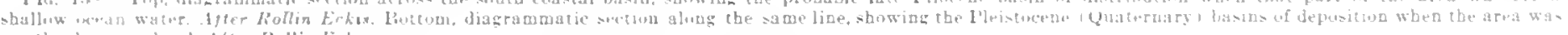

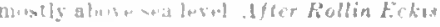




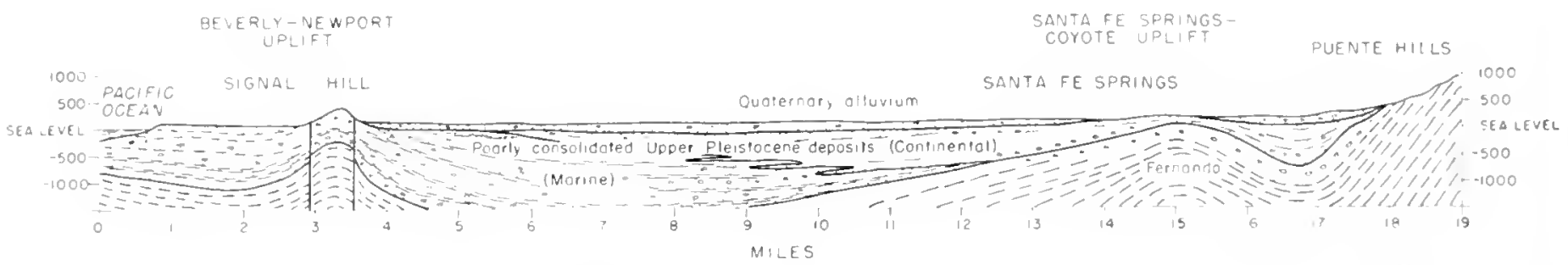

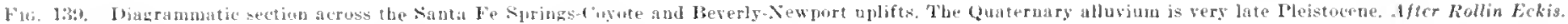

ration of the Peninsular Range. Examples of these little damaged remuants may be seen south of Mpine at 2,000 feet, south and southwest of Cuatay Hountain at 4.000 feet, and the rather large area of the NeCains Plateau between Jacumba and ha l'osta valleys also at about 4.000 feet. Below this advanced erosion surface lies deep residual suil and weathered but still eoherent rock through which projeet matsses of much fresher material.

The old lamelsipe had been evolved by long erosion prior to elevaton of the rance. It seems to he similar in its toporraphy and may once hare been continnous with that in the uplands of the San Fernardino and San Gabriel Mountajn; and in many remnants seattered through the Mojave Desert. This surface has not been sturlies in murch detail hence its history is not well known. Whether it exhibits the nultiple features so finely shown on the western side of the Sierra Nivada las not been determined, but such evidences of recurrent uplift and associatcd bissection are to be expected.

In the l'minsular Ranure there is a "unsiclerahle number of basins: une "f the largest is the Valle San olus between l'alomar, Volean, and Ayma caltinte mountains whose orests rise from 2.500 to 3.500 leet alure a thattish floor of consilerable extunt. Others are Viejas, Cottonwood, and Mlorma valleys. Some of the balsin floors exhibit the ancient landscape little modified by erosion while otbers have stood suffieiently low robative to their surroundings so that they have reecived considerable elepersits of alluvium or hase harbored hatkes in which sediment anoumulated. Field study indieates that these batsins abetually are whabers which either sank as the I'ninsular bluck was being elevated wo linilol tol rise as far as their surromulines. 'Thus they are features

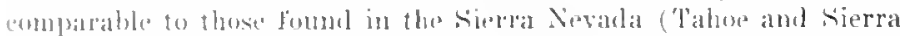

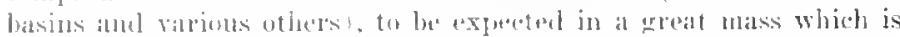

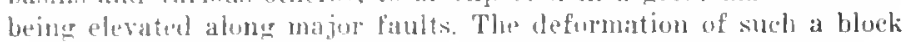

is complex and it yelds to the deforming forces by bending and minor fraturing, the latter finding more expression in relief features than the former.

At various places in the range these are a number of long, narrow depressions which appear to have resulted from erosion in the cruslied zone of larerer faults.

The recency of uplift of the l'eninsular block is testified to by the bolduess and small amount of erosion of the eastern scarp and the deptly and narmwness of eanyons cutting botll it and the western slope. Some have held that the great eastern face is an erosion produet. thourh its avolution by this mechanism has not been very clearly brought unt. However", comparison of its features with those of the eastern fave of the Sierra Sievada and the clear evidence of a major fracture system along the base of the Peninsular block indivate beyont mucly cloubt that this searp is the product of great dislocations which have caused elevation of the range and sinking of the anljitcut Imperial-Coachella graben. The castern Peninsular searp is lighest amd most abrupt at the northern end. Farther soutl in places there is a series of parallel northwest tremding mountinous rieleses, fearly" fault-block montains, between whisly are sharply ontlined sunken blocks like Collins, lBorego, and ckatk Lake valleys. The Santa liosa Nountains is the priucipal of these ridges, with a kong, straipht scolrp a few thousand feret high on the soutliwest side, above which there is a slope (the old erosion surlate) destending to the northeast from 8,000 to abont 6,000 least above seat level. Beyond is the great eastern searp. In other planes the eastern front is less simple indirating paralle finultine with distribution of the disheation alont the rarious fractures giving step-fault topowriplyy.

between the northermmost part of the San Jacinto section of the Peninsular Range and the San Bernardino seetion of the Transverse 

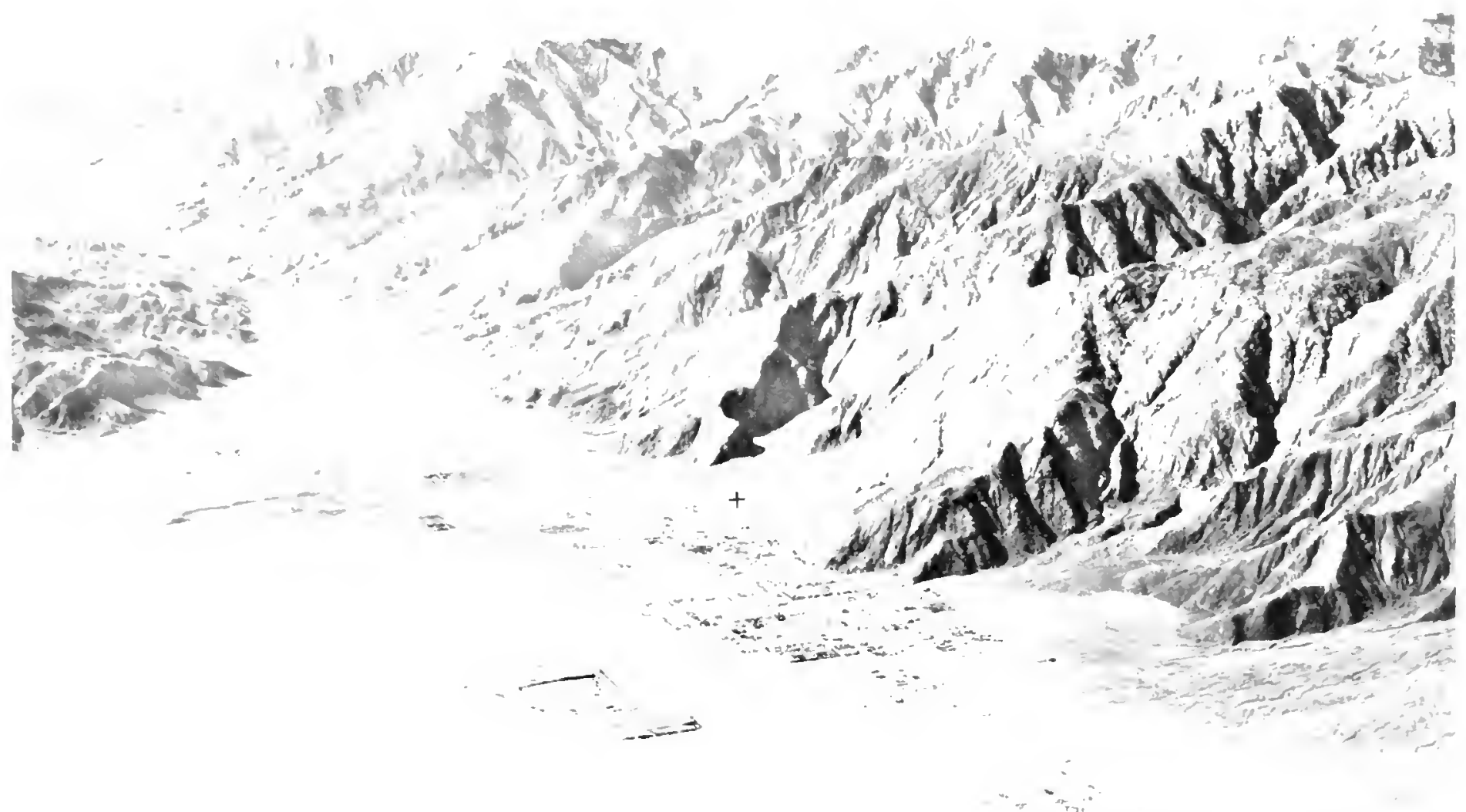


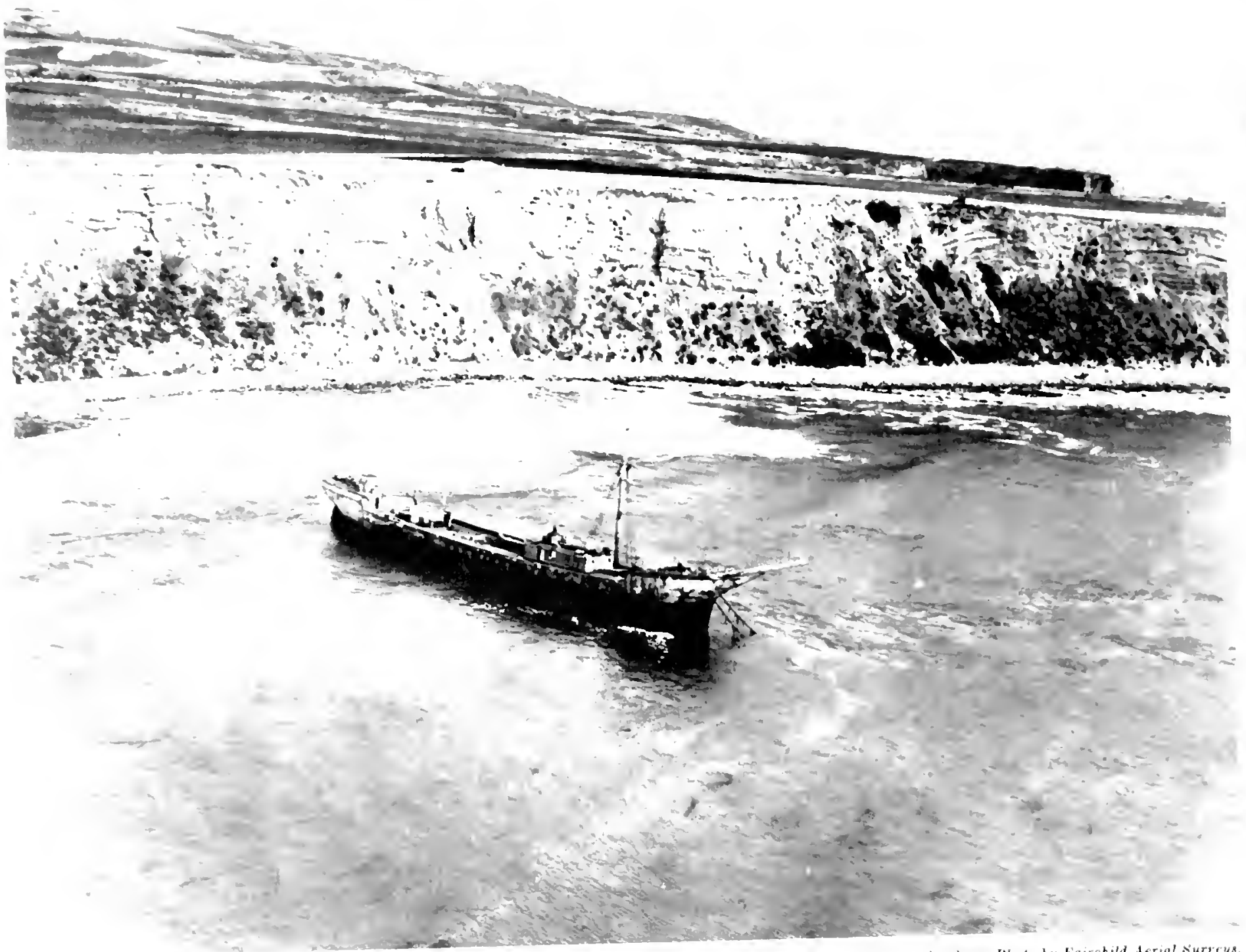


system is sim Gurgonio l'ass whose rest is alwont 2.600 teet above sea level. High points on the ranges immediately anjacent rise from s,000 to 9,000 feet. From its summit, the pass slopes gently eastward where it merges imperceptibly with the northern and of the C'aldiclal valley. on the western side, the slope is cuite as gentle toward the leaumont Plain, but the marein between the pass and this plain. while not prominent, is more eonspienoms than that on the eastern side. The main part of the san (iorgunio depression is a lowland? to 3 miles wide and about 18 miles long: it is a narrow fault trongh or graben filled to a great depth with sediment of quite recent deposition. Bedrouk comparable with that exposed in the adjacent San Jacinto and San Bernardino ranges therefore must stand a considerable distance below the surface of the trough.

The somthern boundary of San Gorgonio l'ass is the spectacular. battered fauts searp of the Sian dacinto Range. It the eastern end of the pass. the sheer mountain front bemds from east-west to more nearly north-south, and in this angle lies the famous desert resort of Palm siprings. The northern marerin of the pass is not so conspicuous, partly heratuse the high peaks of the San Bernardino Range lie firtlier from its base than those of the san Jacinto llountains and partly because of a foothill belt whith lies between the pass and the former range. In the narrow fault trongh betwem the two ranges there bas been greater deposition of sediment from the northern range than from thr southern, hence the northern side of the pass stands 300 to 500 feet higher than the suthern.

Althourh the San Andreas fanlt passes diagonally along the foothill belt of the San Bernarlino kange, otber faults are responsible for the difference in elevation between the pass and the summit of the mountains. The Banning fault makes a gronp of scarps along the northern sile of San Gorgonio l'an, some of the movements being so late that the have tilted recently formed alluvial func.

Wind blowing over sedimentary leposits in the pass have swept sand inte drifts that are fomml on buth windwal and leeward sides of ridges projerting from the Šan Jacinto Monntains. Excellent examples uf sand blasting. the erusive effect of the wind, are fond near some of the drifts.

Iouplyy malleling the southern California coast and lyiner about 20 miles inland are the santa Ana llountains which run for some distance southeast of the Santa Ana liver. The mountains are a fanlt block of rather complex structure which has been edevated on the mortheastern side along the troat Flsingre fault srstem and tilud southwestward tuward the orean. The crese lying along the northerast side of the block, is rather unesen, incrases in elevation sontheast from the santa Ina River, and culninates in tantiano l'eak (elewation $5,6,0$ feet). On the northtastern side of the linck, the range front is a steep, battered fault searp. drained by short streaus that

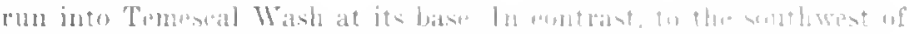

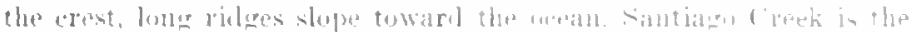

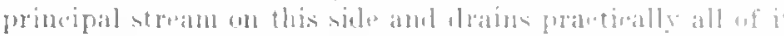

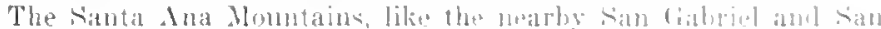

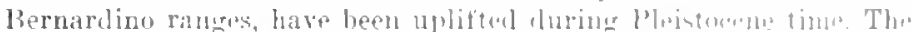
Elsinore fault along which the uplift has ocourrod in an extrenely

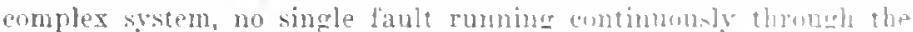
entire length of the zone

The northern side of the range is terminated hy tho Whitier faule which runs westward from the Elsinore zone. Vireheant of the Santa Ana River, this mountainous bet is antinued by the Punte llits. The l'uente Hills are relatively low and inmompinums as comparen with the Santa Ana block.

The Palos Verdes lills are an isolated upland peninsula proferting

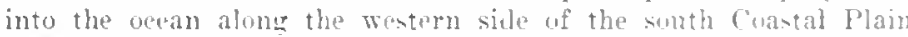
west of the eity of Long beach. The general features ut this uplant resemble those of the islands off the const of southern I'aliformia aml it is evident that during parts of l'leistmeene time it, tow, was separated from the mainland. Northwest of the Palus Verdes llills a belt of irregular sand dumes extends inlanl from the anst, werlaping the lowland and the northwestern borker of the hills.

The peninsula is small, measurine about? nilas lone and 4 is i miles wide: its hirhest point. san l'adro Hill, stands only $1 . t=0$ teet above sea lovel. The erest and most of the upper show of the area arw a rolling upland eomprised of smonthly rounded hills and wide. cently sloping vallevs. Along the luwer slupes is a series of marine terraten which are being indented by deop canyens that are working inland and gradually destroting the rolling upland. "The wey and woth ("rasts of the peninsula terminate in al sea eliff ranting from 50 feet

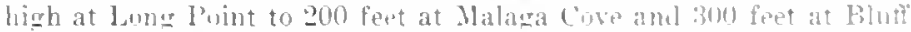

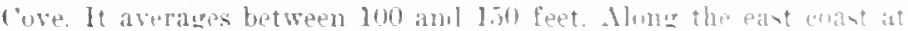

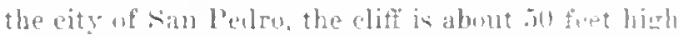

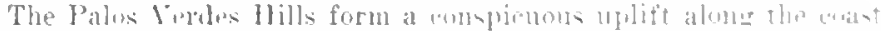

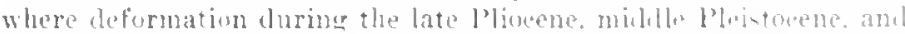

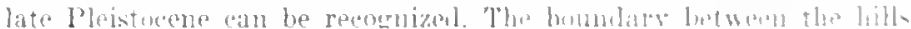

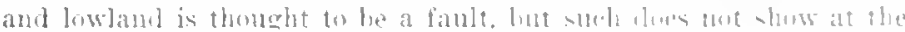

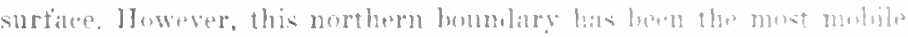

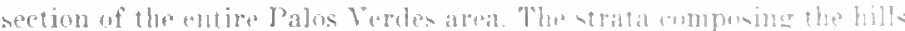

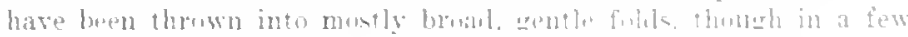

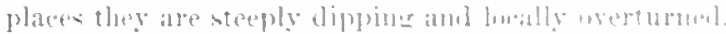

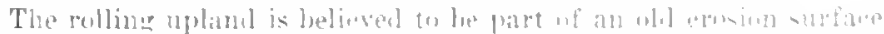

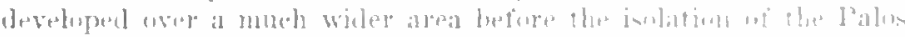

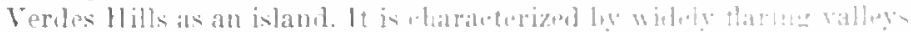

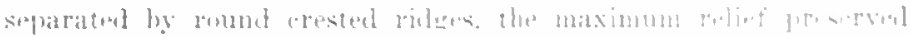

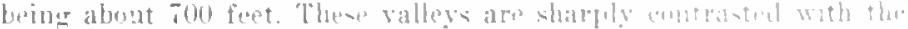

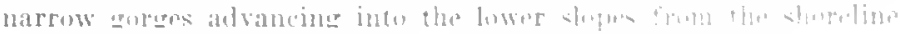


When the uphand topography was evolved eamot be exactly deter-

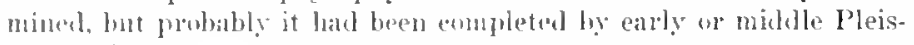
toeene time.

1 number of undrained depresions are present in the upland area. being most numerous at the northwest end. T'ley an thought to have been formed by solution of parts of the thin limestone bods that are known to nuderlie the area with eonseguent suthing of overying strata into the roids which were lelt, though drainare clanges also may be responsible for some of them.

The nost striking features of the palos Verles Ilills are the elevated marine terraces of which 1:3 have been reognized. The terraces range in height above sea level from about 700 to 1,300 feet. The gentle slopes on San Pedro 13 ill above an altitude of 1.425 feet may represent a still higher terrace forned when the ishand was completely submerged, but this bas not yet heen proved. The lower and therefore younger terraces naturally are best preserved and most easily identified; they are most clearly visible on the windward west coast and the soutluwest coast from San l'edro Ilill to l'oint Fermin where they liate been eroled into the most resistant rock. Between the two areas the continuity is broken by erosion of the steep slope and by landsliding. On the leeward slopes where waves ent into weak rock, terraces are exceptionally wide, but, where the roek is more resistant, the weiker wave action developed less well-tefined terraces. In places the terraces appear to merce, probably becuse of accumulation of non-marine debris after emergence. Locally this non-marine cover is at least 300 feet thick. In some places it seems to have spread onto still lower terraces eoncealing the sea diffs between. The height of sea (c)itls between the difterent terraces is not uniform, but actually measurement is not possible becanse of later erosion and deposition.

The terraces indiuate that the elevation of the 1'alos Verdes 1Iills followed the normal pattern, taking place more rapidly during rertain intervals and then jerhaps alnost ceasing for a time. The cutting of the terraces ocenred during the episodes of stability.

Along the northern border of the Palos Verdes ilills the fowest terrace was deformed following emergence and deposition of the nommarine ever. Along most of the west coast and almost all the south coast, the lowest elevated terrace has been destroyed by erosion developing the present terrace at sua lovel. The valley now oecupied by Gaffey Sitreet in San P'edro was cut aross the warped lower terrace by an antecelent stream or by a stream which breached the Gaftey anticline, running through this section, and eapturel a stream formerly draining southeastward north of the anticline. It seems probable that recent slight Erowtl of the Gaffey anticline has eaused imponnding of the water of Bixby slowerh north of the antieline.

There are numerous landshides at various places. One extensive areal forns the lumnocky area inlant from lorturuese Point and
Inspiration l'oint and is explained by movement alone a slipping plane formul by a wat er-soaked beel of thtr." A larereshmp of different type took place in 3129 about a luarter of a mile east of loint lormin. $A$ semi-elliptical area extending for $\mathbf{1 , 0 0 0}$ feet along the sea eliff and 400 feet inland moved seaward as a body, leaving a main fissure 5 to

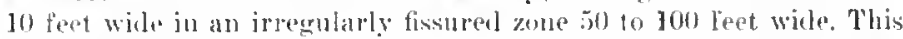
slide was attributed to sliting on the shppery surface of a shale bed inelined seawad in an anticlinal folt. Soon after it was formel th" main fissure was filled with fossiliferous marine sand from beeont and Beacon Streets. Movement took place again in 1940 surgesting that the slumped mass rotated upward as it moved toward the ocean. Exceptionally heary rains in 1941 caused the slide to become active arain indicating that stability has not yet been reached.

\section{San Gabriel Valley}

This plain, like the San Fernando, is about 20 miles long. 7 to 10 miles wide for most of its length, but narrows to little more than 2 miles at its eastern end. The gentle slope of its surface is to the south. Rising abruptly to the north are the high San Gabriel Mountains.

The debris cone being formed by the San Gabriel River oecupies the eentral part of the valley extending from the mouth of the mountain canyon aeross the plain and through the Whittier Narrows to the Coasta] Plain. This area of active deposition is extended east and west of the cone by acemmlations of smaller streams coming from the San Gabriel Mountains. Disseeted older alluvium covers most of the east and west parts of the valley and is found elsewhere, and its soil zone is reddish-brown, whereas this coloration is not present in areas of active deposition. Iplift of the San Gabriel Hountains has been responsible for disseetion of the cones on that side of the valley where there are many high remnants of old eones fringing the mountain front between the eanyon mouths. The head of San Dimas cone which eovers the floor of the narrow eastern part of the valley has been cut ly streams to a depth of 125 feet. Toward the eentral part of San Gabriel Valley, this older dissected surlace grahually merges into the surfact where deposition is going on.

Steep-sided hedrock hills project here and there through the alluvium and contrast strikingly with the general topography of the valley. All are near the sides of the valley and aromd them the alluvial deposits are comparatively thin. Wells in the central part of the valley sbow a thickness of 1,000 to at least 2,000 feet for the allurial fill; this ean only be accounted for by substantial subsidence of the bedrock, since the deposits extend more than a thousand feet below sea level.

$\Lambda t$ the east end of the San Gabriel Valley in the vieinity of 1 a Verne, the alluvial plain narrows to a width of about 2 miles and then widens

- Tuft is a volcanic rock made of small fragments of lava developed during volcanlo 


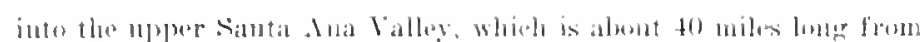
west go east. "l'he width of its westeren part is abunt 20 miles, and

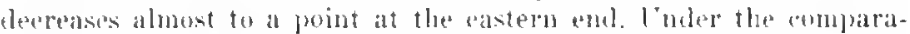

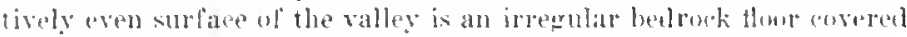
in places by more than 1.000 feot of allurium whinh has rene prin-

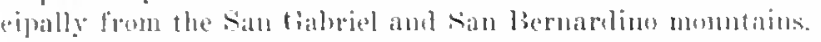

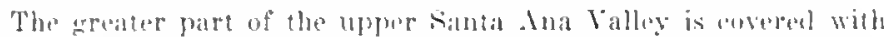

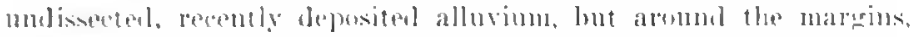
particularly the senthern, and at places farther within the hasin there

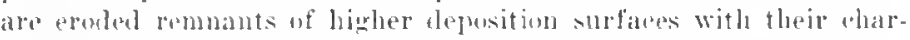
aleteristige reddish-brown soil zones.

The Santa Ana River, below the San ofarinto fandt at Sam lier-

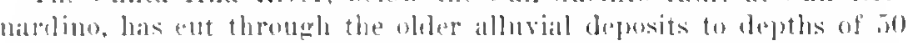

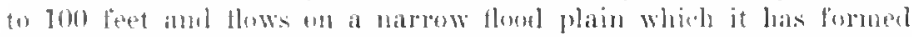
hetwern these high hanks. The river lies sonth of the present atra of atetive ateroumlation of sediment from the san (ialoriel dlountains. "lhe two fants just presented surgest that the antral part of the Silltat Ana Valley has been recently sulusitingr.

The Coastal plain wextends along the orean sonth of the Sianta

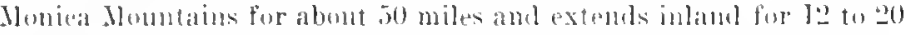

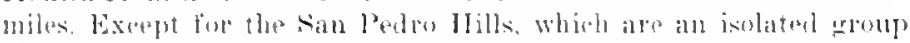

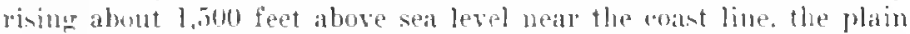
has it relatively erem surface boken here and there by how hills and

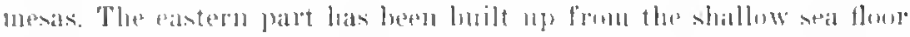

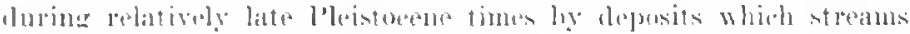

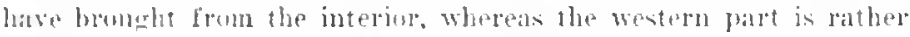

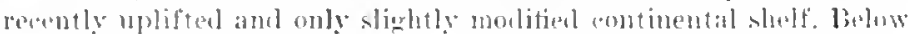

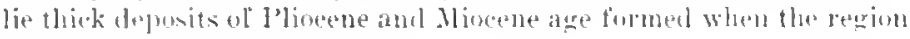
stoud mostly brlow sea level.

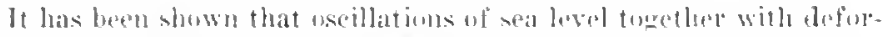

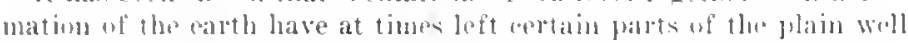
above the presciut level of deposition while wheresetions haw been

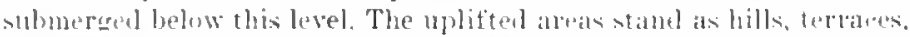

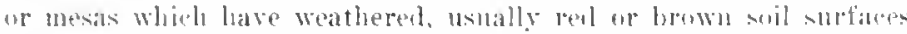

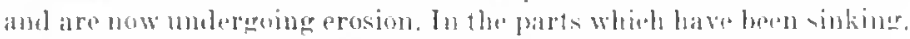

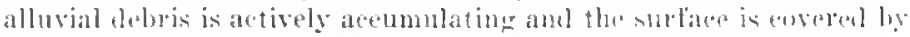
relatively unweathered sandy or silty wil.

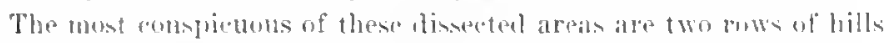

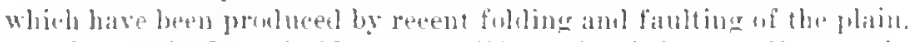

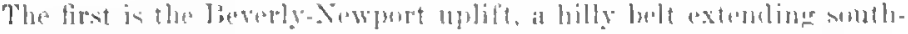

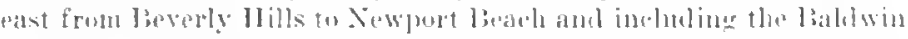

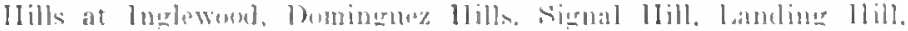

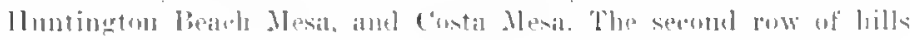

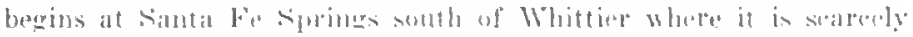

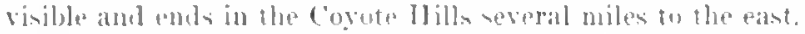

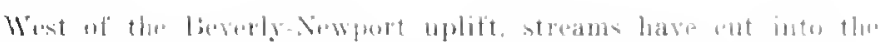

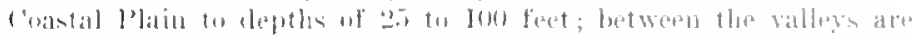

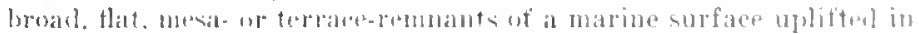

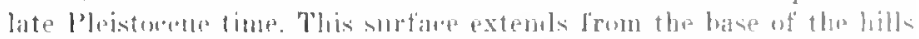
to the coast where it ands ahrianty in al series of blutfs. At its northern

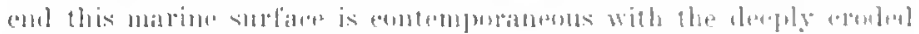

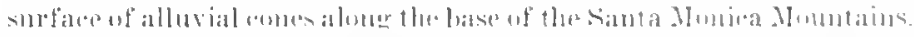

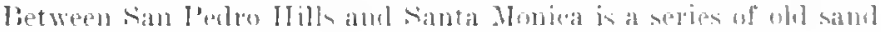

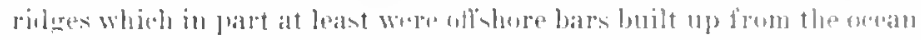

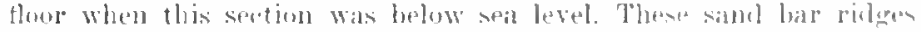

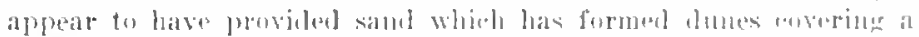

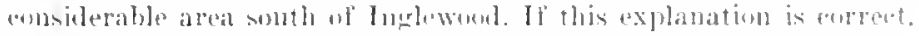

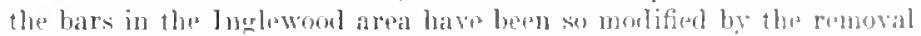
of sanel that their oriorinal form is inrecomizable.

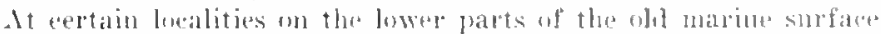

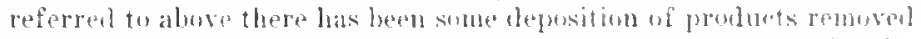

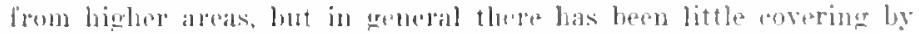

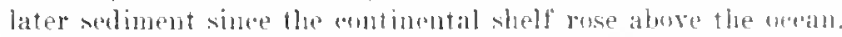

streams erenting the western fart of the coastal l'lain How throurh

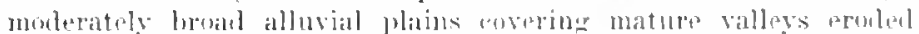

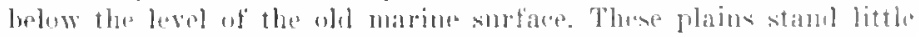

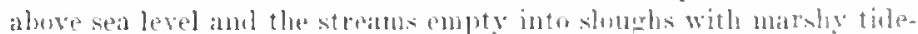

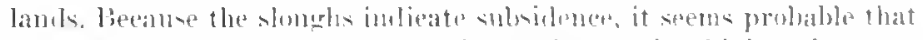

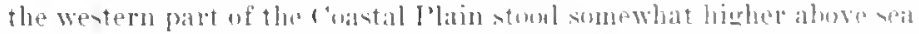

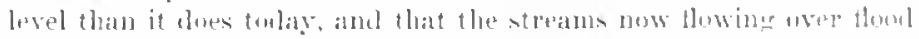

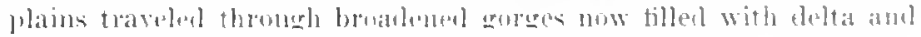

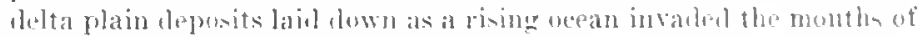
this gritges.

The lieverly-Newport uplift makes an inportant brate in the

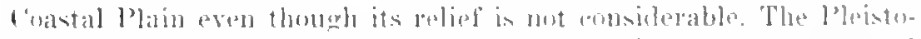

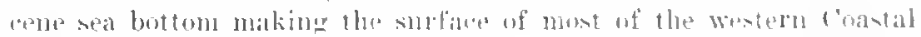

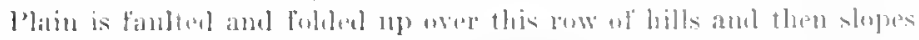

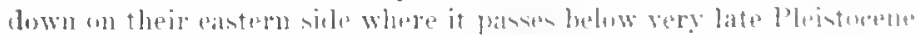

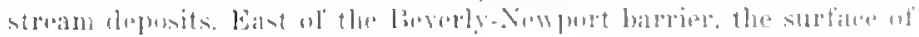

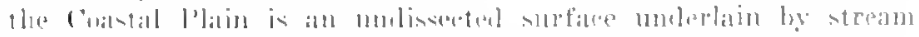

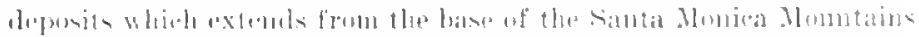

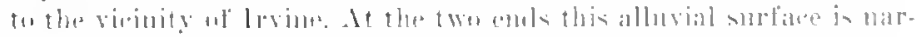

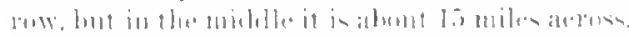

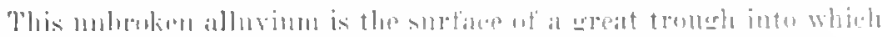

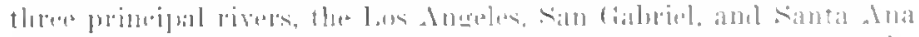

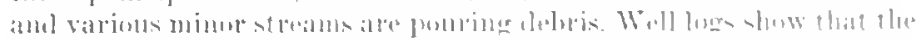

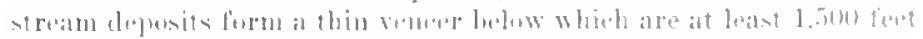

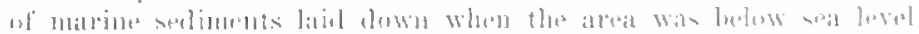

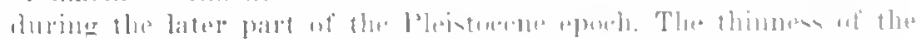

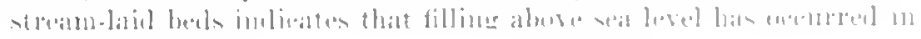
very late time. 
The low hills romming from sinta Te Springs te Coyote Wash have separated a martow depresson. gonerally known as I a llabra liasin. lyug north of the hills from the man Coastal l'ain. This basin there. fore has been filled with stream soliment as it wralually rose while most of the main Coastal l'ain was below sea level and was receiving soliment deposited in the ooran.

Ohder stream deposits, folded up ove the Santa Fe Springs-Coyote uplift, stand above the level ol heposition on the central coastal l'iain. This ohler alluvium has been dissented and weathering has developed a reddish-brown soil zome in its upper part.

Elsewhere between the principal rivers, dissceted alluvial cones with weathered-reddish brown soil zones frincre the north, east, and south margins of the Coastal Plain. The surfaces of these dissected cones, steeper at their apexes than the present streams, converge with them toward the eenter of the Coastal Plain and finally pass beneath the streams.

Considerably dissected remunts of ohl marine terraces, which inchude erosion terraces toretler with beach and inner continental shelf deposits, are found along the coast beyoud both the northwest and southeast ends of the Coastal Plain. Nlons the sunthwest side of

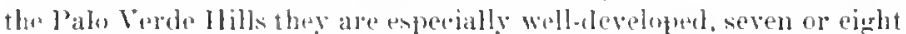
well-defined old shore hines and others less distinct having been recog. nized. The highest terraees remmants stauls more than 1,000 feet above the present shore line, but they are not very distinct because of damage which erosion has wrought since their elevation.

This purtion of (alifornia extends from the l'acific sloreline to the Peninsular Ranges east of the coty of San Diesro and can be divided into two sections, the coastal mesas whith are part of the south Coastal Plain and the rugred mountanous section rising abluptly on the pastern boundary of the mesas. The two parts are composed of quite different rocks and have lad quite listinut histories.

The mesa seotion lass a semi-arid chmate, the precopitation being about 10 inches anmally at San Diego and not mull wreater at the base of the mountains. Host of the rainfall comes between October and April. The temperatures normally have molerate range, freezing luing rare in the wintel and opjressively hot days equally so in the summer. The mountainous section on the other hamb recejves consillerably more rain and snow in the higher parts during the winter. Summer days in some of the valleys have temperatures reaching $100^{\circ} \mathrm{F}$. and mor'. The higher peals and ridges eause speedy condensation of the eastwarl orifting ail" currents as they rise along them, riving precipitation of moro than 40 inches a year on the western slopes of sueh ranges as the l'alomal and ("uyamalods. Within the monntains preapitation dereases somewhat in most plates but exceels 20 inches

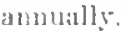

The mesa section extends for many miles nontly anel south of the San Diego region; on the north it is continuous witl the south coustal Plain of the Los Angeles liasin while on the sonth it passes bejond the Nexican borler. The mesis either extend to the east where they are ent oft by cliffs being aroded along the present coast or cleseend by a serius of terraces whieh are somated ly bays or a coastal plain from the shoreline. In width th mesa seetion ranges from 6 to 14 miles and in height from sea level to nore than soo feet. The most conspienous mesa which is nearly that-topped and only slightly disseeted stands at elevations ranging from 300 to 550 feet.

The coast line within this area has two promontories, a brond nonthern one formed by the mass of Soludad Hountain near La Jolla and a southern at the isolated, north trenling l'oint Loma. There ire two embayments, a smaller one, Mission Jiny or False Bay as it was formerly called, between Soldad Mountain and Point I,ona, and the larger and deeper San Ditero liay which is protected by l'oint Joma and a long sand spit ealled the silver strand, Coronado and North Island.

The eastern houndary of the mesa section is deterninod by the abutment of Tortiary sediments arainst much okler rocks forming the foothils of the mountains to the east, thongh this bonndary is rather inclefinite in places where the Tertiary sadiments thin ont to a veneer of soil upon the older formations.

The mesas are teraces cut by wave action and covered by a thin veneer of rather coarse marine deposits; there are seroul ut these terraces, the hirher bein much dissected and less easily identifind. The principal terrace is alled the san Diego, helow which are others developed on the western marrin of this ment. The lower terratces atre of eomparatively small area, but are fuite distinct where they have not been destroyed by later erosion.

The San Diego Mesa Inas been tremehed by stleams from the num tains into a number of sections to which various local names are applied. The name Otay is used south of Otay Valley and linda V"ista Mesa or Terrace north of the san l)iego River. Southward the mesa was clevated hirher and more rabilly than to the north, for near the Hexinn border, its surface stands abont 550 feet above sea level while just sontl of the san Diego River, the elevation is little unve than 300 feet.

The surface of the San Diego Mlesa appears to be an almost foutureless plain broken here and thele by rather cleep gorges ent by streans tlowing from monntains to the west. Aotually, huwever, there are many grante unchulations, such as long, low ridges which may have been beach ridges. Some doubtless have developed herause of differ. enees in weathering and erosion in various parts of the mesa. Also there are many small hillocks 3 feet or more high and having a basal 


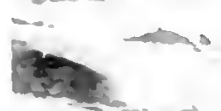

$-3 \pm+\infty$

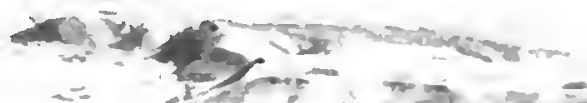

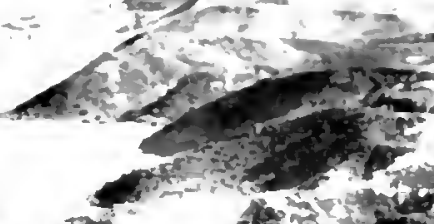

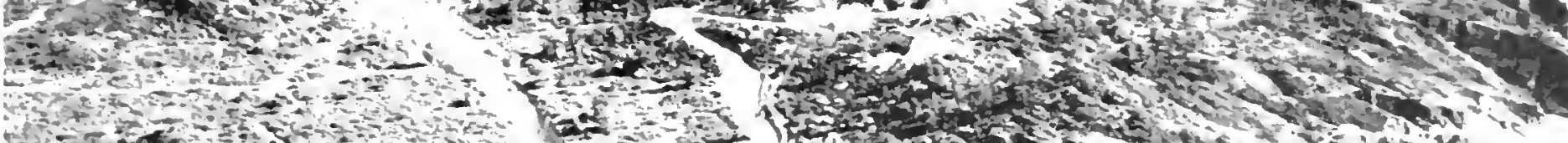

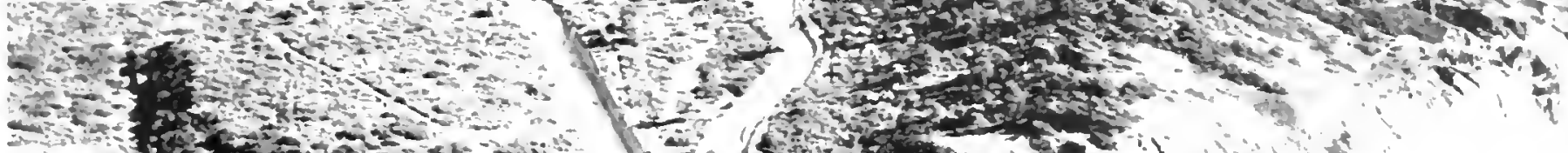

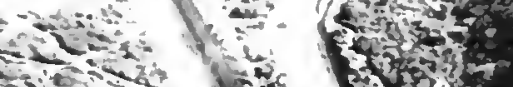

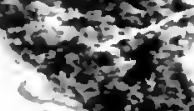

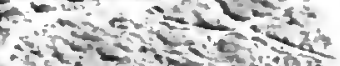
th $7 x^{2}+\sin ^{2}$

5

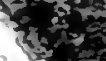

(1)

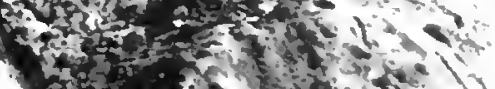

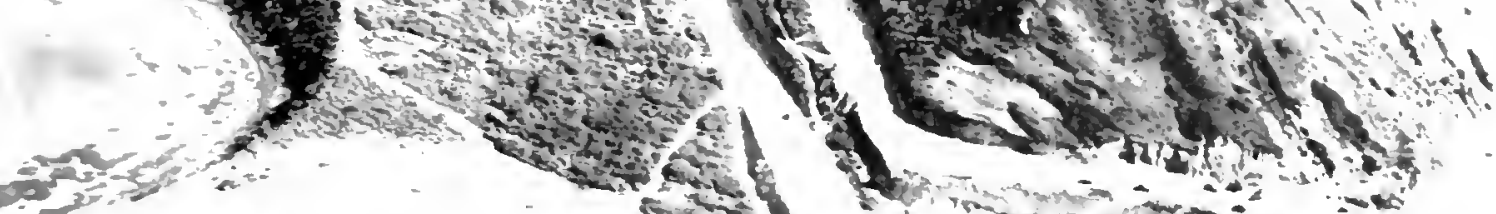

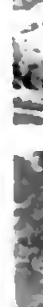

andici-

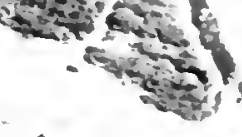

\&.
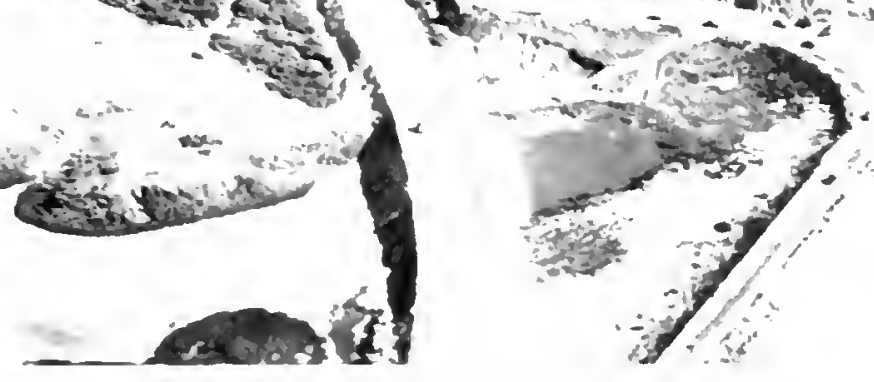

$-4$

(a)

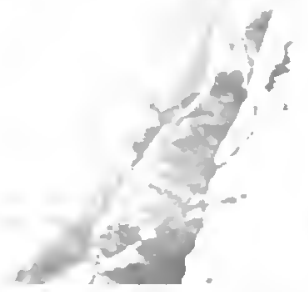




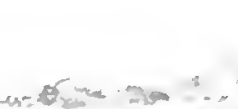

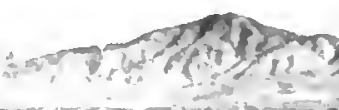

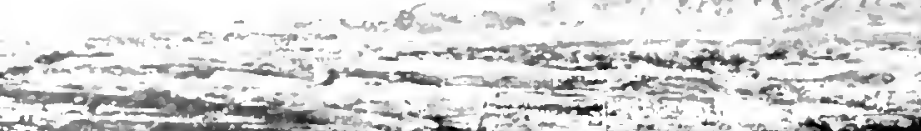
r.

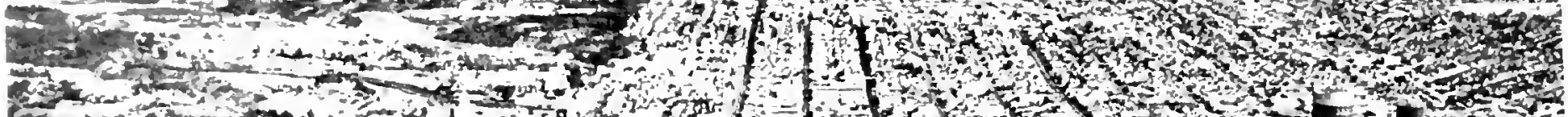

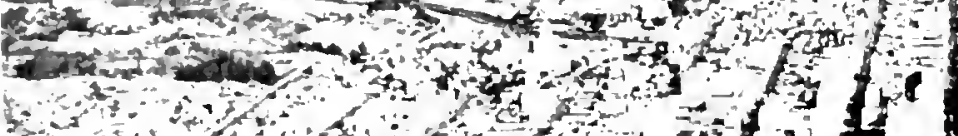

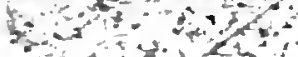

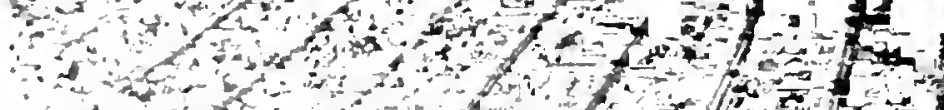
-

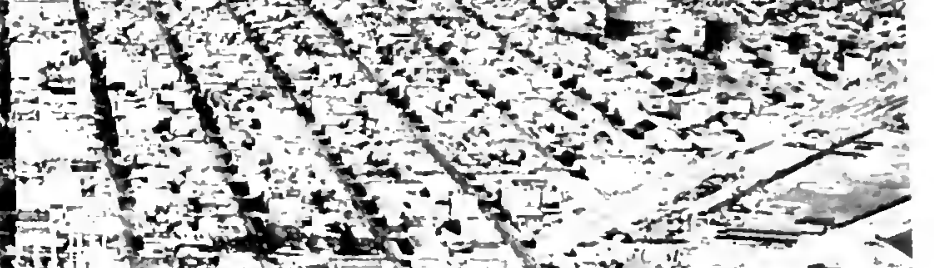

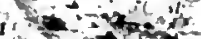

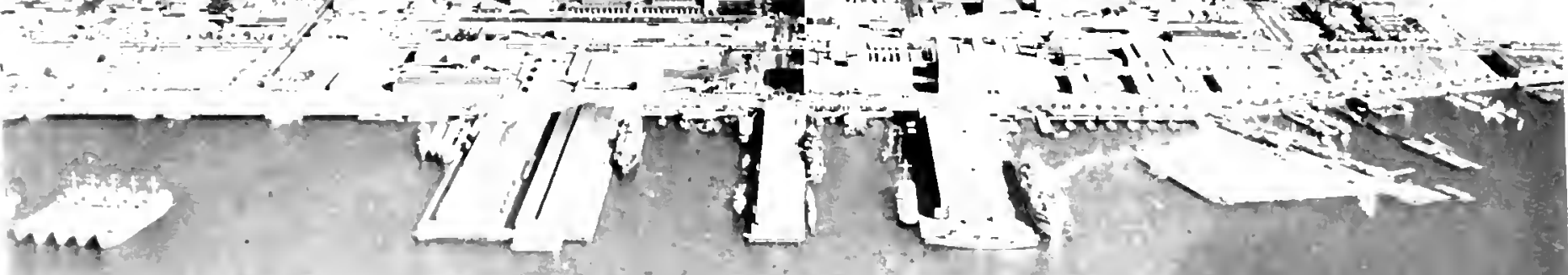

SPENCE

Air thota 


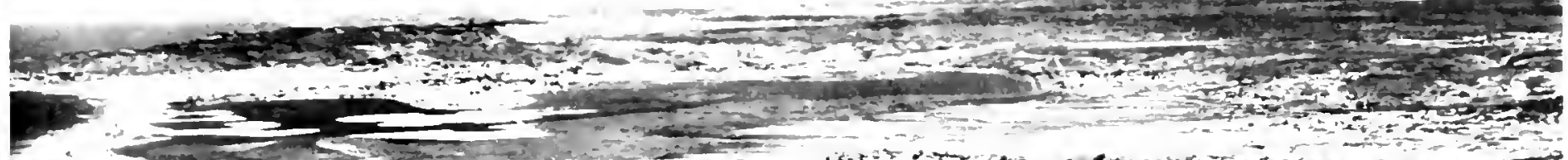

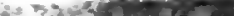
reces ext a $=$ $-20$

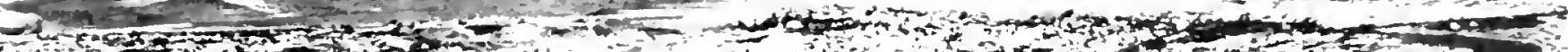

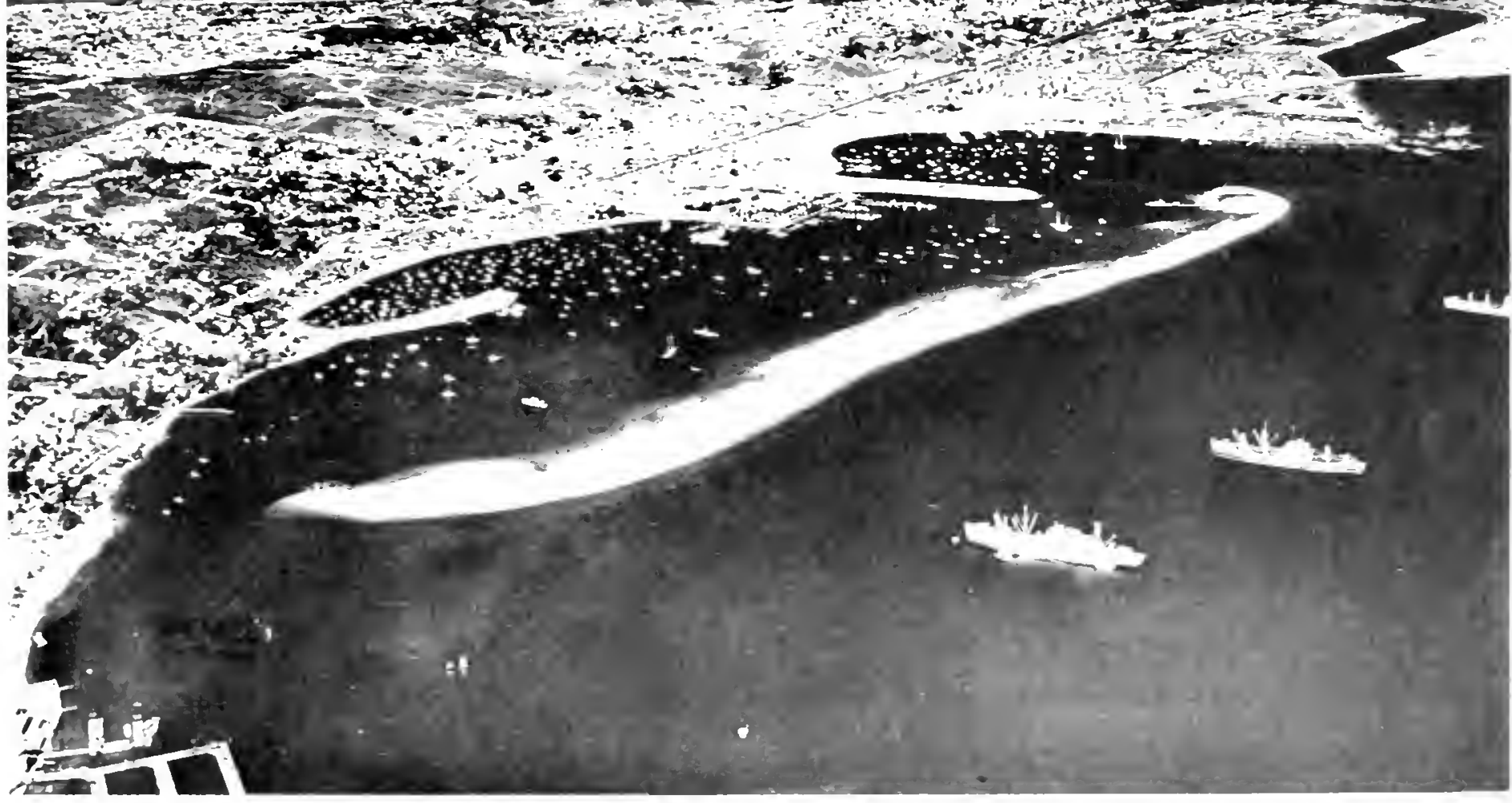


Gianeter of 10 to 20 fert, called promic monnds. 11 is thought that these suall cminenes may represent both the acoumulition ol sand

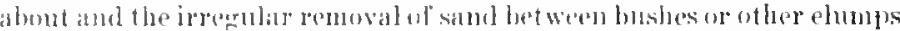
of regetation. Since the hilloeks are present not only over the top of the mesa but along its marginal shope, the probability is that they were formed as the land rose and the ocoun cut teroces below the san biego level. During such an epoch, there probably was plenty of avaibable sand which the wind drifted inland and piled wherever an obstate was present.

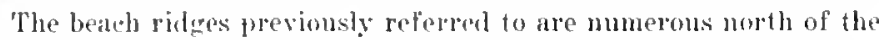
San Djego River where they have cansed the partial devoloment of

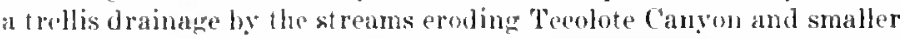
ranyons east of Ia molla. Elsewhero in the mesa section the drainage is the normal dendritic or treelike ty pe. The beach ridres are composed brecty of sand which either shows poor stratifieation or nome at all.

The San 1)iogo Nesal is but little clamaged by stream erosion and therefore is in the ruthloul stage. The northern portion, especially the sertion immediately aljacent to the somth rim of Nesa Valley and linda Vista terraco to the north is loss dissected than the part to the soutl, probahly becallse of the harder rock in the linda Vista area and the eloser spacing of valleys soutl of Choyas Valley.

Many of the canvons cutting the mosa have quite stoplo slopes and their tops neet the nesa surface in a sharp angle.

The Sin Diego Mesa probably is also repuesented by parts of the upper surface ol l'oint homa thourh linlting in that area has tilted some of the remnants, and atso by a much less evident surface about hall-way up the suthern and western stopes of Soledad Mountain where again tilting has oeenred.

The western siles of the San 1)iego Mesa and the sides of some of the larger valleys exhibit well-preservel remmants of lower, younger ieraces, of which there are four principal levels and others much less well developed. The principal ones are the Avondalin standing 200 to 250 feet above sea level the Chula Vista (100 to 130 feot); the Nestor (25 to 100 J'eet); the l'ia Juana (20 to 50 leet). Sonathward from Otay Valley these teraces, like the San Diego Mesil, stand at progressibely highor elevations and aro stparatod by ureater vertical distances. Since the terraces represunt surlaces ol marine erosion eurerod by a thin roner of deposits, it is evident that uplift has been croter and nore rabid toward the Hexican bouder than farther north.

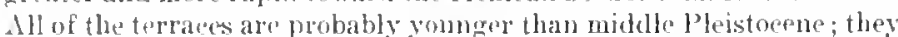
tostify to dominant vertical elevation in the San Diero resion while farther north there was considerable compressional deformation duringer the same "inereh.

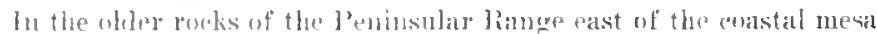

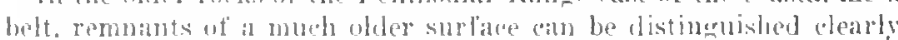

which has been wallow the loway Terrace beause of its eonspicuons drvelopment in tho hillops sonth of loway Valley. Fant of Linda Vista Jesa it can bo seen at the tops of hills 800 to 000 fert aboves sea lovel at the west but stoping upward to elasations of 1,100 to 2,100

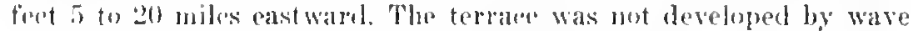

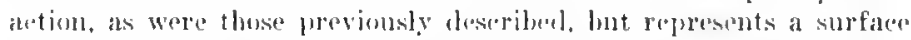
evolved principally by rivers which hal reached advanoed maturity or possibly old are. Nauy enjuences roso above the general level but it is uncertain whieh of these were dreluperl by erosion and whind by fialulting.

The same surface is preserved in parts of the upper drainage basin of the Sin Diego River as a rolling upland only partly destroyed by campons evolved during a late eycle of uplift. Nlso in parts of the recion aromed lotrero and extendine with interruptions far to the east of Carpo and for an unknown distance into lower California, there is an aneient erosion surface which may well be the equivalent of that just deseribed.

Some have comsidered this elevated surlace as an andent, much dissected and warped marine terrace evolved aturing the Eocono epoch. but it stems mueh mose probuble that it was a smrace developel above sen level primarily by rivers not earlier than l'liocene time.

1)iflerences in geoloric structure and rock resistance have cansed rariuns irregularities in the shor cline of the San Diego rerion. Resist. ant masses of rock form promontories because waves eannot so easily destroy them as they can weaker materials. The embarments or coves between the headlands have been partially filled by streams emptying into them and by sand driven in by waves. North of La Jolla, the Sian Jjego Mesa has been quite evenly attanked by wave erosion with the formation of a long stroteh of clifs at the base of whieh there is a narrow beach. The han appears to be sinking slowly so that during storms the waves are able to attack the base of the eliffs, undreutting them with resultant landslicles. In this section the rate of eliff retreat is fairly rapid.

Mbout a milo south of Seripes lustitute near La Jolla, where there is a mass of resistant rock, the coust projoets ahout a mile into the ocean. Because of difterones in rasistano' of various parts of the rock to erosion, waves have soulptured saves, small arches, and irregular stacks. 1 few feet above high tide is a narrow hench or termee which some have believed to represent recent uplift: on the other hand it may be the produrt of erosion during especially sorre storms. South

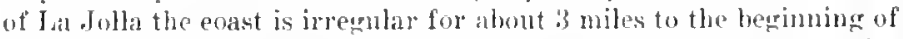

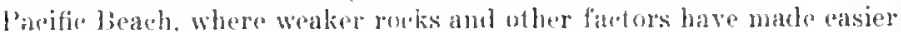

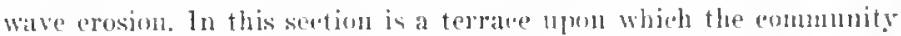

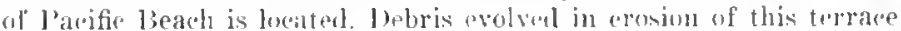
and also that bromert in by stroams has ben shifted sumthwarl by 


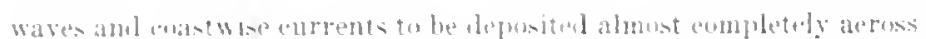

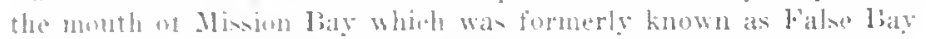

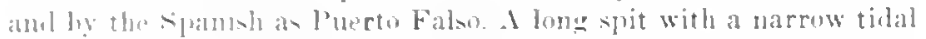
npuning at the south is called Mision lieath.

Mliwjon liay appeare to be a struetural depremion, whits may be

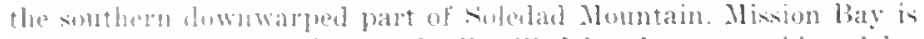
very shalluw and is being eradually tillew by the encroalhing delta plain of the san Dieg River. Intermittent streams from various canyous also are aldeling to this deposit.

A hroul puint, known as liag or C Juwn l'oint, is an extension of

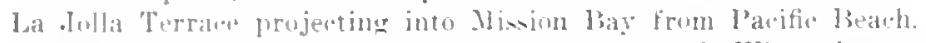

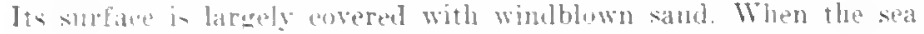
"ont the ("rown Proint section of la Jolla Terrace. it must have swept

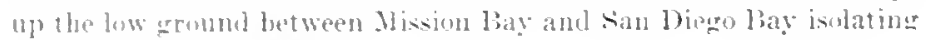
P'uint Luma as an island.

The low that land batween wh Town and the northeast marerin of Point lana in part of the delta plain of the San Diegu liver. As the

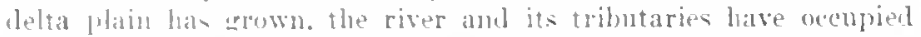
many different fwitions in traversing it, as is shown by earlier maps

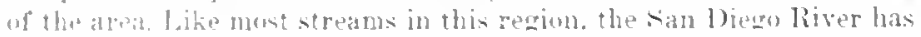
infromust thenls. but when they come a lane amount of sedinent is

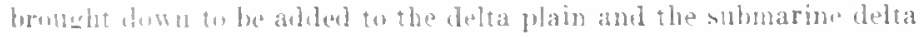

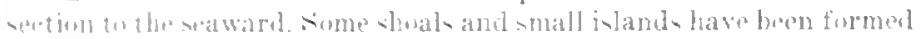
in dliwhon lowg by tidal currents and watres.

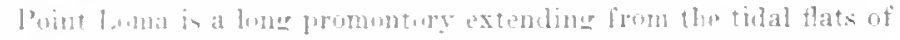

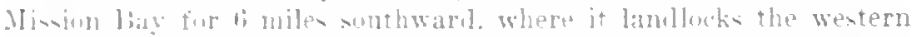

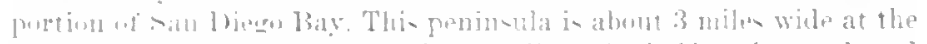

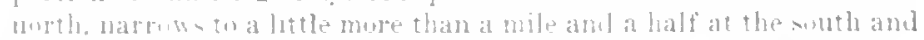

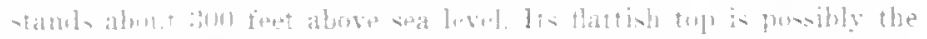

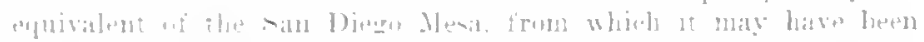

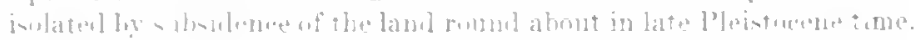

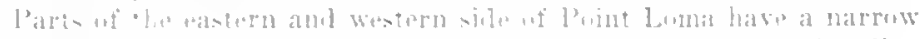

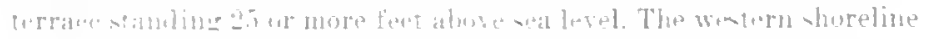

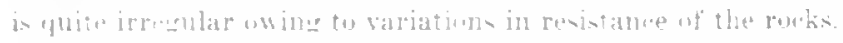

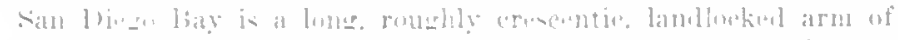

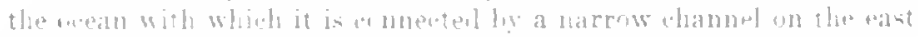

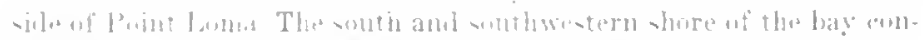

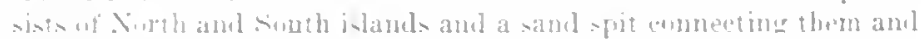
attarhing luth to the mainland. The two islamk may be remnats of

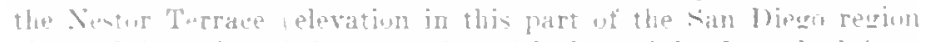
about 25 laset but their connection with the mainlanl rosultal from

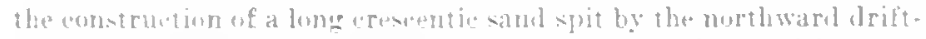

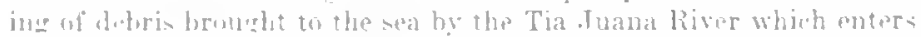

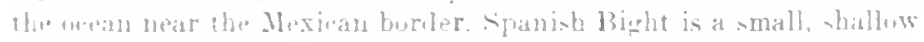

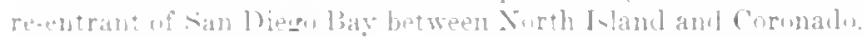

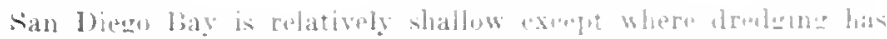

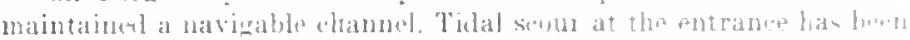
alded by the buidling of a jetty wheh may exentually have impurtant

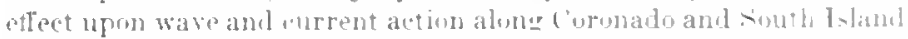
Shortly after it was built, violent storm waves eroded a larga part of

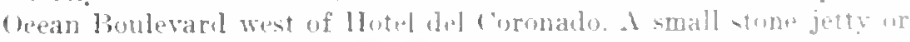

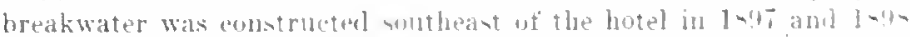
to protect it from waw" "romion. and a sea-wall uf quarry stone way built wextward alome (kean lisulevard in 1906 and 1907. and wan repaired in 1911 and 1912 beands of heary damage by story wasen

The mainland shore of San Whou liay is mainly salt marsles and tidal Hats except where the Nistor terrace produces a small biluf jum? above high tide line. Internittent streams from Las ('huyas. Swept. water, and hay Valleys have construeted small, markly delta plains

There is no delta at the moutl of Thia Juana River which flows into the rean soutl of San Diego Fay near the Vexican border hecan. waves and currents sweeping along the slwre remove debris about as fast is it was deposited.

The Vestor Terrace is continumls from the foot of Sall Dianen Yesa-or citay Mesa ds it in called on s.me maps-westward to th" beach north of the mouth of Tia duana liver. exeejt tor a little wade extending from Tia Juana Valley northwetward to the southern emul

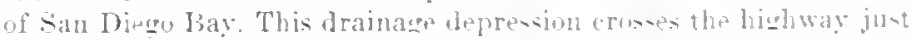
wet of Never and l'alm l'ity, and appears to represent erosion by

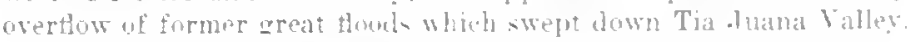

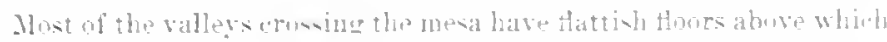
rouk walls rise very abruptly fure sul or more feet: they have heph

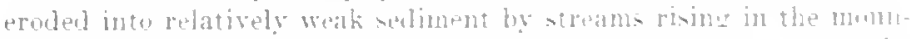

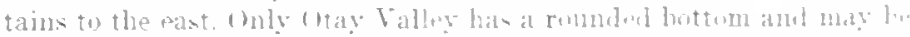

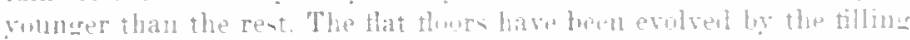

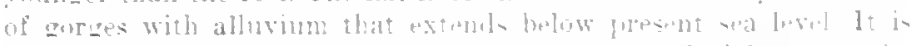

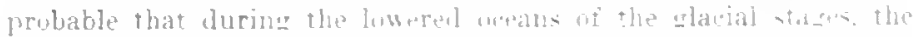
streams cut their valloys through the wak material to meet the tallime

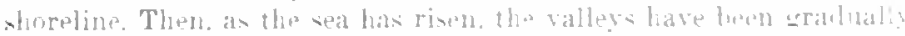
filled in by seliment. Heantrements inticate that wrme of the allurial

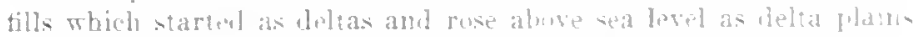

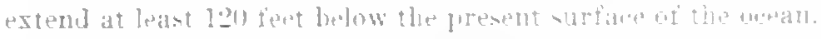

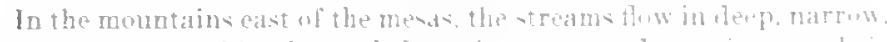

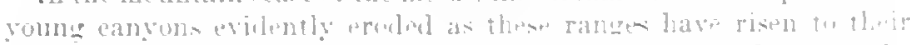
present hojoht in the very late part ot earth histury ln fiat. th monutainous mas is still heing elevated

Faulting has broken up the monntainuus mass an that an qatly it is

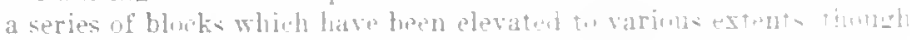

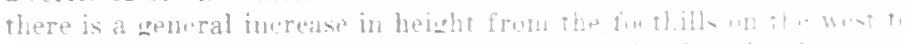

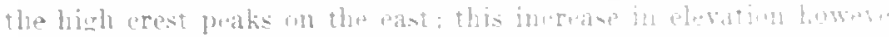




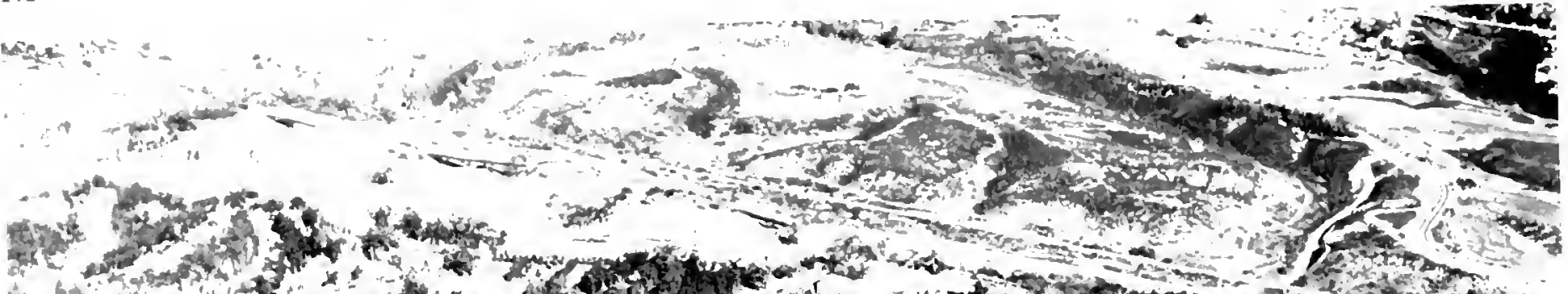

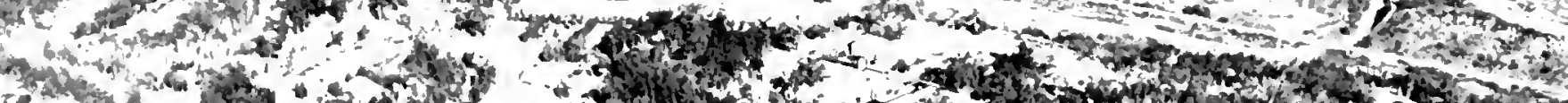

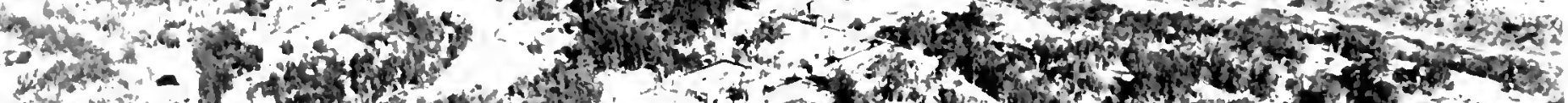

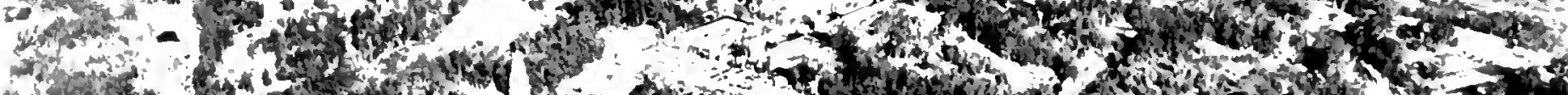
why

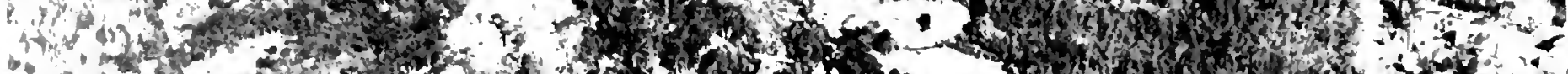

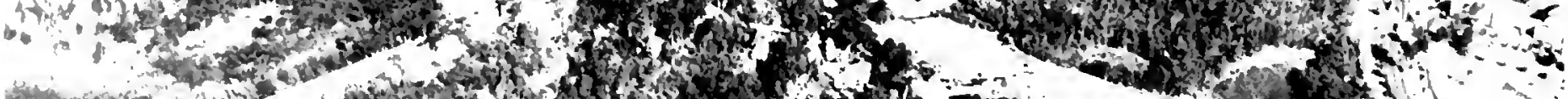

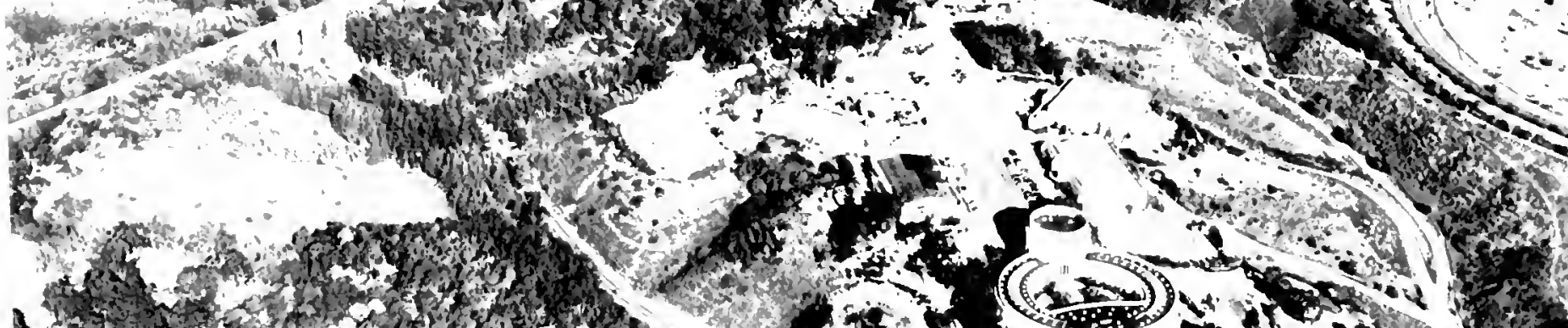

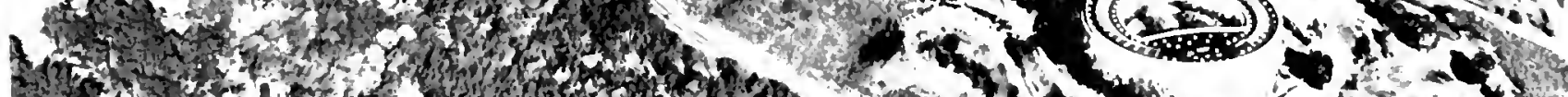

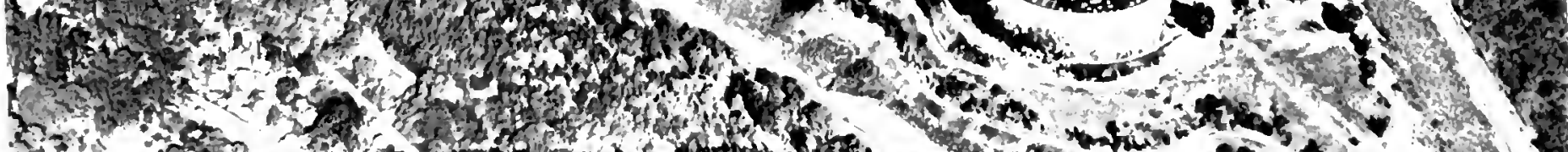

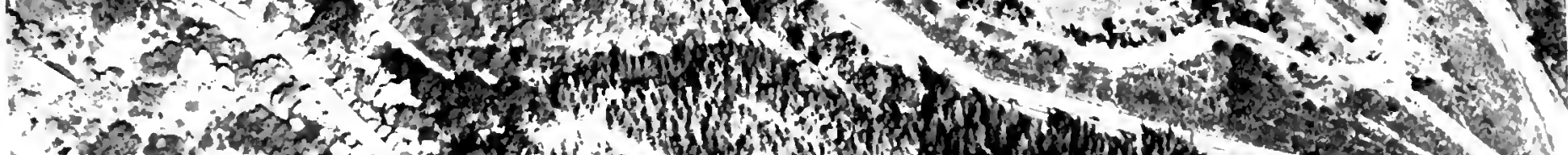

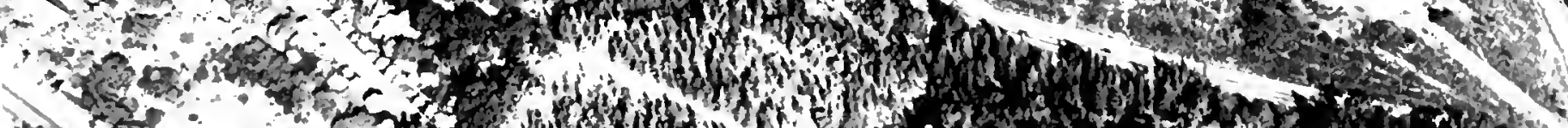

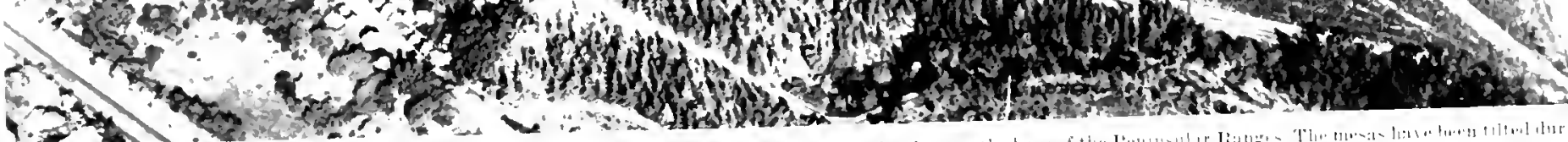


is far from uniform. The Patomar Bountains, Volean benntain, the Latuma Yonntains, and rarious other units appear to be fault blenks. In the western part of the Peninsular Ranges the trend of the prin(.ipal fiults appears to be roushly northeast-south west corresponding to the trent in wher parts of this highland. Rolling uplands alrealy described are present in various parts of the mountains. but whether they are parts of a single erosion surface or of various erosion surfaces has yet to be determined.

In a region where deformation has protuced such profound ehanges in the landseape during late geologieal time, movempnts are still going on in various sections, perhaps in all parts. Topographic features produced by movenents along faults have already been desiribed and many of these show along the active faults of the state. What in not so generally known is that certain areas are slowly rising or sinking Evidence of this has been described along the sea coast, but we are inclined to assuciate this with the past and not think of it as going on today. In the Ios Augeles seetion. instrumental surves have shown that certain parts pither are being elevated or are being depressed so rapuly that survegs nude a few years or even a few months apart show vertieal morement has gone on. As a basis for the surveys, mean sea lepel. whon pustion is deternined by some federal agency such

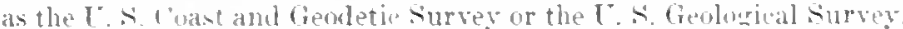
is used. A brief summary of some of these unstable areas follows to give the realler a pioture of the reality of deformation which probably goes on everw where at all times though in most places at rates 160 s suw tis be determined.

(Bne of the vinking areas inclules a large part of the Beverly Hill and some al jawnent cerritory to the east and south. perhaps 15 spuare miles in all. T'k maximum rate of subsidenee centers approximately

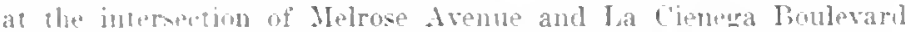
whore it amonnts to abont one tive-hundredthe of a fomt lin yearo at

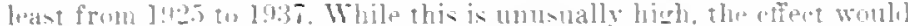

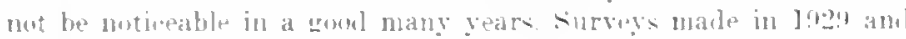

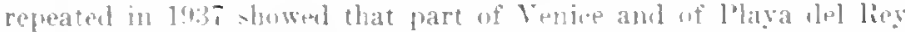
also lad sunk ninets wix hundreds of a font in the 1.2 years, with the maximum at the internection of Forty-semel Arenue and Trolley war in the southern part of Venice.

In contrant. Weat of lnglewnl there is a rising area in which the dotected morement bas been abont three hundredths of a fout a vear This appears tw he artual elevation and not merely relative to sinbsidentes taking plare east and west. This risine area is adjactut to a fault zone which extends from the south base of the santa Monica Munutains near Beverly Ilills sonthease beand Inolewenl as far as Signal llill north of Long Beaeth. As horizontal morement takes place along the fonlt, which apparently runs throurh strun rocks at some depths, the sedimentary beds overlying the fault bencl into small antuclines which are arranged en echelon. Eight wil thello are

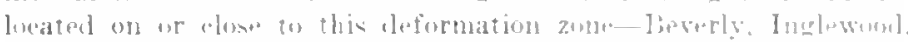

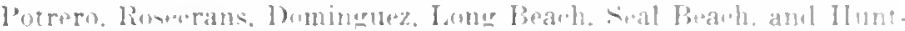

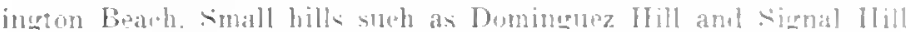
appear to be anticlinas formed alonge this fracture zone whin is ation the Newportesimal Ilill unlift. The fault anmarently is antise for epienters of several recont earthuquaes are located alung it

From Inclewool eastwarl fur several miles there is anuther sub. siding area.

In the dos Angeles and loner Peath llarbor areas thanges of lovel notired by engineers appear to be upward and lownwal in periols of about $i$ months. At Long Beach and the comntry round ahmit evidence of rather rapisl elevation and depression has bean leter. nined in the last 20 years. Tho low, narshy, lagmol som tirn between the Palos Terdes llills and the low, rounded, but rather onspionme hills aloner the Newport-Inglewoul uplift appears to he subidine. Stream. marsh, and beach deposits here are rather think indinting relative subsidene for num longer time than human histury in tho area probably indudes. Before being interfered with by man. the Los Anceles River deposited enoweh spliment in this contial arra th

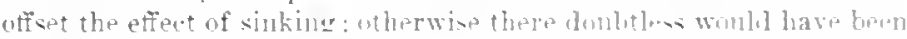

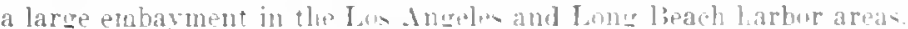
Alome the eastarn marein of thi low area are the kills of the Nowpurt.

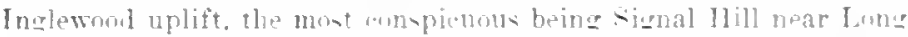
Pealch. These hills are antidines deseloperl by doturmation of sedimentary layes which werlis the fracture zune. Inth Signal and

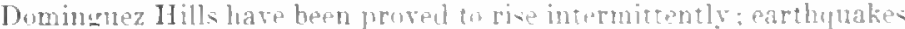
necurring alung the Newport-Inelewoll fanle may control this uprard movement. Between earthunaks when the rust is more siable, the hills sem to subside as dus the area between them and tho Talrm Verdes 11 ills.

In Lone lieath itself buth plevation and whbidenos have been ther

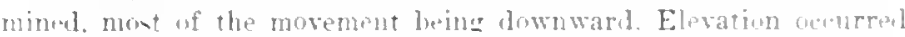
berween 1930 and 1932. before the himhly destrume parthunake wentering along the Sewport-lnglewoul fanlt zune in 19:33, and atain betwen survers mate in 1941 and 1941. There wis a molprate parth quake in $19+1$ and others later. but what effort these lad on the morements is mut known. Surh seanty pridenor as is now asalaho.

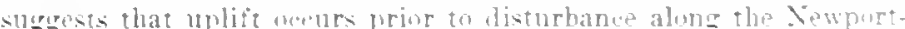
Inglewnd zono. lout this may be onineilental. Instruments whioht have been set up in the area may show definite relations when enongh recordints have been mask

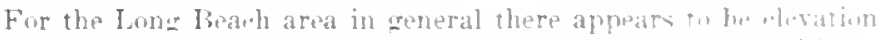
in the northern part ant subsilente toward the solthwer with an

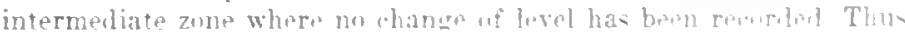
the area is heing warped with silding duwnwal th the whthw wh 


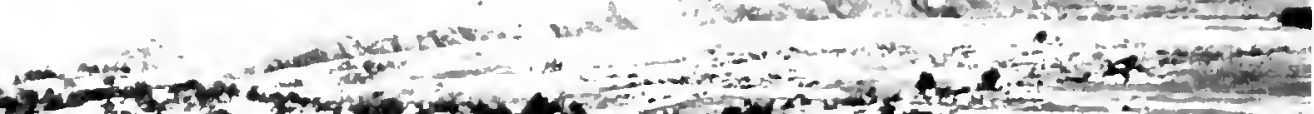

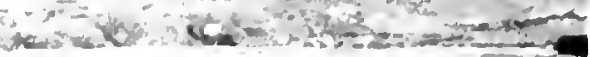

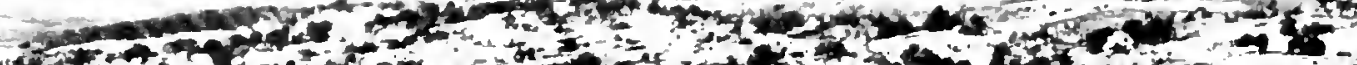
$+a^{2}-1=2$

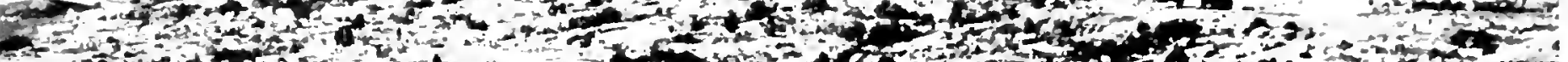

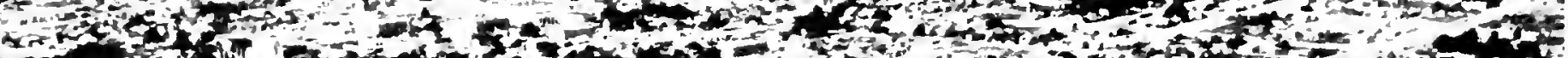

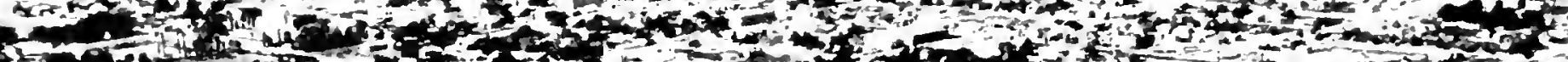
1 3 (N)

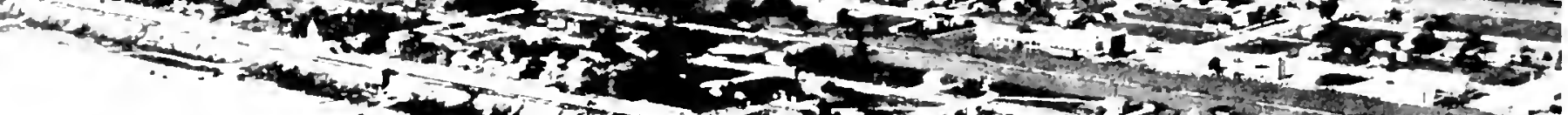

$w^{2}+x^{2}+x^{2}$

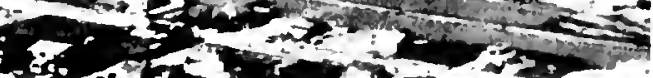

$\therefore$

$$
x
$$

$$
+20
$$

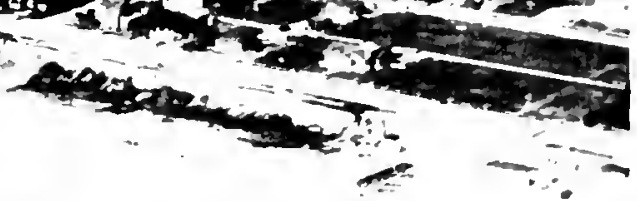

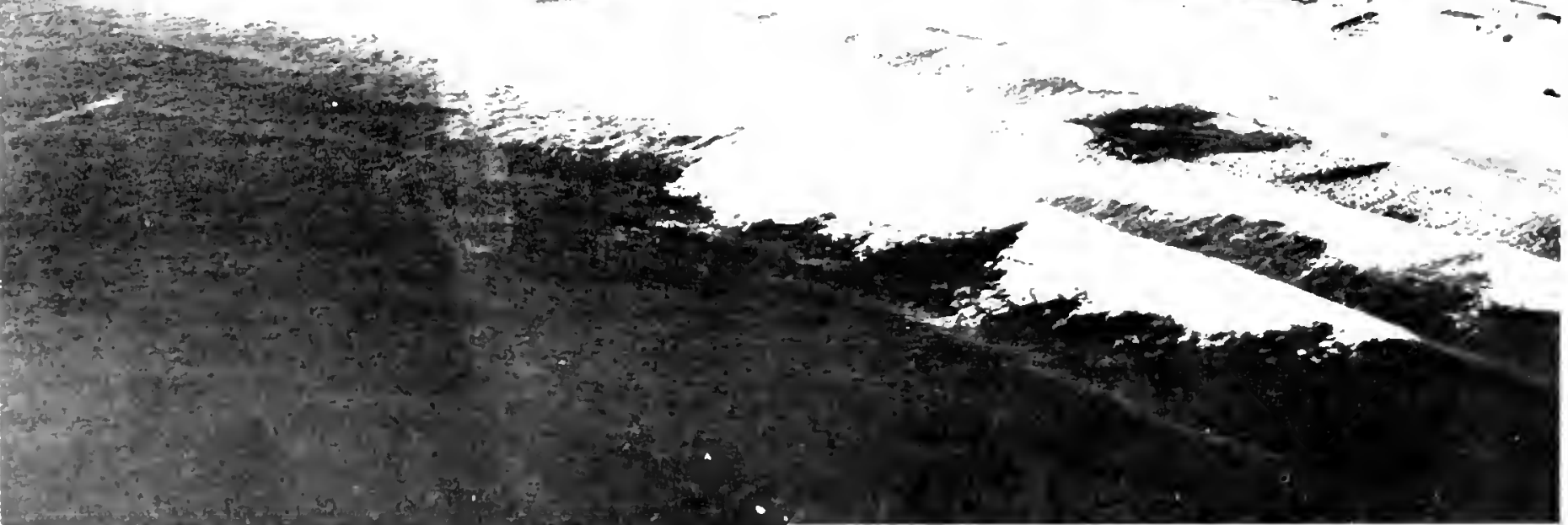


Simnil Hill hats an independent subsidenore area whin indudes the

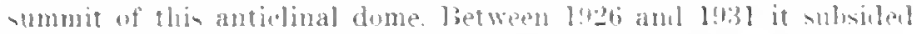

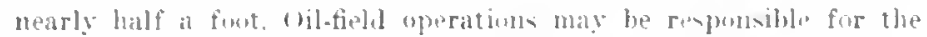
sinking lere and at lenice and latay del key.

In 7 th the concrete founlations of a mumber of oil wells sitnated

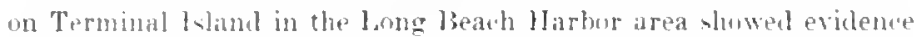
of subsidno at an extrardinarily raphid rate. The sinking apparently was lowal thoun in an area of slower depression. The slurtening of a Alallow superticial layer of sediment and hiel pumping rate from deep water-wells operated by the $L^{\circ}$. S. Xiary in the prior month probably were contributing causes.

The eanses of the elovation and depression are varied. Eartlomose. nento play a very important part and probably are responsible for most. Alw the drying out and onmpation uf "lay liyers and other natura! solume decreases in sedimentary rowek are a factur. In addition the workix of man flay a palt-extraction of water, cill, and foas: drainage and detlection of water either alrealy below the surface or that which would sink in were the artificial controls not used.

ciach clanigu affect the survering of the land for they may prevent establislment of mued needed stations which to not chande in eleras.

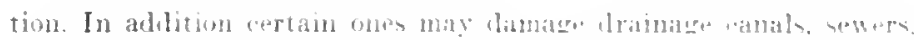

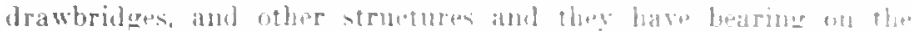

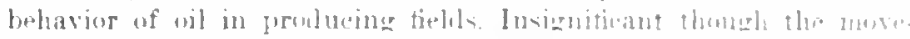

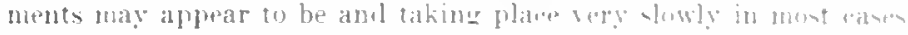

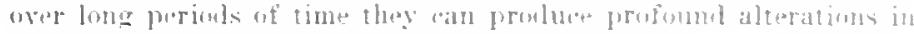

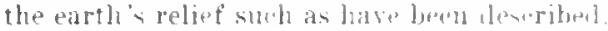

\section{REFERENCES}

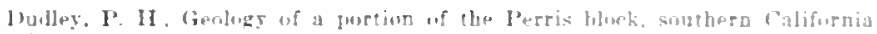

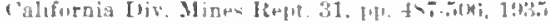

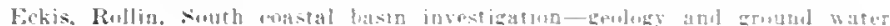

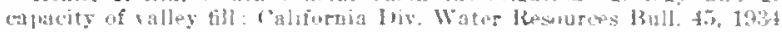

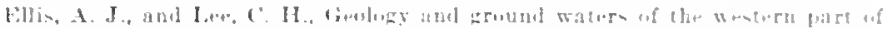

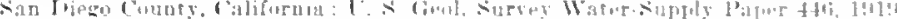

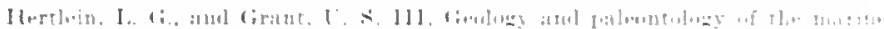

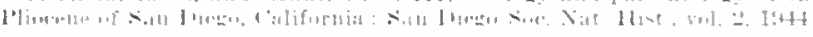

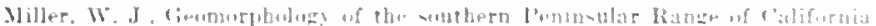

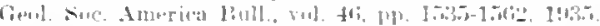

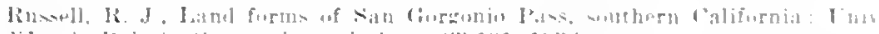

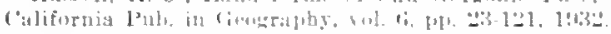

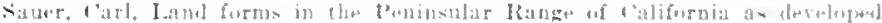

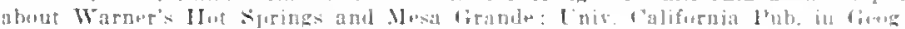

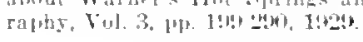



SEA FLOOR 


\section{SEA FLOOR}

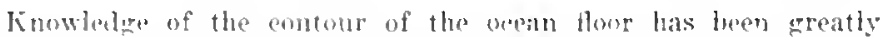
inereased in rewent time because of the development of instruments with which rapisl determinations of depth can he male. Formerly deptlis had to be measured by weighted lines let down to the buttom, a time ansuming process partieulary in the deperer waters. Monsurements obtained in this way were fairly numerous in plaees where navigation made them nowsary but we widely soattered elsewhere, eonsecpnently our eoneept of sulmarine landsupe was extremely sket dy. In tho last two or threedecades instruments alled fathometers liave heen perfouted which measure depth by reflection of sonnd waves from the sea bottom. a much more rapid method. In many places, copecially in the slatlow waters, the topograplyy has been quite aceurately worked ont and good maps have been made of the suboeeanic floor. In deeper waters, although depth measurements are stitt too few, they are numerous enough so that our concept of the rolief has been materially revised.

Haterials from the ocean floor are obtaned by dredging and eoring, but of course these operations ean extend only to very shatlow depths. A molerately amplete knowledre of surface materials on the ocean flwor has beron obtained at shallow depths and exen from the deep orem, but nothing is known of what lies below. Most of the floor of the orean is covorol with sediment and the lower layers untoubtedly have bern molsulixlated into roek. In a few places in slatlow waters there are indieations of the thickness of deposits but nothing is known for the deepert.

l'ratiolly everywhe around continental and island enasts there is the tlattish continental sholf sloping gently wht to sea from the shore line as much as a few tens to a few humbros of miles. Betond this is the contimentul slope which deseends somewhat more or much more abruptly to the areat depths of the oratn. Ilowever, off the sunthern ('alifornia "oast, the pioture is quite umique for there is a sories ul' lampes and basins extenting for about 760 miles that is mudn more rlosely related in strueture and topography to the land than to the

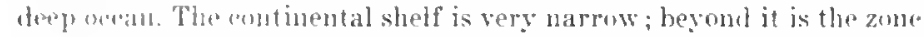
of irregular toporaphy termed the confinentat bordorlamb. The normal damblaspe of the sbelf is quite different from that of the lamel as the contonse are muds simpler: further ont in the mean the Inasins exterd derper lowow their surroundings than basins on the land and the tojes of mountains called submarine banks are much flatter.

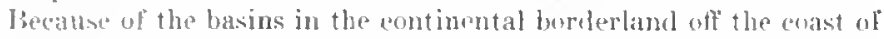
southern ('alifornit. withdrawal of the sea from this area would leave at eroup of large lakes, some up to 1.000 sifure miles in area. and comparable with many of those now existing within the continent.
In depth these imarinary water bodies eould exeed any in the l'nitod

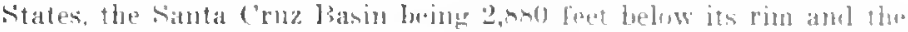

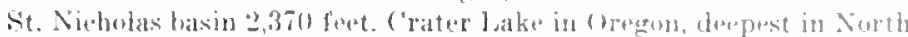

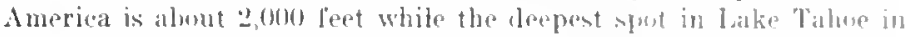
the Sierra Nevala is more than 1,600 feet bekw the surfals. 11, the other hand, there are basins not contaning lakes deeper than any mentioned; for example, Saline Valley, whieh lies betwen (lwents

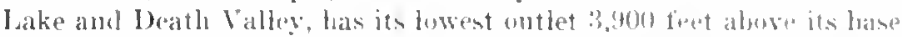

The area of the submarine basins off the coust of sonthern callifornid is about 6,300 miles, approximately a fourth of the total extent of the eontinental borderland in that section. The basins are rondhly elliptieal and are elongated northwest and southeast. Submarine linuings indieate that their walls are lone, strep slopes broken by a few vill. leys, though there are abrupt changes in the direction of the walts

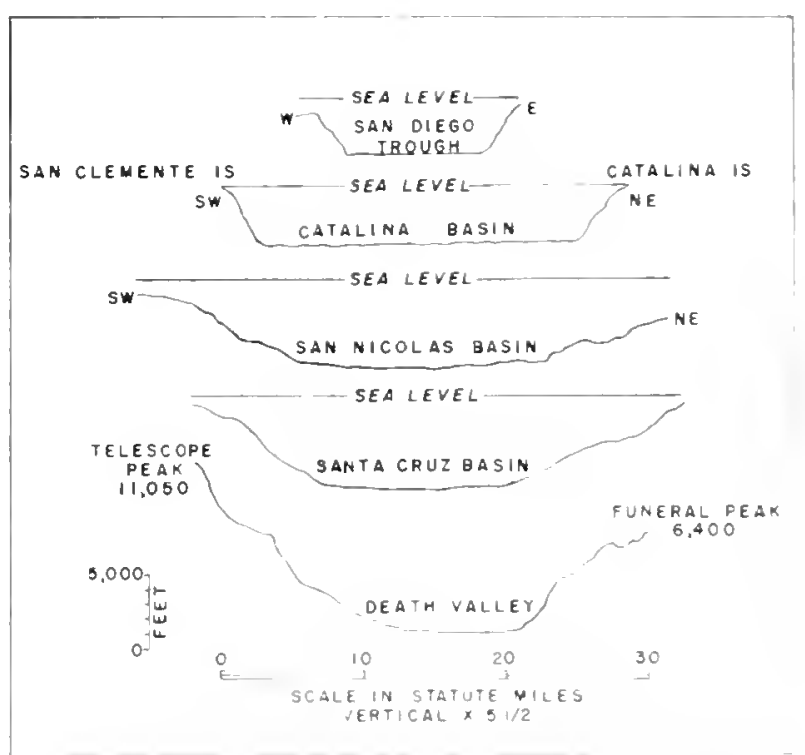

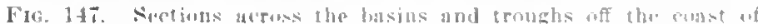

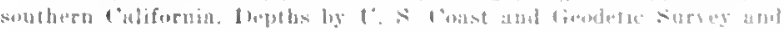

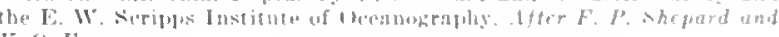
i. O. Fnery. 


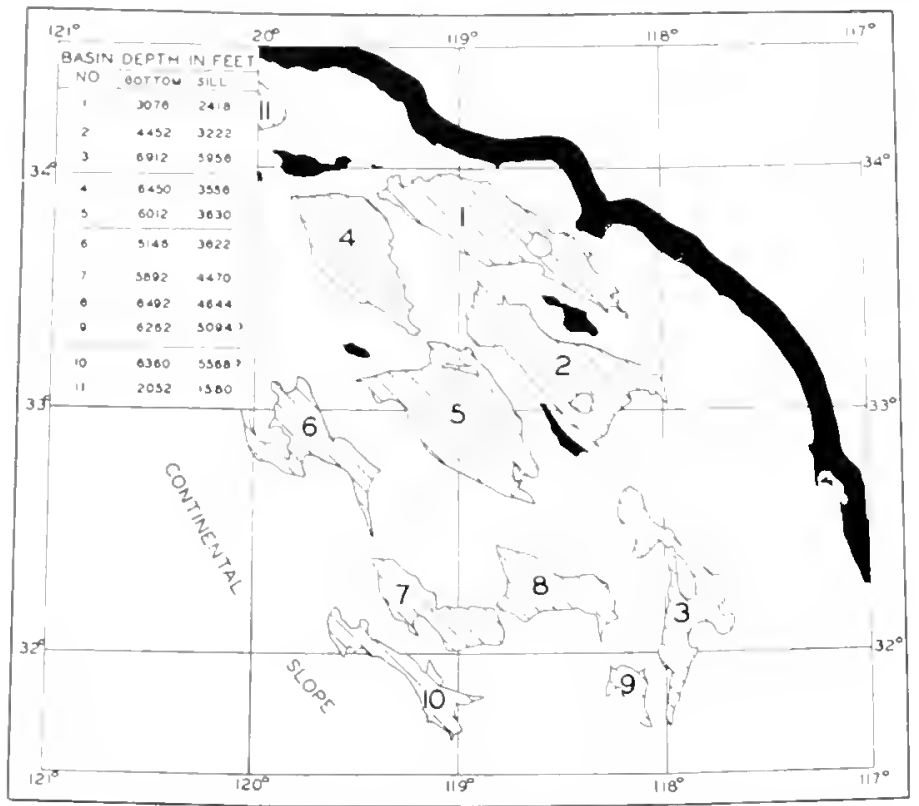

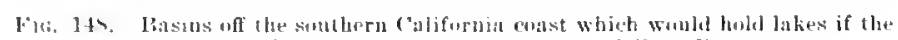

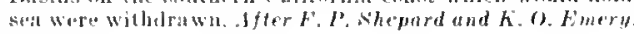

aphanently controlled by folds or laults. Soundings taken across the masins indicata relatively flat floos lorokn by moderate irreoularities.

"lhe rims of the basins which woukl represent outlets of the lakes if the sea were withlrawn beconc" leeper below sea kevel towart the somtheast, and most of the basin flours eleepen in the same direction. such istands as are present rise from the northern part of the shelf. Ill of this suguests that there may have been downwarping in a sulthedsterly direction, a submerenow which would aceount for the notable widening hetween the upper margin of the continental shope and the shore line which so sharply eontrasts this region with the rest of" the California borkerland.

The rolief of this borderland is diverse. At least me peak, probably' "und(al] in shape, is present southwest of the Coronados Islanels and a lew wf the banks are elliptical in plan. Most of the eminences are long, relitively nampw ridges, small portious of some of them rising above sulesil to form the islants off the southern California coast. The higle' parts ol the borderland are comparable in size to the short numutain ramers of the adjacent lands. The San Bernardino Ranges

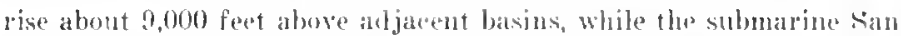
. Han Seamount stands roughly 10,000 foet above neiphloring tats. Santa C'ruz Istand has an elevation of about 9,000 feet abote the thou' of' the santa Cruz submarine basin, while Catalina lsland compares with the Santa Ana Bountains, eacli about 6,000 feet above surrounding territory.

In contrast with the highly sculpturel eontours of the monntains above sea lovel, the submarine slopes even where steep in general are

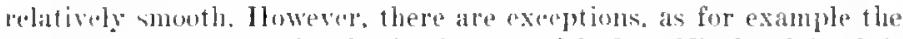
many small canyons in the bank on whel San Nirolas lstand is loroted, distinet valleys around Cortes and Tanner Banks, and one off Catalina Island. Even on the land, some nountains are nuch more intricately disseeted than others.

('onspivous features of this subunarine region are the flattish tops characteristic of the submarine banks, features yet mexplaind.

The sea floor in this southern California section compares with the adjacent tand in showing more than one direction of trend ol ridges. the prevaling being nortluwest-smutheast, like those of the Santa Ana and Sin .Jaeintu nomutains on the land. On the north, an east-west trend cuts across the other, probably a continuation of struetures of the east-west Santa Ynez, Santa Moniea, San Gabriel, and Šan IBernardino Ranges. Below sea level there is also a north-sonth trend. slow in a ridge southeast of San Clemente Island. This islant together with Catalina and the Palos Verdes tlills on the land line up in a north-south direction. A few oval submerad areas are nurtheastsouthwest and thus are at right andes to the dominant trome.

Many of the steep slopes in this borderland area in all probability aro fault searjos, as for example off san Clemente, Catalina, and (ont)nados Islands ant oftshore from the l'alos Verdes IIjls which nww an at anched to the land but formerly were one of the iskands.

The basin between Santa C'atalina and San ('lemente islants appar-

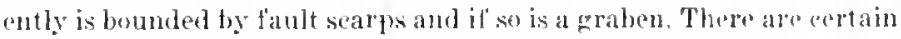
complesities in the scapp on the sin Clemente side whicl have not been explained.

In many places the trends of the submarine fault soraps are broken by offsets in fashon quite similar to that observed in scarps of like oriug on the land.

finder the oesun marring the normal smoothness of the continental

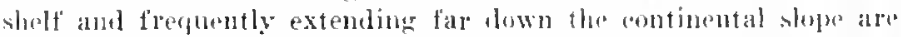
deep, narrow gorges very elosely simulating those puled hy rivers. That many of them are branching further increases the likeness. Aome are confined largely to the continental slofw juto which they lorate to depths of rany thousands of feet while others project back into the shelf, virtually to the shore hine. Siome are located oflishore from the mouths of rivers ruming on the land while others do not liave this 
19.72

SE.I FlaUR

21

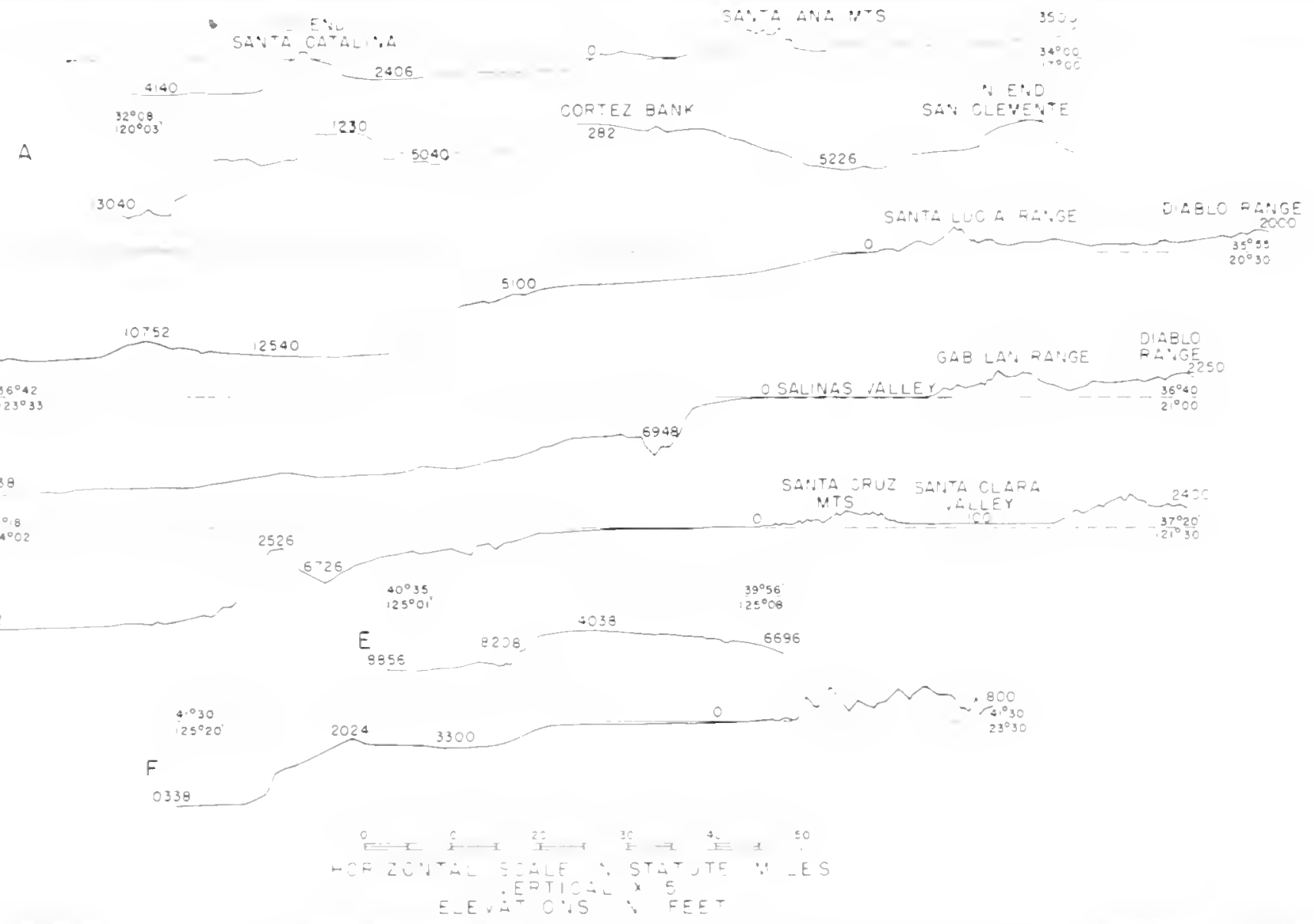

12996

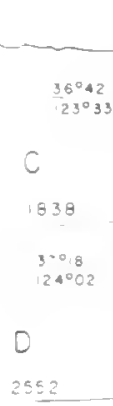




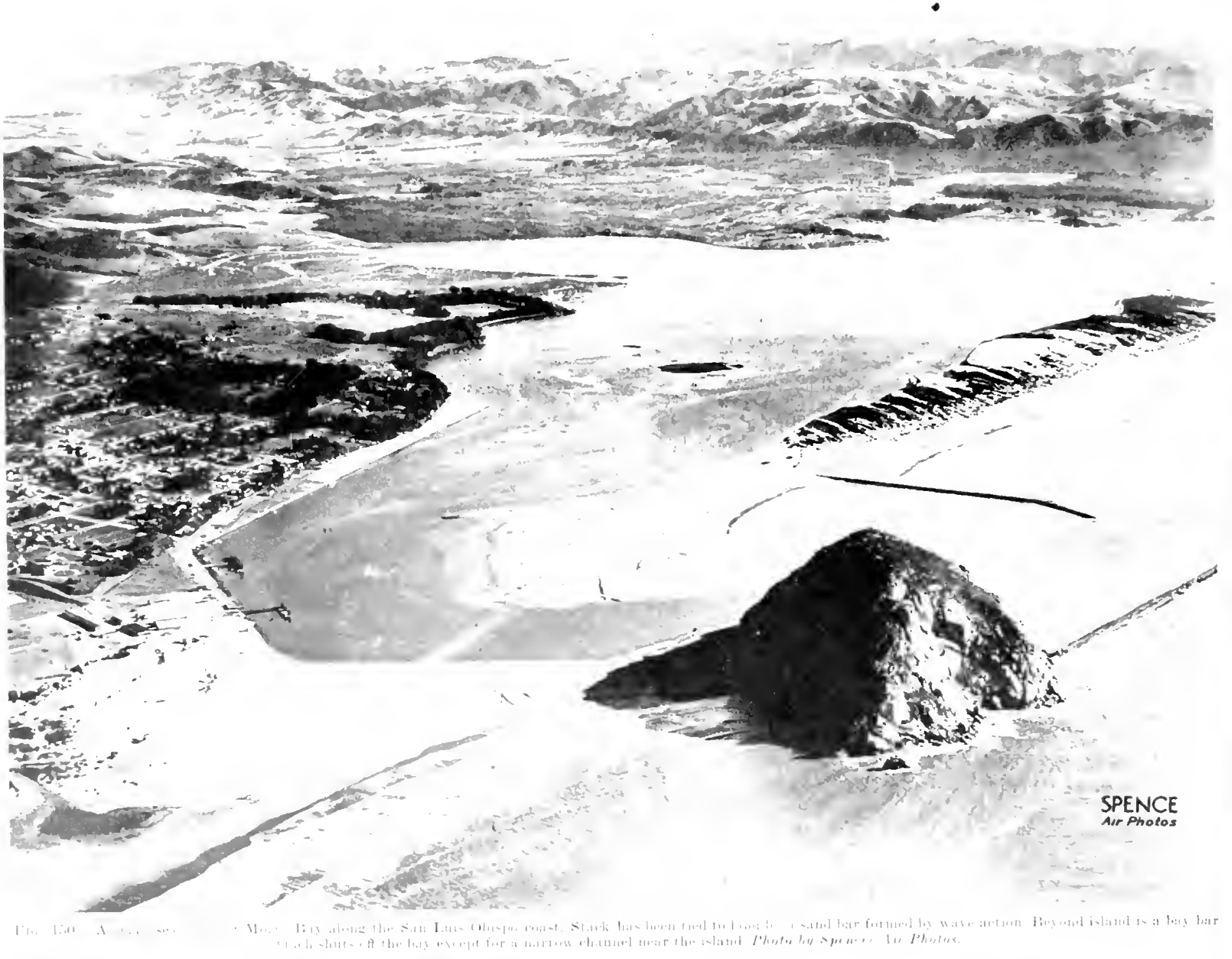




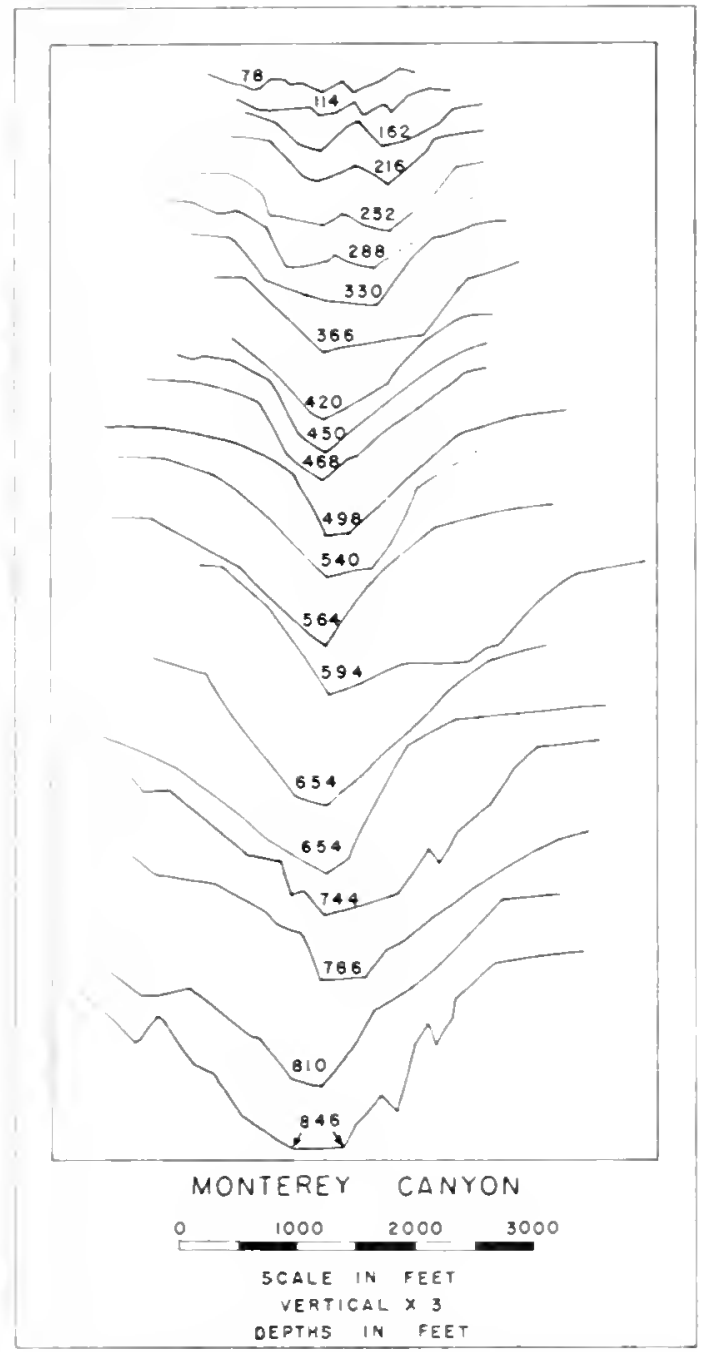

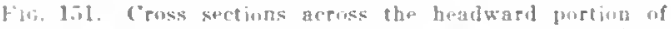

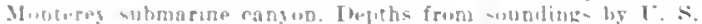
ivat and fipudetic surver. After $k$. $P$. Whepard and $k$. Fimery. relation. The origin of these so-ealled submarine canyms las been much debated but as yet no satisfactory explanation las bern adrancell.

In the southern section of the continental borderland, most of tht submarine canvons found along the coast do not extend to very areat depths. Many are found where the scarps are offset or where the trend "ff an esearpment chanqes, but some are located in different settinus.

From Point conception to Cape San Martin, the submarine lantscape is strikingly wontasted witl that farther suth bxcept for rone extensive valley and the gap which it forms in the eontinental slope. this section is relatively featureless.

Between Cape Sian Martin and Point Año Nuevo north of Monturey Bay, there is the greatest concentration of submarine canyons along the California coast and the eanyons are the largest. Furthermore the gently sloping continental shelf and the long rather straight escarpment of the continental slope so prominent farther south are missing. The slope is much broken, not particularly steep, and is cut by many of the canyons.

In this section there are short canyons extending not far out berond the shore line, while others are much deeper and break the continental slope, the hugest of the lot being Monterey Canyon, which may even extend beyond the margin of the continental slope into the floor of the deep ocean. The inner portion of this giant gorge can be compared with the Grand Canyon of the Colorado River in Arizona but the outer part is a broad trough with gently sloping walls. The gorge section is 50 miles long, the trougl about 56 more.

South of Point Sur a fault extends to the coast and its seamari projection follows a submarine scarp which diverges southeastward from the coast. The group of submarine canyons in this section terminates headward along this structural line and two of the cangon heads appear to bo deflected so that they parallel the supposed fault. This straight portion of the coast with mountains rising boldly above the shore line and a very narrow ecntinental shelf posseses all chara" teristice escential to a fault coast.

. Ionterey submarine canyon and its tributaries also reftect strue. tural features ubserved along the adjacent coast. Carmel Canyon, a larse tributary coming in from the south, parallels the coast, and either is eut along a fault or in relatively weak rock between adjacent resistant materials. Beyond the deep part of IIonterey Canyon, the broad trough previous!y mentioned extends seawarl for about 22? miles. Nortl of Monterey Bay the submarine canton alon terminate in a similar trough. The orign of these broad truughs is not known.

Berond the slope off the sontherm part of this sectum a summarin mountain named Davidson seamount, 16 miles long. T miles wide, and rising 7,000 feet above its 2 -mile deep ocean base. is comparallo with 


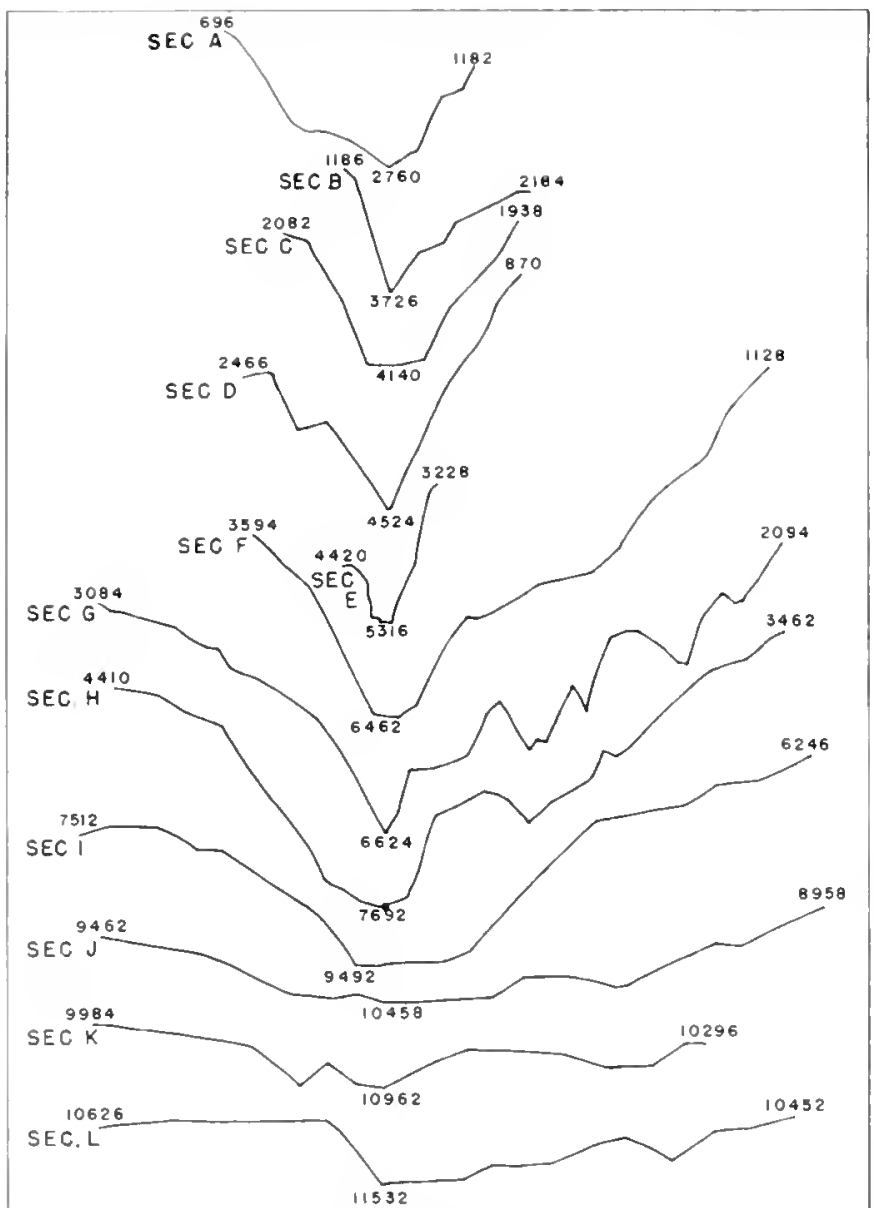

MONTEREY CANYON

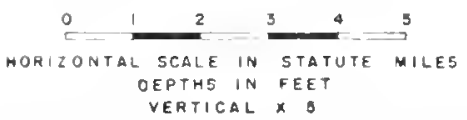

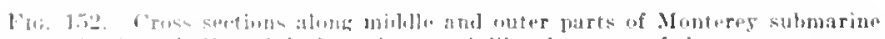

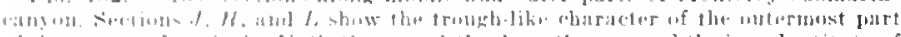

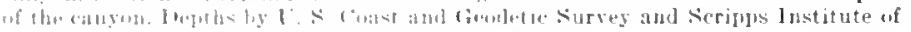

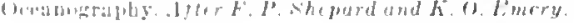

Sinn Juan Seamount in the southern seetion first deseribed. It las three or more peaks and two or three apparent depressions in its summit, wheh are about 500 feet teep and are believed to be eraters. 1)avidson Seamount like its counterpart farther south is probably a voleann.

Northward between Point Año Nuevo and Shelter Cove, the submarine canyons start well ont to sea and are largely confined to the continental slope. This section includes the San Francisco area where the shnllow eontinental shelf extends ontwarl for 25 miles, the greatest distanee along the entire west eonst of the United States, though considerably less than off the east and sonth eoasts.

The great marginal searp deseenting to the deep ocean is less sharply defined for there is a series of slope changes such as are foumd in the section inmediately to the south. In the outer slope there are many canyons some of which may extend as deep at 12,000 feet. Southwest

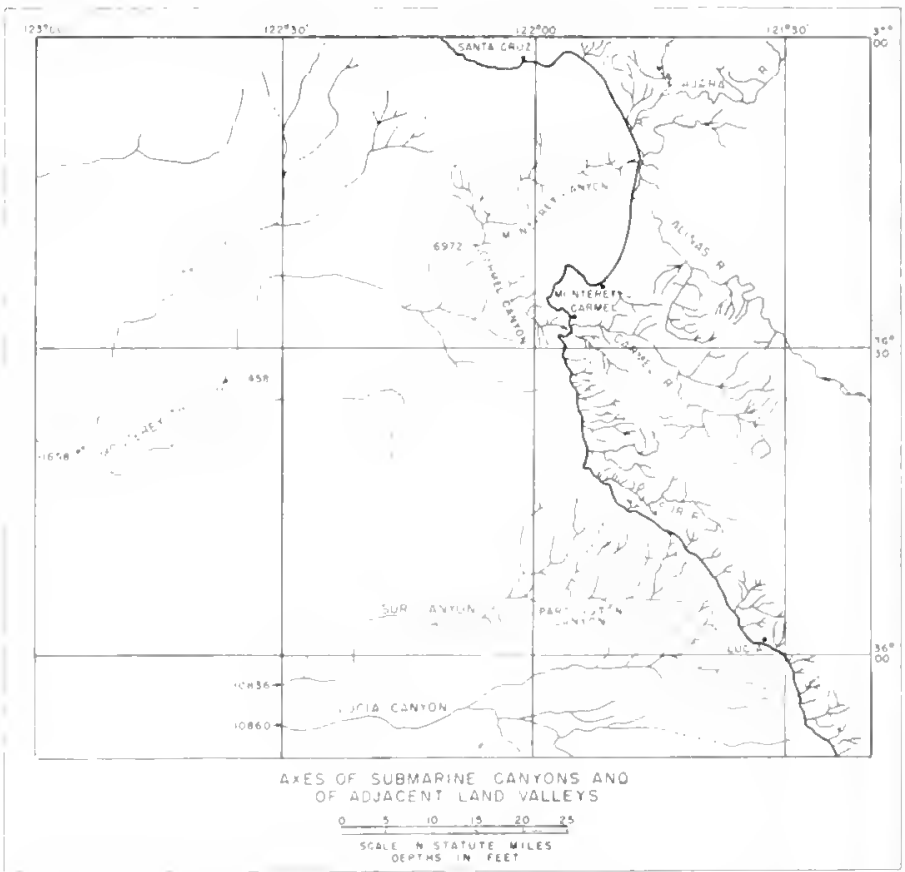

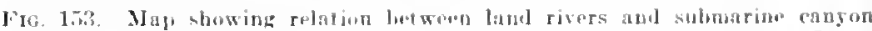

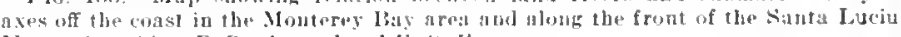
Jumbias. After F. P. Shepard and K. O. Emery. 
of the Farallin Islands, two mountains, which have been called liuile and Pionecr seamounts rise about 3,000 feet above their surroundings at the base of the continental slope. I'ossibly they are volcanoes.

between shelter cove and the Eel River. the chief feature is a prominent submarine esearpment, ealled the Gorda or San Andreas, which extends for about 70 miles from l'oint Gorda. This zone also is notable for its large submarine canyons some of which extend almost to the east.

The Gorda submarine searp runs almost due west and except in oue place is comparatively straight. Its lieight varies from zero at the edge of the narrow rontinental shelf to about 6.000 feet 30 miles out to sea. Beyond this puint, the height decruses to about 4,000 feet at a distance of 60 miles from where it starts. l'ossibly the searp continues farther out (o) sea though the indication is strong that it dies out within the next 20 niles . Along most of its length this imposing dechivity is topped by a narrow ridge which has a series of summits rising to within $T, 200$ feet of the ame surface. but beyond these hills the rilge broadens and is eoverel by water reaching 4.800 feet in depth. Along the north base of the ridge. there is a lung, narrow depression or series of depressions.

The strueture along the Gorda escarpment appears to be far from simple. but eviclence now arailable is insufticient to give a very complete pieture. The esearpment is unique not only for California. but for the worlh. since nu place is known where there is a similar declivity running normal to the general trend of a cuast. Epicenters of earthquakes have heen located in the greneral vicinity of the scarp suggesting possibly that it is still forming.

The San indreas fault has been traced as far as Point Arena. but beyond that there is difference of opinion regarding it. Some say it goes out to sea. while others believe that there is a return to the coast at Shelter Cove and an extension inland beyond that point. The evidenee for the extension as far as Shelter Cove eame from the development of a rift at that locality at the time of the 1906 earthquake. One authority holds that there are two faults beyond this point. one extending north-northwest to the coast at the mouth of Humboldt Creek and the other paralleling it about 2,000 feet inland. The rift noted above still is plain and ean be traced aeross Point Delgada to the eoast on the northwest, and from there about half way between Points Delgada and Gorda. About half way between these two coast prom. inences there is another riftlike feature. Toward Point Gorda the broken zone is less ronspicuous but the formations are much eontorted. The presence of a fault along the crast also is inclieated by the way the strnetural features are eut off at the eoast rather than being traceable in the topography of the adjacent sea bottom. Also Deliraida submarine canyon heads against a steep ungullied mountain sicle while most others are located of land valleys or lowlands, suggesting a shift in the position of this canyon by horizontal movement such as lias been characteristic of the San Antreas fault. At the head of leelzada Canyon is a straight escarpment sloping at 45 derrees which also suggests faulting. All of this evidence indirates that the San Andreas rift extends along the coast almost as far as l'oint forda and if so, it should extend out to sea nearby. The great Gorla submarine escarptment previously described therefore may be the seawarl prolongation of the San Andreas fault.

The zone off Cape Mendoeino is broken by subnarine canyons some of which are very large. One to the south can be traced seaward for more than 40 miles aud to depths of more than 9.000 feet, while others have been followed 2,000 and 3,000 feet below sea level. North of the Gorda searp, the canyons are related to land valleys, as for example the large ones in the area off the mouths of the Eel and Mat tole Rivers.

From Enreka beyond the Oregon boundary, there are few submarine eanyons or other spectacular topographic features.

It is noteworthy that on either side of the three most pronouneed breaks along the California coast Point Conception, Monterey Peninsula, and Cape Iendocino are the largest submarine canyons. To a lesser degree the short eanyons of the southern California coast ean be related to projecting points of land, but in no ease, either with major or minor projeetions, are the canyons located direetly off the points. Snbmarine eanyons are particularly rare in the steepest escarpments especially where the escarpments are topped by ridges, and they are almost as rare in the gently sloping portions of the continental shelf and the smaller banks.

If the prineipal tributaries are included. the number of known submarine canyons along the California coast is about 66, of which 18 , incinding most of the larger ones, head within half a mile of the shore line. The other 48 start bet ween half a mile and 30 miles from the coast with most between 3 and 5 miles. The gradients or slopes of the canyon floors are rather high, comparing with those of land canyons cut into monntain ranges or fault scarps, and there does not seem to be any serious interruption in this steepness at least to depths of 6.000 feet. The eross seetions of the gorges are $V^{*}$-shaped in all but the deeper portions where some apparently wirlen into or are tributary to flattish trougbs.

Dredging and coring operations have been carried on in 21 of the California submarine eanyons and rock has been discovered in the walls of 17 of these: in on]y one, Newport Canyon, has this work been carried on suffeciently to make reasonably certain that solid rock is not present. Ilost of the rock obtained is soft Tertiary material some of it little more eompacted than recent sediment, but in some places limestone. compact sandstune, and comerlomerate have been found. Near the head of Dume ('anymu of Dume Point in the Santa Monica region basalt was obtained from the heal of the eanyon which eorresponded with hasalt exposed on the point above sea level. Sisnta 


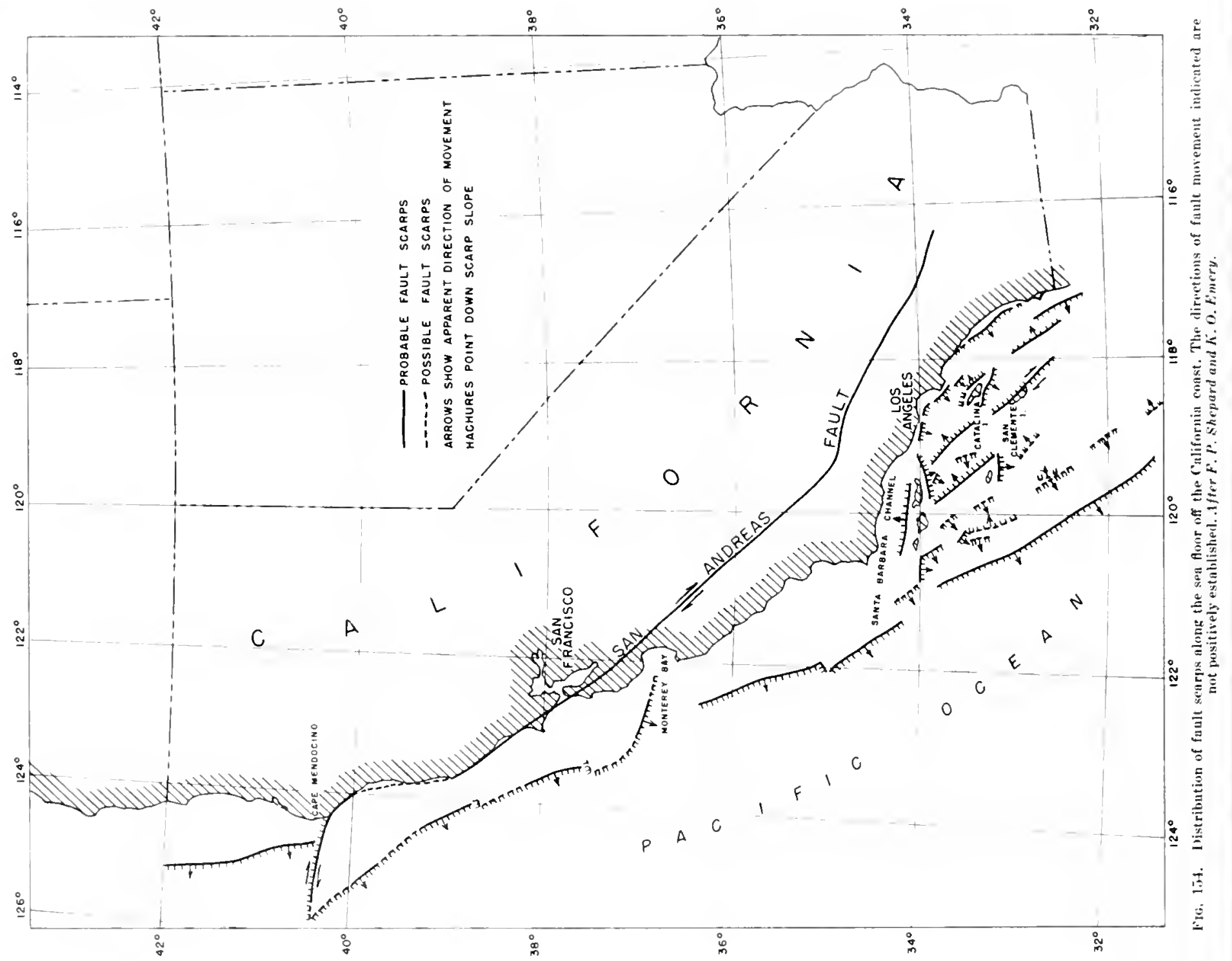




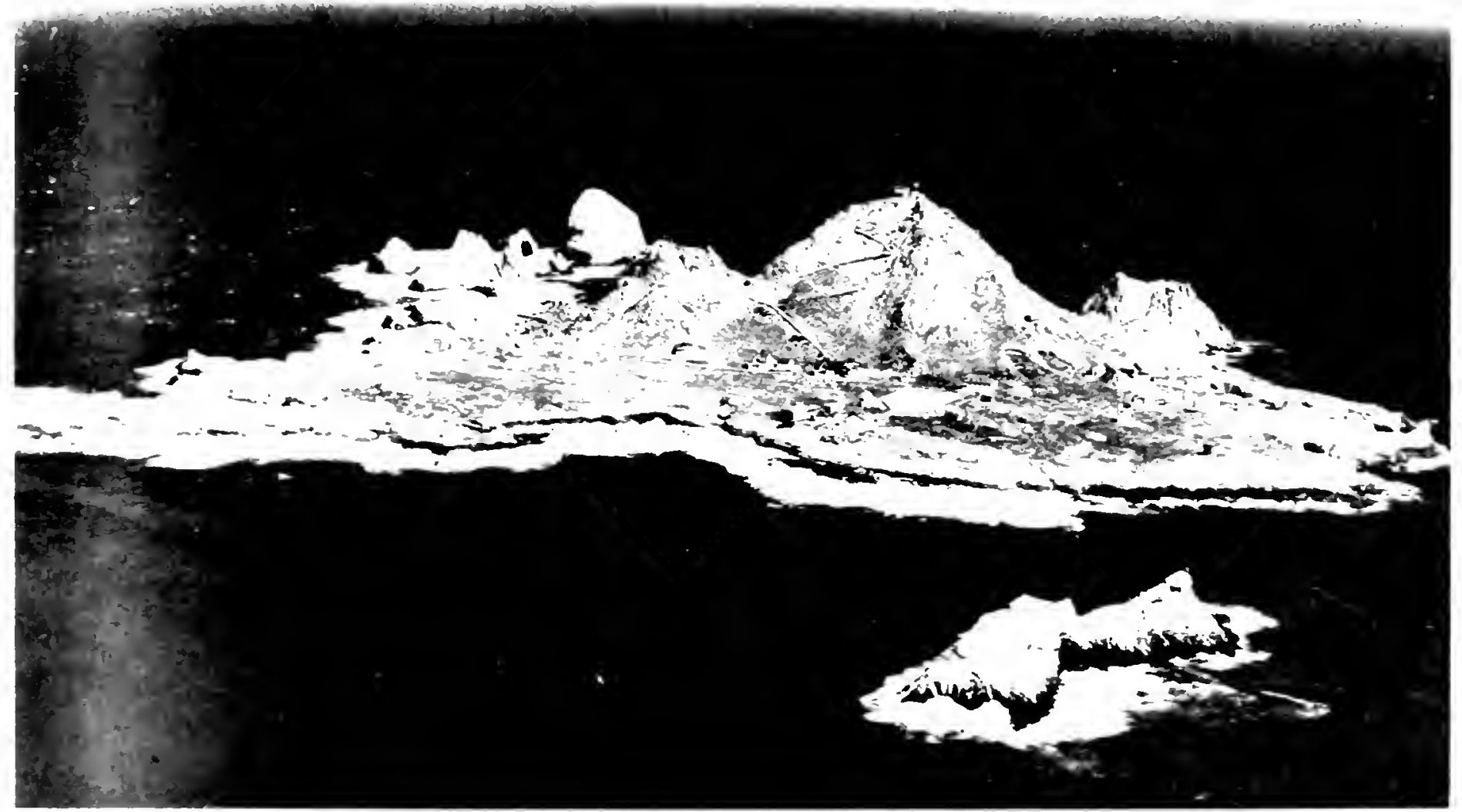

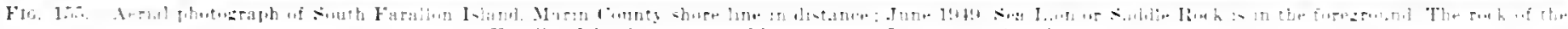

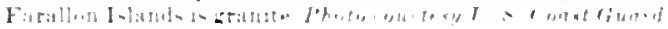




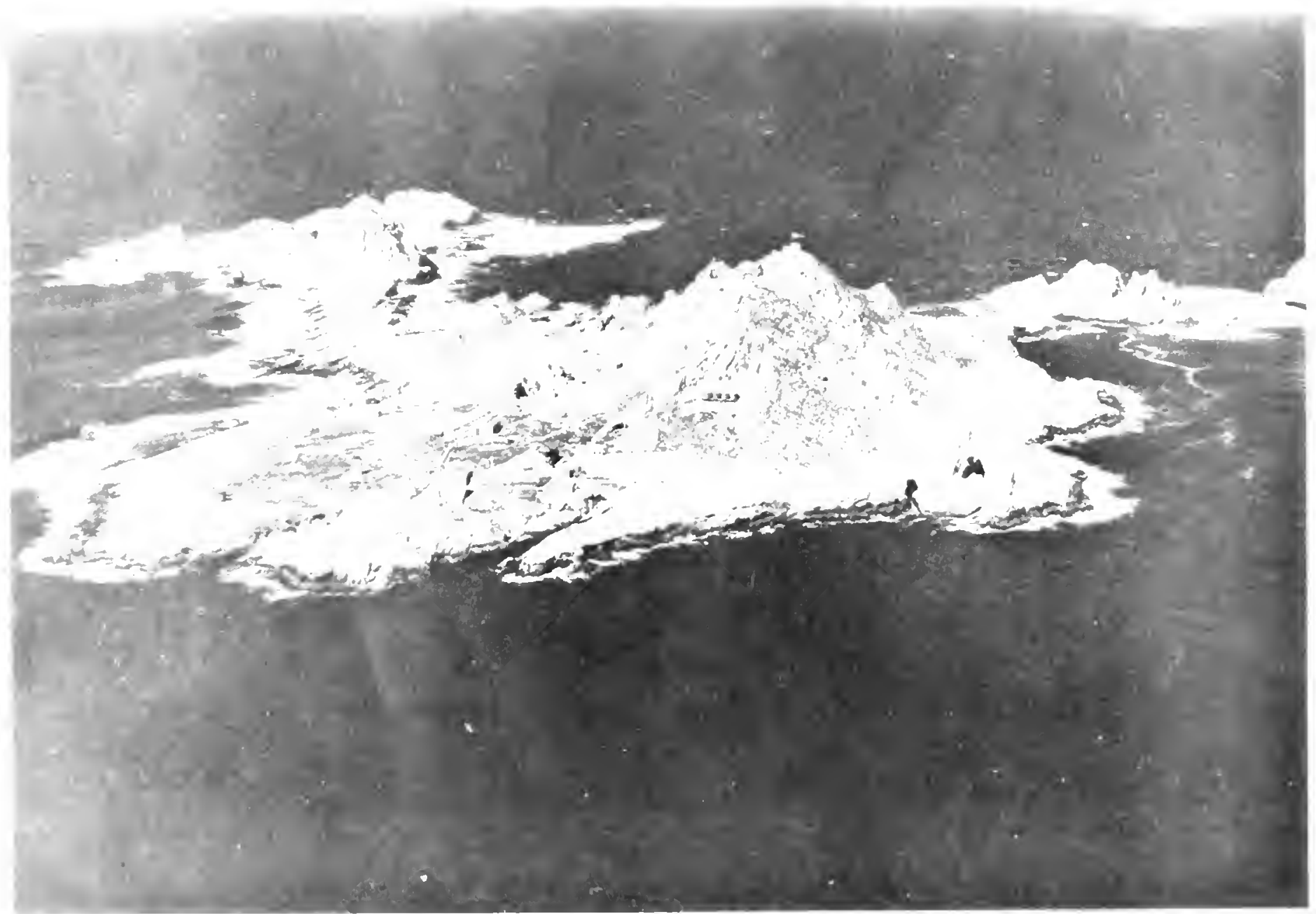

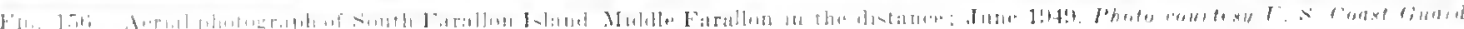




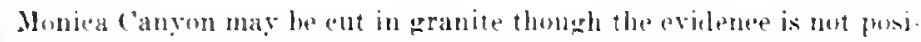
tive Carmed Canyon is equite certainy colt in granite and a steep wall along Honteres (anyon showed the sime rock to a depth of 3,900 feet. In three plide's resistant rock was met on one side of the eangon while the other was eomposed of unconsolitlated sediment.

Submarine eanyons in sea floors where large quantities of sediment are being deposited must mean either that the canyons have been very recently depressed below sea level or some process operates below sea level to keep them open.

The explanation of these renarkable submarine gorges has been actively debated. Some hold that they are river canyens which have been submerged below sea level either by the notable sinking of sections of the land or eroded during much greater sinking of sea level in the Pleistocene glacial stages than most authorities admit. Others believe that they have been formed by some type of erustal deformation. by the work of submarine eurrents or submarine sprines. by landsliding. of by the oceasional disturbances of the ocean when violent undersea earthquakes oceur. No single process so far suggested $x$ plains the exearation of these gashes in the ocean floor. and this is to be expectet for few geological features are simply evolved. Whether the eomplete answer to the question of the origin of the submarine eanyon will ever be obtained is a matter of considerable doubt becanse of the difficulties of undersea exploration and the fart that direct observations are impossible.

The greatest searp along the California coast is the continental slope which separates the deep ocean basin from the continental shelf in the northern area and from the eontinental borderland in the southern section. This escarpment is continuous along practically the entire California coast and may also extend off that of Lower California. It is offset in eertain places. Near Point Coneeption the searp is set shoreward but after about 30 miles it returns to the wineral position. In other places the north side is set shoreward apparently by dislocations along eross faults but withont return to the general position as at Point Coneeption. IIowever, in spite of the offsets, the eontinental slope comes baek in line with the same crently eurving trend which shows of southern California

The struetural tremls off shore are not only shown by fault searps but also by submarine ridges. The general north-northwest trend eharaeteristic of the eoastal ranges of California is well shown in various parts of the sea floor, while the east-west cross trends in the Los Angeles-Santa Barbara region also are expressed by east-west trends in the adjacent sea bottom.

\section{Farallon Islands}

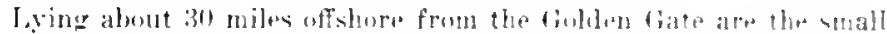

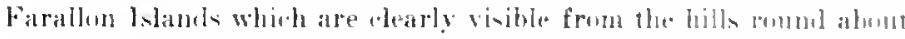

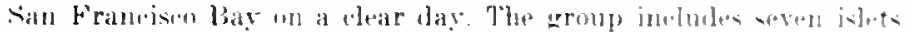

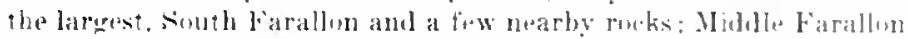
about two and a half niles north of Senth Farallon: and Surth Far.

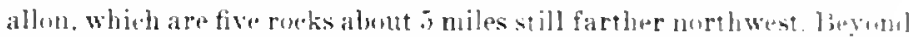
Surth Farallon are Nommay Rouk which is almont awash and cirrilell

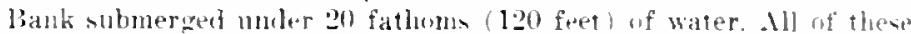

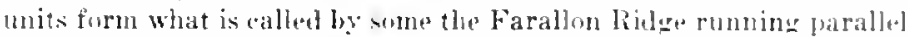
in the shore line from the virinity of the Guleten fiate to Puint lises

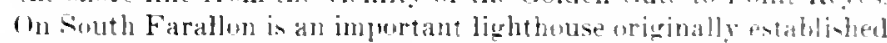
molyably between 18.2 and 18.5.5. During the early part of the las "entury qreat numbers of fur seals aud otters were anugh an and around the islands and inmense quantities of bird wars un watheren

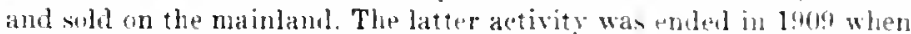
the islants were made a hird refuge now under the juriutiotion of the I. S. Coast Guard.

The Farallons are composed of granitio rock which is levely weathered at the surface. The rock is broken by many juints and probably by faults whose nomt conppicums trend is nortliwest-solltheast. Nany -hamuels have been worn hy wave at ack alone tlese fracturm I littio west of the center of soutli Farallon, two uf these channels met from "pposite sitfes at high tiule lividing the island intu eastern aud wortorn parts: this gorge is called the Jorlan River. The amount uf ruth re-

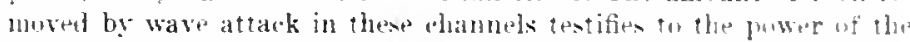
waves as they sweep in and sut, ahrading the ruk with the whiment

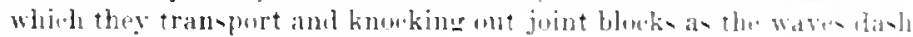
alcainst the rocks.

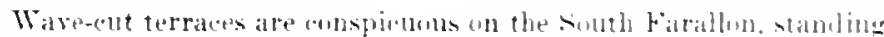

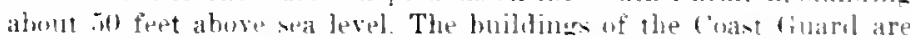
lowatol on one and another is at the west end of the ivland. Where? the terraces join the hither parts of the island at the base uf uriuinal

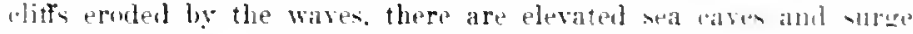
- Hammels like those aloner the present shore.

Nothine is known as to the nature of Midulle and Simh Farallum.

\section{REFERENCE 5}

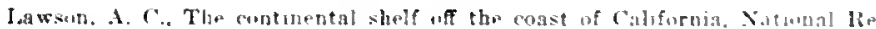
search Conncil, Bull., rol. S, ip. 3.23, 1224

Shepard, F. P. and Emury, K ('., Sillmarine topugrapluy uff the Caldfarms

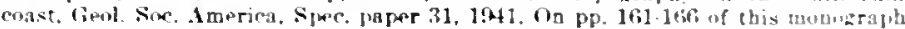
is an extended list of articles desling with the subject.

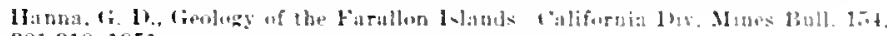
ค. $301-310.1951$. 


\section{ADDENDA}

\section{COAST RANGES}

\section{San Jose-Mount Hamilton District*}

The topugraphy of much of the Coast lianges is vigorously youthful, that is, tho (anyons are depe and rather narrow and there is little or no fat land along their bottoms. The streans are eutting downward. II some parts, however, the landseape has reaclued late youth or early maturity with the streams widening the lower parts of their vallevs whilh lav" flattish surfaced alluvial tils. The canyons also hav" widend ont "onsiderably. Thus erosion and deposition may be going on along the same drainare system. In the San .Jose-Mount IIamilon distriet, the more alvanced phase is met, thougl the develop. ment is far from uniform thromghout the area.

The enting of anyons and their headward growth is the principal feature of the present erosion cyle, but there is clear evidence in various places of an earlier phase of eanyon erosion which is indieated by decreases in slopes along the eanyon walls.

Jrom avidonce which has been recently gathered, it appears that the mountains of the distriet have been elevated twice in rather recent geolonianl time. The older of the two surfaees mentioned above semm to have been a "anyon eomplex though the valles's were shallower and willer than thuse now being leveloped. Their bottoms stand about 1,000 feet above the bottoms of the new gorges. Standing still higher. "1] to 1, 50) feet abnse the floors of the late eanyons, is an older surface which appears in have been a gently rolling late mature or perbaps old lanclsoans which is represented by extensive areas into which the eanvons are rutting.

\section{Healdsburg District ${ }^{\dagger}$}

A repurt mublished after this manuseript was written gives a brief aecount of landsiape evolution in the IJealdsburs alstrict of the northeru Cuast Ranges:

It has lone been repognized that the ridge prests of this region and farthor nopth into the Klamatl Mountains stand at roughly similar clevations abuve sea level, though the elevations elange from one loeality to anotlure. Such riclin crests are said to be accordant. It has been believel that they represent residuals of an aneient surface whielr was elevatel during the rise of the Coast Rances durine Pleistorene time. Betwen Healdsburg and the coast, the dissocted surfave of the Mendowinn latean or Mountains is between I,900 and 2.200 feet above sea level; in other places it stands higher or lower even passing

- Crittenden, M. I., Jr., Geology of the San Jose-Mount Hamliton area, Callfornla t Caliromia ly. Mines Bull. 157, po. 11-14, 1951

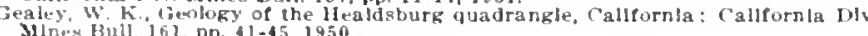

below sea level. Whethor the ridge crosts actually represent the enevation of an old landseape is doulst ful, for there may have been a guneral

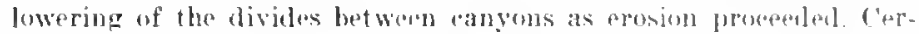
tainly thero ale no llat-topped aroas remaining which may be inter. preted as residuals of the surfaes. Sinco the present landscape is a sucression of ridges and eanyons giviner a nountainous rather than a platran topography, it is quite probabl that the ridere crests stand somewhat below the surface from which thev have been cut, even though the ridges have maintained general acoordanie of erost level.

The surface of the Mendocino l'ateau or Mountains was eonsidrably warped by the deformation which elevated the coast Ranges during midtle lelestocene time, benee it stamb at distinctly different elevations in varions parts of the region. Warping of aneient landseapes is a eommon feature of their cleformation. The nll, eroded landscape also is present in the Mayamas Mountains which lie northcast of Alexander Valley.

The ancient landsoape refarrel to abuve appears to have been developed by late Pliowene time. While in goneral it was a surface of quite Jow relief, there were gently sloping hills which rose above broal vallevs. There is a series of well developed river and marinu terraces in the area which indicate that the uplift was spasmolic as always is the case. Sone of the later terraces eertainly were developed after the principal detormation elosed.

Russinn River. The Russian River is the larest dranage line in the IJealdsburir area and one of the most important in the northern Coast Ranges. Its course through the ranues is striking and its his. tory is complicated because of the series of events which has oecurred since the river startal to How. The lower Russian River ents across the Mendocino Mountains in a llepe, narrow eanvon; in this seetion the river appears to be antecedent, that is the drainage existed before the monntains rose and was able to maintain its ourse acorss them becaus? the rate of uplift was matched by the rate of erosion ol" the cross "anyon. The long seretion of the river strotehing nortliward from the Llano de santa Rosa probably is subsequent lor it follows a zone of faulting whin parallels the trend of the ranges.

Before the uplift of the Mendocino Mountains, the Russian River was a consequent stram which developed on the Mendurino block and thowel neeanwarl becanse the regional slope was in that direetion. Whar eonsempent drainage ronghly paralleling the Russian hiver also is present. An example is the Navarro River which flows into the 


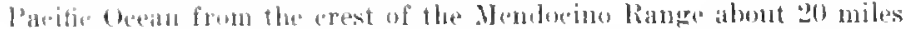

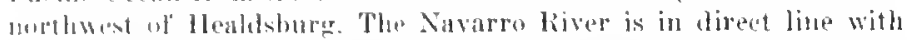
a leng valley tremling sontheast from the erest to join the Russian

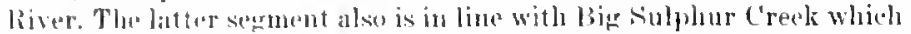
flows inte the linssian liver from the somtheast. At Yorkville there

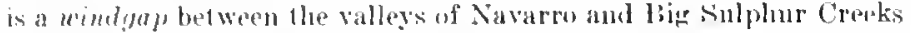
indiating that the Navaro was bethealed by the extension of the kuscian kiver in its subseduent section. A windqay is a short, abandoned grore thromoth which a stream formerly flowed.

Slong the subsequent portion of the Russian River, wide valley coctions are interspersed with narrow. In the Healdshury district at least. it is avident that abmormal widths of the valley are controlled by the presenee of weak strata in the deformed belt.

The "mrious passage of the Russian River throngh Sonoma Rock sulth if Jintown appears to have resulted from superposition, the

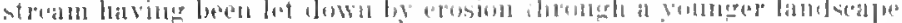
into one morar ancient.

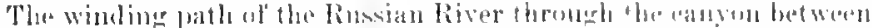

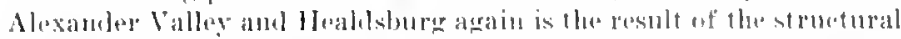

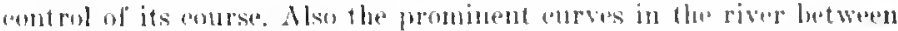

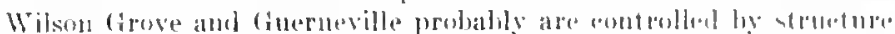

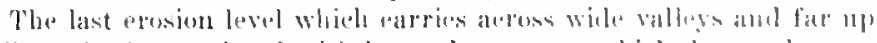

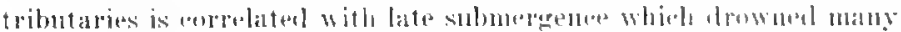
valleys along the coast and epeated fian Frameisen bay. This sub. mergence may have been eatsol by subsideme, hot mure probably was

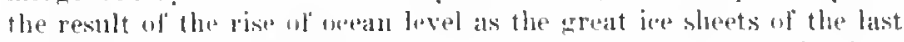

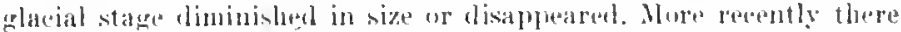

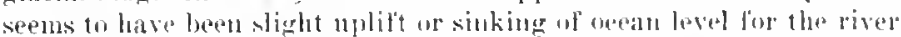

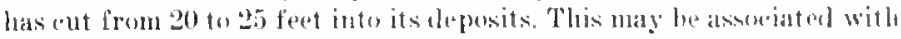

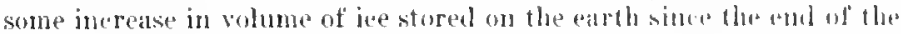
Climatic Optimum. 


\section{INDEX}

Imate Inthe vit

Whe Villey

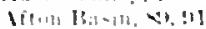

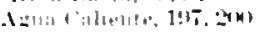
Sirtilen, 10\%

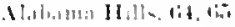

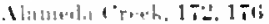

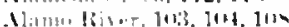

Mlileh:t, 1.5, :-7

Alagerag latinal, 170

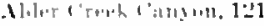

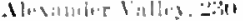

Nlkall J I ikt,

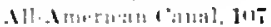

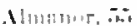

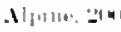
101119? 14

Aintian. 111.113

$$
\text { I" "1) }
$$

Amptos sil

Americian, 3.5. 10 $\{0,1=11,141 ;, 147$

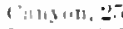

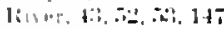

Imon, !

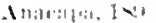

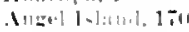

Antropu :-7

Alpinting linter. 10:-3

Irlibehtr. 1t:

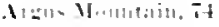
I: $1107,7.7$

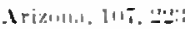

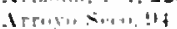

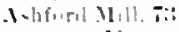

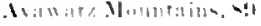

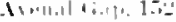

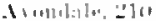

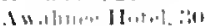

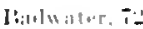

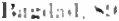

laisherotould, =-

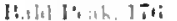

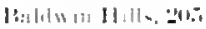

I:allaral, T!

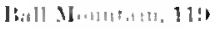

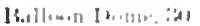

H.1 Hule A

$$
\text { J" in } \quad \therefore
$$

Batninimats

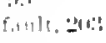

Jartrat?, at;

Ibatequan,

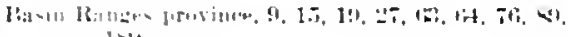$$
\text { Iv" }
$$

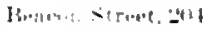

Buir kuten. 1:2. 1:2

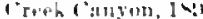

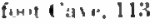

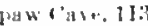

$$
\text { Riv r. } 1+\bar{t}
$$

Pea umung l'lan, :21:

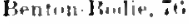

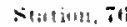

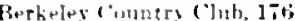
IIilln, 1it, 170,17-2.176

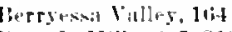

lheverly llill, $20,-21:$ Sewinert. 240.

Bighnrs llaterals in

Bigjunt in tit titi, tis titt

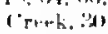

Suljhur Croption

Trumena River. 1!4

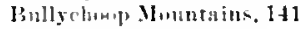

Bireh Ifnutasu. 1!

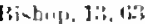
('rek, 1:4. הi

Rixby sloubl, 24

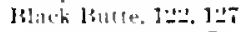
Mroustaine, 7: Range, it, 71,72

Whe I.akn., Ni, iti

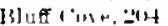

lilytion, 54

liniling I-akn. 1::1

Linlam, 1:21, 1:3

$$
1 \text { rent. 1:2 }
$$

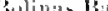

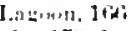

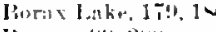

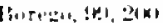

$$
\text { Valles. }
$$

Pur Sinde Hill, 13:2

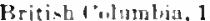

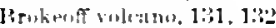

Pirowa Denutain. Tt

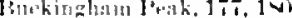

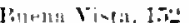
bus-in, 1.2n

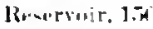

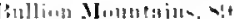

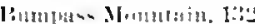

lourituri Rinles. lint

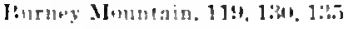

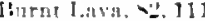

linge cinduge 1 to$$
\text { (reter, 1:1 }
$$

vallis, 11:1, 1:11

C

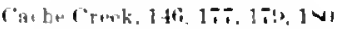

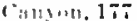

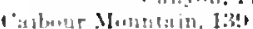

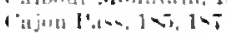

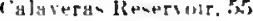

caldera, wi

Cyldrell (cave 11 .

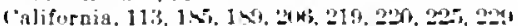

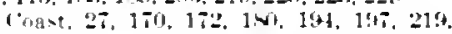
203

ltanges, $13,1394,141,152,156,17$. INi

Collahan, 111

( $\operatorname{atop}$ Curry, 30

('anada. 10

Canada del Jiablo, Iof

('yladian bonder, 11:t

('antu. 11]

Cantua Creek, 1.jin

Cale llendecinn, $=5$ San Martin. :-2:?

Captain Jack. 11 :

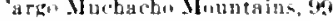

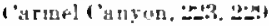

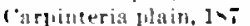

(*ar]*1, :I0)

Carquinez ('anyon. 172 strait. 14.145. 172

("aruen Range. 14., ㄱ)

$$
\text { ville'y. is }
$$

ciarrien, itio

$$
\text { creek. }
$$

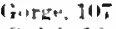

cracale ciulch, 1:-

l.skes, 11, 43, .7

Ilungains, $1 \cdot \cdots, 120,131,139,145,146$

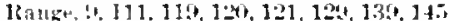

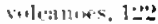

4 2 scadia, 15, 145. 157

caste l'rage 14:3

c!talina. 1!4

In lane. ma

Risetis. is

spiren, 10

("warralle, wi ve

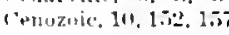
demmits. 73

ra, 17.1.1

Tertary, 1

(imine. It:

rolcanics, 139. 141,14:

Centril Platedu, 1:Bl

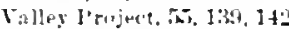

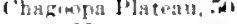

chatle IImotain IVI

chalone crowt. I WI, 14 valles. 10

changel lolands. 1!H

ctrane crage, 13:2, 1:4 Jumblow, 1:3:-134t 135

Chenter, 1:3

('hlere. 1ti;

irtok, 147

1 homa Mlountaus. 13:1 


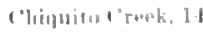

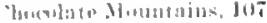

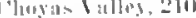

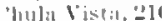

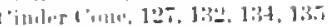

("irulut l'mk, 49 Masulit. 47

(")

$$
\text { crent, } 1710
$$

Cluthlatke athi

churkslsulte 147

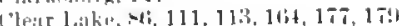

$$
\text { 11:1:it1. } 177
$$

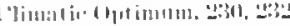

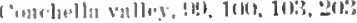

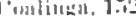

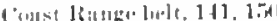

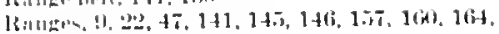
$170,2 \times 31$

foant Hills. 12

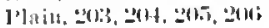

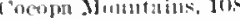

(a)d ("eresti, )

(ia)lins, : $(x)$

Finley, 10

cobracts, 10\%, 104, 19ki Aipuedient. 14

Weaten, !1, $>4, ! 99$

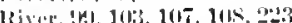

Yallon, 14

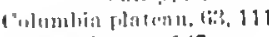

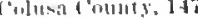

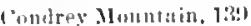

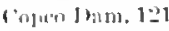

Jitke, 1:1

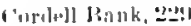

Circlonigen ( reate. ITli

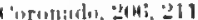

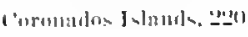

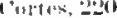

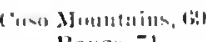

$$
\text { Rnuge, }: 1
$$

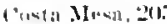

l'mbunum River. 15. 150

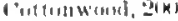

$$
\text { lind tis }
$$

Rห1120. 111

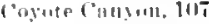

pionetio 1tit. 1 -

Hills, 20.0

11 is - 1, 2016i

1 ingles, 197

crartiel ('rages, ti3

croter loetken. 2l! 13:1 sill, 13:Monutain, tit, tis, re, 11!

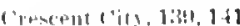

$$
\text { cruter, 13:2 }
$$

I'retuciusus, 10, 17, $1+1$ perjod, 22, 14.x, ]

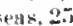
imis, AR, 157

("rown louint, :11

('rystal cave, 11:

sirrings, 764

(c)

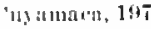

1"11:

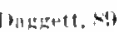

Bultull 1'myon, 1 1 ?

Jarwin, 47

$$
\text { Wills, } 71
$$

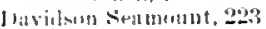

lenth Vulley, :1, 27, f3, 64, 71, 72, 73, 74, 75 Seutty's isstle, $i: 3$

[loter Monutain. 1:0

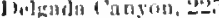

1)

liverulation aren, tio hasin, 4 ? lake, 53 Valley, 41, t3

1) il's J I

(iolf ('turse. T:

Kitchen, 1:31

Postrile, (w)

l'unibhbriwl, so

Diahlo Range, 164, 17? sution, 147

Irithey' ('reek, 2z!

bivisiun ('reat, en

Ihuminguez, 213

$$
\text { If ills. } 20.5
$$

Junuer Iantie, 53, an

$$
\text { l'nss: } 20
$$

Jus Jaluas, 10 -

[lunble llead, 11

lrukeshul, 1:31

Dnek Hat, 8

11mene ("nnyon, 2x

$$
\text { Joint, ㅁos }
$$

1) Hasmuir, 14 '

Jwinuel Rerservoir, 12]

Fitglo latke, so j't'k k, 31, 132 rumse, $10 \pi$ linck. 11! Mlsuntain. 119

bixgleville,

$$
\text { I.ake, 85 }
$$

Finst Perk, lit

Fichul lutes basin. 43 Elacier, 43

loldgewind, 141 valleys, $4:$

liel River, 2:-
J) fopitun, 31, 32, 38

('prritu 11ill, 17

Fit Vulley, 1160, 17:

f.l J'asu Jombtalos,

Purtal, 31, 32

prask, 1.i-

E.lsinore funlt, 213

Emoruld Bay $41,4:$

Eshetne, Jo, 1h, do

equich, 22:2, 2:3, 210

bitna, 112

rilrekt, 141, 142, 225:

Fall Creak Mountajn, 52

Fullen deaf 41

Jake, is

all River, $11:$

Fondnngo Valley, w

False Buy, :GM, 211

Farallon lilands, J72, 2at, 202.

Feather River, 15, 52, 145

Fish ("retek, in

lanke Valles, git

MLuntain, lut

siprings, $10 \%$ sichool. 09

Fort Bilwell, st

Frinnt llam, in

Friuk spring. 10:3

Eryxell. Fritiof, 19

Funeral Ranges, (it, it

furnace C'litek, T: Inn, 12, $7:$

Gabilan Mountains, I

(inffey anticline. 204 Street. 201

(Girlack fault, T., s!)

(inrner Jlounfains, 1:30 Peak, 1:30

inruet lake nis

Genona Peati, 21

Geysers, 131

Gibsin l'ealk, 139

Gila Rives, 94

$$
\text { Valley, it }
$$

Gilbert, li. K., lii:

Rilt

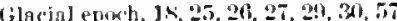

Glacjer Peak, r.:Point, 31

Glen Alpine. $4:$

(i)eudale, 1 in

Glenn Counts, 140 .

(iudel Creek, in

Golien Gate $2 \pi, 164,170,172,229$

Canyon, 172

Internation
Strait, 17:

Gold Lake, 52

Goler Well, 89 
Gouse Jake, tis, Its

(Bonsenest. II! Valles, 82 volcano, 130

liverda. 20:5

(itrilien.

Gravala lianch, 121

Giand Cangon, 203

Grunite l'reek. 14

lirant Take, 7s, 70

Grapevine Canyon, $10 \pi$

Kanges, 64, 71

Grass Iake, 43

Fray Hutte. 120. 125

Prent Rasin.

I'lains, 13

all

$$
151,170,172
$$

Wotern I rivide, 45, 51

Greenland, at

Grizzly l'ak, 129, 130, 176

in poundhog Cone, 57

Huatay Mountains, 2m

Buernewille, 230

Guil of tower Crlifornia, 99, 103, 105

Gull bake, is in

Guset Flat, it?

Ilaight Monntain, 129, 130

llalf lume, 30,31 , th Imon Inke, 13 Vinlles, 43

11all Cansom, In

Harkness volcano, 131

Hat I'roek, 131.134, 135, 136

Hay = Cangun Range, $2,85,111$

Harward $17 t^{\circ}$

$$
\text { fault, } 170,176
$$

rift, 176 syitem, 178

Hessldsburt. 2:31

lleather Lake, 43

liemet $V_{a}$ lley, $10^{-}$

lletch Iletwy Reserroir. 55

Iith Hiwk I ake, 3 *idluy, 17!

Ilitelicenth summit, 47

lleckett P'Hh, 31

Inollimer, ivi

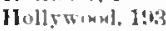

IToney lathe. Is, vi

Houn villey, It:

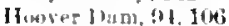

Iforuthems, itl

llors tongyom, 14

Hora. 19mp, 124, 120 1"th, 1:4, 134,

Itoratefief Hutte, 1:2) Janch, 130

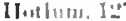
Hacivr. I24
Ilotel del coronado. 31

Howard lesk. 177

Ilumbuldt ("reek, 2:ar"

Humphrey Basin, 53

Huagry Hollow Ilills, 147

Huntington Beach, 213 Mesa. 205

Hyampon, 14:

Idaho, S2, 111

Igneous rucks, 17

I kes Peak, 119

Illilonette Creek,

imprial-Corchella, 197, 300 trough, 99, 106 Valley, 04, 90, 103, 104, 107, 105

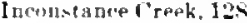

Indelendence, 1!), $6 \mathrm{x}$

I ake, 53

Iadian I3utte. 111

wars, 11,3

Wells, 10

$$
\text { Valley, } 75
$$

Indin, $]$ (m)

Hills. (M.) 107

Inglewowl, 20t, 213

Inspiration Point, 204

Into Monntains, 57, 69

Rance, fon

Whice Monntnins, 64

Jackson, in

Jack's I'eak, 43

J acumbr, 2 m

Jess Lake. of

$$
\text { Valley. } 23,86
$$

I imtown, 230

lohannesburg. 89

Tune I Aake, iti, 7s, is

Jurassic, 10, 15, 16, 17 fuld-faulting, 23

Ilountains, 157

ferind, 15, 17, 157

strata, 135, 141, 142, 145

time, 57

Kane spring. 1(K), 103

Kaweah Busin, 31, 51 group 45 River, 15, 5?

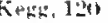

Kelseyville, 177

Kennets Cauyon, is

kipu at

hasin, 51

(atumen, 25

Jinke, in

liver, $14,15,22,29,45,49,170$

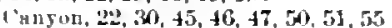

liettleman llills, 1.i2

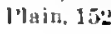

King ( ('it $y, 1, v)$

King's Rasin. si

Creek Valley, 13

River, 15, :4, 45,52,145, 150 a res, 30

Kingston Ranges, $: 9$

Klamath, 139

area, 141

Falls, 111, 113

Iountnins, $9,16,55,125,139,142,145$ 157,230

region, 139, 141, 14?

liver, 121, 139. 141 valley, 120

Klinker Monntain, 75

kilip, 47

Konneti, 17

Konwabitaon, 127

เทบเ 4

La Cima, 152

Cienega Boulevard, 213

Laguna Dam, !

$$
\text { Yumbins, 107, 213 }
$$

La IIabra Basin. :3x)

Jolla, 206, 210, 211

Lake Annin, Si

Cabuita, 103,107

Cits. 85

County, 17\%

IIanix, so

Merced, 146

Russell, it, $>0$

Tahoe, 9, 13, 14, 1R, 21, 29, 41, 43,55, 63 Pyramid Peak, 1 ?

Yosemite, 3:

Laading Hill, 205

langley, 13, 46

La Pusta valley, $2(x)$

Ins Choyas, 211

Lassea County, 0.11

Itome. 134

Tark. 1:2

Peak, 132, 134, 13.,

Voleanic National Park, 130, 131, 136, 1S1

Iase Chance Yountain, tis

Laurel Canyon, 1:13

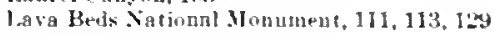

Ia Verne, $2(t+4$

Lesch Puint Mountains, w!

Le Conte livide. ti

Inevining, is

C'ansou, io

liberty Ca[r, 31)

Gap.jiz

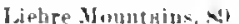

linda Vinta .I tosa, : $2\left(K_{i, 2}, 210\right)$

Linfyuash, 113

Jion Junnthins, IN: 


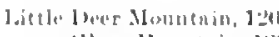

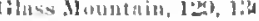

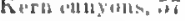

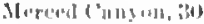

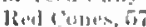

Shantu Vulley, 120)

'lujungu River, 1:H

Whitmey I reete, if Memluw, it

Yosed

L.jermate, 17it Valles, 32, fin

Llago creak, liti

$$
\text { valley, 16t }
$$

1.] anu de Sante lemsa, 2330

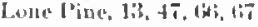

$$
1 \text { 'puk, } 13,4 \text {, }
$$

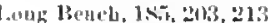

$$
\text { 11urtor, } 213,215
$$

1'int, 204

villey, \&, $8,1<$

loun Iake, iz

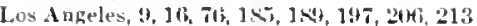
nolleduct, tion

basin, 14?

region, 94

Jiver, 193

Sinta lBarbira region, 220

Gintus ("reek, $1+\bar{j}, 15$

I aost Hills, 1.i:

Creak, 131, 132, 134

Lake, s6

River, $11: 3$

Lover's I and to

Jower l'alifurniн, 15

Kinmath Lake, 111, 113

lake, si

Madeline lyains, No

Minte Moutstain, 135

Inlagul cove, ath

Manuoth orest, itz

$$
\text { Nusntrin, 52, 57 }
$$

Aln

Mlanix 91

Mnoly Iake, 73

vanzuitn Take, 1:30

1 a rbole, 130

$$
\text { Furk, so }
$$

Maria Minntain ranges, 94, 107

Marill bluck, liali

$$
\text { County, 170, } 176
$$

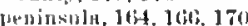

Marysuille, 145, 145

$$
\text { Imain, 14 }
$$

Jison Villey, 107

Jatthes, I)r. F. Fi, 13, 1!

Muttolo kiver, $22-$

Mayacmas Mountrins, 230

lecra llills, (M), 107

Medicine Lake llighland, 111, 113, 128, 129, 130

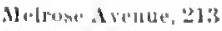

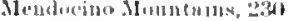

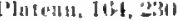

Rungis, 16t

Mereed callyou, to

$$
\text { leiver, 32 }
$$$$
\text { Vinlloy, 1til }
$$

Vesal Vulloy, 2111

II soraje, J0, 1349, 141

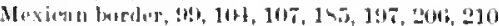

3 t.

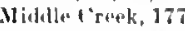

$$
\begin{aligned}
& \text { (w) } 114 \text {, 1, 1, } \\
& \text { (') } 1 \text { ayon (2) }
\end{aligned}
$$

$1, k+4,63, \infty 3, \mathrm{si}$

Ilid l'lejsterene, 167, 160, 164, 170, 214, 210

Mill trepk ("nngen, \&

Millerton I, ake, ins

Miller Mountain, 119

$$
\text { Rosd. 11:t }
$$

Mill Valley, 13

Mineral, 1:30

$$
\text { King, } 4 \text { i, }
$$

Miocene, 10, 16, 23, 113, 205)

eluch, 157

late. 25

- lincene, 21

strilts, 183

time, 19, 23, 5t, 141, 157, 181

$$
\text { valley, } 25
$$

Viramontas, 10,

Virrur I ake, 32: 5,

Mission 15uy, 20Hi, 21

Moder, 111

$$
\text { lbitch. } 211
$$

("unuty,, 4$), 82$

lndimns, 113,145

Modur Lava Biods, $x$

$$
\text { l'lutein 11, 135, } 139
$$

Platollu, ! , 111, 113, 115, 129 sertion, 193

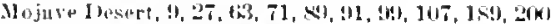
liver $4 !, ! 1,16 !$

Mekelumne, $15,5 \pi, 147$

Manu, 14

13asin, 7it

Colles, 1 si

Crigers 70,80

Inyuratera, 70

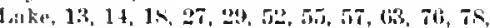
$7 ! 1, *)$

Кнаце, $57, w$

Mestara block, 14ti, 17il

fault likt: Hountain, 164, 16to

Shuteruma 11ills, $1+13,147$

Monterey kay, 16t, 170, 2:3

( 'n nyon, 223, 240?

l'eninsula, 225
Mintument, 1has

Monuraental, $1+1$

Morena valley, :2(x)

MLran llill, l:3:

Mormon loint, T3

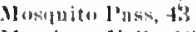

Mosshrae 10ulls, 12k

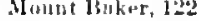

lisutioneff, 1:3

Inckinghum, 177

I 1 mu, 47

limbler, 176

Fidis, 14.5

liilibs, 17

diugot in

llamilen, 17t:

Runge, 164

Ilarkness, liz:

I lelen. 132

1 litcheock, 51

1 loff man, 12!

King .5:

linnocti, 17r, 19

Langles, 13,47

Lec conte, 51

L,yell, 30)

Mullory, 51

Aleddie, il

Meclitre, sil

Montgomery, 69

larker, is

lainiter, 122

Kitter, 57

lase 21

[Russel], 5I

Nun Antonio, 189 Jacinto, 197

Shastu, 9, 119, 120, 121, 122, 128, 129, 130 $1 \times 1$

Tulluc, 13, 21

Tamalpais, 1tit

Willimmsnn, 13, 1!!

Whitney, 13, 19, 25, 43, 45, 47, 49, 50, 51, 52

Woud, is

Viune 49

Nlid rerek, Ji:2

bolcames, 107

Muir, 4i. 4ti, 4

(Pist, 51

Ma' Min Sipring, 1(H)

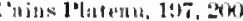

( $)$ and, $113,1 \geq 7,112$

Rivers, 1:3:14, 14;

loy Mountuins, 107

Gavin ['enk. 1]

life Canyon, 15

literiek llills, lint

$\therefore: 112,164$

Navirtu Rifer, 230 
X.41.. :-10

Tirran, :-1

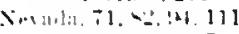

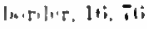

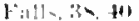

$x+u, k+1,1,3$

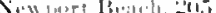

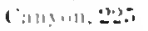
11:210.6....1. 1:13

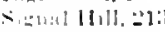

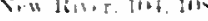

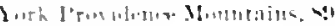

Xine 90

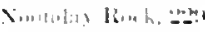

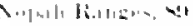

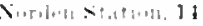

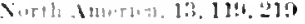

Inoton, its

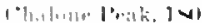

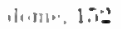

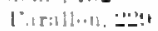

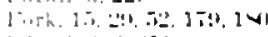

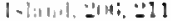

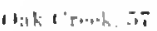

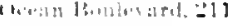

lijisi, 1

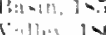

:The 1v:

::1111 4,41

li.1.1, 1 - :

P1.1P $6+1,1: 31 ;$

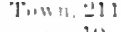

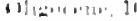

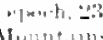

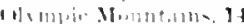

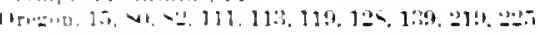

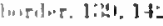

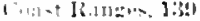

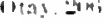

$19 \cdot 0,211$

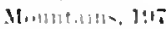

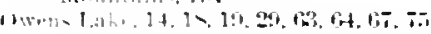

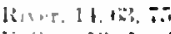

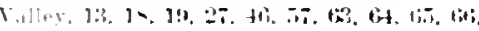

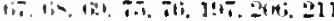

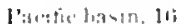

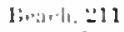
1 in: 110

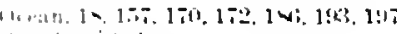

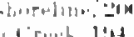

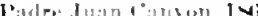

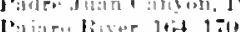

Pijart

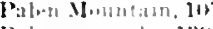

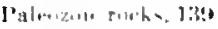

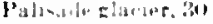

Ialavide...

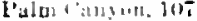

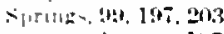
sitatur. 107 1915: 21

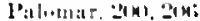

ILnut:111, :21:3

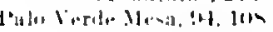

$$
\text { V.1011.4 ranges, got }
$$

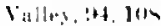

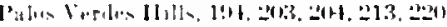

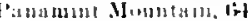

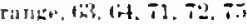

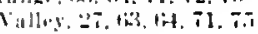

Funther (rwh. I:-

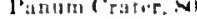

I': whis: lolatul, it

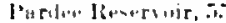

Jiurker ! in

$$
\begin{aligned}
& \text { 1'r...t, 1:11 } \\
& \text { l':um, at }
\end{aligned}
$$$$
\text { J'enk, } 75
$$

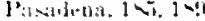

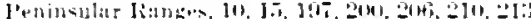

$$
\text { Wretem, } 3: 1
$$

['rt:ilum:1, hit

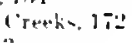

Phillip. tis

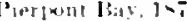

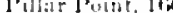

lilut knot at an 10

Inamathes

$$
\text { inlor }
$$$$
\text { is }
$$

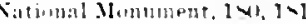

linngertation. Is

Pit:is loumt lo

l'it liver 4 , 113, 1:31, 1391, 14Valley,

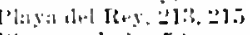

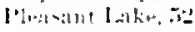

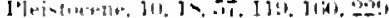

detiornistum, 1 .

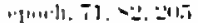

laken, 1vi

lava. 17:

minutian. 7 il

rintive J:t?

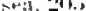

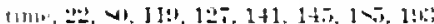
$2010,214.2115,211$

I'liomose, 111. 71, 72. 2015

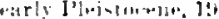

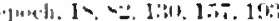

latm.

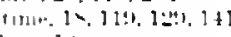

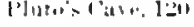

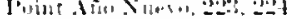

Arinir, 2.:-i

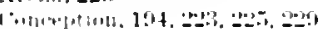

luelenda. :-2:

1 1ини. 1:83

formin. 201

linsolis, in

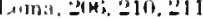

lim.... Jin,

\{roincula, lab)

sur. $2: 2: 3$

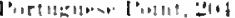

lintren, :-3:B

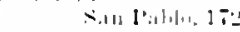

dioners? lith-tit

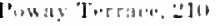

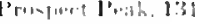

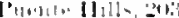

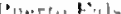

[थנ

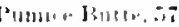
Plat, 4.5.

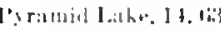
l', ink, 1 ?

R:Al1to, t:i

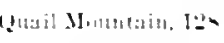

Karoun l'am 17:stratt 171

Latinlwow Pall, ה

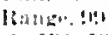

Rahor Prak, Jis, IR:

Ronkhuse.

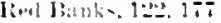

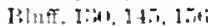

Binter. 12-

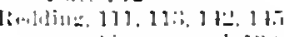

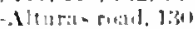

Roull:mla, I

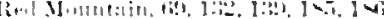
Jinck 1 lisms, 1:11

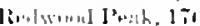

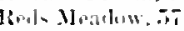

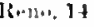

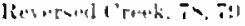

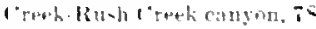
$\operatorname{Vill}+\cdots, 7$

[:]

Rihiten Falla tu

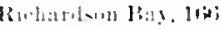

Liclumbnd, Titi

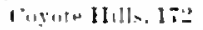

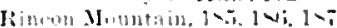

litter Range, 14,4 -

Rining Rism. Jiti

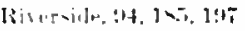

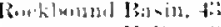

$$
1: 111+3,1: 3
$$

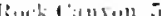

I6, kjom, it:

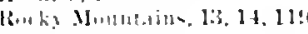

livele 1 tiver, $1+1$

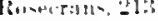

Kone Viallus int

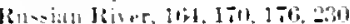

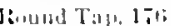

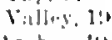

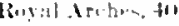

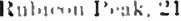

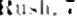

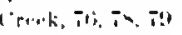

Runnill. thi

Junis. ]"1 


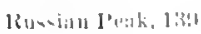

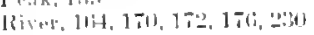

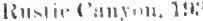

Sil4:

Busn, 147

(1)11

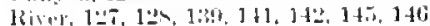
Jit, Jow, Ji), 17-2, 17\%, 17

>nlly, $\pi, 130,142,145,146,147,145$

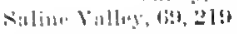

$\therefore$ : $111+\cdots 1,1+1$

$$
\text { Monatain. } 14 \text { I }
$$

sinlun bus $303,104,107,101$

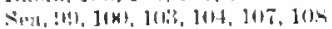

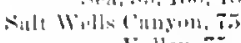

$$
\text { Valley, Ta }
$$

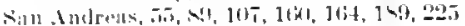

$$
\text { fonlt, 176, is - } 1,203,225
$$

rift 164: 170 1-

siprines, 1tit

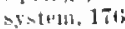

2.61 $14,14 ! 1$

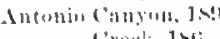

$$
\text { 'renth, } 1 \mathrm{Ni}
$$

ling

cimuty. it

lountains, $71,4 !, 90,189,2(n)$ :itis

Burjo, $1 !$ t

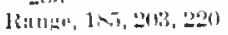

lirune foult , 104, 170

$$
\text { llills, Jir- }
$$

$$
\text { Montutin, 314 }
$$

('lan+'nte', 19:

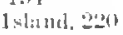

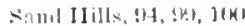

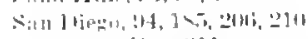
1:ily, 211

M10:2, 214;, 231, 211

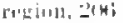

$$
\text { River, 201, 210, 21] }
$$

thimis ensw,

bulipin, niti

$$
\text { creak. 1417 }
$$

$$
\text { Valling, } 193
$$

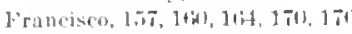

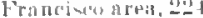

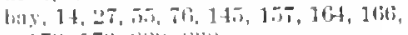

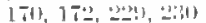

Marin black, 1711,17 th

J'nitusula, 1 hit:

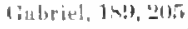

(

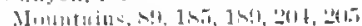

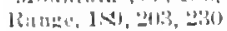

kiter, $21+1$

vallo: 2114

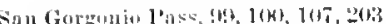

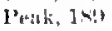

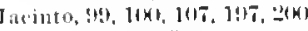
foult, 20).5

llountain, ]!17, 2013, 200

ralnLes, 20)'

Sautil kowil mass, 190

Ionquin, 145, 14ti, 147, 152

1) 1

Miver, $14,15,29,30,45,52,58,5 \pi, 150$

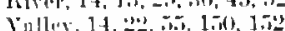

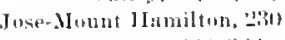

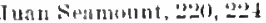

Intat Imint, 17:

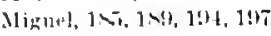

Nicolas, 1!14

$$
\text { [4: } 401,2 \div 0
$$

jedro, Jini, :2t:

1Iill, 2014, 2015, 2010

Nirtir, 145

Quentin J'unt, labi

Rafat Jountains, 1 .

Ramon, 1Ti, ltit Folley, 170

Sautu Ana, 24r

Cropk, 14.5, 14:

T., 2013, 220

River, 18!), 2013, 241,

Valley, 1, 20.5

Larbara, 1s!b, 1!H

(

Islmel, $19,2,194$

Catalina, 200

Clara River, 185, 165

$$
\text { Palley, 164, 174, 1Si, 186, 18 }
$$

(1) 1 13

[3:14in, 219), 2201

Ilenntilins, litit

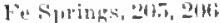

$$
\text { Inuz, 1 } 1, \bar{B}, 2(n)
$$$$
\text { Mountuins, ]<т, 1kt }
$$

Monica, 1983, 20\%

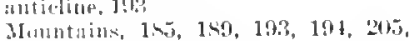
21:3

1 la $13,1 ! 13$

12:311 $1 e^{2}, 113,230$

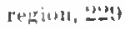

1utก, 1大i

$$
\text { recek, } 1 \text {, in, 1, }
$$

1rost, 1<, 14\%, 1!)

Mountains, $19,107,19 \pi, 200$

Susan Muแntuins, 1:93

Ynez Rant, ]

Satizes l'ak, 2013

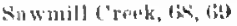

Jountains, 80
Seott, 139

Creek, 177

Iurket, 14

Scripps Institute, 210

Serdiff stntion, 1ht

Seal Burabb, 21:3

$$
\text { lineks, } 1 \text { in: }
$$

Suarles lake is

$$
\text { valley, sis }
$$

Secret Sprime Mluntuin, 119

Sedimentary rocks, 17

stnuer (angon, 1hy

Sentinel Domes, :

$$
\text { Rark, } 33
$$

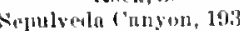

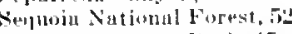

serra Cross 1st

l'ark, $4 i$

Sluasta, 1:1, 1:2, 127, 128

(ounty, i11, 1+1

$1 \mathrm{am}, 5 \mathrm{~s}, 139,1+2$

placiers, 1:0

liver, 1:3!

villey, 110, 120, 121, 128

Shastan activity, 127

Shastina, 121, 12:2, 12k

Shrep llole Mountains, 89

Shelly Cove, 224, 2025

Shepherd Jiass, tis

Shore Line lisutte, its

Siberia, $: \vec{t}$

sierra, $, 12,1,4$

Buttes, 52

- 'nsoude, 1s

Mucle, 1 ist

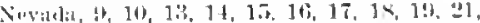

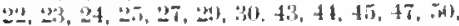

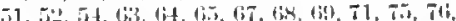
$7 \times, 7 !, 49,1] 14,12 k, 130,141,14 \pm, 14 \pi$

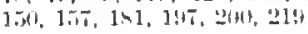

Sierran bedrick. is

eanyons, 3:- is

rrest, 25

frouts, ti.

geulogy, 13

lakes, 65

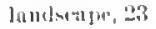

reginu, 19, 4i, :i1

रเ ตा тा, 1!)

slope, 1s

Sierra lidum, kn

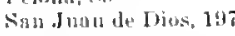

Valley, 21

sigual Hill, 20. 21, 213, 21:

silurian Iake, s?

siper loke, 52, 7s, 79, st

sitrand, $21 \times$ :

Simi Ilills, 11ti

Siskjpou, 130

County, 111,113 
Sivy-1 Athe hasio, 5:

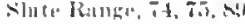

siulat 1 alkas, w"

baxin, !1

Sulmol Mnoutain,:014,:-11

Somoun, Jith

$$
\text { llowng", 16it }
$$

soule IRuthe 1.6

$R: 11 \cdot h, 1: 21,1: 2$

south lkat1\%, 14i

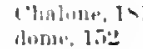

Southeru Colifurnia, 155, 243, 208

$$
\text { l'ilitie Railroald, 14, } 144
$$

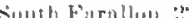

Fork, 14, 311, 43, 27, 13!4, 141

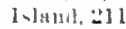

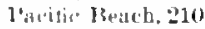

Volla 13.1ly, 1:3!)

suatnish, 211

distonseries, $10: 3$

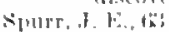

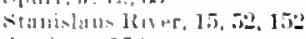

Stometorn, 10.2

Stony ('rosk, 1 th, 147, 135)

stovepige Wells. Ji?

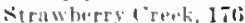

sulumily l"alle. 1310

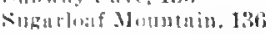

Suisun lias, 14t, 14t, 1.0, 172, 170

s゙ulphur Laık, 17!!, 140

$$
\text { Nountaim, 18.5, J Mri }
$$

I'Ih nol. 19.

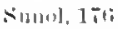

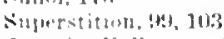

Surpriw Vulley, , *1, \$2, \$43, -5, \$6, 111

Susin latke, 4 ?

sibter liuttes. 145, 14s

$$
1 \text { and }
$$

Swansen ti-

sंueptsat. 211

Tuble Mumutuin, 47

Tnlumencteres, lix

Tabore, T. T!$$
\text { |grsin, 21, 2(k) }
$$$$
\text { taule basm. } 4 \text { : }
$$

Tulat-luk in Itak range, 41

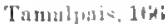

Tamarack it

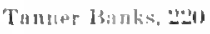

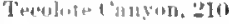

Tthama, 1 Hi

c'inunty. 139
Thathui kange 14.

$$
\text { I'I1: 13, 29 }
$$

Yumutnins, 849, 15)

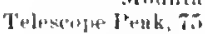

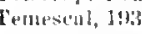

$$
\text { Wa-h, 20:3 }
$$

Тияну

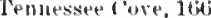

Tertise, sethi

Terptiary 10,63

depmsits, it

matterinl, :-2.:-

recks, $72,113 \%$

sedintells, 1 t:

The diarilens, 8:2

Invoupable Valley, 19

Iinarets, 57

Thompon l'eat, 128)

Thoux:und Is]awi Lake, 5o

There lirothers, :3i

'Thurstous Lake, 17T, 1Ni

Ti:ı Juภna, :210, 211

'Tiburun L'nisula, 160

Timber Munntain, 111

Tiuga, is

$$
\text { Pas, 2?!, (4), 76 }
$$

$$
\text { rosal. } \mathrm{ix}
$$

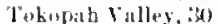

Tua wia lintuge it

$$
\text { Vultey }
$$

lomstes [hay, 1titi, 17i

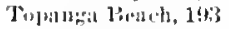

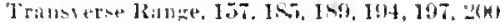
liangess, 16. 10, 15, 16, , ,

'Treisure I Masul, I70

'Tiassie, 10

$$
\text { struta, 134) }
$$
bole'aluis, lit

'rinity Als, 13:1

$$
\text { 1 } 1101313,139
$$

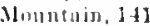

$$
\text { River. } 111
$$

Trobeyny 21:

Trout treation

Eruckere, 21

liver, 14, 14, 21, 43, (is 1.4nywatis

Volley, $4: 3$

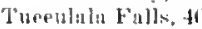

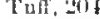

'lajumga ('anyous, 149

Tulare, 19iv

$$
\text { luke, lint }
$$

Tule Iake, ]1], 11:3

$$
\text { baxiu, } 111
$$

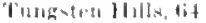

'Tummal,

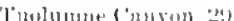

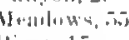
leivel: 1.5

Twin lonkin . is

l'yndall, fis

$$
\text { Cretels, 5o }
$$

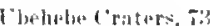

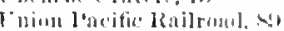

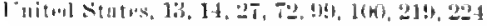

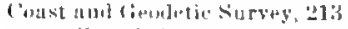
(*uaril, 2:-?!!

fiecolog it Nayy.215

llemther Kurean, 1\%

Vper Inka, s3, s:

Meritillingon, 32

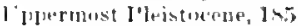

Vatlonitu, 1ut

linlley, 1ut

Salle sian Juse, I(x)

Vemice. 213,215

linturn, 19t;

C'ounty l'ourthouse, 14:

distriet, 19i

liver, 165, 1<6, 157 lalley, 1 $\mathrm{ki}, 1 \mathrm{si}$

lewal bulls, 3 ,

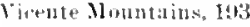

Vјејаs: $2(x)$

Vints, 146

Voleats, $2(\mathrm{HI}$

Mountuin, $: 213$

Volenno ('reek, 37

vulcan's Castli, 13:

Walker River, is

Wuluet dreek, Jist

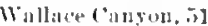
Creek, in

Wuruer buck, :-

canyou, :

Hotmtains, $63,50,81, x^{*}, 85,86,111,140$

linuge, NI, $\times 2, N 3, N i, w$

Villey, N1, 1117, 1:3t

Washingtut, 14, 15, 22, 111, 11!, 132

Irenvervills, 1t (o)

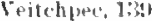

Wrestomaril l'ass, fit

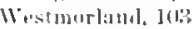

II ese l'eake lit

Whaleturti, 11!n, 1:4 


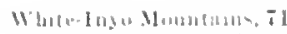

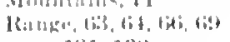
Youmtaln, 1:31, 1:3:link tid

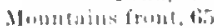

Whituey, 4t, 17, 1:7

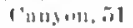

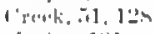

hlmiver 1:1

1lill, ti, ill

l'ils. 51

ranim, it

Whittier, $204,20 \%$

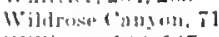

Willings, 1110,147 ('lent lake, $1 \times$
Willamman, Hi

Willuw a rmok, 1 t?

Willowe 1 lli

Monntain, 119

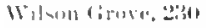

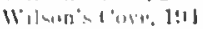

111

Wiallom,

Wintun foluteitr. 12s

Yal. I'minaresty 27

Vollow liut 10.120

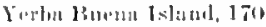

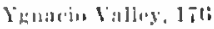

Yulu 1:isin, 1 Hi, 117, 17T

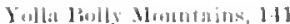

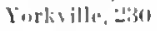

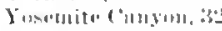

Fillis, tur

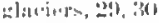

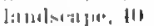

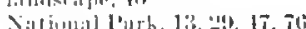

rexint, : : 11,51

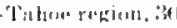

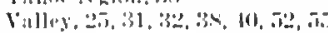

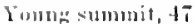

Yreks, $1+1$

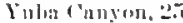

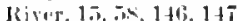

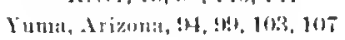




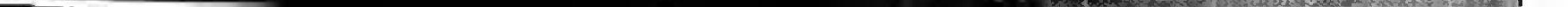





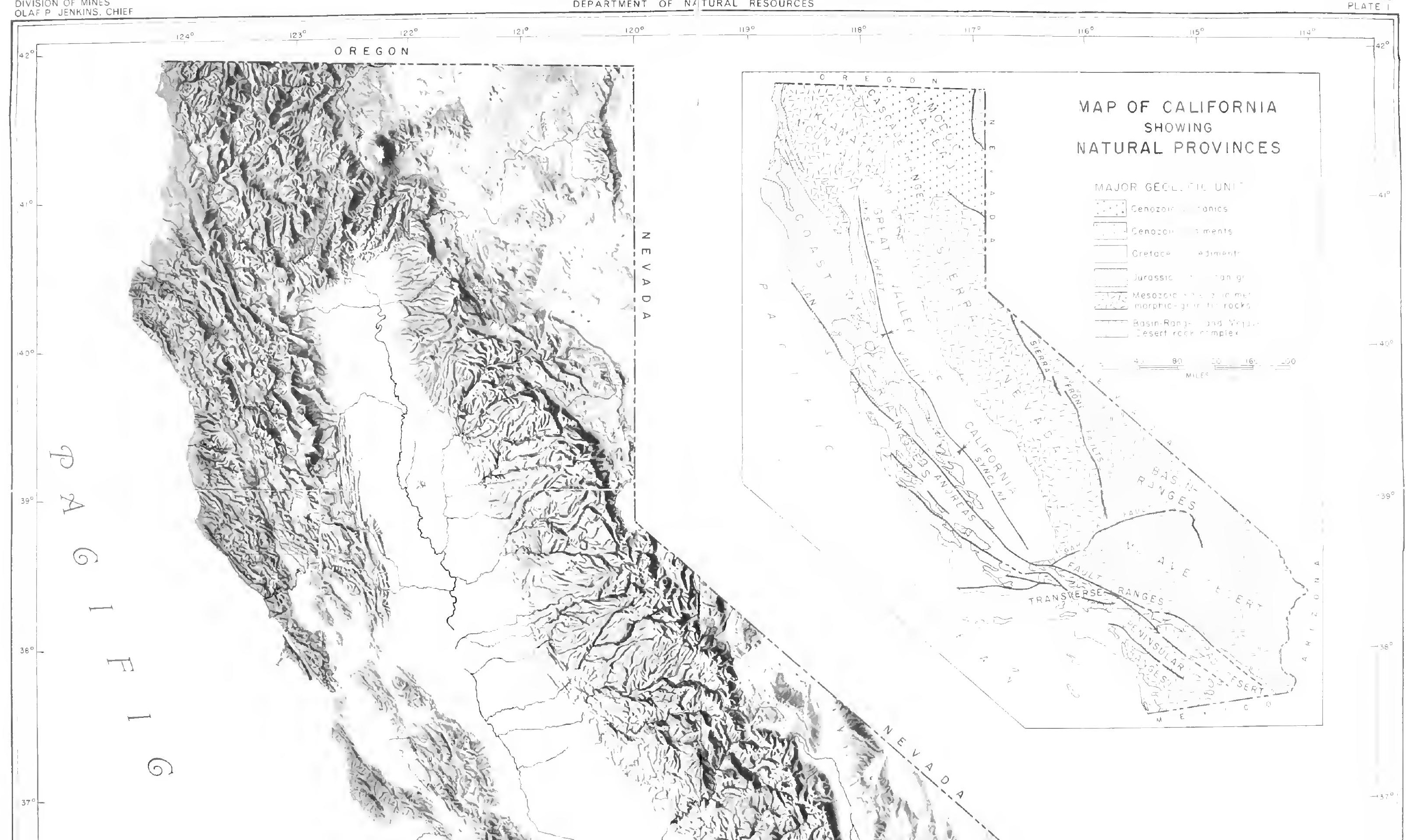




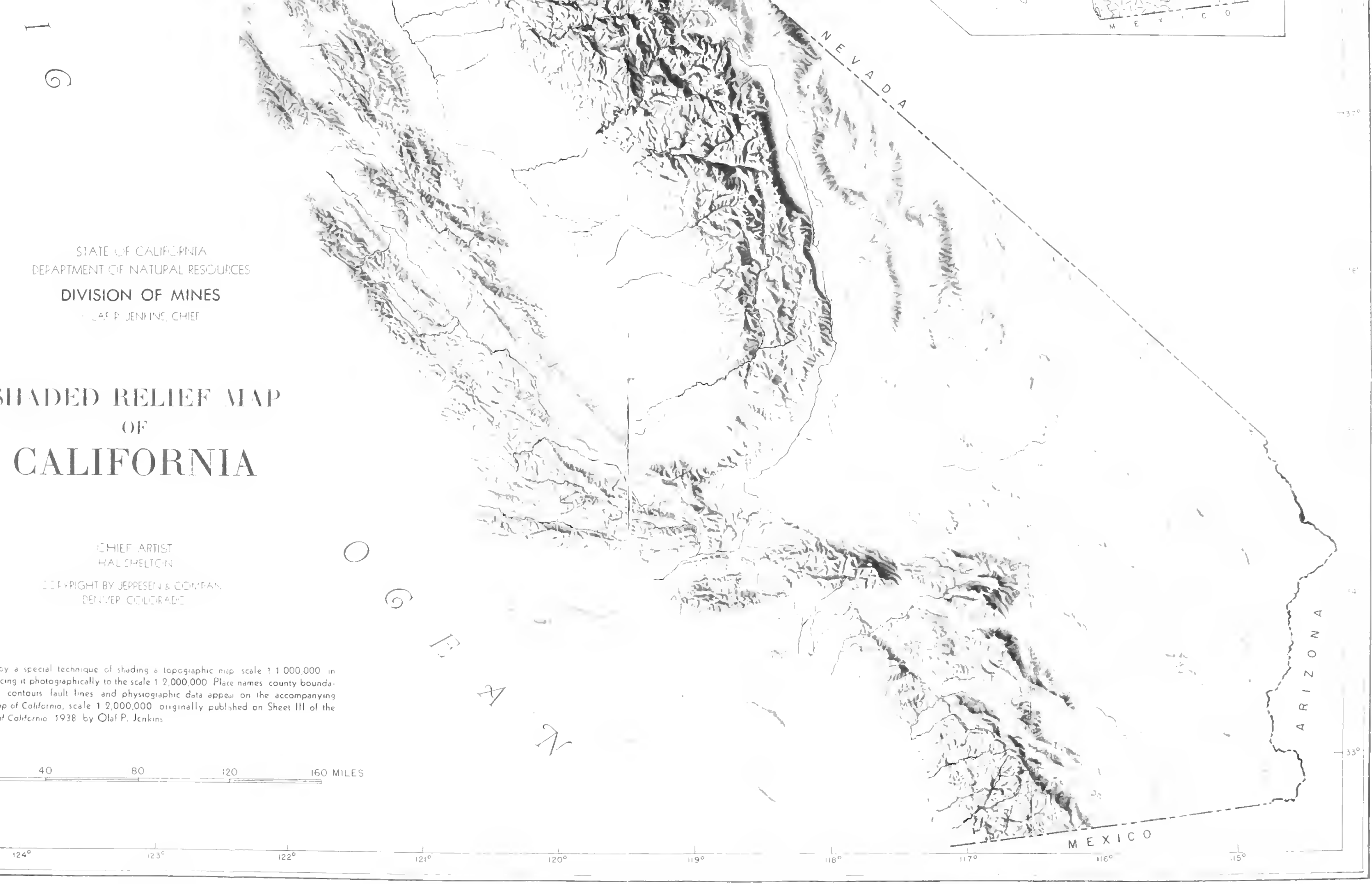




THIS BOOK IS DUE ON THE LAST DATE STAMPED BELOW

BOOKS REOUESTED BY ANOTHEA BORAOWEA

ARE SUBJECT TO IMMEDIATE RECALL

- WR 3 แ

var 6

FEB 32000

4. 9

IBRAAY UNIVERSITY OF CALIFORNIA, DAVIS

hitp /hbnte ucdovis edu/PatronRenew html

http Mnte ucdavisedil (24-hour) (530) 752.1132 Automated Phone Renewal 24.96$)$

$$
\text { - WU. LIẼRAR }
$$




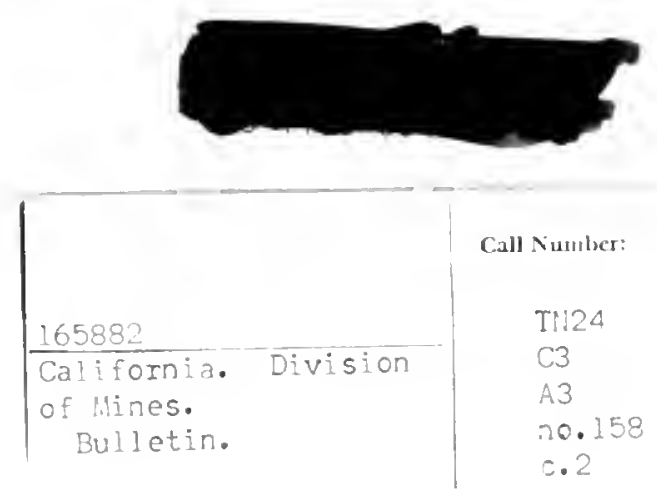

165882

$\begin{array}{ll} & \text { TN24 } \\ \text { California. Division } & \text { C3 } \\ \text { of Mines. } & \text { A3 } \\ \text { Bulietin. } & \text { no. } 158 \\ & \text { C.2 }\end{array}$

LIGADRY
UNIVERSITY OF CALIFORTIA

DAVIS 

4.9. 4.

8. Ho Won 